\title{
IMPROVISATION UND ORGANISATION
}

Muster zur Innovation sozialer Systeme

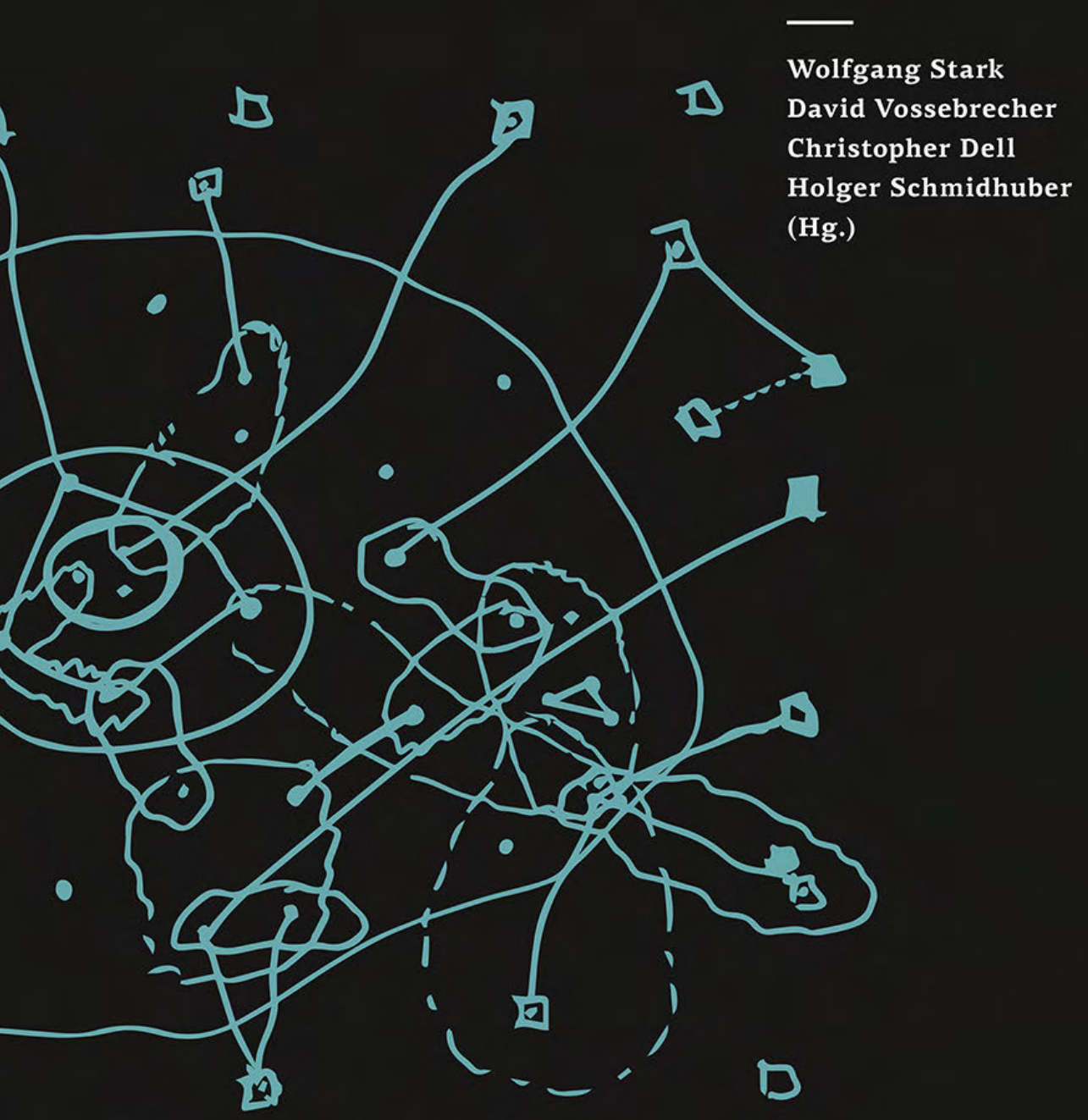

[transcript] Kultur und soziale Praxis 
Wolfgang Stark, David Vossebrecher,

Christopher Dell, Holger Schmidhuber (Hg.)

Improvisation und Organisation

Kultur und soziale Praxis 

Wolfgang Stark, David Vossebrecher,

Christopher Dell, Holger Schmidhuber (Hg.)

\section{Improvisation und Organisation}

Muster zur Innovation sozialer Systeme

[transcript $]$ 
Teile dieser Publikation basieren auf Ergebnissen des Forschungsverbundprojekts MICC (FKZ oIFMo8040-4) aus dem BMBF-Forschungsschwerpunkt >Innovationsstrategien jenseits traditionellen Managements $<$. Die Publikation wurde aus Mitteln des Bundesministeriums für Bildung und Forschung (BMBF), des Europäischen Sozialfonds (ESF) der Europäischen Union und der Fuenfwerken Design AG gefördert.

Erschienen im transcript Verlag 20I7

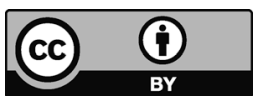

Dieses Werk ist lizenziert unter der Creative Commons Attribution 4.० (BY). Diese Lizenz erlaubt unter Voraussetzung der Namensnennung des Urhebers die Bearbeitung, Vervielfältigung und Verbreitung des Materials in jedem Format oder Medium für beliebige Zwecke, auch kommerziell.

(Lizenztext: https://creativecommons.org/licenses/by/4.o/deed.de)

Die Bedingungen der Creative Commons Lizenz gelten nur für Originalmaterial. Die Wiederverwendung von Material aus anderen Quellen (gekennzeichnet mit Quellenangabe) wie z.B. Schaubilder, Abbildungen, Fotos und Textauszüge erfordert ggf. weitere Nutzungsgenehmigungen durch den jeweiligen Rechteinhaber.

\title{
Bibliografische Information der Deutschen Nationalbibliothek
}

Die Deutsche Nationalbibliothek verzeichnet diese Publikation in der Deutschen Nationalbibliografie; detaillierte bibliografische Daten sind im Internet über http://dnb.d-nb.de abrufbar.

\author{
(C) Wolfgang Stark, David Vossebrecher, Christopher Dell, Holger Schmidhu- \\ ber (Hg.) \\ Umschlaggestaltung: Urheber: Fuenfwerken Design AG, \\ (C) Fuenfwerken Design AG, Wiesbaden 2015 \\ Satz: Justine Haida, Bielefeld \\ Printed in Germany \\ Print-ISBN 978-3-8376-26II-7 \\ PDF-ISBN 978-3-8394-26II-I
}

Gedruckt auf alterungsbeständigem Papier mit chlorfrei gebleichtem Zellstoff. Besuchen Sie uns im Internet: $h t t p: / / w w w . t r a n s c r i p t-v e r l a g . d e$

Bitte fordern Sie unser Gesamtverzeichnis und andere Broschüren an unter: info@transcript-verlag.de 


\section{Inhalt}

Vorwort

Wolfgang Stark $\mid 9$

\section{TEIL 1}

\section{THEORETISCHE UND KONZEPTIONELLE ZUGÄNGE}

\section{Innovationsmuster und Improvisation in Organisationen}

Musikalische Muster als Schlüssel für innovative Prozesse

Wolfgang Stark | 17

Organisation musikalisch denken

Christopher Dell | 31

\section{Reflexivität und Kreativität}

Konträre Quellen kompetenter Improvisation

Manfred Moldaschl | 47

Improvisation durch objektivierendes und subjektivierendes Handeln Fritz Böhle $\mid 73$

\section{Rhythm, Time and Improvisation}

Pedro Teixeira Santos and Miguel Pina e Cunha $\mid 93$

\section{Organisationskultur revisited}

Sechs transdisziplinäre Schnittstellen zwischen Wissenschaft und Kunst beim Versuch, das Ungenannte und Unerwartete in Organisationen zu erfassen Wolfgang Stark und Christopher Dell | 109

\section{Technologie der Improvisation}

Christopher Dell | 131 
From a Pattern Language to a Field of Centers and Beyond

Patterns and Centers, Innovation, Improvisation, and Creativity

Hajo Neis | 143

\section{The Shape of Tacitness to Come}

Erweiterte Zugänge zum Impliziten in Organisationen durch musikalisches Denken

David Vossebrecher | 167

Ein Muster für die Zukunft

Vom künstlerischen Denken in außerkünstlerischen Feldern

Ursula Bertram | 193

\section{TEIL 2}

Forschung, Anwendung und Praxis

\section{Organisationspartituren}

Die implizite Dimension des Organisierens erforschen

David Vossebrecher | 207

\section{Phoenix aus der Asche}

Muster industrieller Transformation auf Zollverein

Oliver Bluszcz, Anne Suchalla und Katrin Heymann | 225

\section{Innovation und kreatives Denken als Produkt}

Organisationskultur als Managementinstrument in Designprozessen

David Vossebrecher und Thorsten Kamin | 253

\section{Musik und Markenentwicklung}

Holger Schmidhuber und Rolf Mehnert | 291

Organisationspatterns entdecken und in der Praxis nutzen Monika Bobzien | 307

\section{Eine Mustersprache für die Didaktik}

Service Learning Patterns auf Grundlage der Mustertheorie Jörg Miller und Nadine Ruda | 325

Wenn das die Lösung ist, will ich mein Problem zurück Angewandte Improvisation als Werkzeug für resiliente Führung Gabriele Amann und Martin Ciesielski | 341 


\section{Silence, Patterns, Structures}

Music and Improvisation within the Context of Organisational Praxis

Michael Spencer | 355

Erfolgsmuster, künstlerische Zugänge und Improvisation - ein Glossar Wolfgang Stark, Christopher Dell, Holger Schmidhuber | 379

Die AutorInnen | 389 



\section{Vorwort}

Wolfgang Stark

Finanzkrise, Klimawandel, Flüchtlingskrise, globales Management, innovative Arbeits- und Technikgestaltung - bereits heute merken wir, dass formalisierte Arbeitsabläufe und geronnene Organisations-Strukturen oft nicht mehr hilfreich sind, um komplexe und dynamische Umwelten aktiv gestalten zu können. Erfolgreichen Organisationen und gesellschaftlichen Strukturen gelingt es, flexibel, kreativ und oft überraschend innovativ auf Herausforderungen zu reagieren, die häufig nicht vorhersehbar und unübersichtlich sind. Unternehmen, non-profitOrganisationen, Bildungs- und andere öffentliche Einrichtungen, aber auch die gesellschaftlichen Strukturen insgesamt, müssen sich in komplexer werdenden Umwelten orientieren und entsprechende Organisationskulturen gestalten.

Der Umgang mit Ungewissheit ist trotz aller Bemühungen des Qualitäts- und Prozessmanagements eine alltägliche Herausforderung für Organisationen. Geplante Strategien und Abläufe - das wissen alle in der Praxis Tätigen - reichen dafür bei weitem nicht aus. Deshalb entwickeln Menschen in Organisationen im Laufe der Zeit ein Repertoire an informellen und impliziten Verfahrensweisen, die sich verfestigen, weil sie sich als viabel (gangbar) erweisen. Damit werden Strategien, Pläne und Arbeitsabläufe oft erst praktikabel. Die Herausforderung besteht jedoch darin, die geplanten und impliziten Prozesse, die für das Funktionieren einer Organisation verantwortlich sind, so zu gestalten, dass sie - trotz notwendiger Routinen - flexibel genug sind, sich ständig verändernden Rahmenbedingungen anzupassen und kreativ nicht nur zu >reagieren<, sondern auch innovativ agieren zu können.

Um das im Rahmen verschiedener Formen der >Selbstorganisation< zutage tretende Potential nutzen und einsetzen zu können, benötigen wir ein fließendes Verständnis von Organisation, das nicht mehr nur auf rationaler Planung basiert: Das oft versteckte individuelle und kollektive Erfahrungswissen (implicit and tacit knowing) wird zur Grundlage der heute benötigten Kunst der Improvisation. Implizites und intuitives, vorausschauendes Wissen und Handeln sind die Grundlage für Innovation und Lernen in Organisationen und sozialen Systemen. Durch die Analyse von organizational patterns und musikalischem Denken 
entsteht ein neues Verständnis flexibler und dynamischer Organisationen für eine neue Zeit.

Vergleichbares geschieht in der musikalischen Improvisation im Jazz (Barrett 1998; Dell 2002, 2012), in der theatralen Improvisation (Johnstone 1993) und beim modernen Tanz (Halprin 1993, Forsythe 2002), aber auch in anderen künstlerischen Feldern (bildende Kunst, dreidimensionales Gestalten - Bertram 2010, Weirich 2002). Akteure (Musiker, Darsteller, Tänzer, Künstler) wirken und spielen auf Basis erprobter musikalischer Muster zusammen. Sie variieren situative Muster vorhandener Erfahrungen im Sinne künstlerischer Tradition, zitieren, variieren und kombinieren sie in neuen Abfolgen und legen damit gleichzeitig neue Muster an. In einem prozessualen Verständnis werden Organisationen und soziale Systeme >performativ< immer neu hervorgebracht und können auch anders sein bzw. agieren. Die von Christopher Dell (in diesem Band) als >Technologie der Improvisation< bezeichneten Verfahrensweisen für eine Innovationskultur fordern von Organisationen, sozialen Systemen und den in ihnen beteiligten Menschen eine neue Perspektive und gleichzeitig verändertes Handeln. Sprunginnovationen (oder: radikale Innovationen) - wie etwa in der Musik oder in anderen Kunstsparten - entstehen aus sich selbst heraus, sind performativ und entwickeln sich in einem Klima des spielerisch-experimentellen Umgangs mit dem Material und der Aufgabe. Diese performativ-spielerische Haltung ist jedoch in einer Welt der Ergebnisorientierung und Rationalität keineswegs selbstverständlich: Da Sprunginnovationen oft außerhalb von Routinen entstehen, glauben viele Führungskräfte in Organisationen und gesellschaftliche Akteure, dass Freiräume oder event-ähnliche Situationen bereits genügen, und sind enttäuscht, wenn allenfalls Mittelmaß entsteht. Daher ist die Entdeckung und Fähigkeit zur Neu-Verschaltung (Re-Design) erfolgreicher Muster gemeinsamen Handelns (tacit knowing) für innovativer Prozesse zentral. Da performativ, muss sich zum (impliziten) Wissen das Handeln, Einüben und erfahrende Lernen gesellen - eine Technologie der Improvisation, die zusätzlich zum kognitiven-rationalen Kanal erst über andere Wahrnehmungs- und Handlungsformen einen performativ-experimentellen Umgang mit dem Material und damit Innovationen erst zulässt.

In fast allen technischen, wirtschaftlichen und sozialen Innovationsprozessen und bei einer wachsenden Zahl von Managementsituationen ist die Kunst der Improvisation entscheidend für das Gelingen rationaler Prozesse und für den Umgang mit Unsicherheit in komplexen Situationen. Als Teil eines neu entstehenden Verständnisses des Managements von Innovationsprozessen geht dies weit über die wirtschaftliche Verwertung von neuen Ideen und Konzepten und die Effektivierung von Planungsheuristiken hinaus. Wir nennen diese Ansätze >Formen strategischer Improvisation<, weil sie in der Lage sind, flexibel und kreativ auf wechselnde, unklare und unsichere Situationen zu reagieren und diese aktiv zu gestalten. Das in strategischen Improvisationsprozessen versteckte gemeinschaftliche implizite Wissen (>tacit knowingく) ist von entscheidender Bedeutung für die heute dringlich geforderte Fähigkeit sozialer Systeme, sich immer wieder neu zu erfin- 
den und damit nicht nur sich verändernden und komplexen Herausforderungen zu stellen, sondern auch neue, oft überraschende Wege bei technischen oder gesellschaftlichen Herausforderungen zu finden. Bisher übliche Organisationsanalysen arbeiten weitgehend mit kognitiven Modellen und haben den rationalen Teil von Organisationen hervorragend erfasst. Sie beziehen sich vor allem auf direkt erkennbare Parameter und auf Zähl- und Messbares. Das funktioniert sehr gut bei hierarchischen Organisationen. Je flacher jedoch Hierarchien werden und je komplexer damit die Organisation, umso mehr werden jene weichen Faktoren der Vergemeinschaftung bedeutend, die Tiefe haben. Deshalb wollen wir in diesem Band nach der Tiefendimension des Organisierens (Weick 1987) fragen, die über rationale Modelle hinausgeht.

Für moderne Unternehmensstrukturen sind oft verschiedene Service- $u$. Produktionsstandorte, unterschiedliche Herkünfte von MitarbeiterInnen und >Diversity<, sehr unterschiedliche Aufgaben und Arbeitsplätze, und damit auch verschiedene Denkweisen und Problemlösungsstrategien kennzeichnend. Für eine erfolgreiche, effektive und innovative Weiterentwicklung der Organisation und ihrer Innovationsfähigkeit spielen deshalb Aspekte der Zusammengehörigkeit, der geteilten Ziele und Werte (Vergemeinschaftung) eine herausragende Rolle.

Die Bedeutung von Organisationskultur für Veränderungsprozesse und Innovationen ist in der Organisationsforschung und -praxis heute unbestritten. Aber Abläufe und Strukturen in Unternehmen und Organisationen werden meist durch Grafiken, Schrift und Sprache dargestellt. Dabei werden wichtige Elemente zur Erschließung persönlicher Ressourcen nicht abgebildet: z.B. Einstellungen, Ansichten, Emotionen und damit wichtige Grundlagen für die Handlungsleitenden mentalen Modelle der Mitarbeiterinnen und Mitarbeiter. Die Analyse und Vermittlung von Organisationskultur durch vor allem durch Zeichen und kognitiv-visuelles Material (Grafiken, Sprache) bedeutet also eine Beschränkung, die vor allem die wichtigen nicht-kognitiven Elemente von innovativer Organisationskultur ausblendet.

Könnten die Kulturen, in denen die Organisationsmitglieder leben bzw. arbeiten, aber klanglich bzw. musikalisch hörbar gemacht werden, wäre dies eine Möglichkeit, das im Arbeitsalltag fast ausschließlich genutzte Kommunikationsmedium >Sprache< sensorisch-emotional zu ergänzen, d.h. über den Kanal der Musik wahrnehmbar zu machen und gleichzeitig als Feedback an die Führungskräfte, Mitarbeiterinnen und Mitarbeiter zurück zu spiegeln. Notwendige Lern- und Veränderungsprozesse in der Organisation könnten über diesen Weg besonders angeregt und unterstützt werden. Die Energie, die in einer lebendigen Organisationskultur >schlummert<, könnte für Veränderungsprozesse und Innovationen, aber auch für die gerade heute notwendigen stabilisierenden Vergemeinschaftungsprozesse (Zusammengehörigkeit, geteilte Werte und geteiltes Wissen) flexibler und effektiver genutzt werden.

Dieser Band ist im Zusammenhang mit einem Forschungsvorhaben entstanden (www.micc-project.org), in dem die Sprache der Musik als Medium zur 
Analyse von Organisationsmustern genutzt und entsprechend anwendbare Instrumente und Methoden für die Förderung einer innovationsfördernden und lebendigen Unternehmens- bzw. Organisationskultur zu entwickelt wurden. Gemeinsam mit den beteiligten Organisationen wurden im Rahmen praxisorientierter Fallanalysen Elemente sichtbarer und verdeckter Organisationsmuster in ihrer Bedeutung und Wirkung für das Unternehmen/die Organisation analysiert und in die Sprache der Musik übersetzt. Dabei wurden relevante und wiederkehrende Erfolgsmuster identifiziert und für die Weiterentwicklung organisationsspezifischer Organisationskulturen genutzt. Die Ergebnisse des Projektes können Unternehmen, Organisationen helfen,

- die vorhandenen (verborgenen) Muster der Organisationsskultur über den Kanal der Musik zu erkennen,

- den Nährboden für diese Muster zu deuten und kritisch zu überprüfen,

- innovative Orientierung bei gleichzeitiger Flexibilität zu ermöglichen, und

- stabilisierende Erfahrungen der Zusammengehörigkeit und geteilter Werte zu erzeugen und zu steuern, um damit einen neuen Zugang für die Entwicklung von Innovationen zu entwickeln.

Die Analyse der jeweiligen Unternehmenskultur und die Übersetzung in die Sprache der Musik lassen Aussagen darüber zu, inwiefern die in Leitbild und Verhaltenscodes verkündeten Werte mit den tatsächlich gelebten Werten in Unternehmen einhergehen. Über diesen Weg ließen sich Maßnahmen der Personal- und Organisationsentwicklung entwickeln, die zum >Alignment<(Vergemeinschaftung) der MitarbeiterInnen beitragen können.

Der thematische Schwerpunkt in diesem Projekt lag dabei auf Prozessen der Innovation und der Improvisation:

- Wie können sich Menschen in hochkomplexen Systemen erfolgreich orientieren und zielgerichtet sowie ergebnisorientiert agieren?

- Wie kann dabei die Innovationskraft bzw. Innovationsfähigkeit in modernen Organisationen gesteigert werden?

Das Buch versammelt in einzigartiger Weise WissenschaftlerInnen, DenkerInnen und PraktikerInnen aus Architektur, Kunst, Musik, Organisationswissenschaften, Psychologie, Pädagogik, Sozialwissenschaften und Soziologie.

Die Beiträge von Wolfgang Stark - Christopher Dell - David Vossebrecher - Oliver Bluszcz, Anne Suchalla a Katrin Heymann - David Vossebrecher \& Thorsten Kamin - Holger Schmidhuber \& Rolf Mehnert beziehen sich direkt auf die Ergebnisse dieses ungewöhnlichen Forschungsprojekts.

Darüber hinaus spiegelt sich in den Beiträgen des Buches der aktuelle internationale Diskurs zur Rolle der Improvisation in Organisation und sozialen Systemen. Konzeptionell nähern sich die Aufsätze von Fritz Böhle - Manfred Moldaschl 
- Pedro Texeiro Santos a Miguel Pina e Cunha - Wolfgang Stark a Christopher Dell - Christopher Dell dem Verständnis von Improvisation als Kunst und Technologie für Organisationen und soziale Systeme aus der Perspektive der Arbeits- und Organisationssoziologie, der Betriebswirtschaft, der Organisationspsychologie und der Musikwissenschaft. Aus dem Blickwinkel der Praxis betrachten Gabriele Amann Q Martin Ciesielski als Organisationsberater und Coaches und Michael Spencer als Musiker und Berater Improvisationsprozesse als künstlerische Methode für den professionellen Einsatz in Organisationen.

Erfahrungswissen, Intuition und stacit knowing< spielt beim Konzept der Handlungsmuster in Organisationen und sozialen Systemen, der dazugehörigen Mustersprache und bei strategischer Improvisation eine entscheidende Rolle. Wolfgang Stark - Hajo Neis - David Vossebrecher - Ursula Bertram - Monika Bobzien - Nadine Ruda \& Jörg Miller analysieren aus den Blickwinkeln von Organisationsund Gemeindepsychologie, Architektur und Stadtplanung, Kunst und Kunsttransfer und den Bildungswissenschaften die in unserer rationalisierten Welt oft zu wenig beachteten, für die Improvisationsfähigkeit aber enorm bedeutsamen Bausteine der Intuition und des simpliziten Wissens<.

Ein kleines Glossar, in dem die wichtigsten Begriffe der in diesem Band repräsentierten Perspektiven der Improvisation - Muster und Mustersprache - künstlerische Forschung beschrieben werden, schließt diesen Band ab. Der mit dem Projekt und mit dem Buch gestartete Versuch, individuelles und kollektives Erfahrungswissen und künstlerische Verfahren für die Gestaltung und die Abläufe von Organisationen und sozialen Systemen fruchtbar zu machen, erfordert den Mut, über die Grenzen der eigenen Disziplin und Fachlichkeit zu springen und sich auf Unbekanntes und Unerwartetes systematisch einzulassen. Für diese inspirierende Offenheit und das oft notwendige Durchhaltevermögen danke ich allen Beteiligten sehr herzlich.

\section{LITERATUR}

Barrett, F. J. (1998): Creativity and Improvisation in Jazz and Organizations: Implications for Organizational Learning. In: Organization Science, 9 (5), 605-622.

Bertram, U. (2010): Kunst fördert Wirtschaft. Zur Innovationskraft des künstlerischen Denkens. Bielefeld, transcript.

Dell, C. (2002): Prinzip Improvisation (Principles of Improvisation). Köln, Walter König.

Dell, C. (2012): Die improvisierende Organisation. Management nach dem Ende der Planbarkeit. Bielefeld, transcript.

Forsythe, W. (2003): Improvisation Technologies. A Tool for the Analytical Dance Eye. Berlin, Hatje Cantz Verlag.

Halprin, D. (2003): The Expressive Body in Life, Art and Therapy. Working with Movement, Metaphor and Meaning. London and New York, Jessica Kingsley. 
Weick, K. (1987): Der Prozess des Organisierens. Frankfurt a.M., Suhrkamp.

Weirich, S. (2002): Stories: Erzählstrukturen in der zeitgenössischen Kunst.

Haus der Kunst, München. München, 2002. 
Teil 1

Theoretische und konzeptionelle Zugänge 



\title{
Innovationsmuster und Improvisation in Organisationen
}

\author{
Musikalische Muster als Schlüssel für innovative Prozesse
}

Wolfgang Stark

Die Frage, weshalb manche Organisationen und sozialen Systeme erfolgreich, innovativ und kreativ mit aktuellen Herausforderungen umgehen können und andere nicht, hat Organisationswissenschaftler, Soziologen, Psychologen und Philosophen genauso beschäftigt wie Politiker und Manager im profit- und nonprofit-Sektor. Experten in Forschung und Praxis waren noch vor 10 Jahren überzeugt, Innovationsmanagement sei ein rational planbarer Prozess, weil die Umgebungsfaktoren vorhersagbar und damit auch beherrschbar seien. Ausgefeilte Technologien und Algorithmen für Planung und Management von Innovationen wurden entwickelt. Heute haben wir es - nicht nur bei Innovationen - immer mehr mit Herausforderungen zu tun, die nicht nur komplex, sondern kaum vorhersagbar und grossenteils überraschend auftauchen und bewältigt werden wollen. Der Grund dafür liegt weitgehend in einer verdichteten Komplexität von Strukturen und Prozessen, die nicht nur parallel laufen, sondern auch mit einer hohen Geschwindigkeit ablaufen, die menschliche Wahrnehmungs- und Analysemöglichkeiten übersteigen und nur noch maschinell beherrschbar zu sein scheinen. Das Mantra der >Komplexitätsreduzierungく und immer ausgefeiltere Algorithmen helfen hier nur beschränkt weiter.

Um den hier benötigten kreativen Wissens- und Handlungstypen auf die Spur zu kommen, haben wir uns im Forschungsprojekt »Music_Innovation_Corporate Culture« (www.micc-project.org) damit auseinandergesetzt, eine neue Sprache der Innovation zu entwickeln, die einerseits weniger auf theoretischen Modellen und rationalen Abläufen, sondern auf dem oft versteckten und intuitiven Erfahrungswissen (tacit knowing oder implicit knowledge) vieler beruht, und die gleichzeitig einen kreativen und erfinderischen Umgang mit aktuellen und zukünftigen Herausforderungen unterstützt. Wie bereits Karl Weick (1987) lassen wir uns dabei von der Sprache der Musik als Metapher inspirieren, gehen jedoch über die metaphorische Verwendung hinaus und begeben uns - in enger Kooperation mit 
professionellen Jazz-Musikern - auf die Suche nach dem Geheimnis innovativer Organisationskulturen, indem mit Hilfe musikalischen Denkens und der Muster der Improvisation die Grundelemente (Dell 2012) einer Sprache der Innovation erarbeiten, die die kreative Kraft künstlerischer Herangehensweisen und künstlerischer Forschung nutzen kann.

\section{Vom Mythos und vom Ende der Planbarkeit}

Menschen in Organisationen oder anderen sozialen Systemen handeln entweder auf der Basis rationaler Analyse und Planung, auf Grundlage ihrer Erfahrung oder Intuition, oder sie improvisieren und finden so neue Lösungen für bislang noch nicht gekannte Problemstellungen und Herausforderungen. Dabei basiert der weitaus grösste Anteil realer organisatorischer Veränderungen und Innovationen auf nur einer der drei Möglichkeiten: Innovationen werden allgemein als planbarer, rationaler Prozess angesehen. Innovationsmanagement in westlich orientierten Volkswirtschaften - dies gilt für wirtschaftliche Unternehmungen genauso wie für non-profit-Organisationen - beruht auf rational kognitiven Modellen der Organisationstheorie der Moderne: Die Logik industrieller Produktion und vermeintlich >moderner< Managementmodelle hat dazu geführt, dass alle Handlungen dem Primat der Zahlen, der Messbarkeit, der Effektivierung und dem quantitativen Wachstum untergeordnet werden. Diese eher einseitige Denkweise ist in den letzten 20-30 Jahren in viele Lebensbereiche übernommen worden und wird manchmal - in einer erstaunlich ahistorischen Weise - als >alternativlos< bezeichnet.

Diese Praxis funktioniert bis zu einem gewissen Grad in traditionell und hierarchisch strukturierten Organisationen und Gemeinschaften, die auf rationaler Planung und top-down-Entscheidungsprozessen aufbauen können. In einer immer komplexer werdenden und sich schnell verändernden Wissensgesellschaft lassen sich industriell geprägte Logiken jedoch immer weniger anwenden. Sozialwissenschaften, Psychologie, Philosophie und Kunst, mehr aber noch viele Praktiker in Unternehmen, non-profit-Organisationen und gesellschaftlichen Institutionen, wissen, dass mit dieser Denkweise nur ein kleiner Teil der Möglichkeiten und und Prozesse abgebildet werden kann, die die Dynamik von Unternehmen, Organisationen und sozialen Gemeinschaften ausmachen. Heute benötigen wir agile technische und soziale Systeme und Organisationsformen, die auf dem Netzwerkprinzip basieren und >weiche< Faktoren und Werte wie Gemeinschaftsbildung und Unternehmenskultur betonen, um in einer unsicheren und sich ständig und schnell verändernden Umwelt bestehen zu können. Unternehmen, Kommunen, non-profit-Einrichtungen und auch politische Strukturen können sich heute und in Zukunft nicht mehr ausschliesslich auf klar definierte Ziele und zentral vorgegebene Startegien verlassen. Selbst Unternehmen, die sich in einem System befinden, in dem quantitativ messbare >key performance indica- 
tors (KPI) die vermeintliche Wirklichkeit bestimmen, müssen mit unerwarteten Dynamiken des Marktes und gesellschaftlicher Entwicklungen umgehen und entdecken mehr und mehr den Wert >weicher Faktoren der Organisationskultur, die eine Kultur des Vertrauens und der Kreativität erzeugen können. Die Fähigkeit, die innovativen Potentiale in den Unwägbarkeiten sich schnell verändernder Welten zu erkennnen und kreativ zu nutzen, gehört wahrscheinlich zu den zentralen Überlebensfaktoren moderner Organisationen, die zunehmend mit hochkomplexen und unplanbaren Situationen und Umeltfaktoren konfrontiert sind.

In dieser Situation ist weniger die Reduzierung von Komplexität durch die Eliminierung oder Externalisierung von Störfaktoren gefordert, sondern - im Gegenteil - die systemische Fähigkeit, Potentiale der Komplexität zu erkennen und Emergenzen zu nutzen (vgl. Looss 2002). PraktikerInnen in Organisation und Gesellschaft ist dies meist >gefühlt< klar; dennoch verdeckt nach wie vor das Diktat der Zahlen und Rationalität die komplexe Dynamik und das Beziehungsmanagement, das zu nachhaltig funktionierenden Organisationen und sozialen Netzwerken nötig wäre (Weick 1989).

Die tatsächlich relevanten (und nicht nur die jeweilige Gewinnmarge erhöhenden) gesellschaftlichen Innovationen der letzten Jahrzehnte haben wir kaum den rational-geplanten Modellen eines tradionellen Verständnisses von Innovationsmanangement zu verdanken, eher kreativen transdisziplinären Grenzüberschreitungen, dem (oft zufälligen) Erkennen neuer Möglichkeiten (>serendipity<) oder dem Brechen alter Muster. Wir entdecken immer mehr, dass die wahren organisatorischen und gesellschaftlichen Herausforderungen der heutigen Welt von Unsicherheiten, Ambiguitäten und unerwarteten Situationen geprägt sind. Die Fähigkeit, darauf nicht nur schnell und angemessen zu reagieren, sondern Ambiguität als kreatives Gestaltungselement und Möglichkeitsraum unserer modernen Welt zu begreifen, ist die Kunst der Improvisation, die sich als Schlüsselfaktor für den Erfolg von Unternehmen, Organisationen und soziale Gemeinschaften, aber auch für die nachhaltige Gestaltung unseres Gemeinwesens und unserer Gesellschaft erweist. Das Problem: In einer vermeintlich rationalen und nur auf Effizienz ausgerichteten Welt wird die Kunst der Improvisation als Schlüssel-Kompetenz weder erkannt noch wertgeschätzt; die Fähigkeit und das zugehörige Wissen ist oft versteckt und informell (>tacit knowingく).

\section{IMPLIZITES WisSEN UND IMPROVISATIONALE FELDER IN ORganisationen}

Komplexe Zusammenhänge in sich schnell ändernden Umgebungen lassen sich mit hierarchischen oder rationalen Begrifflichkeiten oder Strukturen weder vollständig beschreiben noch beherrschen; daher ist eine Orientierung an den klassischen Managementinstrumenten der Zielvereinbarungen, des Controlling und der mittel- und langfristigen Strategien in dieser Situation nur noch teilwei- 
se nutzbringend. Erfahrungswissen und Intuition ist in fast allen Branchen und gesellschaftlichen Bereichen verstärkt gefragt. Da aber industriell-betriebswirtschaftliche Modelle und die dazugehörigen Bildungsstränge genau dieses individuelle simplizite Wissen > oder das kollektive >tacit knowing (Polanyi 1966) über Jahre hinweg eher negiert oder manchmal sogar desavouiert haben, fehlt nicht nur ein anerkanntes und erprobtes Instrumentarium zum Umgang mit Unsicherheit und Komplexität, sondern sogar die entsprechende Sprache und Begrifflichkeit.

Vor diesem Hintergrund sind die sozialen Systeme, aus denen unsere - speziell die ökonomische - Welt besteht, erstaunlich widersprüchlich aufgebaut: Organisationen wie Firmen, öffentliche oder soziale und kulturelle Einrichtungen sind - oberflächlich gesehen - weitgehend bestimmt durch rationale, geplante und meist hierarchisch aufgebaute Strukturen. Hier läuft alles wie >am Schnürchen oder im Räderwerk des Charlie Chaplin. Betrachtet man jedoch die innere Dynamik dieser Systeme, so funktionieren sie durch ein kompliziertes Zusammenspiel von Beziehungen und Partnerschaften auf unterschiedlichen Ebenen: (a) Kooperationen in Teams oder in Arbeitsgruppen, (b) das Organisationsdesign von Firmen oder Institutionen mit den Beziehungen zwischen Abteilungen und unterschiedlichen Funktionsträgern, oder (c) temporäre oder dauerhafte strategische Allianzen zwischen Organisationen und (mittlerweile immer häufiger) zwischen Organisationen und ihren Stakeholder-Gruppierungen.

$\mathrm{Ob}$ diese Kooperationen erfolgreich sind, hängt dabei weit weniger von rationalen Planungen und Strukturen ab, sondern eher von Vertrauen (Sprenger 2002; Möller 2012) und Erfahrungen erfolgreicher Zusammenarbeit (Leonard \& Swap 2005) und dem impliziten, nur selten dokumentierten Wissen, wie die Dinge laufen müssen (Neuweg 2015), sollen sie den gewünschten Erfolg bringen. Entscheidungen werden nur selten aussschliesslich auf der Basis rationaler Eckdaten und Kennzahlen getroffen, sondern mindestens auch (wenn nicht oft vornehmlich) unter der Prämisse, ob sich das Ganze richtig und gut anfühlt. Dies haben auch Gigerenzer und Selten (2002) mit dem Konzept der Bounded Rationality auch auf der Basis experimenteller Forschung nachgewiesen. Die emotionale Basis von Abläufen und Entscheidungen gewinnt umso mehr Bedeutung, je komplexer die Situationen und Abläufe sind (Weick \& Westley 1996).

Intuition und implizites Wissen basierend auf Erfahrung gehört daher nicht nur für erfolgreiche Praktiker in Organisationen und sozialen Systemen zum Standardrepertoire. Die systematische Verwendung und Dokumentation von (oft verdecktem) Erfahrungswissen spielt eine immer bedeutendere Rolle in komplexen Systemen, die organisatorisch und technisch rational nicht vollständig beherrschbar sind. Vielleicht am bedeutsamsten ist (war traditionell schon immer) die Rolle impliziten Wissens bei der Frage, wie das Neue in die Welt kommt. Erfolgreiches Innovationsmanagement nutzt >improvisationale Felder (Stark \& Dell 2014) in Organisationen und sozialen Systemen, in denen Intuition und implizites Wissen eine zentrale Rolle spielen. Improvisationale Felder sind die 
Ebene unterhalb von Planung und Handeln, sie steuern die Bedeutung einzelner Elemente in Planung und Handeln auf der Basis impliziten Wissens. Bei der Umsetzung einer Planung kommt das implizite Erfahrungswissen und die Fähigkeit, Intuition richtig einzusetzen, zum Tragen. Da unvorhersehbare Prozesse unseren Alltag bestimmen und Planbarkeit - quasi kontraintuitiv - eher eine Ausnahme darstellt, gibt es auch in Organisationen und sozialen Systemen neben kodifiizierten Ablaufplänen vielfältige implizite Verfahren, die sich sich reingespielt< haben. Sie haben sich im Sinne der Systemtheorie also als gangbar (viabel) erwiesen (Glasersfeld 1992). Ähnlich wie in der Jazz-Improvisation (oder Modern Dance oder anderen performativen Künsten) werden (meist implizite) Handlungsmuster in unterschiedlicher Form genutzt, arrangiert und re-arrangiert: Aufbauend auf bisherigen Erfahrungen werden bisher erfolgreiche Muster in neuen Situationen eingesetzt, andere verändert oder neu kombiniert. Hier kann man von Musikern und Künstlern lernen: Auch dort werden bekannte Muster verwendet, zitiert, neue zusammengestellt und ergeben so Sinn.

Dorothy Leonard hat diese Bereiche unter dem Begriff >deep smarts< untersucht (Leonard \& Swap 2005). Ihre Ergebnisse zeigen, dass implizites Wissen, Intuition und der rationale Bereich der Strukturen und Kennzahlen in sozialen Systemen (wie Firmen oder Organisationen, Kommunen, Gemeinschaften) nicht getrennt betrachtet werden können; dass sie sich gegenseitig bedingen und unterstützen.

\section{EINE MUSTERSPRACHE FÜR IMPLIZITES WISSEN IN ORGANISATIONEN: IMPROVISATIONSMUSTER IN SOZIALEN SYSTEMEN ERKENNEN}

Der Ansatz der Handlungsmuster (Patterns) ist ein Verfahren, das ursprünglich von dem Architekten und Mathematiker Christopher Alexander (Alexander et al. 1977) entwickelt wurde. Es ist verankert im philosophisch-soziologischen Konzept des Erfahrungswissens: Der amerikanische Philosoph und Pädagoge John Dewey (Dewey 1938; Joas 2000) und ungarische Chemiker und Philosoph Michael Polanyi (der Bruder des Wirtschaftswissenschaftlers Karl Polanyi - siehe Polanyi 1985; Neuweg 2006) sind hier die bekanntesten Vertreter. Der Ansatz des impliziten Erfahrungswissens und die darauf begründete Mustertheorie (Leitner 2007) wird mittlerweile in so unterschiedlichen Disziplinen und Bereichen wie Architektur und Stadtplanung, Softwareentwicklung, Pädagogik oder Organisationsentwicklung benutzt. ${ }^{1}$ Um mit wiederkehrenden Herausforderungen kreativ umzugehen und Lösungen bzw. Antworten zu entwickeln, werden dabei erfolg-

1 | In der Architektur und Software-Entwicklung ist häufig auch von 'Design Patterns im Sinne des gestaltenden Handelns die Rede, in der Pädagogik und Organisationsentwicklung eher von Erfolgs- oder Handlungsmustern (vgl. Stark, Stieger und Tewes 2016). 
reiche, oft nicht explizite Lösungs- oder Handlungsmuster herausgearbeitet und beschrieben. Anders als eine Betriebsanleitung beschreiben Patterns das Prinzip einer Lösung, an der sich die Anwendung in einer konkreten Situation orientieren kann. Auf diese Weise entstehen vielfältige Variationsmöglichkeiten, die sich - durch die systematische Verbindung unterschiedlicher Handlungsmuster - zu einer jeweils situativ spezifischen Mustersprache formen.

Handlungsmuster guter Praxis sind ein in vielen Praxisdisziplinen bewährter Ansatz, um Erfahrungswissen zu dokumentieren und mit anderen zu teilen. Sie entstehen vor dem Hintergrund einer erfolgreichen und funktionierenden Praxis: Das damit verbundene implizite (verdeckte oder nicht-bewusste) Erfahrungswissen wird systematisiert und zu erprobten Handlungsmustern (Patterns) verdichtet.

Muster bauen auf Erfahrungswissen auf - auf Strategien, die sich über einen längeren Zeitraum bewährt haben. Die wichtigsten und interessantesten Erfahrungen aber sind oft nicht dokumentiert und werden von erfahrenen PraktikerInnen für selbstverständlich gehalten. Dieses Erfahrungswissen kann erst in intensiven Gesprächen und Reflexionen mit PraktikerInnen identifiziert werden. Das oft implizite Wissen und das >bewusst werden< darüber sind für den Prozess des Musterschreibens besonders wertvoll. Organisationale Abläufe werden nicht konzeptionell oder theoretisch als Ganzes beschrieben, sondern erfolgreiche Faktoren und Strategien in einzelne Handlungsmuster zerlegt. Im Gegensatz zu einem linearen und relativ starren Leitfaden können diese >Erfolgsmuster nach Perspektive und Situation ausgewählt, kombiniert und angewendet werden.

Muster werden oft nach Kategorien geordnet, um die Struktur verschiedener Tätigkeitsbereiche mit erfolgreichen Handlungsmustern lebendig werden zu lassen. Durch die Kombination verschiedener Muster und Kategorien entsteht eine Mustersprache, in der das Potential der vorhandenen Lösungsmöglichkeiten verdichtet ist. Eine Mustersprache durchläuft ständige Ergänzung, Weiterentwicklung und Verbesserung (Leitner 2007; Schuler 2008), wird also weitgehend kommunikativ validiert und verdichtet und systematisiert so >gefühltes<, intuitives und implizites Erfahrungswissen.

\section{Wie sind die Muster aufgebaut? Wie kommen sie zustande?}

Die Beschreibung des Problems (oder der Herausforderung) und der Lösung sind die Hauptbestandteile eines Musters. Die Geschichte der Herausforderung beschreibt den Kontext, in dem das Problem für gewöhnlich entsteht, während die Kräfte die Einflussfaktoren auf das Problem und die Lösung aufzeigen. In der Diskussion der Lösung können Vor- und Nachteile des Musters abgewogen, die Machbarkeit diskutiert und angrenzende Herausforderungen genannt werden. Anschließend wird die neue Situation, die aus der Anwendung des Musters entsteht, beschrieben. Verwandte Muster zu benennen ist besonders wichtig, um dem Leser zu ermöglichen, zu angrenzenden Themen und sich neu ergebenden Herausforderungen überzuspringen. 
Erfolgreiche Handlungsmuster werden durch mustergenerierende Interviews und speziell dafür entwickelte Workshopformate ${ }^{2}$ erarbeitet. Dabei werden erfolgreiche Handlungsmuster in einem iterativen Prozess von reflektierten PraktikerInnen mit unterschiedlichen Hintergründen auf Grundlage kommunikativ validierter Erfahrungen geschrieben, benannt und illustriert.

Erfolgreiche und validierte Handlungsmuster repräsentieren die Quintessenz der Erfahrung in verschiedenen Handlungsbereichen. Eine >lange Form Muster, die ursprünglich von Alexander $(1977,1979)$ entwickelt und in der Software-Community in verschiedender Form aufgegriffen, ermöglicht einen intensiveren Diskurs der erfahrungsbasierten Handlungsprinzipien (Schuler 2007). Die >kurze Musterform< der Karten (Group Pattern Language Project 2008; Iba 2014 a,b; Stark et al. 2016) verdichtet den jeweiligen Kern eines Musters auf ca. 500 Zeichen und kombiniert die verdichtete Aussage mit einem entsprechenden Bild/ einer Grafik. Damit wird es möglich, die Muster als praxisorientiertes Tool im Sinne eines Reflektionsinstruments zur Selbstevaluation oder für Innovationsprozesse in Seminaren oder Workshops einzusetzen.

Ähnlich wie in der Musik oder anderen performativen Künsten ist die Identifikation der Muster des Erfahrungswissens bedeutsam, um zu verstehen, wie explizites Wissen (Handlungsanweisungen, Vorschriften, Partituren, Pläne) gedeutet und interpretiert, und auf welche Weise explizites, kodiertes Wissen umgesetzt wird. Das im Alltag gewissermaßen >eingebaute< Erfahrungswissen konstituiert gewissermaßen die Praxis von Organisationen und Gemeinschaften: Erfolgreiche Muster impliziten Wissen werden intuitiv immer wieder wiederholt und variiert. Gleichzeitig sind diese Muster die Grundbausteine für kreative und innovative Lösungen und Konzepte, mit denen Regeln und Routinen hinterfragt und neu gestaltet werden können.

\section{Die Kunst der Improvisation: Das Unerwartete nUtzen}

Um eine Sprache für das implizite Wissen in Organisationen und sozialen Systemen zu entwickeln, hilft es, neue sensorische Kanäle in Ergänzung zu den rein kognitiv-rationalen Ansätze zu entdecken: Wenn wir die dynamischen Prozesse in Organisationen zB >hören<, also akustisch wahrnehmen können, ist es möglich, unser kommunikatives Sensorium zu erweitern und zu vertiefen und damit auch emotionale und ästhetische Elemente der Organisationskultur wahrzunehmen und zu analysieren. Musik als dynamische und performative Kunst kann daher einen Schlüssel zum Verständnis organisatorischer und innovativer Prozesse bieten und bei Managern und Mitarbeitern jenseits von Plänen und Rationalität gleichzeitig vorhandenes und noch nicht gekanntes kreatives Potential freisetzen.

2 | Ein Beispiel für mustergenerierende Workshops ist der sog. ,Patongo-Storm، ('Patongor steht für Patterns of Non-Governmental-Organisations - siehe www.patongo.de). 
Stellt man sich die Organisation (die Abteilung, ein soziales System) als Musik vor, befreit es die Wahrnehmung, die oft in Strategieplänen, Arbeitsabläufen und Kennzahlen gefangen ist und hilft, das soziale System auf kreative Weise neu zu designen (vgl. Dell 2014 und 2016 a,b in diesem Band).

Eine besondere Form der musikalischer Performance, die den spielerischen und kreativen Umgang mit Tönen, Rhythmen und Harmonien zum Programm erhebt, ist für die Herausforderung innovativer Prozesse in komplexen Systemen besonders lehrreich: Improvisation (im Jazz, aber auch bei Tanz und Theater) ist das Abbild kreativen Lernens in komplexen und ständig sich verändernden settings und ermöglicht und fordert die Fähigkeit des (oft zufälligen) Entdeckens (>serendipity<) von situativen Potentialen (Weick \& Westley 1996). Improvisation hat als Metapher seit den 9oer Jahren des vergangenen Jahrhunderts die Organisationstheorie inspiriert - ua bei Weick (1995), Hatch (1999) und Barrett (2012). Eine Technologie der Improvisation (Dell 2002, 2012) ist für innovative Prozesse umso mehr bedeutsam, weil sie musikalische Performance nicht ausschliesslich als Rezeption und Interpretation begreift (wie in der klassischen Musik), sondern als permanent schöpferischen Akt. Dies ist gleichzeitig eine der zentralen Anforderungen an erfolgreiches Innovationsmanagement: Innovation als integraler Bestandteil lernender Organisationen (Scharmer 2009). Die Kunst der Improvisation in diesem Sinne ist dann nicht nur die Fähigkeit, mit Ungewissheit und Unsicherheit schöpferisch umzugehen, sondern auch vorhandene Elemente von Organisationen und sozialen Systemen kreativ neu zu verschalten.

Immer mehr Firmen und Organisationen sind bereits heute so gestaltet, dass sie sich und ihre Produkte/Dienstleistungen beständig neu erfinden: Das Vorläufige und Ungewisse, das Ausprobieren ist in vielen Firmen des kreativen und digitalen Sektors der staus quo. Aber auch auf gesellschaftlicher und globaler Ebene lösen sich fest geglaubte Strukturen immer mehr auf; sie werden fluide und für die traditionelle Welt des Planbaren und Rationalen nicht mehr vollständig greifbar. Beispiele dafür sind auf verschiedenen Ebenen zu finden: Technologische und umweltbezogene Katastrophen (Fukushima, Deep Sea Horizon), gesellschaftliche Krisen (Hunger, Krieg und daraus folgende weltweite Flüchtlingsbewegungen) oder der Crash der Finanzsysteme benötigen die Wieder-Entdeckung von Erfolgsmustern jenseits des Planungswahns. Improvisation entwickelt sich von der Ausnahme zur Norm - als Herausforderung und Möglichkeitsraum.

Improvisation (lat. »improvisus« - unerwartet, unvorhergesehen) benennt immer etwas noch nicht Vorhandenes oder Vorstellbares. Improvisation ist daher keine Aktion oder Handlung an sich, sondern beschreibt eine kontinuierliche Wachheit und Aufmerksamkeit. In der fluiden Situation des Unerwarteten und der Ambiguität ist Wachheit und Präsenz, die Fähigkeit, alle Möglichkeiten und Potentiale wahrzunehmen und zu nutzen, eine der zentralen Schlüsselkompetenzen. Das entsprechende Führungsmodell ist das der Moderation und Ermöglichung (Empowerment); der Erweiterung der Handlungsmöglichkeiten. 
Schön nutzt bereits 1983 in seiner Beschreibung des >reflektiven Praktikers das Bild des Jazz-Musikers als Improvisationskünstler, der kontinuierlich in der Lage ist, Zusammenhalt und Sinn aus unvorhersehbaren Situationen aus unvorhersehbaren und nicht-planbaren settings zu entwickeln. Jazz-Musiker sind (meist gemeinsam) auf der Suche nach der kreativen und inspirierenden Dynamik des Klangs, und nutzen und verändern dabei konstant die rhythmischen, melodischen und harmonischen Muster, die ihnen allen geläufig sind und die den besonderen Klang prägen. Wenn Jazz-Musiker improvisieren, so nutzen sie meist intuitiv die Idee und die Möglichkeiten, die eine Melodie oder eine Harmonie ihnen eröffnet; daraus entwickelt sich ihr Spiel (vgl. Monson 1996). Erfolgreiche Improvisationensequenzen sind inspirierende Beispiele für Donald Schön's >reflexive Praxis<; organisationale Improvisation ist in dieser Hinsicht eine Form reflexiver Praxis in komplexen Systemen, die die Innovation in sich trägt. Ähnliche Prinzipien lassen sich im modernen Tanz (Forsythe 2003) und im Improvisationstheater (Johnstone 2011) beobachten.

Insofern unterscheidet Improvisation nicht zwischen Denken (Planung) und Handeln (Ausführung). Die Kunst der Improvisation wirkt wie ein Steuerungssystem, das zwischen kollektiver und intersubjektiver Wachheit und Responsivität und reflexiver Subjektivität wirkt und die Bewegung der unterschiedlichen Systeme des Körpers intensiver erleben lässt. Dann verschmelzen intellektuelle Reflexion, soziale Erfahrung und praktische Intuition - ähnlich wie der Unterschied zwischen dem Ich und den Anderen, zwischen Vergangenheit und Zukunft verebbt.

Improvisation ist ein

"[...] lösungsorientierter Umgang mit vorhandenen Materialien [...], der sich durch die Praktik auszeichnet [...] bestehende Regeln zur Kenntnis zu nehmen, umzudeuten und für eigene Zwecke zu transformieren." (Dell 2002: 157)

\section{IMPROVISATION LERNEN}

Auf den ersten Blick wirkt Improvisation ungeordnet und uneffektiv - mit vielen Schleifen und Suchbewegungen eher wie das Gegenteil von geplantem Vorgehen. Doch genauer betrachtet sind das >Suchen<, >sich verlieren< und >etwas entdecken genau die Aspekte, die Improvisation heute so wichtig machen. Improvisation spielt mit Kontrasten, Unterschieden, Ambiguität, Lücken und hilft, für diese >fuzzy logic s sensibel zu werden. Improvisationsprozesse nutzen die impliziten Erfolgsmuster, interpretieren sie neu, deuten sie um und machen sie in neuer Form nutzbar. »In the improvisational mode, people act in order to learn.« (Cunha 2005: 14) Improvisation ist daher eine Technologie, die das Unbekannte und Überraschende in einen proaktiven Lernprozess integriert. Obwohl Improvisation den Modus des schnellen, spontanen Agierens betont (>act-in-an-instant<), 
sind die analytischen Sinne im performativen Prozess eingebunden: Komplexität wird nicht reduziert, sondern die Handlungsmöglichkeiten erweitert - eine wesentliche Grundvoraussetzung für innovative Prozesse. Mintzberg \& Westley (2001) haben darauf hingewiesen, dass Organisationen und soziale Systeme entweder durch analytische Reflektion, durch Intuition, oder durch Improvisation lernen. Die Analyse ist dabei der langsame und strukturierte Prozess, der davon ausgeht, dass die richtige Lösung (>die Wahrheit<) schon vorhanden ist und nur noch zu finden sei. Sie führt eher zu Komplexitätsreduzierung und entdeckt nur selten neue Möglichkeiten. Intuition lebt davon, (manchmal überraschende) Verbindungen herzustellen, die vorher nicht gesehen wurden oder denkbar waren. Für Improvisation ist lernen nicht ausserhalb des Handelns, sondern im Handeln kontinuierlich eingebaut und im Handeln offen für neue Entdeckungen. Insofern ist Improvisation ein Lernlaboratorium für den reflektiven Praktiker (Schön 1983). Graebner (2008) hat darauf hingewiesen, dass eine der wichtigsten Quellen für Wertschöpfung >das zufällige Entdecken neuer Möglichkeiten< (Serendipity) darstellt. Dies ist der Ansatz für innovatives organisationales Lernen im Sinne von Improvisation.

Innovative, lernfähige Organisationskulturen bilden am ehesten den Prozess des Improvisierens (Cunha \& Cunha 2006) ab, der im Jazz oder auch in Teilen der Neuen Musik identitätsbildend ist (Dell 2002, 2012). Dies gilt insbesondere für Organisationen, die sich aufgrund neuer Anforderungen aus der Organisationsumgebung immer wieder neu erfinden müssen. Komplexe Anforderungen benötigen hoch qualifizierte Mitarbeiter/innen mit hohen Freiheitsgraden, die Innovationspotenziale erkennen und flexibel agieren können; sie benötigen jedoch keine komplexen Strukturen.

Improvisationen als Muster innovativer Organisation(skulturen) sind beabsichtigte, aber ungeplante Abweichungen von den Organisationsroutinen (Cunha, Cunha \& Chia 2007), die eben dadurch unerwartete Problemlösungen und Entwicklungsmöglichkeiten erkennen und nutzen können. Innovative Prozesse erfordern das Brechen vorhandener Regeln, mit dem Möglichkeiten in der aktuellen Entwicklung aufgegriffen werden können, die eine neue Figur ergeben.

Organisationen sind immer öfter damit beschäftigt, sich selbst und ihre Umgebungen in einen Zustand zu versetzen, in dem die Routinen wieder funktionieren. Anders gesagt: Organisationen, die vormals zur Aufrechterhaltung von bestimmten Routinen in der Veränderlichkeit der Umwelt eingerichtet wurden, stehen heute vermehrt selbst unter dem Druck, sich permanent zu wandeln. Oftmals wird dann mit dem Versuch des >mehr an Planung « versucht, der Lage Herr zu werden, was zu einer Konfrontation mit den Dilemmata des Realen führen kann, da sich die Organisation durch jede Planung von den realen Bedingungen entfernt.

Wenn eine Organisation improvisiert, agiert sie genau umgekehrt: Sie scannt die Möglichkeiten, die Potentiale die in einer Situation vorhanden sind, um diese anschlussfähig und nutzbar zu machen. Wenn aber Organisationen keinen Zu- 
gang zu dem Potential der Improvisation haben, wenn Mehrdeutigkeit durch Ordnung und Improvisation durch Routine ersetzt wird, nimmt ihre Befähigung zur differenzierten Wahrnehmung von und aktivem Umgang mit Wandel ab. Man könnte sagen, dass Organisationen, die sich wandeln wollen, gut daran tun, MetaLernen (vgl. Argyris \& Schön 2002) zu fördern und Improvisation zur Routine zu machen, sprich improvisationale Tätigkeiten und Denkweisen in alltägliche Aktivitäten einzuweben. Vermittels Improvisation bringt sich eine Organisation permanent auf den neusten Stand und ermöglicht so eine antizipatorische Haltung zum Wandel ohne ihm ausgeliefert zu sein. Diese Vorstellung von einer Organisation ist eine andere als eine, die Organisationen als Gebilde interpretiert, die auf Veränderungen nur reagieren und Wandel so lange ausblenden wie irgend möglich. Das traditionelle Bild der Organisation und des Organisierens (vgl. Weick 1985) basiert darauf, zu ignorieren, dass Organisationen dauerhaft an der Gestaltung ihrer Umwelten partizipieren, ob sie es wollen oder nicht. Improvisation als Organisationsmodus erkennt diesen Fakt nicht nur an, sondern sucht aktiv mit ihm zu spielen. Das bedeutet, dass Improvisation Akteuren nicht ein Weniger, sondern ein Mehr an Verantwortung zuweist.

\section{LITERATUR}

Alexander, C.; Ishikawa, S. \& Silverstein, M. (1977): A Pattern Language: Towns, Buildings, Construction. New York. Oxford University Press.

Alexander, C. (1979): The Timeless Way of Building. New York, Oxford University Press.

Argyris, C. \& Schön, D. A. (2002): Die lernende Organisation. Stuttgart, KlettCotta.

Borchers, J. (2008): >A pattern approach to interaction design<. In: Satinder P. Gill (Ed), Cognition, Communication and Interaction: Transdisciplinary Perspectives on Interactive Technology, 114-129. Springer-Verlag, London.

Brockman, J. (1995): The Third Culture. Beyond the Scientific Revolution. New York, Simon \& Schuster.

Coker, J., Casale, J. \& Campbell, G. (1990): Patterns for Jazz - A Theory Text for Jazz Composition and Improvisation. Los Angeles, Warner Bros.

Crossan, M.; Cunha e Pina, M.; Cunha J. V. \& Vera, D. (2008): Time and Organizational Improvisation. Unpublished Paper, Nova SBE Papers. Lisboa, Universidade Nova.

Cunha e Pina, M. (2005): Serendipity. Why some organizations are luckier than others. Unpublished Manuscript, Nova SBE Papers. Lisboa, Universidade Nova. Cunha e Pina, M. \& Cunha J.V. (2008): Towards the Improvising Organisation. Business Leadership Review III/IV, 1-6, 2008.

Cunha J.V., Cunha e Pina, M. \& Chia, R. (2007): Routine as Deviation. FEUNL Working Paper 501, Lisboa. 
Deleuze, G. \& Guattari, F. (2009): Anti-Oedipus. Capitalism and Schizophrenia, Penguin. New York.

Dell, C. (2002): Prinzip Improvisation (Principles of Improvisation). Köln, Walter König.

Dell, C. (2012): Die improvisierende Organisation. Management nach dem Ende der Planbarkeit. Bielefeld: transcript.

Dell, C. (2014): Zum Begriff Improvisation. In: Praeview - Zeitschrift für innovative Arbeitsgestaltung und Prävention 2014, 5 (1), 6-8.

Forsythe, W. (2003): Improvisation Technologies. A Tool for the Analytical Dance Eye. Karlsruhe, Zentrum für Kommunikation und Medien.

Gigerenzer, R. \& Selten, R. (2002): Bounded Rationality. The Adaptive Toolbox. Cambridge, MA, MIT Press.

Glasersfeld, E. v. (2002): Radical Constructivism. A Way of Knowing and Learning. Routledge. London.

Graebner, M. (2004): Momentum and serendipity: How acquired leaders create value in the integration of technology firms. Strategic Management Journal 2004 (25), 751-777.

Group Pattern Language Project (2008): Group Works. A Pattern Language for Bringing Life to Meetings and Other Gatherings. Portland.

Iba, T. (2014a): Learning Patterns. A Pattern Language for Creative Learning. Yokohama, CreativeShift Lab.

Iba, T. (2014b): Collaboration Patterns. A Pattern Language for Creative Collaboration. Yokohama, CreativeShift Lab.

Johnson, S. (2011): Where Good Ideas Come From. The Natural History of Innovation. New York, Penguin.

Johnstone, K. (2010): Improvisation. Berlin, Alexander Verlag.

Kant, I. (1987): Critique of Judgement. Hackett Publishing, Indianapolis.

Keidel, R. W. (1995): Seeing Organizational Patterns. San Francisco, Berrett-Koehler Publishers.

Latour, B. (2005): En tapotant légèrement sur l'architecture de Koolhaas avec un bâton d'aveugle(...), in: L'Architecture d'aujourd'hui, 361, Nov-Dec 2005.

Leitner, H. (2007): Mustertheorie. Graz, Nausner \& Nausner.

Looss, W. (2002): >Der blinde Tanz zur lautlosen Musik.<In: Lenz, A. \& Stark, W. (eds): Empowerment: Neue Perspektiven für psychoziale Praxis und Organisation. Tübingen, DGVT-Verlag.

Manns, M. L. \& Rising, L. (2005): Fearless Change. Patterns for Introdusing New Ideas. San Francisco, Addison Wesley.

Mintzberg, M. \& Westley, F. (2001): Decision making: It's not what you think. Sloan Management Review 2001; 42 (3): 89-93.

Monson, I. (1996): Saying Something. Jazz Improvisation and Interaction. Chicago, University of Chicago Press. 
Neuweg, H.-G. (2006): Könnerschaft und implizites Wissen: Zur lehr-lerntheoretischen Bedeutung der Erkenntnis- und Wissenstheorie Michael Polanyis. Münster, Waxmann.

Polanyi, M. (1966): The Tacit Dimension. London, University of Chicago Press.

Polanyi, M. (1985): Implizites Wissen. Frankfurt, Suhrkamp.

Scharmer, O. (2009): Theory U - Learning from the Future as it Emerges. San Francisco, Berett-Koehler.

Schön, D. (1983): The Reflective Practitioner: How Professionals Think in Action. New York, Basic Books.

Schuler, D. (2008): Liberating Voices: A Pattern Language for Communication Revolution. Boston, MIT Press.

Stark, W.; Stieger, A. \& Tewes, S. (2016): Group Works. Erfolgsmuster für die Arbeit mit Gruppen und Teams. Essen/Pähl.

Weick, K. (1987): The Social Psychology of Organizing. San Francisco, Sage.

Weick, K. E. \& Westley, F. (1996): >Organizational Learning: Affirming an Oxymoron. In S. R. Clegg; C. Hardy; W. R. Nord (Eds.), Handbook of Organization Studies (440-458). London, Sage. 



\section{Organisation musikalisch denken}

Christopher Dell

Das Forschungsvorhaben >Music, Innovation and Corporate Culture $<$ (MICC) entwickelte an der Schnittstelle von Musik und Organisation neue Ebenen, Plattformen und Erfahrungen, anhand derer komplexe organisatorische Prozesse sichtbar, erfahrbar und - wenn möglich - gestaltbar werden. Wenn in dem Zusammenhang Gestaltung in den Blick gerät, kommt dem Begriff der Ästhetik eine vorgeordnete Rolle zu. Daraus begründet sich, ästhetische Verfahren als Beispiel, als Metapher und als Referenzquelle für spezifische Organisationsweisen heranzuziehen bzw. mit diesen quer zu schalten.

Die Entscheidung für das ästhetische Verfahren Musik bildet in dem Zusammenhang die Grundlage für das Verständnis des Projekts. Warum Musik? Weil Musik als ästhetisches Verfahren über einen komplexen Organisationsverlauf verfügt und gerade in ihrem Abstraktionsgrad und ihrer Immaterialität das Wie des Organisierens der ihr eigenen Praxis in den Vordergrund stellt. Trotz ihres Abstraktionsgrades ist Musik direkt erfahrbar, wirkt affektiv in unserem Körper. Man wagt in dem Konnex wohl nicht zuviel, wenn man Musik als die verknüpfendste, die relationalste aller Künste erachtet. ${ }^{1}$ Musik existiert in der Zeit, existiert durch Handlung, kommt performativ in die Welt. Sie ist auf Kommunikationsverläufe ebenso angewiesen wie auf strukturell geordnete Codes, die sich in die Ausführung selbst einbetten.

Worin aber bestünde der Mehrwert, den eine Organisation erlangte, setzte sie sich mit Musik auseinander? Musikalisches Denken könnte etwa als Filter und Perspektive in der Analyse komplexer organisatorischer Prozesse zum Einsatz

1 | Der Neurologe Oliver Sacks konstatiert: "Man kann heute buchstäblich sehen, was beim Hören passiert". So ist beispielsweise das dickste Nervenbündel, das die Hirnhälften verbindet, das Corpus Callosum, bei Profimusikern so ausgeprägt, dass ein Neurologe sie allein daran von anderen Menschen unterscheiden könnte. Das Hirn formt sich den Anforderungen entsprechend und entwickelt eine "Plastizität" die sich in den musikalischen Handlungsraum projiziert. Vgl. Hagedorn, Volker, Musik vergisst man nie, DIE ZEIT, 29.05.2008 Nr. 23. 
gebracht werden, um damit, gewissermaßen in einer Meta-Organisations-Weise, nicht nur auf neue Weisen organisationale Strukturen sichtbar zu machen, sondern auch neu zu denken.

\section{Konzeption eines musikalischen Denkens}

Welche Konzeption steht hinter dem musikalischen Denken von Organisation? Welche Form der Sinnproduktion entsteht dadurch, dass auf Musik Bezug genommen wird? Zunächst mutet solches Vorgehen erst einmal fragwürdig an, schon allein deshalb, weil Musik kein Inhalt ist, der sich auch anders zum Ausdruck bringen ließe: Musik ist ja radikal nicht gegenständlich, sie ist, wie Matthias Vogel konstatiert, »nichts Bezeichnetes, auf das man sich auch mit anderen Zeichen - beispielsweise solche der Sprache - beziehen können. Es ist ein ganz und gar unübersetzbarer Sinn, der sich nur im Medium der Musik [...] ausdrücken lässt« (Vogel 2007: 9). Andersherum lässt sich Musik auch nicht in eine eindeutige semantische Beziehung setzen. Man kann nicht sagen, dass Musik $\mathrm{M}$ irgendein X bedeutet. Vogel stellt klar, dass die Relation einer Musik M und einem X niemals eine Repräsentationsbeziehung darstellen kann. »Wir können das >bedeutet in unsere Formel nicht in dem Sinne interpretieren, dass M auf X referiert, dass M X denotiert, dass M X abbildet oder darstellt, und zwar schlicht deshalb nicht, weil Musik keine prädikative Struktur hat, sie also deshalb keine Gegenstände herausgreifen kann, denen sie Eigenschaften zuweist.« (A.a.O.: 17)

Auch weist Musik weder Ähnlichkeitsrelationen noch kausale Relationen auf. Wir können also nicht sagen: >Musik $\mathrm{M}$ ist Organisation $\mathrm{X} \prec$, selbst die Behauptung >klingt wie Organisation $\mathrm{X}<$ ist problematisch, weil die Art und Weise, wie Hörer auf Musikstücke mit bestimmten Assoziationen reagieren, mehr auf ihre eigene ontogenetische Geschichte und ihren kulturellen Kontext aussagt als über die Musik. Aber genau darin liegt der Punkt unseres Vorhabens: Wir wollten eben nicht auf die Semantik der Musik abheben, sondern etwas über die Geschichte und Verfasstheit der Hörer als Organisationsmitglieder erfahren. In diesem Sinne ist es auch nicht schlimm, dass eine Musik M keine Übersetzung der Organisation sein kann, weil sie diese in wichtigen Hinsichten nicht vertreten kann. Es gilt ganz einfach offen und konstruktiv mit der Tatsache umzugehen, dass »Musik anders ist als alles, was wir verstehen können.«(A.a.O.: 19) Das geht nur, wenn wir versuchen, die Erfahrung, die wir mit Musik machen, differenzierter auszuloten und in andere Kontexte zu stellen.

Da die Inhalte der Musik-Ereignisse nicht bestimmbar sind, sprengen sie die tradierten Formen der Darstellung von Organisation und bringen damit auch unsere konstitutiven Rahmensetzungen in Bewegung. Das bedeutet: Unterschiedliche, situationsbezogene Rahmen relativieren sich wechselseitig. Repräsentation und Sinnproduktion werden in der Strategie nicht ausgeschlossen, sondern als Nebeneffekte der Konfrontation mit dem Publikum als Materialität 
beobachtet und genutzt. Im Auslösen von Oszillation und Transformation einer produktiven Unsicherheit erfüllt sich die spezifisch-ästhetisch wie ethische Erfahrung. In den Fokus rückt somit das Diffundieren der Strategien des performativen musikalischen Verlaufs als Sinnproduktion in unserer Deutung von Organisation als Prozess. Das hieße auch, sich von der einfachen semantischen Relation >y gleich $\mathrm{x}$ < zu lösen und die Musik zum Anlass zu nehmen, andere Formen des Sinns in Betracht zu ziehen.

Welcher Sinn aber könnte das sein? Wie oben angemerkt, kann Musik das Kriterium der informativen Angabe nicht erfüllen, eben weil sie unersetzbar ist. Vogel (2007) schlägt deshalb vor, nicht von einer Bedeutung eines Musikstücks, sondern vom Verstehen seines Sinns zu reden. Vogel verweist hier auf Wittgenstein, der zwischen zwei Formen des Sinns unterscheidet: Entweder verstehen wir Sätze, die durch andere Sätze ersetzt werden können, die das Gleiche ausdrücken, oder aber auch Sätze, die nicht durch einen anderen ersetzt werden können. Wittgenstein vergleicht dies mit einem musikalischen Thema, das >verstanden werden kann, aber unersetzbar ist: »[...] in dem einen Fall ist der Gedanke eines Satzes was in verschiedenen Sätzen gemeint ist; im anderen Fall etwas, was nur diese Worte, in dieser Stellung ausdrücken.« (Wittgenstein, zit.n. Vogel, a.a.O.: 317). Der zweite Fall ist dann nur durch einen Nachvollzug der Rede sinnvoll: Wie ein Kunstwerk ist er nur aus seiner immanenten Bewegung heraus verständlich, als eine Form der vermittelnden Praxis. Es sind für Wittgenstein nicht nur spezifische Worte, sondern vor allem auch deren Stellung, die den Sinn eines unersetzbaren Satzes ausdrücken. Der Sinn entsteht hier also aus dem relationalen Zusammenhang, aus einer Topologie der strukturellen Momente eines Satzes. Aber diese Relationalität muss hervorgebracht werden, gesprochen werden. In der Musik können wir von einem ähnlichen Phänomen sprechen: Der Sinn entfaltet sich aus der Relationalität von Rhythmus, melodischer Anteile, harmonischer Verläufe, Klangfarbe etc., die nicht allein als physikalische Vorgänge von akustischen Schwingungen wahrgenommen, sondern als ein >sinnvolles< Konglomerat wahrgenommen werden. Musikalische Logik fügt sich nicht aus wahrheitserhaltendem Schließen zusammen, sondern aus der Relationalität einer spezifischen Nachbarschaftsordnung musikalischer Elemente.

Vogel spricht in diesem Zusammenhang von medialen Praktiken. »Im Mittelpunkt medialer Praktiken stehen tradierte und erlernbare Tätigkeitstypen, die wahrnehmbare Ereignisse hervorbringen, wobei Produzenten und Rezipienten dieser Ereignisse sich nicht an deren physikalischen Eigenschaften, sondern anderen beobachterrelevanten Eigenschaften orientieren.« (A.a.O.: 319) Die Voraussetzung dafür, die tertiären Eigenschaften Rhythmus, Melodie, Harmonie von Musik wahrzunehmen (neben primären Eigenschaften wie Schall und sekundären wie Klangfarbe und Lautstärke), erfordert eine strukturierte Lerngeschichte des Hörers als Teil eines bestimmten Kulturkreises. Vogel zieht daraus den Schluss, dass wir Musik dann verstehen, wenn wir die mediale Ebene der tertiären Eigenschaften erfassen und identifizieren können. Vogels Folgerung jedoch, 
dass dies vor allem in der Wiederholbarkeit gründe, und in der Re-Identifikation von Ebenen, im Erkennen dessen, dass die zweite Aufführung die selben tertiären Eigenschaften aufweise verliert aus dem Blick, dass improvisierte Musik, die fast nie zwei gleiche Aufführungen hervorbringt, nichts desto trotz im Sinne tertiären Eigenschaften verstanden werden kann. Wir gehen davon aus, dass dies in der strukturellen, musterhaften Anordnung und Systematik von Improvisation begründet liegt, in ihrem Verfahren angewandter Relationalität, dem Zusammenfügen unterschiedlichster Muster in unterschiedlichen Ebenen, rhythmischen, harmonischen Matrizes und so eine Durchsicht ermöglichen oder zumindest das Verfolgen des Spiels zu einem >sinnvollen $<$ Ereignis werden lassen.

Im Konnex von Unvertretbarkeit und der Angabe von Bedeutung spricht Vogel von einer >generischen Vertretbarkeit<: Die Befähigung »[...] Typen musikalischer Ereignisse entlang ihrer tertiären Eigenschaften zu identifizieren.« (A.a.O.: 321) Der Schluss jedoch, dass die generische Vertretbarkeit in einem nicht trivialen Sinn ihre Wiederholbarkeit sichert, muss auf unterschiedlichen Maßstabsebenen betrachtet werden. Unserer Ansicht nach kann improvisierte Musik dann nur Sinn machen, wenn nicht die ganze Form des Werks wiederholbar ist, sondern interne musikalische Muster wiedererkannt werden können, die dann ein Ganzes in unterschiedlichen Formen wieder entstehen lassen. Dabei macht dann eben nicht nur die >Vollendete<, abgeschlossene Form Sinn, sondern auch die strukturelle Arbeit an der offenen Form.

Die generische Vertretbarkeit erklärt uns, dass wir bestimmte strukturelle Verläufe verfolgen, in einem gewissen Sinne verstehen können und dieses Verstehen auch durch das wiederholte Hören von Musik schulen können. Gleichzeitig bleibt die Frage nach der Bedeutung von Musik offen. Vogel schlägt deshalb vor, den Sinn in Relationen außermusikalischer Praktiken zu suchen, die Korrelate zur Musik bilden, wie Atmen, Körperbewegung, Tanz, Geste. Die Strukturen dieser Vorgänge bilden für alle Hörer gleichermaßen Grundlagen, jenseits tertiärer Eigenschaften »[...] Anlass für zusammenhängende Erfahrung [...]« (a.a.O.: 327) zu sein. Sie bilden sozusagen wahrnehmungsstrukturierende Modelle, die nicht nur Spezialisten der Musik, sondern auch jedem Laien zugänglich und plausibel sind. Diese Modelle sorgen dafür, dass die Hörer, und das ist für die von MICC entwickelte Methode der Organisationspartituren entscheidend, eine Praxis, ein Tun nachvollziehen und daraus eine Form der Kohärenz ableiten können. Dieser Nachvollzug ist jedoch stark subjektiv gefärbt; zusätzlich verstärkt durch die Tatsache, dass hier organisationale Strukturen auf einen musikalischen Verlauf projiziert werden und umgekehrt. Wichtig bleibt: Die Musik bedeutet nicht die Organisation, sondern das Tun eines Partiturspiels wird nachvollzogen oder im Schreiben der Partitur vorgedacht. Der Erfahrungsraum des Musikmachens oder Musikhörens wird also umgekehrt zum strukturierenden Moment einer Reflexion über Organisation als Partitur. Das ist wichtig, denn wir gehen ja davon aus, dass Musikhören, ebenso wie das daran angeschlossene oder vorgeschaltete Partiturenzeichnen, nicht bloß rezeptiv oder interpretatorisch zu verstehen ist, son- 
dern dass darin Elemente einer Praxis enthalten sind, die sich daran beteiligen, musikalischen Sinn überhaupt erst $\mathrm{zu}>$ produzieren<.

Für ein >Verstehen< von Musik sind, darauf weist Vogel hin, kulturelle Kontexte von hoher Bedeutung. Sie bilden die »[...] transindividuellen Relationen zu Wahrnehmungen und Tätigkeiten [...]« (a.a.O.: 330) aus, bilden »[...] den Hintergrund dafür, dass uns unterschiedliche Nachvollzugsweisen [von Musik] unterschiedlich plausibel erscheinen« (ebda.). In unserem Versuchsaufbau drehen wir das Verhältnis um: Kultureller Kontext ist von der musikalischen Aufführung der Partitur unabhängig (ob sie von einer Pop-, Rock-, Jazzband oder sonst wem aufgeführt wird), sie bleibt abstrakter organisationaler Verlauf, in dem allein dessen minimale Strukturen (Muster) und deren Verknüpfungen wiederum Rückschlüsse auf Elemente der Kultur der Organisation geben sollen. Das ist auch deshalb schlüssig, weil wir ja nicht die Musik, sondern die Organisation über die mediale Praxis von Musik verstehen wollen. Der Ansatz besteht also darin, über die mediale Praxis der Musik in die Situation der Organisation als Erfahrungsraum >hinein< zu kommen. Ganz in dem Sinne der Anekdote vom Fisch X, der Fisch Y fragt, wie er denn das Wasser heute finde, und Fisch Y fragt: >Was ist Wasser?<

\section{ERfahrung als Wissen}

Musik produziert gefühlte Formen des Wissens, die alle Sinne ansprechen. Als Generatoren von Primär-Erfahrung ist es die Strategie von den Partituren, Erfahrung zu ermöglichen und so ein Verstehen für den eigenen Ort in der Welt zu erlangen und den Weg zu den Objekten selbst zu denken. Primäre, körperliche Erfahrung als Kunst zu thematisieren beinhaltet aber auch die Infragestellung des normativen Organisationsbegriffes und seiner Definition von Namen, Zahlen, Bedeutung, Psychologie und Kontext.

Durch den temporären Fokus auf minimale Strukturen (Muster) und die Differenzierung von sekundären Assoziationen, die mit den Mustern verbunden sind, wird eine radikale Multiplikation von Erfahrungen ermöglicht. Bedeutung hat dann eine viszerale, innerkörperliche Basis. Bedeutung ist an die physikalische Aktion geknüpft und eröffnet so einen Einblick in die Logik des organisationalen Handelns selbst. Doch dies ist nur ein Teil der Produktion: Entscheidender Faktor neben der physikalischen Aktion ist die musikalische Zeit selbst. Seit John Cage meint musikalische Zeit: Die Akzeptanz und das Verständnis für all das, was in der Zeit des Ereignisses (Events) geschieht. Die minimalistische Struktur und das reduzierte Format der Events sind geknüpft an die Musikalisierung von Zeit. Musikalität der Zeit ermöglicht Öffnung von Bedeutung durch das Konzept der radikalen Präsenz dessen >was ist<.

Subjekt und Objekt generieren gemeinsam ein wechselndes interreagierendes Feld »[...] for the investigations between actions, language object and sounds« (Sti- 
les 1993: 65). Die Strategie besteht darin, direkte Erfahrung mit Sekundärwissen (das mentale Konzept der Erfahrung) zu verknüpfen und zwar so, dass verkörpertes Wissen abstraktes Wissen produziert und nicht umgekehrt. Die gespielten Partituren stimulieren Erfahrung als aktive Partizipation der individuellen Sinne der Organisationsmitglieder. Bezugnehmend auf John Deweys Definition als »[...] active and alert commerce with the world[...] complete interpretation of self and the world of objects and events« (Dewey 1934: 25) wird Erfahrung zu einem spezifisch transaktionalen, interpretativen Rahmenwerk und zur Kapazität, um einen Sinn für Kontinuität in der Welt zu entwickeln. Erfahrung ist dann immer kontextuell: Eingebettet in menschliches Bewusstsein und in die Situation, die eine spezifische Erfahrung ermöglicht. Erfahrung als Form der Aneignung von Zeit und Raum wird Schnittstelle zum Alltag: Denn Erfahrungen kann jeder Mensch machen. Das Konzept der Verschiebung künstlerischer Strategien kann dann im Bezug auf seine eigenen Grenzen neu hinterfragt werden. Alltag, Prozesse und Handlungen von Organisation stellen so die Bereiche dar, in welche die Kunst der Musik als Verfahren überführt wird.

Dewey erinnert daran, dass Erfahrungen keine unstrukturierten oder unzusammenhängenden Elemente darstellen, sondern vielmehr stets in Situationen eingebettet sind. Das Schärfen der Wahrnehmung für die minimalen Strukturen spielt für diejenigen eine Rolle, die darum bemüht sind, eine Situation zu strukturieren. Die Schulung der Wahrnehmung als Ästhetik oder in ästhetischem Zusammenhang lässt uns die Formwerdung des Organisation im Prozessverlauf und unserer eigenen Bewegung erkennen: Als Voraussetzung für das diagrammatische Vorgehen, das sich im Diagramm (beispielsweise der OrganisationsPartitur $)^{2}$ spiegelt. Denn die ästhetische Erfahrung ist eine übergeordnete Wahrnehmung sozusagen eine Metafunktion: Sie lässt uns gewahr werden, wie wir die von der Erfahrung als dynamischem Prozess gelenkten, gelernten Einflüsse, Elemente integrieren und Foci bilden. Bezogen auf die Musik bedeutet dies, dass Musik eine ästhetische Erfahrung auslöst, die durch unseren Versuch lernend wirkt, dem strukturellen Verlauf, der inhärenten Grammatik, dem relationalen Verschalten innerhalb der Parameter Melodie, Harmonie und Rhythmus sowie zwischen den Parametern des jeweils Gespielten zu folgen und damit zu definieren oder ihr Sinn zuzuordnen,. Vogel sagt deshalb zu Recht: »Wir können die Logik einer Musikdarbietung nur in Begriffen von Relationen erläutern, die deutlich machen, wie Eigenschaften des Werks in die Erfahrung seines Nachvollzugs so eingehen, dass sie zur Einheit des Werks beitragen« (Vogel 2007: 332). Die Einheit entfaltet sich dann aus der gewonnen Form. Der Erkenntnisprozess für die Organisation entspringt aus einem Verfahren, in dem aus einem musikalischrelationalen Denken heraus ein Erfahrungsraum geöffnet wird, der den Nachvollzug organisationaler Prozesse in unterschiedlichen Maßstäben ermöglicht.

2 | Zur Frage von Partitur und Notation vgl auch: Dell, Christopher, Replaycity, Berlin 2011. 


\section{Musikalisches Denken und Organisation}

Musik gilt, wie oben bereits konstatiert, als sowohl abstrakte, wie auch konkrete Form der Steuerung komplexer Prozesse in der Zeit. Organisationsweisen in das Medium Musik zu übersetzen zielt also darauf, organisationale Information irgendwie lesbar, verarbeitbar zu machen.

Phänomene wie Organisationen haben als Prozesse mehr mit unsichtbaren Vorgängen in der Zeit zu tun als mit visuellen Strukturen. Man könnte sogar sagen, sie sind ihrem Wesen nach eher musikalisch. Am Anfang unseres Forschungsvorhabens stand die Idee einer Organisationsmusik: einer möglichen musikalischen Intervention in Organisation. Solches warf Fragen auf: Gibt es Organisationsmusik? Wie muss man sie vertonen? Kann jede Organisation ihre eigene Musik unter anderen wiedererkennen? Woran kann man entscheiden, ob sie stimmig ist oder nicht? Kann man sie gezielt beeinflussen? Wie kann man sie erleben? Indem man selber musiziert? Nichts dergleichen. Vielmehr rücken nicht-akustische musikalische Variablen - wie Notationen und Diagramme - in den Vordergrund der Bemühungen.

Musikalisch Denken heißt dann: Über die Musik einen Transfer zum Organisieren selbst herstellen. Das wäre in drei Ebenen ${ }^{3} \mathrm{zu}$ kategorisieren:

- Der phänomenologischen Ebene: Wie wird Musik bzw. Organisation >als< Musik wahrgenommen? Im Rahmen unserer Überlegungen und im Sinne der Organisationsentwicklung kann somit eine Beschreibung des jeweiligen Zustandes der Organisation gegeben werden (passiv).

- Der konzeptuellen Ebene - wie wird Organisation auf musikalische Art und Weise konzipiert? Daraus ist abzuleiten, wie eine Organisation musikalisch geplant, geordnet, rationalisiert wird.

- Und der gelebten Ebene: Wie wird Organisation musikalisch gelebt, praktiziert? (hier spielen sowohl strukturelle, funktionale und formale Parameter hinein als auch Atmosphäre, Erleben, Dynamik, Körperlichkeit, >grooveく, Stimmigkeit). Auf der gelebten Ebene wird nicht der Zustand als Phänomen, sondern der gelebte musikalische Raum der Organisation zum Gegenstand der Erkenntnis. Der Zustand der Organisation kann von der Erlebnisperspektive der einzelnen Organisationsmitglieder und dem, wie sie etwas tun, abweichen (aktiv).

Mit den Kategorien der Wahrnehmung, Konzeption und Erleben von Organisation >als Musik < wird zu zeigen sein, ob und wie diese Ebenen auch unstimmig, unharmonisch sein können und eine Organisation trotzdem gut funktioniert

3 | Diese Ebenenkategorien sind angelehnt an das Konzept des respace vécu, conçu, perçu von Henri Lefèbvre in: La production de l'espace, Paris 2004 (1974: 48/49). 
oder auch nicht. Das heißt auch: Diese drei Ebenen existieren nicht losgelöst voneinander. Sie können jedoch zur Analyse dessen, was so schwer zugänglich ist, nämlich der Organisation als Prozess (und nicht als Produkt), methodologisch beitragen.

Das zeigt, dass die Analyse komplexer Prozesse nicht mit einer Matrix allein bespielt werden kann und somit nach der Verschaltung unterschiedlicher Matrizes verlangt. Deshalb sei der Trias >Erfahren - Konzipieren - Erleben « eine weitere Trias an die Seite gestellt, die von einer anderen Perspektive aus Zugang zum Prozess bieten soll: Sie besteht aus den Parametern >Rhythmus, Melodie und Harmonie<. Je nach Gewichtung dieser Parameter, bilden sie als musikalische Elemente ein offenes und dynamisches Feld, das aus den unterschiedlichen Wechselwirkungen und Lagebeziehungen besteht, wobei im musikalischen Prozess unter >Feld « nicht nur die aufeinanderfolgenden oder einander überlagernden Schichten aus Fakten und Erscheinungen zu verstehen ist, sondern auch und vor allem Denk-, Handlungs- und Lebensweisen. Genau deshalb ist Organisation als Musik nicht bloß leerer, mit Objekten angefüllter Raum.

\section{Rhythmus}

Rhythmen wirken direkt aufs Nervensystem und direkt auf unseren Körper. Rhythmus ist Paradox oder Tautologie: Rhythmus verbindet die Ebenen des Wahrgenommenen und des Gelebten direkt, ist gelebte Erfahrung, wird erst durch das Gelebte lebendig, plastisch. Wenn wir nicht >im Rhythmus < sind - im >groove <in der Gestimmtheit des Flusses, können wir uns noch so abzappeln: Rhythmus ist dann nicht $>$ da<.

Was könnte aber der Begriff Rhythmus in punkto Organisation bedeuten? Vielleicht ließe sich der Begriff der Veränderung via Rhythmus auf die Musik beziehen und so neu denken: Statt als Wachstum und Fortschritt kann Transformation als rhythmisch-variierende Wiederholung beschrieben werden. So lässt sich zeigen, wie Organisationen durch kontinuierliche Veränderung weiterentwickelt werden. Ein Tatbestand, der nicht gleich sichtbar, jedoch u.U. hörbar ist.

Das allerdings würde Oliver Sacks widerlegen, der Musik selbst keinen transformierenden Effekt zuschreibt, sondern einen konstruktiven. Ihm zufolge liefert Musik eher einen Anker: Sie hält mich zusammen. In der Trias Funktion, Form und Struktur steht Rhythmus für das Strukturelle, für die Art und Weise, wie Muster entstehen. Paul D. Miller aka DJ Spooky sagt in seinem Buch >Rhythm science $<$ : Rhythm science uses an endless recontextualizing as a core compositional strategy.« (Miller 2004: 90) Er fordert eine Wissenschaft des Rhythmus, die es ermöglichen würde, zu erkennen, wie ästhetisches Wissen als Form des Erkennens von Mustern zuallererst entsteht: >Aesthetics begins as pattern recognition<. Das verlangt in unserem Kontext die Kompetenz, Ereignisse, Formen, Funktionen der Organisation in Muster zerlegen zu können, samples in unterschiedlichen Maßstäben anzulegen, zu ordnen und in einer Art diagrammatischer und katalog- 
hafter Weise für neue Situationen zu speichern und anschlussfähig zu machen: >That's what I ask: Break the loops.<

\section{Harmonie}

Oktaven und Quinten werden als wohltuend empfunden, eine kleine Sekunde, die Dissonanz, kann ein Baby zum Weinen bringen, lässt die Neurobiologie verlauten. Jedoch kann hier ebenso Ideologie - das heißt hier: Naturalisierung von Geschmack - unterstellt werden, wie bei der traditionellen Zuordnung von Moll zu Trauer sowie Dur zu Frohsinn. Das ist weder in der Musik des Mittelalters noch bei Mendelssohn sinnvoll.

Wir dürfen in Rechnung stellen, dass der konservative Geschmack der Neurobiologen auch ihre Experimente beeinflusst. Sacks selbst wundert sich, dass ihn jüngst etwas ganz ohne Melodie und Metrum >ins Herz getroffen $<$ habe: der Gesang der Wale nämlich. Walgesang aber ist, nach traditionellem (>konservativem $<$ ) Hörverständnis sehr dissonant und abstrakt. Vielleicht hat sich ja durch die experimentierende Handlung an der Musik Sacks ästhetische Urteilskraft >gebildet<, sein Geschmack sich erweitert. Das spräche einmal mehr dafür, dass Musik als kulturelles Konstrukt zu verstehen ist. Derlei Tatbestand wirft uns wiederum auf die Urteilskraft als Transmissionsriemen von Geschmack zurück. Sicherlich müssen wir, um Musik angenehm zu empfinden zunächst empfinden: Ergo die Affekte in Rechnung stellen. Gleichwohl lassen sich, darauf hebt Kant ja in seiner dritten Kritik ab, die Affekte sehr wohl trainieren und darin besteht letzten Endes die Fakultät der Urteilskraft, von der Kant sagt, sie sei nicht lehrbar sondern nur durch Übung zu erwerben. Urteilskraft, darin sind sich alle einig, ist nicht nur verhandel- sondern auch veränderbar in der Zeit. Daher können und müssen alle heutigen Versuche von Hirnforschern, musikalischen Geschmack zu naturalisieren, als obsolet bezeichnet werden. Sie sind in der Organisationsentwicklung nicht hilfreich, mehr noch: hinderlich. ${ }^{4}$ Umgekehrt besteht hier womöglich gerade die Öffnung zum Möglichen; und zwar dann, wenn die Bildung musikalischer Urteilskraft an der Musik Folgen auf die Organisationsbefähigung der Organisationsmitglieder erkennen lässt.

\section{Melodie}

Die Musik bringt gleichsam ihr eigenes Gedächtnis als Struktur mit. >Eine Melodie zu hören heißt, mit der Melodie zu hören<, weiß Victor Zuckerkandl (1964). Die Komposition avanciert zum Faden an dem ein Subjekt aus dem Abgrund des

4 | So z.B. in einem Experiment von Stefan Koelsch und Tom Fritz, indem die Probanden eine, so Koelsch wörtlich: eine für uns eher schauerliche Endung, nämlich in C-Dur auf einem Dis Akkord, erkennen sollen. Eine solche Endung ist im Jazz nicht unüblich und kann sogar ,toll klingen, es kommt halt darauf an, 'wier man das 'machtı. (Koelsch 2007: 242) 
Vergessens zum Leben hochklettern kann. Wenn man das Gedächtnis verliert, ist man immer noch im Stande zu spielen.

Musikalische Verläufe selbst bestehen aus permanenten Rückkoppelungen der Musizierenden. Würde man musikalische Parameter auf organisatorische Parameter übertragen können, ließe sich zeigen, wie nicht allein repetetive oder reproduzierende, sondern auch kreative Muster bzw. Handlungsweisen entstehen und wo sie im Prozess des Organisierens zu verorten sind.

\section{Adapter 1}

Um die Parameter Rhythmus, Melodie und Harmonie Organisationen zuordnen zu können, haben wir uns auf die Suche nach geeigneten Adaptern umgesehen. Nach eingehender Diskussion erschien uns Ed Scheins ${ }^{5}$ Modell zur strukturierten Darstellung von Organisationskulturen als geeigneter Adapter OrganisationMusik. Scheins Modell als tiefer gehende Differenzierung von Organisationskultur, bietet sich sowohl inhaltlich als auch strukturell an: Auch sie ist triadisch gegliedert. Schein zeigt anhand der Parameter der Artefakte, der bekundeten Werte und der Grundprämissen auf, wie die unterschiedlichen Verbindungen dieser Parameter die Kultur einer Organisation ausmachen und mit regulieren. Dies ließe sich parallel in der Musik von Rhythmus, Melodie und Harmonie sagen.

Schein gliedert Organisationskultur modellhaft in drei Pfeiler (Schein 1995: 30):

a) Artefakte (sichtbare Strukturen und Prozesse im Unternehmen - leicht zu beobachten, aber schwer zu entschlüsseln)

b) Bekundete Werte (Strategien, Ziele, Philosophie - bekundete Rechtfertigungen)

c) Grundprämissen (unbewusste, selbstverständliche Anschauungen, Wahrnehmungen, Gedanken und Gefühle - Ausgangspunkt für Werte und Handlungen)

In der nachfolgenden stechnischen Umsetzung < geht es nun darum, auf Basis der Überlegungen von Schein:

1. eine Analyse der verschiedenen Ebenen der Organisationskultur vorzunehmen,

2. parallel ein geeignetes Übersetzungstool zu entwickeln

3. sowie die Ergebnisse der Analyse in ein musikalisches Ergebnis zu übersetzen (Translation) und hörbar zu machen.

5 | Edgar H. Schein gilt als Mitbegründer der modernen Organisationspsychologie. Seine Hauptwerke sind "Career Dynamics" (1978), "Organizational Psychology" (1980), "Organizational Culture and Leadership" (1985) und "The Corporate Culture Survival Guide" (1999). 
Innerhalb dieser zunächst einfach erscheinenden Arbeitsschritte gilt es, folgende Herausforderungen zu bearbeiten:

- Aufbereitung der Daten aus der Kulturanalyse, so dass sie für eine Übersetzung geeignet sind

- Identifizierung von organisationalen Mustern bzw. Zustandsparametern

- Identifizierung von musikalischen Mustern

- Zuordnung der Muster zueinander durch einen Feedback-Prozess

- Entwicklung einer geeigneten Schnittstelle für die Übersetzung (Software)

- Entwicklung von Möglichkeiten zur Klang- und Tonerzeugung

- Berücksichtigung der zeitlichen Ausdehnung der Kulturanalyse im musikalischen Ergebnis

- Erarbeitung geeigneter Feedbackszenarien, um das musikalische Produkt wieder an die Organisation zurück zu spiegeln

Die drei Ebenen der Organisationskultur nach Schein können, so zeigte sich anhand des Experimentes, als Ausgangsmaterial für die Erzeugung eines musikalischen Ergebnisses dienen. Dieses musikalische Ergebnis stellt eine Art auditives Diagramm der Organisation dar. In einem Gesamtergebnis liefern die Ebenen die >Regler $<$ oder >Filter $<1$ bis 3. Die Messergebnisse müssen über einen >Signalbzw. Messumformer<, über eine zu entwickelnde Software realisierbar, die musikalische Ebene ansprechen. Das Interessante ist nun: Da sich Musik, wie Organisation in der Zeit abspielt, haben die Untersuchungen in unterschiedlichen Zeitmaßstäben zu erfolgen. D.h. um die zeitliche Dimension von Organisationskultur abzubilden und z.B. immer wiederkehrende Muster entdecken zu können, müssen sowohl kurze als auch längerfristige Zeitverläufe beobachtet werden.

\section{Adapter 2}

Nun verfügen wir über zwei Parallelstrukturen, die sich miteinander verschalten lassen und sozusagen eine Brücke zwischen Organisation und Musik bauen sollen. Um hier strukturell tiefer einsteigen zu können, bedarf es noch eines Metaadapters, also einer Trias, die sich sowohl auf die Musik als auch die Organisation anwenden lässt. Wir schlagen hier vor: Form, Funktion und Struktur. So könnten Querbeobachtungen entstehen, wie z.B. die Beobachtung, dass eine bestimmte Form der Organisation bestimmte musikalische Strukturen besser verarbeitet als andere Formen.

\section{Struktur, Muster und Affekt}

Musikalische Strukturen halten Prozesse zusammen und können in ihrem Verbindungsgrad in die Zeit hinaus greifen. Sacks (2007) zieht hier das Beispiel des Patienten Clive Wearing heran. Wearing, Musiker und Musikwissenschaftler, erkrankte an einer Hirninfektion, die von seinem Gedächtnis kaum etwas übrig 
ließ. Dann geschah etwas Merkwürdiges: Jedes Mal, wenn er seine Frau wieder sah, verliebte er sich aufs Neue in sie. Und als sie zu einem Treffen Noten mitbrachte, erwies sich, dass ihr Mann nichts von seinen musikalischen Fähigkeiten verloren hatte. Ganze Stücke konnte er ablesen, erinnern, singen, am Klavier spielen, ohne Fehler und mit ganzer Seele, sogar einen Chor dirigieren - »auch wenn er sofort vergaß, dass das Stück beispielsweise eines von Bach oder Beethoven war« (Sacks 2007: 34). Daraus geht hervor, dass musikalische Strukturen jenseits des >episodischen< Gedächtnisses verarbeitet werden und zwar auf der Ebene der Affektstruktur, in diesem Fall der Gefühle, die Wearing für seine Frau bis heute empfindet. Wenn sie bei ihm ist und er spielt, wird er als Person wach. »Was da herauskommt«, schreibt Sacks, »ist alles andere als automatisch« (a.a.O.: 36 ). Das kann daran liegen, dass in der Musik ein Ton das ganze Stück wachruft, zu dem er gehört.

Musik entsteht aus Handlung in der Zeit. Wenn wir nach dem Organisieren fragen, wird es interessant zu prüfen, welche Strukturen, Muster in der Musik wirken, um eine fortlaufende >Existenz < der Musik zu sichern. So entsteht die Frage: Wie lassen sich Muster in der Musik orten und definieren und wie können diese Muster in Analogie zum Organisieren selbst gedacht werden? Das gilt ebenso für Verhaltens- wie für Handlungs- oder Kommunikationsmuster. Wenn wir Organisation musikalisch denken, gibt es dann überhaupt pathogene Muster? Oder gibt es nur Muster, die ohne musikalisches Bewusstsein eingesetzt werden und so >zum falschen Ort zur falschen Zeit< sind? Ist es möglich, solche unstimmigen Synchronizitäten und Konflikte in ihrer musikalischen Seinsweise anzuerkennen und umfassender zu deuten (z.B. situativ auch als Potential) statt punktueller Reparaturen anzubringen.

\section{Funktion und Nutzung}

Musik ist, wie Organisationskultur eine kulturelle Konstruktion. In unserer Untersuchung rückt ins Zentrum des Interesses, auf welche Weise organisationale und musikalische Prämissen bei den Mitgliedern sich überlagern oder widersprechen. Der Begriff der Funktion meint dann nicht mehr nur eine formal zugeordnete Tätigkeits- bzw. Ausführung bezüglich eines bestimmten Ziels, sondern die Weise, wie Praktiken in Organisation geschehen und welche Gebräuche bzw. Nutzungen sie über die strategische Zielbestimmung hinaus mit sich führen. Darin äußert sich eine Hinwendung vom Ziel zum Zielkorridor bzw. -horizont.

\section{Form}

Wenn wir diese Analyse verfolgen, so erweist es sich als wichtig, zu erkennen, wie die Verbindungen zwischen den Parametern organisiert werden, z.B. wie formal offen eine musikalische Organisation agiert. Die musikalischen Organisationsformen lassen sich aufspannen zwischen den extremen Polen von Komposition 
(komplette Planung) und Improvisation 1 (keine Planung). Dazwischen bilden sich Gradationen der Durchmischung von Improvisation und Komposition. Der Strahl geht also von ○ \% bis $100 \%$ Improvisation. Genau an der Schnittstelle von Improvisation und Komposition lassen sich Formen der Organisation erkennen, die in der Lage sind, den Dualismus zu überschreiten und Improvisation 2 (Improvisation zweiter Ordnung als konstruktiver Umgang mit Unordnung in Organisation, als kreatives, lebendiges Handeln) in kooperative Verläufe einzubetten. Es lohnt sich daher, wenn von Organisation die Rede ist, den Terminus der Improvisation neu aufzuspannen und in einer neuen Dimension auf die Organisation zu beziehen. Bezogen auf den Parameter Rhythmus wäre so z.B. zu untersuchen, wie und ob der Rahmen einer improvisierenden Organisation Spielraum rhythmischer Verbindungen bietet als die perfekte Synchronisation anderer Organisationsformen.

\section{Embodiment - gelebter Raum}

Wir sprachen von dem Zusammenhang zwischen Struktur und Affekt. Auseinandersetzungen mit Tönen hinterlassen im Hirn besonders dann tiefe Spuren, wenn die Finger mit ins Spiel kommen - durch die Verbindung mit der Motorik. Für den Pianisten Leon Fleisher entstand daraus ein Teufelskreis. Als er 1963, mit 36 Jahren, bemerkte, dass beim Spielen zwei Finger seiner rechten Hand verkrampften, übte er mit denen besonders emsig. Man wusste damals nicht, dass dadurch auf der >Landkarte< des Gehirns die für die einzelnen Finger zuständigen Bereiche immer weiter wachsen, bis sie sich überlagern, verschmelzen und außer Kontrolle geraten. Selbst das Gehirn hat nicht unbegrenzt viel Platz. Was bei virtuosen Passagen an Koordination zahlreicher Muskeln geleistet werden muss, bringt das Wunderwerk an seine Grenze. Vielleicht hatte Fleisher sie schon zuvor überschritten, doch mit dem verbissenen Training der betroffenen Finger legte er sie vorerst völlig lahm. Diese Geschichte wirft die Frage danach auf, wie durch musikalische Praxis Körperlandkarten zur Orientierung entstehen, und ob und wie anhand der Verbindung von musikalischer mit organisatorischer Praxis Orientierungskompetenzen in Organisation sich transformieren lassen oder neuartige mentale Organisationsmappings entstehen.

Wenn wir nach dem gelebten Raum der Musik, bzw. der Organisation fragen, fragen wir demnach auch nach der Dimension des >Embodiment<, was soviel wie Verkörperung bedeutet. Zu den Ebenen Fakten, Daten (empirisch Wahrgenommenes), Pläne (Konzipiertes), kommt die Ebene der körperlichen Bewegung, Gesten hinzu. So erscheint also das Wahrgenommene als Realität von Konzeptionen, welche ihrerseits als verkörperte Diagramme von Gesten vorliegen. Damit wird das Wahrgenommene nicht eliminiert, sondern aufgehoben in eine Dynamik der >Gerinnung < von Körperlichem. Diese Erweiterung wäre in Kongruenz mit einem Musikdenken, das sich nicht in der Reflexion verfängt, sondern Praxis und Reflektion zu verknüpfen im Stande ist. Die Landkarten entstehen in der Zeit und 
geben uns die Orientierung in der Zeit und versorgen uns mit Orientierung im Prozess ohne die Bewegung des Prozesses zu stoppen.

Adorno stellt in $\mathrm{Zu}$ einer Theorie der musikalischen Reproduktion fest (Adorno 2001: 201), dass es die Aufgabe eines Interpreten sei, »Noten so zu betrachten, bis sie dem insistenten Blick in Originalmanuskripte sich verwandeln; nicht aber als Bilder der Seelenregung des Autors — sie sind auch dies, aber nur akzidentiell - sondern als die seismographischen Kurven, die der Körper der Musik selber in seinen gestischen Erschütterungen hinterlassen hat.« Als seismographische Kurven werden Noten internalisiert und die musikalische Handlung nicht auf ein Objekt außerhalb des Subjekts bezogen. Durch den Prozess der Verinnerlichung lösen sich die Interpreten von den Noten, sind indes immer noch bestimmt von den Koordinaten des Raumes. Emotion würde sich in der musikalischen Handlung in gestische (Raum-)Koordinaten hinausbewegen. Wie Mazzola und Andreatta (2007) in ihrem Aufsatz Formulas, Diagrams, and Gestures konstatieren, lässt sich die musikalische Geste als eine räumliche Kategorie fassen, deren Darstellung in Form gerichteter Graphen in einem topologischen Raum mathematisch bestimmbar ist. Allerdings erweist es sich hierbei in ontologischer Hinsicht als entscheidend, dass Gesten nicht auf semiotische Zeichenbestandteile reduzierbar werden können. Zwar gibt es semiotische Gesten, wie in der Pantomime, aber die Geste an sich ist präsemiotisch, denn: Sie folgt nicht der Regel (Struktur), sondern erzeugt sie in der Handlung selbst, wie es der französische Philosoph Charles Alunni in seinem Aufsatz Diagrammes Q catégories comme prolégomènes à la question: qu'est-ce que s'orienter diagrammatiquement dans la pensée? aus dem Sammelband Penser par le diagramme, herausgegeben von Batt und Noelle, aufzeigt. Dieser Tatbestand ist auf der nächsten formalen Ebene wiederum konstituierend für das Gelingen-Können von Improvisation. Denn Improvisation orientiert sich nur an einem minimalen oder gar keinem Notentext.

\section{Diagrammatik}

In der Vermittlung zwischen Struktur und Affekt, zwischen Organisation und dem Ensemble korporaler Praxen erweist sich somit der Begriff des Diagramms als entscheidende mediale Schnittstelle. ${ }^{6}$ Was aber sind Diagramme? Diagramme gehören zum Standardinventar der Repräsentation abstrakter Wissensbestände. Sie lassen sich als bildhafte Darstellung von Informationen, Daten und Sachverhalten, Situationen beschreiben. Als Medientyp und Zeichenklasse in einer Mittellage zwischen Text und Bild überschreiten Diagramme die prinzipielle Dualität von Schriftlichkeit und Bildlichkeit. Diagramme werden häufig eingesetzt, um abstrakte Zusammenhänge von Funktionsprinzipien und Gesetzmäßigkeiten zu repräsentieren. Anders gesagt: Sie dienen dem >Sichtbarmachen des Unsichtba-

6 | Zu Diagrammatik und Organisation siehe ausführlich: Dell, Christopher, Die improvisierende Organisation, Bielefeld 2012. 
ren . Weder als Schriften noch als Bilder klassifizierbar, stellen Diagramme eine eigenständige Zeichenklasse dar, deren Stärke es ist, begrifflich erfasste Sachverhalte auf ihre Grundrelationen zu abstrahieren und bildlich zu repräsentieren. Sie wirken als Repräsentationsformen für Wissen demnach besonders dann, wenn es um abstrakte Sachverhalte und um die Darstellung komplexer Funktionszusammenhänge mit synchronen und diachronen Faktoren geht. Im Zentrum steht dann die Frage, inwieweit sich anhand von Diagrammen spezifisches Wissen generieren lässt, das sich wiederum als Erkenntnistool für Organisationen dient.

Nach der Theorie der Diagrammatik der semio-pragmatischen Philosophie von Charles S. Peirce (vgl. Wirth \& Bernard 2000) umfasst das Analysemodell des Diagramms drei Ebenen: Diagrammatische Strukturen, diagrammatische Referenzen und diagrammatische Schlüsse. Diagramme erlauben eine Kombination von Einblick und Überblick, reduzieren Komplexität und ermöglichen mit dem >diagrammatic reasoning a abduktives Schlussfolgern. Es wäre in diesem Zusammenhang allerdings danach zu fragen, wie diagrammatische Ordnungen des Wissens, sowohl in der Ausbildung einer Transferlogik zwischen Organisation und Musik als auch in dem oszillieren zwischen linearen und nicht-linearen Wissensrepräsentationsformen, eine zunehmend eigenständige Rolle in der Wissensproduktion zukommt.

Das erinnert daran, dass mit der Untersuchung auch eine neue Realität entsteht: Die Welt des hörbaren Organisierens, der musikalischen Erfahrung von bisher neutral, klanglos erachteten Vorgängen. Gerade mit organisationalen Dysfunktionen ließe sich dann, durch die Kombination von organisationaler und klanglicher Analyse, in den Groove kommen. Das hieße, Arhythmien nicht zu beheben sondern konstruktiv zu bespielen. Bisher erweisen sich solche fühlbaren, aber nicht offen sichtbaren Effekte von Organisation als schwer zugänglich, mehr noch sie hindern den flow. Durch Auseinandersetzung mit dem musikalischen Denkens von körperlichen Erlebnissen, von in Organisation eingelagerten Affektstrukturen, z.B. von Arhythmien, könnten sich möglicherweise Kriterien dafür finden, wie solche Störungen organisatorisch wirksam werden und welche Faktoren daran beteiligt sind. Wir wagen die Hypothese, dass gerade bei Organisationen durch das >Musikalisieren < ihrer Selbstbeobachtung Erfolge zu erwarten sind. Und zwar dann, wenn es gelingen könnte, den Inhalt ihrer Aktivität musikalisch >verständlich< zu machen. Unter Umständen ist der Weg von komplexen organisationalen Interaktionen zu einem verständlichen Bild oder zu verständlicher Sprache sehr weit, zur Musik hingegen sehr kurz.

Es war der Künstler Paul Klee (vgl. Düchting 2005), der das praktisch probierte. So konnte Klee Zeichen und Rhythmus in musikalischen Diagrammen (die er aus den Bewegungen des Taktstocks des Dirigenten ableitete) zusammenfassen. Nun wäre es an der Zeit, diesen Gedanken weiterzuspielen, zu erproben und daraus eine diagrammatische Konzeption zu gewinnen, die es erlaubt, in organisatorischem Zusammenhängen abstrakte Strategien, Prozessverläufe und 
Transformationen darzustellen, Musik mit Organisation zu verbinden und so Zugang zur Organisation als performativem Verlauf zu erhalten.

\section{LITERATUR}

Adorno, T. (2001): Zu einer Theorie der musikalischen Reproduktion. Suhrkamp, Frankfurt a.M.

Batt, N. (Hg.) (2005): Penser par le diagramme. Presses Universitaires de Vincennes, Paris.

Dewey, J. (1934): Art as Experience. Berkeley Publ. (Penguin), New York.

Dell, C. (2011): Replaycity. Jovis, Berlin.

Dell, C. (2012): Die improvisierende Organisation. transcript, Bielefeld.

Düchting, H. (2005): Paul Klee: Malerei und Musik. Prestel, München.

Koelsch S. \& Fritz, T. (2007): Musik verstehen - eine neurowissenschaftliche Perspektive, in: Vogel, Matthias \& Becker, Alexander (Hg.) (2007). Musikalischer Sinn: Beiträge zu einer Philosophie der Musik, Suhrkamp, Frankfurt a.M.

Lefèbvre, H. (2004): La production de l'espace. Editions Anthropos/Editions Economica, Paris.

Mazzola, G. \& Andreatta, M. (2007): Formulas, Diagrams and Gestures in Music, in: Journal of Mathematics and Music, Vol 1, Nr. 1, 2007.

Miller, P.D. aka DJ Spooky (2004): Rhythm Science. MIT Press, Cambridge.

Sacks, O. (2008): Der einarmige Pianist: Über Musik und das Gehirn. Rowohlt, Reinbek.

Schein, E.H. (1995): Unternehmenskultur. Campus, Frankfurt a.M.

Stiles, K. (1993): Between Water and Stone, Fluxus Performance: A Metaphysics of Acts. In: Armstrong \& Rothfuss (Hg.). In the Spirit of Fluxus, Minneapolis.

Vogel, M. (2007): Nachvollzug und die Erfahrung musikalischen Sinns, in: Becker \& Vogel (Hg.). Musikalischer Sinn, Frankfurt a.M.

Wirth, U. \& Bernard, J. (2000): Die Welt als Zeichen und Hypothese: Perspektiven des semiotischen Pragmatismus von Charles Sanders Peirce. Suhrkamp, Frankfurt a.M.

Zuckerkandl, V. (1964): Vom musikalischen Denken. Rhein-Verlag, Düsseldorf. 


\title{
Reflexivität und Kreativität
}

\author{
Konträre Quellen kompetenter Improvisation
}

Manfred Moldaschl

"Ich erleuchte den Weg durch das Unbekannte, indem ich das Beste aus der Vergangenheit als Laterne benutze." WAYNE SHORTER (in einem Interview 2001)

\section{Improvisation UND Ihre GRENZEN}

Schöner als Wayne Shorter kann man kaum ausdrücken, was Improvisation bedeuten kann - in der Musik und vielleicht auch anderswo. Der Saxophonist könnte aber auch das Komponieren gemeint haben, denn gefragt wurde er, woran er sich mit seiner Musik orientiere. Die Grenze zwischen beidem ist unscharf. Was notiert und fortan als Vorlage benutzt wird, verliert den Charakter des Spontanen und wird zur Komposition, zur Struktur, zum Format. Das ist der allgemeine Prozeß, in dem sich die menschlichen Potentiale kollektiv entwickeln. Und genau darum soll es in diesem Beitrag gehen: Das Erfinden neuer Muster, ihr Kanonischwerden und ihre Variation durch Andere, Folgende. Es geht um das Verhältnis von Fixierung und Variation, von Regel und Ausnahme. Dieses ist spannungsreich: »Die Improvisation ist eine Disziplin der Unvollkommenheit«, so der französische Klarinettist Louis Sclavis auf die Frage, wie er seinen Hang zu Perfektion und Improvisation zusammenbekomme. Paradox! Die völlig freie, regellose Improvisation ist die Ausnahme. Als stilistisches Programm hat sie sich in der Musikgeschichte auch nur kurz gehalten. Gleichwohl war sie ein entscheidendes Stadium in der Gewinnung musikalischer Freiheit gegen die Konvention.

Die Improvisation führt aber auch ein seltsames Doppelleben. Als Begriff ist sie im Sprachgebrauch recht eng an bestimmte Handlungsfelder gebunden überwiegend an künstlerische, dort mit strahlendem Glanz. Außerhalb ist von ihr weniger die Rede - und wenn, dann glanzlos, quasi rostig. Wer improvisiert, hat keinen Plan, kein Geld bzw. keine adäquaten Mittel (etwa bei der Autoreparatur), oder keine Zeit. Das sind übliche Zuschreibungen: Improvisation als ein Phänomen und Indikator des Mangels. Beides ist zu eng. Nicht nur die Mangeldeutung 
- siehe unten - sondern auch die uneingeschränkt positive im künstlerischen Umfeld.

»Die Improvisation schöpft nur aus schon Gemachtem und geht nicht über den Kreis persönlicher Vorlieben hinaus « - meinte John Cage einmal in einer Diskussion. Das bringt zum Ausdruck was auch Jazzhörer und -macher kennen: Wenn sich Improvisierende in ihren Mustern wiederholen, in der Repetition ihrer Spielfiguren stranden, im Akt des Variierens schematisch werden. ${ }^{1}$ Der Grad des Schöpferischen in der Improvisation ist begrenzt. In nicht notierenden Musiktraditionen, etwa in Indien, gilt das explizit: Improvisation ist hier schon mangels Notierung zugelassen, in ihren Mustern aber wiederum verbindlich. Generell kann Improvisation zum Präservativ des Wesentlichen werden wenn sie sich in Verzierungen er-schöpft.

Auffällig ist, dass in vielen Bereichen, in denen ständig improvisiert wird, dieses Wort kaum in Gebrauch ist. Im Alltag ohnehin, aber auch im Sport beispielsweise. Im Amateursport ist das naheliegend: Wo etwas nicht weitgehend verregelt ist, wird auch das Variieren nicht zum Thema. Im Profisport hingegen - etwa im Fußball - gibt es Aufstellungen, Strategien, und Taktiken für Spiel und Training, die zuvor festgelegt werden - und oft nicht aufgehen. >Beim Fußball verkompliziert sich alles durch die Anwesenheit des Gegners<, hatte Jean-Paul Sartre den Strategiegläubigen (aller Disziplinen!) spottend mitgegeben. Ob das Theorem des Fußballers Lukas Podolski >Fußball ist wie Schach, nur ohne Würfek die sokratische Essenz dieser Einsicht einholt, ist zweifelhaft. Auch beim Klettern in oberen Schwierigkeitsgraden - dort wo prima facie nicht sichtbar ist wie man der Wand Begehbarkeit abringen soll - ist fast alles Improvisation. Doch niemand nennt es so.

Sartres Strategieskepsis scheint von jenen, die das Ursprungsfeld des Strategiebegriffs vertreten, geteilt zu werden: on s'engage, et puis [...] on voit (>Schlagt zu, und dann sehen wir!), wie Napoleon seine militärische Wissenschaft beschrieb, und andernorts mit den Worten: Unglücklich der General, der mit einem System das Schlachtfeld betritt. >Lieber schnell was falsch machen als lange zögern < ist ein alter Militärspruch. Improvisation, Versuch-Irrtums-Strategie oder Planlosigkeit? Im Managementdiskurs hingegen - dem wichtigsten Abnehmer der militärisch-historischen Strategieliteratur von Sun Tsu bis Clausewitz (dazu Moldaschl 2008) - beherrschte bis von wenigen Jahren ein anderes Doppelleben die Szenerie: Die Führungsetagen und die ihnen zuliefernden Managementwissenschaften feilten am Anschein einer wissenschaftlich fundierten strategischen Führung, während ein Teil der Beraterszene sowie der humanistisch oder systemtheoretisch ausgerichteten management science Grenzen der Planbarkeit beschrie-

1 | Man denke etwa an einen bekannten norwegischen Bläser und sein trauriges Fiepsophon, oder den Pianisten seiner Anfangsjahre, der später als Spieluhr unzählige Soloplatten veröffentlichte. 
ben und mehr Raum für Selbstorganisation, Improvisation, und Fehlertoleranz forderten - mehr Freiheit, weniger Kontrolle.

Die Definition des Begriffs haben wir damit nur umkreist. Es ist Zeit, eine explizite einzuführen. Das Wort beruht auf dem lateinischen im-pro-visus, einer Verneinung von pro-videre, vorhersehen. Improvisieren ist danach der Umgang mit dem Unvorhergesehenen - gleich, ob es unvorhersehbar war oder nicht. Weitere Bestimmungsmomente liefert uns - da die Definition der deutschen Wikipedia unterdurchschnittlich ist - der Artikel der englischen:

"Improvisation is the practice of acting, dancing, singing, playing musical instruments, talking, creating artworks, problem solving, or reacting in the moment and in response to the stimulus of one's immediate environment and inner feelings. This can result in the invention of new thought patterns, new practices, new structures or symbols, and/or new ways to act. This invention cycle occurs most effectively when the practitioner has a thorough intuitive and technical understanding of the necessary skills and concerns within the improvised domain. Improvisation can be thought of as [...] spontaneous activity."

(https://en.wikipedia.org/wiki/Improvisation)

Also: Improvisierendes Handeln kann reaktiv oder aktiv sein, ist dabei aber wesentlich spontan; es kann innovative Anteile enthalten, die Erfindung neuer Handlungsweisen und Symbole; Intuition spielt eine Rolle; und es ist an bestimmte Wissensdomänen bzw. Erfahrungsfelder gebunden. Alles sinnvolle Annahmen, denen wir weiter nachgehen werden.

\section{Die Ausnahme Rettet die Regel - Dialektik der Moderne}

Ohne Improvisation würde die moderne Welt nicht funktionieren. Sie ist eine ungeheuer verregelte Welt. Eine, die ihre Leistungsfähigkeit allerdings auch der ungeheuren Kumulation von Regeln verdankt: Denk- und Sprachregeln (z.B. Logik und Grammatik), Normen und Verhaltensregeln (z.B. Schulpflicht, Recht), Verkehrsregeln (z.B. sozialer Umgang, Mobilität), materialisierte Regeln (z.B. Maschinen, Stadtstrukturen), und so fort. Jedes gesellschaftliche Leben funktioniert nach Regeln - eben dadurch zeichnet sich Gesellschaft aus, jede gesellschaftliche >Struktur<; moderne Organisationen ebenso wie schon die primitivste Stammesgesellschaft. Das Neue der Moderne ist nicht die Existenz von Regeln, sondern ihre Übermacht. Weil aber schon die natürliche Welt so komplex ist und ihre >Gesetzmäßigkeiten ‘ auf so vielfältige Weise miteinander interagieren (Kontingenz), dass sie im Ganzen weder berechenbar noch vorhersagbar ist, und weil die soziale Welt dem viele weitere Komplexitätsdimensionen hinzufügt, ist die Ausnahme als Gegenstück zur Regel in Sprache und Alltagswissen höchst präsent. Erst die Verregelung der Welt macht die Improvisation zum Thema und führt sie - im späten 18. Jahrhundert - in einige Sprachen als Wort erst ein. 
Diese Dialektik im Maschinenraum der Moderne kann man so zusammenfassen: Die Notwendigkeit der Ausnahme und der Auslegung von Regeln nimmt mit der Zahl der Regeln und ihrer interaktiven Komplexität zu. Eher exponentiell als linear. Entsprechend reich ist der Wortschatz moderner Gesellschaften für das Auslegen und Ausnehmen: Interpretation, Hermeneutik, Improvisation, ziviler Ungehorsam, Schweijkiade etc., hier nur im Deutschen, bis hin zur subversivsten Form der Regelbefolgung: Dienst nach Vorschrift. Wer das tut, will die Herrschaft der Regel zu Fall bringen, ihren Geltungsbereich einschränken und seine Freiheit ausdehnen, indem er oder sie das Auslegen und Ausnehmen verweigert. Oder er oder sie leben in einem stalinistischen Umfeld, indem jede Form der Subjektivität (also der Interpretation, Improvisation, des eigenständigen Handelns) gefährlich ist. Es gibt Organisationskulturen, die auch heute durchaus Züge davon haben.

Ein kleines Beispiel für nur einen Typ von Regeln und Regelverletzung aus unserer Produktionsforschung. Für eine Gruppe von Maschinenbedienern gelten folgende Regeln - nicht alle expliziert, aber man kennt sie: Befolge die Vorgaben der Produktionsplanung. Halte die Auftragsreihenfolge ein. Minimiere die unproduktiven Zeiten (Gemeinkosten). Sei flexibel. Fahre die Maschine nicht an ihrer Leistungsgrenze. Halte die Wartungsintervalle ein. Alle diese Regeln haben gute Begründungen und damit Sinn. Nur widersprechen sie sich oftmals. Fällt eine Maschine oder ein Werkzeug oder ein Zulieferteil aus, muss die Auftragsfolge geändert werden. Hat man Ausfallzeiten, muss man Maschinen ggf. auf Volllast fahren, um Konventionalstrafen bei Liefertermin-Verfehlung zu vermeiden. Hält man geplante Wartungsintervalle ein, können die Gemeinkosten steigen. Und so fort. Kein computergestütztes Steuerungssystem kann dergleichen heute balancieren. Das tun Menschen als kreative Problemlöser. Sie tun es allemal, auch wenn es keine Metaregel gibt, dass sie das Zusammenspiel regeln sollen bzw. dürfen. Wenn sie es dennoch tun und nicht mit Dienst nach Vorschrift reagieren, ist das in der Regel mit hoher psychischer Belastung verbunden. Ähnliches gilt für Rettungssanitäter, die im Interesse des Patienten oft tun müssen, was sie nicht dürfen (dazu Moldaschl 2005).

Wo Regeln quasi hauptamtlich produziert werden, etwa in der Politik, und dort, wo sie hauptamtlich ausgelegt werden, etwa im Rechtssystem - ist das eine permanente Gratwanderung. Eine mit der Tendenz, rekursiv zur Komplexitätssteigerung beizutragen. Wenn schon Auslegung nicht vermeidbar ist und das anerkannt wird, darf sie andererseits nicht beliebig sein; also entstehen wieder Regeln, die den Raum, das Ausmaß und die Legitimität der Auslegung und der Ausnahme regeln. Ein beliebtes Beispiel für eine praktisch nicht mehr beherrschbare Wucherung so gewachsener Regelsysteme ist das deutsche Steuerrecht. Von ihm wird behauptet wird, es umfasse soviel Regel- und Auslegungsliteratur wie die der übrigen Welt zusammen; und es beschäftige so viele Menschen, wie anderenlands ganze Wirtschaftsbranchen. De facto schafft es eine.

Um die Gratwanderung von Regel und Variation geht es auch überall dort, wo Innovation stattfindet oder stattfinden soll. Der Normalfall des Alltagslebens, 
der Organisation, der Wirtschaft ist aber die Routine - die ge-regel-te Praxis, die Herrschaft der Regel. Das ist äußerst vorteilhaft, denn es entlastet die Akteure davon, alles ständig überdenken und entscheiden zu müssen. Routine verschafft ihnen Freiheit, Kapazität für Anderes, macht sie produktiv in dem, was sie ohnehin ständig tun. Doch erstens ändern sich in der modernen Welt ständig Dinge, ohne dass man etwas tut, und zweitens muss oder will man sich (unter anderem aufgrund von Wettbewerb) mitunter hier oder da verbessern. Das heißt: Immer wieder funktioniert die Routine nicht mehr, oder sie ist nicht mehr gut genug. Man muss sie ändern. Gesellschafts- und Wirtschaftsdiagnostiker ${ }^{2}$ werden nicht müde zu betonen, dass das immer öfter und schneller nötig sei: InnoFlation. Entsprechend blüht der Wortschatz der Begriffe, welche über die Innovation hinaus Neuerungen fassen und den Bedarf formulieren, Routinen und Pfadabhängigkeiten in Wirtschaft und Gesellschaft aufzubrechen: Wandel, Fortschritt, Evolution, Wachstum (als ein Modus der Entwicklung), Modernisierung, Reform, Revolution, Invention etc.

\section{Rationalität als Feind der Kreativität?}

Wieder haben wir zunächst nur umkreist, worum es beim Verhältnis von Regel und Ausnahme geht: um kreative Leistungen. Es können aber auch subversive, perversive und destruktive sein (regelkritische und illegitim regelverletztende Handlungen, z.B. Verbrechen; das klammern wir hier aus). Leisten wir also ein wenig Abgrenzungsarbeit - zunächst am Beispiel der Musik - und stellen gleich fest: Absolute Abgrenzungen gibt es auch hier nicht. So wurde im Stalinismus etwa der Anspruch von Komponisten auf kompositorische Freiheit vom Regime als Ausdruck bürgerlichen Individualismus, als illegitime Ablehnung des Auftrags proletarisch >verständlicher< Musik interpretiert, ja generell einer Kunst mit sozialdienlicher Funktion, und natürlich als Angriff auf den Herrschaftsanspruch dieser Deutung. Das konnte zu Gefängnis und Lagerhaft führen, und damit auch zum Tod. Analog bekanntlich im Faschismus. Jede Interpretation, Variation und Modifikation von Regeln hat aber auch in pluralistischen Kontexten stets Konfliktpotential. In der Regel haben Regelwahrer die Mehrheit.

Kreativität ist das große Mysterium. Quasi aus dem Nichts wird Neues geschaffen; etwas, was zuvor nicht da war und was so auch nicht vorhersehbar, ableitbar, planbar war. Aus diesem Grund (oder besser: weil das so gesehen wird) wird Kreativität in ästhetischen Diskursen der Rationalität entgegengesetzt. In den Hyperion-Fragmenten (1794) klang es bei Friedrich Hölderlin so: »O ein Gott ist der Mensch, wenn er träumt, ein Bettler, wenn er nachdenkt«. Rationalität als ein

2 | Im Interesse der Lesbarkeit verzichte ich in diesem Text auf die grammatische Vervollständigung der Geschlechtlichkeit ([...] und Wirtschaftsdiagnostikerinnen etc.); die weibliche Form ist immer mitgedacht. 
menschliches Vermögen, abstrakt (kategorial) ${ }^{3}$, in Ursache-Wirkungs-Beziehungen (Kausalität) und Zweck-Mittel-Beziehungen (Instrumentalität) zu denken und zu handeln (entscheiden). Etwas, was nach Gesetzmäßigkeiten beschrieben werden könne, speziell jenen der Logik. ${ }^{4}$ So etwa das Portrait der Rationalität im cartesianischen Rationalismus. Gegenpositionen findet man bei Pragmatisten wie Ryle (1969) oder Schön (1983).

Wie so oft gaukelt der eine Begriff dem Benutzer der Sprache vor, es handle sich um einen Gegenstand mit Identität, mit klar definierten Eigenschaften. Fetischisierung nennt man es, wenn man das Bezeichnende für das Bezeichnete hält. Sieht man sich an, was bereits vor 24 Jahrhunderten Aristoteles in seiner Nikomachischen Ethik (1991, VI, 231ff.) an Rationalitätsformen bzw. >Verstandestugenden $>^{5}$ beschreibt, wird man verstehen, warum das Wort auch heute wieder im Plural gebraucht wird - zumindest in über die Aufklärung aufgeklärten Diskursen. Zugleich besteht andernorts die monistische Verengung fort, die es schon vor Aristoteles gab. Insofern wäre, was die moderne Ökonomik und generell die Rationalwahltheorien in den Sozialwissenschaften heute vertreten (be-rechnendes Denken), von gebildeten Griechen vor zweieinhalb Millennien als reduktionistisch angesehen worden. Soviel nebenbei zur Ungleichzeitigkeit des Fortschritts und zur nötigen Offenheit im Gebrauch des Begriffs Kreativität. Wenn wir, unseren Verstand benutzend, gezielt etwas Neues schaffen, ist das dann ein Ergebnis unserer Rationalität oder unserer Kreativität? Oder einer Mischung? Oder schreiben wir nur bestimmte Ergebnisse unserer geistigen Tätigkeit dem einen, andere dem anderen $\mathrm{zu}^{6}$

Es ist modisch, Rationalität und Kreativität einander entgegenzusetzen. Es ist schön schlicht. Tendenziell kann es ja zutreffen: Der Künstler will nicht das Bewusstsein des Ingenieurs haben und nicht in dessen Denkwelt leben; deshalb hat

3 | "Urteilskraft überhaupt ist das Vermögen, das Besondere als enthalten unter dem Allgemeinen zu denken" so Kant in der Kritik der Urteilskraft (1790/1974, A XXIII/B XXV).

4 | Das vorherrschende Rationalitätsverständnis hat nicht nur eine Geschichte, sondern unterliegt zudem einer kuriosen Selbstreferenzialität, die Luhmann (als oberster Experte solcher Selbstbezüglichkeiten) so beschreibt: "Der Begriff der Rationalität unterwirft sich seiner eigenen Regie; er unterstellt sich selbst der Forderung nach Richtigkeit - während der Begriff des Brotes gerade nicht eßbar und der Begriff der Schönheit nicht selbst schön zu sein hat" (2008: 187).

5 | In Aristoteles eigenen Worten: "die Mittel, mit denen die Seele bejahend oder verneinend die Wahrheit trifft" (ebd.: 234). In der Philosophie streitet man darüber, ob er vier, fünf oder sechs Formen unterscheide.

6 | Dass Hörer konventioneller Musik unkonventionelle häufig als "intellektuell «, "konstruiert", "nicht emotional" bzw. als "kalt" empfinden und bezeichnen, ist allerdings ein anderes Phänomen. Es ist ein Effekt des Egozentrismus, die Unfähigkeit zu dezentrieren von der eigenen Erlebnisperspektive; was einen selbst emotional nicht anspricht, muss emotionslos sein. Ein Mangel an Reflexivität (vgl. 4.). 
er sich für ein anderes Berufsfeld entschieden. In Bestimmungen der Kreativität wird das Sinnliche und Anschauliche, das Spontane und Unsichere betont, und dem Primat des Abstrakten, Kognitiven, Berechenbaren entgegengesetzt. Allerdings erklärte schon Kant in seiner Kritik der reinen Vernunft:

"Ohne Sinnlichkeit würde uns kein Gegenstand gegeben, und ohne Verstand keiner gedacht werden. Gedanken ohne Inhalt sind leer, Anschauungen ohne Begriffe sind blind." (1787/1974, A 51/B 75)

Auch wird man wohl nicht allen Ingenieuren pauschal vorwerfen wollen, sie würden nichts Neues schaffen. Was schaffen denn Banker? Was Manager, Steuerberater, Totengräber? Man tut gut daran, sich mit den Rationalitäten in diesen Praxisfeldern und ihren jeweiligen Kreativitätsräumen zu befassen. Jedes wird seine eigene Konfiguration von rationalen und intuitiven Momenten des Handelns haben. In der Regel überschätzen wir dabei den Anteil und die Bedeutung der rationalen Momente, wobei wir später noch diskutieren müssen, was das Wesen der intuitiven Anteile ausmacht, und wo sich darin kreative Körner verstecken (Abschnitt 6).

Grundsätzlich ist Kreativität nicht alleine individuell zu verstehen: Sie ist ein überwiegend kollektives Phänomen (dazu z.B. Joas 1996), eine Ensembleleistung. Das Paradigma des einsamen Künstlers ist nur ein Pixel im Gesamtbild der Kreativität. Aus einem Bildpunkt kann man das Wesen und den Sinn eines Bildes nicht erschließen, so wenig man ein Programm versteht, wenn man die Definition eines Byte kennt. Den Entstehungsraum von Kreativität kann man erweitern bis auf die Ebene des Staates (und darüber hinaus - es gibt heute Weltkulturen). John Dewey, pragmatistischer Philosoph und Pädagoge und einer der Denker der Kreativität, brachte den Begriff der kreativen Demokratie (1939/1989) ins Spiel, die mit Pluralismus längst nicht ausreichend beschrieben ist. Nimmt man Carl Friedrich von Weizsäckers auf Kant beruhende Unterscheidung hinzu »Verstand dient der Wahrnehmung der eigenen Interessen, Vernunft ist Wahrnehmung des Gesamtinteresses «, ${ }^{7}$ so wird vorstellbar, welche Aufgaben ein Bildungssystem hätte, das nicht am Bildungsziel zweckrationaler Wissensaneignung zum individuellen Bestehen im beruflichen Wettbewerb geeicht ist.

Von den Gelegenheitsstrukturen der Kreativität aber zurück zum mehr oder weniger kreativen Handeln - und der Frage, woran wir dessen mehr oder weniger kategorial (oder sonst wie) festmachen können. Greifen wir nochmals die oben benutzten und in der musikalischen Domäne gebräuchliche Begriffe auf:

\section{Interpretation - Improvisation - Komposition}

7 | "Wir erklärten [...] den Verstand durch das Vermögen der Regeln, hier unterscheiden wir die Vernunft von demselben dadurch, dass wir sie das Vermögen der Prinzipien nennen wollen." Immanuel Kant in seiner Kritik der reinen Vernunft 1787/1974, S. 300). 
In dieser Reihenfolge kann man diese Tätigkeiten als qualitativ eigene Formate kreativen Handelns (einschließlich des geistigen) betrachten, aber auch als grobe Rangfolge der Originalität. In der Musikwelt schreibt man einem als Interpretation bezeichneten Handeln den geringsten Grad schöpferischer Leistung zu. In der >ernsten< Musik geht es dabei u.a.: Um die Auslegung der Kompositionsanweisungen hinsichtlich Stimmung, Tempi etc., und hinsichtlich der kompositorischen Intention, dem Sinn oder der Aussage eines Stückes. Im Jazz etwa kann Interpretation schon wesentlich mehr Freiheiten und damit mehr subjektiven Beitrag bedeuten in allen Dimensionen, auch der Instrumentierung, Tonlage, und so fort. Im Theater geht das weit über Kontextuierungen hinaus bis hin zum Anspruch auf eine Neuschöpfung des Stückes, was Regisseuren oft auch als Überhöhung ihrer Person gegenüber den Urhebern vorgeworfen wird. Wie eng oder wie weit Interpretation gefasst wird (von beiden Seiten: Produzenten und Rezipienten!) ${ }^{8}$, ist also selbst wieder eine Frage der Interpretation, mit den Polen Werktreue versus expressive Neuschöpfung auf der Basis vorliegenden Materials. Wenn ein Material gut ist, also originell, wird es andere zu Neuschöpfungen anregen.

Die erste Interpretation der Interpretation wird in der Regel gering geschätzt, außer im klassischen Musikbetrieb mit seiner Altgier. Das ist nicht immer angemessen. Der Soziologe und Sozialpsychologe Gabriel Tarde hat eine Theorie des Wandels vorgelegt (1890/2003), welche die beiden Nachbarn des Innovationsbegriffs zum Thema macht, Invention und Imitation. Überraschenderweise weist er letzterer die zentrale Bedeutung im sozialen Wandel zu. Inventionen sind zwar singuläre, meist ungeplante Ereignisse, doch sie sind selbst »aus Elementen früherer Nachahmung aufgebaut [...], und aus diesen Zusammensetzungen, die wiederum selbst nachgeahmt und zu neuen Elementen von komplexeren Zusammensetzungen werden « komponiert (Tarde 1890/2003: 69). Die Imitation ist eine Quelle der Variation, da keine neue Idee, kein Modell ohne Interpretation und Kontextuierung angewandt werden kann. Kaum eine Imitation kann eine getreue Kopie der Vorlage darstellen, selbst wenn das gewollt ist. ${ }^{9}$ Aller Kulturaustausch vollzog sich auf diese Weise. Das nennt Tarde Lois de l'imitation, die Gesetze der Nachahmung. Ihnen spürt er in allen gesellschaftlichen Institutionen nach: Erziehung, Bildung, Wissenschaft und so fort. Tardes Ansatz könnte heute auch ein

8 | "In den Konzertsälen herrscht die Altgier", so der deutsche Komponist Peter Ruzicka in einem Rundfunk-Interview. Und von Hanns Eisler wird der Satz überliefert: "Wenn Sie ins Konzert gehen - geben sie an der Garderobe mit dem Hut gleich den Kopf ab."

9 | Man denke nur an die Genetik: Es gäbe keine Evolution, wenn die Reproduktion immer identisch abliefe. Man wird sich hier aber auch erinnern an Walter Benjamins Aufsatz zum Kunstwerk im Zeitalter seiner technischen Reproduzierbarkeit (1935/1980). Diese Assoziation wäre aber unangemessen, denn selbst die Imitation hat - als Tätigkeit - noch einen Rest an schöpferischer Leistung, was bei technischer Reproduktion nur noch als Kopierfehler auftreten kann. 
Korrektiv sein gegenüber der maßlosen Überschätzung von Innovation und der verbreiteten Geringschätzung von Imitation (analog zur Geschichtsschreibung der >großen Männer<).

Bei der zweiten, expressiv-heroischen Interpretation der Interpretation verschwindet tendenziell der Unterschied zur Komposition bzw. zur Autorschaft - im Ausmaß des Schöpferischen, die Differenz im Ausmaß der Spontaneität bleibt. Auch die Komposition geschieht nie im luftleeren Raum - verknüpft sie doch stets selbst >Material< (Ideen, Modelle, Stile, die schon in der Welt sind) neu. Ganz so, wie der Nationalökonom Schumpeter den Begriff der Innovation definiert (neue Kombination von Vorhandenem), und die Problemlöseforschung das problemlösende Handeln. Umgekehrt gilt auch für die Komposition, was Cage zur Improvisation gesagt hatte: Egozentrisches Kreisen um sich selbst gibt es auch im Akt des Schöpfens. So kann man Leonardo da Vincis >Jeder Maler malt sich selbst< verstehen, aber auch jegliche Schematik des Komponierens (Schreibens, Choreografierens, [...]). Kommerziell ausgerichtete Autorschaft arbeitet nur mit Maschen. Die für den akustischen Krabbeltisch hergestellten hirnzersetzenden Kreischprodukte der Unterhaltungsmusik sind oft derart schematisch, dass große Teile davon computergeneriert werden (können); ähnlich die volksdümmliche Musik, die Volksmusik inhaltlich so weit strippt, dass ihre Vorhersehbarkeit bis auf die Millisekunde einer militärischen Okkupation des Gehörs gleicht - von der debilen Verjustusfrantzung klassischer Werke zur >Kuschelklassik< fremdschämend ganz zu schweigen. Doch auch die >unkonventionelle< oder >zeitgenössische< Musik bildet ständig Konventionen heraus und repetiert diese auf so hörbare Weise, als akademische Leerverkäufe, dass Rezipienten mit geringer Monotonieresistenz mitunter nur der Genrewechsel in kreativere Welten bleibt, z.B. in die der Improvisierten Musik. ${ }^{10}$ Von >Komponisten, denen die Partitur unterm Arm zur Akte geworden ist « sprach etwa ein Besucher der Darmstädter Ferienkurse für Neue Musik 1996 in einer vom SWR durchgeführten Publikumsbefragung. Schon Karlheinz Stockhausen hatte Jahre gebraucht, bis er sich vom seriellen Nachkriegsdogma der Darmstädter Zeitgenossen zu lösen wagte, während sich Mauricio Kagel spottflott davon befreite.

Es ist dies, noch einmal, die Kehrseite dessen, was ich oben als Prozeß der kollektiven Kumulation menschlicher Potentiale beschrieb. Alle Aktivitäten neigen zur Routinisierung und damit zur Schematisierung, Verkrustung, Verhärtung. Natürlich, nicht sie tun es, sondern wir. Wir speichern das Gelernte, indem wir es habitualisieren, unserem Körper zur bewusstlosen Wiederholung übergeben. Oder indem wir es externalisieren, z.B. in Form von Werkzeugen (physische oder

10 | Sie wäre ein eigenes Hauptthema, als Zusammenfassung von Strömungen, sie zum einen dem Jazz-Idiom (und dessen afrikanischen Wurzeln) verpflichtet sind, sich zum anderen aber jeweils eigener kulturhistorischer Wurzeln kreativ bedienen, z.B. der europäischen in Gestalt mittelalterliche Tänze, Pentatonik, Folklore, jiddische Musik etc., aber letztlich aller musikalischen Traditionen der Welt. 
symbolische, Templates, Regelsätze). >We shape our tools and then they shape us<, so beschrieb der Ökonom Kenneth Boulding (1958) diese Dialektik. Ein unschönes Beispiel für negative Institutionalisierungsfolgen liefert die Partei der Institutionalisierten Revolution (PRI) in Mexico, die in den Jahrzehnten ihrer Herrschaft nach der mexikanischen Revolution zur maßgeblichen Kraft der politischen Versteinerung dieses Landes wurde. Der Mechanismus bedroht jede Person, jedes Kollektiv, jede Organisation. Man muss sich permanent dagegen wehren und Vorkehrungen gegen das Einrasten treffen - wenn man das denn will (und akzeptiert, dass sich damit zur unbequemen Minderheit macht). Oder mit John Cage:

»I can't understand why people are frightened of new ideas. I'm frightened of the old ones.«

\section{Reflexivität als Gegenspieler der Kreativität?}

Gegen das Einrasten hilft also, so mein Versprechen: Reflexivität. Jeweils morgens und abends 20 Milligramm, mit einem Schluck verdünnten Wassers. Gut, nicht praktikabel; was also dann? Was heißt reflexiv? Ich gebe hier eine möglichst alltagssprachliche Definition ${ }^{11}$ und diese zuerst ex negativo: Reflexivität ist nicht Reflexion oder Nachdenklichkeit - andernfalls könnte man sich einen eigenen Begriff dafür sparen. Es geht nicht um Reflexion als Aktivität, als Anwendung von Rationalität im praktischen oder geistigen Handeln. Gemeint ist vielmehr eine Haltung und ein Verhältnis.

Reflexiv sein heißt, eine epistemisch kritische Haltung einzunehmen in Bezug auf Wissen und Gewissheiten, seien es eigene oder solche der sozialen Welt, in der man sich bewegt. Eine Haltung, die von der Vorläufigkeit, Fragilität und Unvollständigkeit des Wissens ausgeht, mit dem der Akteur umgeht. Kritisch heißt distanziert, d.h. diesem Wissen nicht verhaftet und verfallen. Viele verstehen das leichter, wenn man die Haltung sokratisch nennt.

Als Selbstverhältnis sagt Reflexivität etwas darüber aus, wie egozentrisch oder dezentriert die Wirklichkeits- und die Selbstwahrnehmung einer Person oder eines Kollektivs (z.B. einer Gruppe, Organisation, Nation) ist; inwieweit man vom eigenen Blick auf die Welt de-zentrieren und sich in ihr >von außen< sehen kann; wie sehr sich ein individueller oder kollektiver Akteur dabei des Verhältnisses von Standpunkt und Perspektive bewusst ist; und damit der Ausschnitthaftigkeit des vorhandenen Wissens, der konstruierten Modelle, Theorien und Methoden. Weil diese immer von bestimmten Akteuren in bestimmten Kontexten für bestimm-

11 | Angebote einer wissenschaftlichen Definition in verschiedener theoretischer Begründungstiefe - von der Psychologie über die soziologische Modernisierungstheorie bis zur Erkenntnistheorie - findet man in zahlreichen der per download verfügbaren Texten auf unserem Forschungsportal dazu: www.reflexivitaet.de. 
te Zwecke generiert wurden. Oder schlichter gesagt: Weil die Welt komplex und dynamisch ist. ${ }^{12}$

Ein solcher Bewusstseinsmodus ist also nicht nur kritisch in Bezug auf >außenweltliche< Ansprüche auf Wissens- und Regelgeltung, sondern auch in Bezug auf sich selbst: selbst-kritisch hinsichtlich der Herkunft des eigenen Wissens und seiner Grenzen. Er schafft eine Schutzatmosphäre gegen den Glauben an die Überlegenheit der eigenen Gruppe (Chauvinismus). Ein historisches Beispiel für diesen Modus der Selbstaufklärung ist die Frankfurter Schule der Kritischen Theorie, die nach dem Faschismus den noch emphatischen Aufklärungsoptimismus der Moderne mit Aufklärung über Aufklärung beenden wollte. ${ }^{13}$ Ein Beispiel für ein egozentrisches Wahrnehmungsmuster bei Musikhörern habe ich oben (Abschnitt 3) schon gegeben. Ein weiteres wäre - auf der Ebene individueller und nationalkultureller Wahrnehmungsmuster - Nationalismus; eines, das sich überdies historisch als äußerst gefährlich erwiesen hat. Es beinhaltet, die eigene Perspektive als einzig mögliche oder einzig sinnvolle, zumindest aber als prinzipiell überlegene zu betrachten, und die eigene Person oder Gruppe dabei als a priori als Maßstab der Beurteilung vorauszusetzen. Die Bereitschaft zum Diskurs, zur Verständigung, zur Aufnahme fremder Ideen und neuem Wissen ist hier prinzipiell und erfahrungsgemäß gering.

De-zentrieren ist schwer. Die Beobachtung der eigenen Beobachtung auch. Ein Therapeut kann sich nicht selbst therapieren, und - so der Volksmund - der Schuster hat immer die schlechtesten Schuhe. Epistemologisch gesehen könnte man daher zuspitzen: Jeder ist sich selbst der Fernste. ${ }^{14}$ Auch das hat mit der Macht der Routinisierung zu tun. Der Psychologe Jean Piaget hat gezeigt, dass die Fähigkeit zu de-zentrieren (eine intellektuelle Reife) in der Individualentwicklung eine bestimmte biologische Reife voraussetzt. Und dass damit die Fähigkeit, sich seiner eigenen Perspektive bewusst zu werden sowie die der Anderen als eine Realität zu erkennen, erst mit einem bestimmten Lebensalter durchschnittlich gegeben ist; als Voraussetzung, im nächsten Schritt auch die Notwendigkeit zu

12 | Insofern ist es bemerkenswert sokratisch, wenn ausgerechnet Albert Einstein als Urheber einer der bis heute "haltbarsten" (falsifikations-resistentesten) Theorien der Wissenschaft eine Aussage wie diese macht: "Alle Modelle sind falsch, aber einige sind nützlich." (Quelle infolge der Zitierhäufigkeit - stets ohne Quelle- nicht auffindbar). In welchem Verhältnis die Haltung und das Selbstverhältnis stehen, wo sie herkommen, wie sie - im doppelten Sinne - ausgebildet werden, ist eine ganz andere und sehr komplexe Frage (s. Abschnitt 6).

13 | Ich weiß, es ist kritisch, hier ausgerechnet die kritische Theorie zu nennen, deren oberster Repräsentant sich in der Einschätzung des Jazz als elitärer Banause und Chauvinist präsentierte.

14 | Es gibt aber eine Popgruppe namens simple minds. Soviel Reflexivität hätte man der Popwelt gar nicht zugetraut. Allerdings kann man auch bezweifeln, dass die Selbstbeschreibung selbstkritisch gemeint war. 
erkennen, sich in andere hineinzuversetzen, um sie verstehen zu können. Sein Schüler Lawrence Kohlberg wiederum konnte zeigen, dass die biologische Reifung nur eine notwendige, keine hinreichende Bedingung dafür ist, ob eine Person tatsächlich das Niveau der De-zentrierung erreicht, und hier wiederum unterschiedliche Kompetenzniveaus (untersucht hatte er moralische Urteilsfähigkeit, z.B. Kohlberg 1997). Dies hängt vom Sozialisationsverlauf ab.

Reflexive Kulturen sind pluralistische Kulturen. Solche, die die Unterschiedlichkeit der Weltwahrnehmung begrüßen und fördern (diversity), weil sie der Begrenztheit der jeweils bestimmten (auch der jeweils eigenen) gewahr sind. Solche, die sich darin gefangen fühlen und nach mehr Freiheitsgraden dürsten. Solche, die der Komplexität der Wirklichkeit und der Begrenztheit ihres Verständnisses davon (begrenzte Rationalität) auch insofern gewahr sind, als sie stets mit Nebenfolgen intentionalen Handelns rechnen: Die Intervention in komplexe und dynamische Systeme, etwa Ökosysteme, kann aus dieser Sicht nicht nur die gewünschten, intendierten Folgen haben. Die Erderwärmung beispielsweise war kein Projekt.

Wenn sich Organisationen heute von durchgehend hierarchischen Steuerungslogiken verabschieden, sie zumindest durch Entscheidungsfindung in funktions-, abteilungs- und/oder disziplinübergreifenden Teams ergänzen, dann institutionalisieren damit Verfahren der Reflexivität. Die Politik tut das, indem sie z.B. vermehrt Gesetze mit Evaluierungsklauseln verabschiedet; diese legen Zeitpunkte und Verfahren fest, wann die Folgen der Gesetzesanwendung untersucht und wie sie an den Zielen gemessen werden sollen (reflexives Recht). Dies, um die Gesetze ggf. den Lernerfahrungen gemäß modifizieren zu können.

Was hat das nun mit Improvisation zu tun, und mit dem Grad an Kreativität, den wir ihr zuschreiben können? Nun, Reflexivität scheint allem entgegenzustehen, was kreativem Handelns als wesentlich zugeschrieben wird: Der Primat der Intuition, der >flow < eines weitgehend ohne rationale Kontrolle ablaufenden Tuns; das >Sich-einlassen < auf einen vom Gegenstand bestimmten Prozess; und das darin Aufgehen (wie der nun wieder so aktuell gewordene Dagobert Duck in seinem Geldspeicher $>$ Es ist mir ein Hochgenuss, hineinzuspringen und wie ein Maulwurf darin herumzuwühlen<). Reflexivität dagegen ist Distanzierung, epistemische und methodische Skepsis: Begangenen Pfaden nicht blind trauen und bessere für möglich halten; sich nur bedingt einlassen, nicht restlos im Tun aufgehen; eine Außenperspektive zumindest ergänzend behalten; am Erfolg eigener Intentionen und Handlungen zweifeln; auf Nebenfolgen des Handelns achten, sogar nach ihnen suchen; eigene Ziele, Mittel und Wege auf ihren Sinn prüfen, nicht nur deren Instrumentalität rational abwägen; nochmals nach dem Sinn und den Gründen für die emotionale Rendite des Herumwühlens im Geldspeicher fragen.

Was aber, wenn wir uns nicht den Schlagzeuger im Postchorus-solo oder Dribbelkünstler in Aktion oder den Maler beim schmatzenden Auftrag der Farbe auf Leinwand oder Wand vorstellen, vielleicht noch alkoholisch von letzten rationalen Bremsen befreit? Wenn wir stattdessen an einen Manager denken, der eine defizitäre Firma retten muss, möglichst ohne deren Innovationsfähigkeit zu be- 
schädigen und das interne Sozialkapital zu mindern? ${ }^{15}$ Oder ein Ingenieursteam, das ein ganzes Bündel widersprüchlicher Ziele in einem Produkt unterbringen soll (Leistungssteigerung, Kostensenkung, Sortenreinheit, Emissionsminderung, Demontagefreundlichkeit etc.)? Oder den computer-starrenden Kommandostand eines Formel 1-Teams, oder ein Architekturbüro oder eine Stadtplanungsabteilung oder einen Maschinenbediener unter modernen Produktionsbedingungen? Dann wird man es sich nicht so leicht machen können mit der Empfehlung, doch im sinnlichen Feilen an Prototypen aufzugehen oder sich für Tage in ergebnisoffenes Brainstorming (1. Regel: Quantität vor Qualität; 2. Ideenproduktion ohne unmittelbare Bewertung) zu verabschieden.

In unserer Innovationsforschung fanden wir, weit mehr als von uns selbst erwartet, empirische Belege für unsere theoretisch begründete Ausgangshypothese: Dass Organisationen mit einem höheren Grad an institutioneller Reflexivität in verschiedensten Innovationsindikatoren besser abschnitten als andere (Anteil neuer Produkte am Produktportfolio; Umsatzanteil dieser Produkte; Anzahl innovativer Organisationslösungen; Umsetzungsgeschwindigkeit solcher Lösungen etc.). ${ }^{16}$ Gleichwohl würden wir auf Ergebnisse standardisierter Erhebungen (wie auch unserer) nicht viel geben, könnten wir nicht zugleich anhand unserer qualitativen Fallstudien nachvollziehen, warum das so ist. Einige Antworten habe ich bereits mit dem Nationalismusbeispiel gegeben, weitere findet man in den angegebenen Empirietexten. ${ }^{17}$

Auch auf die maßgebliche Folgerung war ich oben schon auf einem anderen Wege gelangt: Kreativität kann nicht alleine in der konventionellen Weise verstanden werden, wo sie als das etwas der Rationalität (und der Reflexivität) Entgegengesetztes gilt: Intuition, Spontaneität, Aufgehen im Spiel ohne rationale Kontrolle. Das geht vor allem nicht in wissensintensiven Handlungsfeldern. Kreativität kann sich in den intellektuellsten, analytischsten, abstraktesten geistigen Operationen ereignen. Nennen wir das, was man als >kreatives Handeln < bezeichnet (weil es von außen so aussieht) besser intuitiven Handlungsmodus (Fritz Böhle nennt ihn >subjektivierend<, vgl. dazu seinen Beitrag in diesem Band), und betrachten Kreativität als emergentes Resultat des Zusammenwirkens intuitiver und reflexiver Modi des Tuns. Der kritische, reflexive Modus hilft dabei, von den eigenen Routinen und Gewissheiten Abstand zu gewinnen, sich und anderen Fehler und Irrtümer leichter einzugestehen, und im Improvisieren nicht nur die bewährten Schemata zu variieren.

Dass beim Entstehen und Schaffen des Neuen auch noch die >Objekte<- die Vergegenständlichungen früherer Tätigkeiten, anderer Akteure, anderer Felder

15 | Über die Rolle der Regelauslegung und der Improvisation in organisationalen Transformationen vgl. z.B. Gillet de Monthoux 1981; Bahrdt 1956, 1996; Ortmann 2003; Shaw/ Stacey 2006; in der Wissenschaft: Feyerabend 1980, 1984.

16 | Jeweils neueste empirische Befunde stehen zum download unter www.reflexivitaet.de. 17 | Eine andere gab zu Lebzeiten Steve Jobs in einem Interview des Computermagazins ct:: "Apple basiert auf Flüchtlingen aus anderen Firmen. Das sind ausgesprochen helle Köpfe, die individuelle Beiträge leisten und in anderen Unternehmen nur Unruhe stiften." 
eine maßgebliche Rolle spielen können, kann ich hier aus Platzgründen nur anfügen; es zu diskutieren bedürfte eines eigenen Beitrags (vgl. dazu etwa Marx 1858/1981, Jörgensmann/Weyer 1991; Latour 2001, und bes. Miettinen 2009).

Während wir die Improvisation von Künstlern erwarten (sie ist Bestandteil dieses Berufsrollenschemas), wollen wir sie in anderen Lebensbereichen weniger haben; im Krankenhaus z.B. gar nicht und in dessen Operationssaal erst recht nicht. Wir wollen, dass es dort geregelt, also sicher zugeht. Zugleich aber hoffen wir darauf, dass die Professionellen dieser Organisation bei unvorhergesehenen Ereignissen (Unsicherheit) dennoch professionell agieren. Das heißt, nicht panisch, nicht kopflos, nicht planlos, und dabei notfalls eben mit jenen Mitteln improvisierend, die ihnen bleiben. Dabei erwarten wir allerdings wiederum, dass für bestimmte, mögliche, prinzipiell denk- und vorhersehbare Ereignisse schon Regeln (z.B. Notfallpläne, technische Automatismen) bestehen und implementiert sind; etwa das Anspringen eines Notgenerators bei Stromausfall. Wir hätten (sofern bei Bewusstsein oder im Nachhinein) überhaupt kein Verständnis dafür, müsste bei Stromausfall in rußendem Kerzenlicht weiteroperiert werden.

Dies gilt für alle High Reliability Organizations (HROs, z.B. Roberts 1990) wie Flughäfen, Luftleitzentralen, Kernreaktoren, Einrichtungen der Raumfahrt, der Schiffahrt, des Militärs u.ä., von denen bei menschlichem oder technischem Versagen großes Risikopotential für Mensch und Umwelt ausgeht. Weil Improvisation als Handeln unter Unsicherheit und nicht vorgesehenen Mitteln unvermeidlich mit einer höheren Rate nicht gelingender Handlungen (>Fehler<) einher geht, wollen wir in solchen Kontexten nur regel-befolgende Handlungsweisen legitimieren. Natürlich ist das ein Dilemma. Dilemmata sind unlösbar - das ist konstitutiv für diesen Begriff. Man kann aber mehr oder weniger sinnvoll mit ihnen umgehen.

Forscher, die sich mit Fragen der Sicherheit und der Gestaltung von HROs befassen, haben die aus ihrer Sicht sinnvollsten Strategien und Haltungen beschrieben als negotiated order (Schulman 1993), also als eine unter den relevanten Beteiligten (bei Bedarf immer wieder neu) ausgehandelte, nicht oktroyierte Ordnung; und als collective (!) mindfulness (Weick, Sutcliffe 2001, übersetzt mit Achtsamkeit, Weick, Sutcliffe 2003). Diese beschreiben sie als capability to discover and manage unexpected events. Konzeptionell gefasst und empirisch erhoben wird sie anhand der folgenden fünf sehr grob zusammengefassten Kriterien. Achtsame Kollektive

- richten ihre Aufmerksamkeit in überdurchschnittlichem Maß auf Fehler

- lehnen grobe Vereinfachungen bei Interpretationen und Lösungen ab

- investieren viel in eine gemeinsame kognitive Landkarte der Beteiligten ${ }^{18}$

18 | Sie nennen das Kriterium 'sensitivity to operations und heben hervor, Maßnahmen zielten auf "cognitive integration and collective mind that allows the integration of tightlycoupled interactive complexity as a dynamic operational process" (1999: 43). 
- legen großen Wert auf Robustheit bzw. Fehlerfreundlichkeit (Resilienz)

- pflegenhohe Wertschätzungfür Expertise (professionelles Wissenund Können) und organisieren Entscheidungsverantwortung daher dezentral

Diese phänomenologisch, auf der Basis von teilnehmender Beobachtung gewonnenen Kriterien (inklusive derer von Shulman) haben viel gemein mit jenen, die wir auf ganz anderer, theoretischer Grundlage erarbeitet haben, um den Grad der Institutionellen Reflexivität von Organisationen messen (dargestellt z.B. in Moldaschl 2006). Während wir dieses Maß als eines für Innovationfähigkeit interpretieren, interessiert Weick und Sutcliffe eher Improvisationfähigkeit, was sich aus der überragenden Bedeutung von Sicherheitsfragen in den HROs gibt. In späteren Texten haben die Autoren ihren Geltungsanspruch auf >Hochleistungsorganisationen ausgedehnt und stellen auch damit nicht primär auf Innovation ab. Ungeachtet dieser Akzentuierungen bleiben die Ähnlichkeiten relevant; beide Ansätze beschreiben bestimmte Haltungen und Selbstverhältnisse und bestimmte Einrichtungen der Praxis.

Es gibt noch andere Deutungsformate, der den Umgang mit Unsicherheit und die Befähigung im Umgang damit behandeln. Eines ist das Konzept der Profession, mit dem sich eine ganze Subdisziplin der Soziologie befasst. Der Professionssoziologie zufolge kennzeichnen folgende Merkmale die Professionen (vgl. Abbott 1988; Freidson 2001; Mieg/Pfadenhauer 2003):

- Institutionalisierung als wissenschaftliche Disziplin oder >professional purity<

- Anwendung der Standards dieser Disziplin in der Praxis

- Verfügung über eine >Technologie< und Qualitätsstandards

- Rechtlicher Schutz des Professionszugangs, der formalen Abschlüsse und Qualifikationsnachweise und damit der Märkte

\section{Professioneller 'Habitusı}

Es fällt sogleich auf, dass die Bestimmungen recht rationalistisch ausfallen: Technologie im Sinne standardisierter Verfahren, strikte Einhaltung in der Anwendung, Interessenpolitik zum Schutz der eigenen Märkte via Errichtung rechtlicher Markteintrittsbarrieren. Was die interdisziplinäre Expertiseforschung herausfand, ist allerdings, dass sich die Könnerschaft erfahrener Professioneller gerade nicht darin von jener der Novizen unterscheidet, dass sie die Standards kennen und genauestens einhalten - im Gegenteil. Den Experten zeichnet aus, dass er professionelle Standards situationsgemäß - unter Umständen auch unkonventionell interpretiert, variiert und sich in neuen Situationen auch souverän von ihnen löst (Barley/Orr 1997; Böhle 1989; Böhle/Weyrich 2009; Dreyfus 2000; Gruber/Ziegler 1996; Hagemann u.a. 2007; Mieg 2001; Neuweg 1999; Sternberg/Horvath 1999). Experten kennen auch die Grenzen ihres Wissens besser als Novizen, die eher zu dessen übergeneralisierter Anwendung neigen. 
Zugespitzt könnte man sagen, die rationalistische Strömung der Professionssoziologie sei auf die Legitimationsfassade der Professionen hereingefallen, die den Erwartungen ihrer Kunden mit demonstrativer Ingenieurmäßigkeit begegnen. Improvisation und Reflexivität kommen in den entsprechenden Selbst- und Fremdbeschreibungen professioneller Leistung nicht vor.

Was in vielen Organisationen als hypocrisy beschrieben wird (als Heuchelei, z.B. Brunsson 1993), entspricht eben dem: Alle Parteien versuchen, den Anschein der Regeleinhaltung zu erwecken, damit sie beim Versuch, das Ganze durch Regelbeugung am Laufen zu halten, nicht von den Verständnislosesten am Notwendigen gehindert werden. Ein rationaler Grund für die frappierende Haltbarkeit dieser Irrationalität ist natürlich die nie auszuschließende Möglichkeit, dass Regeln auch illegitim, im Partialinteresse gebeugt werden. Im Notfall ist Improvisation aber im Nachhinein immer legitim, sofern es gut ging, wie im folgenden Beispiel, das wohl allen denkbaren Regeln der Flugsicherung widersprach:

Am Mittwoch, dem 15. Januar 2009 startete der Flug 1549 vom Flughafen La Guardia in New York City. Zwei Minuten nach dem Start, in 975 Meter Höhe, meldete der Pilot Chesley B. Sullenberger III einen , doppelten Vogeleinschlag, - in beiden Triebwerken seines Airbus A320. Die Folge: Triebwerkausfall. Glücklicherweise ging dieser Unfall glimpflich aus. Sullenberger konnte die Maschine auf dem Hudson River notwassern; alle 150 Passagiere und die fünf Besatzungsmitglieder kamen ohne ernsthafte Verletzungen davon.

\section{IMPROVISATIONSVERMÖgEN UND INTUITION}

Wir sind nun so weit, auf ein vielleicht irritierendes Adjektiv im Untertitel meines Beitrags zu kommen: kompetentes Improvisieren. Darin ist offenkundig die Annahme enthalten, dass nicht jeder gleich gut darin ist; dass es ein prinzipielles menschliches Vermögen sein mag, man aber Gleichverteilung nicht voraussetzen kann. Manche sind nahezu komplett unfähig dazu (man nennt sie unflexibel, hölzern oder >deutsch<), andere (der Charlie Parker/Eric Dolphy-Typus) werden für ihr Vermögen vergöttert. Auf die Erklärung solcher Unterschiede, oder zumindest Beschreibung, zielte ja auch das Konzept der Achtsamkeit. Wie auch immer wir es nennen, Fähigkeit, Kompetenz, Vermögen, Potenz oder Potential (Arno Schmidt sprach von Poetenz): Improvisation ist nicht nur ein Prinzip und ein Prozess, sondern auch ein Können, ein Vermögen, etwas zu tun, und das mehr oder weniger gut. Oder besser: Improvisation setzt ein Können voraus, wenn sie professionell sein und kein Mist dabei herauskommen soll. Nennen wir es hier also Improvisationsvermögen (mit aller reflexiven Distanz zu dieser Begrifflichkeit, vgl. dazu Moldaschl 2010).

Die nächste Frage bzw. die zu explizierende Annahme wäre, wie sehr man bezogen auf Personen die Unterschiede biologisch (>Begabung $<$ ) oder sozialisatorisch erklären will. Da ich des ersteren in den meisten Fällen für höchst zweit- 
rangig halte, befasse mich nur mit letzterem. Es schließt sich dann die Frage an, wie Improvisationsvermögen angeeignet werden kann. Wie eine beliebige andere Kompetenz? Wie ein Anteil jeder Kompetenz? Oder muss man es eher ansehen als nicht direkt beeinflussbare >Metakompetenz<, als ganzheitlichen Effekt der Lebenserfahrung?

Wenn ich das oder hier für unangemessen erkläre, wird sich womöglich der Eindruck einstellen, ich plädierte den ganzen Beitrag hindurch im Duktus eines ängstlichen >Sowohl-als-auch-ismus<. Meine Argumentation zielte aber auch bisher nicht auf die Unmöglichkeit von Unterscheidung, sondern vielmehr auf ihre Notwendigkeit. Dies ausgehend von der epistemischen Prämisse, dass die Wirklichkeit komplex sei, während uns unsere Begriffe (das, womit wir Vielheit greifbar machen, indem wir sie in ein Gefäß schütten) zu simplifizierendem Denken verführten. Das heißt hier: Wenn wir von einem Improvisationsvermögen sprechen, müssen wir uns nicht dazu verführen lassen, es als homogen zu denken. Meine Hypothese ist: Unsere Fähigkeit zu variieren und zu improvisieren variiert selbst, von Feld zu Feld unserer Tätigkeit, von Situation zu Situation, und das auf verschiedenen Ebenen der Generalisierung.

Dass es Ähnlichkeiten gibt, muss man nicht ablehnen, wenn man annimmt, die Komplexität der Welt bedinge bedeutsame, also interessante Unterschiede. Wer als Jazzer gut improvisieren kann - das heisst, originelle Ideen und zugleich gute handwerkliche Fertigkeiten hat, sie flüssig umzusetzen, hat dieses Vermögen keineswegs gleichzeitig in anderen beruflichen Sphären, etwa beim Verhandeln über Honorare, oder beim Kochen oder im Freizeitsport. ${ }^{19}$ Aber worin liegen die Unterschiede der Improvisation im Jazz und jener in der kubanischen Autowerkstatt, wo man nicht eben mal Ersatzteile für die dort gefahrenen Oldtimer bestellen kann? Die Antwort kann ich hier nicht geben, aber die Suchrichtung ist klar: Sie muss gesucht werden in den Spezifika der Tätigkeit und der Gegenständlichkeit, in die sie eingebettet ist. Das ist meine erste von drei Antworten.

Die zweite bezieht sich auf den grundlegenden Mechanismus, wie sich Fähigkeiten im flexiblen Umgang mit wiederkehrenden Aufgaben - umschreiben wir die Improvisation hier einmal so - herausbilden. Ich gehe hier kurz und exemplarisch auf eine psychologischer Theorie ein, die pragmatistisch argumentiert, jenseits des in der Psychologie vorherrschenden Kognitivismus. ${ }^{20}$ Eine ist die Handlungsregulationstheorie (z.B. Volpert 1994). Ihr Grundgedanke ist die Entstehung flexibler Muster, genannt Schemata, im Handeln. Der Handelnde erfährt die Welt im Handeln,

19 | Es gehört zum Elend der Improvisation, dass auch jene, die kaum Kompetenz haben, rege davon Gebrauch machen.

20 | Kognitivismus ist eine Erscheinungsform des Rationalismus, also (hier sehr verkürzt) der Vorstellung, die Welt sei berechenbar und könne daher mit menschlicher Vernunft und Logik komplett erschlossen werden. Der Kognitivismus interessiert sich weniger für die Welt als für das, was im Kopf des Individuums vorgeht; inm zufolge erfasst das Individuum die Welt vornehmlich kognitiv, also durch Wahrnehmung und Denken, nicht durch Handeln. 
und zwar in all ihrer Regelhaftigkeit und zugleich >Indeterminiertheit<. Er bildet Operationsfolgen aus, die zu gelingendem Handeln, also Zielerreichung führen; beispielsweise erfolgreichem Schalten im Automobil als Koordination von Teiloperationen mit Hand und Fuß, also Aus- und Einkuppeln, Gas wegnehmen und geben, Gangwechsel. Die Routinisierung dieser Operationen erlaubt dem Akteur, seine Aufmerksamkeit auf andere Dinge zu lenken, etwa auf das Lenken, Verkehrsschilder beachten, den Verkehrsfunk einstellen etc.; im Lauf der Zeit sind dann alle Schemata, die man zum Autofahren regelmäßig braucht, »psychisch automatisiert«, so dass man sich zugleich unterhalten oder über einen Vortrag zum Thema Improvisation nachdenken kann. Während Anfänger unflexibel sind, durch Variation leicht aus den Konzept zu bringen, sind die Schemata der Erfahrenen flexibel. Nicht nur in ihrer Re-Kombinierbarkeit oder freien Konfigurierbarkeit, sondern auch in sich selbst. Denn in sie sind Ausschnitte der realweltliche Variabilität eingegangen, etwa unterschiedliche Schaltungen, Fahrbahnbeschaffenheiten, und so fort. Je variabler diese Erfahrungen, desto flexibler werden die Schemata, und - so können wir hinzufügen - desto mehr Potential für Improvisation bieten sie. So können beliebig komplexe Handlungsgestalten aufgebaut werden.

Das heißt in Kurzform: Das Improvisationsvermögen wächst mit der Variabilität der Erfahrungen (und dem materialen Reichtum des Erfahrungsfeldes). Es gibt ähnliche Ansätze wie die psychologische Tätigkeitstheorie (z.B. Miettinen 2009), auf Michael Polanyi aufbauende phänomenologische Ansätze (z.B. Neuweg 1999) und andere, die ich schon als Beiträge zur Expertiseforschung zitiert hatte. Faktisch argumentieren alle mit dem Konzept der Erfahrung; ihr Aufkommen und ihre zunehmende Verbreitung sind Teil des practice turn (vgl. z.B. Schatzki 2001, Stern 2003), der sich in den Sozial- und Geisteswissenschaften >ereignet< hat; auch wenn er die rationalistischen Positionen nicht verdrängen konnte.

Diese Rehabilitation von Erfahrung gegenüber der Kognition bringt uns nun zu einem in diesem Beitrag mehrfach gebrauchten, aber noch nicht definierten Begriff: Intuition. ${ }^{21}$ Sie behandelt man wie Ikone des Unerklärbaren, des Bauchgefühls (Gigerenzer 2007), oft mit der Konnotation des angeboren, dem Menschsein inhärenten Potentials: >menschliche Intuition<, oder die der Hälfte der Menschheit >weibliche Intuition< (z.B. Davis 1989). Deshalb kommt sie als Begriff auch praktisch nicht vor in den Lehr- und Grundlagenbüchern der Psychologie ${ }^{22}$, teils

21 | Im Latein als Herkunft ist das Substantiv intuitio nicht gebräuchlich, nur das Verb: intueri, intuitus sum hinschauen, anschauen, ansehen, aufmerksam betrachten; erblicken, geistig: Betrachten, erwägen (Langenscheidt Wörterbuch Latein-Deutsch von 2006). Ohne Betrachtung seiner semantischen Geschichte besagt Intuition also in wörtlicher Übersetzung etwas wie Anschauung, Erwägung (und Entscheidung?) auf der Basis sinnlicher Anschauung.

22 | Aus deren überwiegend rationalistischer Sicht ist der Begriff kein wissenschaftlicher, kein wissenschaftstauglicher, einer der mit Spiritualität, Spiritualismus, Erweckungserlebnissen u.ä. zu tun hat. 
nicht einmal in deren Lexika, auch nicht in den Handbüchern der Arbeitswissenschaft, der Soziologie u.ä. (eine der seltenen Ausnahmen: Böhle 2010, 158ff). Nur in den zitierten pragmatistischen Ansätzen stößt man gelegentlich darauf; sie sprechen sonst eher von implizitem Wissen oder Erfahrungswissen; eines, das in der Regel eben nicht sprachlich expliziert vorliegt und auch kaum so expliziert werden kann (und andernfalls zu teils absurden Blüten führt wie im Jargon der Weinkritik). Das war schon die Sache, mit der sich Sokrates unbeliebt gemacht hatte.

Da Erfahrungswissen an die leibliche bzw. körperlich-sinnliche Erfahrung gebunden ist (man nennt es daher alternativ auch Können), kann es eher >gezeigt< werden, wie etwa die Feinheiten des Fersenschwungs beim Skifahren oder die Haltung der Feile beim Feilen; sie werden per unmittelbarer sinnlicher Anschauung im Vormachen weitergegeben. Empathie kann man als eine interaktionsbezogene Form der Intuition betrachten, als ein Vermögen der Einfühlung basierend auf Erfahrungen mit anderen Menschen und mit sich selbst (was man wiederum paradox als >intuitive Reflexivität < bezeichnen könnte). Das aufeinander Eingehen der Musiker in einem improvisierenden Ensemble wird man auch so beschreiben können, mit generellen empathischen Vermögen und solchen, die sich aus der gemeinsamen Spielpraxis entwickelt haben.

Insofern, als alle Menschen irgendwelche Erfahrungen machen, haben alle auch irgendeine Intuition, oder besser, irgendwelche intuitiven Potentiale, so wie sie auch über Potentiale rationalen Kalküls in dieser oder jener Menge und Qualität verfügen. Divergent eben, in Abhängigkeit von divergenten Erfahrungen. Ein Trobriander hat kein Smilla-Gespür für Schnee, keine Intuition für Schneearten und Lawinenrisiken, weil (oder soweit) ${ }^{23}$ er keine Erfahrung mit Schnee hat. Man kann Intuition quasi als Summe der Erfahrungen verstehen, als Sediment des in einzelnen Handlungsfeldern und des im Leben Erfahrenen. So kommen wir zurück zum Anti-Sowohl-als-auch-ismus: Man muss nicht nur von inhaltlich verschiedenen intuitiven Vermögen ausgehen (auch in einer Person), sondern auch von unterschiedliche Generalisierungsgraden. Den höchsten konstituiert die Lebenserfahrung. Menschen, die viel davon haben, schreibt man gerne Weisheit zu. Altwerden reicht dazu nicht.

Diese Unterscheidung von Feldern und Niveaus des Improvisationsvermögens - oder wie immer man die Potentiale der kompetenten Variation performativen Handelns nennen mag, ist zugleich meine dritte Antwort auf die Frage, wie man diese Art menschlichen Vermögens sanspart<.

Natürlich ist das selbst noch eine sehr schlichte, >reduktionistische< Annahme, und eine fast mechanistische dazu. Denn der Mensch und sein Köper erscheinen

23 | In der reflexiven Moderne kann man davon nicht mehr ohne weiteres ausgehen. Es kann durchaus sein, dass Anthropologen im afrikanischen Busch auf Stammesgesellschaften stoßen, in denen sie, als - des stolz Bantu mächtige westliche ,Entdecker', in perfektem Englisch von Stammesmitgliedern mit Doktorgrad in Computerwissenschaften begrüßt werden (ich empfehle die wunderbaren Studien Barleys, z.B. 1997). 
hier zunächst nur als Recorder, der irgendwelche Erfahrungen >aufzeichnet<, sie leiblich einschreibt wie ein Hologramm. Hier nun würde unsere Untersuchung eigentlich erst interessant werden: Wo dieser Geist und Körper selbst aktiv wird, Räume der Erfahrung aufsucht oder flieht; wo Sozialisationswirkungen nicht nur von gegebenen Kontexten und >Zeitläuften< abhängen, sondern Selektionseffekte hinzukommen, ja mehr noch: Selbstselektion und Selbstsozialisation. Diese vier Entwicklungsmodi sind verknüpft in einem Prozess der Koevolution von Person und Kontext. ${ }^{24}$

Wer eine Kunsthochschule besucht, wird von vorneherein ein größeres Maß an beruflicher und biografischer Unsicherheit in Kauf nehmen, wohl auch in seiner Tätigkeit ein höheres Maß an Improvisation wünschen, ertragen und bewältigen als das, was ihm etwa eine Ingenieurskarriere verspricht. Personen, die sich in solche Sozialisationskontexte begeben, sich Improvisationsanforderungen stellen, werden sich vielleicht von vorneherein vom Klischee >Karohemd und Samenstau< absetzen und darauf setzen (eher intuitiv natürlich), dass der rekursive, sich selbst verstärkende Mechanismus von Anforderungen und Kompetenzentwicklung auch sie befähigen werde, ihr Improvisationsvermögen in einer weniger vorhersehbaren Berufsbiografie kontinuierlich entwickeln. Soweit sie das eben wollen.

Das sind keine einmaligen Entscheidungen. In restriktiven Organisationen vom Typ >Behörde < leiden die Mitglieder in der Regel nicht an einem Mangel an kreativer Atmosphäre. Die, die das tun oder taten, sind schon weg. Oder sie gingen gar nicht erst hin. Sie sammeln sich anderswo. So ergeben sich sehr kumulative, >pfadabhängige< Prozesse, die schwer und nur langfristig veränderbar sind. Eine Organisation kann nicht einfach beschließen: Wir sind jetzt kreativ, und zwar sofort. Alles hat sich aufeinander eingestellt, eingeschwungen; es ist eingerastet. Allerdings kann es auch umgekehrt laufen; wenn etwa der wissenschaftliche Mitarbeiter genug hat von den prekären Bedingungen an der Uni, von den befristeten und den Stückelverträgen, von der Unmöglichkeit einer >vernünftigen < Familienplanung vor dem Ergattern eines Lehrstuhls; wenn er also mit dem improvisierten Leben Schluss macht, sich dann doch gegen die Freiheit der Forschung und für eine konventionelle Laufbahn in einem Unternehmen entscheidet. Oder,

24 | Zum Kontext und zur Koevolution gehört selbstverständlich auch die Hörerkompetenz: Man könnte sagen, der Musikmarkt ist eingeteilt in Erwartungsniveaus, entlang dem Verhältnis von Bestätigung und Erstmaligkeit (Neuheit, Unvorherhörbarkeit), Märkte des Bestätigungsbedarfs, auf denen Gewissheitsanbieter einen nachhaltigen Wettbewerbsvorteil haben, weil die Nachfrage nach Fragezeichen eben durchschnittlich schwach ist. Je weiter sich Musiker auf die Seite der Unvorherhörbarkeit schlagen, desto prekärer wird ihre Einkommens- und Lebenssituation sein. Der Satiriker Max Goldt (1999) formulierte es so: "Das Publikum klatscht doch nicht, weil ein Lied besonders gut ist, sondern weil es ein Lied bereits kennt. Es beklatscht sein eigenes Gedächtnis. "Und Arnold Schönberg meinte (passim): „Die Hörer scheinen notwendig zu sein, denn ein leerer Raum klingt nicht gut.» 
wenn umgekehrt der Ingenieur die Nase voll hat vom Spoilerkonstruieren und selbständiger technischer Berater wird, oder gar sich zum Organisationsberater umschulen lässt. Pfade können verlassen, >gebrochen< werden. Meist aber unter Inkaufnahme einer Phase erheblicher Unsicherheit.

Noch spannender würde es, wenn wir Erfahrung nicht mechanistisch als >Ereignis< verstehen, sondern als konstruktiven Prozess. Erfahrungen macht man. Denn »Das schlechthin Unbedingte wird in der Erfahrung gar nicht angetroffen « so Kant in seiner Kritik der reinen Vernunft. ${ }^{25}$ Ob ein Ereignis der Welt, ein selbst verursachtes (intendierte oder nichtintendierte Handlungsfolge) oder vom Handelnden unabhängiges ein ephemeres bleibt (eines von Millionen und für die Person bedeutungslosen), oder ob es zur Erfahrung gemacht wird, hängt davon ab, ob es dazu gemacht wird. Ob man den Falklandkrieg als einen von Tausenden der Geschichte betrachtet oder daran seinen Fortschrittsoptimismus verliert, ist in diesen Krieg selbst nicht eingeschrieben. Aber es wird hier leider nicht spannender, weil ich an dieser Stelle abbrechen aus Platzgründen muss.

Zwei Dinge sind aber noch nachzutragen: Erstens, dass die oben vorgeschlagenen Antworten auf die Frage nach Entstehungs- und Entwicklungsbedingungen von Kreativität (incl. Improvisationsvermögen) keine qualitative Antwort auf das Phänomen der Originalität geben können. Warum jemand so viel origineller sein kann als ein anderer mit ähnlicher Berufs- und Lebenserfahrung, verstehen wir nicht. Ich bezweifle, dass wir es können werden.

Zweitens, zur Unterscheidung von Eigenschaft und Kompetenz. Man kann sagen, eine Person habe Improvisationsvermögen. Üblicher ist es zu sagen, eine Person sei >offen<, >flexibel< oder >kreativ<. Ebenso ist es, wenn man jemanden als stark bezeichnet. Man schreibt ihm dann die >Eigenschaft $<$ zu, stark zu sein. Man kann auch sagen, die Person hat Kraft, oder, je nachdem worum es geht, sie habe >Biege- oder Hebevermögen<. Das sind dann keine unterschiedlichen Dinge, sondern nur unterschiedliche Begriffe. Aber mit unterschiedlichen Konnotationen. Bei Fähigkeiten konnotiert man eher Aneignung, Training, Entwicklung, bei Eigenschaften eher dauerhafte, strukturelle Merkmale der Person. ${ }^{26}$ Wir können das nicht aus der Welt schaffen. Aber wir müssen es wissen.

\section{Folgerungen}

Zwei konträre Quellen kompetenter Improvisation zu besprechen, versprach der Untertitel meines Beitrags: Kreativität und Reflexivität (so der Titel). Was ist nun dabei herausgekommen? Nun, erstens und überraschend wie Schnee im Januar,

25 | An anderer Stelle ergänzt er: "Die Kinder benutzen nicht die Lebenserfahrung der Eltern; die Nationen kehren sich nicht um die Geschichte. Die schlechten Erfahrungen müssen immer wieder aufs Neue gemacht werden."

26 | Nur für biologistisch Denkende sind Vermögen und Eigenschaften eins. 
das wovon ich im Titel schon ausging: Reflexivität sei nicht der Feind der Improvisation, sondern eine weitere Quelle von Kreativität, aber eine andersartige. Mehr noch: Ich hatte in den einzelnen Kapiteln verschiedene Konstrukte daraufhin geprüft, inwieweit man sie als Gegenspieler dessen verstehen müsse, was dieser ganzen Band behandelt: Improvisation als kreatives Handeln; Strategie (1), Regeln (2), Rationalität (3), Reflexivität (4) und Profession bzw. Professionalität (5). Das Ergebnis war, dass, wenn man beim Begriff Gegenspieler bleiben möchte, diesen nicht in einem linearen und kausalen Sinn als das Ausschließende und Vernichtende verstehen darf. Ein Fußball- oder Basketballspiel kommt auch nur zustande, wenn die >Gegner< wissen, dass sie einander brauchen und einander respektieren. >Gegenspieler ist also in einem dialektischen Sinn zu verstehen (wechselseitige Bedingtheit). Und in einem diskursiven: Die einander entgegengesetzten Begriffe sind Vereinfachungen und Verallgemeinerungen, als Schmiermittel der Kommunikation. Wie jedes Mittel hat auch dieses in der Anwendung Kosten: Nebenfolgen, unerwünschte Effekte, etwa die erwähnte Fetischisierung. Das muss man wissen.

Aus dieser Diskussion ergab sich zweitens mein Vorschlag, Kreativität als emergentes Resultat der spannungsvollen Mischung intuitiver und reflexiver Handlungsweisen und Befähigungen dazu zu betrachten. Das mag zumindest ein wenig zur Entknotung des sehr komplexen Problems beitragen, Kreativität als Leistung zu verstehen. Aus der Diskussion der Rolle von Erfahrung und ihrer Sedimentierung in der Intuition leitete ich drittens die Empfehlung ab, möglichst auch hier nicht der Verführung zu erliegen, das für Eines zu halten, was einen Namen hat. Man sollte vielmehr annehmen, dass es entsprechend der enormen Vielfalt der Erfahrungsfeldern und Erfahrungen auch unterschiedliche Inhalte, Formen und Generalisierungsgrade >der< Intuition gibt; und man diese auch empirisch untersuchen solle.

Nochmals angewandt auf Jazz als Beispiel. Dass ein Jazzmusiker Kreativität braucht (besser: intuitives Handeln), ist schnell akzeptiert. Wird Jazz im Format der Unterhaltungsmusik mit sehr wenig davon auskommen? Wohl nicht: Je routinehafter er abläuft, desto intuitiver. Der Anteil der Intuition am Handeln sagt eben nichts aus über den Grad der Originalität der Musik. Im größten Genre des Jazz, dem Spielen von Standards, trägt sie dazu kaum mehr als kleinere Variationen und Girlanden bei. Vielleicht hat sie es noch schwerer in den digitalen Ablenkungsgewittern der Online-Welt, weil dieser die Konzentration abhanden kommt.

Und Reflexivität? Braucht ein Jazzmusiker die? Das hängt von der Art des Jazz ab, den er macht. Sofern es nicht um komplett frei improvisierten Jazz geht, um das Kaputtspielen der Konvention analog zur seriellen Musik (das reicht als Phase, >ontogenetisch $<$ und >phylogenetisch<, um einen erweiterten Freiraum für eigenständige Kreationen zu schaffen), und soweit es nicht um komplett standardisierten geht, wird er sie brauchen. Alle Arten von >Avantgardemusik $<$ sind angewiesen auf die Kultivierung eines kritischen Selbstverhältnisses (u.a., um das Einrasten zu vermeiden), und einer kritischen Haltung im Umgang mit histori- 
schem, schon bestehendem musikalischen Material (um ihm nicht anheim zu fallen und um nicht seine originären Leistungen zu missachten). Deshalb findet man sie auch nie auf der rechten Seite der Kultur. Was man ferner nicht übersehen darf: Wo es nicht um Standards geht, geht es um eigene Kompositionen der oder eines der Musiker. Die größte Reputationsausschüttung findet ein Musiker letztlich über seine Kompositionen. In gutem Jazz vermählen sich kompositorische und improvisatorische Phasen und Leistungen, Reflexivität und Intuition. ${ }^{27}$ Erst diese Mischung macht die Musik interessant (für manche Ohren aber auch >chaotisch $<$ ).

Um eine Brücke zu anderen Feldern der Improvisation zu schlagen, etwa dem der Organisation (oder besser: des Organisierens, wie Karl Weick 1985 die Perspektive veränderte), muss man sich nur ansehen, wie Arbeit in der Welt der Musik organisiert wird, insbesondere in der Improvisierten. Da zeigt sich die materielle Seite des Spruches vom Jazz oder von der >Improvisation als Lebensform<. Hier arbeitet man fast ausschließlich in Projekten, bei denen sich Musiker temporär um einen originellen Kern (Idee, Stil, Musiker) sammeln. Zugleich sind sie in anderen Projekten tätig, meist in mehreren, ihren eigenen oder jenen anderer. Ensembles, die in mehr oder weniger fester Formation über Jahre und Dekaden zusammenarbeiten, werden immer seltener (nicht unbedingt zum Vorteil der Musikwelt insgesamt). Und/oder es ändern sich die Führungsverhältnisse in diesen Ensembles, wie etwa beim deutschen Ensemble Modern. Dort bestimmen die Musiker selbst, wer sie leiten soll, und zwar auch projektspezifisch: Den Dirigenten für dieses Stück oder diese Phase, jenen für andere. Hier nähern sich Kunst und Wirtschaft in ihrem Organisieren einander an. Insbesondere in Bereichen wissensintensiver Arbeit gibt es kaum mehr andere Formen des Arbeitens als die im Projekt, und auch hier zunehmend in Arrangements des »Multiprojektmanagements«.

In solchen Kontexten braucht man mehr von beidem: Improvisation und Reflexivität. Das, wie gesagt, widerspricht sich nicht im Bereich des Heavy Mental (Titel eines Stücks von Tim Berne). Damit nähert sich die Wirtschaft den Verhältnissen in den kreativeren Segmenten der Kunst an. Sie wird hier auch demokratischer, braucht mehr an Pluralismus, Selbstbestimmung und Subjektivität. Diktatoren swingen nicht, so hatte es Joachim Ernst Berendt einmal ausgedrückt (und Fundamentalisten aller Sorten sicher auch nicht). Was bleibt, ist die grundlegende Differenz: Die Seite der Kunst behält ihren deutlichen Überhang des Romantischen gegenüber dem Rationalisierungsideal der Moderne.

27 | Es gab daher auch immer wieder Versuche, das Verhältnis von Komposition und Improvisation in neuen Formen zu organisieren, z.B. im Konzept der Conduction (Butch Morris), der Comprovisation (u.a. John Wolf Brennan) oder des Instant Composing (Willem Breuker et al.). 


\section{Literatur}

Abbott, A. (1988): The System of Professions. An Essay on the Division of Expert Labor. Chicago, London: Univ. of Chicago Press.

Aristoteles (1991): Die Nikomachische Ethik. München: dtv (Orig. ca. 340 v. Chr.) Bahrdt, H.P. (1956): Fiktiver Zentralismus in den Großunternehmungen. In: Kyklos, Vol. IX, S. 483-491.

Bahrdt, H.P. (1996). Himmlische Planungsfehler. Essays zu Kultur und Gesellschaft. München: C.H. Beck.

Brunsson, N. (1993): Ideas and Actions. Justification and Hypocrisy as Alternatives to Control. In: Accounting, Organizations and Society, Jg. 18, S. 489-506.

Barley, N. (1997): Traumatische Tropen. Frankfurt a.M.: Fischer.

Barley, S.; Orr, J. (1997): Between Craft and Science. Technical Work in US Settings. Ithaka: Cornell Univ. Press.

Benjamin, W. (1980): Das Kunstwerk im Zeitalter seiner technischen Reproduzierbarkeit (1. Fassung, 1935). In: Gesammelte Schriften Band I, Werkausgabe Bd. 2, Frankfurt a.M.: Suhrkamp.

Boulding, K. (1958): The Skills of the Economist. Cleveland: Howard Allen Publ.

Brunsson, N. (1993): Ideas and Actions. Justification and Hypocrisy as Alternatives to Control. In: Accounting, Organizations and Society, Jg. 18, S. 489-506. Böhle, F. \& Weyrich, M. (Hg.) (2009): Handeln unter Unsicherheit. Wiesbaden: VS.

Böhle, F. (1989): Körper und Wissen - Veränderungen in der sozio-kulturellen Bedeutung körperlicher Arbeit. In: Soziale Welt, Jg. 40, Heft 4, S. 497-512.

Böhle, F. (2010): Arbeit als Handeln. In: F. Böhle; G.G. Voß \& G. Wachtler (Hg.): Handbuch Arbeitssoziologie. Wiesbaden: VS, S. 151-176.

Cage, J. (1973): Silence: Lectures and Writings. Wesleyan University Press.

Davis, E. (1989): Women's Intuition. Berkeley, CA: Celestial Arts.

Dewey, J. (1939/1989): Freedom and Culture. Buffalo, New York: Prometheus.

Dreyfus, H.L. (2000): Minds, Brains, and Computers: The Foundations of Cognitive Science. Oxford: Blackwell.

Ericsson, K.A. \& Charness, N.; et al. (eds.) (2006): The Cambridge Handbook of Expertise and Expert Performance. Cambridge: Cambridge Univ. Press.

Feyerabend, P.K. (1984): Wissenschaft als Kunst. Frankfurt a.M.: Suhrkamp.

Feyerabend, P.K. (1980): Erkenntnis für freie Menschen. Frankfurt a.M.: Suhrkamp.

Freidson, Eliot (2001): Professionalism. The Third Logic. On The Practice of Knowledge, Chicago.

Gigerenzer, G. (2007): Bauchentscheidungen. Die Intelligenz des Unbewussten und die Macht der Intuition. München: Goldmann.

Goldt, M. (1999): Okay Mutter, ich nehme die Mittagsmaschine, Zürich: Haffmanns. 
Graham, T. \& Ickes, W. (1997): When women's intuition isn't greater than men's. In: W. Ickes (Hg.): Empathic accuracy. New York: Guilford Press, p. 117-143.

Gruber, H. \& Ziegler, A. (Hg.) (1996): Expertiseforschung. Opladen: Westdeutscher Verlag.

Guillet de Monthoux, P. (1981): Vulgärkantianische Unternehmenslehre. Eine Einführung in die Kunst, Industrie und Technologie zu konstruieren. München: Leudemann.

Hagemann, N.; Tietjens, M. \& Strauß, B. (Hg.) (2007): Psychologie der sportlichen Höchstleistung: Grundlagen und Anwendungen der Expertiseforschung im Sport. Göttingen: Hogrefe.

Hölderlin, F. (1998): Hyperion oder der Eremit in Griechenland. Stuttgart: Reclam (Orig. 1790).

Joas, H. (1996): Kreativität des Handelns. Frankfurt a.M.: Suhrkamp.

Jörgensmann, T. \& Weyer, R.-D. (1991): Kleine Ethik der Improvisation: vom Wesen, Zeit und Raum, Material und Spontangestalt. Essen: Augemus Musikverlag.

Kant, I. (1974): Kritik der reinen Vernunft (Bd. 1). Frankfurt a.M.: Suhrkamp (Orig: 1787, 2. verb. Aufl.)

Kant, I.: (1974): Kritik der Urteilskraft. Frankfurt a.M.: Suhrkamp (Orig: 1790).

Kohlberg, L. (1997): Die Psychologie der Moralentwicklung. Frankfurt a.M.: Suhrkamp.

Latour, B. (2001): Das Parlament der Dinge. Für eine politische Ökologie. Frankfurt a.M.: Suhrkamp.

Luhmann, N. (2008): Rationalität in der modernen Gesellschaft. In ders.: Ideenrevolution. Beiträge zur Wissenssoziologie (hg. von A. Kieserling). Frankfurt a.M.: Suhrkamp, S. 186-233.

Marx, K. (1981): Die technologisch-historischen Exzerpte (hg. v. H.-P. Müller). Frankfurt a.M.: Ullstein (Orig. 1858).

Mieg, H.A. (2001): The social psychology of expertise. Case studies in research, professional Domains, and expert roles. New Jersey: Lawrence Erlbaum.

Mieg, H. \& Pfadenhauer, M. (Hg.) (2005): Professionelle Leistung - Professionelle Performanz. Positionen der Professionensoziologie. Konstanz: UVK.

Mieg, H. \& Pfadenhauer, M. (Hg.) (2005): Professionelle Leistung - Professionelle Performanz. Positionen der Professionensoziologie. Konstanz: UVK.

Miettinen, R. (2009): Dialogue and Creativity Activity Theory in the Study of Science, Technology and Innovations. Berlin: Lehmanns Media.

Moldaschl, M. (2005): Ressourcenorientierte Analyse von Belastung und Bewältigung in der Arbeit. In: M. Moldaschl (Hg.): Immaterielle Ressourcen. München: Hampp, S. 243-279.

Moldaschl, M. (2006): Innovationsfähigkeit, Zukunftsfähigkeit, Dynamic Capabilities. Managementforschung 16, 1-36. 
Moldaschl, M. (2008): Strategisches Management - Ansätze, blinde Flecken, Alternativen. In: U. Götze, R. Lang (Hg.): Strategisches Management. Wiesbaden: Gabler, S. 11-40.

Moldaschl, M. (2010): Das Elend des Kompetenzbegriffs. In: M. Stephan u.a. (Hg.): 25 Jahre ressourcen- und kompetenzorientierte Forschung. Wiesbaden: Gabler, S. 3-40.

Neuweg, H.G. (1999): Könnerschaft und implizites Wissen. Münster: Waxmann.

Ortmann, G. (2003): Regel und Ausnahme. Paradoxien sozialer Ordnung. Frankfurt a.M.: Suhrkamp.

Roberts, K.H. (1990): Some Characteristics of High-Reliability Organizations. Organization Science, 1, 160-177.

Ryle, G. (1969): Der Begriff des Geistes. Stuttgart: Reclam. (The Concept of Mind. London: Hutchinson 1941).

Schmid B. \& Gérard, G. (2008): Intuition und Professionalität. Systemische Transaktionsanalyse in Beratung und Therapie. Heidelberg: Carl-Auer-Verlag. Schön, D. (1983): The Reflective Practitioner. How Professionals Think in Action. New York: Basic Books.

Schulman, P.R. (1993): The Negotiated Order of Organizational Reliability. Administration \& Society, 25(3), 353-372.

Shaw, P. \& Stacey, R. (eds.) (2006): Spontaneity and Improvisation in Organizational Change. London et al.: Routledge.

Schmid B. \& Gérard, G. (2008): Intuition und Professionalität. Systemische Transaktionsanalyse in Beratung und Therapie. Heidelberg: Carl-Auer-Verlag. Sternberg, R.J. \& Horvath, J.A. (1999): Tacit Knowledge and Professional Practice. Tarde, G. de (2003): Die Gesetze der Nachahmung. Frankfurt a.M.: Suhrkamp (Orig: Les lois de l'imitation 1890).

Volpert, W. (1994): Wider die Maschinenmodelle des Handelns. Aufsätze zur Handlungsregulationstheorie, Lengerich.

Weick, K.E. (1985): Der Prozeß des Organisierens. Frankfurt a.M.: Suhrkamp.

Weick, K.E. \& Suthcliffe, K.M. (2003): Das Unerwartete managen. Wie Unternehmen aus Extremsituationen lernen. Stuttgart: Klett-Cotta. [Orig.: Managing the Unexpected; San Francisco: Wiley 2001]. 


\section{Improvisation durch objektivierendes und subjektivierendes Handeln}

Fritz Böhle

In diesem Beitrag wird ein Konzept menschlichen Handelns vorgestellt, das sich von planmäßigem Handeln grundlegend unterscheidet. Ausgangspunkt ist der Umgang mit Unwägbarkeiten und Ungewissheit in Arbeitsprozessen. Anhand von Untersuchungen in unterschiedlichen Arbeitsbereichen wird gezeigt, wie Menschen ohne Planung, formelle Regeln und explizites Wissen erfolgreich Ziele erreichen und Probleme lösen (Abschnitt 2). Daran anschließend wird diskutiert, inwieweit hier Ähnlichkeiten zwischen der Improvisation in der Musik und in der Arbeit bestehen (Abschnitt 3). Abschließend wird der Frage nachgegangen, ob und inwieweit musikalische Improvisation als Modell für die Arbeit in Unternehmen dienen kann - und umgekehrt (Abschnitt 4). Der Beitrag beginnt mit einer Begründung der gewählten Perspektive der Betrachtung (Abschnitt 1).

\section{IMPROVISATION: Offene Fragen jenseits von Entmystifizierung}

Es besteht weitgehend Einigkeit darin, dass sich Improvisation auf Ungeplantes und Unvorhersehbares bezieht. ${ }^{1}$ Weit weniger Einigkeit besteht allerdings hinsichtlich des Kreativen und Schöpferischen bei der Improvisation. Wie Kurt bei einem internationalen Vergleich der (Musik-)Improvisation hervorhebt, wird in der westlichen Kultur Improvisation mit dem schöpferischen Hervorbringen von Neuem und dem Ausdruck von Individualität und Subjektivität assoziiert, wäh-

1 | So beispielsweise in dieser Definition: "Improvisation bedeutet im allgemeinen Sprachgebrauch unerwartetes, unvorbereitetes [...], unvorhergesehenes Handeln, genauer: eine Handlung (u.U. auch als Ergebnis einer Handlung), die in wesentlichen Aspekten als unvorhergesehen (eventuell auch unvorhersehbar, lat. improvisibilis) erscheint - und zwar nicht nur für die von der Handlung betroffene(n) Person(en), sondern auch für die handelnde(n) Person(en)“ (Frisius 1996: 538, zit.n. Figueroa-Dreher 2012: 3). 
rend beispielsweise in Indien die Improvisation in der Musik zwar einen hohen Stellenwert hat, zugleich aber die Musiker »gemessen am westlichen Kreativitätsideal [...| weder originell noch schöpferisch sind « (Kurt 2008: 29). ${ }^{2}$ Zugleich hat aber die Improvisation in Indien eine hohe soziale Anerkennung und Stellung, während sie in der westlichen Kultur eine Geringschätzung erfahren hat. Sie konnte sich im Bereich der Musik lediglich im Jazz entfalten, während sie - insbesondere im Alltagssprachgebrauch - insgesamt eher mit Dilettantismus und mangelnder Perfektion assoziiert wird.

Vor diesem Hintergrund ist es bemerkenswert, dass seit den 1990er Jahren verstärkt die Improvisation von der Organisationstheorie entdeckt und als Leitbild für wirtschaftliche Unternehmen propagiert wird (vgl. als Überblick Eikels 2o11: 125; Dell 2012). Improvisation steht hier im Zusammenhang mit der Erkenntnis von Grenzen der Planung, Berechenbarkeit und Beherrschbarkeit sowohl der Beziehung zur Umwelt als auch organisationsinterner Prozesse. Vor allem die Improvisation im Jazz dient dabei als Modell für eine neue Praxis in Unternehmen. Doch aus dem Verweis auf das Unplanbare und Unvorhersehbare in der Improvisation folgt noch nicht, dass die »[...] Jazzmetapher wirklich einen substanziellen Beitrag zur Organisationstheorie leisten kann« (Dell 2012: 279). Bei der Übertragung auf wirtschaftliche Organisationen stellt sich u.E. vor allem die Frage, wie es möglich ist, zu improvisieren und damit zugleich Ziele zu erreichen und Probleme zu lösen. Die Diagnose von Grenzen der Planung besagt allein noch keineswegs, dass nun nicht mehr geplant wird. $\mathrm{Zu}$ beobachten ist vielmehr, dass lediglich auf Modifizierung von Planung etwa durch Dezentralisierung, Prozessualisierung wie auch Risikomanagement u.a. umgestellt wird. Solche Strategien richten sich auf eine weitmögliche Planung >trotz< Ungewissheit (vgl. Böhle/ Busch 2012). Auch die Improvisation könnte sich letztlich >nur< als eine modifizierte Planung erweisen. Zu berücksichtigen ist dabei allerdings, dass sich solche Strategien der Modifizierung weitestmöglich am bereits Bekannten festhalten und das hiervon >Abweichende nur in diesem Bezugsrahmen wahrnehmen bzw. wahrnehmen können. ${ }^{3}$ Die Betrachtung von Improvisation als modifizierte Planung kann zu einem realistischen Verständnis und einer Entmystifizierung beitragen. Und so ist es zweifellos richtig und wichtig, darauf aufmerksam zu machen, dass sich die Improvisation im Jazz mehr oder weniger an festgelegten Harmonien, Rhythmen sowie tonalen Folgen orientiert und damit keineswegs völlig >frei<, >spontan< oder >intuitiv< ist. Doch ist dies lediglich das Material und Gerüst. Jeder Musiker und Zuhörer weiß, dass daraus noch keine >Musik< entsteht, oder anders ausgedrückt: Das Material und dessen Kenntnis allein entscheiden (noch)

2 | Bei der Improvisation im Rahmen des Raga geht es nicht primär darum, "Neues" zu schaffen, sondern es gilt "nur" zu entdecken und zu entfalten, "was im Raga immer schon der Möglichkeit nach enthalten war" (Kurt 2008: 30).

3 | Sie können damit systemtheoretisch formuliert ınicht sehen, was sie nicht sehen können, (Luhmann). 
nicht darüber, ob eine Improvisation >gelingt<, ob sich etwas >ereignet< und etwas >entsteht<. Im konkreten Fall ist im Verlauf der Improvisation jeweils eine Vielzahl von Optionen möglich - auch dann, wenn auf bereits bekannte Harmonien, Tonfolgen und Rhythmen zurückgegriffen wird. So bleibt (zumindest) die Frage offen, wie im konkreten Fall >Entscheidungen < über mögliche Optionen getroffen werden und der konkrete Verlauf einer Improvisation zustande kommt. Denn soll der Begriff der Improvisation (überhaupt) einen Sinn ergeben, so ist er nicht nur in Relation zu Planung zu sehen, sondern vor allem auch zur bloßen Routine und Wiederholung des immer Gleichen.

Vor diesem Hintergrund soll im Folgenden nicht das Regelhafte und ggf. Planbare aufgedeckt, sondern vielmehr das hierdurch nicht Erfassbare genauer beleuchtet werden. Dabei wird die Improvisation in zweifacher Perspektive betrachtet:

- Unser Ausgangspunkt ist nicht die Improvisation in der Musik, sondern das Handeln in Organisationen und hier speziell Arbeit. Im Mittelpunkt steht der Umgang mit Unwägbarkeiten und Ungewissheit in Arbeitsprozessen. Unsere Absicht ist es, aufzuzeigen, wie in Arbeitsprozessen ohne vorherige Planung, explizites Wissen und explizite Regeln Ziele erreicht und Probleme gelöst werden.

- Unser Blick richtet sich dabei auf eine bisher wenig beachtete und weithin verdeckte Seite von Arbeit. Sie unterscheidet sich substanziell von planmäßigem Handeln - und zwar sowohl hinsichtlich der Planung als auch hinsichtlich anderer Elemente des Handelns, wie Denken, Wahrnehmen und Beziehung zur Umwelt. Wir bezeichnen sie als >erfahrungsgeleitet-subjektivierendes Handeln<.

- Auf dieser Grundlage wird der Frage nachgegangen, inwiefern die Improvisation in der Musik ebenfalls auf einem solchen Handeln beruht und ob sich hierauf eine neue Begegnung von künstlerischer Praxis und Ökonomie bezieht bzw. beziehen könnte.

\section{Arbeit als objektivierendes UND SUBJEKTIVIERENDES HANDELN}

In der Sozialwissenschaften wird menschliches Handeln als ein intentionales, zielorientiertes Handeln bestimmt. Paradigmatisch hierfür sind die Konzepte des zweckrationalen Handelns von Weber (1956/1964) und des entwurfsbezogenen Handelns (Schütz 2004). Ein wesentliches Merkmal menschlichen Handelns besteht demnach darin, dass vor der praktischen Durch- und Ausführung des Handelns die Ziele, Mittel und Folgen sowie auch die Berücksichtigung sozialer Normen und Werte festgelegt und zwischen möglichen Alternativen entschieden wird. Das Handeln wird solchermaßen geplant - auch wenn die Planung nicht immer als solche bewusst ist. 


\section{Arbeit als objektivierendes Handeln}

Bewusst und explizit ist die Planmäßigkeit in besonderer Weise bei der Arbeit und beim Arbeitshandeln. So hat Marx dies bekanntlich als das besondere Merkmal menschlicher Arbeit gegenüber den mit Arbeit vergleichbaren Leistungen von Tieren hervorgehoben (Marx 1974, S. 193). In der psychologischen Theorie der Handlungsregulation wird die Planung des Arbeitshandelns als das entscheidende Merkmal für die Selbstregulation der Arbeit bestimmt (vgl. Hacker 2005). Dies unterstreicht, dass es hier nicht um die Planung von Arbeitsprozessen durch das Management geht, sondern vielmehr um die Planung durch den Arbeitenden. ${ }^{4}$ Mit der Planmäßigkeit des Handelns verbinden sich noch weitere Merkmale, die allerdings zumeist kaum beachtet bzw. als mehr oder weniger selbstverständlich erachtet werden. Joas hat hier beispielsweise darauf aufmerksam gemacht, dass ein solches Handeln eine besondere (Selbst-)Kontrolle des Körpers voraussetzt, die jedoch kaum (mehr) bewusst ist (Joas 1992). Für unsere Betrachtung erscheinen drei weitere Merkmale bedeutsam. Sie beziehen sich auf Wissen und Denken, die sinnliche Wahrnehmung und die Beziehung zur Umwelt: ${ }^{5}$

Wenn die Planung des Handelns dem praktischen Handeln vorausgeht, ist ein Wissen notwendig, das unabhängig von Erfahrung vorliegt, die durch das praktische Handeln entsteht. Dem entspricht in besonderer Weise ein wissenschaftlich begründetes Wissen und damit verbunden logisch-analytisches Denken. Soweit Erfahrung eine Rolle spielt, bezieht sich dies entweder auf die durch vorangegangene Handlungen gewonnenen Erfahrungen und die Überprüfung des Erfolgs der Planung oder auf die Habitualisierung und Routinisierung von Handlungsvollzügen. Die sinnliche Wahrnehmung spielt dabei ebenso wie der Körper eine eher untergeordnete und nachrangige Rolle. Sie hat sich darauf zu richten, Informationen aus der Umwelt möglichst exakt und objektiv zu registrieren und der verstandesmäßigen Interpretation zuzuführen. Ohne eine solche verstandesmäßige Durchdringung erscheint die sinnliche Wahrnehmung als blind und wenig zuverlässig. Die verstandesmäßige Lenkung und Verarbeitung der sinnlichen Wahrnehmung ist umso eher möglich, als sie vom subjektiven Empfinden getrennt wird. Am ehesten erscheint daher die visuelle Wahrnehmung, im Unterschied zu den sogenannten niederen Sinnen wie Tasten, Riechen und Schmecken, für die Orientierung und Entscheidungsfindung geeignet. Der Körper wird weitgehend ruhiggestellt oder wie ein stechnisches Instrument< zur Ausführung des praktischen Handelns eingesetzt. Und schließlich beruht ein solches Handeln auf einer distanzierten, sachlich-affektneutralen Beziehung zur Umwelt. Im Besonderen gilt dies für den Umgang mit materiellen und immateriellen Objek-

4 | Die Trennung von Planung und Durchführung, so wie sie in der tayloristischen Arbeitsorganisation vollzogen wird, degradiert demnach Arbeit zur bloßen Ausführung und quasi mechanisch vollzogenen Tätigkeit.

5 | Siehe hierzu ausführlicher auch Böhle 2003. 
ten. Dem widerspricht nicht, dass mit Engagement und ggf. auch Leidenschaft Probleme aufgegriffen und Ziele verfolgt werden. Solche Gefühle sind jedoch lediglich als Motivation und Antrieb einbezogen, während sie bei der Planung und Durchführung des Handelns als störend erscheinen und dementsprechend auszuschalten sind. Das planmäßige Handeln wird auch als planmäßig-rationales oder planmäßig-objektivierendes Handeln bezeichnet. Mit Ersterem wird die Rolle verstandesmäßig geleiteter Wahrnehmung und Entscheidungen betont; Letzteres bezieht sich auf die Orientierung an allgemeinem und - im Prinzip subjektunabhängig gültigem Wissen und entsprechenden Regeln sowie auf eine Wahrnehmung der Umwelt als vom menschlichen Subjekt unterschiedenes und getrenntes Objekt. Da mit dem Begriff >rational< oft sehr Unterschiedliches assoziiert wird - von der Dominanz des Verstandesmäßigen bis zu Effizienz und Nützlichkeit -, erscheint uns die Bezeichnung >objektivierend < neutraler; sie bezieht sich auch umfassender auf die weiteren mit der Planmäßigkeit verbundenen Elemente des Handelns.

Planmäßig-objektivierendes Handeln ist in der Praxis ein sehr wirkmächtiges Leitbild für >richtiges< Handeln - und zwar insbesondere, wenn es sich auf die Lösung von Problemen und die Herstellung nützlicher Dinge bezieht. Dies besagt auch: Je mehr sich das konkrete Handeln diesem Leitbild der Planmäßigkeit annähert, umso eher kann es mit sozialer Anerkennung und Wertschätzung rechnen - und zwar selbst dann, wenn die Ziele und Ergebnisse des Handelns als zwecklos erscheinen. Die Komposition in der Musik und die notengetreue Wiedergabe bei der Aufführung beziehen sich hierauf und sind ein Beispiel dafür, dass sich Kunst in modernen Gesellschaften zwar als eigenständiger Bereich ausdifferenziert hat, zugleich aber auch durch allgemeine gesellschaftliche Entwicklungen beeinflusst und geprägt wird. ${ }^{6}$ Die Diagnose und Propagierung des Improvisierens im Bereich der Ökonomie ist vor diesem Hintergrund insofern bemerkenswert, als hiermit die Konnotation von nützlich und problemlösend mit planmäßigem Handeln aufgebrochen wird. Und zugleich erscheint das Bemühen, bei der Improvisation Elemente des Planmäßigen oder zumindest Regelhaften aufzudecken - seien sie bewusst oder unbewusst - als Versuch, das Improvisieren als ein Handeln auszuweisen, das sich in den Kanon für >richtiges< Handeln einfügt und die damit verbundene soziale Wertschätzung und Anerkennung gewinnt. Im Folgenden wird demgegenüber in eine entgegengesetzte Richtung argumentiert: Es sei gezeigt, in welcher Weise Menschen noch in einer anderen Weise als durch planmäßiges Handeln Probleme lösen und nützliche Dinge herstellen können. Dabei ist es notwendig, den Blick nicht nur auf Unterschiede gegenüber der Planmäßigkeit des Handelns zu richten, sondern auch auf Unterschiede im Denken, der sinnlichen Wahrnehmung und der Beziehung zur Umwelt.

6 | In dieser Perspektive hat beispielsweise Max Weber den Prozess gesellschaftlicher Rationalisierung auch in der Musik nachgewiesen (vgl. Weber 1921). 


\section{Arbeit als subjektivierendes Handeln}

Soweit bisher in den Sozialwissenschaften nicht-planmäßiges menschliches Handeln analysiert und bestimmt wird, erscheint es als ein Handeln, das nicht oder nur begrenzt bewusst reguliert wird - ob es nun von Tradition, sozialen Normen, Emotionen und Affekten oder körperlicher Dynamik und inkorporierten Praktiken geleitet wird.7 Es erscheint - trotz unterschiedlicher Akzentuierungen - durchweg als prä-reflexiv. Vor allem in der neueren Diskussion wird argumentiert, dass dies dem alltäglichen Handeln weit mehr entspricht als ein planmäßig-objektivierendes Handeln und dass Letzteres nur dann notwendig wird, wenn neuartige Anforderungen und problematische Situationen auftreten. Das Konzept des erfahrungsgeleitet-subjektivierenden Handelns hingegen beruht auf empirischen Untersuchungen, die zeigen, dass gerade bei neuartigen Anforderungen und problematischen Situationen das planmäßig-objektivierende Handeln an Grenzen gerät. Es entstehen Situationen der Ungewissheit und Unbestimmtheit. Ausreichendes Wissen oder ausreichende Informationen für eine Planung des Handelns sind nicht verfügbar; und zudem muss zumeist innerhalb eines begrenzten zeitlichen Rahmens entschieden und gehandelt werden. Das in der betriebswirtschaftlichen Entscheidungs- und Organisationstheorie entwickelte Konzept der »bounded rationality« (Simon 1957) besagt, dass in solchen Situationen Defizite auf der Ebene individuellen Handelns durch die Organisation kompensiert werden und sich der Erfolg der Handlung nicht an der theoretisch besten, sondern an der praktisch zufriedenstellenden Lösung bemisst. ${ }^{8}$ Wie Untersuchungen in verschiedenen Arbeitsbereichen zeigen, werden solche Situationen der Ungewissheit und Unbestimmtheit jedoch noch auf eine grundlegend >andere < Weise erfolgreich bewältigt. Typisch hierfür sind Situationen, in denen bei der Arbeit mit hochtechnischen Systemen nicht vorhersehbare Unwägbarkeiten im technischen Ablauf auftreten. ${ }^{9}$ Weiterführende Untersuchungen hierzu kommen zu dem Ergebnis, dass nahezu in sämtlichen Arbeitsbereichen der Umgang mit Unwägbarkeiten in technischen und organisatorischen Abläufen eine zentrale Anforderung an menschliche Arbeit ist (vgl. Böhle u.a. 2004) und dass sich bei fortschreitender Technisierung und Verwissenschaftlichung die Anforderungen an menschliche Arbeit zunehmend auf das richten, was sich der wissenschaftlich-technischen Beherrschung entzieht (Deutschmann 2003, S. 484).

7 | Siehe hierzu beispielsweise die Typologie des Handelns bei Weber (1956/1964), das Konzept des Habitus bei Bourdieu (1987), die Theories of Practice (Reckwitz 2000, Schatzki 1999) sowie das Konzept kreativen Handelns von Joas (1992).

8 | Siehe hierzu und zu weiteren Erklärungsansätzen der Enscheidung unter solchen Bedingungen ausführlicher Neumer 2012.

9 | Diese können durch Qualitätsunterschiede bei den verarbeiteten Materialien und Rohstoffen, Verschleißerscheinungen oder externe Einflüsse wie Witterung und Temperatur verursacht sein (vgl. Böhle/Rose 1992). 
In besonderer Weise treten Ungewissheiten und Unbestimmtheiten bei Dienstleistungen im Kontakt zu Kunden und Klienten, bei der Arbeit in Projekten sowie im Rahmen von Produkt- oder Prozessinnovationen auf. Dabei findet sich in der Praxis ein Umgang mit Unbestimmtheit und Ungewissheit, der sich von einem planmäßig-objektivierenden Handeln sowohl in der Vorgehensweise als auch in den damit verbundenen mentalen Prozessen, der sinnlichen Wahrnehmung und Rolle des Körpers sowie der Beziehung zur Umwelt grundlegend unterscheidet. ${ }^{10}$ Dieser Umgang lässt sich als erfahrungsgeleitet-subjektivierendes Handeln bezeichnen. Die Bezeichnung erfahrungsgeleitet bezieht sich auf die Rolle von Erfahrung im Sinne des prozessualen >Erfahrens $<$ und >Erfahrung-Machens $<$ sowie >Sich-in-Gefahr-Begebens<. Dies unterscheidet sich von einem Verständnis von Erfahrung als Routinisierung oder als Nutzung von in der Vergangenheit gesammelten Erfahrungen. Bei neuartigen, unbekannten Situationen kann dies durchaus hinderlich sein. Erfahrung im Sinne des >Erfahrens< hingegen bezieht sich vielmehr gerade auf die Auseinandersetzung und Erkundung ex ante nicht bekannter und nicht vorhersehbarer Eigenschaften und Verhaltensweisen der Umwelt. Die Bezeichnung subjektivierend weist einerseits auf die handlungsleitende Rolle sogenannter subjektiver Faktoren hin, etwa Gefühle und subjektives Empfinden, und andererseits auf die Subjektivierung der Umwelt (siehe unten). Die Unterscheidung zwischen objektivierendem und subjektivierendem Handeln ist daher nicht zu verwechseln mit der zwischen fremd- und selbstbestimmtem Handeln. Auch das objektivierende Handeln kann autonom und selbstgesteuert sein - oder anders ausgedrückt, autonomes, selbstgesteuertes Handeln kann sowohl objektivierend als auch subjektivierend erfolgen. Im Einzelnen sind wesentliche Merkmale des subjektivierenden Handelns in Arbeitsprozessen:

\section{Vorgehensweise}

Von außen entsteht leicht der Eindruck eines >Sich-Treiben-Lassens eines >unüberlegten Aktivismus<. Eine genauere Betrachtung lässt demgegenüber ein herantastendes, explorativ-entdeckendes und dialogisch-interaktives Vorgehen erkennen. Praktisches Handeln dient hier nicht nur dazu, Entscheidungen zu vollziehen oder zu überprüfen, sondern es richtet sich darauf, Anforderungen sowie Möglichkeiten ihrer Bewältigung auf dem Weg praktischen Erfahrens zu eruieren. So verbindet sich mit diesem Vorgehen zwar eine bestimmte Absicht - wie beispielsweise die Gewährleistung eines reibungslosen technischen Ablaufs oder der Zufriedenheit von Kunden -, wie und mit welchem konkreten Ergebnis dies erreicht wird, ist jedoch nicht ex ante festgelegt. Man tritt dementsprechend >in einen Dialog < mit den Dingen und wartet ihre >Antwort< ab. Im Unterschied zu einem schrittweisen, inkrementellen Entscheiden vollzieht sich dabei das praktische Handeln in einem kontinuierlichen Fluss von Aktion und

10 | Siehe zu hierzu vorliegenden empirischen Untersuchungen insbesondere Böhle/ Rose 1992, Carus/Schulze 1995, Böhle u.a. 2004, Pfeiffer 2007, Weishaupt 2006. 
Reaktion. So sprechen beispielsweise technische Fachkräfte davon, dass sie bei Unwägbarkeiten von technischen Anlagen mit diesen >kämpfen< und/oder mit ihnen >zusammenarbeiten<, um einen reibungslosen Ablauf zu gewährleisten. Leitend ist der Grundsatz, die Eigenheiten und Möglichkeiten des >Gegenübers zu erkunden, um sich hierauf einzustellen und die eigenen Absichten hiermit zu verbinden. Dies ist nicht mit einem bloß reaktiven Handeln oder passiver Anpassung bis hin zur Selbstaufgabe zu verwechseln. Entscheidend ist vielmehr, dass das eigene Handeln und die eigenen Absichten in »Abstimmung « mit den jeweiligen Gegebenheiten und deren Widerständen wie auch Potenzialen zu realisieren versucht werden.

\section{Sinnliche Wahrnehmung}

Um in der beschriebenen Weise auf konkrete Gegebenheiten einwirken und reagieren $\mathrm{zu}$ können, ist eine besondere sinnliche Wahrnehmung notwendig. Sie konzentriert sich nicht nur auf Informationen, die präzise und exakt definiert und verstandesmäßig beurteilt werden können. Eine wesentliche Rolle spielt vielmehr die Wahrnehmung diffuser, vielschichtiger Eigenschaften und Wirkungsweisen der infrage stehenden Gegebenheiten. Beispiele hierfür sind Geräusche bei technischen Prozessen, die Stimmigkeit eines Ablaufs, die Atmosphäre in einer Gruppe. Diese sinnliche Wahrnehmung ist verbunden mit subjektivem Empfinden und leiblichem Spüren. Ein Geräusch wird als warm, rund oder schräg, eine Atmosphäre als wohltuend oder erdrückend empfunden. Dies bezieht sich nicht nur auf ein >inneres Erleben<, es informiert vielmehr über äußere Gegebenheiten. Ein schräges Geräusch informiert über sich anbahnende Störungen, eine gespannte Atmosphäre macht auf Konflikte aufmerksam, ein mulmiges Gefühl weckt die Sensibilität dafür, dass etwas schief läuft. Die sinnliche Wahrnehmung liefert nicht nur einen >Rohstoff<, der verstandesmäßig strukturiert und interpretiert werden muss, sondern stellt vielmehr selbst bedeutungsvolle Zusammenhänge her. So werden etwa bei der visuellen Wahrnehmung einzelne Elemente verknüpft und zu einem >Bild<konfiguriert. Dies ergibt sich nicht unmittelbar aus der Sache, sondern ist eine subjektive Leistung. Es handelt sich hier gewissermaßen um eine >Intelligenz der Sinneく (Arnheim 1996). Sie zeigt sich auch bei der Verknüpfung von unmittelbar wahrnehmbaren Gegebenheiten mit (visuellen) Vorstellungen von damit zusammenhängenden, aber nicht unmittelbar wahrnehmbaren Gegebenheiten. Man sieht damit >mehr<, als man sieht. Auf diese Weise wird es möglich, sich anhand >objektiv< spärlicher und disparater Informationen ein komplexes >Bild< von den infrage stehenden Gegebenheiten zu machen. Diese Verbindung von unmittelbarer Wahrnehmung und Imagination kann auch bei der akustischen Wahrnehmung von Geräuschen u.Ä. stattfinden. 


\section{Denken}

Die empfindende und spürende Wahrnehmung unterliegt keiner verstandesmäßig geleiteten Lenkung oder Verarbeitung. Dies besagt jedoch nicht, dass mentale Prozesse ausgeschaltet sind und nur Gefühle zählen. Es wird durchaus auch gedacht, jedoch nicht analytisch und logisch schlussfolgernd. Ein wesentliche Rolle spielt vielmehr ein in praktisches Handeln eingebundenes Denken im Sinne einer »reflection in action« (Schön 1983/2002). Denken vollzieht sich hier wahrnehmungs-, verhaltens- und handlungsnah und ist assoziativ, analog und bildhaft. Assoziationen erfolgen dabei nicht beliebig und willkürlich, sondern sind gegenstandsbezogen und folgen einer aus der Sache sich ergebenden >Logik<.

\section{Beziehung zur Umwelt}

Dialogisch-interaktives Vorgehen, spürende Wahrnehmung sowie wahrnehmungs- und handlungsbezogenes Denken sind analytisch, aber nicht in der Praxis trennbar. Sie bedingen sich wechselseitig und beruhen auf einer Beziehung zur Umwelt, die sich durch Nähe, Einheit und Verbindung auszeichnet. Im Unterschied zum planmäßig-objektivierenden Handeln wird Gegenständliches nicht nur als Objekt betrachtet, sondern als etwas, das Ähnlichkeiten mit dem handelnden Subjekt aufweist und mit dem eine Verbundenheit besteht. Man steht einer Sache nicht distanziert >gegenüber<, sondern bildet eine >Einheit< und wird zum Teil einer gemeinsamen Sache. Die >Vermenschlichung< sachlicher Gegebenheiten und ihre Wahrnehmung als etwas Lebendiges ist hier keineswegs eine bloße subjektive Projektion. Man bezieht sich hier vielmehr - durchaus realistisch - auf Eigenschaften von materiellen und immateriellen Objekten ebenso wie menschlichen Subjekten, die als >lebendige erscheinen und daher in ihrem Verhalten bzw. Handeln Unbestimmtheiten und Ungewissheit enthalten. Auf einem solchen subjektivierenden Verhältnis zur Welt beruht auch die Orientierung an Gemeinsamkeiten und Ähnlichkeiten, und hierauf beruhen wiederum die empathische Beziehung zur Umwelt, der subjektive - gefühlsmäßige und körperliche - Nachvollzug äußerer Gegebenheiten und die Synchronisation des eigenen Handelns mit der Umwelt.

Das Konzept des subjektivierenden Handelns beruht auf umfangreichen empirischen Untersuchungen (siehe oben). Auf theoretischer Ebene lässt es sich durch unterschiedliche Forschungsansätze, die sich bisher allerdings überwiegend nur auf einzelne der genannten Aspekte richten, fundieren: So beispielsweise hinsichtlich der geschilderten Vorgehensweise durch die Konzepte situativen Handelns (Suchman 1987/2007); unter Bezug auf die sinnliche Wahrnehmung insbesondere durch die phänomenologischen Theorien des >leiblichen Zur-WeltSeins< von Merleau-Ponty (1966) und Hermann Schmitz (1978) sowie des impliziten Wissens (Polanyi 1985); für das Denken vor allem durch Erkenntnisse aus der kognitionspsychologisch ausgerichteten Expertiseforschung, die die Rolle analogen und synthetischen Denkens sowie eines in praktisches Handeln eingebundenen Denkens bei der Problemlösung aufzeigen; und schließlich unter 
Bezug auf die besondere subjektivierende Beziehung zur Umwelt durch das ebenfalls in phänomenologischen Theorien entwickelte Konzept der >leiblichen Kommunikation< und >Einleibung< (Schmitz 1978; 1980, S. 23; 1994). ${ }^{11}$ Bevor wir der Frage nachgehen, inwiefern zwischen dem subjektivierenden (Arbeits-)Handeln und der Improvisation in der Musik Ähnlichkeiten bestehen, kurz noch eine Ergänzung:

Oben wurde das erfahrungsgeleitet-subjektivierende Handeln bei der Arbeit mit materiellen und immateriellen Gegenständen (Produktion, technische Entwicklung usw.) sowie Menschen (Dienstleistungen) dargestellt. Darüber hinaus findet sich in der Praxis das subjektivierende Handeln auch bei der sozialen Interaktion zur wechselseitigen Abstimmung und Kooperation. Dem planmäßig-objektivierenden Handeln entspricht hier eine diskursive Koordinierung und die von Habermas allgemein konzipierte kommunikative Rationalität (vgl. Schwarzbach 2005). Charakteristisch hierfür sind die sprachliche Kommunikation und die Verständigung zur gemeinsamen Entscheidungsfindung. Beim subjektivierenden Handeln ist hingegen die wechselseitige Abstimmung und Kooperation unmittelbar in das praktische Handeln eingebunden. Ob und wie kooperiert wird, bestimmt sich damit im und durch den Prozess der Kooperation. ${ }^{12}$ Grundlegend für die wechselseitige Verständigung ist dabei die sinnliche Wahrnehmung sowohl anderer Akteure als auch von Gegenständen, auf die sich das gemeinsame Handeln bezieht und/oder die in das Handeln einbezogen werden. Solche Gegenstände dienen als Medien wechselseitiger Verständigung, indem an ihnen etwas demonstriert wird oder indem sie etwas >mitteilen<, das ein gemeinsames und aufeinander abgestimmtes Handeln hervorbringt und ermöglicht. Konkrete Gegenstände werden damit als Quasi-Akteure in den Interaktions- und Kooperationsprozess einbezogen. Exemplarisch hierfür ist, dass Probleme und Unstimmigkeiten in technisch-organisatorischen Abläufen >vor Ort< anhand der infrage stehenden Gegebenheiten und nicht hiervon abgetrennt in >Meetings< besprochen werden. Dies ist umso eher möglich, als die Beteiligten über gemeinsame Erfahrungen und ein gemeinsames Erfahrungswissen über die infrage stehenden Sachverhalte verfügen. ${ }^{13}$ Die für das subjektivierende Handeln charakteristische Orientierung an Ähnlichkeiten und Gemeinsamkeiten der Umwelt ist bei der wechselseitigen Abstimmung und Kooperation eine wesentliche Grundlage für das subjektive Nachvollziehen wie auch Antizipieren des Handelns und Verhaltens anderer. Ein Beispiel hierfür ist die Entwicklung eines gemeinsamen Arbeitsrhythmus oder Arbeitsstils. Dies verweist auch ein weiteres Mal auf die

11 | Siehe ausführlicher zur theoretischen Fundierung subjektivierenden Handelns Böhle 2009 sowie Böhle/Milkau 1988.

12 | Siehe hierzu ausführlicher Böhle/Bolte 2002, Bolte/Porschen 2006, Porschen 2010. 13 | Erfahrung und Erfahrungswissen beziehen sich hier ebenfalls vor allem auf gemeinsames "Erfahren " und "Erfahrung-Machen ". 
Notwendigkeit einer sinnlichen Wahrnehmung, die diffuse und vielschichtige >Informationen< spürend und empfindend aufnimmt.

\section{Subjektivierendes Handeln bei der Improvisation IN DER MUSIK}

Speziell im Arbeitsbereich ist das subjektivierende Handeln immer auch mit einem objektivierenden Handeln verbunden, wobei Letzteres zumeist dominiert. Wie die hierzu vorliegenden empirischen Untersuchungen zeigen, werden Organisationen und Arbeitsprozesse keineswegs umfassend unbestimmt und ungewiss, wie dies oft bei der Diskussion von Improvisation in Organisationen anklingt oder assoziiert wird. Es kommt vielmehr zunehmend zu einer Verschränkung von Planung und Nicht-Planung bzw. Planbarkeit und Nicht-Planbarkeit. Diese Dimensionen sind nicht (mehr) klar getrennt und können nicht mehr jeweils unterschiedlichen Bereichen und Entwicklungen zugeordnet werden, wie dies beispielsweise traditionell bei der Planung der Produktion einerseits und der weitgehenden Offenheit von Forschung und Entwicklung andererseits in Unternehmen der Fall war. So wird zum einen nun die Planung auch auf Prozesse ausgeweitet, die traditionell hiervon weitgehend ausgenommen wurden, wie beispielsweise Forschung und Entwicklung sowie Dienstleistungen an der Schnittstelle zu Kunden; zum anderen tritt das Unplanbare nun auch dort auf, wo die Planung bisher vergleichsweise erfolgreich war und teils noch immer ist, wie beispielsweise in der Produktion. Unbestimmtheiten und Ungewissheit treten damit zunehmend nicht mehr neben dem Geplanten, sondern im Rahmen des Geplanten auf. ${ }^{14}$

Auch bei der Improvisation in der Musik ist eine Verschränkung von Planung und Nicht-Planung festzustellen. Planung bezieht sich dabei nicht nur auf eine vorgegebene Planung - wie dies beispielsweise bei der komponierten Musik der Fall ist-, sondern auch auf die Planung durch die Akteure selbst. Dabei empfiehlt es sich, zwischen der Planung in Abgrenzung zur Improvisation einerseits und der Planung als Teil der Improvisation andererseits zu unterscheiden. Ersteres bezieht sich auf planmäßig ablaufende Prozesse, in denen Situationen der Unwägbarkeit und Ungewissheit auftreten. In der Musik wäre dies beispielsweise ein festgelegtes Arrangement, das Teile für Improvisation vorsieht, aber auch die Struktur, dass an die Vorstellung eines Themas eine Improvisation über dieses Thema anschließt. Im Unterschied zur Arbeit in Unternehmen ist dabei allerdings der Anstoß zur Improvisation vorhersehbar und/oder von den Akteuren

14 | In Diagnosen und Prognosen der Veränderung von Organisationen, die die Aufmerksamkeit auf die Grenzen der Planung und die Entstehung neuer Organisationsformen richten, wird dieser Sachverhalt - trotz wichtiger Erkenntnisse und Neuorientierungen - leicht übersehen oder zumindest in der Rezeption und weiteren Diskussion ungenügend beachtet. 
selbst beabsichtigt und inszeniert. Der Anstoß zur Improvisation in Unternehmen kommt demgegenüber überwiegend >von außen < durch Unwägbarkeiten der Materialien, der Technik, der Anforderungen von Kunden, Klienten usw. und ist somit selbst ungewiss und unbestimmt. Dieser Unterschied sei hier zunächst lediglich erwähnt, aber nicht weiter verfolgt. Die Verschränkung von Planen und Nicht-Planen in diesem Sinne einer sequenziellen Abfolge ist unmittelbar offensichtlich - auch wenn sie bei der Diskussion von Improvisation nicht immer berücksichtigt wird.

Unklarer hingegen ist die Verschränkung in oder bei der Improvisation. Die Untersuchungen in Unternehmen zeigen, dass in Situationen, in denen subjektivierend gehandelt wird, das planmäßig-objektivierende Handeln nicht völlig ausgeblendet wird - es tritt aber in den Hintergrund, bildet eher einen Rahmen, bzw. es kommt zu einer laufenden Oszillation zwischen diesen beiden Handlungsweisen. ${ }^{15}$ So ist man sich beispielsweise bei der Subjektivierung materieller Gegenstände durchaus der grundsätzlichen Unterscheidung von Menschlichem und Nicht-Menschlichem bewusst und ebenso verfügt man über wissenschaftlich fundiertes Fachwissen und ist in der Lage, analytisch zu denken und Informationen exakt wahrzunehmen. Gerade die Fähigkeit, sowohl objektivierend als auch subjektivierend handeln zu können, erweist sich hier als eine besondere Kompetenz. ${ }^{16}$ Bei der musikalischen Improvisation erfolgt ein objektivierendes Handeln beispielsweise bei der Orientierung an notierten Themen, Harmoniefolgen, rhythmischen Strukturen und einem bestimmten tonalen Rahmen. Des Weiteren zählen hierzu auch die Kenntnis von möglichen Tonfolgen (Patterns) und stilistische Eigenheiten $u$.Ä. Zu beachten ist dabei nicht nur, ob und in welcher Weise bei der Improvisation geplant wird, sondern auch, inwieweit eine Orientierung mittels expliziten Wissens (etwa Kenntnisse über Tonarten, Harmonien usw.), eine Wahrnehmung eindeutiger Informationen (z.B. Noten, Taktzahlen, vereinbarte Gesten usw.) sowie eine neutral-sachliche Beziehung zur Umwelt (z.B. Instrument, andere Musiker usw.) vorkommen. Je intensiver man die musikalische Improvisation in dieser Weise betrachtet und >durchleuchtet<, umso mehr werden solche Elemente objektivierenden Handelns sichtbar. Doch lenkt gerade dies zugleich den Blick darauf, dass darin die Improvisation nicht völlig aufgeht bzw. aufgehen kann. Ganz ähnlich, wie das objektivierende Han-

15 | Eine systematische Analyse solcher Verschränkungen steht allerdings noch aus. Gegebenenfalls könnten sich hierfür neue Anstöße aus der Diskussion von Improvisation im künstlerischen Bereich ergeben.

16 | Das Konzept des subjektivierenden Handelns und die hierzu vorliegenden empirischen Untersuchungen unterscheiden sich damit grundlegend von Forschungsansätzen, die eine Entwicklungslogik vom subjektivierenden zum objektivierenden Handeln (bzw. einzelner Elemente des Handelns) oder in umgekehrte Richtung unterstellen. Paradigmatisch für Ersteres ist der entwicklungspsychologische Ansatz von Piaget (1969), für Letzteres das Stufenmodell der Entwicklung professioneller Kompetenz bei Dreyfus/Dreyfus (1988). 
deln im Arbeitsbereich beim Umgang mit Unwägbarkeiten und Ungewissheit an Grenzen gerät und ein subjektivierendes Handeln notwendig wird, ist dies auch bei der Improvisation in der Musik der Fall - und zwar unabhängig davon, ob der Anstoß hier von raußen< oder von den Akteuren selbst kommt. Es sei versucht, dies näher zu erläutern. ${ }^{17}$

\section{Vorgehensweise}

Figueroa-Dreher hebt in einer Untersuchung über Free Jazz hervor, dass die Musiker in der Lage sein müssen, »in Bruchteilen von Sekunden musikalisch $\mathrm{zu}$ agieren und $\mathrm{zu}$ reagieren « (Figueroa-Dreher 2010: 190). Dies ist auch dann der Fall, wenn nach standardisierten Patterns gespielt wird (bzw. würde). Auch dann muss im Prozess des Spielens situativ entschieden werden, was konkret zur Anwendung kommt. Dieses >Entscheiden im Tun <ässt sich mit dem Grundsatz >erst denken, dann handeln n nicht (mehr) erfassen, selbst wenn es als ein inkrementelles und prozessuales Entscheiden konzipiert wird. Hierauf bezieht sich beispielsweise die Beschreibung des Improvisierens als ein bewusstes >Verlieren der Kontrolle< und ein >Geschehen-Lassen< (vgl. Lehmann 2005: 932, zit.n. Figueroa-Dreher 2010). Auch die in der Praxis oft anzutreffende Formulierung >es spielt< bezieht sich hierauf und macht zugleich auf die Schwierigkeit der Beschreibung der hiermit angesprochenen Sachverhalte aufmerksam. Denn es sind ja durchaus die Akteure selbst, die hier am Werk sind, und sie betätigen sich keineswegs nur bewusstlos und mechanisch. Die Untersuchungen zu subjektivierendem Handeln lenken hier die Aufmerksamkeit auf den Dialog und die Interaktion mit einem >Gegenüber<. Dies richtet sich nicht nur auf andere an der Improvisation beteiligte Akteure. Ein wesentliches Gegenüber ist vielmehr die entstehende und bereits entstandene Musik (Töne, Harmonien, Rhythmen) - sowohl beim eigenen Spiel als auch im Zusammenspiel. In der unmittelbaren Verbindung des aktiven Hervorbringens und zugleich Reagierens auf das Hervorgebrachte verliert das Spiel seine bloße Beliebigkeit und Zufälligkeit. Es erhält Aufforderungen wie auch Beschränkungen durch das jeweils Vorangegangene. ${ }^{18}$ Treffend ist hier die Antwort von Miles Davis auf die Frage, ob es einen falschen Ton beim Improvisieren gibt: »Es hängt dies vom jeweils nächsten Ton ab.« Ein weiteres Gegenüber ist das Instrument, mit dem gespielt wird (sein Ton, seine Mechanik usw.). Die für subjektivierendes Handeln charakteristische Interaktion im Unterschied zur einseitigen Beherrschung und Manipulation verweist auf einen besonderen Umgang mit dem Instrument. Seine Eigenarten werden nicht einem ex ante entwickelten Entwurf unterworfen, sondern als Anregung für die

17 | Empirische Basis sind hierfür u.a. eigene Erfahrungen bei der Improvisation im Jazz, in der traditionellen Volksmusik sowie in experimenteller freier Musik. Siehe allgemein zu Improvisation und subjektivierendem Handeln ansatzweise auch Porschen 2011.

18 | Figueroa-Dreher verweist hier auf das musikalische Material als ein die Improvisation und das Zusammenspiel strukturierendes Element (Figueroa-Dreher 2010: 189ff.). 
Improvisation aufgegriffen. So ist beispielsweise bekannt, dass derselbe Musiker in demselbem Stück bei einem Wechsel des Instruments sanders< improvisiert.

Ein weiteres die Entscheidungen im laufenden Prozess beeinflussendes Element ist die Intention, mit der gespielt wird, ebenso wie ggf. von >außen tende Anforderungen. Die Intention kann durch eine bewusst hervorgebrachte oder situativ gegebene emotionale Verfassung, aber auch durch eine bestimmte Absicht, die mit der Improvisation verbunden wird, hervorgerufen werden. Dies reicht von der bloßen >Lust, sich musikalisch auszudrücken< (Klausmeier 1978), bis hin zur Interpretation eines außermusikalischen Themas. Von >außen< gesetzte Anforderungen ergeben sich bei der konzertanten Performance durch Erwartungen der Zuhörer oder auch schon durch einen zeitlichen Rahmen. Sowohl die Intention, mit der improvisiert wird, als auch von >außen < kommende Anforderungen/Erwartungen verweisen darauf, dass unter diesem Aspekt durchaus Ähnlichkeiten zwischen der nicht zweckgerichteten musikalischen Improvisation einerseits und einem auf die Lösung von Problemen und die Erzielung bestimmter Ergebnisse gerichteten (subjektivierenden) Arbeitshandeln andererseits bestehen.

\section{Sinnliche Wahrnehmung}

Ein großer Teil musikalischen Ausdrucks und musikalischer Wirkung lässt sich nicht eindeutig und exakt wahrnehmen und beschreiben. Es handelt sich vielmehr um situationsgebundene >vielsagende Eindrücke< (Schmitz 1994). Beispiele hierfür sind die Klangfarbe eines Tons, die Phrasierung und Rhythmisierung einer Tonfolge wie auch der Stil, in oder mit dem etwas gespielt wird. Zwar besteht durchaus die Möglichkeit einer Explizierung und Festlegung. Doch handelt es sich hier - gerade bei der Improvisation - bestenfalls um Annäherungen und eine Abstraktion von den damit benannten Sachverhalten. Gerade bei der Improvisation kommt es darauf an, dem Ton, der Phrasierung usw. >Individualität $\mathrm{zu}$ verleihen. Aber auch unabhängig davon, ob eine Explikation prinzipiell möglich wäre, ist es bei der Improvisation notwendig, während des Spielens die jeweils situativ entstehenden Klangfarben, Phrasierungen und Rhythmisierungen unmittelbar ohne weitere Explikationen zu erfassen. Im Besonderen bezieht sich dies auf das >Erkennen < einer sich in der Improvisation entwickelnden musikalischen Struktur und >Logik<. Hierauf beruht die Möglichkeit der Antizipation im Sinne eines Erahnens des weiteren Verlaufs.

Auf die hier beschriebene empfindende und spürende Wahrnehmung musikalischen Ausdrucks beziehen sich in der Praxis beispielsweise Beschreibungen wie >Feeling< oder >Stimmigkeit<. Eine bemerkenswerte Ähnlichkeit zwischen musikalischer Improvisation und Arbeit in Unternehmen zeigt sich hier bei der Wahrnehmung von Geräuschen. Diese werden - auch in der Beschreibung der Arbeitskräfte selbst - als bzw. wie Musik wahrgenommen, wobei sich dies auf den qualitativen Ausdruck als >warmes oder >rundes< Geräusch bezieht (vgl. Böhle 1999). Zugleich wird damit nicht nur das >Wie< wahrgenommen, auch der Be- 
reich dessen, >was< wahrnehmbar ist, wird erweitert. Er beschränkt sich nicht auf unmittelbare physikalische Gegebenheiten, sondern bezieht gerade auch physikalisch nicht unmittelbar Fassbares und Beschreibbares ein, wie eine Atmosphäre, ein Stimmigkeit, eine sich aus der Sache ergebende Entwicklungslogik o.Ä.

\section{Denken}

Bei Untersuchungen mit Experten stellte Donald Schön fest, dass sie bei der Lösung von Problemen - so wie weiter oben beschrieben - in einen Dialog mit der Sache treten und dabei in Verbindung mit praktischem Tun denken. Bei der genaueren Beschreibung des Denkens illustriert er dies mit dem Beispiel des Denkens von Jazz-Musikern bei der Improvisation. Er nennt es ein >Bei-der-SacheSein<, ohne allerdings genauer zu analysieren, worauf dies konkret beruht und wie es sich vollzieht. Ein solches im praktischen Handeln >mitlaufendes Denken< (Volpert 2003: 63f.) lässt sich weder als bewusste Reflexion noch als lediglich prä-reflexiv und unbewusst angemessen erfassen. ${ }^{19} \mathrm{Zu}$ berücksichtigen sind des Weiteren akustische Imaginationen und/oder assoziativ-bildhafte Vorstellungen. So ist beispielsweise bekannt, dass geübte Musiker in der Lage sind, sich nach einer Improvisation daran zu erinnern, >was sie gespielt haben. Ebenso ist es möglich, prospektiv einen weiteren Verlauf zu imaginieren. Dies ist nicht zu verwechseln mit dem Entwurf einer Handlung vor der praktischen Durchführung (vgl. Abschnitt 2). Wesentlich ist hier vielmehr, dass sich aus dem konkreten Tun heraus eine mögliche weitere Entwicklung ergibt, die vor ihrer praktischen Realisierung antizipiert wird. Auch visuelle Vorstellungen können die Improvisation anregen und leiten. So berichtet ein Jazzmusiker, dass er bei der Improvisation zwar >weiß<, welche Harmonien und Tonfolgen er spielt, aber eigentlich erotisch hoch aufgeladene Bilder >im Kopf hat.

Und schließlich stellt sich die Frage, ob es sich bei den für das Spielen eines Instruments notwendigen Fertigkeiten lediglich um anfänglich bewusste und durch häufiges Üben dann allmählich antrainierte und routinisierte, quasi mechanisch ablaufende Fertigkeiten handelt. In der neueren Diskussion wird an Beispielen wie dem Fahrradfahren darauf aufmerksam gemacht, dass bei scheinbar einfachen motorischen Abläufen ein beständiger situativer Abgleich der Bewegungen mit nicht kontrollierbaren externen Einflüssen, wie - beim Fahrradfahren - Bodenbeschaffenheit, Windstärke, entgegenkommende Fahrzeugen usw., notwendig ist. Dabei wird auf ein besonderes simplizites Wissen<, das körperlich fundiert und inkorporiert ist, verwiesen (vgl. Polanyi 1985; Neuweg 1999). In Untersuchungen zum Fußballspiel und anderen sportlichen Bewegungen wird dies als >praktischer Sinn < bezeichnet, der es ermöglicht, situativ - ohne langes Nachdenken - die richtigen Bewegungen zu vollziehen (Alkemeyer 2009). So

19 | Hieran wird auch deutlich, dass sich die hier in den Blick genommenen Phänomene nur schwer im Bezugsrahmen der bisher etablierten Beschreibungen menschlichen Handelns und menschlicher Fähigkeiten verorten Iassen. 
entsteht bei der musikalischen Improvisation oft nicht nur der bereits zuvor erwähnte Eindruck, dass >es spielt<, sondern auch, dass >meine Hände und Finger spielen $<$ Die übliche Trennung zwischen mentalen Prozessen und sensomotorischen Fertigkeiten wird damit aufgebrochen und fließend. In den Blick geraten ein >Wissen des Körpers $<$ und eine >Intelligenz der Sinneく.

\section{Beziehung zur Umwelt}

Eine distanzierte affektneutrale Beziehung sowohl gegenüber dem Instrument und anderen Musikern wie auch gegenüber der musikalischen Vorlage - z.B. einem Thema - kann ggf. für die Vorbereitung oder nachträgliche Reflexion einer Improvisation förderlich sein. In der Improvisation selbst muss sie jedoch überwunden und in eine Beziehung der Nähe und Einheit transformiert werden. Hierauf beziehen sich Beschreibungen wie >Auflösung von Grenzen<, >gemeinsames Verfallen in einen Rhythmus, das Gefühl der >Verschmelzung « mit dem Instrument und der Gruppe oder eine quasi »telepathisch-wechselseitige« Verständigung, ein >unausgesprochener< Konsens (vgl. Figueroa-Dreher 2012: 8ff.). Dabei kommt es aber keineswegs zu Selbstaufgabe und Autonomieverlust. Im Gegenteil: Gerade die musikalische Improvisation zeigt, dass die >Verschmelzung<, dass ein >Sich-Einlassen $<$ und >Eintauchen $<$ die Entfaltung von Individualität zulässt und zugleich (erst) ermöglicht. Der Philosoph Schmitz erläutert dieses Phänomen an dem Erlernen der Muttersprache und dem Umgang mit ihr. So wird man einerseits zum Mitglied einer Sprachgemeinschaft und die Sprache wird zum Teil der Persönlichkeit, gegenüber dem man sich kaum distanzieren kann. Zum anderen wird man damit keineswegs zum bloßen Vollzugsorgan sprachlicher Stereotypen, sondern kann sie individuell handhaben, ausformen und damit (erst) eigene Gedanken und Überlegungen zum Ausdruck bringen und mitteilen (vgl. Schmitz 1999, S. 31f.).

\section{Perspektiven für eine neue Begegnung von kÜnstlerischer Praxis und Ökonomie/Arbeit}

Bei der Diskussion von Improvisation in Unternehmen wird zumeist auf organisationstheoretische Erkenntnisse und Diskussionen rekurriert. Wir haben dies im Vorhergehenden durch den Bezug auf Arbeit und Arbeitsprozesse erweitert. Ausgangspunkt waren Forschungen zum Umgang mit Ungewissheit und Unbestimmtheiten in Arbeitsprozessen. Es wurde die Unterscheidung zwischen planmäßig-objektivierendem und erfahrungsgeleitet-subjektivierendem Handeln dargelegt und Letzteres näheres erläutert. Auf dieser Grundlage wurde dann der Frage nachgegangen, welche Rolle ein subjektivierendes Handeln bei der Improvisation in der Musik spielt. Dabei wurden u.E. bemerkenswerte Ähnlichkeiten sichtbar, die sich primär auf allgemeine >Prinzipien < und >Methodiken < des subjektivierenden Handelns beziehen. Zugleich ergab sich hieraus auch ein besonde- 
rer Zugang zur Analyse der musikalischen Improvisation. Bisher bereits bekannte und beschriebene Merkmale lassen sich neu ordnen, bisher weniger beachtete Aspekte lassen sich in den Blick rücken. Im Unterschied zu den Bemühungen, bei der Improvisation objektivierbare Elemente aufzudecken, ging es dabei speziell um das, was sich hiermit nicht erfassen lässt. Dies erweist sich in unserer Analyse als ein subjektivierendes Handeln. Die Improvisation beruht keineswegs allein hierauf. Doch - so unser Befund - ohne subjektivierendes Handeln wird sie kaum möglich sein und >gelingen<.

Die Improvisation in der Musik eignet sich vor diesem Hintergrund in besonderer Weise als Praxisfeld subjektivierenden Handelns. Es ließe sich hier quasi unter >Laborbedingungen < eingehender erforschen, insbesondere auch hinsichtlich der Verschränkung von subjektivierendem und objektivierendem Handeln. Und zugleich wäre die musikalische Improvisation ein Praxisfeld, um zu erfahren, worum es bei der Improvisation in Unternehmen jenseits planmäßig-objektivierenden Handelns letztlich geht:

Obwohl das subjektivierende Handeln in der Praxis in Unternehmen stattfindet und zunehmend notwendig wird, ist es bisher kaum bewusst und anerkannt. Sofern es (überhaupt) wahrgenommen wird, gilt es als unprofessionell. Doch wie gezeigt, handelt es sich gerade um eine besondere professionelle Kompetenz. Der Blick auf die Improvisation in der Musik könnte das Bewusstsein hierfür schärfen und die Anerkennung und Weiterentwicklung fördern. Und umgekehrt könnten sich aus der Erkenntnis der Nützlichkeit subjektivierenden Handelns neue Impulse für die Wertschätzung musikalischer Improvisation ergeben - und zwar speziell jener Elemente, die sich dem planmäßig-objektivierenden Blick entziehen. Es erweist sich, dass Improvisation nicht nur >kreativer Einfall<, >Spontaneität< oder verbleibender unaufgelöster >Rest< ist, sondern auch eine bewusste Form und >Methodik $<$ menschlichen Handelns.

\section{LITERATUR}

Alkemeyer, T. (2009): Handeln unter Unsicherheit - vom Sport aus beobachtet. In: Böhle, Fritz; Weihrich, Margit (Hg.): Handeln unter Unsicherheit (S. 183202). VS Verlag für Sozialwissenschaften, Wiesbaden.

Arnheim, R. (1996): Anschauliches Denken. DuMont, Köln.

Böhle, F. (1999): Selbstbeobachtung als Methode zur Erfassung subjektivierenden Arbeitshandelns. In: Journal für Psychologie, 7. Jg., Heft 2, S. 53-56.

Böhle, F. (2003): Subjektivierung von Arbeit - Vom Objekt zum gespaltenen Subjekt. In: Moldaschl, Manfred; Voß, Günter G. (Hg.): Die Subjektivierung von Arbeit (S. 115-148). Hampp, München.

Böhle, F. (2009): Weder rationale Reflexion noch präreflexive Praktik. Erfahrungsgeleitet-subjektivierendes Handeln. In: F. Böhle; M. Weihrich (Hg.): 
Handeln unter Unsicherheit (S. 203-230). VS Verlag für Sozialwissenschaften, Wiesbaden.

Böhle, F. \& Milkau, B. (1988): Vom Handrad zum Bildschirm - Eine Untersuchung zur sinnlichen Erfahrung im Arbeitsprozeß. Campus, Frankfurt a.M.

Böhle, F. \& Rose, H. (1992): Technik und Erfahrung - Arbeit in hochautomatisierten Systemen. Campus, Frankfurt a.M.

Böhle, F. \& Bolte, A. (2002): Die Entdeckung des Informellen. Der schwierige Umgang mit Kooperation im Arbeitsalltag. Campus, Frankfurt a.M.

Böhle, F. \& Busch, S. (2012): Von der Beseitigung und Ohnmacht zur Bewältigung und Nutzung - Neue Herausforderungen und Perspektiven im Umgang mit Ungewissheit. In: Böhle, Fritz; Busch, Sigrid (Hg.): Management von Ungewissheit. Neue Ansätze jenseits von Kontrolle und Ohnmacht (S. 13-36). transcript, Bielefeld.

Böhle, F.; Pfeiffer, S. \& Sevsay-Tegethoff, N. (Hg.) (2004): Die Bewältigung des Unplanbaren. VS Verlag für Sozialwissenschaften, Wiesbaden.

Bolte, A. \& Porschen, S. (2006): Die Organisation des Informellen - Modelle zur Organisation von Kooperation im Arbeitsalltag. VS Verlag für Sozialwissenschaften, Wiesbaden.

Bourdieu, P. (1987): Sozialer Sinn. Kritik der theoretischen Vernunft. Suhrkamp, Frankfurt a.M.

Carus, U. \& Schulze, H. (1995): Leistungen und konstitutive Komponenten erfahrungsgeleiteter Arbeit. In: Martin, Hans (Hg.): CeA. Computergestützte erfahrungsgeleitete Arbeit (S. 48-82). Springer, Berlin.

Dell, C. (2012): Die improvisierende Organisation. Management nach dem Ende der Planbarkeit. transcript, Bielefeld.

Deutschmann, C. (2003): Industriesoziologie als Wirklichkeitswissenschaft. In: Berliner Journal für Soziologie, 4, S. 477-495.

Dreyfus, H. L. \& Dreyfus, S. E. (1988): Künstliche Intelligenz. Von den Grenzen der Denkmaschine und dem Wert der Intuition. Rowohlt, Reinbek bei Hamburg.

Eikels, K. van (2010): Collective Virtuosity, Co-Competition, Attention Economy. Postfordismus und der Wert des Improvisierens. In: Bormann, Hans-Friedrich; Brandstetter, Gabriele; Matzke, Annemarie (Hg.) (2010): Improvisieren. Paradoxien des Unvorhersehbaren (S. 125-16o). transcript, Bielefeld.

Figueroa-Dreher, S. K. (2010): Abstimmungsprozesse im Free Jazz. Ein Modell des Ordnens. In: Böhle, Fritz; Weihrich, Margit (Hg.): Die Körperlichkeit sozialen Handelns. Soziale Ordnung jenseits von Normen und Institutionen (S. 185-206). transcript, Bielefeld.

Figueroa-Dreher, S. K. (2012): Improvisation und implizites Wissen. Unveröffentlichtes Manuskript, München, 8./9. März 2012.

Frisius, R. (1996): Improvisation, I. Zur Terminologie. In: Finscher, Ludwig (Hg.): Musik in Geschichte und Gegenwart. Sachteil 4. Kassel u.a.: Bärenreiter, S. 538-541. 
Hacker, W. (2005): Allgemeine Arbeitspsychologie. Psychische Regulation von Wissens-, Denk- und körperlicher Arbeit. 2. Auflage, Huber, Bern.

Joas, H. (1992): Die Kreativität des Handelns. Suhrkamp, Frankfurt a.M.

Klausmeier, F. (1978): Die Lust, sich musikalisch auszudrücken. Eine Einführung in sozio-musikalisches Verhalten. Rowohlt, Reinbek bei Hamburg.

Kurt, R. (2008): Komposition und Improvisation als Grundbegriffe einer allgemeinen Handlungstheorie. In: Kurt, Ronald; Näumann, Klaus (Hg.) (2008): Menschliches Handeln als Improvisation. Sozial- und musikwissenschaftliche Perspektiven (S. 17-46). transcript, Bielefeld.

Lehmann, A. C. (2005): Komposition und Improvisation: Generative musikalische Performance. In: Stoffer, Thomas; Oerter, Rolf (Hg.): Allgemeine Musikpsychologie (S. 913-954). Hogrefe, Göttingen.

Marx, K. (1864/1974): Das Kapital. Dietz, Berlin.

Merleau-Ponty, M. (1966): Phänomenologie der Wahrnehmung. de Gruyter, Berlin.

Neumer, J. (2012): Entscheidung unter Ungewissheit. Von der Bounded Rationality zum situativen Handeln. In: Böhle, Fritz; Busch, Sigrid (Hg.): Management von Ungewissheit (S. 38-67). transcript, Bielefeld.

Neuweg, G. H. (1999): Könnerschaft und implizites Wissen. Zur lehr- und lerntheoretischen Bedeutung der Erkenntnis- und Wissenstheorie Michael Polanyis. Waxmann, Münster.

Pfeiffer, S. (2007): Montage und Erfahrung. Warum Ganzheitliche Produktionssysteme menschliches Arbeitsvermögen brauchen. Hampp, München/Mering.

Piaget, J. (1969): Nachahmung, Spiel und Traum. Klett, Stuttgart.

Polanyi, M. (1974): Personal Knowledge. Towards a Post-critical Philosophy. University of Chicago Press, Chicago.

Polanyi, M. (1985): Implizites Wissen. Suhrkamp, Frankfurt a.M.

Porschen, Stephanie (2010): Andere Form - anderer Rahmen. Körper- und gegenstandsvermittelte Abstimmung in Arbeitsorganisationen. In: Böhle, Fritz; Weihrich, Margit (Hg.): Die Körperlichkeit sozialen Handelns. Soziale Ordnung jenseits von Normen und Institutionen. Bielefeld: transcript, S. 207-227.

Porschen, S. (2011): Künstlerische und spielerische Zugänge zur Innovationsförderung und Organisationsentwicklung. In: Jeschke, Sabina (Hg.): Innovation im Dienste der Gesellschaft. Beiträge des 3. Zukunftsforums Innovationsfähigkeit des BMBF (S. 415-418). Campus, Frankfurt a.M.

Reckwitz, A. (2000): Die Transformation der Kulturtheorien. Zur Entwicklung eines Theorieprogramms. Velbrück, Weilerswist.

Schatzki, T. (1999): Social Practices: A Wittgensteinian Approach to Human Activity and the Social. Cambridge University Press, Cambridge.

Schmitz, H. (1978): Die Wahrnehmung. System der Philosophie. Band III, 5. Teil. Bouvier, Bonn. 
Schmitz, H. (1980): System der Philosophie. Band 5: Die Aufhebung der Gegenwart. Bouvier, Bonn

Schmitz, H. (1994): Situationen und Sinnestaten - Was wird wahrgenommen? In: Allgemeine Zeitschrift für Philosophie. Jg. 19, Heft 2, S. 1-21.

Schmitz, H. (1999): Der Spielraum der Gegenwart. Bouvier, Bonn.

Schön, D. A. (2002): The Reflective Practioner. How Professionals think in Action. Ashgate, Aldershot.

Schütz, A. (2004): Der sinnhafte Aufbau der sozialen Welt. Eine Einleitung in die verstehende Soziologie. In: Endreß, Martin; Renn, Joachim (Hrsg): Der sinnhafte Aufbau der sozialen Welt. Eine Einleitung in die verstehende Soziologie. Konstanz: UVK.

Schwarzbach, F. (2005): Entscheidungsfindung in Projektteams. Zum Umgang mit unterschiedlichen Perspektiven und Rationalitäten. Hampp, München/ Mering.

Simon, H. A. (1957): Models of Man. Wiley, New York.

Suchman, L. (2007): Plans and Situated Actions. The Problem of Human-machine Communication. Cambridge University Press, Cambridge.

Volpert, W. (2003): Wie wir handeln - was wir können. Ein Disput als Einführung in die Handlungspsychologie. Artefact, Sottrum.

Weber, M. (1956/1964): Wirtschaft und Gesellschaft. Grundriß der verstehenden Soziologie. Tübingen.

Weber, M. (1921): Die rationalen und soziologischen Grundlagen der Musik. DreiMasken-Verlag, München.

Weishaupt, S. (2006): Subjektivierendes Arbeitshandeln in der Altenpflege - Die Interaktion mit dem Körper. In: Böhle, Fritz; Glaser, Jürgen (Hg.): Arbeit in der Interaktion - Interaktion als Arbeit. Arbeitsorganisation und Interaktionsarbeit in der Dienstleistung (S. 85-106). VS Verlag für Sozialwissenschaften, Wiesbaden. 


\title{
Rhythm, Time and Improvisation
}

\author{
Pedro Teixeira Santos and Miguel Pina e Cunha
}

As we interact with the world we find rhythm all around us. It manifests in natural phenomena such as tides, day-night cycle, lunar cycle, and seasons, but also in social structures such as in the flow of the working week, or the patterns of activity in the academic year. A growing interest in the study of rhythm in biology and neurobiology has washed over diverse fields such as sociology, psychology, child development, music theory, artificial neural networks, and organization studies. While this listing is not exhaustive it gives a sense of the pervasiveness of interest in rhythmic structures.

Rhythms in work life have changed significantly with the advent of rationalized work. It is commonly accepted that the work life of the peasant and even the craftsman in the early stages of the Industrial Revolution was adapted and conditioned to fit the natural rhythms of workers and their psycho-physical needs (Ferrarotti 1985). In the aftermath of the scientific organization of work (Taylor 1911) artisan production was replaced by the logic of the production cycle, resulting in a new type of rhythm, independent of the operators, adopted to guarantee the continuity and regularity of the task or job flow in the production system. The implementation of the scientific method at Ford plant in River Rouge resulted in $800 \%$ improvements in productivity, rendering obsolete the craft factories of the early automotive industry (Womack, Jones and Roos 1991) and became the dominant design for organization of work in the mass production era. In rationalized work, the methods and time required for work are out of the workers' control, regular rhythms are emphasized, it »[...] bears the acquired consciousness of a permanent tension between calculation and feeling (Ferrarotti 1985: 32). In the post-industrial period, the worker has regained some control over their work, and as Nadeem (2009: 23) stated: »One is tempted to ask whether the irregular working rhythm of the pre-industrial era have been recaptured in the flexibility of the post-industrial period?«

In this chapter we explore the concept of rhythm from an improvisational perspective. Managing time is a highly complex endeavor and has a high degree of uncertainty. Time is experienced in relation to points of emphasis and the 
organization of time in the vacant spaces between points of emphasis is many times left to intuition and provides room for temporal improvisation. Temporal improvisation consists on improvising temporal dimensions of rhythm. We propose four rhythmic dimensions on which temporal improvisation can occur - sequential structure, duration, temporal organization, and rate of recurrence. Improvising each of the dimensions will have different implications for organizing.

By exploring rhythmic dimensions we hope to contribute to a better understanding of the implications of temporal improvising. Our question for this chapter is the following: How can improvisation alter rhythm, and what implications may these changes have to the organization?

The chapter is divided into three main sections. We will start by examining rhythm as a defining element in establishing order in organizations. Our analysis suggests that rhythm provides a temporal structure for flow, which aligns the energy of the people working on a group or organization. In a second section we will discuss the relationship between temporal improvisation and its implications for maintaining rhythm, and explain how rhythm is an important factor to create the enabling conditions of temporal improvisation. In the third section we look into the dimension of rhythm which can be improvised and assess the implications of their change for the functioning of organizations.

\section{Time ANd Rhythm}

Time is one of the dimensions through which individuals experience organizational life. In order to interpret time we use references to perceive difference, whether it's one more minute on a clock or the day turning into night. These points of emphasis, which may be created by clock-time (e.g. leaving work at 5 p.m.) or by an event (e.g., a deadline) are then interpreted not only as a succession of independent points, but also as a flow of experiences, in which events merge into one another and create a socially-constructed and collectively-shared time experience (Clegg et al. 2005). These points of emphasis allow us to organize the vacant spaces of time to create identifiable patterns. When these patterns are recurring they create a rhythm. The notion of rhythm has been used to explain the functioning of organizations (see e.g. Stewart and Raman 2007) and to describe timing decisions (see e.g. Albert and Bell, 2002). It can then be understood as interweaving the ideas of time, movement, and flow (Cunha 2008). Previous research indicates that individuals (Frost and Taylor 1996), teams (Gersick 1988, 1989), dyads (Bluedorn and Jaussi 2008), and organizations (Brown and Eisenhardt 1997) develop rhythmic processes as they organize.

In organization theory rhythm-type processes refer to the degree of regularity or consistency of organizational processes; to the pattern of variability in the intensity and frequency or organizational activities (Shi \& Prescott 2007); typically characterized by periods of accelerated activity and slowed activity (Huy 2001). 
Brown and Eisenhardt (1997) have demonstrated the role of rhythm in successful computer firms: »rhythm, which depends on a consistent ritual of uniformly recurring behaviors, enables people to pace their work, synchronize their energies with one another, and ultimately get into a flow. (213)« By providing a better understanding of rhythm we contribute to the evolving paradigm of organizations as processes highly sensitive to time (Langley et al. 2013).

Implicitly or explicitly, people make sense of, regulate, coordinate, and account for their activities via temporal structures. Like social structures in general, temporal structures simultaneously constrain and enable. Furthermore, the repeated use of temporal structures reproduces and reinforces their legitimacy and influence in organizational life. Because they are often routinely adopted, they tend to be taken for granted. In a planned or improvised way, more subtly or more openly, people can and do reinforce/modify their community's temporal structures over time (e.g., Zerubavel 1981; Ballard and Seibold 2004).

Social systems develop their own rigidities in terms of sequence, duration, timing or uniformity in recurrence of events (Zerubavel 1981) that influence their perception of rhythm. Perceptions of fast and slow are associated with skipping steps or ignoring the prompt to move to the next step after the end of an activity or an event (for instance an excessively long pause). Examples of the different forms of rigidity include the expectation of receiving an email with the agenda before a meeting, the idea of the proper duration of a meeting, the weekly schedule where events start at the hour or half hour. These rigidities build in due to our fear that activities would not be coordinated otherwise. We may have our offices cleaned when it's scheduled and not when it's dirty - metaphorically or not.

Much organizational activity relies on the synchronization of actions among independent agents. Several ways in which efficient coordination can be achieved have been explored, such as the use of institutions or mechanisms that allow agents to organize tasks and communicate prior to having to coordinate their actions. Rhythm provides a structure that aligns the energy of the people working on a group or organization. More recent studies suggest that coordination at the team level is achieved via implicit mechanisms such as shared mental models (Rico et al. 2008). By creating a shared temporal structure of events within organizational life, rhythms can be entrained, generating synchronization of action.

\section{RHYTHMS FOR IMPROVISATION}

As is the case of rhythm, improvisation is a time-based phenomenon (Crossan et al. 2005). Cunha, Clegg and Kamoche (2012) presented it as >real time foresight<, in an illustration of the role of time in improvisation. In this section we will begin by pointing out the key dimensions of understanding improvisation (Crossan et al. 2005) and then problematize the relationship between improvisation and rhythm. 
Definitions of improvisation seem to have two major dimensions, one of time, defined as >spontaneity< (Crossan and Sorrenti 1997), >on the spot< (Weick 1996), >just-in-time< (Weick 2001) or, >as it unfolds (Cunha et al. 1999); and another of action, which refers to intuition and creativity. As pointed out by Crossan, Lane, White, and Klus (1996), improvisation represents the meeting point of planning and opportunity, comprising a blend of strategy formulation and implementation. In order to understand the way organizations improvise, Crossan et al. (2005) relate planning and improvisation to (1) uncertainty and (2) time pressure. It is from these two elements that we depart to explore the role of rhythm in supporting improvisation. Before proceeding it should be noted that in this chapter we are referring to forms of improvisation that are framed and stimulated by the organization rather than to those that occur outside the organization's scope of managerial attention (e.g., Cunha, Clegg, Rego \& Story 2013; for a typology see Cunha, Neves, Rego \& Clegg 2013a). In other words, we are mostly considering improvisations that purposefully aim to adjust the organization to environmental change - not those other forms occurring outside the formal organization's scope of empowerment (Cunha, Neves, Rego \& Clegg 2013b).

Inherent to the characteristic of flow associated to rhythm is a strong sense of order. Order in organizations is thought of as resulting from the visible hand of managers (Chandler 1977) or the invisible hand of evolutionary processes (McKelvey 1997). Rhythm, as order, can be an imposed or emergent phenomenon, either internally or externally motivated. Ancona and Chong (1996) suggest that cycles of activities can become entrained. Entrainment refers to the process through which rhythm is modified and synchronized by an external influence. This occurs through external triggers, which serve as tangible synchronizers or pacing agents (Ancona and Chong 1996). Linking aspects of entrainment (Ancona and Chong 1996) to the experience of time, Cunha (2008) suggested that varying intensities of $>$ Kairos $<$ and $>$ Chronos $<{ }^{1}$ lead to organizations with different rhythmic typologies.

As observed by Brown and Eisenhardt (1997), organizations may develop and cultivate internal rhythms. One important dimension of rhythm that contributes to the internalization of rhythm is repetition. Rhythm, by definition, requires some sort of repetition. If there were no repetition then there would be no rhythm, on the contrary, there would be arrhythmia - or lack of rhythm. It is these repeated patterns, which allow the use of rhythm to anticipate and prepare for future events. Rhythm can be viewed as a mechanism for linking past and future. At a higher level of abstraction, rhythm can only exist if past and future are present as it is the continuity in time, which makes the rhythm perceivable. What we perceive as rhythmic is that which abides to a certain temporal order, linking past and

1 | These views of stem from the Greek vision of time: 'Chronos can be viewed as objective, or clock time. Kairos s on the other hand is the psychological perception of time, thus evading from the intellectual straightjacketı of Newtonian time (Davies, 1995). 
future, in a cyclical manner. Rhythm can therefore be seen as a construction of an expectation based on past experience, paradoxically creating flow and rigidity. Past experience may be a good indicator of future events but it cannot grasp the complexity of reality, and as such, there will be deviations between >expected rhythm and expressed rhythm. Accurately predicting the duration and timing of planned events or constructing precise temporal contingency plans for unexpected events poses a significant challenge. When a deviation occurs it can be argued that rhythm creates unwritten rules for the management of time. Rhythm creates the perception of the future in the present. With rhythm it is possible to anticipate the future. The perception of an interruption of rhythm creates, in the absence of a contingency plan, the need to improvise.

Improvisation focuses on sin the moment actions, which are guided in an intuitive, non-scripted way. There are many rich examples of improvisation in organizations; however, they tend to focus on procedural actions of organization and tend to overlook the temporal aspects of improvisation. If for instance an organization receives an unexpected order from a client the organization will probably not improvise the way the order is processed. The organization may however have to improvise in time. The organization is forced to make an intuitive decision about how to reorganize in time in order to face this unexpected temporal demand. But the argument above is still short for creating the enabling conditions for improvisation - (1) uncertainty, and (2) time pressure. In the example above we are assuming that the organization does not have a clear script to deal with reorganization of time and as such it must draw upon its' intuition to make an sin the moment< decision of how to deal with the time constraint, and second, it is assumed that the organization will respond with urgency to the client's demands. Uncertainty is created if, when there is a deviation from what was scheduled, there is no planned way to respond. In effect, planning time in more creative tasks is a very demanding and complex ordeal and time is often unscripted. To make sense of time a structure based on points of emphasis emerges or is imposed, and then much of the organization of time is improvised through vacant spaces. For instance, if an order must be processed by 3 p.m., and there is an incoming phone call, or an urgent email to reply, the expected temporal process associated with the order will be altered and therefore there is the need for an adaptation of the temporal structures, be it by changing sequence, duration, temporal location, or rate of recurrence (Zerubavel 1981). If there is no clear plan to readjust the temporal process it is left to the individual's discretion to do so. However, there is only a need to improvise if there is time pressure. In the example above, time pressure is created by the 3 p.m. deadline. But organizations could have different interpretations of deadlines dependent on the cultures, procedures and routines. An individual may receive the order and put it >in a stack $<$ to be dispatched later on. In that case there is no time pressure and there is no altering of the temporal structures associated with filling the order and no interference with other rhythmic levels (e.g. daily rhythm). It is thus important to understand that time urgency 
may be derived from the expectations of what should be done, and by when. At an organizational level one can look for instance at hypercompetitive organizations. These compete in »an environment characterized by intense and rapid competitive moves, in which competitors must move quickly to build advantages and erode the advantages of their rivals.« (D'Aveni 1994: 57). These organizations may have to intuitively change their temporal structures, either by reprioritizing or enacting periods of higher and lower levels of intensity to face the pressures of the market.

Rhythm allows organizations to create meaning though time in order to link the past to the future in a recognizable pattern, which may then be accepted as parts of culture (Cunha 2008). Dikel, Kane and Wilson (2001) pointed out with regard to software architecture that a shared rhythm helps autonomous groups »to work together across organizational boundaries because it helps establish shared assumptions about when and how key events will occur « (183). This shared rhythm facilitates the coordination between stakeholders and their integration at each stage of the productive process. Rhythm also contributes to create the sense of urgency by creating the expectation of points of emphasis. For instance, Gersick (1988: 32) found that »at their calendar midpoints, groups experience transitions - paradigmatic shifts in their approaches to their work - enabling them to capitalize on the gradual learning they have done and make significant advances«. One should also consider entrainment as an important aspect of determining the points of emphasis as entrainment acts as coordinating mechanism with the environment, or even one rhythm may potentially >capture< other rhythms (Bluedorn \& Jaussi 2008). Shi and Prescott (2012) suggest firms do best when they time their alliance schedule to their competitors.

Cunha's (2008) typologies of pressed and pulsed organizations present a contrast between organizations which are reactive and are managed by their environment, and those whose internal rhythms allow them to keep track with the pace of market changes while maintaining their inner established temporal logic. As noted by Ancona and Chong (1996), everyday life in organizations has a rhythmic component. These rhythmic structures paradoxically constrain and enable action by creating a predictable pattern between past and future. The organization will thus already have prepared itself for a particular future, before it happens. Brown and Eisenhardt (1997) suggest that organizations can create semi-structures and sequenced steps to link time horizons. Organizations poise themselves on the edge of chaos, creating a paradoxical mix of structure and freedom (Cunha, 2008). When an unexpected event occurs, the organization will adapt the sequential structure, duration, temporal location, or rate of recurrence, as a corrective measure to get back in rhythm. The rhythm and enactment of time in relation to points of emphasis may thus be key factors to understand the creation of time urgency.

Above we have discussed rhythm as a temporal structure, which may create the enabling condition for temporal improvisation to occur - uncertainty and time pressure. Complementarily to this, we argue that it is through improvisation 
that a rhythmic order is maintained. It is interesting to note that it is temporal improvisation, which allows rhythms to be stable over time. If there were no improvisation it would not be possible to reorganize or adjust time in order to maintain the same points of emphasis. Take for instance the case where a machine in the production line breaks down and takes one hour to fix. The organization will then have to decide how to recover or if it is necessary to recover from this event. The organization can choose to accelerate the production process to make up for the lost time, or may maintain speed but work overtime. These are examples of rhythmic alterations, which allow the organization to readjust to the regular rhythm in the next cycle. Conversely, an organization may choose not to adapt to the external demand and obey an inner logic, which is loosely coupled from the environment. Shi and Prescott (2012) suggest that in environments where alliances and acquisitions happen frequently, the best-performing firms strike a balance between being predictable and opportunistic, signifying changes in rhythm may be desirable in order to take advantage of market opportunities. In the absence of a plan, temporal improvisation is the mechanism through which unexpected temporal complexities, either by external demands or internal adjustments are regulated. These adjustments momentarily alter rhythm until it can be reverted to its original state. Temporal improvisation is a conservative force, acting as a countermeasure to maintain temporal order when facing unplanned phenomena.

\section{Managing the Improvisational Dimensions of Rhythm}

In the previous section we have discussed the relation between rhythm and improvisation. It was argued that rhythm is a critical factor in enabling improvisation and that improvisation is a critical aspect of rhythm. In this section we break down some aspects of organizational rhythms which may be adjusted, and provide examples of how they may alter the functioning of organizations. We argue these are the dimensions in which improvisation takes place. By focusing on the different dimensions we try to better understand what may be the implications of temporal improvisation in an organization. We argue that adjusting different temporal elements may have different organizational impacts.

Zerubaval (1981) considered the major dimensions of the temporal profile of a situation or event include the sequential structure or order, their duration, temporal location, and rate of recurrence. By looking closer into these dimensions we can break down the aspects of rhythm, which can be being improvised. Improvising any of these dimensions will temporarily change the rhythm. We explain each of the dimensions and provide some examples in order to understand the implications of changing each of the dimensions. Although we focus on each dimension individually it is likely that more than one of these factors will change simultaneously. 
Sequential structure represents the order in which events or activities happen in a timeline. For example, even if two companies showed the same pace in their internationalization processes, each one could adopt different sequences regarding the entry process. Two interviewers can interview five candidates in five hours, one per hour. But each one can interview candidates in different sequences and ask questions in different orders, and this may not be irrelevant for the selection outcomes. Changing the sequential structure will fundamentally alter the rhythm and create different points of emphasis, which may lead to different interpretations of time. Brown and Eisenhardt (1997) discussed the notion of >sequenced steps<, which are the recipe by which these organizations are created over time, as a core capability of successful companies. They argue that this creates advantages, which are more difficult to replicate as imitating requires both knowledge of process and of sequence in time. Regularity in sequence may create routines, which lead to more efficiency and competitive advantages yet it may also constrain adaptation, change and renewal. Improvising in sequence may act as an experiment for the evolutionary process and lead to new, more efficient sequences.

Duration refers to the time period between the beginning and the end of an activity or event. This concept is tightly associated with pace, which refers to the density of events or activities per unit of time (Huy 2001). For example, if company A creates ten subsidiaries in five years, and company B creates twenty in the same period, the pace of internationalization of the first company is lower than that of the second one. Maurice Ravel's Bolero is an interesting story from a temporal perspective. Ravel claims to have written the one movement orchestral piece for a 17-minute duration. His recording however has 15 minutes and 40 seconds. Other interpretations of Ravel's Bolero, depending on the conductor, have spanned from 12 minutes to 19 minutes. The meaning and experience of time varies, even in a well-scripted piece of music. Different organizations create unique timescapes, which once in place, these timescapes become one ingredient of the organization's cultural fabric (Cunha 2008). As an example of altering the duration of events, Wilms et al. (1994) describe the Toyota and General Motors assembly plant (NUMMI) whose production line obeys a preset speed known as the takt time (the German word for meter or musical rhythm). Managers are responsible for determining the length of time, which a team member has to perform his or her task, which in turn keeps the production line under continuous tension. Inadequate pacing may at an organizational level lead to detachment from the environment and negatively affect firm performance and, at an individual level, act as a source of stress, affecting motivation, job satisfaction, and burnout.

Given the uncertainty associated with timing activities, improvising duration is a normal part of everyday functioning of individuals and organizations. However, if taken to extremes (too fast or too slow) it can distort the functioning of the organization. At an organizational level this may have implications on firm performance, and at an individual level, over motivation, job satisfaction, stress, and burnout. 
Temporal location refers to the moment an event or activity happens or is planned to happen (the timing) in a sequence of related events or activities (Huy 2001). It refers to the fact that an event or activity is done when it should be done. Without a schedule, successful execution requires a shared perception that the temporal location of an activity is adequate. You don't tell a musician to start playing at a specific temporal location during a concert. In change interventions, for example, good timing captures windows of opportunity so that the intervention can profit from better receptivity to change and more bountiful resources.

Timing is also important when supervisors give feedback to their subordinates or when a certain organization launches a new product, enters a market or a business. In an operational setting we may know what routines to apply, and even the order in which they are performed, but the practical question that often requires practice and experimentation is when to take action, when to transition from one action to the other, and how much action is required at a specific time. Brown and Eisenhardt (1997) suggest that transitions provide the continuity and tempo of change. Transitions keep organizations relentlessly and sometimes even rhythmically moving from the past to the present and forward into the future, helping >to promote change without pain in the organization (Abrahamson, 2004). This transition requires practice and learning as in a child learning how to ride a bike or practicing the timing of hand closure to catch an object.

Experts in infant development suggest that natural rhythms play a large role in enabling movement control, as response replication would be unreliable without a rhythmic tagging system (Ashton 1976). Social interaction is viewed as a process of adapting rhythm between agents, requiring coordination in time and space to produce a smooth rhythm. Effective sequencing relies, in part, on appropriate timing of every intervention, in a given sequence of events, activities, and decisions. These events shape the organizational rhythm, as organizations are forced to design structures and sequence their actions to respond to them. The synchronization of humans' natural rhythms to those of social structures, is usually explained in terms of high level time markers in the environment, such as the calendar or weekly schedule, that generate hidden rhythms (Zerubavel 1981).

Improvising transitions may be important to create smooth rhythms and be able to effectively respond to threats and take advantage of unforeseen opportunities in the market.

Rate of recurrence represents the repetition of the event over time. Time and events are not entirely separable, as events shape temporal structures of individuals and organizations (Staudenmayer et al., 2002). A corporation with a meeting that is scheduled weekly or monthly creates different points of organizational emphasis, which in turn create different rhythmic processes.

The case of Unilever offers a good example of changes in this dimension when it abolished quarterly reporting in order to provide a more long term approach to the organization (Polman 2012). An organization may also alter the rate of 
recurrence temporarily, in order to accommodate a threat to the organizational rhythm. For instance, on a busy day a worker may not go on a break with the same regularity as in a normal day to face the increasing pressures, thus altering the rate of recurrence of events within a rhythmic cycle (i.e. the day).

In addition to the structure of time, it is important to understand these dimensions as interpretation time. Markers or points of emphasis are filled with vacant time spans, which in turn are filled with significance by human actors. The organizing of rhythm evolves into a unique rhythm of organizing. High and low recurrence of events will generate different perceptions of pace and of repetition.

Another dimension of recurrence is the focus of the markers. Rhythmic structures occur simultaneously at different levels. By changing the focus between levels organizations and individuals can speed up or slow down time and create more repetitive or more flexible time. For instance in a factory setting, if a line worker puts emphasis on the individual items being packaged, there will be a very rapid and repetitive cycle. If points of emphasis are at a higher level (e.g. between break times) the focus will shift to a slower, less repetitive cycle and may have different implications for motivation and effectiveness. A similar distinction occurs when equating short versus long-term perspectives in organizations, the shift in these perspectives may drastically redefine the meaning of an organization (e.g. Unilever, see Polman 2012).

Improvising with the rate of recurrence will typically be less common given that a change to the rate of recurrence will probably be a planned event. However, what may be more common is the shift in focus between different rhythmic levels, which may create a different experience and new meaning for individuals and organizations. 
Table 1: Temporal Dimensions of Rhythm

\begin{tabular}{|c|c|c|c|}
\hline Dimension & Explanation & Implications & Illustration \\
\hline $\begin{array}{l}\text { Sequential } \\
\text { structure }\end{array}$ & $\begin{array}{l}\text { The order in which } \\
\text { events or activities } \\
\text { happen in a timeline. }\end{array}$ & $\begin{array}{l}\text { Different order or } \\
\text { sequence of events } \\
\text { will lead to differ- } \\
\text { ent outcomes. }\end{array}$ & $\begin{array}{l}\text { Improvising in } \\
\text { this case may } \\
\text { emerging in the } \\
\text { form of experiment- } \\
\text { ing with new, } \\
\text { more efficient } \\
\text { sequences. }\end{array}$ \\
\hline Duration & $\begin{array}{l}\text { The time period } \\
\text { between the begin- } \\
\text { ning and the end of } \\
\text { an activity or event. } \\
\text { Tightly associated } \\
\text { with pace, which } \\
\text { refers to the density } \\
\text { of events or activities } \\
\text { per unit of time. }\end{array}$ & $\begin{array}{l}\text { Inadequate pacing } \\
\text { may lead to } \\
\text { detachment from } \\
\text { the environment } \\
\text { and negatively } \\
\text { affect firm perfor- } \\
\text { mance as well as } \\
\text { negatively affecting } \\
\text { motivation, job } \\
\text { satisfaction, stress } \\
\text { and burnout. }\end{array}$ & $\begin{array}{l}\text { Improvising } \\
\text { duration, at an } \\
\text { organizational } \\
\text { level may have } \\
\text { implications on firm } \\
\text { performance, and at } \\
\text { an individual level, } \\
\text { on motivation, job } \\
\text { satisfaction, stress } \\
\text { and burnout. } \\
\text { Improvisation may } \\
\text { offer opportuni- } \\
\text { ties to reestablish } \\
\text { rhythm in an } \\
\text { appropriate way. }\end{array}$ \\
\hline Temporal location & $\begin{array}{l}\text { The moment an event } \\
\text { or activity happens or } \\
\text { is planned to happen } \\
\text { (the timing) in a } \\
\text { sequence of related } \\
\text { events or activities. }\end{array}$ & $\begin{array}{l}\text { Improvisation } \\
\text { is often a response } \\
\text { to events. Deciding } \\
\text { which is the } \\
\text { best moment to } \\
\text { respond is a critical } \\
\text { improvisational } \\
\text { skill. }\end{array}$ & $\begin{array}{l}\text { Improvising } \\
\text { transitions may } \\
\text { be important } \\
\text { to create smooth } \\
\text { rhythms and be } \\
\text { able to effectively } \\
\text { respond to threats } \\
\text { and take advantage } \\
\text { of unforeseen } \\
\text { opportunities in } \\
\text { the market. }\end{array}$ \\
\hline Rate of recurrence & $\begin{array}{l}\text { The repetition of the } \\
\text { event over time. } \\
\text { The rate of recur- } \\
\text { rence must be related } \\
\text { to a particular cycle } \\
\text { (e.g. a year or } \\
\text { a product life cycle) }\end{array}$ & $\begin{array}{l}\text { Changes in rate } \\
\text { of recurrence, at } \\
\text { an organizational } \\
\text { level, will shift the } \\
\text { focus of the organi- } \\
\text { zation. } \\
\text { Focusing on cycles } \\
\text { of different levels } \\
\text { create a different } \\
\text { experience for } \\
\text { organizational } \\
\text { members. }\end{array}$ & $\begin{array}{l}\text { Improvisation helps } \\
\text { organizations to } \\
\text { define recurrence } \\
\text { as it gives temporal } \\
\text { flexibility within } \\
\text { established organiza- } \\
\text { tional rhythms. }\end{array}$ \\
\hline
\end{tabular}




\section{Conclusion}

Throughout the chapter we have explored the relation between rhythm and improvisation; determined the dimensions of rhythm, which can be improvised; and discussed the implications of improvising rhythm, where we argue that adjusting different temporal dimensions may have different impacts on the organization.

Rhythm creates a predictable pattern, thus creating expectations, which guide agents through vacant spaces of time. When there is a deviation from the expectation, agents will improvise - via the altering of one of the rhythmic dimensions - to bring the rhythm back to its normal state. Rhythm is thus kept relatively stable over time through improvisation. Although improvisation may be an »in the present « characteristic, it may have a long-lasting effect on the organization. Through temporal improvisation the organization may also discover new ways of organizing which may produce rhythmic mutations. Still with a narrow focus on efficiency and a scientific approach to time, organizations may not experiment with temporal structures often enough, and may be missing out on opportunities to construct new meanings and experiences for organizations and their members. By not improvising organizations may also be missing out on market opportunities. As Prescott (2013) pointed out »it's not that you will be unsuccessful if you have a regular-paced rhythm. You'll just be less successful because you'll be missing opportunities«. In more competitive environments firms accept the need for improvising in the present (Brown and Eisenhardt 1997) and incorporate that need when establishing rules and processes. For example, establishing rhythms via cycles of goals and organizational calendars, combined with simple rules, may free individuals to act in an improvisational way that facilitates coordination without harming freedom and real time adjustment. In a sense it offers a combination of order with a "yes to the mess « (Barrett 2012) type of attitude. More aware of the impacts that improvisation in different dimensions may have, managers may opt to use each the dimensions in their favor when responding to the unexpected.

\section{REFERENCES}

Abrahamson, E. (2004): Change without pain: How managers can overcome initiative overload, organized chaos, and employee burnout. Boston, MA, Harvard Business School Press.

Albert, S. \& Bell, G. (2002): `Timing and music<. In: Academy of Management Review 27: 574-593.

Ancona, D., \& Chong C. (1996): >Entrainment: Pace, cycle and rhythm in organizational behavior<. In: Research in Organizational Behavior 18: 251-284.

Ashton, R. (1976): >Aspects of Timing in Child Development<. In: Child Development 47/3: 622-626. 
Ballard, D.I., \& Seibold D.R. (2004): >Communication-related organizational structures and work group temporal experiences: The effects of coordination method, technology type, and feedback cycle on members' construals and enactments of time<. In: Communication Monographs 71: 1-27.

Barrett, F.J. (2012): Yes to the mess. Boston, MA, Harvard Business Review Publishing.

Bluedorn, A.C., \& Jaussi K.S. (2008): >Leaders, followers and time<. In: The Leadership Quarterly 19: 654-668.

Brown, S.L., \& Eisenhardt K.M. (1997): >The art of continuous change: Linking complexity theory and time-paced evolution in relentlessly shifting organizations $<$ In: Administrative Science Quarterly 42: 1-34.

Brown, S.L., \& Eisenhardt K.M. (1998): Competing on the edge. Strategy as structured chaos. Boston, MA, Harvard Business School Press.

Chandler, A. (1977): The visible hand: the managerial revolution in American business. Cambridge, MA: Harvard University Press.

Clegg, S., Kornberger M., \& Rhodes C. (2005): >Learning/becoming/organizing ‘. In: Organization 12: 147-167.

Crossan, M., Lane, H., White, R. E., \& Klus, L. (1996): The improvising organization: Where planning meets opportunity. In: Organizational Dynamics, 24(4): 20-35.

Crossan, M., \& Sorrenti, M. (1997): Making sense of improvisation. In: Advances in Strategic Management, 14: 155-180.

Crossan, M.M., Cunha, M.P., Vera, D. \& Cunha, J.V. (2005): >Time and organizational improvisation. In: Academy of Management Review, 30, 129-145.

Cunha, M.P. (2008): >The organizing of rhythm, the rhythm of organizing<. In: Time in organizational research: Approaches and methods. R.A. Roe, M.J. Waller and S.R. Clegg (Eds.), 220-237. Routledge, London.

Cunha, M.P., Clegg, S. \& Kamoche, K. (2012): >Improvisation as real time foresight.<In: Futures, 44 (3), 265-272.

Cunha, M. P., Cunha, J. V., \& Kamoche, K. (1999): >Organizational improvisation: What, when, how and why.< In: International Journal of Management Reviews, 1: $299-341$.

Cunha, M.P., Neves, P., Rego, A. \& Clegg, S. (2013a): Organizational improvisation: Spontaneity, creativity, power. Unpublished manuscript, Lisboa.

Cunha, M.P., Neves, P., Rego, A. \& Clegg, S. (2013b): >From the physic of change to realpolitik: Improvisational relations of power and resistance.< In: Journal of Change Management, 2013 (4), 460-476

D’Aveni, R.A. (1994): Hyper-competition. Managing the dynamics of strategic maneuvering. Free Press, New York.

Davies, P. (1995): About time: Einstein's unfinished revolution. Simon \& Shuster, New York.

Dikel, D., Kane D., \& Wilson J. (2001): Software architecture: Organizational principles and patterns. Prentice-Hall, Englewood Cliffs, NJ. 
Ferrarotti, F. (1985): The Myth of Inevitable Progress. Greenwood Press, Westport, CT.

Frost, P.J. \& Taylor, M.S. (Eds.) (1996): Rhythms of academic life. Personal accounts of careers in academia. Sage, Thousand Oaks, CA.

Gersick, C.J.G. (1988): >Time and transition in work teams: Toward a new model of group development<. In: Academy of Management Journal 31: 9-41.

Gersick, C.J.G. (1989): >Marking time: Predictable transition in task groups $<$ In: Academy of Management Journal 32: 274-309.

Huy, Q.N. (2001): >Time, temporal capability, and planned change <. In: Academy of Management Review 26/4: 601-623.

Langley, A., Smallman, C., Tsoukas, H., \& Van de Ven A.H. (2013): Process studies of change in organizations and management: Unveiling temporality, activity and flow. In: Academy of Management Journal 56(1): 1-13.

McKelvey, B. (1997): >Quasi-natural organization scienceく. In: Organization Science 8: 351-380.

Nadeem, S. (2009): >The uses and abuses of time: Globalization and time arbitrage in India's outsourcing industries<. In: Global Networks 9/1: 20-40.

Polman P. (2012): >Captain Planet: Unilever CEO Paul Polman interviewed by Adi Ignatius.< In: Harvard Business Review, Jun 2012, Volume: 90 Issue: 6 pp. $112-118$.

Prescott, J.E. (2013): Sports and Organizational Rhythm. University of Pittsburgh Katz Graduate School of Business. Web. 23 Apr. 2013.

Rico, R., Sanchez-Manzanares, M., Gil, F., \& Gibson, C. (2008): >Team implicit coordination processes: A team knowledge-based approach<. In: Academy of Management Review 33/1: 163-184.

Shi, W., \& Prescott J.E. (2007): >Rhythm and synchronization of firms $<$ M\&A and alliance behaviors: An entrainment view<. In: Academy of Management best paper proceedings.

Shi, W., \& Prescott J.E. 2012, >Rhythm and Entrainment of Acquisition and Alliance Initiatives and Firm Performance: A Temporal Perspective. In: Organization Studies, 33, 1281-1310.

Staudenmayer, N. Tyre, M., \& Perlow L. (2002): >Time to change: Temporal shifts as enablers of organizational change<. In: Organization Science 13/5: 583-597.

Stewart, T.A., \& Raman A.P. (2007): >Lessons from Toyota's long drive [an interview with K. Watanabe]<. In: Harvard Business Review 85/4: 74-83.

Taylor, F.W. (1911): The principles of scientific management. W.W. Norton, New York.

Weick, K. E. (2001): Making sense of the organization. Blackwell, Malden, MA.

Weick, K. E. (1996): >Drop your tools: An allegory for organizational studies.< In: Administrative Science Quarterly, 41: 301-313.

Wilms, W.W., Hardcastle A.J., \& Zell D.M. (1994): >Cultural Transformation at NUMMI<. In: Sloan Management Review 36/1: 99-113. 
Womack, J.P., Jones D.T., \& Roos D. (1991): The Machine that Changed the World: The Story of Lean Production. Harper Perennial, New York.

Zerubavel, E. (1981): Hidden rhythms: Schedules and calendars in social life. University of Chicago Press, Chicago. 



\title{
Organisationskultur revisited
}

\author{
Sechs transdisziplinäre Schnittstellen zwischen \\ Wissenschaft und Kunst beim Versuch, das Ungenannte \\ und Unerwartete in Organisationen zu erfassen
}

Wolfgang Stark und Christopher Dell

Viele der bisher üblichen Organisationstheorien und -analysen arbeiten weitgehend mit kognitiven Modellen: Sie haben den rationalen Teil von Organisationen hervorragend erfasst, indem sie sich vor allem auf direkt erkennbare Parameter und auf Zählbares beziehen. Das funktioniert gut bei klar hierarchischen Organisationen; je flacher jedoch Hierarchien werden und je komplexer damit die Organisation, umso mehr werden jene weichen Faktoren der Vergemeinschaftung bedeutend, die Tiefe haben. Aber auch die bislang vermeintlich klar an Kennzahlen orientierten Organisationen entdecken zunehmend die Bedeutung des Unzählbaren für den Erfolg von Unternehmungen und der Bewältigung und Gestaltung mit Unerwarteten in hochkomplexen sozialen Systemen. Hier befinden wir uns in den Tiefendimensionen von Organisationskulturen, deren Erforschung weit über rationale Modelle der Organisationsentwicklung hinaus geht (Horsmann et al. 2007).

Erfahrungen und Ergebnisse des Projekts >Music_Innovation_Corporate Culture $\prec^{2}$ zeigen, dass ästhetisch-performative Zugänge aus verschiedenen Disziplinen und Muster innovativer Kulturen nicht nur für den individuellen, sondern auch für den kollektiven Umgang mit Feldern des Unerwarteten in Organisationen immer wichtiger werden. In Improvisations-Laboratorien (MICC-ImproLabs) lässt sich die Kunst der Improvisation erfahren und erlernen. Die Grundlagen eines neuen, improvisatorischen Umgangs mit den Elementen und Mustern von

1 | Ist in kürzerer Form in Böhle, F. \& Busch S. (Hg.): "Management der Ungewissheit Neue Ansätze jenseits von Kontrolle und Ohnmacht", Bielefeld, transcript 2013 erschienen. 2 | Das Forschungsprojekt "Music-Innovation-Corporate Culture (www.micc-project. org)" wird gefördert im Programmschwerpunkt "Innovationsstrategien jenseits traditionellen Managements" vom BMBF und der ESF (Förderkennzeichen 01FM08040). 
Organisationskulturen und die Struktur erster Prototypen werden in diesem Beitrag vorgestellt.

Die Schnittstellen zwischen Disziplinen und Sichtweisen in diesem Beitrag charakterisieren Wege, die helfen, Organisation und Organisationskultur auf neue Weise wahrzunehmen. Sie sind dabei - als Übergänge - oft Orte des Neuen und der Transformation, weil sich hier die Kultur (Rituale und Werte) des einen mit dem anderen begegnen und neue Verbindungen entstehen können. Schnittstellen als Orte der Transformation sind aber auch besonders sensible Bereiche, die besonderer Aufmerksamkeit und Pflege bedürfen.

\section{Die Bedeutung der Kultur in Organisationen}

Die Bedeutung von Kultur in Organisationen und sozialen Systemen wird und wurde in der Fachliteratur zur Organisationsforschung der letzten 20 Jahre vielfach wiederholt: Die Kultur einer Organisation ist (über längere Zeiträume gesehen) neben den üblicherweise bestimmenden Faktoren Struktur und Strategie (vgl. Mintzberg 1999) ausschlaggebend für

- für den Erfolg und die gelingende Performanz (Leistung),

- für das Funktionieren und das Zusammenspiel (Beziehung, Prozessqualität),

- für den >sense of community< und die Zugehörigkeit (Gemeinschaft, alignment) und

- für das Bild nach Außen und Innen, das als Attraktor auf beiden Seiten dienen kann.

Peter Kruse (2004) identifiziert in seinem grundlagen- und praxisorientiertem Buch zum Management der Instabilität sechs Kernbereiche der Unternehmenskultur und verbindet sie mit praxisorientierten Fokusfragen:

- Vision und Strategie - Welche Marktausrichtung und Kernkompetenzen unserer Organisation hebt ein Journalist in einem zukünftig erscheinenden Artikel über unser Unternehmen hervor?

- Managementmethodik - Welche konkreten Stärken unserer Managementmethoden wird ein Unternehmensberater bei einer vergleichenden Analyse unserer Organisation vorfinden?

- Führungsverhalten - Woran wollen sich Führungskräfte im Sinne einer Selbstverpflichtung von ihren Mitarbeitern bewerten lassen?

- Kommunikation und Kooperation - Welche positiven Besonderheiten im internen Umgang und im Arbeitsstil bemerkt ein neuer Mitarbeiter als Erstes?

- Personalentwicklung - Welche persönliche Perspektiven und Anreize veranlassen einen Leistungsträger, sich ohne zu Zögern auf eine Stelle in unserer Organisation $\mathrm{zu}$ bewerben? 
- Angestrebte Außenwirkung - Mit welchen positiven und konkreten Aussagen beschreiben verschiedene Kundengruppen unsere Organisation?

In der bisherigen Forschung zu Organisationskultur (Schein 2003) wird auf der deskriptiven Ebene unterschieden zwischen

1. der Ebene des Appells oder der Selbstbeschreibung (bekundete Werte wie >So sind wir!<, >So wollen wir sein!<, >Daran glauben wir!<),

2. den Zeichen und Symbolen (Artefakte), die bestimmte, meist kollektiv sanktionierte, selten aber jedoch für alle klar benannte Bedeutungen haben ( $\mathrm{Zu}$ gänge, Treffpunkte, Rituale, Gegenstände), die auf

3. zugrunde liegende Werte und Glaubenssätze verweisen, die die >Tiefendimension $<$ der Organisation insofern ausmachen, als sie meist weder sichtbar, noch benannt sind.

Um die Kulturmuster von Organisationen zu verstehen, muss aber die Beschreibung der Organisations-Kultur eingebettet sein in ein Gesamtbild der Organisation. Nach Wunderer (1999) werden Organisationen als soziale Systeme durch folgende drei Komponenten bestimmt:

- Die Form des Organisierens beschreibt die Struktur und die Abläufe in einer Organisation, die Art der Hierarchie und die Funktion und Logik der Administration,

- die Strategie bestimmt die Ziele und Ergebnisse einer Organisation und die Frage, wie ökonomische und inhaltliche Werte mit welcher Effizienz (Wirtschaftlichkeit) erzielt werden sollen,

- die Kultur einer Organisation schließlich zeigt Verhaltens- und Handlungsmuster, Formen der Beziehungen zwischen Gruppen und Individuen, beinhaltet (geteilte) Werte und Gebräuche und lässt Rückschlüsse auf Status und Rollen im sozialen System Organisation zu.

In Praxis und Wissenschaft haben sich Konzepte hinsichtlich der Form des Organisierens und der Strategie entwickelt; auf den ersten Blick gibt es hierfür eine Sprache, die hinreichend geübt und ausdifferenziert ist (vgl. Weick 1995; Mintzberg 1999). Dies trifft für die Organisationskultur nur in geringerem Maße zuDas oben dargestellte Modell von Schein (2003) ist zwar deskriptiv plausibel, aber noch nicht ausreichend theoretisch und empirisch gefüllt - eine eigene Sprache für Organisationskultur ist noch nicht gefunden. Die Bedeutung von Organisationskultur in ihren sichtbaren, insbesondere aber nicht sichtbaren Ausprägungen für das Funktionieren des sozialen Systems Organisation wird zwar allgemein erkannt, diese Argumentation wird in der Fachliteratur der letzten Jahre aber eher wiederholt, als vertieft. 
Dazu kommt, dass die Beschäftigung mit der Kultur einer Organisation in der Praxis auf den ersten Blick nur wenig Relevanz besitzt, weil sie vorhandene Managementprobleme nicht direkt löst. Organisationskultur wird zwar in ihrer Bedeutung für motivierte Mitarbeiter und damit auch gute Leistung erkannt, die Managementpraxis folgt eher der Maxime: Über Kultur können wir nachdenken, wenn alles gut läuft.

Kultur ist jedoch die Zivilgesellschaft der Organisation (Giddens 1999); hier entwickeln sich individuelle und gemeinschaftliche Werte, die erst ökonomische Werte hervorbringen. Sie können in der folgenden Form beschrieben werden (in Anlehnung an Wunderer et al. (1999): Haben - Welche Ressourcen stehen zur Verfügung? Können - Welche Kompetenzen sind vorhanden? Sollen - Was wird von den Mitarbeitern erwartet? Wollen - Womit identifizieren sich Mitarbeiter? Dürfen - Welche Befugnisse haben Mitarbeiter? Die folgende einfache Matrix einer Organisationsanalyse - leere Felder werden je nach Organisation individuell ausgefüllt - hilft zu einem ersten selbstreflexiven Selbstbild, kann aber auch für die Einschätzung von außen (Fremdbild) genutzt werden.

Tabelle 1: Organisationsanalyse im Kontext von Kultur, Strategie und der Funktion des Organisierens (eigene Darstellung in Anlehnung an Wunderer 1999)

\begin{tabular}{|l|l|l|l|}
\hline & Kultur & Strategie & Organisation \\
\hline $\begin{array}{l}\text { Haben - Verfügen } \\
\text { Welche Ressourcen stehen zur Verfügung? }\end{array}$ & & & \\
\hline $\begin{array}{l}\text { Sollen - Verpflichten } \\
\text { Was wird von den Mitarbeiterinnen } \\
\text { erwartet? }\end{array}$ & & & \\
\hline $\begin{array}{l}\text { Können - Qualifikation } \\
\text { Welche Kompetenzen sind vorhanden? }\end{array}$ & & & \\
\hline $\begin{array}{l}\text { Wollen - Motivation } \\
\text { Womit identifizieren sich } \\
\text { die Mitarbeiterinnen? }\end{array}$ & & & \\
\hline $\begin{array}{l}\text { Dürfen - Ermächtigen } \\
\text { Welche Befugnisse haben } \\
\text { die Mitarbeiterinnen? }\end{array}$ & & & \\
\hline
\end{tabular}

Schnittstelle 1: Auch wenn die Organisationskultur in diesem Kontext ein Schwerpunkt der Forschung ist, die möglicherweise das Ungenannte, nicht Zählbare und damit auch das Unerwartete in Organisationen verstehen und gestalten hilft, wird sie doch gleichzeitig auch bestimmt durch die Funktion des Organisierens und die Strategie der Organisation. Alle drei ergeben erst das gesamte Bild einer Organisation; sie beeinflussen sich wechselseitig und sind jeweils als Ganzes Bild in jedem einzelnen Teil vorhanden. 
Damit enthüllt sich hier ein Prinzip, das in der Kunst (Literatur, bildende Kunst, Design) als mise en abyme bezeichnet wird: Ein Bild, das sich selbst enthält. Als Grundprinzip der Hologramme ist dieses Prinzip systemtheoretisch von Bedeutung: Bricht man ein Hologramm in Teile, so enthält jeder Teil die gleichen Informationen (das gleiche Bild) wie das Gesamtbild - allerdings je kleiner, desto unschärfer (siehe Abb. 1. mise en abyme oder Droste-Effekt). Genauso verhält es sich in Organisationen als eine Spielart sozialer Systeme: Die spezifischen Elemente Kultur, Strategie und Organisation (im Sinne von Aufbau - und Ablauforganisationen) enthalten und spiegeln sich wechselseitig - entweder in den darin vorhandenen Brüchen und den sich daraus ergebenden Brüchen oder in ihrer Balance und Harmonie.

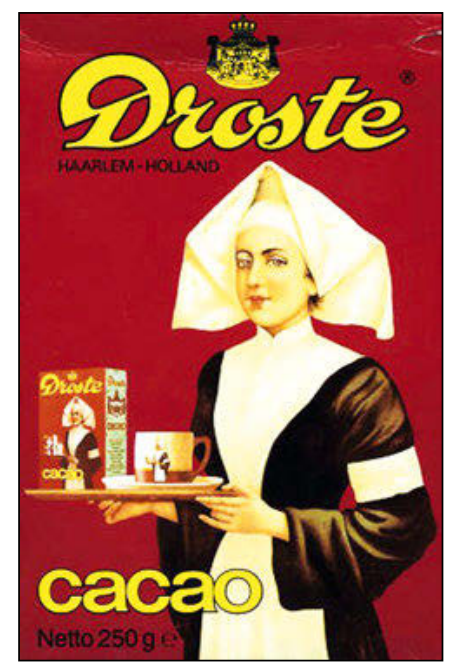

Abbildung 1: mise en abyme (Droste-Effekt)

Ein anderer Blickwinkel ergibt sich, wenn man - in Anlehnung an Mary Douglas (1991) - unterschiedliche Kulturtypen unterscheidet, die sich aus der Verhaltensregulation nach Zugehörigkeit (group) oder durch die Befolgung von Organisationsregeln (grid) ergeben (vgl. Kamarsin \& Kamarsin 1997). Dieser Zugang aus der anthropologischen Kulturtheorie zeigt bereits grundlegende Kulturmuster, die unterschieden und die als Grundlage einer interdisziplinären Kulturanalyse von Organisationen herangezogen werden können.

Organisation wird im Rückgriff auf ihre Kultur daher nicht als substantielle Form oder neutraler Behälter verstanden, in dem organisationale Akteure handeln. Vielmehr wird Organisation performativ gedacht, d.h. sie entsteht durch Ausübung - Wiederholung, Routine, Rituale, Muster - und ihr Wissen ist implizit und nicht kodifizierbar (tacit knowing). Als performativer Akt ist Organisation prozesshaft und entwickelt sich durch ein Handeln, das an Wertvorstellungen, Materialien und Strukturen geknüpft ist. Das erforschungswürdige an diesem 
Konzept ist, dass wir meist kein bewusstes Konzept der Performanz von Organisation haben, also von dem, was wir als Kultur einer Organisation >machen < - uns fehlt mithin die Urteilskraft fürs Relationale, Situative und Performative.

Das Erforschen der impliziten Formen des Wissens ist bereits seit langem Bestandteil der Organisationstheorie. Neu ist, das künstlerische Forschen in diesen Komplex mit einzubeziehen. Künstlerisches Forschen (Klein 2010) fragt neu nach den ontologischen Bedingungen von Forschung, also der Beschaffenheit des Forschungsgegenstands, der Form der Episteme und den damit verknüpften methodologischen Ansätzen. Forschung in der Kunst wird von Borgdorff (2009) als >performative Perspektive< (a.a.O.: 30) bezeichnet, Donald Schön als Organisationstheoretiker beschreibt sie als >Reflexion in der Aktion<. Die Trennung von Objekt und Subjekt wird hier problematisiert, denn die Distanz des Forschenden zum Gegenstand ist minimiert - im Gegenteil sucht der Forschende in performativen Kontakt mit den Dingen zu kommen um aus praktischen Situationen heraus Wissen zu destillieren. Dieser Ansatz geht davon aus, dass die künstlerischen Praktiken selbst ein Reservoir an Wissen bereitstellen, die es für die Forschung fruchtbar zu machen gilt.

Schnittstelle 2: Es zeigt sich, dass nicht nur die parallele Berücksichtigung mehrerer Ebenen, sondern damit insbesondere der transdisziplinäre Zugang gerade für das Verständnis von Organisationskultur unabdingbar ist. Insbesondere das auf den ersten Blick nicht rein rationale, künstlerische Vorgehen kann helfen, die verborgenen Muster von Prozessen und Strukturen in Organisationen sichtbar und diskursfähig zu machen. Hier sind Verbindungen zwischen Kulturanthropologie, Kunst und sozialen Systemen noch weiter zu systematisieren, um eine Folie zum Verständnis von Kulturmustern herzustellen.

\section{Kulturelle und innovative Muster in Organisationen}

Kultur entsteht durch Wiederholung und Variation, durch Rituale und (meist unausgesprochene) Regeln (Kroeber 1963). Kultur wird aber nicht bestimmt, sondern >spielt sich ein<, ist prozesshaft und entwickelt sich durch das Handeln (nicht durch Vorschriften). Paul Bate (2004) vergleicht deshalb Organisationskultur mit einem Flussbett: Die Handlungsmuster der Mitarbeiter und die Strukturmuster der Organisation suchen sich den gangbaren Weg, der dann (temporär) zu Flussbett wird. Grundlage ist hier das Prinzip der >Viabilität< (Glasersfeld 1999), das auch für die Theorie der Selbstorganisation ausschlaggebend ist.

Kulturmuster von und in Organisationen können daher branchen- oder typenspezifisch identifiziert und analysiert werden. Grundlage für die Analyse von Kulturmustern sind einerseits Dokumentenanalysen (bekundete Werte und Ar- 
tefakte), teilnehmende Beobachtung und Interviews oder andere Formen der Befragung und Datenerhebung.

Eines der bekannteren Verfahren zur Analyse von Werten in Organisationen und sozialen Systemen ist das von Peter Kruse (2004) entwickelte partizipativinteraktive Tool des NextExpertizer, mit der er sprachlich erhobene Aussagen über Werte und Wirklichkeitskonstruktionen in Organisationen oder Systemen zu räumlichen drei-dimensionalen Konstrukten verdichtet. Theoretische Grundlage ist dabei das von George Kelly (1955) bereits in den 5oer Jahren entwickelte Repertory-Grid-Verfahren, mit dem die individuelle Realitätswahrnehmung (die subjektive Wirklichkeit) auf Basis persönlicher Konstrukte gemessen wird. Dieses Verfahren ermöglicht zwar wichtige Einsichten in die (subjektive) Wertewelt von Organisationen und - durch die Aggregation zahlreicher individueller Aussagen - in ein potentielles Wertemodell einer Organisation oder eines sozialen Systems (Kruse ua. 2003) und liefert erste Muster der Tiefendimension von Organisationskulturen. Es bleibt jedoch noch auf der kognitiven und bewussten Ebene der Kulturanalyse und kann noch nicht ausreichend das Ungenannte und Unerwartete in Organisationen erfassen, geschweige denn Möglichkeiten bieten, Kulturmuster flexibel im Tun einzusetzen und damit neue Möglichkeiten zu entdecken.

Hilfe, so nehmen wir an, kann uns hier die Beschreibung in Mustern von Organisationen, abgeleitet von C. Alexanders >Mustersprache<, bieten. Nach Alexander (1977) sind >Muster (patterns)< die geronnene Form erfolgreicher Problemlösungen, die eben nicht die Form statischer Handlungsanweisungen einnehmen, sondern die Werte und Prinzipien vertreten, nach denen verschiedene Herausforderungen gemeistert werden können. Diese Muster sind flexibel und variabel einsetzbar und können sich dabei auch selbst verändern und neu gestalten - sind also performativ. Die >Notation< von Mustern folgt in allen Anwendungsfeldern bestimmten Prinzipien, die Borchers (2001) formal wie folgt dargestellt hat:

"Each pattern is a set $p=\{n, f 1[\ldots] f i, s$, e1---ej $\}$ of a name $n$, forces $f 1[\ldots] f i$, the solution $s$, and examples e1[...]ej. It describes a commonly encountered design problem, and suggests a solution that has proven useful in this situation. A pattern language is a directed acyclic graph. Each node represents a pattern. There is a directed edge from pattern $p 1$ to $p 2$ if $p 1$ recruits $p 2$ to complete its solution. Edges pointing away from a pattern are its consequences, showing what lower-level patterns need to be applied next. Edges pointing to a pattern are its context, the situations in which it can be applied. This relationship establishes a hierarchy within the pattern language. It leads the designer from patterns addressing large-scale design issues, to patterns about small details." (Borchers 2001: 361).

Eine erweiterte Form der Bestandteile von Mustern, wie sie für Organisationen und soziale Systeme relevant sind, zeigt das folgende Notationsprinzip:

- $\quad P=\left\{n^{c}, f_{1}[\ldots] f_{i}\right.$, set,$t$, sol, $e_{1} \ldots e_{i}$, con $\}$

- Jedes Muster ( $\mathrm{p}=$ pattern) in Organisationen ist dabei eine Funktion 
- $\quad$ einer typischen Herausforderung $\left(\mathrm{n}^{\mathrm{c}}=\right.$ name/challenge),

- verschiedener hier einwirkender Kräfte im Kontext) ( $f=$ forces),

- zeitlicher Dynamik (t) und räumlichen Gegebenheiten (set = setting)

- $\quad$ einer oder verschiedener Lösungsvariante(n) (sol = solution)

- verschiedener Anwendungsbeispiele ( $\mathrm{e}=$ example) und

- möglicher Konsequenzen (con = consequence)

und beschreibt ein typisches, situationsspezifisches und viables Beziehungssystem in einer Organisation. Keidel (1995) hat die in Organisationen zentral wirkenden Kräfte (f) mit Autonomie, Kontrolle und Kooperation beschrieben. Alle drei Kräfte können als fundamental zum Verständnis der Dynamik in Organisationen bezeichnet werden und bestimmen die Beziehungen in diesen sozialen Systemen: Autonomie als Bestreben des Individuums (oder der Gruppe), selbstständig uns selbstorganisiert agieren und entscheiden zu können, Kontrolle als koordinierende Bestreben sowohl der Einzelnen, als auch des Ganzen, gesetzte Ziele auch zu erreichen sowie individuelle und kollektive Interessen auszubalancieren, und Kooperation als integrative Kraft des Gemeinsamen und der Notwendigkeit, nur durch Zusammenarbeit Neues erreichen und wachsen zu können. Keidel plädiert damit für eine triadische Sicht auf Organisationen und Systeme, beklagt aber eine oft vorherrschende duale Sichtweise in der Praxis.

Wenn Muster auf diese Weise die Klammer zum Verständnis der Organisation auf verschiedenen Ebenen bilden können und insbesondere einen Zugang zur Tiefendimension, zum »Ungenannten« der Organisation, bieten, dann ist es sinnvoll - in Anlehnung an Alexander et al. (1977) - eine Mustersprache für Organisationen zu entwickeln. Da Muster und eine Mustersprache für moderne Organisationen jedoch die Möglichkeit bieten müssen, beweglicher statt statischer zu werden, einen kreativen Prozess des Erfindens, und nicht nur des Findens (Dell 2002: 228) anstoßen sollen und im Sinne einer >lebendigen (Muster)Sprache< sich aufeinander beziehen sollen, müssen die Prinzipen der Mustersprache (die Muster der Muster) diesen Anforderungen entsprechen

Die Frage, wie sich Muster in Systemen wiederholen, weiterentwickeln und variieren, wird bei der Beschäftigung mit nicht-linearen Systemen in ähnlicher Weise gestellt. Fraktale und das bekannte Sierpinski-Dreieck (Abb. 2a und 2b) sind dafür gute Beispiele und können uns einiges über die Grundprinzipien von Mustern lehren (vgl. Brockman 1995).

Nach welchen Prinzipien Muster aufgebaut sind, ist daher entscheidend für einen gestaltenden und nicht nur konstatierenden oder affirmativen Umgang mit Mustern in sozialen Systemen: Kann dazu ein Vergleich der Nutzung von Mustern in verschiedenen Disziplinen (Muster in der Stadtplanung und Architektur, Software, funktionales Design, Muster der Organisation, Physik etc.) helfen? Ist die Notation der Muster in verschiedenen Disziplinen vergleichbar und bis zu welchem Maße? Gibt es übergreifende Prinzipien (siehe etwa Keidel 1995), die in 
allen Branchen gleich oder vergleichbar sind? Gibt es innovative und hemmende Muster?

Das Wissen, wie ein soziales System funktioniert oder wie innovative Prozesse ermöglicht werden, wird als >practical body of knowledge $<$ meist intuitiv und implizit angewandt und kontinuierlich ergänzt - ist daher immer in Bewegung. Die Analyse und Entwicklung von Mustern (Patterns) hat sich nicht nur zur Beschreibung des impliziten Wissen, das sich für Herausforderungen des Alltags in Organisationen als erfolgreich (viabel) erwiesen hat und ist in vielen Bereichen etabliert (z.B. in der bildenden Kunst, Musik und Literatur, aber auch in Disziplinen angewandter Wissenschaft wie Architektur, Softwareentwicklung oder Pädagogik). Muster bilden auch jene >minimal structures<, durch die das Potential für improvisatorische und kreative Problemlösungen im Handeln entdeckt werden kann.
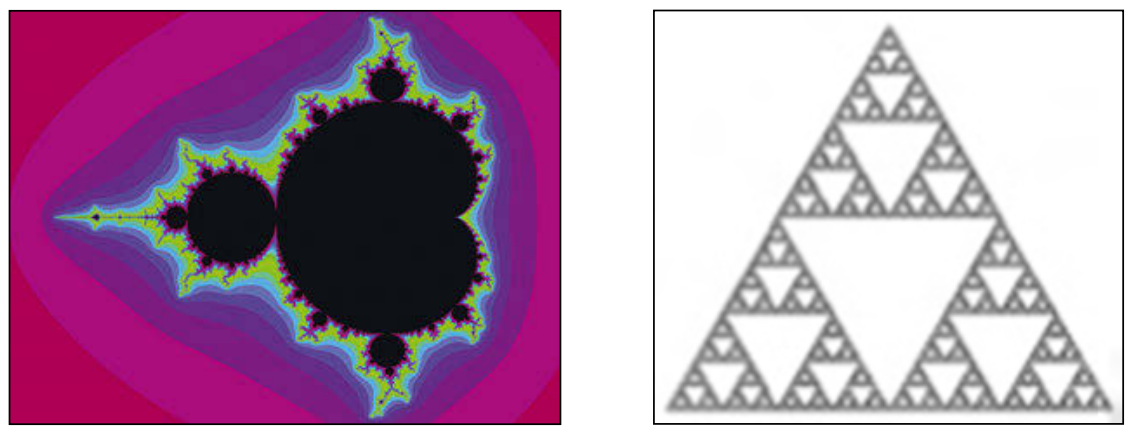

Abbildung: 2a und 2b: Fraktale und Sierpinski-Dreieck

(links - BY Wolfgangbeyer - Own work, CC BY-SA 3.0, https://commons.wikimedia.org/w/index. php?curid=2207386)

(rechts - Von PiAndWhippedCream - Eigenes Werk, Gemeinfrei, https://commons.wikimedia.org/w/ index.php?curid=2155993); aus: https://de.wikipedia.org/wiki/Fraktal

Patterns in der Kunst und in Organisationen sind Ergebnisse eines gemeinschaftlichen Prozesses, in dem Potentiale und Lösungsstrategien verdichtet werden, die sich durch die Beschäftigung mit dem Material sowie in den eingeübten Vorgehensweisen, Vorstellungen und Kompetenzen der Handelnden herausgebildet haben. Auf diese Weise verbinden sie betriebswirtschaftlich orientierte Wertschöpfungsprozesse mit Kultur, Wissen und Performanz. Der Prozess der Mustererkennung in Organisationen dient (a) dazu, die Strukturen zu identifizieren und zu dokumentieren, die das Wesen einer Organisation ausmachen und ihr den je spezifischen Stempel aufdrücken und (b) dazu, aus den Mustern die Möglichkeiten der stetig lernenden Organisation in Handlungen zu übertragen. 
Die Schnittstelle 3 fragt daher danach, wie die Struktur von Mustern in Organisationen und sozialen Systemen beschaffen sein muss, damit sie wiederholbare Grundprinzipien und Lösungsansätze bei gleichzeitig hoher Variabilität und Zeitdynamik beschreiben und generieren können. Eine Frage, die sich in ähnlicher Weise die Theorie nicht-linearer Systeme (Gell-Mann 1996; Bais \& Farmer 2007), aber insbesondere performativ auch die Musik (Dell 2011; Stark 2010) stellt.

\section{Organisationen musikalisch denken - EINE NEUE SPRACHE FÜR DIE TIEFENDIMENSION VON ORGANISATIONSKULTUREN?}

Können die Kulturen, in denen die Organisationsmitglieder leben bzw. arbeiten, klanglich >hörbar gemacht< bzw. musikalisch verstanden werden, so wird das im Arbeitsalltag fast ausschließlich genutzte Kommunikationsmedium >Sprache< sensorisch-emotional ergänzt und dem Management von Organisationen eine neue Dimension hinzugefügt. Die Tiefendimension von Organisation und Innovation wird über den Kanal der Musik wahrnehmbar und gleichzeitig als Feedback für die Führungskräfte, Mitarbeiterinnen und Mitarbeiter nutzbar, um notwendige Lern- und Entwicklungsprozesse auf individueller und organisationaler Ebene, anzuregen. Das musikalische Feedback regt das System Organisation an und ermöglicht eine positive Neuordnung des Systems.

Musik entsteht sui generis aus dem relationalen Zusammenhang, aus einer Topologie ihrer strukturellen Momente. Wichtig dabei ist: Diese Relationalität muss hervorgebracht werden. Der Sinn von Musik entfaltet sich erst aus der Relationalität von Rhythmus, melodischer Anteile, harmonischer Verläufe, Klangfarbe etc. die nicht allein als physikalische Vorgänge von akustischen Schwingungen, sondern als ein >sinnvolles< Konglomerat wahrgenommen werden können. Wichtig ist außerdem, dass jeder mitmachen kann: Strukturen dieser Vorgänge bilden für alle Hörer (und Musiker) gleichermaßen eine Grundlage. Sie können jenseits tertiärer Eigenschaften »Anlass für zusammenhängende Erfahrung« (Vogel 2007: 327) sein und bilden so wahrnehmungsstrukturierende Modelle, die nicht nur Spezialisten der Musik, sondern auch jedem Laien zugänglich und plausibel sind. Diese Modelle sorgen dafür, dass die Hörer, eine Praxis, ein Tun nachvollziehen und daraus eine Form der Kohärenz ableiten können. Dieser Nachvollzug ist jedoch stark subjektiv gefärbt; eine Eigenschaft, die durch die Tatsache, dass organisationale Strukturen auf einen musikalischen Verlauf projiziert werden und umgekehrt noch verstärkt wird. Musik >bedeutet< also nicht die Organisation, sondern das Tun eines musikalischen Spiels wird nachvollzogen oder etwa im Schreiben einer Partitur vorgedacht. Der Erfahrungsraum des Musikmachens oder Musikhörens wird also umgekehrt zum strukturierenden 
Moment einer Reflexion über Organisation. Wir gehen davon aus, dass Musikhören ebenso wie das daran angeschlossene oder vorgeschaltete Partiturenzeichnen nicht bloß rezeptiv oder interpretatorisch $\mathrm{zu}$ verstehen ist, sondern dass darin Elemente einer Praxis enthalten sind, die sich daran beteiligen musikalischen Sinn überhaupt erst >produzieren<.

Der Fokus auf die Produktion von Sinn, auf das Verfahren des Musizierens selbst rückt ein spezifisches Verfahren der Musikproduktion in den Blick: das der Improvisation. Dieses Verfahren ist für Organisationen zunehmend interessant. Aktuell beobachten wir, wie sich die Perspektiven im Komplex der Organisationstheorie verschieben.

Auf der Basis eines >organisationalem Lernens< wurde ein »Prozeß der Erhöhung und Veränderung der organisationalen Wert- und Wissensbasis, die Verbesserung der Problemlösungs- und Handlungskompetenz sowie die Veränderung des gemeinsamen Bezugrahmens von und für Mitglieder innerhalb der Organisation « in Gang gesetzt (Probst/Büchel 1994: 17). Damit ändert sich auch die Organisation von Organisation. Organisation ist nicht mehr nur als Planung und Ausbildung von Routinen, sondern vor allem als organisatorischer Wandlungsprozesse zu verstehen. Innerhalb dieses Komplexes ist in den letzten zehn Jahren ein Untersuchungsfeld emergiert, das Improvisation als Kompetenz des konstruktiven Umgangs mit dem Unerwarteten stärker in den Blick nimmt. »Organizational Improvisation is one of the more recent theoretical developments, and one which is only now beginning to capture the imagination of organization theorists « konstatieren Kamoche et al. (2002: 12). Dies hätte einen Paradigmenwechsel in der Organisationstheorie zur Folge: In ihr wird herkömmlicher Weise Planung »als langfristig der Improvisation überlegene und erstrebenswerte Form der Problemlösung definiert, während die Improvisation eine untergeordnete Rolle spielt. Aufgrund von Planungsgrenzen wird in den Unternehmen in einem Maße improvisiert, welches über dem der theoretischen Darstellungen liegt.« (Probst \& Büchel 1994: 17)

Schön (1983) rekurriert bereits in seiner Beschreibung des >reflexiven Praktikers auf die Arbeit von Musikern, und zwar Jazzmusikern im Speziellen, weil diese Improvisation nutzen und so im Unvorhersehbaren Kohärenz zu erzeugen in der Lage sind:

"Sie (die Musiker) können das hauptsächlich deshalb tun, weil sie sich bei ihrem kollektiven Bemühen um eine einfallsreiche musikalische Gestaltung eines metrischen, melodischen und harmonischen Schemas bedienen, das allen Beteiligten vertraut ist und dem Musikstück eine vorhersehbare Gestalt verleiht. [...] Indem die Musiker ein Gespür für die Richtung bekommen, in der sich das Musikstück aufgrund ihrer zusammenwirkenden Beiträge weiterentwickelt, gewinnen sie daraus einen neuen Sinn und passen ihr Musizieren diesem neuen, von innen begleiteten Sinn an." (Schön 1983: 55) 
Die Analyse des reflektierten Handelns geht somit von einer bestimmten Organisationspraxis aus, und zwar der der organisationalen Improvisation.

Fassen wir zusammen: Musikalische Logik fügt sich nicht aus wahrheitserhaltendem Schließen zusammen, sondern aus der Relationalität einer spezifischen Nachbarschaftsordnung musikalischer Elemente. Matthias Vogel spricht in diesem Zusammenhang von medialen Praktiken.

"Im Mittelpunkt medialer Praktiken stehen tradierte und erlernbare Tätigkeitstypen, die wahrnehmbare Ereignisse hervorbringen, wobei Produzenten und Rezipienten dieser Ereignisse sich nicht an deren physikalischen Eigenschaften, sondern anderen beobachterrelevanten Eigenschaften orientieren."(Vogel 2007: 319)

Der Zugang über die Sinneswahrnehmungen der Musik ist eine Chance und Herausforderung, um die Tiefendimension der jeweils spezifischen Organisationskulturen zu erfassen - und damit auch in der Praxis zu vermitteln. Ausgehend von Musik als Modell von Organisation gilt es, neue Erfahrungshorizonte des Organisierens und Managens zu erforschen, denn:

- Musik kann die Komplexität (der Kulturebenen) einer Organisation oder eines sozialen Systems zeitgleich darstellen, da Musik über verschiedene Ebenen und Dimensionen (z.B. Melodie, Harmonik, Rhythmus) verfügt.

- Musik ist als Analyseinstrument zur Selbstreflexion und zur Evaluation der Organisation und ihrer Kultur besonders geeignet, da sie jenseits von Sprachcodes ein unmittelbares Feedback auf der strukturellen und emotionalen Ebene gibt.

- Musik ist Aktion (Performanz) in der Zeit und erfasst damit die zeitlichen und performativen Aspekte des Organisierens, die in bisherigen (oft statischen) Organisationsmodellen meist vernachlässigt werden.

Durch die Verbindung von Organisationskultur und Musik lassen sich neue Wege zur Entwicklung innovativer Unternehmen und sozialer Systeme entdecken: Dabei kommt es besonders darauf an, auch die Erfahrungsbestände in Organisationen für Innovation zu erschließen, die nicht ausschließlich kognitiv repräsentiert sind. Fähigkeiten zur Selbstreflexion sind entscheidend für Innovativität, Erfolg und organisationales Überleben (Moldaschl 2006). Muster innovativer Organisationen - in ihrer Tiefenstruktur bislang nur schwer erkenn- und darstellbar - können durch die Musiksprache auf einer neuen Reflexionsebene erfahrbar gemacht werden.

Innovative und lernfähige Organisationskulturen bilden am ehesten den Prozess des Improvisierens ab, der im Jazz oder auch in Teilen der Neuen Musik identitätsbildend ist. Dies gilt insbesondere für Organisationen, die sich aufgrund neuer Anforderungen aus der Organisationsumgebung immer wieder neu erfinden müssen. Komplexe Anforderungen benötigen hoch-qualifizierte Mitarbeite- 
rinnen mit hohen Freiheitsgraden, um Innovationspotentiale erkennen und flexibel agieren zu können; sie benötigen jedoch keine komplexen Strukturen (siehe Abb. 4).

Tabelle 2: Komplexität in Organisationen

(aus Pina e Cunha a Viera da Cunha 2006)

\begin{tabular}{|l|l|l|}
\hline & Simple People & Complex People \\
\hline Complex Structure & Machine Bureaucracies & Intelligent Bureaucracies \\
\hline Simple Structure & Simple Organisations & $\begin{array}{l}\text { Improvising } \\
\text { Organisations }\end{array}$ \\
\hline
\end{tabular}

Improvisationen als Muster innovativer Organisation(skulturen) sind nach Cunha, Cunha \& Chia (2006) beabsichtigte, aber ungeplante Abweichungen von den Organisationsroutinen, die eben dadurch unerwartete Problemlösungen und Entwicklungsmöglichkeiten erkennen und nutzen können. Innovative Prozesse erfordern das Brechen vorhandener Muster (Wüthrich, Osmetz \& Kaduk 2006) mit dem Möglichkeiten in der aktuellen Entwicklung aufgegriffen werden können, die eine neue Figur ergeben.

Schnittstelle 4: Die Fragen nach den Mustern der Innovation ergeben die nächste Schnittstelle: Was ist die Besonderheit von Innovationmustern und ihrer Dynamik - wann gebiert ein Handlungsmuster Neues, wann kommt es zu einem Ende? Hier sind sowohl die Prinzipien der Mustersprache (unter welchen Bedingungen, wie und mit welchen Folgen lassen sich Muster miteinander verbinden?), als auch die Grundlagen aus der Musikimprovisation (Barrett 1998; Hatch 1998), dem Improvisationstheater (Meisieck \& Barry 2007) und dem Tanz (Forsythe 2003) zentral: Was kann in der Improvisation wann wie aufgegriffen werden, wie entsteht Kommunikation in und zwischen Mustern durch Nutzung minimaler Strukturen? Werden dazu >Transmittersubstanzen benötigt, die - ähnlich den Synapsen im Gehirn - spezifische Informationsträger sind/sein können?

\section{INNOVATIONSMUSTER UND IMPROVISATORISCHE FELDER IN ORGANISATIONEN ENTDECKEN}

Turbulente Umgebungen führen Organisationen mehr und mehr in widersprüchliche Prozesse: Reflektion steht gegen Lernen, Lernen gegen Handlung bzw. Geschwindigkeit, Unbestimmtheit gegen Planung, Entscheidung gegen Unbestimmtheit usw. Der Ansatz der Improvisation als Technologie (Dell 2002) geht davon aus, dass es sich hier nicht a priori um destruktive Widersprüche han- 
delt, sondern um Komplexität. Eine Unordnung, die konstruktiv genutzt werden kann. Es sind nicht mehr die starken Signale der Umgebung, die Wegweiser für anschlussfähige Entscheidungen darstellen, sondern die schwachen Signale, die minimalen Strömungen/Strukturen und ihre flows von Handlungen und Kommunikation.

Organisationen sind immer öfter damit beschäftigt, sich selbst und ihre Umgebungen in einen Zustand zu versetzen, in dem die Routinen wieder funktionieren. Anders gesagt: Organisationen, die vormals zur Aufrechterhaltung von bestimmten Routinen in der Veränderlichkeit der Umwelt eingerichtet wurden, stehen heute vermehrt selbst unter dem Druck, sich permanent zu wandeln. Oftmals wird dann mit dem Versuch des >Mehr an Planung< versucht, der Lage Herr zu werden, was zu einer Konfrontation mit den Dilemmata des Realen führen kann, da sich die Organisation durch jede Planung von den realen Bedingungen entfernt.

Wenn eine Organisation improvisiert, agiert sie genau umgekehrt: Sie scannt die Möglichkeiten, die Potentiale die in einer Situation vorhanden sind, um diese anschlussfähig und nutzbar zu machen. Wenn aber Organisationen keinen Zugang zu dem Potential der Improvisation haben, wenn Mehrdeutigkeit durch Ordnung und Improvisation durch Routine ersetzt wird, nimmt ihre Befähigung zur differenzierten Wahrnehmung von und aktivem Umgang mit Wandel ab. Man könnte sagen, dass Organisationen, die sich wandeln wollen, gut daran tun, Meta-Lernen (Argyris \& Schön 2002) zu fördern und Improvisation zur Routine zu machen, sprich improvisationale Tätigkeiten und Denkweisen in alltägliche Aktivitäten einzuweben. Vermittels Improvisation bringt sich eine Organisation permanent auf den neusten Stand und ermöglicht so eine antizipatorische Haltung zum Wandel ohne ihm ausgeliefert zu sein. Diese Vorstellung von einer Organisation ist eine andere als eine, die Organisationen als Gebilde interpretiert, die auf Veränderungen nur reagieren und Wandel so lange ausblenden wie irgend möglich. Das traditionelle Bild der Organisation und des Organisierens (Weick 1985) basiert darauf, zu ignorieren, dass Organisationen dauerhaft an der Gestaltung ihrer Umwelten partizipieren, ob sie es wollen oder nicht. Improvisation als Organisationsmodus erkennt diesen Fakt nicht nur an, sondern sucht aktiv mit ihm zu spielen. Das bedeutet, dass Improvisation Akteuren nicht ein Weniger, sondern ein Mehr an Verantwortung zuweist. Zu beachten gilt: Improvisation ist keine spezifische Reihe von Handlungen (Hegel) sondern spielt sich auf der Metaebene ab. Improvisation könnte eher gedeutet werden als eine Art und Weise, Handlung so zu organisieren, dass eine Situation ihr Potential voll ausschöpfen kann.

Einer Improvisationstechnologie geht es deshalb um die Entwicklung einer Improvisationskultur in der Organisation, die diese »minimal structures « (Cunha \& Cunha 2006), feinen Strömungen und Potentiale komplexer Situationen in- und außerhalb der Organisationen wahrnimmt, anerkennt und sicht- bzw. nutzbar macht. Handelnde werden zu Beobachtern und umgekehrt; Donald A. 
Schoen (1983) nennt dies den Reflective Practitioner. Für den Improvisator, den Reflective Practitioner, gibt es viel, das falsch gemacht werden kann, aber es gibt keine Fehler an sich. In der Improvisation wird Komplexität Bedingung für die Fehlerfreundlichkeit von Systemen, Fehler werden zu Generatoren neuer Lösungen. Es ist, mit Weick (2003) gesagt, eine Frage der Vorbereitung auf das Unerwartete. Improvisation geht davon aus, dass die Koordination von Operationen und Beobachtungen offen bleibt: Komplexität wird zum Katalysator multipler Lösungsansätze die sich im Prozess der Handlung selbst generieren. Das bedeutet auch, dass sich die Beobachter in die Analyse mit einbeziehen.

\section{IMPROVISATIONSLABORATORIEN ALS DIALOGISCHE FORM}

Ergebnisse von Organisationsanalysen und der Mustererkennung in Organisationen werden dabei in Form musikalischer Feedbacks zunächst verfügbar gemacht. Grundlage dafür sind Zuordnungen von Rhythmus, Melodie und Harmonie und anderer musikalischer Parameter zu Ereignissen im Prozess des Organisierens und zu Mustern in Organisationen. Der indirekte musikalische Ausdruck eröffnet Reflexions- und Handlungsräume, die die Lernpotentiale der Organisation stimulieren. Drei Formate sind hier bislang ausschlaggebend:

Im Format der Gesprächskonzerte wird die Frage diskutiert und reflektiert: Wie klingen wir? Mit Jazz-Improvisationen, die die jeweilige Organisationskultur widerspiegeln, werden Gespräche und Diskussionen zwischen Musikern und Publikum (sprich Führungskräfte, Mitarbeiterinnen und Mitarbeiter, Akteure im Umfeld, Kunden, Stakeholder usf.) angeregt.

Als Methode reflexiver Organisationsentwicklung werden Organisations-Partituren (vgl. Vossebrecher in diesem Band; Vossebrecher, Dell \& Stark 2013) als Verfahren 'musikalischen' Denkens entwickelt und eingesetzt. Partituren sind Formen des Erschließens von Sinn in der Musik: Wenn wir eine Symphonie von Beethoven strukturell genießen und >verstehen< wollen, besorgen wir uns eine Partitur und lesen beim Hören mit. Die Partituren der Neuen Musik (vornehmlich aus der Mitte des 20. Jhd.) jedoch sagen nicht mehr den genauen Verlauf der Musik vorher bzw. bilden ihn 1:1 ab. In diesen nicht-repräsentationalen Partituren hängt die Sinnproduktion nicht mehr nur vom Autor (Komponisten) ab, sondern ebenso von den Ausführenden (Interpreten). Die Ausführenden interpretieren nicht nur ein Notensystem, sondern müssen auch aus der Partitur - die eher >diagrammatisch a angelegt ist - eigene Handlungsformen entwickeln. Dieses Verfahren ist für Innovation in Organisationen deshalb wertvoll, weil hier sunscharfe< Anweisungen $\mathrm{zu}>$ scharfen< Ergebnissen führen sollen: Eine beabsichtigte, aber nicht geplante (oder planbare) Nutzung von Freiheitsgraden und Handlungsspielräumen von Akteuren in Organisationen für Innovationsprozesse.

Über Gesprächskonzerte und Organisationspartituren (vgl. auch Vossebrecher \& Stark 2010) werden mit dem Medium der Musik neue Reflexionsebenen 
für die Analyse von organisationalen Zusammenhängen, Abläufen, Prozessen und Ereignissen erschlossen und nutzbar. Muster der Organisationskultur und musikalische Muster verbinden sich damit zu einer Mustersprache der Organisationen, die Zugänge zu den Tiefendimensionen von Organisationen erlaubt (vgl. Baitsch \& Nagel 2008). In weiteren Schritten können organisationale Mustersprachen dazu genutzt werden, Überlegungen zur Neugestaltung von Abläufen und Prozessen (z.B. im Rahmen einer Krisenbewältigung) zu unterstützen. Insofern sind Gesprächskonzerte und Partituren Elemente eines Instrumentenportfolios, das Organisationen nicht nur als Analogie »musikalisch denkt«, sondern die Sensibilität für Innovation und die Ermöglichung von Improvisationsprozessen in Organisationen im Sinne einer lernenden Organisation neu erklingen lässt.

In einem weiteren Schritt erfolgt eine systematische Verzahnung von musikalischen/klanglichen Mustern mit Mustern der Organisation hin zu einer Mustersprache, mit deren Hilfe interaktive klangliche Diskurse Grundlage für Design und Re-Design von Organisationen und Organisationsteilen werden können. Im Format des MICC_Impro_Labs besteht die Möglichkeit, das bereits dokumentierte Erfahrungswissen zum Thema Muster auf Improvisation hin zu fokussieren. Der Prozess des Improvisierens löst Fragen aus, denn nicht nur die Performanz sondern vor allem das Verfahren der Improvisation enthält, Differenz, Lücken, Lockerheit und Zwischenräume. Das ImproLab stellt diese Differenzen die für aktive Deutungsarbeit der Rezipienten zur Verfügung und sucht so deren Erfahrung zu qualifizieren. Dabei steht die Erarbeitung und Gestaltung der Schnittstelle von Improvisations- mit Organisationstheorie bzw. -praxis im Zentrum.

\section{OrganisationspartituREN: ZUgÄNGE ZUR TIEFENDIMENSION DER ORganisationskULtUR}

Organisationspartituren erschließen Teile der Tiefendimension des organisatorischen Feldes, indem sie einen neuen Zugang zum Verständnis von Organisationen und sozialen Systemen eröffnen. Partituren beginnen mit einer Vorstellung des Ungenannten und ermöglichen einen neuen >Blick auf die Organisation, bei der auch das Wahrnehmungsmedium wechselt: >Wie klingt deine Organisation/ deine Abteilung/deine Arbeit?< Der Übergang vom visuellen zum akustischen Sensorium verändert die Vorstellung, die Idee der Organisation. Da diese Vorstellung nicht nur notiert (zweidimensional als cognitive map und als Notation), sondern auch gespielt und aufgeführt werden kann, eröffnet nicht nur mehrere Ebenen der Wahrnehmung, sondern - über den link zu musikalischen >patterns (Coker et al. 1970) und den spielerischen Einsatz des Reactable - auch die Möglichkeit, tatsächlich damit zu spielen: Nämlich sowohl die Partitur, als auch die sperformance $\mathrm{zu}$ interpretieren, neu $\mathrm{zu}$ verstehen, sich selbst $\mathrm{zu}$ verorten und weiter zu entwickeln. 
Organisationspartituren enthalten immer auch Hinweise auf Kulturmuster der Organisation; in vielen Fällen ergeben sich diese Muster aus der Legende zur Partitur, mit denen die (individuellen oder kollektiven) AutorInnen der Partituren einzelne Phasen oder Räume benennen. In den Mustern finden sich - so nehmen wir an - jene >minimal structures $<$ die das Basismaterial für Improvisationen in der Kunst wie auch in Organisationen darstellen und es erlauben, mit den Potentialen von sozialen Systemen zu spielen und sie zu erneuern.

Schnittstelle 5: Lassen sich Partituren als >Methode< der Notation mit der Entwicklung von organisatorischen und musikalischen Mustern systematisch verbinden? Was passiert mit (meist visuellen) Mustern, wenn sie bereits in der Vorstellung in den akustischen Vorstellungsraum wechseln? Welche Rolle spielt die Performanz der Diagramme (hinsichtlich der Veränderung der in den Partituren angelegten Muster? Gibt es hier eine Kommunikation zwischen verschiedenen Interpretationen? Wie lässt sie sich organisieren?

Die größte Herausforderung - und das größte Potential - besteht in der Verbindung zwischen organisationalen und den musikalischen Mustern. Tangible User Interfaces können zwar >Jazz-Patterns und andere musikalische Muster miteinander verbinden und ggf. sogar iterative Prozesse, die Muster verändern, unterstützen - werden aber damit Muster der Organisationskultur und neu verstanden? Basierend auf dem Einsatz des Reactable (www.reactable.com) - eines für musikalische Anwendungen entwickelten Tangible User Interfaces (vgl. Kaltenbrunner u. a. 2006; Kaltenbrunner 2009) arbeiten die Teilnehmer interaktiv und intensiv mit vorab eingespielten >musical patterns $<$, die sich im Verlaufe des MICC-Projekts als bedeutsam für das >musikalische Denken von Organisationen< erwiesen haben. Diese musikalisch-organisatorischen Muster werden mit Hilfe interaktiver Softwareanwendungen im Verlaufe des Workshops von den Teilnehmern immer wieder neu arrangiert und erprobt; sie ermöglichen so einen nutzer-orientierten experimentellen Zugang zum erarbeiteten Material. Auch bereits erstellte Organisationspartituren können hier zum Einsatz kommen und von Organisationsmitgliedern selbst vertont werden.

Beim ReacTable (Abb. 3) kann der Benutzer über verschiedene Kunststoffgegenstände (Würfel, Quader, Scheiben) synthetische Klänge, wie auch kurze musikalische Muster (Patterns, Loops) auswählen, anordnen, steuern und modulieren. Durch die Möglichkeit, den ReacTable als Musikinstrument haptischintuitiv zu bedienen, entfallen typische Barrieren, die bei anderen Musikinstrumenten grundsätzlich gegeben wären. Eine Anwendung von Geräten dieser oder ähnlicher Bauweise in der Fläche, als vielversprechend bezeichnet werden kann.

Der momentane, prototypische Entwicklungsstand des ReacTable als organisatorisch innovativ gestaltendes Instrument erlaubt es, 80 organisationale Muster mittels musikalischer Patterns (kurzer Sample-Loops) zu repräsentieren. Mit Hil- 
fe der oben beschriebenen physischen Elemente können diese Patterns verschaltet bzw. miteinander kombiniert werden. Direktes akustisches Feedback erhält der User über die von ihm ausgewählten und abgespielten Samples. Projizierte Zeichen und Symbole bieten Orientierung bei der Bedienung und informieren über den Status der Manipulationsmöglichkeiten. Ein User kann jederzeit verschiedene neue Konfigurationen der Anordnung von physischen Elementen erzeugen oder gewählte Konfigurationen erweitern. Die grundsätzliche Besonderheit des dabei erzeugten Feedbacks ist, dass es im Handeln durch Körpereinsatz entsteht und damit performativ ist. Der User bewegt sich damit in der Zone seines impliziten Wissens, jenseits gedanklich-rational-sprachbasierter Kommunikation. Der User wird über sensorisch direkt erfahrbare und multiple wirkende Elemente (akustisch, visuell, haptisch) in die Lage versetzt, eine musikalische Repräsentation seines Wissens über seine Organisation durch schnelles Ausprobieren und Testen von Konstellationen zu finden und damit jenseits der sprachlich-kognitiven Ebene Dekonstruktionsarbeit zu leisten.

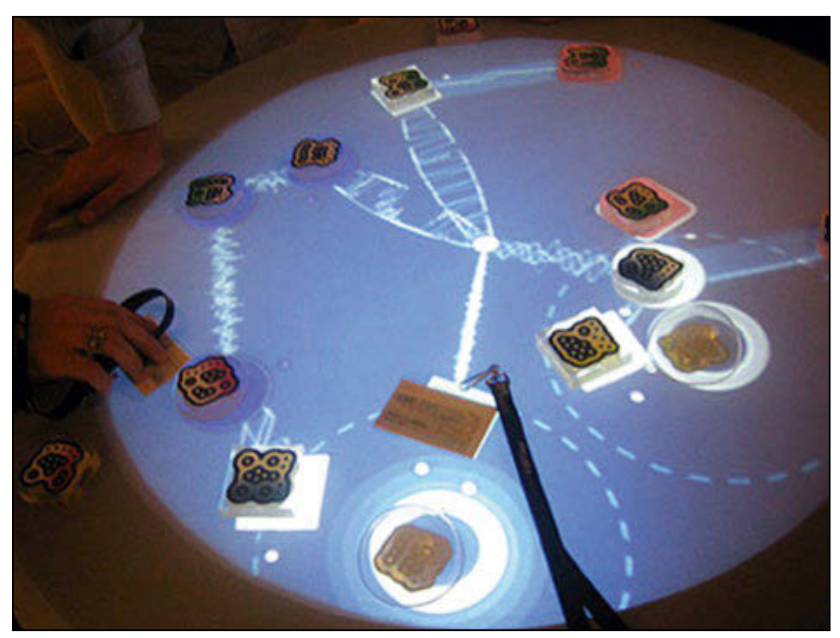

Abbildung 3: ReacTable (http://reactable.com)

Voraussetzung dafür ist, dass die Grundstruktur der beiden Mustergattungen (Organisation und Musik) angleichbar ist, und gleichzeitig an der Arbeit der Verbindungen etwas Neues entsteht - und nicht nur die Angleichung der Strukturmerkmale. Dazu muss experimentiert mit Kunst zu experimentieren, sondern selbst einen künstlerischen Prozess (Brater 2011; Arens-Fischer et al. 2011) einzugehen. Da Performanz (auch die ökonomische) nicht nur Interaktion mit dem Material, den Akteuren, dem Raum und Veränderung in der Zeit bedeutet, sondern auch Bewegung im Raum (Dell 2002), sind ein- oder zweidimensionale Instrumente immer gehandicapt. 
Daher ausblickend eine Vision: Wie können musikalische Muster und Muster der Organisation als interaktive Tools performativ im bewegten Raum eingesetzt werden? Wäre dies die Simulation und Erzeugung einer modernen Organisation? Oder vielmehr, im Sinne Bruno Latours (1999), eine Politik der Organisation, die sich der realen Unsicherheit dergestalt konstruktiv aussetzt, dass sie gerade nicht mehr planbare, vorauszusetzende Realität behaupten (simulieren) muss, sondern sich so aufstellt, dass sie in der Lage ist, sich Wirklichkeit im organisationalem Aushandlungsprozess als verhandelbare Tatsache auszusetzen?

Umgesetzt ist das ansatzweise bisher nur im belletristischen Fiction-Modus: in einem Buch des amerikanischen Schriftstellers Richard Powers (>Schattenflucht< Fischer, Frankfurt 2002).

Schnittstelle 6: Lassen sich interaktionsfähige Muster (Mustersprache) als Simulation und Produktion von Mustern der Organisationskultur herstellen, die dann als Grundlage der Interaktion von Mustern für >Organisational Design< dienen können?

\section{LITERATUR}

Arens-Fischer, W.; Brater, M.; Denisow, K.; Porschen, S.; Ruping, B.; Stark, W. \& Trobisch, N. (2011): Vom Entdecken des Neuen durch die »Entüblichung« des Denkens. Zur Programmatik eines ästhetisch-performativen Ansatzes in der Organisationsforschung und -gestaltung. In: Praeview - Zeitschrift für innovative Arbeitsgestaltung und Prävention, 1, 2011 (Themenheft: Das Andere - ästhetisch-performative Zugänge zur Organisationsforschung), S. 32-34.

Argyris, C. \& Schön, D. A. (2002): Die lernende Organisation. Stuttgart, KlettCotta.

Bais, A. \& Farmer, D. J. (2007): The Physics of Information, SFI Working paper 07-08-029 ITFA-2007-37; Sante Fe Institute, Sante Fe, NM, USA (www.san tafe.edu)

Baitsch, C. \& Nagel, E. (2008): >Organisationskultur - das verborgene Skript der Organisation.< In: Meissner, J., Wolf, P. \& Wimmer, R. (Hrsg.). Praktische Organisationswissenschaft. Heidelberg, Carl Auer-Verlag.

Barrett, F. J. (1998): Creativity and Improvisation in Jazz and Organizations: Implications for Organizational Learning. In: Organization Science, 9 (5), 605-622

Borchers, J. O. (2001): A Pattern Approach to Interaction Design. AI \& Society, Journal of Human-Centred Systems and Machine Intelligence, 15 (4), 359-376.

Borgdorff, H. (2009): >Die Debatte über Forschung in der Kunst.< In: Rey/Schöbi, (Hrsg.): Künstlerische Forschung, Institute for the Performing Arts and Film, Zürich. 
Brater, Michael (2011): Wie Künstler vorgehen - das Konzept des künstlerischen Handelns. In: Praeview - Zeitschrift für innovative Arbeistgestaltung und Prävention, 1, 2011 (Themenheft: Das Andere - ästhetisch-performative Zugänge zur Organisationsforschung), 14-16.

Coker, J.; Casale, J. \& Campbell, G. (1970): Patterns for Jazz. A Theory Text for Jazz Composition and Improvisation - Treble Clef Instruments. Los Angeles, Warner Bros.

Dell, C. (2002): Prinzip Improvisation. Köln, Verlag Walther König.

Färber, A. (2002): Ausstellungen als Instrument der Wissensvermittlung, Workshop am 26. und 27. April 2002, Helmholtz-Zentrum, Berlin.

Forsythe, W. (2003): Improvisation Technologies. A Tool fort he Analytical Dance Eye. Karlsruhe, Zentrum für Kunst und Medien.

Gell-Mann, M. (1996): Das Quark und der Jaguar - Vom Einfachen zum Komplexen. München, Piper.

Hagedorn, V. (2008): Musik vergisst man nie. In: Die Zeit, 29.05.2008 Nr. 23.

Hatch, M. J. (1998): Jazz as a Metaphor for Organizing in the 21st Century. In: Organization Science 9 (5), 556-557

Horsmann, C. S., Pundt, A., Martins, E. \& Nerdinger, F. W. (2007): Beteiligungskultur als Kontextfaktor für das Ideenmanagement. In: Wirtschaftspsychologie, 9 (2), 103-114.

Kaltenbrunner, M. \& Jordà, S. \& Geiger, G. \& Alonso, A. (2006): The reacTable: A Collaborative Musical Instrument, Proceedings of the 15th International IEEE Workshops on Enabling Technologies (WETICE 2006). Manchester, U.K.

Kaltenbrunner, M. (2009): reacTIVision and TUIO: A Tangible Tabletop Toolkit, Proceedings of the ACM International Conference on Interactive Tabletops and Surfaces (ITS2009). Banff, Canada.

Kamoche, K.; Cunha, M.P. \& Cunha, J.V. (Hg.) (2002): Organisational Improvisation. London/New York, Routledge.

Kroeber, A. L. (1963): Culture Patterns and Processes. San Diego, Harvest HBJ.

Kruse, P.; Dittler, A. \& Schomburg, F. (2003): >nextexpertizer und nextcoach: Kompetenzmessung aus der Sicht der Theorie kognitiver Selbstorganisation.< In: John Erpenbeck \& Lutz von Rosenstiel (Hg.): Handbuch Kompetenzmessung. Stuttgart, Schäffer-Poeschel.

Kruse, P. (2004): NextPractice. Über erfolgreiches Management von Instabilität. Offenbach, GABAL.

Latour, B. (1999): Politiques de la nature. Paris, La Devouverte.

Meisiek, S. \& Barry, D. (2007): Through the Looking Glass of Organizational Theatre: Analogically Mediated Inquiry in Organizations. In: Organization Studies, 28, 1805-1827.

Mintzberg, H.; Ahlstrand, B. \& Lampel, J. (1999): Strategy Safari. Eine Reise durch die Wildnis des strategischen Managements. Überreuter, Wien. 
Moldaschl, M. (2006): >Innovationsfähigkeit, Zukunftsfähigkeit, Dynamic Capabilities.<In: Schreyögg, Georg \& Conrad, Peter (Hg.): Managementforschung 16: Management von Kompetenz. Wiesbaden, Gabler.

Pina e Cunha, M. \& Vieira da Cunha, J. (2006): Towards the Improvising Organization; Business Leadership Review. Vol 3 Issue 4.

Powers, R. (2002): Schattenflucht. Frankfurt, Fischer.

Probst, G. J. B. \& Büchel, B. (1994): Organisationales Lernen: Wettbewerbsvorteil der Zukunft, Wiesbaden.

Schön, D. A. (1983): The Reflective Practitioner: How Professionals Think in Action, Basic Books, New York.

Stark, W. (2010): >Kann man Innovation hören? - Musik als Muster der Organisationskultur. Zur Realität und Rhetorik von Innovationen.< In: Heike Jacobsen \& Bernhard Schallock (Hrsg.), Innovationsstrategien jenseits traditionellen Managements. Stuttgart, Fraunhofer Verlag, 318-326.

Viera da Cunha, J.; Pina e Cunha, M. \& Chia, R. (2006): Routine as Deviation. Working Paper: Faculdade de Economia, Universidade Nova, Lisboa, Portugal.

Vogel, M. (2007): >Nachvollzug und die Erfahrung musikalischen Sinns.<In: Becker/Vogel (Hg.) Musikalischer Sinn, Frankfurt, S. 327.

Vossebrecher, D. \& Stark, W. (2009): >Music, Innovation, Corporate Culture innovative Organisationskulturen musikalisch verstehen.< In: Gatermann, Inken \& Myriam Fleck (Hg.), Innovationsfähigkeit sichert Zukunft. Berlin, Duncker \& Humboldt, S. 129-137.

Weick, K. E. (1985): Der Prozess des Organisierens. Frankfurt/Main, Suhrkamp.

Weick, K. E. \& Sutcliffe, K. (2003): Das Unerwartete Managen. Wie Unternehmen aus Extremsituationen lernen, Stuttgart, Schäffer-Poeschel.

Wüthrich, H. A.; Osmetz, D. \& Kaduk, S. (2006): Musterbrecher. Führung neu leben. Wiesbaden, Gabler. 



\title{
Technologie der Improvisation
}

\author{
Christopher Dell
}

Meine zentrale These lautet: Es verschiebt sich aktuell nicht nur das Verständnis der Konstitution von Organisationen von objektalen ${ }^{1}$ Modellen hin zu performativen Praxen organisationaler Akteure (vgl. Dell 2012). Auch die Frage des Erkennens bzw. Lesens von Organisation verändert sich. Externalisierungsstrategien, d.h. Behauptungen eines >dort ist ein Problem, ich denke mir was dazu aus, dann implementieren wir das und das Problem ist gelöst<, verfangen nicht mehr. Vielmehr geht es nun darum, in organisationale Situationen hinein zu kommen, Situationen zu kreieren, anhand derer man sich Zugang auch zur Transformation der Seinsweise als organisationaler Akteur verschafft. D.h. was in der Organisationsmodi der Industrialisierung als Negativum galt - Improvisation - avanciert, in der aufgehobenen Form der Improvisations-Technologie, zur wesentlichen Ressource des Organisierens. Daraus erwächst auch eine neue, ganz spezifische Herangehensweise an das Thema Improvisation. In dieser Perspektive ist Improvisation weder etwas das passiert, wenn etwas nicht klappt, noch eine Angelegenheit für Genies. Sondern sie folgt folgender einfacher Formel: Improvisation als Technologie $=$ konstruktiver Umgang mit Unordnung in Gemeinschaft. Als solche stellt Improvisation, so meine Annahme, eine Verfahrensweise dar, die zuerst benötigt wird, um einen spezifischen Blick auf die Handlungswirksamkeit von Unbestimmtheit zu erlangen.

\section{Das Vier-Ebenen-Modell}

In diesem Kontext möchte ich vier Organisationsebenen unterscheiden. Auf der ersten oder auch untersten Ebene verorte ich den Modus Improvisation erster Ordnung, ein Modus, der rein reaktiv und reparierend zu Werke geht, alles ad hoc löst und ohne Plan ist. Auf der zweiten Ebene ist die geplante Organisation anzusie-

1 | Objektalı ist ein tiefenpsychologischer Begriff (C.G. Jung) und bedeutet, dass Phantasien oder Träume auf real existierende Verhältnisse oder Personen bezogen werden (vgl. https://de.wikipedia.org/wiki/Objektstufe). 
deln, die erkenntnistheoretisch vorgeht und versucht, Kontingenz zu überschreiben, sie auszulöschen. Die Parameter >Funktion< $>$ Form $<$ und >Struktur $<$ sind hier statisch. Die dritte Ebene enthält die performative, kybernetische Organisation. Diese erkennt Kontingenz an und ist formal geöffnet. Allerdings sucht sie aus Kontingenz ein Objekt zu machen und Prozess auf Input/Output-Variablen zu reduzieren. Struktur wird außerhalb der Zeit stehend (synchronisch) gedacht. Die Funktion ist festgelegt, der Prozess wird auf die Funktion hin gesteuert. Erst auf der vierten Ebene, der Ebene der Improvisation zweiter Ordnung (als Improvisationstechnologie) kann die Organisation Struktur, Form und Funktion als variabel und verhandelbar konzeptionalisieren. Die Improvisation zweiter Ordnung (als Improvisationstechnologie) konzentriert sich auf die Ordnung der Ordnung, mithin die Organisation von Unordnung. Indem sie das Vektorfeld der Kräfte in Situationen fokussiert, wird in Potenzialen gedacht; auch Funktionen, Nutzungen können innerhalb des Prozesses entstehen, ebenso wie Strukturen und Formen.

Das Handlungsmodell Improvisation wird in Situationen relevant, in denen organisationales Handeln Komplexität und Unvorhersehbarkeit ausgesetzt ist. Die Zahl solcher Situationen nimmt zu, auch wenn dies in den Strategien der Organisationen meist noch nicht sichtbar ist. D.h. die Bedingungen von Organisationen haben sich in den vergangenen Jahrzehnten grundlegend gewandelt, das organisationale Bild, an dem sich Organisationen orientieren, dagegen kaum. Das stellt Organisationen zunehmend vor die Frage, wie sie in unordentlichen kontingenten Situationen handlungsfähig bleiben und diese Agency strukturell und lernend ausbauen können. »Die organisationsexterne Umwelt ist durch ein bestimmtes Maß an Komplexität und Unsicherheit sowie Schnelligkeit von Veränderungen gekennzeichnet [...]. Dieses Maß bestimmt [...] die Notwendigkeit zur Improvisation.« (Müller 2007: 271) Für Organisationen bedeutet dies, sich besonders achtsam innerhalb des Spannungsverhältnisses zwischen Sicherheitsbedarf durch Planung auf der einen Seite und der real existierenden Erfahrung der Unsicherheit auf der anderen Seite zu bewegen. Daraus lässt sich ableiten, dass der Modus 2 der Improvisationstechnologie als »Handlungsmodell zum konstruktiven Umgang mit Unordnung « (Dell 2004, S. 119) den Modus 1 der Improvisation als Reparatur abzulösen beginnt. Improvisation als Technologie erkennt Unordnung an und versucht, mit den Potentialen, die in einer Situation vorhanden sind, zu agieren. »Improvisation bedeutet dann, mit den Materialien der Wirklichkeit zu arbeiten und gleichzeitig diese Wirklichkeit mit zu gestalten.« (Ebda.)

\section{BRICOLAGE VS. IMPROMPTU}

In der Diskussion über die Improvisation taucht immer wieder der Begriff >Bricolage auf. Oft werden beide Begriffe unscharf nebeneinandergestellt oder ineinander geblendet. Im Folgenden soll jedoch - Miguel Pina e Cunha (2004) folgend Improvisation als Überbegriff einer Methode oder Verfahrensweise des Agierens 
verwendet werden und als Subkategorien >Impromptu< und >Bricolage < gegeneinander abgesetzt werden. Deren Differenz kann wie folgt definiert werden als

" [...] (1) impromptu action in an organizational context, and (2) bricolage, or the ability to draw on the available material, cognitive, affective and social resources, in order to solve the problem at hand." (Cunha 2004, S. 2.)

Wie bereits oben dargelegt, ist Improvisation nicht gegen Planung auszuspielen. Vielmehr nimmt Improvisation die Planung in Anspruch und überschreitet diese. Was bedeutet das? Man kann sagen, dass man nicht nur im Kontext bestimmter Strukturen improvisiert, sondern dass diese Strukturen die Improvisation rahmen oder stabil halten können. Weick (2001a) und Hatch (1999) haben gleichermaßen überzeugend dargestellt, dass Improvisation auf vorkomponierten Materialien beruht - seien es Pläne, Erfahrungen, vorgeschriebene Interaktionen oder Rollen. Das wäre als der Bricolage-Anteil der Improvisation zu bezeichnen, als die Fähigkeit, Potenziale aus Vorhandenem abzuleiten. Grabher (2004: 103) beschreibt Bricolage auch als »[...] creation of novel combinations of familiar elements and by-products from previous projects«. Es ist wichtig, gerade diesen strukturellen Aspekt der Bricolage hervorzuheben, weil dieser als gesamtes Handlungskonzept eher einen Reparaturcharakter aufweist und zum Einsatz kommt, wenn Mangel an Materialien herrscht. Ihr operativer Wert liegt vor allem darin, Potenziale im Hinblick auf bestimmte Funktionen hin auszuloten. Auch Weick (2001b: 59) definiert Bricolage als »[...] using whatever resources and repertoire one has to perform the task one faces.«

Nach Thayer kann Bricolage verstanden werden als: »[...] making things work by ingeniously using whatever is at hand, being unconcerned about the proper< tools and resources.« (Thayer 1988, S. 239) Bei all diesen Definitionen wird jedoch nicht das Wie, also die Konzeptionalisierung des Umgangs mit Ressourcen mitgedacht bzw. thematisiert. Bei einer Gleichsetzung von Bricolage und Improvisation bliebe Letztere im Modus 1 - dem Bricolage- oder Reparaturmodus hängen. Bricolage hebt vor allem auf den strukturell-materialen Modus des Umgangs mit Situationen ab. Impromptu hingegen impliziert die Befähigung, Achtsamkeit für den Moment, subjektive Spontaneität und Handlungsschnelligkeit hervorzurufen. Im Gegensatz zur Improvisationstechnologie verfügen beide Modi weder über einen Metablick auf die strukturelle Ordnung von Situationen noch über konzeptionelle Speicherungsmethoden bezüglich situativer Prozessmaterialien.

\section{Deep Listening}

Wie schon angeführt ist Improvisation nicht planlos. Sie hat einen flüssigen Plan, einen Plan, der in die Navigation der Spielenden selbst als Matrix und Reservoir für Handlungsoptionen eingelagert ist. Um einen solchen flüssigen Plan in im- 
provisatorische Handlung übersetzen zu können, wird beispielsweise im Jazz die Fähigkeit der Musikerinnen und Musiker zu Listening and Responding vorausgesetzt. Zuhören ist nicht passiv, sondern Inspiration für zukünftiges Handeln - als »aktiver, komplexer Prozess der Informationsverarbeitung (Busch 1996, S. 81) zu begreifen. In diesen Bereich spielt das >Impromptu< hinein, das Weick (2001a) auch als Mindfulness beschreibt. Das Konzept der Mindfulness erinnert stärker als die vorangegangenen Arbeiten Weicks an die Wichtigkeit, eine enge Anbindung körperlicher Regungen, individueller Wahrnehmungen und kollektiver Sinngebungsprozesse an die Entscheidungen eines Unternehmens herzustellen. Unternehmen bleiben nur dann sensibel gegenüber Umweltveränderungen, wenn es ihnen gelingt, diese affektiven wie affizierenden Ressourcen der Mitarbeiter in situ in Entscheidungsprozesse einzubeziehen. Jedes Subjekt einer Impro-Combo muss befugt sein, Stopp zu sagen, wenn etwas nicht stimmt, wenn die Lage zu externalisieren droht, weil man nicht mehr sim Spiek ist, wenn man das vage Gefühl hat, es stimmt etwas nicht. Diese Konzeption weist zukünftigen Organisationstheorien den Weg: Es geht um die Frage, wie physische, psychische, soziale und technische Prozesse produktiv und zugleich evolutionsfähig gekoppelt werden können. Hier zeigt sich der Impromptu-Aspekt der Improvisation als Modus der Aufmerksamkeit, Achtsamkeit für und das Embodiment von Situation als Gefüge, wie sie auch in Aspekten der Theorie $U$ von Scharmer (2009) dargestellt sind. Scharmer zeigt, wie »tiefere Felder der gemeinsamen Wahrnehmung, der gemeinsamen Willensbildung, der gemeinsamen Gegenwärtigung und des gemeinsamen Experimentierens« (a.a.O.: 27) entstehen. Stationen des U-Prozesses zeigen sich als »Fähigkeit, im Moment des Aufbrechens der alten Strukturen einen sich öffnenden Möglichkeitsraum zu sehen, sich darauf einzulassen, einzutauchen, Ereignisse kommen zu lassen, dann den neuen Impuls zu verdichten und in die Welt zu bringen.« (A.a.O.: 25)

\section{VERS L'IMPROTECHNOLOGIE}

Aktives Zuhören ermöglicht adäquates Handeln in Echtzeit, die Antizipation von Transformation und die Konstruktion von Ordnung in der Arbeit mit Unordnung (statt Projektion von Ordnung über Unordnung). Man braucht also zur Improvisation ein Team, das die Technik der Improvisation beherrscht und aufeinander eingespielt ist. Dabei ist die Improvisationstechnik Voraussetzung für die Befähigung der Akteure, Verantwortung für die Formen und die Dramaturgie zu übernehmen. Dies geht weit über die Interpretation eines Plans bzw. einer Partitur hinaus. Im spielerischen Prozess entstehen die Formen aus und während der Ausführung - sozusagen in Realtime. Improvisationstechniken stellen hierfür die Navigationswerkzeuge dar. Die Übernahme von Verantwortung ermöglicht es organisationalen Akteuren, selbstständig in das Geschehen einzugreifen. Damit verknüpft ist eine Alertheit, eine konstante Aufmerksamkeit für das zu Entstehen- 
de. Aufmerksamkeit erhöht die Spannung und Intensität der Wahrnehmung und Erfahrung prozessualer Zeitverläufe. Die Voraussetzung eines solchen Arbeitens könnte man mit dem Theatermacher Jan Lamers als eine Atelier-Hierarchie bezeichnen (Lamers 1994: 44-69). Diese Art der Hierarchie ermöglicht der Gruppe ein offenes Strukturieren des Prozesses in Form von >multipler Autorenschaft< (Dell, 2002). Improvisation ist sozialer Prozess, der aufgrund seiner relationalen Beschaffenheit Konflikte nicht ausblendet sondern als Material gebraucht. »Im Moment der Nichtübereinstimmung wird das Finden und Erzeugen neuer Übereinkünfte eröffnet. Dabei ist der Konflikt nicht Ende der Situation, [...], sondern als Beweggrund für die Suche nach weiteren Anschlussmöglichkeiten in der Improvisation selbst gedeutet.« (A.a.O.: 55)

Improvisation als Technologie (im Modus 2) impliziert das maximale Verschalten vorhandener Strukturen und Ressourcen. Dies kann durchaus auch ein Plan, ein Set von Annahmen, ein Diagramm, eine soziale Struktur darstellen, auf deren Basis Variationen gebildet werden können. Der Dualität von Impromptu und Bricolage wäre also als ein Drittes die diagrammatisch-reflexive Handlung als Improvisationstechnologie hinzuzufügen. Improvisation als Technologie ist darauf ausgerichtet, auch den funktionalen Rahmen zu erweitern und neue Funktionsformen aus gegebenem Material (wie Pläne oder Karten etc.) abzuleiten. Jedoch ist nicht nur das gegebene Material von Bedeutung, sondern die durch die prozessuale Ontologie erzeugte Transformation. Das Material wird erlebbar durch Improvisation, durch stetige Vitalität der Performanz, eine spannungsgeladene Unbestimmtheit des Spiels bei maximaler Vielschichtigkeit der in- sowie externen Ressourcen, dem relationalen Verweben unterschiedlicher Strukturen. Durch das diagrammatische Verfahren der Improvisation werden bisher noch nicht gefundene Verschaltungen kreiert. Das Interessante dabei ist: Je besser ich improvisieren kann - also je mehr ich über die Situation weiß -, desto mehrdeutiger wird sie. Je mehr ich ersetze, alteriere und je größer ich den organisationalen Raum machen kann, desto mehrdeutiger wird dieser Raum. Und deshalb gibt es die Improvisation: Als Befähigung, in Gemeinschaft (mithin organisational) konstruktiv mit Mehrdeutigkeit (als Kontingenz) umzugehen. Berliner (1994) sagt in diesem Zusammenhang: »Improvisation involves reworking pre-composed material and designs in relation to unanticipated ideas conceived, shaped, and transformed under the special conditions of performance, thereby adding unique features to every creation.« (Berliner 1994: 241) Im organisationalen Kontext zeigt Eisenbergs Definition von Improvisation sehr gut das Verfahren der Improvisation: »[...] making do with minimal commonalties and elaborating simple structures in complex ways.« (Eisenberg 1990: 154)

Dies impliziert, Strukturen essenziell umzuformen und damit, als rekursiver Prozess, Strukturen aus Handlungen entstehen zu lassen (siehe auch: Scribner 1986; Thayer 1988). Brown und Duguid (1991) haben gezeigt, dass vor diesem Hintergrund das Teilen einer professionellen Kultur der Improvisation eine wich- 
tige Bedingung für Improvisation in Organisation darstellt. Perky (1991) sowie Brown und Eisenhardt (1997) stellen dar, wie durch den Rahmen der Improvisation Strategien so artikuliert werden können, dass sie als struktureller Rahmen für stark strukturierte Organisationen in unsicheren Situationen wirken können. Gleichzeitig weisen Bastien und Hostager (1991) sowie Lanzara (1983) darauf hin, dass unstrukturierte Gruppen bzw. schwach strukturierte Organisationen ihrerseits Centering-Strategien anwenden, um so eine Struktur aufzubauen, auf der sie improvisieren. Beim Aufbau dieser Strukturen achten sie jedoch darauf, den Fixierungsgrad der Struktur nur bis zu dem Punkt voranzutreiben, dass Improvisation als Differenz möglich bleibt. Während also das Bricolage-Konzept eher auf Adaptation rekurriert, ist Improvisation als Technologie eine Form, Rahmungen für Innovation herzustellen. Adaptation kann als ein Ausrichten nach externen Konditionen bezeichnet werden. (Hutchins 1991). Diese Konstruktion ist mit Improvisation insoweit verbunden, als eine Anerkennung des Bestehenden mit Transformation verknüpft wird. Außerdem kann Adaptation als Konzept dienen, alle Ressourcen so zu organisieren, dass sie für den Fall der Fälle vorhanden sind. Nichtdestrotz ist Adaptation ein defensives Agieren, dass mehr auf das Außen als das Innen der Organisation rekurriert. Daher ist dieses Konzept in hoch turbulenten Umgebungen zu langsam und nicht variabel genug.

\section{Things at Play}

In ihrer Studie Organizational Improvisation and Learning: A Field Study zeigen Miner, Bassoff und Moorman (2001), dass Organisationsmitglieder in improvisationalen Settings vor allem auf zwei Momente rekurrieren: Sie rahmen die Bedeutung unerwarteter Ereignisse auf neue Weise, um so vorhergehende Ereignisse mit neuen Bedeutungen zu versehen. Improvisation impliziert somit nicht nur Interpretation, sondern auch Um-Interpretieren von Ereignissen. Dies entsteht jedoch nur, wenn die Akteure in die Praxis selbst eingebunden sind. Das bedeutet, dass Wissen nicht unabhängig ist von der Aktion: »Some of these episodes resembled musical improvisation in which a musician plays an unintended note but goes on to play additional notes that create a pattern in which the previous wrong note now appears meaningful and melodic« (a.a.O.: 8). Die Autoren schließen daraus, dass Improvisation einen neuen Lerntyp darstellen könnte: »Our observations revealed [...] that improvisation represents a special type of learning.« (Ebda.) Sie folgen hier Weicks These, dass bei der Improvisation »[...] no split between composition and performance [...] no split between design and production« (Weick 2001b: 82) herrscht. Moorman und Miner (1988a) konzentrieren sich in diesem Zusammenhang darauf, die Form von Improvisation zu beurteilen. Diese besteht darin, die Enge des Zeitraums zwischen Design und Ausführung zu bestimmen. Bei neuen Formen der Arbeit mit digitalen Medien stellt sich jedoch heraus, dass es Konvergenzen zwischen Ausführung und Design gibt, die nicht der 
Improvisation zugerechnet werden können: »The result is substantial temporal convergence between design and execution but is not improvisation, in our view, because each stage is still substantively distinct« (Miner et al. 2001: 9). Deshalb - so die Autoren - ist vor allem der Modus der Produktion selbst zu analysieren. Daraus folgt, dass Improvisation vor allem so aufgebaut ist, dass designte Dinge und der Designverlauf als Handlung sich gegenseitig affizieren: »In our study, we saw products being designed and created as the teams enacted them.« (Ebda.) Das bedeutet, dass der Produktionsmodus entscheidenden Einfluss auf das Wie der Komposition, des Entwurfs, jenseits der Reduktion auf zeitliche Konvergenz von Design und Aktion, hat: »With only temporal convergence, design could take place just prior to an action, yet action would little influence how the design might unfold.« (Ebda.) Die Autoren ziehen daraus den fundamentalen Schluss, dass Designprozess und Entwurf als Produktionsverlauf konvergieren: »assembly informed design at the same time that design informed assembly.« (Ebda.)

Improvisation impliziert also nicht nur ein Metalernen, welches sich rein organisational oder nur in Kommunikation abspielt, sondern Improvisation erweist sich als mit der Materialität der Dinge direkt verknüpft: »[...] improvisation requires material or substantive convergence.« (Ebda.) Aber: Substanzielle Konvergenz impliziert temporale Konvergenz, temporale Konvergenz jedoch nicht zwangsläufig substanzielle Konvergenz. Hieraus ergibt sich eine neue Qualität in der Definition von Improvisation: »[...] improvisation is the deliberate and substantive fusion of the design and execution of a novel production.« (Ebda.) Aus dieser Definition lässt sich nicht nur die Improvisation im Modus 2 (= Improvisationstechnologie) ableiten - es wird ebenfalls aufgezeigt, wie Modus 2 aus Modus 1 emergiert. Der Modus 1 als Reperaturmodus kann genutzt werden, um Fehler zu korrigieren; gleichwohl kann in dieser Fehlerkorrektur Innovation entstehen: »In some instances, team members initially framed their activity as solving a problem, but as they improvised, they generated novel actions or interpretations that transformed the problem into a perceived opportunity.« (A.a.O.: 11)

Improvisationales Lernen ist somit von experimentellem Lernen zu unterscheiden. Improvisation in Organisationen zielt darauf ab, spezifische Fragestellungen und Optionen im Spiel mit spezifischen Materialien, Medien und Situationen zu generieren. Auch wenn Improvisation neue Einsichten in und Rekombination von vorgängigen Praktiken einschließt, ist sie doch immer eng an lokale Bedingungen geknüpft. Diese lokalen Bedingungen können jedoch immer und überall in der Organisation auftreten. Experimentelle Lernsituationen hingegen sind Situationen, die kontrollierte Organisationsräume konstituieren, in denen neues Wissen produziert werden soll: »In experimenting, the organizations deliberately varied activities and conditions, such as changing the temperature in which a part was tried or giving potential customers different sizes of a product. The nature and degree of this variation was typically planned in advance and was designed to elicit general, explicit knowledge about causal factors.« (Ebda.) Nach Miner, Bassoff und Moorman zielt Improvisation nicht direkt auf neues Wissen ab, auch 
wenn dort Wissen entsteht: »This new knowledge was a collateral - not an intrinsic or even intentional - outcome of the improvisation and was constrained by the specific material, temporal, and cognitive situation.« (Ebda.)

In den von den Autoren untersuchten Firmen gibt es sehr ausgeprägte Routinen für Wissensproduktion in und durch Experimentieren. Weil Lernen als spezifisches Ziel des Experimentierens definiert wird, werden die Ergebnisse mit Sorgfalt beobachtet und aufgezeichnet. Der Ansatz des intentionalen Lernens sorgt dafür, dass Reflektion und Interpretation angeregt werden. Improvisationale Settings hingegen richten sich nicht auf Lernen aus - anders ausgedrückt: haben kein Bewusstsein für das Lernen entwickelt: »Rather, improvisation arose as the firms struggled to deal with surprises.« (A.a.O.: 23) Hier zeigt sich, dass Improvisation im Modus 1 dazu führt, die Aufmerksamkeit nur auf die spezifische Situation zu legen, ohne jedoch größere diagrammatische Zusammenhänge damit verknüpfen zu können:

"When a problem was solved or an unexpected opportunity was exploited meant that improvisational learning was far more likely to produce context-dependent knowledge. Moreover, improvisational learning could not be used to test interaction effects in the way that experimentation could. Finally, because the goal was not learning, knowledge outcomes were often not recorded or preserved for retention or transmission in the organization." (Ebda.)

Traditionelle Organisationstheorien verorten Wissen in Subjekten oder Gruppen. Die Autoren stellen aber nun die gegenläufige These auf, dass Wissen von Improvisation im Organisationalen selbst $\mathrm{zu}$ finden ist. Individuelle Improvisation ist schon aus der Tatsache heraus, dass sie von Situationen, Dingen, Assemblagen affiziert wird und mit den Dingen, Situationen spielt, immer Teil eines Kollektivs, sei es von Dingen oder Menschen. Damit ist auch das Design immer relational zum Vorhandenen, jedoch nur dann, wenn das Vorhandene relational interpretiert wird. Dies impliziert, dass ein Kollektiv neue Muster gestalten kann, ohne sie vorher zu planen (Hutchins 1991). Damit können wir bei Improvisation von kollektivem Design, Co-Design oder auch von kollektiver Autorschaft sprechen, die sich strategisch in die Zeit projiziert. Kompetenzen residieren damit nicht nur in Subjekten, sondern sie flottieren zwischen organisationalen Routinen, Kulturen und kollektiven Fähigkeiten: »These factors also imply that improvisational action can occur and be studied at any level of analysis, including strategic improvisation by an entire firm.« (Baum und Singh 1994: 8; vgl. auch Stein 1989)

Miner, Bassoff und Moorman belegen in ihrer Studie die oben aufgestellte These, dass Planung und Improvisation nicht gegeneinander ausgespielt werden können. In den Modellen emergenten Wandels wird in diesem Zusammenhang sichtbar, wie Organisationen planen können, zu improvisieren, Routineprozesse $\mathrm{zu}$ implementieren, um Improvisation und die Beobachtung anzuregen, und in der Lage sind, die Auswertung eigener Improvisation vorzunehmen, auch wenn 
der aktuale Inhalt der Improvisation offen bzw. ungeplant bleibt. Modelle, die sich mit der Verbindung von ungeplanter Innovation und Ordnung auseinandersetzen, beschreiben, wie aggregate emergente Muster aus rationalen Handlungen auf niedrigen Ebenen entstehen und wie unintendierte Ergebnisse und Handlungen auf der gleichen Ebene der Analyse auftreten (Alinsky 1971; March und Olsen 1976). Im Gegensatz dazu stammen organisationale Improvisationen nicht aus Lower-level Actions, die den Improvisatoren nicht bewusst sind; im Gegenteil: »They are designed and enacted at the same level of analysis« (Miner et al. 2001, S. 25). Auch sind sie keine nicht intendierten Ergebnisse, sie stellen vielmehr die reflektierte, absichtliche Kreation neuer Produktionen und Produktionsebenen dar. Improvisation kann somit als wichtiger Typus emergenter Ordnung (Berger und Luckmann 1967; Giddens 1984) bezeichnet werden: »Its most distinct feature is that the design unfolds during and is fundamentally shaped by the interaction of the designer and the immediate moment and materials« (Miner et al. 2001, S. 25).

Als Kritik an der Studie wäre allerdings anzumerken, dass die Autoren mit der Unterscheidung zwischen improvisationalem und experimentalem Lernen hinter sich selbst zurückfallen. Sagten sie am Anfang, Improvisation würde neues Wissen hervorrufen, so sehen sie nun Improvisation mit einer Nichtintentionalität verknüpft, die sie vom Experimentieren unterscheidet. Dem Standpunkt dieser Studie entsprechend wären jedoch in der Improvisationstechnologie beide Modi zusammenzudenken; dadurch wäre dreierlei erreicht: Erstens würde dann - Rheinberger ${ }^{2}$ folgend - anerkannt, dass Experimentalsituationen immer Rahmungen zum Improvisieren sind, also selbst aus Improvisationen bestehen; zweitens würde die Intentionalität auf eine Metastufe gehoben werden; drittens wäre das Experimentieren nicht nur auf den Experimentalraum beschränkt, sondern der ganzen Organisation als Option zugänglich gemacht. Dies kann jedoch nur gelingen, wenn die Organisation über eine Improvisationskultur und organisationale Kompetenzen in der Improvisation verfügt, in der immer neue Rahmungen von Improvisation hergestellt werden können. Damit würde wieder an die Erkenntnis angeknüpft, dass Organisationen aus Improvisationen mehr gewinnen als nur schnelle Reparaturen, nämlich ein Bewusstsein für Rahmung von Aktion überhaupt und den instrumentellen Einsatz von Improvisation als konstruktivem Umgang mit Unordnung.

2 | Rheinberger, Hans Jörg, 1995-2014 Direktor des Max-Planck-Instituts für Wissenschaftsgeschichte in Berlin, hat sich vor allem mit der Geschichte und Epistemologie des Experiments beschäftigt (https://de.wikipedia.org/wiki/Hans-Jörg_Rheinberger). 


\section{LITERATUR}

Alinsky, S. D. (1971): Rules for radicals. A practical primer for realistic radicals. New York: Random House.

Bastien, D. T. \& Hostager, Todd J. (1991): Jazz As Social Structure, Process and Outcome. In: Reginald T. Buckner (Hg.): Jazz in mind. Essays on the history and meanings of Jazz. Detroit: Wayne State Univ. Press (Jazz history, culture, and criticism series), S. 148-165.

Baum, J. A. C. \& Singh, J. V. (Hg.) (1994): Evolutionary dynamics of organizations. New York: Oxford University Press.

Berger, P. L. \& Luckmann, T. (1967): The social construction of reality. A treatise in the sociology of knowledge. New York: Doubleday (Anchor books/Anchor books, 589).

Berliner, P. (1994): Thinking in jazz. The infinite art of improvisation. Chicago: Univ. of Chicago $\operatorname{Pr}$ (Chicago studies in ethnomusicology).

Busch, S. (1996): Improvisation im Jazz. Ein dynamisches System. Rottenburg: Advance Music.

Brown, S. L. \& Eisenhardt, K. M. (1997): The Art of Continuous Change: Linking Complexity Theory and Time-Paced Evolution in Relentlessly Shifting Organizations. In: Administrative Science Quarterly 42 (1), S. 1-34. Online verfügbar unter www.jstor.org/stable/2393807.

Cunha, M. P. (2004): Management Improvisation. FEUNL Working Paper No. 460. Universidade Nova de Lisboa, Faculdade de Economia. Lisboa. Online verfügbar unter http://ssrn.com/abstract $=882455$.

Dell, C. (2002): Prinzip Improvisation. Köln: Verl. der Buchhandlung König

Dell, C. (2004): Möglicherweise Improvisation. In: Wolfram Knauer (Hg.): Improvisieren [...] Darmstädter Beiträge zur Jazzforschung, Band 8; [Symposium des 8. Darmstädter Jazzforums im September 2003]. Jazz-Institut; Darmstädter Jazzforum. Hofheim: Wolke (Darmstädter Beiträge zur Jazzforschung, 8), S. 9-16.

Dell, C. (2012): Die improvisierende Organisation. Management nach dem Ende der Planbarkeit. Bielefeld: transcript

Eisenberg, E. M. (1990): Jamming: Transcendence Through Organizing. In: Communication Research 17 (2), S. 139-164.

Giddens, A. (1984): The constitution of society. Outline of the theory of structuration. Berkeley, Los Angeles: Univ. of California Press.

Grabher, G. (2004): Learning in Projects, Remembering in Networks: Communality, Sociality, and Connectivity in Project Ecologies. In: eur urban reg stud 11 (2), S. 103-123.

Hatch, M. J. (1999): Exploring the Empty Spaces of Organizing: How Improvisational Jazz Helps Redescribe Organizational Structure. In: Organization Studies 20 (1), S. 75-100. 
Hutchins, E. (1991): Organizing Work by Adaptation. In: Organization Science 2 (1), S. 14-39. Online verfügbar unter www.jstor.org/stable/2634937.

Lamers, J. (1994): Theatertexte: Gedächtnis. Hg. v. Marianne v. Kerkhoven. Brüssel.

Lanzara, G. F. (1983): Ephemeral Organizations in Extreme Environments: Emergence, Strategy, Extinction. In: J Management Studies 20 (1), S. 71-95.

March, J. G. \& Olsen, J. P. (Hg.) (1976b): Ambiguity and choice in organizations. Bergen: Universitetsforlaget.

Miner, A. S.; Bassoff, P. \& Moorman, C. (2001): Organizational Improvisation and Learning: A Field Study. In: Administrative Science Quarterly 46 (2), S. 304-337. Online verfügbar unter www.jstor.org/stable/2667089.

Moorman, C. \& Miner, A. S. (1998): Organizational Improvisation and Organizational Memory. In: The Academy of Management Review 23 (4), S. 698-723. Online verfügbar unter www.jstor.org/stable/259058.

Müller, David (2007): Bestimmungsfaktoren der Improvisation im Unternehmen. In: Zeitschrift für Planung \& Unternehmenssteuerung 18 (3), S. 255-277.

Scharmer, C. O. (2009): Theorie U - von der Zukunft her führen. [Öffnung des Denkens, Öffnung des Fühlens, Öffnung des Willens; Presencing als soziale Technik]. 1. Aufl. Heidelberg: Carl-Auer-Systeme (Management). Online verfügbar unter www.socialnet.de/rezensionen/isbn.php?isbn=978-3-89670-679-9.

Scribner, S. (1986): Thinking in Action: Some Characteristics of Practical Thought. In: Robert J. Sternberg und Richard K. Wagner (Hg.): Practical intelligence. Nature and origins of competence in the everyday world/edited by Robert J. Sternberg and Richard K. Wagner. Cambridge: Cambridge University Press, S. 13-30. Stein, D. L. (1989): Preface. In: Daniel L. Stein (Hg.): Lectures in the sciences of complexity. The proceedings of the 1988 Complex Systems Summer School held June - July, 1988 in Santa Fe, New Mexico. Redwood City, Calif: Addison-Wesley Publ. Co (Santa Fe Institute studies in the sciences of complexity. Lectures, 1), S. XIII-XXIII.

Thayer, L. (1988): Leadership/communication: A critical review and a modest proposal. In: Gerald M. Goldhaber (Hg.): Handbook of organizational communication. Norwood/N. J. Ablex Publ (Communication and information science), S. 231-263.

Weick, K. E. (2001a): Improvisation as a Mindset for Organizational Analysis. In: Karl E. Weick: Making sense of the organization. Oxford, UK, Malden, MA: Blackwell Publishers, S. 284-304.

Weick, K. E. (2001b): Organizational redesign as improvisation. In: Karl E. Weick: Making sense of the organization. Oxford, UK, Malden, MA: Blackwell Publishers, S. 57-92. 



\section{From a Pattern Language to a Field of Centers and Beyond}

Patterns and Centers, Innovation, Improvisation, and Creativity

\section{Hajo Neis}

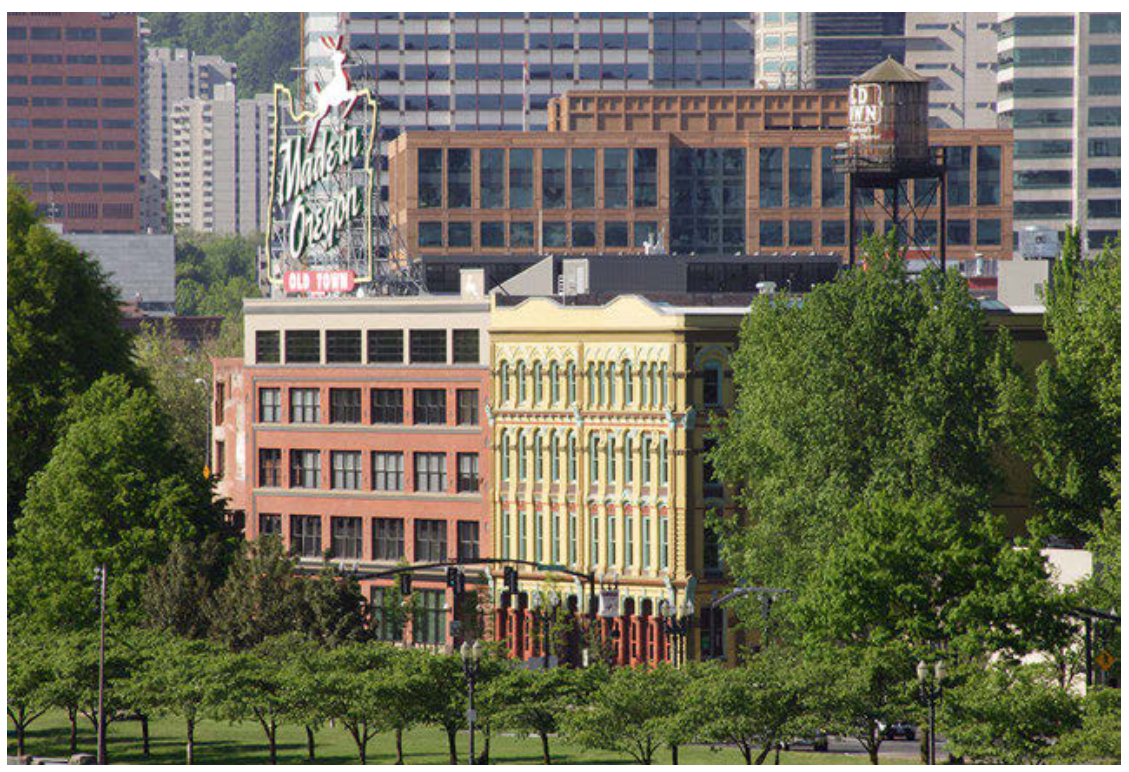

Illustration 1: University of Oregon in Portland Downtown Urban Campus

The Campus is located in downtown Portland in adapted old warehouse buildings, and was first designed in the Oregon pattern language method with the principles of patterns and user participation. The White Stag building facilities are open since 2009 . 


\section{INTRODUCTION}

What we call now the >overall pattern language approach < in architecture, urban design, and planning has grown from its original principle of >pattern and pattern language< into a large and solid body of theory and professional work. Today, pattern theory and practice includes a large number of principles, methods, techniques and practical project applications in which patterns themselves play a specific part within this larger body of knowledge. Not only has the pattern language approach grown in its original area of architecture, but it has also (though less triumphantly than silently) expanded into a large number of other disciplines and fields, in particular computer and software science, education, biology, community psychology, and numerous practical fields. Nevertheless, we first have to acknowledge that the pattern approach originally started with a single principle almost 50 years ago, the principle of pattern and pattern language that gave the name to this school of thought and practical professional project work.

In this article we want to trace some of the theoretical and practical development of the pattern method and its realization in practical projects. We want to explore how challenges and opportunities resulted in the adaptation of the pattern language method into various forms of pattern project formats and formulations including >pattern language < and >project language. $<$ We want to look at various forms of innovations and techniques that deal with theoretical improvements as well as the necessities of adaptation for practical cases and projects. Finally, we want to understand how the principle of pattern and pattern language was modified and adapted for theoretical and practical project reasons, slowly developing into a sizable body of knowledge and practical application, supplemented with new principles that were added to make the principle of patterns work better in a complex context and real applications. Here, in particular, we want to explore the principle of >Formation of Field of Centers $<$ that helped to give geometrical structure to the more functional structure of patterns.

Before the principle of Formation of Field of Centers is introduced, the context of this article has to be understood within the larger framework and perspective of patterns and pattern languages, particularly how it relates to the theme of this publication: Innovation and Improvisation for Organization and Social Systems. From my perspective as an architect, urban designer, and also part of the original pattern group (second generation) within architecture, I will show some of the development of patterns and pattern languages within the field of architecture and then make connections to other disciplines and the wider context of pattern language use and application with regard to innovation, improvisation and creativity. Finally, we will start to explore new ground in theoretical and practical issues, such as the investigation of >Types of Production that Can Generate Living and Beautiful Environments< and the construction processes for the $93 \%$. We will also look at innovative interdisciplinary models for urban design and planning projects. 


\section{Life as the Essence and Starting Point}

Let me first briefly talk about the essential notion and umbrella of pattern theory, which makes patterns meaningful and shows how patterns are connected in a pattern language, like blood connects different parts of the body, and ultimately connects aspects of different disciplines in a social system-like fashion. The notion of life can be considered the essential philosophical starting point and category, and life is also the central practical focus of work with the intent of making the notion of life an integral part of a scientific method. The central idea here is the understanding of a gradual quality of life. This quality of life, or as Alexander originally called it, >quality without a name, < can be attributed to all systems and structures, including biological as well as non-biological systems. And while this is at first unusual, it is scientifically not as strange as one may think. And for a practicing architect and builder this notion indeed helps very practically to do good work with building structures, material, space and functional life.

Speaking from today's multidisciplinary perspective, we can say that the overall pattern language approach has reached a point where we can describe it as a general theory and a practice of development (design and building) that has become relevant for many disciplines, organizations and social systems. The main target of this thinking is the improvement of life, human development and improvement of the environment in which we live. And while it has always been a central task of philosophy to explain the good life, the pattern language school of thought may offer a new way of dealing with and thinking about the world today that opens up new ways at looking at and solving problems in a practical fashion, starting with an advanced understanding of life defined in gradual steps of quality of life.
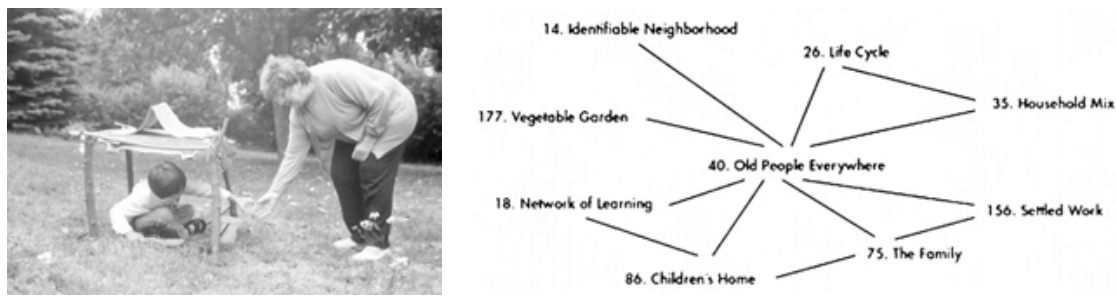

Illustration 2: OLD PEOPLE EVERYWHERE »Old People need old people, but they also need the young, and young people need contact with the old.« From APL p.216. (pattern 40)

The key central category and practical starting point of this endeavor is the notion of a pattern. Here, we are not interested in just any kind of pattern but specifically, those kinds of patterns that support life. We are interested in patterns that have the capacity to solve practical problems or what can also be called problem-solution patterns. 


\section{Patterns as Atoms of the Environment ${ }^{1}$}

The idea of a pattern in this specific understanding is first based on the observation of repetition of particular building elements, such as TATAMI FLOOR in the Japanese House, or ENTRANCE DOOR, COURTYARD, OLD PEOPLE EVERYWHERE, and PEDESTIAN STREET, elements which form substantial knowledge of a building culture or culture in general when we include other kinds of patterns such as BIRTHDAY, COMMUNAL EATING, MARKET, BANKING, MEDICATION, SUNBATH, and HOLIDAYS. Looking at specific contemporary or traditional cultures and finding archetypal solutions to fundamental problems is a good start to begin to understand the notion of patterns. Hundreds of these patterns may define the building knowledge of a given culture and thousands may define close to the overall cultural knowledge of a given culture.

But repetition alone is not enough to define a pattern. More specifically, a pattern in this approach is a general planning or design principle, a rule which addresses a clear problem which may occur repeatedly in the environment, states the range of contexts in which this problem will occur, and gives the general features required by buildings or plans which solve this problem. Patterns in this understanding can be defined as a method to solve recurring problems:

\section{Pattern $=$ Problem - Discussion - Solution}

- Problem: For example, a problem that occurs repeatedly in the United States and elsewhere is that of ENTRANCE TRANSITION. In the book A Pattern Language, a problem with entrances has been formulated in the form of a hypothesis: Buildings and especially houses, with a graceful transition between the street and the inside are more tranquil than those which open directly off the street.

- Discussion: Then the range of contexts in which this problem will occur is discussed based on evidence, i.e., in residences or other cases that thrive on a sense of seclusion such as churches, public libraries, or a clinic. After this investigation a general solution based on empirical and/or analytical evidence is proposed to solve this problem. In the case of entrance transition the proposed general solution is as follows:

- Solution: Make a transition space. Bring the path which connects street and entrance through this transitional space, and mark it with a change of light, a change of sound, a change of direction, a change of surface, a change of level, perhaps by gateways which make a change of enclosure, and above all with a change of view.

1 I Understanding patterns as atoms of the environment was expressed in an earlier publication by Chris Alexander and Barry Poyner, "The Atoms of Environmental Structure," Ministry of Public Building and Works, 1st edition, 1967. 


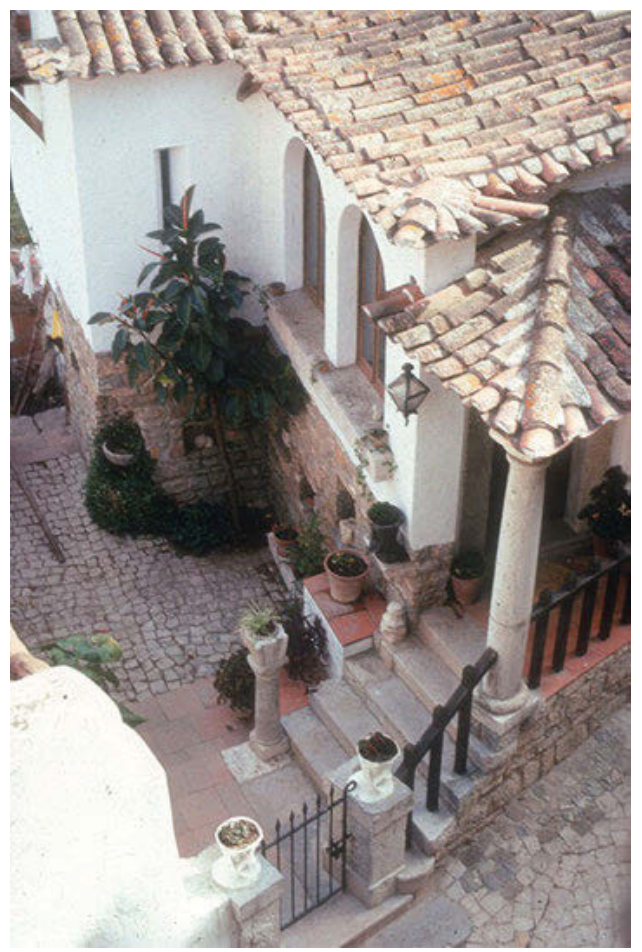

Illustration 3: ENTRANCE TRANSITION (APL pattern 112) The example of a good solution to the problem of entrance transition is taken from Obidos in Portugal (Photo: Sara Ishikawa)

Based on this brief description of a solution-pattern, we can see that a pattern is formulated in such a way that its correctness or incorrectness can be supported by evidence. In this way, the formulation of a pattern follows scientific procedure. Yet, a pattern is, first of all, oriented towards practical application. It can be discussed in public, and according to the outcome of the discussion, it can be adopted or not, by a planning board for example, which may be responsible for the community building design guidelines. In that sense we may say that a >problem-solution-pattern < is an empirically or analytically grounded imperative, which states the precondition for the solution of an environmental or building problem, or any other problem in society that can be approached in this way.

The underlying theory for patterns and the pattern language design approach has been laid out in a book by C. Alexander titled The Timeless Way of Building. (Alexander, 1979) Here we find that the format of a single pattern is much more elaborate than the threefold division of problem-discussion-solution, and this for a good reason. Since we want to arrive at a Pattern Language as a system of patterns, the format needs a structure that actually connects these various patterns in a meaningful and understandable way. It begins with the title of the pattern 
and a photo, which introduce you to the topic and also illustrate a solution to the problem. Then there is a short definition of the problem, an extensive discussion of the problem with possible solutions, followed by a formulation of the proposed problem solution and a diagram to illustrate the solution. Furthermore, patterns have stars attached to the title to indicate the validity or quality of a pattern itself: Two stars are the highest validity such as in LOOPED LOCAL ROADS, and one star or no stars indicate lower universality.

What is important for our discussion here is the notion of Pattern Language as a network. Here, each pattern has a section at the beginning and a segment at the end that make direct references to other patterns. The section at the beginning of a pattern refers to patterns connected at a higher level of hierarchy and references at the end refer to patterns at a lower level. The pattern ENTRANCE TRANSITION (112) for example is connected at a higher level to the pattern MAIN ENTRANCE (110) and at a lower level to the pattern ENTRANCE ROOM (130). In this way we get a network of patterns that are all connected, and we can enter the network at any level and let the connections lead us to other patterns and clusters of patterns. It is these connections in a network that transform patterns into pattern languages. And while this system was developed before any personal computers were in place more than 40 years ago, avant la lettre, it is a system that is ideal for computer application, and was in fact later adopted and used by many other disciplines including computer science after it started in the field of architecture (see Illustration 4).

\section{A Pattern language or APL - the Book}

The book A Pattern Language, written by Alexander, Ishikawa, Silverstein, and others (Alexander et al., 1977), is a collection of 253 patterns that range in scale from large regions to cities and towns to construction details. ${ }^{2}$ Here, the traditional use and idea of patterns has been transformed into a modern mathematical system, which can be used by designers and builders today. A pattern can be defined as a generic solution to an environmental context problem, derived from functional arguments. And a pattern language can be defined as a coherent set of generic solutions which can be used in various combinations - quite language like - by architects, craftsmen, users and clients for creating their own particular spaces and environments. Patterns can also be considered archetypal solutions to environmental problems, examples of good environments, which can be applied repeatedly for similar contexts or used and adapted to local conditions and

2 The book APL is also one of the most well-known and recognized books of architecture with more than 200,000 copies sold just in the US alone. It has been translated in various languages, including Japanese, German, Chinese, Spanish. 


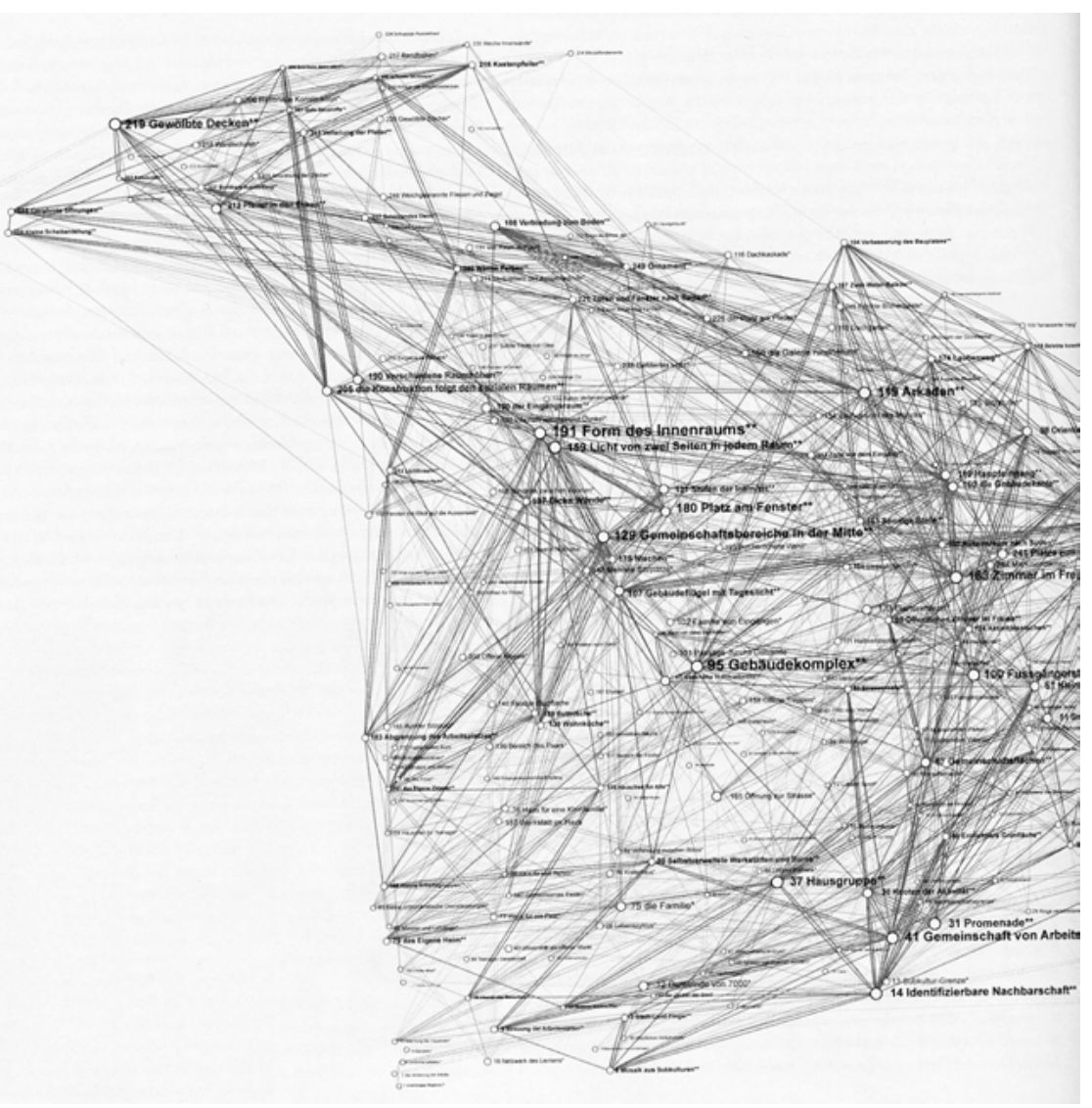

Illustration 4: Graphic Representation of A Pattern Language (APL)

Stefan Tietke and his students have used the software »GraphViz« in order to show the hidden connections of all 253 patterns from APL. Arch+189. October 2008, pp. 18-19

specific communities. A Pattern Language provides a general reference and point of departure for creating pattern languages for various types of projects in different locations. The principle of patterns and pattern languages is therefore closely connected to the principle of user participation, because it provides the users an organized procedure to help make sense out of otherwise complex situations such as planning, design, and decision-making processes. In most of the projects that I have applied pattern languages, the principle of user participation also was part of the process of starting and guiding a project.

These archetypal patterns cover four or more major levels of scale of the built environment: Regions and cities, urban areas and neighborhoods, buildings and spaces, construction, engineering and materials. The importance of using a Pattern Language is that it combines all of the different visions and needs of the people involved into a common language that everyone can understand. As dif- 
ferent agents such as users, architects, builders, and planners continue to work on individual aspects of the project, they can work within this framework of a common language so that the resulting physical spaces, buildings, apartments, gardens, streets, and gateways will all have the intended structure and a familial resemblance. The simplest form of applying a pattern language to a given design project - for example a residence - is to select a set of patterns and use these solution-patterns as archetypal starting points for a design and building process.

\section{Project Pattern Language: The Oregon Experiment}

A >Project Pattern Language < can be defined as a pattern language applied to a particular project. While various projects at different scales have been developed with a pattern project language as a starting point, the example which is of interest here is the language developed for the University of Oregon in Eugene, reported in the book The Oregon Experiment. (Alexander, Silverstein, et al. 1975) It shows the first modifications and alterations of pattern formulation and presentation. After almost 40 years this book still serves as the basis of the Main Campus Plan at the University of Oregon. (Campus Plan, 2005) It was this book that prompted the invitation to work in Japan on the design and construction of the Eishin High School and College Campus.

The book describes the formation of the Oregon campus master plan, based on various principles including the principle of pattern language. The full list of main principles is enumerated in the table of contents as chapters: 1) Organic Order, 2) Participation, 3) Piecemeal Growth, 4) Patterns, 5) Diagnosis, and 6) Coordination. As a starting point the architects, users, and campus planners identified and selected 37 broad patterns from the book A Pattern Language that were appropriate for solving problems in the campus at the time including: LOCAL TRANSPORT AREA, NETWORK OF LEARNING, IDENTIFIABLE NEIGBORHOOD, FOUR STOREY LIMIT, ACCESS TO WATER, MINI BUSES, PROMENADE, and so on. These 37 patterns were rather general and did not take into account some of the important specifics of a university and the local situation. And this is of course very typical. Patterns from the book APL are solutions that had been developed as examples of good patterns. It was never intended that they would cover all possible cases, which might run in the tens of thousands in any building culture. Each new project requires work on a new set of patterns appropriate for that particular project alone. It is therefore critical that pattern development takes place in each project as innovation and creative work in an otherwise rather complex situation.

Consequently the planners together with the users derived another 18 patterns specifically for this university project. The first six of these specific patterns were the following: UNIVERSITY POPULATION, OPEN UNIVERSITY, HOUSING STUDENT DISTRIBUTION, UNIVERSITY SHAPE AND DIAMETER, UNIVERSITY STREETS, LIVING LEARNING CYCLE, as pars pro toto. 
When these two sets of patterns are interwoven, we get a single list and discussion of 55 patterns, which form the basis for the Campus plan that is still in use today and updated every 5 years. It is these 55 patterns that also form what we call a >Project Pattern Language< (sometimes also Pattern Project Language). The detailed list and explanations of these patterns as proposed solutions can be read in The Oregon Experiment, pages 101-143. In terms of pattern presentations, we find a first modification or simplification in which patterns are not represented in their full form but in the much shorter problem-solution form.

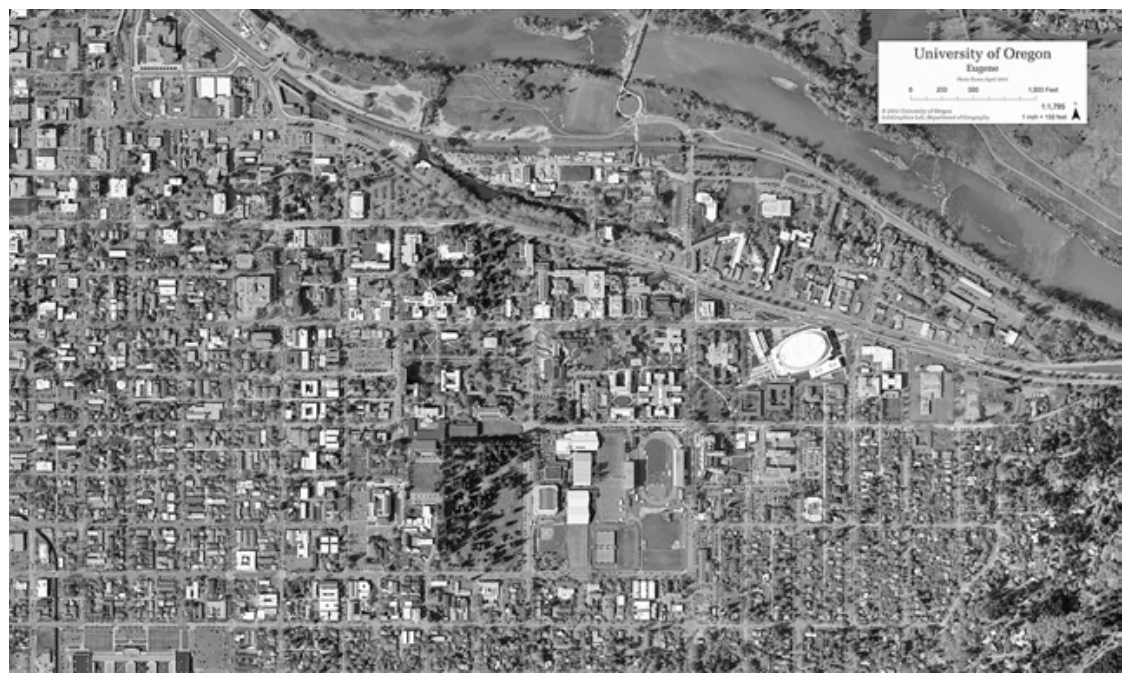

Illustration 5: University of Oregon Campus in Eugene, Oregon (Air-photo) The Oregon University continuously is applying the principles of patterns and user participation since 1974 in planning and design of their Campus

The most important lesson in this section is to understand that each project is different and unique in its own way and therefore needs its own Project Pattern Language as an important aspect of innovation, originality, and creativity within a larger complex system of functionality and harmony. New patterns are being developed in various projects all the time. The latest set of new project patterns was developed for the new UO University Campus in Portland, Oregon, where an urban block of three 4- 6 story buildings was remodeled for the purpose of providing a new urban Campus to the University of Oregon about two hours' car drive from Eugene. ${ }^{3}$ (see Illustration 1)

3 | Neis, Hajo, Theodoropoulos, Christine, Thallon, Rob. "New Facilities and Expansion of the University of Oregon Department of Architecture, " in City Campus: Proceedings of the 2007 Fall ACSA Central Fall Conference, pp.1/22-1/33. Riverside Architectural Press, University of Waterloo 2007. 


\section{Project Language - Eishin Campus in Japan}

A >Project Language < forms the next step in the evolution of design and building languages for particular projects. As mentioned earlier, we want to understand how challenges and opportunities resulted in adaptations of the pattern language method into various forms of pattern project formats and formulations, such as the format of a sproject language.< The idea and development of what we call a project language is defined first by the way one works with users and second, by the form of the language or the way the language is presented. Working with users assumes a rather fluid relationship in which those users are encouraged to present all their specific proposals, ideas, dreams and wishes for a particular project. Since these ideas, proposals, visions and wishes more often than not take the form of individual projects, or are expressed as such, the result may or may not be a pattern in the formal sense (or it might take a lot of time to formulate simple ideas into elaborate problem-solution-pattern format). Still, even a Project Language may contain quite a few patterns in their solution or hypothesis form. The task of the architect or planner then is to start to create a coherent product or project program out of these various (sometimes conflicting) projects, proposed by various users. The outcome of this work is a story, a narrative that tries to capture and describe all the various individual projects in one coherent form.

A Project Language distills and describes the essence and character that a specific building or urban planning project will have, and defines its connection to the town or landscape and to each of its individual occupants. The particular character of the project is presented in the Project Language as a carefully structured sequence of statements, which arise from observation and interviews with users and other interested participants. The key aspect of a Project Language is that it describes the particular nature, essential components, and relationships a project and all of its elements will have, yet at the same time maintaining a childlike openness and ambiguity as to the exact form of the project and its elements. Thus, the Project Language defines the framework within which the exact form will arise directly from work on the site and in the process of building. The language is also presented in a sequential fashion, and with descriptive headings. Just by reading the headings (or first sentences) in a sequence one should be able to build up a picture of the important features of the overall project.

The concept of a project language emerged, developed, and was first applied in a larger project for the design of the Eishin College and High School Campus in Japan. The Eishin project language is recorded in a document of about 100 pages describing a whole new campus as if it were already existing. It consists of 8 chapters, each one dealing with a different aspect. One (non-illustrated) version of this Project Language can be found in the book The Battle for the Life and Beauty of the Earth (Alexander, Neis, Alexander Moore, 2012) whereby one can start to actually find an understanding of this form of language formulation and presentation and, in our case, appreciate the practical differences in format from a >pattern project language 

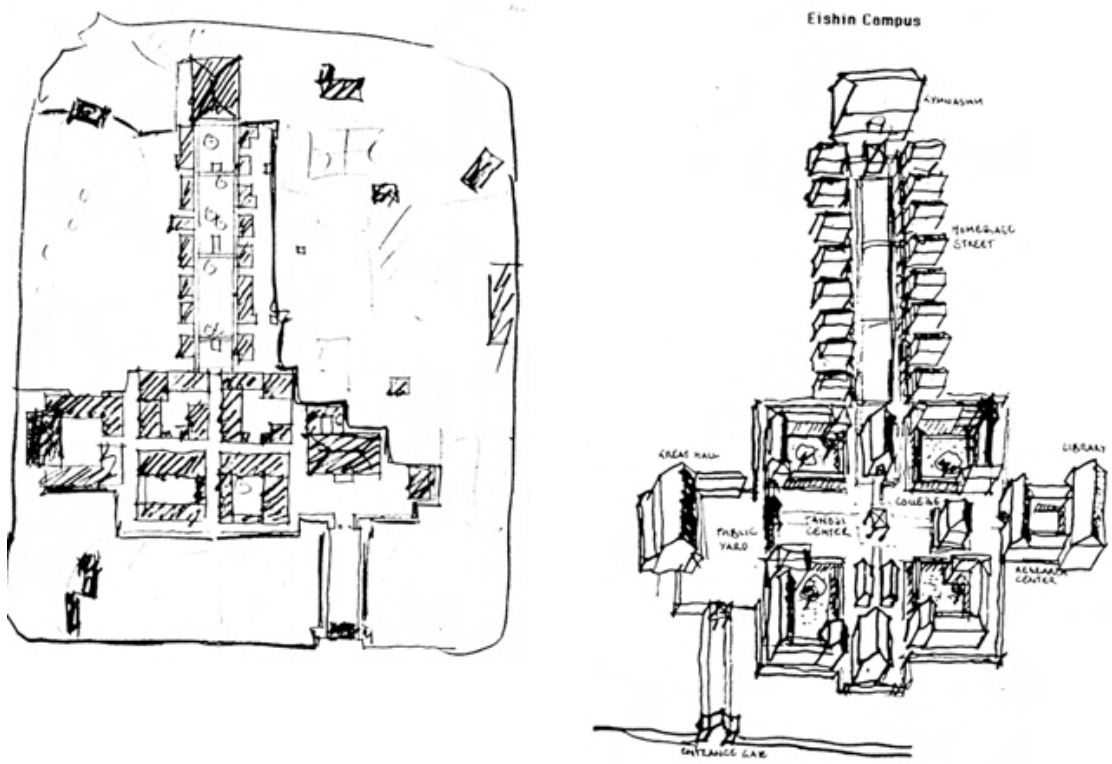

Illustration 6: Two Diagrams of Eishin Pattern Language Representation Diagram Diagram a) shows a graphical representation of the Pattern Project Language for the Eishin Campus with >Inner and Outer Precinct< in plan for an ideal site.

Diagram b) shows the inner precinct with an interpretation of possible buildings

Other projects, in which I have applied the format of a >Project Language, < include the Christian Music Village in Nagano Prefecture/Japan. The project language describes the overall structure of the village in the mountains of Fujimi and was partially built. The formation of a project language for the Saida Project in Lebanon was published as »Weaving in Life.« And the project language for the Wertheimer Tor Project in the Castle Town of Breuberg/Germany is presented in a short solution version and a longer format version. Each of these project languages is formulated in a sequential fashion and sometimes in a short and long version, so that one can understand these projects quickly and/or in more detail. ${ }^{4}$

4 | The Christian Music Village in Nagano Japan is captured in a poetic project language. Published as an HNA Working Paper with numerous illustrations of building designs and completed buildings. HNA 1997. The formation of the Project Language for the Saida Project in Lebanon for the Prince of Wales Urban Design Task Force (UDTF) 1997 was published in The Lebanon Projectı, Prince of Wales Institute of Architecture, 1998, pp. 70-80. Hajo Neis weaving in Life: The Formation of a Project Language for Zoutini،. A full Project Language for the Project is also available as a HNA Working Paper: New Memory for the Old City of Sidon. 1998. The Wertheimer Tor Project in Breuberg, Odenwald, is documented in a summary version and in a richly illustrated long version (HNA documents). Also see: Hajo Neis. 'Planning 


\section{From a Pattern Language to a Project Language: Innovation, Improvisation and Creativity}

Modifications and adaptations of pattern language formats to particular contexts as well as changes into new formats came mostly out of very practical considerations and necessities, as well as opportunities in real project situations. But there are also theoretical issues that have to do with innovation, improvisation, complexity, creativity and appropriateness of response.

Projects should be dealt with at the appropriate level of the context, principle selection and formulation, especially when working with users. For particular contexts it is indeed refreshing that not everything is called a pattern nor every little idea, issue or dream handled as a pattern. (It is also not quite appropriate when the world is carved up into millions of patterns.) Quite often it seems to be appropriate to initiate a process that is different from the formulation of a pattern or pattern language. This might be a narrative or project language, a story, even a poem. There should be a loose variety of approaches, giving flexibility, permitting improvisation, innovation, joy and creativity. New forms are being tested in various contexts, notably sequential formulations are being tested that can be combined more directly with architectural and urban design processes. All of these various approaches still have at their heart the improvement of life and the problem solving intention of design patterns.

Pattern and pattern language discussion and development is going on continuously in a variety of different groups and different locations around the world, either strictly in the rigorous format of patterns, or in more loosely organized project languages for particular projects, even in specialized formats and applications. A recent effort has been started to develop an innovative repository for space patterns and pattern languages by members of the Building Process Alliance Group (BPA) and other related groups, in a format similar to the Wikipedia organization. In fact one of the pioneers of the wiki, Ward Cunningham, explained in one of our conferences in Portland how the idea of a wiki is based on the idea and format of a pattern. ${ }^{5}$ Another recent development addresses the idea of anti-patterns. These so called anti-patterns were first simply >rejects < in the original pattern language development because they created more problems than they solved, including the

Designing and Building Three villagesı. ACSA Regional Meeting. Designing in the Democratic City. Hampton University, Virginia, October 1996. Published in Conference Proceedings. And: Hajo Neis and Susan Ingham. 'Planning and Designing for Making Urban Villagesı. International Making Cities Livable Conference, IMCL, Carmel, California, March 1996.

5 | Fall 2009 International PUARL Symposium 2009. Current Challenges for Patterns, Pattern Languages \&Sustainability. Published by PUARL Press. 2010. Michael Mehaffy and Nikos Salingaros have also taken up this topic in an article called "The Pattern Technology of Christopher Alexander." Friday, October 2011. www.metropolismag.com/pov/20111007/ the-pattern-technology-of-christopher-alexander. 
>madhouse balcony< that Chris Alexander sometimes talks about. More recently people have started to develop anti-anti-patterns intended to avoid all kinds of existing wrong solutions to problems. ${ }^{6}$ People are also working on different kinds of pattern language formats. Card decks have become popular ways for communicating and working with patterns, so that users can more easily access them and use them in a playful fashion.?
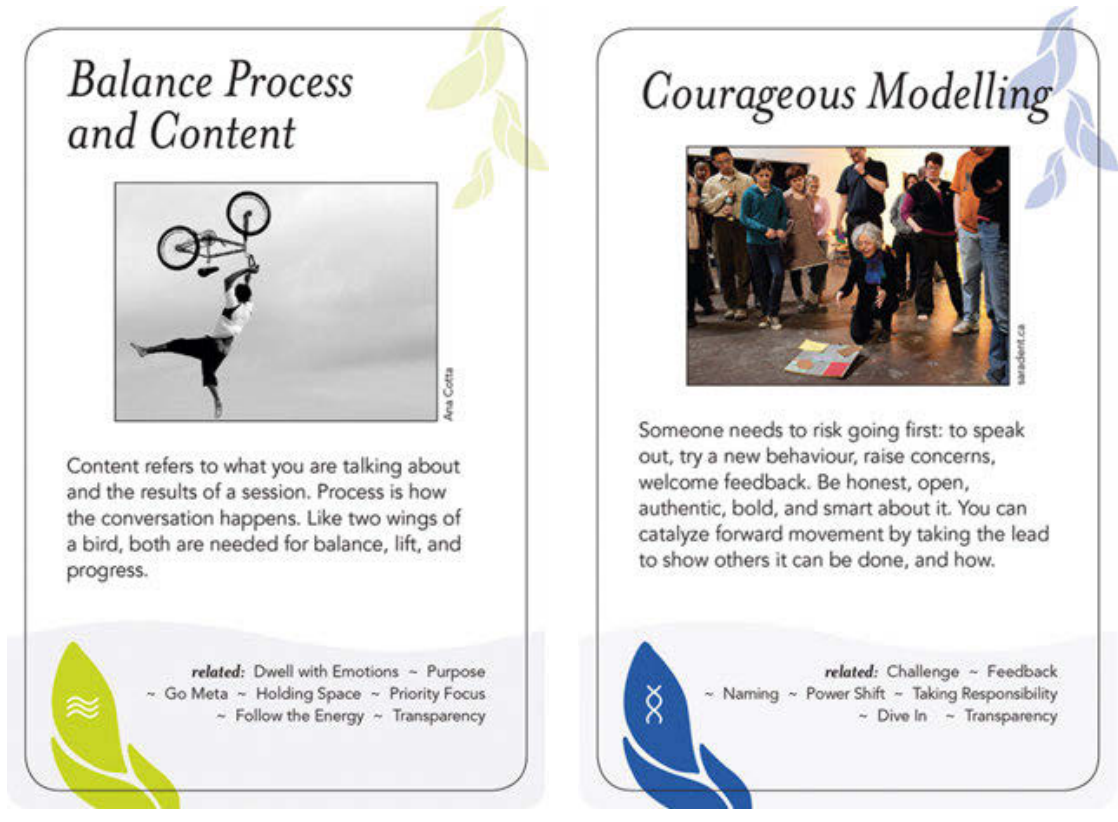

Illustration 7: 91 Cards' Deck: A Pattern Language for Bringing Life to Meetings and other Gatherings (by Group Works, 2012)

The strongest quality of any Pattern or Pattern Language in its formal problem solving articulation seems to be the fact that it is a system based primarily on functional considerations. Most people can easily understand how a pattern works, and how various patterns work together, and how they solve problems in architecture and in many other fields. It is for that reason that patterns and pattern

6 | Doug Schuler is working on a project that he calls quite dramatically: How to Destroy the World and Make Life a Living Hell for Most People in the Process: A How-To Guide also known as A Diabolical (Anti-)Pattern Language. Evergreen College, Spring 2013.

7 | Tree Bressen and Group Works have developed a pattern language deck in solution form with instructive illustrations: Group Works: A Pattern Language for Bringing Life to Meetings and Other Gatherings. The deck was published in 2012 by Group Works and can be bought as a deck or downloaded for free: www.groupworksdeck.org. Doug Shuler is finishing a deck of pattern cards as part of his project and book ,Liberating Voices. 
languages have been so successful in many disciplines, a result of their universal applicability to almost any problem with a problem-context-solution situation. It is the universal format of patterns that is of interest here, and which seems to have the potential to tackle and solve complex problems in interdisciplinary ways, especially for the ever-more complex problems that we are faced with today. We will come back to the issue of interdisciplinary use of patterns and pattern languages in complex problem-solving at the end.

However, the fact that we are dealing here primarily with functional arguments and logical organization can also be considered to be a weak point of the principle of patterns, at least for architects, and certainly for people who primarily work with space, geometry, material, and color. For architects, a pattern language can (but does not have to) form the starting point of a building project or design. Even with a pattern language or project language as a programmatic starting point of design, for the architect the building still needs to be designed as a physical and spatial entity, and for the builder the building still needs to be build physically according to spatial and physical ideas, plans and instructions. Many people, especially pattern language enthusiasts, scholars, and supporters seem to think that the main work of a design is the formulation of a pattern language, as if it is at least $50 \%$ or more of a project. In reality, work on a pattern language may be $5-10 \%$ of any building project's design work. This means that $90 \%$ of the work is related to other aspects and principles of a building design and construction process. Here, it means first of all that you have to understand space and geometry as a major category for creating a successful building project.

\section{Patterns, Centers, and Fields of Centers}

Space and geometry are such essential features in any architecture, that we may as well consider these at least as important as functional elements such as patterns. It is Chris Alexander's second large achievement in this overall pattern language theory and school of thought to bring space and geometry into this theory and practice with a new and innovative perspective. The first important element is the understanding of space as a life-giving feature. The second important innovation is the formulation of 15 properties of space and geometry, and the third critical element is the combination of these two features in to what is called a field of centers.

Space as a basis of life is an age-old idea that appears in religion as well as in philosophy. What is new in the theory on space and spatial quality is that it is considered part of the modern scientific world and subject to the scientific method. Life occurs and starts in space because of a life-giving potential and opportunity that exists in space, similar to gravity that exists (equally invisible) in large bodies of material. Centers are essential in this theory, specifically the geometrical relationships of centers. A center emerges in space and supports other emerging 
centers to create more life. Space is not a lifeless container, but it is an active entity that together with centers forms the foundation of life.

Centers are observable everywhere in nature and also with man-made objects. They are pervasive all around and take on different forms. Over a long period of studies, Alexander found 15 kinds of geometrical centers that can be identified by their different kinds of qualities depending on their position in space and their configuration in a whole. These fifteen centers or geometric properties of life are the following:

1. Levels of Scale

2. Strong Center

3. Boundaries

4. Alternating Repetition

5. Positive Space

6. Good Shape or Form

7. Local Symmetries

8. Deep Interlock

9. Contrast

10. Gradients

11. Roughness

12. Echoes - Family Resemblance

13. The Void

14. Inner Calm/Simplicity

15. Connectedness - Not Separateness

The notion of centers and field of centers was first tested in a larger project at the San Francisco waterfront in a general formulation without the fifteen properties of living space, published in A New Theory of Urban Design (Alexander, Neis, Anninou, King, 1987). The full human geometry or fifteen geometric properties are fully discussed in The Nature of Order (Alexander, 2003). Here also the relation of centers to patterns is discussed in a way that centers can also be understood as patterns and patterns can also be understood as centers. Sometimes, specific geometrical centers can be connected with very specific patterns such as the geometric property DEEP INTERLOCK can be found in the pattern COUNTRY CITY FINGERS, the geometric property BOUNDARIES can be found in the pattern ARCADES, and the property GRADIENTS can be identified with the pattern ENTRANCE TRANSITION.

The principle of centers and fields of centers has been applied in numerous projects. Excellent examples have been carried out in their purely geometric form in the following projects: 1) The façade of the Sakura Tsutsumi Building in Japan exhibits beautifully the properties of UNIFYING CONTRAST and ALTERNATING REPETITION with its alternating diamond shaped exterior concrete elements. 2) The property of GRADIENTS is well shown in the overall volumetric structure of the Emoto Apartment Building in downtown Tokyo. 3) The property 
of VOID exists peacefully in the lake at the center of the Eishin Campus in Japan. 4) The property GOOD SHAPE is marvelously embedded in the windows and window frames of the West Dean Visitor Center in West Sussex, England. 5) The property of POSITIVE SPACE can be strongly felt in the Vineyard Farmer's Market in Fresno, California, with its wonderful heavy wooden trellis structure. 6) The properties of BOUNDARIES and DEEP INTERLOCK can be strongly felt in the courtyard arcade of the Julian Inn Shelter for the Homeless in San Jose, California 7) The property of FAMILY RESEMBLANCE or ECHOES is a major feature of the Agate Student Housing Project in Eugene, Oregon. 8) And finally, the Eishin Campus in Japan is probably the best example of a large urban built project with FIELD OF CENTERS qualities. ${ }^{8}$ (see illustration 7)

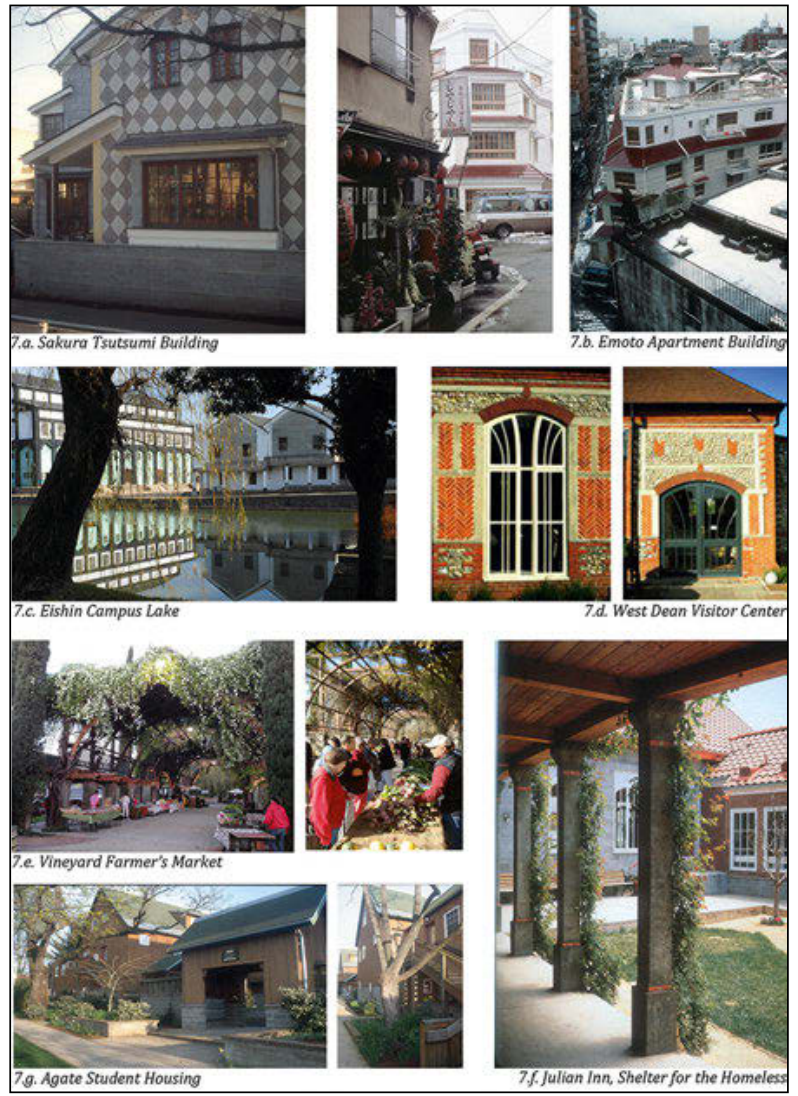

Illustration 8: Expression of geometrical Properties as designed and built in Projects

8 I The Sakura Tsutsumi Building by HNA is published in: Howard Davis. The Culture of Building. New York: Oxford University Press, 1999. The Emoto Apartment Building by CES is published in: Nikei Architecture. "Maison de Louran: Good Reaction to the Landscape and Urban Space - It succeeds to Interweave with Delicate Shape. 6-13-1988. 
How to work with the two essential principles of centers, patterns and pattern languages, and fields of centers individually or both together in an integrated fashion in project formulation, design, construction and development, is an ongoing process of theoretical explorations of creative thinking, practical application, improvisation and experimentation in a creative process. One such exploration was the development of a new Form Language, in which centers and patterns, as well as urban and architectural context concerns were all combined and connected in a way that created a form language for a particular urban project design. Form Language principles were researched and developed by Chris Alexander, the author of this article, and students from the University of California in Berkeley in a way that was very specific for a local project on Telegraph Avenue in Berkeley and, at the same time, was general enough so that most of these principles could very well apply to other urban projects in different urban locations. Thirteen principles were identified such as for example >positive space< and >building volumes are formed by positive space < or >structure and building construction is real.< A key point here is to understand that form languages differ considerably from New Urbanism form-based codes in the way that for each urban project the principles applied are to be a dynamic part of the actual development, design and construction of a project but are not fixed beforehand in regulations and finished design form. At the >Formensprachen Symposium< in Dresden, Germany, in 2001 the results of the form language work were presented and later published in the German Architecture Theory Journal >Wolkenkuckucksheim $<.{ }^{9}$ Form Language exploration has continued at the University of Oregon with a Form Language for downtown Portland as well as other explorations and ongoing coursework at the UO.

Here we want to summarize some basic points regarding the understanding of these concepts and principles of the overall pattern language approach, and we also want to explore possible research investigations and project applications in various contexts including interdisciplinary arrangements.

\section{Summary: InNovation, Improvisation and Creativity in the Pattern Language Approach - Solving Complex Problems with Patterns and Centers}

First of all it is important to acknowledge that the Pattern Language Approach itself is an important and innovative theory and method that helps us to understand and organize the world in a new and helpful way, but it also helps us find new

9 | Hajo Neis. 'Versuche einer neuen Formsprache in der Architektur. Howard Davis. 'Architektonische Fakten bei der Suche nach einer Sprache،. In: Wolkenkuckucksheim. Thema Formsprachen. 6.Jg., Heft 2 (Januar 2012). www.tu-cottbus.de/theoriederarchi tektur/Wolke/deu/Themen/themen012.htm. 
ways of solving problems and complex problems in architecture, urban design and planning as well as many other fields and disciplines.

In particular the principle of patterns lays out a way of tackling problems so that we can try to find solutions in a problem-discussion-solution format. Furthermore these patterns are formulated as archetypal patterns, which means they are understood as general solutions that can find endless forms of specific solutions and applications according to context and interpretation in many creative ways.

Many patterns together can form pattern languages for particularly large and difficult problems or complex situations. Numerous patterns together as a pattern language can also be understood as forming the knowledge of a particular building culture or even a specific spatial culture as a whole. Some people critically look at pattern languages mostly from the perspective of knowledge and information management, but at the same time, they miss the more important point that it is a collective knowledge based on qualitatively good solutions to environmental and building problems.

Patterns and pattern languages were first invented and applied in the combined fields of architecture, urban design and planning for project program formulation and project design. Patterns and pattern languages are one particular kind of principle that can be applied in combination with other relevant principles to develop an architecture, building or planning project. For example, combining the principle of pattern and pattern language with the principle of user participation, the principle of organic order, and the principle of piecemeal growth, will create a project in which process is becoming relevant (because of the inclusion of piecemeal growth).

Experience in real world projects in architecture and urban design had an impact in modifying and even changing a pattern language into what is called a project language. In a project language, patterns are not the only defining elements any more, but all kinds of specific ideas, dreams, vision, may make up a coherent language for a particular project. Narratives, stories and poems could serve as starting points for a project and can serve as starting points of innovation, improvisation and creativity.

Patterns and pattern languages are determined by functional arguments and functional considerations. For an architect function is not quite enough to design a building, and pattern languages do not replace design, but they are part of the design process. A building project still needs to be designed at a minimum in spatial and geometrical terms. Consequently, a complimentary principle was developed that deals with space and geometry to help the design of buildings and spaces. This principle is called centers and fields of centers, or action oriented it is called >formation of centers and fields of centers < to help to create more life in space and in buildings.

Space is not an empty container but contains the beginning of life in forms of centers that support each other to create more centers and more life. Centers are expressed in fifteen different geometrical building blocks that together create 
fields of centers in endless variation. Centers and fields of centers are key innovations in the overall Pattern Language approach that make the theory much richer as a body of knowledge, and make the practice of designing and building quite a bit more specific, artistic, playful and fun.

By now numerous projects have been designed and built with the principles of centers and patterns, pattern languages and fields of centers combined. The Eishin Campus in Japan is a prime example, and the Emoto Apartment Building, also in Japan is another example. The Agate Student Family Housing project at the University of Oregon is another built example, so is the Visitor Center in West-Sussex, England, as well as the Market in Fresno, or the Sakura Tsutsumi Building in Tokyo, are works by CES or HNA. ${ }^{10}$ At a planning and larger urban design level, one earlier project by CES stands out: Gusasare New Town in Venezuela was planned as a new mining town in the jungle close to the Colombian border. The principles of patterns and centers were used here in an innovative dynamic growth pattern system, clearly demonstrating how the city can grow over time in a combination of certainty and uncertainty or organized improvisation. More recently two projects by PUARL for the City of Tigard in Oregon explicitly include the principle of patterns and implicitly also include the principle of centers for a town center and an urban corridor. ${ }^{11}$ By now we can count numerous examples of architecture and urban projects by many of the architects who use the pattern language approach in their work. Some also work explicitly and successfully with the geometric principle of field of centers.

The individual application, but more so the combination of these two major principles of centers and patterns, are now seen as key principles in trying to create buildings and environments with life, or at least with the beginnings of life according to pattern language theory and practice. And while there are a number of other relevant principles for a building or urban design project to succeed, here we want to specifically emphasize connections to other disciplines and interdisciplinary work in a research and creative project that has little to do with architecture but with social organization and at the same time employing the pattern principle.

It was certainly fun and exciting to be involved in the interdisciplinary MICC research project (as a Verbundpartner) during my research year 2010 in Germany,

10 | CES stands for Center For Environmental Structure. It is the main organization of the pattern/center approach to architecture urban design and planning, with Chris Alexander as its president. HNA stands for Hajo Neis Atelier, which is my own architecture office. Recently I gave a lecture at Meiji University in Tokyo featuring works of both companies in Japan "CES and HNA in Japan." Meiji University December, 2012.

11 | 1) New Town Guasare Project in Venezuela, published in The Nature of Order by Chris Alexander. 2a) TIGARD HW99W CORRIDOR: Pacific Highway to a Sustainable Future. PUARL Research Report 2010. (Hajo Neis, PI) 2b) TIGARD DOWNTOWN FUTURE VISION: A Visual Refinement of the TDIP. PUARL Research Report, 2009. (Hajo Neis, Managing PI) puarl. uoregon.edu. 
a project that has little to do with architecture and urban design, but a lot with patterns and pattern languages (and a little with centers). The project exhibited the rich variety of applications of the principle of patterns and pattern language for Music, Innovation and Corporate Culture (MICC) ${ }^{12}$. But what was even more impressive for me was the recognition of the large potential that is implicit in this principle. With so many disciplines already using the principle of patterns in different forms as a problem solving method, there seems to be a huge potential for trying to connect these various disciplines for solving relevant problems that might not so easily be solvable otherwise. This could be done by being part of a larger pattern language project within one's own discipline while working together with other disciplines; it could also be accomplished by expanding and extending outside one's own discipline with a project in another discipline.

\section{Outlook: The City of iThe Dalles، Sustainable Urban Downtown Project}

Two key questions in the pattern language school of thought, research, and practical application, always are: 1) What are relevant open questions and next steps to pursue in theory and research of patterns and centers; and 2) What are practical issues and projects that we want to pursue in order to solve more problems and make the world a better place?

With regard to 1), there are always a number of questions and issues that need attention on a theoretical level, such as the question of >Types of Production that will generate Living and Beautiful Environments.< More socially oriented, we can ask the question how to formulate and provide these kinds of production for the $93 \%$ of people in the world who do not have access to organized construction of this kind. But here we want to end with 2) a rather more practical project question that takes up some of the issues that we were trying to elucidate in this article: How can we start a project within our own discipline and field of architecture, and expand, extend, and include relevant issues and ideas from other disciplines and make them relate within the method of patterns and centers to our field of architecture and urban design?

12 | Music_Innovation_Corporate Culture MICC is a research project by Professor Dr. Wolfgang Stark und Professor Christopher Dell at the University of Duisburg-Essen, based on a research grant in the research cluster on Innovation Strategies Beyond Traditional Management, funded by the German Government and the European Science Foundation. "In a quest to disclose the secrets of innovative cultures, our methodological approach aims to identify the patterns of innovative cultures in organizations and communities by using musical thinking and the patterns of improvisation." (Dell 2002) 


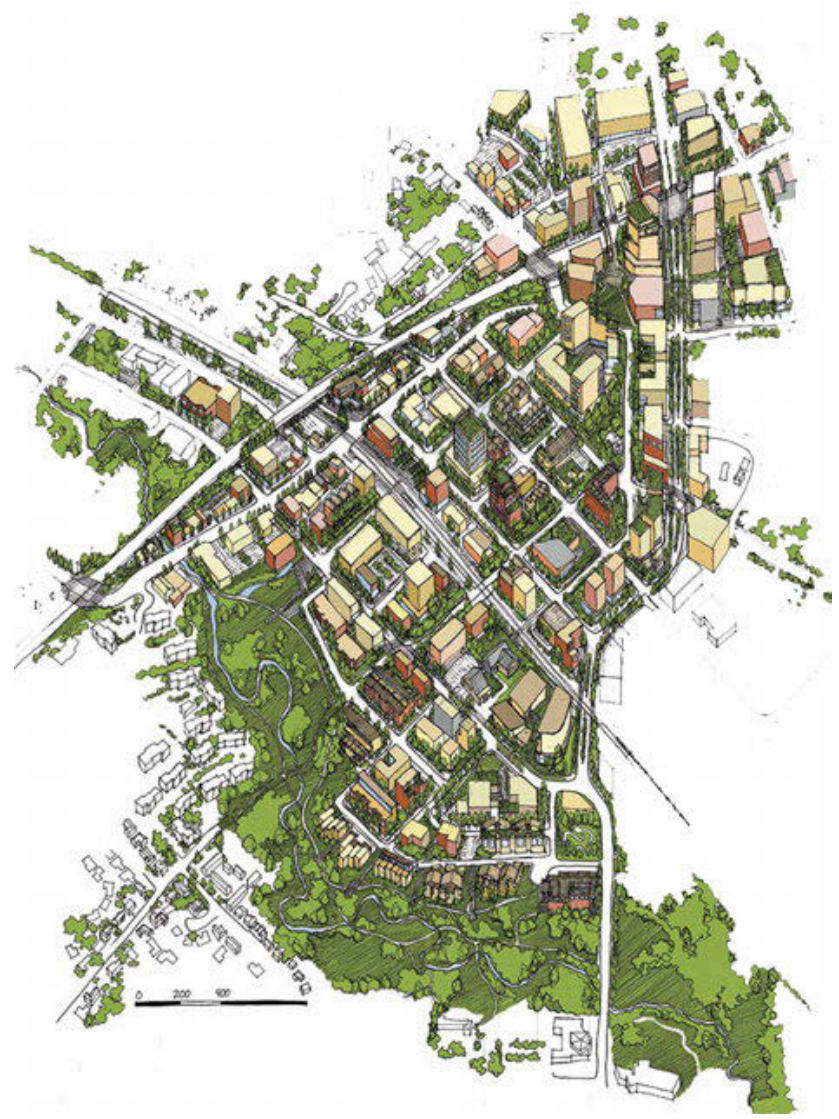

Illustration 9: Urban Design Axonometric of the Downtown of the City of Tigard (Developed and designed by Portland Urban Architecture Research Laboratory PUARL, 2009)

What we imagine is an urban project, specifically an urban design and development project that includes smaller architecture projects within it that possess numerous concerns and issues that are not only architectural and urban spatio-physical but could cover a range of other relevant topics such as ecology, economy, equality etc. Such a project seems to be shaping up for the City of The Dalles on the mighty Columbia River, which acts as the border between the states of Washington and Oregon in the northwestern United States. ${ }^{13}$ The problem here is one of re-urbanization, or, how to rejuvenate the Old Town Center in a way that it becomes attractive again for living, working, and simply enjoying life there. For

13 | We are currently preparing for the project, Sustainable Downtown Growth in The Dalles، at the Portland Urban Architecture Research Laboratory PUARL in an interdisciplinary approach that uses patterns and centers as key categories for the project. 
this project, we obviously would work with the principles of pattern and pattern language as well as the principle of centers and fields of centers with regard to the urban and architectural approach. Possibly, the format of the Form Language may also be applicable here. Further, we imagine that we could go across disciplines in a way that architects would work not only with clients, users, and technical consultants but would work with an appropriate range of disciplines, all applying the pattern language approach in a way that all disciplines can actually connect their patterns in a larger interdisciplinary pattern language.

In this way we are testing a theoretical issue, that is, if and how much we actually could work together with different disciplines applying one main integrated method as a central core to which all different disciplines relate and contribute. At the same time we are trying to work together on a very practical urban design and development project in an interdisciplinary way, trying to solve urban design and other urban problems of an individual city in a creative way.

If this combined interdisciplinary problem-solving method could actually be applied successfully, we might approach larger problems with this method and start to tackle more complex and major urban problems in the world with the vital intention to support and enhance life.

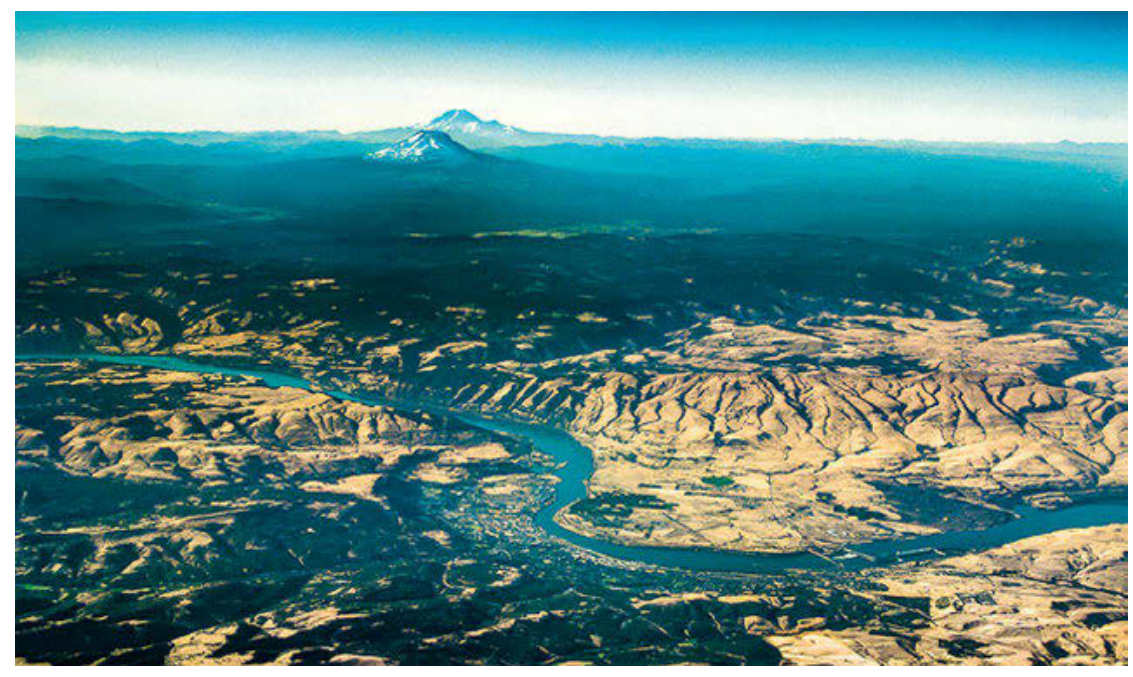

Illustration 10: The City of The Dalles at the Magnificent Columbia River in Oregon, USA 


\section{BIBLIOGRAPHY}

Alexander, C.; Neis, H. \& Moore Alexander, M (2012): The Battle for the Life and Beauty of the Earth. New York: Oxford University Press.

Alexander, C. (2001-2004): The Nature of Order - An Essay on the Art of Building and the Nature of the Universe. Volumes 1-4. Berkeley: Center for Environmental Structure; and New York: Oxford University Press.

Alexander, C.; Neis, H.; Anninou, A. \& King, I. (1987): A New Theory of Urban Design. New York: Oxford University Press.

Alexander, C.; Davis, H.; Martinez, J. \& Corner, D. (1985): The Production of Houses. New York: Oxford University Press.

Alexander, C. (1979): The Timeless Way of Building. New York: Oxford University Press.

Alexander, C.; Ishikawa, S.; Silverstein, M. et al. (1977): A Pattern Language. New York: Oxford University Press.

Alexander, C.; Silverstein, M.; Angel, S.; Ishikawa, S. \& Abrams, D. (1975): The Oregon Experiment. New York: Oxford University Press.

ARCH+ 189 (2008): Entwurfsmuster: Raster, Typus, Pattern, Script, Algorithmus, Ornament. Koeln: Meire and Meire, October 2008.

Davis, H. (2012): Architektonische Fakten bei der Suche nach einer Sprache. In: Wolkenkuckucksheim. Thema Formsprachen. 6.Jg., Heft 2 (Januar 2012). www.tucottbus.de/theoriederarchitektur/Wolke/deu/Themen/themeno12. htm

Dell, C. (2002): Prinzip Improvisation (Principles of Improvisation). Köln: Walter Koenig.

Leitner, H. (2007): Mustertheorie - Einführung und Perspektiven auf den Spuren von Christopher Alexander. Graz: Nausner \& Nausner.

Neis, H. J.; Brown, G.; Gurr, J. M. \& Schmidt, A. J. (Hg.) (2012): Generative Process, Patterns, and the Urban Challenge. Portland, OR: PUARL Press.

Neis, H. J. \& Brown, G. (Hg.) (2010): Current Challenges for Patterns, Pattern Languages, and Sustainability. Portland, OR: PUARL Press.

Neis, H. J. (2002): Versuche einer neuen Formsprache in der Architektur. In: Wolkenkuckucksheim. Thema Formsprachen. 6. Jg., Heft 2 (Januar 2002). www. tucottbus.de/theoriederarchitektur/Wolke/deu/Themen/themeno12.htm

University of Oregon Planning Office (2005): Campus Plan. Eugene, OR: University of Oregon.

Schuler, D. (2008): Liberating Voices: A Pattern Language for Communication Revolution. Cambridge, MA: MIT Press.

Stark, W. (2012): Tacit Knowledge and Innovation Patterns for Communities and Social Systems. In: Hajo Neis et al., (Hg.) Generative Process, Patterns and the Urban Challenge. Portland OR: PUARL Press, pp. 89-95. 


\section{LIST OF ILLUSTRATIONS}

Illustration 1: University of Oregon in Portland Downtown Urban Campus

The Campus is located in downtown Portland in adapted old warehouse buildings, was first designed in the Oregon pattern language method with the principles of patterns and user participation. The White Stag facilities are open since 2009 .

Illustration 2: OLD PEOPLE EVERYWHERE »Old People need old people, but they also need the young, and young people need contact with the old.« From APL p.216. (pattern 40) and connections to the patterns forming a particular pattern language or web of life.

Illustration 3: ENTRANCE TRANSITION (APL pattern 112) The example of a good solution to the problem of entrance transition is taken from Obidos in Portugal (Photo: Sara Ishikawa).

Illustration 4: Graphic Representation of A Pattern Language (APL)

Stefan Tietke and his students have used the software »GraphViz« in order to show the hidden connections of all 253 patterns from APL. Arch+189. October 2008, pp. 18-19.

Illustration 5: University of Oregon Campus in Eugene, Oregon (Air-photo)

The Oregon University continuously is applying the principles of patterns and user participation since 1974 in planning and design of the Campus.

Illustration 6: Two Diagrams of Eishin Pattern Language Representation

Diagram a) shows a graphical representation of the Pattern Project Language for the Eishin Campus with >Inner and Outer Precinct< in plan for an ideal site.

Diagram b) shows the inner precinct with an interpretation of possible buildings.

Illustration 7: 91 Cards' Deck: A Pattern Language for Bringing Life to Meetings and other Gatherings (by Group Works, 2012).

Illustration 8: Expression of geometric Properties as designed and built in Projects.

Illustration 9: Urban Design Axonometric of the Downtown of the City of Tigard (Developed and designed by Portland Urban Architecture Research Laboratory PUARL, 2009).

Illustration 10: The City of The Dalles at the Magnificent Columbia River in Oregon, USA. 


\title{
The Shape of Tacitness to Come
}

\author{
Erweiterte Zugänge zum Impliziten in Organisationen \\ durch musikalisches Denken
}

David Vossebrecher

\section{Einleitung}

Die >implizite Dimension`, bei aller Differenz darüber, was im jeweiligen Fall darunter zu verstehen sein soll, hat im Management und in der Reflexion über Organisation immer wieder eine Rolle gespielt, wenn auch eine nachrangige gegenüber Fragen der Struktur und Strategie. Obwohl eine Reihe wichtiger Managementund Organisationstheoretiker hierzu gearbeitet haben - wie zum Thema Sensemaking in Organisationen Karl Weick, im Rahmen von Theory U und Presencing Peter Senge und Otto Scharmer oder zu lernenden Organisationen und reflexiven Praktikerinnen und Praktikern Chris Argyris und Donald Schön - dominieren in der Managementpraxis wie im Mainstream der Managementtheorie weiterhin die Fokussierung auf Struktur und Strategie, Steuerung und Planung. Daran haben auch die seit Jahren debattierten Herausforderungen nichts geändert, die sich aus zunehmender Komplexität - nicht nur Kompliziertheit - der Umwelten und Kontexte ergeben, in denen Organisationen und Unternehmen sich bewegen. Selbst die Erfahrung der wiederkehrenden globalen ökonomischen, sozialen und ökologischen Krisen - die gegenwärtige erscheint sogar schon als semi-permanenten Krise - lässt bisher wenig Umdenken erkennen, obwohl die Komplexität und Unsicherheit mittels herkömmlicher Strukturen und Strategien, Steuerung und Planung im Grunde nicht mehr zu bewältigen ist. Unter der impliziten Dimension wird das Kulturelle, Weiche, nicht Bewusste, unter der Oberfläche Liegende, das schwer einzugrenzende >Soziale<verstanden, welches weder befriedigend zähl-, mess- und wägbar noch ohne weiteres plan- und steuerbar ist. Es betrifft Werte, Überzeugungen, Sinnfragen, Handlungsdispositionen und Gewohnheiten, die sich jenseits von Kennzahlen und einfachen Festlegungen der Strategien und Organisationsstrukturen auswirken. 
Zwei wichtige organisationstheoretische Ansätze werden im Folgenden zusammen mit der Kritik, die an Ihnen geübt wird - aufgegriffen und als Anknüpfungspunkte für die Entwicklung weiterführender Gedanken genommen. In einer Bewegung aus Darstellung, Kritik und Erweiterung dieser Theorien wird die Kontur der Shape of Tacitness, das heißt einer erweiterten Gestalt des Verständnisses der impliziten Dimension des Organisierens (organisationale Tacitness) gezeichnet. Die beiden Ansätze sind implizites Wissen (tacit knowledge; Nonaka \& Takeushi 1997) und Organisations- bzw. Unternehmenskultur (Schein 1985). Sie deuten das Implizite bzw. Tacitness als entweder wissensbezogenes oder wert- und sinnbezogenes, kulturelles Phänomen, stellen also jeweils ein spezifisches Element - Wissen bzw. Kultur - in den Vordergrund. Sie haben dabei aber entweder Schwierigkeiten, ihre eigenen Ansprüche einzulösen (das Tacit Knowledge-Konzept sensu Nonaka) oder Schwierigkeiten, über Deskription hinaus ihre Einsichten für grundlegend neue organisationale Praxis nutzbar zu machen (das Organisationskultur-Konzept) (vgl. Vossebrecher et al. 2012). Vor allem Kritiken am Konzept des impliziten Wissens wie bspw. von Neuweg (2001) weisen jedoch in vielversprechende Richtungen, die sich in innovativer Weise mit musikalischen (und anderen künstlerischen) Konzepten verbinden lassen. Eine solche Verbindung wurde im Rahmen des Projektes Music - Innovation - Corporate Culture (MICC) ${ }^{1}$ entwickelt, an dem der Autor mitgearbeitet hat und das das Möglichkeiten untersucht und entwickelt, mit Hilfe von Musik und mittels eines musikalischen Verständnisses von Organisationen deren Innovationsfähigkeit zur erhöhen, zur Weiterentwicklung von Innovationsstrategien beizutragen und Management-Innovationen, insbesondere Prozessinnovationen anzuregen (MICC-Projekt 2009).

Parallel zu diesen Ansätzen bzw. Theorien in Organisationsforschung und Sozialwissenschaft und -psychologie existieren in den Kulturwissenschaften sowie in Teilen der Künste Konzepte, die ebenfalls das Implizite (Tacitness) thematisieren und von denen aus sich sinnvoll Schnittstellen zu den obigen Konzepten erzeugen lassen. Auf diesem Weg lassen sich neue Gedanken in die Diskussion einführen resp. dort bereits vorhandene Überlegungen weiter pointieren. Diese kulturwissenschaftlichen und künstlerischen Konzepte, die ein verändertes Ver-

1 | 'Music - Innovation - Corporate Culture (MICC)، in Federführung des Labor für Organisationsentwicklung (OrgLab) an der Universität Duisburg-Essen (www.orglab.org), unter Beteiligung des Institut für Improvisationstechnologie (IFIT) Berlin (www.ifit.de), sowie vier Organisationen bzw. Unternehmen als Projektpartnern. Projektwebseite: www.micc-pro ject.org. Das Projekt wurde 2009-2011 gefördert im Programmschwerpunkt "Innovationsstrategien jenseits traditionellen Managements" vom Bundesministerium für Bildung und Forschung (BMBF) und vom Europäischen Sozialfonds (ESF). 
ständnis von Tacitness befördern, sind Diagrammatik und Performanz/Performativität; die Kunstform, auf die insbesondere Bezug genommen wird, ist Musik. ${ }^{2}$

\section{Organisationskultur UND IMPLIZITES WISSEN}

\subsection{Organisationskultur: offene Fragen}

Die Bedeutung von Organisationskultur für Veränderungsprozesse und Innovationen ist in der Organisationsforschung und -praxis heute unbestritten: Sie ist für eine Reihe Dimensionen mit ausschlaggebend (vgl. Mintzberg et al. 1999). Dazu gehören Beziehung und Prozessqualität, Gemeinschaft bzw. Vergemeinschaftung und Kohärenz, die Leistung (Performance), sowie das Bild, das nach außen wie nach innen entsteht. Die Kultur einer Organisation zeigt Verhaltensund Handlungsmuster, Formen der Beziehungen zwischen Gruppen und Individuen, beinhaltet (geteilte) Werte und Gebräuche und lässt Rückschlüsse auf Status und Rollen im sozialen System Organisation zu. (vgl. Stark \& Dell 2012).

Darüber hinaus ist die Kultur einer Organisation mit deren Struktur und Strategie gerade in praktischer Hinsicht eng zur Gesamterscheinung verbunden, Organisationskultur entsteht und entwickelt sich innerhalb der Strukturen und passt zu ihnen - zumindest zunächst, im Moment der Entstehung einer Organisation (Schein 1985). Andersherum ist die (gravierende) Veränderung von Strukturen ist nur dann erfolgreich, wenn sich die Kultur entsprechend anpasst. Ähnliches gilt für das Verhältnis von Strategie und Kultur.

Das Modell von Edgar Schein (1985) beschreibt drei Ebenen, zum einen die Artefakte, das heißt Objekte und Verhaltensweisen, die sichtbar und erlebbar, aber in ihrer Bedeutung nicht leicht zu entziffern sind: Sie müssen interpretiert werden. Zum zweiten die Werthaltungen: offizielle bzw. bekundete Werte (z.B. aus Leitbildern) und nicht-offizielle Werte. Sie sind teils sichtbar, teils der Organisation und ihren Mitgliedern selbst nicht bewusst. Drittens die Basisannahmen der Organisationsmitglieder, dazu zählen bspw. Annahmen hinsichtlich Motivation und menschlicher Aktivität, hinsichtlich Beziehungen zur Umwelt, hinsichtlich Annahmen zur Beschaffenheit von Wirklichkeit, Zeit und Raum etc. Sie sind unsichtbar und den Organisationsmitgliedern normalerweise nicht bewusst.

2 I Im Rahmen des MICC-Projektes konnten dabei Elemente eines Ansatzes entwickelt werden, denen die Bezeichnung 'musikalisches Denken von Prozessen des Organisierens، bzw. 'Organisation musikalisch denken gegeben wurde; vgl. dazu 3.3 sowie Dell 2011; Stark et al. 2011; Vossebrecher et al. 2012. 


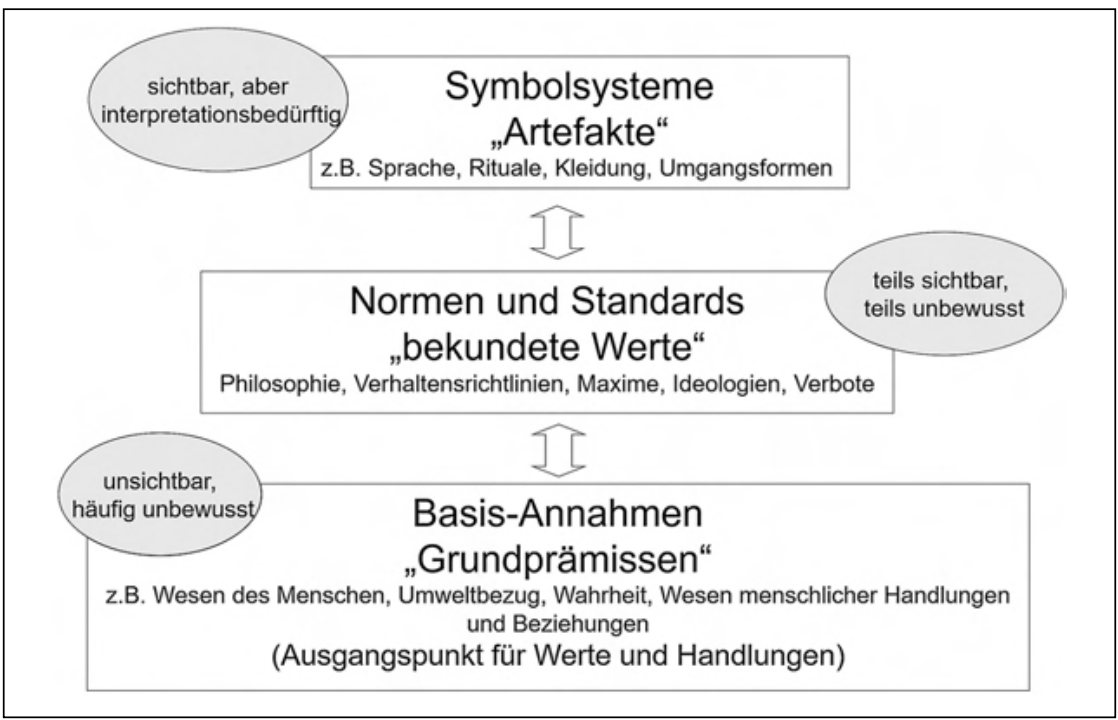

Abbildung 1: Modell der Unternehmens-/Organisationskultur nach Schein; entnommen aus Bluszcz 2009

Das Modell hat für die Erweiterung des Verständnisses organisationalen Geschehens nachhaltige Bedeutung. Edgar Scheins Absicht liegt besonders darin, der vernachlässigten >kulturellen< Ebene neben strukturellen und strategischen Ebenen eine ebenbürtige Rolle zu verleihen; die Stärke seines Modells liegt unter anderem in der Darstellung der drei Ebenen, die sehr anschaulich macht, dass die Kultur der Organisation wesentliche implizite Anteile hat, die im organisationalen Alltag nicht bewusst, sondern - wie im Modell des Eisbergs - zum großen Teil unterhalb der Oberfläche und somit kaum zugänglich sind.

Allerdings gelangt man mit Scheins Modell über Deskription kaum hinaus. Es ermöglicht die Beschreibung entlang der Frage >Welches System an Grundannahmen und basalen Werten, die das Handeln der Organisation sublim prägen, wurde erlernt? und auch die Rekonstruktion der zugehörigen Lern- und Verlerngeschichte: >Wann und wie ist das Wertesystem aufgenommen worden/entstanden? Wie ist es aus dem Bereich ihres >Bewusstseins< heraus gedriftet? Aber es fehlt beispielsweise ein Modell, das aufzeigt, wie eigentlich die nicht bewussten Wertsysteme das Handeln von Organisationsmitgliedern, die Prozesse, Entscheidungen etc. in alltäglichen Situationen tatsächlich beeinflussen und in welchen Situationen, unter welchen Umständen sich die jeweiligen Werte auf konkretes Handeln stärker oder weniger stark auswirken. Mit anderen Worten bleibt unklar, wie genau die Werte und Basisannahmen, Situationen und die Handlungen zusammen hängen (vgl. Vossebrecher et al. 2012). Ein zweiter Kritikpunkt ist, dass Scheins Konzeption inkohärent in der Nutzung von Begrifflichkeiten aus Lerntheorie vs. Psychoanalyse ist, so dass auch hier wesentliche Probleme ungelöst bleiben (ebd.). 


\subsection{Probleme des impliziten Wissens}

Wesentlicher Bezugspunkt beinahe aller Beiträge zum impliziten Wissen ist Polanyis Wissenstheorie, besonders The Tacit Dimension (Polanyi 1966). Daran anknüpfend hat Nonaka in einer Reihe von Arbeiten zum impliziten Wissen (implicit oder tacit knowledge; Nonaka et al. 2001; Nonaka \& Takeushi 1997) einen ebenfalls einflussreichen Ansatz zu Tacitness in Organisationen formuliert, der diese unter anderem als non-linguistisches, non-numerisches Wissen (Nonaka 1994; Nonaka et al. 2001) versteht. Implizites Wissen spielt in der Literatur zu Wissensmanagement eine wichtige Rolle und stellt dar, wie in Organisationen implizites Wissen nutzbar gemacht werden kann, das heißt insbesondere, wie implizite Wissensbestände expliziert werden können (Nonaka \& Takeushi 1997). Wissenstransformation erklären sie anhand von vier Formen der Umwandlung und Entwicklung von implizitem und explizitem Wissen, nämlich Sozialisation, Externalisierung, Kombination und Internalisierung (daher im Englischen: SECIModell). Die Bewegung durch diese Teilprozesse auf individueller wie kollektiver Ebene wird als >Wissensspirale< bezeichnet (a.a.O.; Baumard 1999).

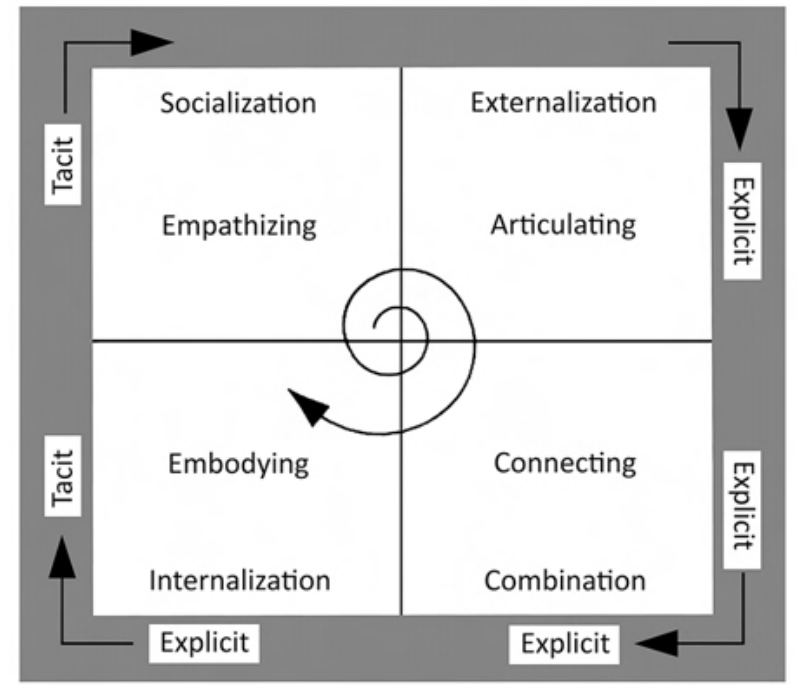

Abbildung 2: The four modes of knowledge conversion and the evolving spiral movement (aus Nonaka et al. 2001, 500)

Ihr Modell ist allerdings oft und zudem grundsätzlich kritisiert worden (vgl. Porschen 2008; Neuweg 2001; Schreyögg \& Geiger 2003). Während Nonaka und Takeushi die Explikation impliziten Wissens definitiv für möglich halten, wird dies von vielen Autor/innen deutlich skeptischer gesehen, insbesondere da explizites und implizites $>$ Wissen , grundlegend (logisch-kategoriell) verschieden sind (Schreyögg \& Geiger 2003, Neuweg 2001). Das wird an folgender Überlegung 
deutlich: Der Versuch, mit Regeln, also explizitem Wissen, Handeln zu instruieren, erreicht schnell nicht mehr zu bewältigende Ausmaße und Komplexität. Einen Musiker bspw. würde die bewusste Konzentration auf alle Bewegungsdetails sofort paralysieren (Polanyi 1966: 18). Dagegen erfordert praktisches Gelingen unweigerlich, dass die Instruktion wieder inkorporiert, also auf praktischem, erfahrendem, übendem Wege körperlich-implizit wird. In Interaktionen zwischen Klavierschüler und Lehrer lässt sich schön beobachten, dass auf präzise verbal-sprachliche Instruktionen zugunsten des Vorspielens oder -singens sowie zugunsten >unpräziser bildhafter Instruktionen verzichtet wird. Weite Teile des impliziten Wissens sind überhaupt nicht, nicht vollständig oder nicht angemessen artikulierbar (Porschen 2008).

Implizites Wissen ist in Neuwegs (2004) Sicht kein eigener Wissenstypus, der vom explizitem Wissen abgegrenzt wäre, sondern eher eine Perspektive auf die impliziten Anteile des im Gebrauch befindlichen Wissens (>knowing<). Das heißt, dass bei allem Handeln (und Lernen) explizites wie implizites >Wissen < im Spiel sind (Neuweg 2004) - explizites Wissen ist ohne jeweils spezifische implizite Kenntnisse nicht verstehbar. Darüber hinaus wendet Neuweg gegen Nonakas Konzept ein (das ja anhand der SECI-Wissensspirale die Explikation und Repräsentation impliziten Wissens verspricht), dass die Repräsentationsformen des expliziten Wissens als solches kein Wissen sind:

"If we use the prevalent signs for representing knowledge - e.g. the spoken sentence, the textbook or the database - are we really talking about knowledge? Clearly we are not. Sound waves, printing ink, and magnetic disks are just physical objects, not knowledge, until somebody understands what they mean. Knowledge is a psychological phenomenon, not a physical one. Consequently, [the term] tacit knowledge may also refer to the tacit roots of all our explicit knowledge, i.e. to its semantic and pragmatic basis." (Neuweg 2004: 140)

Neuweg hält also die Trennung von implizitem und explizitem Wissen für irreführend. Stattdessen gehe es nicht mehr primär um die Analyse von Formen und Strukturen des Wissens, sondern um »Prozesse des Wahrnehmens, Beurteilens, Antizipierens, Denkens, Entscheidens, Handelns« (Neuweg 2005, 557; kursiv i. O.), kurz also um >Könnerschaft mungs- und Handlungsdispositionen und der entsprechenden Akte der Performanzregulation. Tacit knowing wird so zu einer prozesshaften und >performativen Sichtweise, die auch die implizite Dimension verständlich werden lässt. Im Fokus steht die Beziehung von Wissen und Können in der Praxis, die »in ihrem fortwährenden Gelingen ein ihr >implizites Wissen< zur Schau stellt« (a.a.O., 558). Das Wissen als solches ist dann vor allem die »artikulierte Entsprechung« der jeweiligen Praxis.

Von dieser Erkenntnis aus lässt sich an Nonakas Konzeption kritisieren, dass die Inkorporiertheit des Wissens bzw. der »Wissensträger Körper« (Porschen 
2008, 64) neben den kognitiven Facetten des Wissens konzeptuell grundsätzlich zwar vorhanden ist, aber abstrakt bleibt und somit in Bezug auf organisationale Praxis und organisationales Wissensmanagement letztlich vernachlässigt wird. Es »wird kaum mehr berücksichtigt, dass der Körper nicht nur [...] als Informationsträger für kognitive Verarbeitungsprozesse im Gehirn oder schlicht organischer Wohnort impliziter Wissensformen fungiert« (ebd.). Körperliche Empfindungen, Sinnlichkeit und »ganzheitliche Wahrnehmungsfähigkeit [als] eine Voraussetzung ganz eigener Qualität für die Genese impliziten Wissens« (ebd.) bleiben vernachlässigt (vgl. auch Böhle \& Porschen 2011). Für das hier verfolgte Interesse am Impliziten organisationaler Praxis und an organisationskulturell vermittelten Dispositionen $^{3}$ - also an einem Verständnis jenseits der sintellektualistischen Legende< (Gilbert Ryle; vgl. Neuweg 2001) - stellt das eine Verflachung dar.

Die Frage der Tacitness organisationalen Handelns richtet sich also nicht auf (relativ schwer veränderliche) Wertebestände und grundlegende Festlegungen der Wahrnehmung und Deutung von Situationen und auch nicht auf als eigenständige Einheiten verstandene explizite Wissensbestände, sondern auf Praktiken bzw. die Praxis des Organisierens als Prozess und Performanz in der Zeit. Das >Implizite < ist dabei Teil jeder Praxis, jedes Könnens, jeder Performanz. Zum tacit knowing view lassen sich laut Neuweg (2005) entsprechend Handlungsarten und Konzepte wie situiertes Handeln (Suchman 1987), subjektivierendes Handeln (Böhle \& Schulze 1997), intuitiv-improvisierendes Handeln (Volpert 1994, 2003) und künstlerisches Handeln (Brater 1984), Habitus (Bourdieu 1987) und knowing-in-action (Schön 1983) zuordnen. Das mit den letztlich statischen Konzepten Organisationskultur und implizites Wissen (sensu Nonaka und Co.) zunächst nur unzureichend Verstehbare wird als prozesshaftes und performatives Geschehen klarer, wenn man sich vergegenwärtigt, dass für kompetentes Handeln das artikulierbare, aber noch nicht artikulierte, noch implizite Wissen die weitaus geringere Rolle spielt gegenüber einem nicht oder nur indirekt verbalisierbaren Handlungs->Wissen<. Anders ausgedrückt: Können/Könnerschaft hat zwar auch Anteile, die man sinnvoll als Wissen ansehen kann, aber nur mittels dieser Anteile können Dritte nicht instruiert, kann Können nicht weiter gegeben oder irgend ausreichend erläutert werden. Die Befähigung zu kompetenter Praxis erlangt man stattdessen nicht ohne die Inkorporierung von Kompetenzen im Zuge von Praktiken, Handlungsweisen und performativen Akten.

\subsection{Konturen der Shape of Tacitness}

Zusammenfassend lässt sich festhalten, dass die implizite Dimension des Organisierens mit den Konzepten zur Organisationskultur, insbesondere soweit sie sich auf das Modell von Schein (1985) beziehen, höchstens deskriptiv veranschau-

3 | Der Begriff der Disposition spielt in Pierre Bourdieus praxeologischer Theorie des Habitus eine Rolle. 
licht werden kann. Die Frage aber, wie die impliziten, nicht bewussten Grundannahmen und Werte dass alltägliche Handeln der Organisationsmitglieder beeinflussen und dynamisieren, ist aus dem Modell heraus nicht zu beantworten. Das Konzept des impliziten Wissens nach Nonaka (1994) wiederum kann seinen Anspruch eines breiteren Verständnisses von Wissen und organisationalem Handeln nur unzureichend einlösen, die Rolle des Körpers für Wissen ist aber letztlich nicht berücksichtigt, daher kann Nonakas Konzept eine rationalistische Verkürzung bescheinigt werden. Die Ausweitung des impliziten Wissens durch Neuweg öffnet hin auf Handeln von Expertinnen und Könnerinnen bzw. Experten und Könnern, also >Könnerschaft< (Neuweg 2001). Dieses Verständnis hat Verwandtschaften zu einer Reihe von handlungstheoretischen Ansätzen, sowie zu Praxistheorien wie der Praxeologie Pierre Bourdieus.

Aus der Diskussion bis hierher sind zwei Problemstellungen deutlich geworden: Erstens die Herausforderung der (sprachlichen) Explikation bzw. Repräsentation impliziter Gehalte; diese kann, wenn man ausschließlich sprachlich zu explizieren und zu repräsentieren versucht, offenbar niemals hinreichend sein. Zweitens wurde die Schwierigkeit deutlich, den Handlungsbezug impliziten Wissens bzw. seinen Bezug auf (alltags-)praktische Verfahrensweisen/Vollzüge zu klären, die nämlich mit Konzepten wie »Werten« und »Wissen« nur unzureichend handhabbar sind, da sie die Dynamik des Handelns nicht verständlich machen. Ersterer Problemstellung lässt sich, so der Vorschlag hier, mittels musikalischer und genereller Diagrammatik begegnen, der zweiten mittels Performanz und ebenso einem Konzept von Praxis aus kulturwissenschaftlich-sozialwissenschaftlicher und musikalischer Perspektive. Zunächst wenden wir uns im nächsten Abschnitt der zweiten Herausforderung zu, ist doch der Begriff Performanz (bzw. Performativität) bereits verschiedentlich aufgetaucht.

Zuvor lassen sich noch folgende Konturen der bislang herausgearbeiteten Gestalt - der »Shape of Tacitness« aus dem Titel dieses Beitrags - herausheben:

- Können/Wissen ist, verstanden als knowing (>wissen< in der Verbform), auf das Engste mit Handeln verbunden. Wissen im engeren Sinne stellt nur noch einen bestimmten Teil - und nicht den praktisch bedeutsamsten - von Können/Handeln/Praxis dar.

- Die Trennung Körper - Verstand ist artifiziell und irreführend. Körperlichkeit ist ein zentraler Bestandteil unserer wissenden-könnenden Orientierung in der gesellschaftlichen und sozialen Welt; ihre Bedeutung wird ganz offensichtlich weithin stark unterschätzt.

- Jedes Können (Wissen) hat immer implizite Dimensionen, die sich bei weitem nicht restlos - und wahrscheinlich nicht einmal überwiegend - sprachlich auf den Punkt bringen lassen, weder für je mich selbst, noch im Versuch, andere $\mathrm{zu}$ instruieren.

- Damit wird experimentierendes, erprobendes, spielerisches Handeln, in dem Verstand und Körper zusammenwirken, zu einem fundamental wichtigen 
Werkzeug für die Produktion und Weitergabe von Können/Wissen, besonders aber für Innovationsstrategien. Zudem stellen spielerisch-experimentelle Handlungsformen, da sie ergebnisoffen sein müssen, traditionelle Formen von Planung stark infrage; sie sollten Planung zumindest komplementär ergänzen.

\section{Performanz, Praxis und Musik}

\subsection{Performanz}

Der Begriff Performanz entstammt Austin's (1975) sprachphilosophischer Theorie der Sprechakte und hat besonders in den Kultur- und Medienwissenschaften Karriere gemacht. Austin untersucht Sprechakte, die zugleich Handlungen sind. Häufig zitiert ist das Beispiel der Eheschließung: Im >hiermit erkläre ich Euch zu Mann und Frau< und im zugehörigen gegenseitigen Eheversprechen wird mit der sprachlichen Äußerung eine wirkungsmächtige Handlung vollzogen (Austin 1975). Unter anderem hat sich Judith Butler (1991, 2002) auf Austin bezogen, gebraucht Performanz aber in erheblich weiterem Sinne (vgl. Volbers 2011), indem sie damit umfassend die Konstituierung sozialer (Geschlechts-)Identität bezeichnet, in welcher dem Körper bzw. der Körperlichkeit eine wesentliche Rolle zukommt. Butler greift die Perspektive dramatischer, theatralischer performance auf und argumentiert, dass Geschlechtsidentität durch Akte hervorgebracht und aufrechterhalten wird.

"Die Realität der Geschlechterzugehörigkeit ist performativ, was ganz einfach bedeutet, dass die Geschlechterzugehörigkeit real nur ist, insoweit sie performiert wird. Man darf wohl sagen, dass bestimmte Arten von Akten gewöhnlich als Ausdruck eines Kernes der Geschlechterzugehörigkeit oder der Geschlechteridentität interpretiert werden [...]. Wenn Geschlechterattribute jedoch nicht expressiv, sondern performativ sind, dann konstituieren diese Attribute in Wirklichkeit die Identität und drücken sie nicht etwa nur aus oder verdeutlichen sie nur. Der Unterschied zwischen Expressivität und Performativität ist von entscheidender Wichtigkeit, denn [...] dann gibt es keine zuvor schon bestehende Identität, an der sich ein Akt oder ein Attribut messen ließe." (Butler 2002: 315f)

Aus diesem Ausgangspunkt der dramatischen Performanz, der Aufführung, der Posen und Gesten, ergibt sich (unter anderem) der besondere Stellenwert des Körpers in Butlers Konzeption ${ }^{4}$. Geschlechtsidentität ist, obwohl sie als biologisch gegebenes Sein erscheint, ein körperlich eingeübter und aufgeführter Akt: »Der

4 | Selbstverständlich spielen noch andere Gründe eine Rolle, unter anderem ihr Thema Geschlechtsidentität, welche ja vor der feministischen Kritik als untrennbar mit dem (weiblichen oder männlichen) biologischen Körper verbunden schien. 
Akt der Geschlechterzugehörigkeit [ist] der Akt, der jeder verkörperte Handelnde ist, sofern jeder von ihnen dramatisch und aktiv gewisse kulturelle Bedeutungen verkörpert und diese in der Tat wie Kleidungsstücke trägt« (a.a.O., 312; kursiv i. O.). Die >Akte $<$ gehen nicht auf bloß individuelle Entscheidungen und Intentionen zurück, sondern sind kulturell eingebettet und in diesem Sinne kollektiv und in einer Verbindung mit der Vergangenheit stehend. Der »Körper [setzt] seine Rolle in einem kulturell beschränkten Körperraum um und inszeniert Interpretationen innerhalb der Grenzen« (a.a.O., 313) bereits gegebener Rollenanweisungen. Es handelt sich sozusagen nicht um einen einzelnen Akt, sondern um eine re-iterative Praxis (Posselt 2003), um Wiederholungen von Akten in zitatförmiger Weise und als Anrufung bestehender Konventionen und Ordnungen (Butler 1997; vgl. auch Krämer 2001). Grundlegend für Butlers Perspektive ist, dass es die Akte sind, die performativ die Subjekte und Körper konstituieren, nicht umgekehrt; Performativität der sozialen Geschlechtsidentität heißt gerade nicht, dass das Subjekt seine Identität bereits hat und nur noch auszudrückt oder aufführt, sondern dass das Subjekt als Effekt der (Geschlechts-)Performanz erst konstituiert wird (Butler 2002). Im Rahmen dieser Vorstellung von performativ im Tun konstruierten - und immer neu konstruierten, zur Aufführung gebrachten - Ordnungen untersucht Judith Butler auch deren De-Konstruierbarkeit und betont damit auch die subversiven, Konventionen brechenden Möglichkeiten der Performanz, die transformierenden (Krämer 2001) oder auch innovativen Möglichkeiten.

Äquivalent zur >Geschlechterwirklichkeit<, die Judith Butler vorrangig untersucht, werden auch andere soziale Wirklichkeiten (wie z.B. organisationale Wirklichkeit) durch »nachhaltige soziale performative Vollzüge« (Butler 2002: 315) konstituiert, gleichzeitig wird im Zuge der Konstituierung »der performative Aspekt [...] verschleiert« (a.a.O., 316).

Die nachhaltigen sozialen performativen Vollzüge, von denen Butler spricht, bezeichnen Wulf et al. (2001) als performativ-mimetische Prozesse, bei denen jeweils eine Bezugnahme auf Vorangegangenes erfolgt und die für soziale und kulturelle Sachverhalte und Arrangements »konstitutiven Charakter« (a.a.O., 12) haben. Butler sehr ähnlich, vertreten Wulf et al. (2001) eine Sicht, nach der soziale (nicht aber notwendig nur sprachliche) Handlungen »körperlich, szenisch und expressiv [sind]. Sie haben ludische Elemente und erfordern ein praktisches Wissen darüber, wie sie in bestimmten Situationen aufgeführt werden sollen.« (Wulf et al. 2001, 11f). Wiederholung - nicht des identischen, sondern des musterhaft ähnlichen - nimmt demzufolge eine zentrale Position ein, wenn Organisationen performativ gedacht werden (a.a.O., 13).

"praktisches Wissen ist performativ, es ist körperlich, ludisch, rituell und zugleich historisch, kulturell; [...] es ist ästhetisch und entsteht in mimetischen Prozessen; performatives Wissen hat imaginäre Komponenten, [...] und lässt sich nicht auf Intentionalität reduzieren; es artikuliert sich in Inszenierungen und Aufführungen des alltäglichen Lebens, der Literatur und der Kunst." (Wulf et al. 2001: 13) 


\subsection{Praxis}

Performative Theorien des Sozialen und Praxistheorien des Sozialen bzw. der Kultur weisen eine Reihe geteilter Grundgedanken auf. Reckwitz (2003) versteht dabei performative Sozialtheorien als Teilmenge des Feldes der Theorie sozialer Praktiken, Volbers (2011) argumentiert, dass sich die Idee des Performativen, d.h. der Gedanke der Erzeugung von Ordnung bzw. »Strukturierung im Vollzug « (a.a.O., 142), auch im Bereich der Sozialwissenschaften und der Sozialphilosophie verorten lässt. In der Entdeckung der Ähnlichkeiten zwischen den >Theoriefamilien sind sich beide Autoren weitgehend einig.

„Innerhalb des Paradigmas der sogenannten ,Praxistheorien`, [...] erfüllt der Begriff der Praxis dieselbe Funktion [wie der Begriff der Performanz; DV]. Auch hier geht es darum, die Konstruktion von Sinnzusammenhängen an eine Logik des Vollzugs zu binden, die nun aber als eine wesentlich 'praktisch، gedachte Logik angesprochen wird." (Volbers 2011: 142)

Die Praxeologie Bourdieus (Bourdieu 1976, 1987; Bourdieu \& Wacquant 1996) hat als soziologische Theorie größere Berührungspunkte zur Idee der Performanz im engeren Sinne (Volbers 2011) bzw. eine »Familienähnlichkeit« (Reckwitz 2003: 283) mit Performanztheorien. Bourdieu bezieht sich insbesondere in seinen Reflexionen zum Zusammenhang von Sprache, Praxis und Gewalt auch auf Austin (Bourdieu 1990). Für ihn folgt soziales Handeln einer ihm eigenen >Logik der Praxis< (Bourdieu 1987), das heißt es ist keine Aufführung eines zuvor gedachten, entworfenen, komponierten, regelhaft geplanten oder sonst wie strukturell festgelegten Skripts, also keine Aufführung von >theoretisch Konzipiertem. Handeln folgt nicht nur expliziten/explizierbaren Absichten und Intentionen, Überzeugungen und Wünschen, sondern ist in bedeutsamen Teilen habituell (Bourdieu 1976). Somit geht Praxis in der Theoretisierung - und somit auch im Expliziten - niemals vollständig auf, sondern entzieht sich dieser. Vermeintliche Regeln des Handelns werden von außen, aus der Perspektive des (wissenschaftlichen) Beobachters und als seine Theoretisierungen an Praxis herangetragen und in sie >hineingesehen ${ }^{5}$. In diesem Sinne kann man auch das Organisationskulturmodell von Schein (1985) mit seinen das Handeln vermeintlich leitenden Werten und Grundannahmen als Beobachterkonstruktion kritisieren.

Die Überlegung, dass Praxis in weiten Teilen habituell ist, besagt, dass es unter Rückgriff auf Strukturen und Regeln nicht zu verstehen ist, aber ebenso wenig einfach aus Interaktionen zwischen Akteuren (intersubjektive Handlungen) erklärt werden kann. Bourdieu grenzt sich sowohl von Strukturalismus wie vom symbolischen Interaktionismus ab. Praxishandeln ist weder strukturell-regelhaft determiniert noch in Interaktionen frei aushandelbar, sondern steht in sozial-kulturell-gesellschaftlichen Traditionen und Kontexten, aus denen sich

5 | Sie sind dadurch natürlich nicht gleich nutzlos oder 'falsch. 
Dispositionen ergeben, die Bourdieu unter anderem mit dem Konzept des $\mathrm{Ha}$ bitus (Bourdieu 1997, 1982) erklärt. ${ }^{6}$ Die Dispositionen des Habitus sind die »Erzeugungs- und Ordnungsgrundlagen für Praktiken und Vorstellungen, die objektiv an ihr Ziel angepasst sein können, ohne jedoch bewusstes Anstreben von Zwecken und ausdrücklich Beherrschung der zu deren Erreichung erforderliche Operationen vorauszusetzen« (Bourdieu 1987: 98f), sie erscheinen »>objektiv< geregelt und >regelmäßig< [...], ohne irgendwie das Ergebnis der Einhaltung von Regeln zu sein, und genau deswegen kollektiv aufeinander abgestimmt [...], ohne aus dem ordnenden Handeln eines Dirigenten hervorgegangen zu sein.« (a.a.O.: 99). Somit ist Praxis nicht regelhaft determiniert, aber in ihrer Varianz mehr oder minder eingegrenzt. Dennoch ist der Habitus zugleich konstruktiv:

"Mit dem Habitus [können] wie mit jeder Erfinderkunst unendlich viele und (wie die jeweiligen Situationen) relativ unvorhersehbare Praktiken von dennoch begrenzter Verschiedenartigkeit erzeugt werden [...]. Kurz, als Erzeugnis einer bestimmten Klasse objektiver Regelmäßigkeiten sucht der Habitus die ,vernünftigen ' Verhaltensweisen des 'Alltagsverstands، zu erzeugen." (a.a.0., 104: kursiv i.0.)

Mit Disposition ist keine persönliche oder psychologische Eigenschaft oder Substanz gemeint, sondern eine Relation in einem sozialen Sinne: eine Bezogenheit von Individuum, Situation und gesellschaftlich-kulturellem Kontext aufeinander. Es geht Bourdieu, wenn er Voraussetzungen konkreter gesellschaftlicher Praxen und Handlungen erklären will, insgesamt um >Konfigurationen von Relationen (vgl. Rehbein 2006), das bedeutet, man muss sich einen Komplex aus Subjekten, konkreten Situationen und kulturell-gesellschaftlichem Kontext ansehen, um Praxis zu verstehen.

Die Dispositionen des Habitus entstehen vor allem als Einlagerung in die Körper im Prozess der Sozialisation bzw. Enkulturation, also in der Regel sehr subtile und kaum bewusste Inkorporierung. ${ }^{7}$ Sie sorgen für soziale Anschlussfähigkeit von Handlungen und kulturellen, gesellschaftlichen Ordnungen. Der Habitus wirkt sub-verbal und implizit, und stellt - zumindest zunächst - Einverständnis mit kulturell-gesellschaftlichen Normen und Sinnsystemen her, wie sie im konkreten sozialen Feld, in dem ein Subjekt aufwächst, bestehen. Da der Habitus nicht determinierend und starr operiert, sondern dynamisch-produktiv, und da Praxis relational gedacht werden muss, gestattet es »eine kleine, endliche Anzahl von Schemata unendlich viele, an stets neue Situationen sich anpassende Praktiken zu erzeugen [...] ohne dass hierfür die Schemata als explizite Prinzipien formuliert werden müssten« (Bourdieu 1976: 204).

6 | Von Bedeutung ist zudem Bourdieus (2005) Konzeption von Kapital, vor allem des sozialen, kulturellen und symbolischen Kapitals.

7 | Bourdieu spricht auch davon, dass die Ausbildung des Habitus ein Prozess der Verinnerlichung der Äußerlichkeit oder "Interiorisierung der Exteriorität“ (Bourdieu 1987: 102) ist. 
Andererseits wird gesellschaftliche, kulturelle Veränderung durch die Inkorporierung des Sozialen erschwert, da die sozialen Dinge »Angelegenheiten nicht des Bewusstseins, sondern des Körpers sind und die Körper die Sprache des Bewusstseins nicht immer und in keinem Fall sehr schnell verstehen.« (Bourdieu 1997, 213). Neue Handlungsweisen, die man z.B. in Beziehungen anwenden möchte, müssen also nicht nur intellektuell und intentional gewollt, sondern auch eingeübt bzw. zu Angewohnheiten werden. Aber, auch wenn dies bei Bourdieu weniger stark betont ist als bei Butler (vgl. Sonderegger 2010), birgt die Performanz/Praxis-Perspektive eben auch das Potential zu Dekonstruktion, Subversion und - in weitem Verständnis - Innovation neuer sozialer Praxen.

\section{Zwischenfazit zu Performanz, Praxis und Tacitness}

Ein Verständnis des Sozialen - Organisationen, Systeme, Handlungen und Handlungskontexte, (Alltags-)Kultur etc. - als Performanz hat insbesondere deshalb Erklärungswert für die Dimension Tacitness, weil die Rolle der Körper für die Entstehung sozialer Gewissheiten und Selbstverständlichkeiten hervorgehoben wird. Soziale Realität wird durch körperliche >Aufführungen< konstituiert, wozu sowohl Prozesse des Einübens gehören, wie auch die Anknüpfung an bestehende, in gewisser Weise vorab geschriebene soziale Akte (im Sinne von Skripten) und Praxen/Praktiken. Diese Praktiken sind zeitlich gebunden und >lokak: »Performatives Handeln schafft soziale Konstruktionen [...] und je nach kultureller Praxis unterschiedliches praktisches Wissen« (Wulf et al. 2001: 13).

Praxistheorien lenken zudem die Aufmerksamkeit darauf, dass soziale Praxis ist nicht mit Regeln, wozu auch strukturierende Wertesysteme etc. zählen, verstehbar ist, sondern einer eigenen, impliziten Logik der Praxis folgt, einem »praktischen Sinn« (Bourdieu 1987), den die Handelnden entwickelt haben. Stabilität von gesellschaftlichen Institutionen und Systemen entsteht durch immer wieder neu und normalerweise hochgradig ähnlich aufgeführte, zeitlich und sinnmäßig aufeinander bezogener Handlungen, ist also >performte< Praxis in der Zeit. Der Teil von Praxis, der nicht im Regelsinne beschreibbar ist - auch nicht bzw. oft erst recht nicht von den Handelnden selbst -, ist durchaus groß. Dieser implizite Teil stützt sich auf Dispositionen, die sich mit Bourdieus Habitus-Konzept verstehen lassen, und die im Prozess der Enkulturation (auch) in die Körper eingeschrieben werden. Zugleich zeichnet soziale Praxis aber auch Offenheit aus. Sowohl die konkrete Praxis ist offen, da der Habitus kein starr fixiertes Reiz-Reaktions-Prinzip, sondern eine produktive Instanz ist, bei der es um die Relationalität von Subjekt/ Akteur, Situation und gesellschaftlich-kulturellem Kontext geht. Und auch generell ist Praxis offen, da sie immer auch spielerische und experimentierende, inkrementelle Weiterentwicklung ist, die von aktuellen, verschiedenartigen und möglicherweise unvertrauten Handlungssituationen und -kontexten angeregt wird. 


\subsection{Musik}

Der Begriff der Performanz, unmittelbarer als der der Praxis, entnimmt Überlegungen aus dem Theater, wie sich bspw. an Judith Butlers Verwendung der Attribute theatralisch oder dramatisch sehen lässt. Auch in den bildenden Künsten existieren performative Kunsttraditionen und -begriffe, nach denen das fertige Werk selbst nicht mehr die Kunst darstellt, da Kunst in diesem Verständnis nicht mehr auf die Erzeugung von >Werken $<$ zielt. Stattdessen ist der Entstehungs- und der damit verbundene soziale, ästhetische und Erkenntnisprozess das wichtige und wesentliche Moment. ${ }^{8}$ Schließlich und selbstverständlich ist auch die Musik eine performative Kunstform, was insbesondere dort deutlich wird, wo sie, wie im Jazz, von Improvisation lebt. Ein musikalisches Werk, auch wenn es uns, insbesondere in Form einer Audioaufnahme, als Entität, als seiendes Ding, erscheint, ist doch radikal an Aufführung gebunden, Musik also eine essentiell performative Kunst. Dass jede Aufführung ein jeweils neues, (leichter oder stärker) verändertes Ergebnis hervorbringt, wird in den Musiktraditionen des Jazz oder der aleatorischen Neuen Musik ${ }^{9}$ am deutlichsten, denn improvisierte oder vor$\mathrm{ab}$ erarbeitete Variation ist dort Prinzip statt unerwünschter Abweichung. Musik lässt sich, besonders in Musikformen, die Improvisation zulassen, somit als >performative Konstruktion< von Form, Struktur, Ordnung oder Sinn verstehen. Sie lässt somit besonders augenscheinlich werden, dass es sich bei vermeintlichen Werken - im Sinne von Entitäten, festen Ordnungen oder Strukturen - um Verläufe bzw. Prozesse in der Zeit handelt, und ist für die Konsumierenden, also die Zuhörerinnen und Zuhörer, wie die Produzierenden, die Musikerinnen und Musiker, als körperlich-sinnliches Medium erfahrbar.

Die in Organisationen hervorgebrachten Ergebnisse und Strukturen sind ähnlich flüchtig, wie die verklingende Musik. Der Eindruck fester Organisationsstruktur formt sich nur durch die relative zeitliche Stabilität von Handlungsmustern, also die stetige Wiederholung sich (sehr) ähnelnder Handlungen, die aufeinander und auf Vergangenes bezogen sind - vergleichbar mit der oben dargestellten >Strukturierung im Vollzug< (Volbers 2011) in performativ-mimetischen Prozessen (Wulf et al. 2001). Die performative Differenz zwischen den per se niemals vollkommen identischen Handlungen schafft Raum für Kreativität und Innovation (vgl. Vossebrecher et al. 2012).

Dieser performativen Grundperspektive fügt Musik - im Rahmen des Projektes Music - Innovation - Corporate Culture (MICC) wurde insbesondere auf die freien Formen des Jazz und die aleatorische und verwandte Neue Musik Bezug genommen - eine explizit ludische (spielerische), erprobende und experimentierende und in dieser Hinsicht innovierende Denk- und Vorgehensweise hinzu. Zu-

8 | Beispiele geben Aktionskunstformen wie Happening und Fluxus oder auch die Soziale Plastik bei Beuys (Harlan et al. 1976) ab.

9 | Siehe 4.1. 
dem erfolgt musikalische Aufführung oft (wenn auch nicht immer) in Gruppen, d.h. Ensembles, Combos, Orchestern etc., so dass Musik auch spezifische Perspektiven auf Zusammenarbeit und Kollaboration mitbringt, die darauf beruhen, dass qualitativ hochwertige Ergebnisse vor allem in gemeinsamer Produktion und gegenseitiger Unterstützung entstehen können. Die Begriffe Groove oder Swing können dabei Qualitätsmerkmale sein. In improvisierten Teilen einer Musikaufführung kommen verschiedene $>$ soziale $<$ Improvisationsregeln zum Einsatz ${ }^{10}$ wie: bereits vorhandene Elemente verwenden; Angebote annehmen; Impulse der Situation und der Partner nicht blockieren oder widerlegen und in diesem Sinne Andere/Partner gut aussehen zu lassen. Dazu gehört auch ein Mindset der Komplexitätsoffenheit und der Suche nach Neuem (vgl. Dell 2002).

Zuletzt lässt sich aus dem musikalischen Feld ein Medium und Instrument aufgreifen, dass für Organisationen bedeutsam sein kann und dessen theoretische Hintergründe im Folgenden behandelt werden: Die musikalische Notation in Partituren, für die im Laufe der Musikgeschickte verschiedene Systeme entwickelt wurden. Partituren, die als diagrammatische Notationen verstanden werden können, kommen bei der Frage nach den Möglichkeiten der sprachlichen oder anderweitigen Explikation und Repräsentation impliziten >Wissens $<$ ins Spiel.

\section{Diagrammatik und die Repräsentation von Tacitness}

Wie bereits diskutiert, ist die implizite Dimension oder Tacitness des Organisierens bzw. in Organisationen mit den Konzepten Könnerschaft, Praxis und Performanz besser verstehbar als mittels des impliziten Wissens (Nonaka) oder Werten und Grundannahmen der Organisationskultur (Schein). Dies hat praktische Bedeutung für das Problem der sprachlichen oder in anderem Modus arbeitenden Explikation impliziten >Wissens<, welches sich z.B. stellt, wenn implizite Gehalte - Handlungswissen, praktische Kompetenzen, Prozesswissen usw. - innerhalb von Organisationen weitergegeben werden soll und Dritte instruiert werden müssen. Folgt man der Argumentation, dass >Wissen $<$ nicht das bedeutendste Element von gelingender Praxis und Könnerschaft ist (Neuweg 2001) und dass der Versuch sprachlicher Explikation rasch an deutliche Grenzen stößt, jenseits derer die wesentlichen Gebiete erst liegen, dann ist die Suche nach Repräsentationsformen für gelingende Praxen/für Können erst recht herausfordernd und dringlich.

10 In einer über die hier gegebenen Hinweise deutlich hinausgehenden Weise kann man Improvisation als eine soziale Technologie verstehen, die sich auch in Organisationen einsetzen lässt, vgl. Dell $(2002,2012)$. Improvisation ist dabei kein Notfall- oder ReparaturhandeIn, sondern ist konstruktiver Umgang mit Unordnung. 


\subsection{Musikalische Notationen/Partituren als Diagramme}

Musik ist dabei interessant, da sie schon immer mit Instruktionsweisen jenseits der Schrift- und jenseits verbaler Sprache arbeiten muss: Am eingangs genannten, Polanyi (1966) entnommenen Beispiel des Musikers, den die Konzentration auf alle Details seiner Bewegungen nur lähmen würde, wird anschaulich, wie Könnerschaft bzw. gelingende Praxis nicht über detailliert-präzise instruierende Information entsteht, sondern jede solche Instruktion ins je eigene Spiel und >Können rücküberführt werden muss, wofür erproben, experimentieren und einüben wesentlich sind.

Ein zentrales Werkzeug der Instruktion in der Musik sind die verschiedenen, im Laufe der Zeit entstandenen Notationssysteme und Formen von Partituren. Die Notationsformen, auf die im Folgenden Bezug genommen wird, entstanden im Kontext der >Neuen Musik in der Mitte des 20. Jahrhunderts (Karkoschka 2004), insbesondere der sogenannten Aleatorik ${ }^{11}$. Musikalische Notationen - Partituren - lassen sich als Diagramme, d.h. als eine besondere Art von Zeichen(-systemen) verstehen, wenn man berücksichtigt, dass die >Kulturtechnik der Diagrammatik nicht nur Diagramme im engeren Sinne, sondern unter anderem Schemata, Karten und sogar Schriften umfasst (Krämer 2010). Während es in den musikalischen Notationssystemen lange Zeit ausschließlich darum gegangen war, mittels eines wie eine Sprache erlernbaren Symbolsystems die Handlungsanweisungen des Komponisten eins-zu-eins abzubilden und zu repräsentieren, entstehen Mitte des 20. Jahrhunderts, bspw. bei John Cage oder Earle Brown, freiere Formen der Notation, die unscharfe und interpretationsbedürftige Anweisungen geben, mit Freiheitsgraden operieren und somit als nicht-repräsentational zu charakterisieren sind (Dell 2009; Vossebrecher et al. 2012). Eine andere große Musiktradition, der Jazz, hat ebenfalls musikalische Formen hervorgebracht, die mit sehr wenig Festlegungen bzw. Vorab-Ordnungen und großem Freiheitsgrad arbeiten und entsprechend sehr offene, >rudimentäre und nicht-repräsentationale Notationen nutzen. Trotzdem leiten diese Notationen und Partituren - in >unscharfer $<$ Weise Praxis an, die zu qualitativ hochwertigen, gekonnten und sscharfen< Ergebnissen führt bzw. führen kann. Die aufführenden Musiker sind quasi Mit-Komponisten des Musikstücks und haben insofern eine stärkere Art von Verantwortung als in Musikformen mit klarer Rollentrennung zwischen Komponist und Dirigent oder Bandleader einerseits und ausführenden Musikern andererseits.

Wichtig für den Zusammenhang hier, die Suche nach Repräsentationsmöglichkeiten für Tacitness, ist, dass Partituren Diagramme sind, die einen spezifi-

11 | Aleatorik/aleatorisch: Vom Zufall abhängig, auf Zufall beruhend, dem Zufall überlassen (von lat. aleatorius ızum Würfelspieler gehörend،, alea 'Würfel, Risiko, Zufalı) meint in der Musik die Verwendung von nicht-systematischen, nicht-deterministischen Operationen, die zu offenen, unvorhersehbaren Ergebnissen führen; vgl. Dudenredaktion (2013); Frobenius (1977); Karkoschka (2004). 
schen Umgang mit >Wissen< erlauben, den man auch als diagrammatisches Denken bezeichnen kann.

\subsection{Diagramme und diagrammatisches Denken}

Diagramme können, symboltheoretisch gesehen, als Hybride von Wort und Bild gelten (Bauer \& Ernst 2010), also als »Zwischenformen, die gleichermaßen an Visualität wie an Diskursivität partizipieren und Sichtbarkeit und Lesbarkeit derart ineinander verschränken, dass Übertritte entstehen und Diskursives als Ikonisches und Ikonisches als Diskursives rezipierbar wird.(43)« Durch diese »eigentümliche Verschränkung« erscheinen Piktoralität und Skripturalität nicht als getrennt, »sondern [gehen] im jeweils anderen auf (Mersch 2009, 120). Damit sind sie auf spezifische, über die Möglichkeiten von Schrift und Bild hinausgehende Weise in der Lage, Erkenntnis und >Wissen $<$ zu transportieren und zu transformieren. Diagrammatik untersucht nun diese Entwurfs- und Erkenntnismöglichkeiten von Diagrammen, also die erkenntnistheoretische Operationen, die Charles Peirce (1965) als diagrammatic reasoning (diagrammatisches Denken) bezeichnet hat, und die stark mit anschaulichem Denken verbunden sind (Bauer \& Ernst 2010).

Diagramme zeichnet eine >exhibitive graphische Darstellung eines Sachverhalts aus: Sie »sind graphische Abkürzungsverfahren für komplexe Schematisierungen. Sie bewahren ein Minimum an ästhetischer Anschauung, das wir benötigen, um zu verstehen, wovon die Rede ist, vor allen Dingen, um uns von abstrakten Sachverhalten in buchstäblichen Sinn ein Bild machen zu können.« (Stetter 2005, zit. nach Bauer \& Ernst 2010: 17). Diagramme machen also die Grundrelationen des Objekts in reduzierter und rudimentärer Weise anschaulich (Ikonizität). Sie stellen nicht »einfach Dinge, Elemente oder Sachverhalte [dar], [sondern] vielmehr Relationen, also Verhältnisse zwischen Elementen. Strukturbildlichkeit ist das Grundprinzip diagrammatischer Darstellungen.« (Krämer 2010: 37; kursiv i.O.). Diagramme sind daher nicht einfach nur Abbildungen (ebd.). Sie sind eine schematische Darstellung genereller Beziehungsmerkmale für pragmatische Anwendungen und können gelten als »eine Zeichenkategorie, die als regelgeleitetes Muster für weitere einzelne Anwendungsfälle und für die Produktion weiterer Zeichen oder Schlussfolgerungen verwendet werden.« (Bauer \& Ernst 2010: 19; kursiv DV). Diagramme sind sowohl extern-materielle Manifestationen als auch intern-mentale »Gedankenbilder« (ebd.). Die beiden Seiten sind nicht voneinander getrennt:

"Als eine Theorie der Auseinandersetzung des Geistes mit in Medien verkörperten Zeichen hebt die Diagrammatik jedoch auf eine Modalität des Wissens ab, die ein solche dualistische Auffassung unterläuft, weil es stets um die prozedurale Vermittlung von Kompetenzen geht, die sich performativ, also aus der Praxis der Konfiguration und Rekonfiguration ergeben." [Ebd., Herv. i. 0.] 
Partituren wären somit also mediale Darstellungen (Symbole, Zeichen), mit denen sich >spielen< lässt, und zwar sowohl auf der Ebene des Darstellungsmediums bleibend, nämlich indem man aus einer Darstellungsweise (Partitur) eine alternative Darstellungsweise entwickelt (Konfiguration, Rekonfiguration), als auch indem man die Darstellungsweise des symbolsprachlichen Mediums in eine musikalische (oder soziale) Praxis, in Handeln überführt. Beide Formen, >Diagramm - neues Diagramm< und >Diagramm - Praxis <, sind performativ und beide sind erkenntnisträchtig bzw. epistemisch gehaltvoll.

Diagrammatische Darstellungen ermöglichen einen beweglichen - d.h. prozeduralen, performativen und in diesem Sinne praktischen - Umgang mit >Wissen<, der sich nicht (vorrangig) auf verbale Sprache stützt (Vossebrecher et al. 2012, Vossebrecher 2017 i.d.Band). Mit anderen Worten handelt es sich beim diagrammatischen Wissen also um eine performative und prozedurale Form von >Wissen<, die weitere wichtigen Eigenschaft darin hat, dass es auch implizite Dimensionen erfasst: »Die Diagrammatik ist keine logische Entfaltung von bereits vorformuliertem Wissen, sondern sie ist das Erzeugen von neuem Wissen im praktischen Umgang mit medial verkörperten Zeichen « (Bauer \& Ernst 2010, 22f: kursiv DV).

Mittels dreier Prinzipien lässt sich dieser Erzeugungs- bzw. Erkenntnisprozess konkreter bestimmen ${ }^{12}$ : Entsprechend dem Virtualitätsprinzip erlauben Diagramme quasi unendlich viele Re-Konfigurationen des relationalen und proportionalen Gefüges, das sie darstellen, das heißt sie erlauben die Entdeckung und Erprobung neuer Konfigurationen, z.B. in der Praxis einer Organisation. Das im Diagramm dargestellte Gefüge setzt hypothetische Vorstellungen frei; man entdeckt abduktiv Veränderungsmöglichkeiten. Ein weiteres Charakteristikum und Prinzip ist, dass Diagramme zeigen, aus welchen Elementen oder Relationen ein Sachverhalt oder Ereigniszusammenhang besteht, so dass deduktive Schlüsse gezogen werden (Evidenzprinzip). Und schließlich stehen Diagramme in einem Zusammenhang mit der >Realität<, hier verstanden als Kontinuum geteilter Erfahrungen, wie es bspw. innerhalb einer Organisation besteht (Kontinuitätsprinzip); sonst könnte ein Diagramm keine Aussage über sein Bezugsobjekt treffen (Bauer \& Ernst 2010: 24f; siehe auch Referenzialität als Merkmal von Diagrammen in Krämer 2010: 37). In der Verschränkung dieser drei Prinzipien lässt »die diagrammatische Veranschaulichung abstrakter Verhältnisse und Funktionen nicht nur mentale Operationen der Umgestaltung, sondern auch konkrete Rückschlüsse auf die Welt der Erfahrung« (a.a.O.: 25) zu. Daraus ergibt sich

"ein produktiver Regelkreis aus Konfiguration und Deduktion, abduktiver Rekonfiguration und Induktion, der durch Zeichen und Medien in Form gebracht wird. Folgerichtig müssen diagrammatische Operationen als Schlüsselverfahren einer jeden Kultur betrachtet wer-

12 | Vgl. die Überlegungen von Bauer und Ernst (2010); andere, in vieler Hinsicht vergleichbare Merkmale trägt z.B. Sybille Krämer (2010) zusammen. 
den, in der die Welt nicht einfach nur als gegeben hingenommen, sondern als Gestaltungsaufgabe wahrgenommen und begriffen wird." (Bauer \& Ernst 2010: 25; kursiv i. 0.)

Hierin liegt das Potential des Verfahrens, Partituren in Organisationen und anderen sozialen Kontexten einzusetzen, um Dimensionen von Tacitness reflektierund nutzbar zu machen.

\subsection{Organisationspartituren}

In Anwendung der musikalischen (diagrammatischen) Notation auf Organisationen wurden im Projekt MICC »Organisationspartituren« in Anlehnung an Aufzeichnungsweisen der Neuen Musik als Instrument der Analyse und Selbstreflexion und als Ausgangspunkt für Veränderung und organisationales Lernen entwickelt (Vossebrecher et al. 2012, Vossebrecher 2017). Im Hinblick auf die Repräsentation impliziter Dimensionen des Organisierens erlauben Organisationpartituren die Darstellung performativ-praktischen Handlungswissens und prozessbezogenen Erfahrungswissens sowie typischer, musterhafter Elemente von Prozessen - und zwar eben auch (einiger) jener Bereiche, die verbal-sprachlich nicht formulierbar sind.

Die Methode Organisationspartituren bedient sich eines Workshop-Formats (Vossebrecher 2017), in dem die Teilnehmenden - bspw. Mitarbeiterinnen und Mitarbeiter aus verschiedenen Bereichen und Ebenen einer Organisation - aufgefordert werden, sich Ereignisfolgen und Prozesse in ihrer Organisation als musikalische Phänomene und als musikalischen Verlauf vorzustellen und dann zeichnend in selbst-,erfundenen< Symbolen zu Papier zu bringen (Vossebrecher 2010; Vossebrecher \& Stark 2009). Organisationspartituren sind eine nicht-standardisierte (qualitative) Methode zur Erhebung und Re-Konstruktion von Prozessund Handlungswissen (Mustern) der Mitglieder einer Organisation und, soweit prinzipiell möglich, von implizitem Wissen in organisationalen Kontexten. Die Workshop-Teilnehmenden gestalten also diagrammatische Darstellungen aus ihrer bzw. über ihre Organisation, sie notieren Prozesse, Ereignisse und Ereignissequenzen, Muster sowie Relationen und Verbindungen zwischen Einheiten und Akteuren, und lassen somit auch handlungsleitende und -begründende Prinzipien, Problembestimmungen und Handlungsvorschläge sowie Dispositionen in konkreten Organisationen und Situationen erkennbar werden (Vossebrecher 2014; Vossebrecher \& Kamin 2014). Sie eröffnen somit Zugänge zu organisationaler Tacitness.

Auf Basis der Überlegungen aus Kapitel 4.2 sind Organisationspartituren als Diagramme geeignet, jenseits tradierter Handlungs- und Denkweisen die Erzeugung neuer Problemlösungen zu fördern. Sie können dies auch deshalb, weil ihnen - in kommunikationstheoretischen Begrifflichkeiten - kein SenderEmpfänger-Modell der Instruktion bzw. des Wissenstransfers zugrunde liegt: Die Notation eines Sachverhalts in einer Partitur erfolgt aus der jeweils eigenen Per- 
spektive, Praxis und (Performanz-)Erfahrung der Gestalterin bzw. der Gestalters heraus, mitsamt ihrer impliziten Dimensionen. Die Leserin bzw. der Leser der Partitur wiederum gewinnt daraus in einer eigenständigen kreativen, konstruktiven Bewegung eigene Handlungen und Handlungsoptionen (befördert durch die Trias von Kontinuitäts-, Evidenz-, und Virtualitätsprinzip) und erschließt sich und anderen so einen Weg zu ludischer, experimentierender oder sogar improvisierender ${ }^{13}$ neuer bzw. weiterentwickelter Praxis. Dabei können die Differenzen und Brüche zwischen der Erfahrungsperspektive der Gestalterin bzw. des Gestalters und derjenigen der Leserin bzw. des Lesers der Partitur erkennbar, produktiv und für zukünftige Re-Konfigurationen der Praktiken fruchtbar werden.

Organisationspartituren haben, wie andere Diagramme auch, Verknüpfungspunkte zum Gedankenexperiment, zur Modellierung und Simulation und zu anderen Verfahren, die »einen Regelkreis von anschaulichem Denken und Probehandeln, von Entwurfshandlungen und Erkenntnisprozessen, von Ermittlungs- und Vermittlungsakten begründen « (Bauer \& Ernst 2010, 15). Diagramme stiften in diesem Sinne ein »Wechselspiel von Medienformat und mentaler Operation, von Perzeption und Kognition, von Kommunikation und Konstruktion« (ebd.). Die Produktion von >Wissen<, von Können, von Praxis im Rahmen der OrganisationspartiturenMethode ist aktiv-subjektives und kreatives Handeln, aber materialbasiert/medial basiert und nicht völlig frei.

\section{Finaler Chorus}

Musik lässt sich als performative Konstruktion von Form, Struktur, Ordnung oder Sinn verstehen; im besonderen Fall der improvisierten Musik als ad hoc Konstruktion. Sie kann somit verdeutlichen, dass es sich bei vermeintlichen Werken - im Sinne von Entitäten, festen Ordnungen oder Strukturen - um Prozesse in der Zeit handelt. Der Eindruck zeitlicher Stabilität und fester Organisationsstruktur formt sich nur durch kontinuierliche Wiederholung sich ähnelnder, performativer Akte und Praktiken, die mimetisch aufeinander und auf Vergangenes bezogen sind. Musik hat Verfahrensweisen entwickelt, mit performativer Konstruktion produktiv umzugehen, die als Modell für Organisationen dienen können.

Das Verständnis des Impliziten, die im Titel dieses Beitrags annoncierte Gestalt der Shape of Tacitness to Come für den Kontext >Organisation< wurde zum Abschluss des zweiten Kapitels bereits skizziert und lässt sich nun klarer konturieren. Dort wurde bereits die Bedeutung der Körper und der Inkorporierung für das Verständnis von Tacitness bzw. des Impliziten benannt, aber noch nicht weiter bestimmt. Zweitens wurde festgestellt, dass Tacitness eher eine Dimension von Könnerschaft, d.h. kompetentem Handeln und gelingender Praxis ist, statt vor allem eine Dimension von Wissen zu sein. Diese beiden Punkte sind,

13 | Zur Improvisierenden Organisation، siehe Dell (2012). 
wie wir nun sehen, miteinander eng zu einer Erklärung verbunden; erprobende, experimentierende und spielerische (ludische) Handlungsformen spielen dafür eine wichtige Rolle.

Für die Konstitution sozialer Gegenstände, Ordnungen und Realitäten - ob Organisationen, Systeme oder Beziehungen - haben die Körper als Träger des individuellen wie kollektiven Handlungswissens eine gewichtige Rolle. Performative Akte werden - ohne damit die Akteure auf nur ihre Körper bzw. ihre Körperlichkeit zu reduzieren - durch die Körper aus- und mit den Körpern aufgeführt und konstituieren so das Soziale, sie etablieren also sowohl Organisationen, die wir als gegebene, von unserem Zutun unabhängig existierende Strukturen oder sonstige Entitäten erleben, als auch die Subjekte (d.h. Akteure und ihre Körper) selbst. Zugleich geschieht eine Inkorporierung des Sozialen, d.h. es wird in Prozessen der Enkulturation eine Kompetenz, ein praktischer sozialer Sinn, gewonnen, Kontext-angemessene und anschlussfähige Gesten, Denk- und Handlungsweisen zu vollziehen, die auch unterhalb der intellektuellen Absichten oder kognitiv gesteuerter Regelanwendung auf körperlicher Ebene funktioniert; diese Inkorporierung sorgt für ein Mindestmaß an Stabilität von Organisationen, Kulturen und Systemen.

Aus dieser Perspektive einer performativen Praxistheorie des Sozialen sind die >sozialisierten Körper als Träger einer nicht artikulier- und explizierbaren Praxiskompetenz - um den nunmehr wenig passenden Begriff Praxiswissen zu vermeiden - und zugleich als Medium der Erzeugung/Konstitution des Sozialen zu verstehen. So wie der Weg vom Können zum Wissen (die Explikation des Wissens) im Großen und Ganzen verstellt ist, so ist übrigens auch der umgekehrte Weg vom Wissen zum Können (die Instruktion kompetenten Handelns) höchstens indirekt zu gehen: Um Wissen für Praxis nützlich zu machen, muss es rückübersetzt werden; es kann nicht allein denkend, sondern muss handelnd wieder in Praxis überführt werden. Für diese Überführung wesentliche Kriterien sind: (Re-)Kontextualisierung, anpassende Variation bzw. anpassendes Re-Design, Spiel/Experiment/Erprobung sowie Subjektivierung im Sinne der Erfordernis, eine eigene >Spielweise $<$ zu entwickeln.

Diesen Prozess unterstützt die aus der Musik gewonnene Notation in »Organisationspartituren« (Vossebrecher 2017; Vossebrecher et al. 2012), die als diagrammatische Darstellungen mit besonderen Eigenschaften ein Medium der Anregung neuen Handelns und neuer Praxis sein können. Sie machen nichtsprachliches Material über Praxis verfügbar, anhand dessen auch Tacitness reflektierbar werden kann. Sie arbeiten mit der musikalisch-visuellen >Materialisierung< von Relationen, Bewegungen, Konstellationen, Mustern, Ordnungen etc. und über den Impuls zum Re-Design der materialisierten Konfigurationen, der Diagrammen eigen ist (Stichwort diagrammatisches Denken). Die Methode der Organisationspartituren ist ein - hier zugunsten einer ausführlicheren Diskussion der Erkenntnispotentiale von Diagrammatik nur kurz skizziertes - Beispiel für ein aus der Musik entnommenes Konzept und Verfahren für Prozesse der Selbst- 
reflexion und des Lernens in Organisationen und zur Erzeugung neuartiger Problemlösungen, Prozesse und Praxen des Organisierens und des Innovierens. Sie ist ein Anwendungsfall des musikalischen Denkens von Prozessen des Organisierens bzw. des Organisation musikalisch Denken (vgl. Dell 2011; Stark et al. 2011; Vossebrecher et al. 2012).

\section{Literatur}

Austin, J. L. (1975): How to Do Things with Words. Oxford, Clarendon Press.

Bauer, M. \& Ernst, C. (2010): Diagrammatik. Einführung in ein kultur- und medienwissenschaftliches Forschungsfeld. Bielefeld, transcript.

Baumard, P. (1999) : Tacit knowledge in organizations. Thousand Oaks, Sage Publications.

Bluszcz, O. (2009): Organisationskultur. Präsentation beim MICC-Einführungsworkshop am 1.1.2009. Essen, unveröffentlichtes Manuskript.

Böhle, F.; Porschen, S. (2011): Körperwissen und leibliche Erkenntnis. In: R. Keller, M. Meuser (Hrsg.), Körperwissen, Wiesbaden, VS Verlag, 53-67.

Böhle, F. \& Schulze, H. (1997): Subjektivierendes Arbeitshandeln - Zur Überwindung einer gespaltenen Subjektivität. In: Christina Schachtner (Hrsg.), Technik und Subjektivität. Das Wechselverhältnis zwischen Mensch und Computer aus interdisziplinärer Sicht. Frankfurt a.M., Suhrkamp. 26-46.

Bourdieu, P. (1976) : Entwurf einer Theorie der Praxis. Frankfurt a.M., Suhrkamp. Bourdieu, P. (1982): Die feinen Unterschiede. Kritik der gesellschaftlichen Urteilskraft. Frankfurt a.M., Suhrkamp.

Bourdieu, P. (1987): Sozialer Sinn. Kritik der theoretischen Vernunft. Frankfurt a.M., Suhrkamp.

Bourdieu, P. (1990): Was heißt sprechen? Zur Ökonomie des sprachlichen Tausches. Wien, Braumüller.

Bourdieu, P. (1997): Die männliche Herrschaft. In: Irene Dölling, Beate Krais (Hrsg.), Ein alltägliches Spiel. Geschlechterkonstruktion in der Sozialen Praxis. Frankfurt a.M., Suhrkamp, 153-217.

Bourdieu, P. (2005): Ökonomisches, kulturelles und soziales Kapital. In: ders., Die verborgenen Mechanismen der Macht. Schriften zu Politik \& Kultur 1, Hamburg, VSA-Verlag, 49-75.

Bourdieu, P. \& Wacquant, L. D. (1996): Reflexive Anthropologie. Frankfurt a.M., Suhrkamp.

Brater, M. (1984): Kunst in der beruflichen Bildung: theoretische Überlegungen zu den pädagogischen Chancen künstlerischen Übens. Grosshesselohe.

Butler, J. (1991): Das Unbehagen der Geschlechter. Frankfurt a.M., Suhrkamp.

Butler, J. (1997). Körper von Gewicht. Die diskursiven Grenzen des Geschlechts. Frankfurt a.M., Suhrkamp. 
Butler, J: (2002): Performative Akte und Geschlechterkonstitution. Phänomenologie und feministische Theorie. In: Uwe Wirth (Hrsg.), Performanz. Von der Sprachphilosophie zu den Kulturwissenschaften. Frankfurt, Suhrkamp, 301321.

Dell, C. (2002): Prinzip Improvisation. Köln, Verlag Walther König.

Dell, C. (2009): Notation und Performanz. Arbeitspapier Nr. 7 aus dem Projekt MICC. Essen, Universität Duisburg-Essen. [Online: http://micc-project.org/ wp-content/uploads/MICC_WP_o7-notation-und-performanz1.pdf.]

Dell, C. (2011): Organisation musikalisch denken. In: praeview - Zeitschrift für innovative Arbeitsgestaltung und Prävention, 01-2011, 24-26.

Dudenredaktion (2013): Duden. Mannheim, Bibliographisches Institut. [Online: www.duden.de/rechtschreibung/aleatorisch und www.duden.de/recht schreibung/Aleatorik; Zugriff: 11.6.2013]

Frobenius, W. (1977): Aleatorisch, Aleatorik. In: Albrecht Riethmüller (Hrsg.), Handwörterbuch der musikalischen Terminologie. [Online: www.sim.spkberlin.de/static/hmt/HMT_SIM_Aleatorisch-Aleatorik.pdf; Zugriff: 1.8.2013]

Harlan, V.; Rappmann, R. \& Schata, P. (1976): Soziale Plastik. Materialien zu Joseph Beuys. Achberg, Achberger Verlagsanstalt.

Karkoschka, E. (2004): Das Schriftbild der Neuen Musik. Celle, Hermann Moeck.

Krämer, S. (2010): Notationen, Schemata, Diagramme: Über >Räumlichkeit< als Darstellungsprinzip. Sechs kommentierte Thesen. In: Gabriele Brandstetter, Franck Hofmann, Kirsten Maar (Hrsg.), Notationen und choreographisches Denken, Freiburg i.Br., Rombach, 29-46.

Mersch, D. (2009): Wissen in Bildern. Zur visuellen Epistemik in Naturwissenschaft und Mathematik. In: Bernd Hüppauf, Peter Weingart (Hrsg.), Frosch und Frankenstein - Bilder als Medium der Popularisierung von Wissenschaft. Bielefeld, transcript.

MICC-Projekt (2009): Forschungsaufbau: Musik und Klang als Medium der Organisationskultur? Internetdokument. [Online: http://micc-project.org/ ?page_id=2; Zugriff 21.7.2013.]

Mintzberg, H.; Ahlstrand, B. \& Lampel, J. (1999): Strategy Safari. Eine Reise durch die Wildnis des strategischen Managements. Wien, Überreuter.

Neuweg, G. H. (2001): Könnerschaft und implizites Wissen. Zur lehr-lerntheoretischen Bedeutung der Erkenntnis- und Wissenstheorie Michael Polanyis. Münster, Waxmann.

Neuweg, G. H. (2004): Tacit knowing and implicit learning. In: Martin Fischer, Nicholas Boreham, Barry Nyhan (Eds.), European Perspectives on Learning at Work: The Acquisition of Work Process Knowledge. (Cedefop Reference Series.) Luxembourg, Office for Official Publications for the European Communities.

Neuweg, G. H (2005): Der Tacit Knowing View. Konturen eines Forschungsprogramms. In: Zeitschrift für Berufs- und Wirtschaftspädagogik, 101, 4, Stuttgart, F. Steiner Verlag, 557-573. 
Nonaka, I. (1994): A dynamic theory of knowledge creation. Organization Science, 5, 15-17.

Nonaka, I. \& Takeuchi, H. (1997): Die Organisation des Wissens. Wie japanische Unternehmen eine brachliegende Ressource nutzbar machen. Frankfurt, Campus.

Nonaka, I., Toyama, R. \& Byosière, P. (2001). A theory of organizational knowledge creation: under-standing the dynamic process of creating knowledge. In: Meinolf Dierkes, Ariane Berthoin Antal, John Child, Ikujiro Nonaka (Eds.), Handbook of organizational learning and knowledge. Oxford University Press, 487-491.

Peirce, C. S. (1965): Collected Papers. Volume 3: Exact Logic; Volume 4: The Simplest Mathematics. (Ed. by C. Hartshorne and P. Weiss.) Cambridge, Harvard University.

Polanyi, M. (1966): The Tacit Dimension. London, University of Chicago Press.

Porschen, S. (2008): Austausch impliziten Erfahrungswissens. Neue Perspektiven für das Wissensmanagement. Wiesbaden, VS Verlag.

Posselt, G. (2003): Performativität. In: produktive differenzen. forum für differenz- und genderforschung. [Online: http://differenzen.univie.ac.at/glossar. php?sp=4, Zugriff: 6.8.2013.]

Reckwitz, A. (2003): Grundelemente einer Theorie sozialer Praktiken. Eine sozialtheoretische Perspektive. In: Zeitschrift für Soziologie, 32/4, 282-301. [Online: www.zfs-online.org/index.php/zfs/article/viewFile/1137/674, Zugriff: 4.8.2013.]

Rehbein, B. (2006): Die Soziologie Pierre Bourdieus. Konstanz, UVK-Verlagsgesellschaft.

Schein, E. (1985): Organizational Culture and Leadership: A dynamic view. San Francisco, Jossey-Bass.

Schön, D. (1983): The Reflective Practitioner. How Professionals Think in Action. London, Temple Smith.

Schreyögg, G. \& Geiger, D. (2003): Kann die Wissensspirale Grundlage des Wissensmanagements sein? Diskussionsbeiträge des Instituts für Management an der FU Berlin, \#20. Berlin.

Sonderegger, R. (2010): Wie emanzipatorisch ist Habitus-Forschung? Zu Rancières Kritik an Bourdieus Theorie des Habitus. In: LiTheS Zeitschrift für Literatur- und Theatersoziologie, 3, 18-39.

Stark, W. \& Dell, C. (2012): Organisationskultur revisited - Transdisziplinäre Schnittstellen zwischen Wissenschaft und Kunst beim Versuch, das Ungenannte und Unerwartete in Organisationen zu erfassen. In: Fritz Böhle \& Sigrid Busch (Hrsg.), Management von Ungewissheit. Neue Ansätze jenseits von Kontrolle und Ohnmacht. Bielefeld, transcript, 327-346.

Stark, W., Vossebrecher, D., Bluszcz, O., Humpert G., Wendekamm, M. \& Margiciok, M. (2011): Music - Innovation - Corporate Culture - die Tiefendimension 
von Organisationskulturen musikalisch erfassen. In: praeview - Zeitschrift für innovative Arbeitsgestaltung und Prävention, 01-2011, 22-24.

Suchman, L. (1987): Plans and Situated Actions. The Problem of Human-Machine Communication. Cambridge, Cambridge University Press.

Volbers, J. (2011): Zur Performativität des Sozialen. In: Klaus W. Hempfer, Jörg Volbers (Hg.), Theorien des Performativen. Sprache - Wissen - Praxis. Eine kritische Bestandsaufnahme. Bielefeld, transcript, 141-160.

Volpert, W. (1994): Wider die Maschinenmodelle des Handelns. Aufsätze zur Handlungsregulationstheorie. Lengerich.

Volpert, W. (2003): Wie wir handeln - was wir können: ein Disput als Einführung in die Handlungspsychologie. Sottrum, Artefact-Verlag Weber.

Vossebrecher, D. (2017): Organisationspartituren: die implizite Dimension des Organisierens erforschen. In: Wolfgang Stark, David Vossebrecher, Christopher Dell, Holger Schmidhuber (Hrsg.), Innovation und Improvisation in Organisationen und sozialen Systemen. Bielefeld, transcript.

Vossebrecher, D. \& Kamin, T. (2017): Innovation und kreatives Denken als Produkt und Organisationskultur als Managementinstrument - Prozessmuster im Design. In: Wolfgang Stark, David Vossebrecher, Christopher Dell, Holger Schmidhuber (Hrsg.), Innovation und Improvisation in Organisationen und sozialen Systemen. Bielefeld, transcript.

Vossebrecher, D., Bluszcz, O., Humpert, G. \& Stark, W. (2012): Organisation musikalisch denken: die implizite Dimension des Organisierens entdecken. In: Arbeit: Zeitschrift für Arbeitsforschung, Arbeitsgestaltung und Arbeitspolitik. 21/2+3, 132-146.

Wirth, U. (2002) (Hg.): Performanz. Zwischen Sprachphilosophie und Kulturwissenschaften. Frankfurt a.M., Suhrkamp.

Wulf, C., Göhlich, M. \& Zirfas, J. (Hg.) (2001): Grundlagen des Performativen. Eine Einführung in die Zusammenhänge von Sprache, Macht und Handeln. Weinheim: Juventa. 



\section{Ein Muster für die Zukunft}

\section{Vom künstlerischen Denken in außerkünstlerischen Feldern ${ }^{1}$}

\section{Ursula Bertram}

Wer hat das nicht als Kind gemacht: Mit Zitronensaft auf Papier geheime Botschaften geschrieben, die nur durch die Flamme einer Kerze zu entschlüsseln waren? Für Erwachsenenaugen unlesbar, unsichtbar, eine geschützte Sprache nur für Kinder. So dachten wir als Kinder zumindest, da wir uns schwerlich vorstellen konnten, dass die Erwachsenen auch mal Kinder waren und unsere Geheimschrift bereits von Generation zu Generation weitergegeben und immer wieder begeistert ausprobiert wurde.

Und nun dürfen Erwachsene das auch oder wieder tun in Emden in der Kunsthalle bei einem Projekt mit dem Namen: »WTFT-11/1«. ${ }^{2}$

Ist das nicht albern? Schreiben in einem weißen Raum, ohne dass es erkennbar ist. Nur einmal am Tag wird das Schwarzlicht eingeschaltet und dann werden Gedanken sichtbar, heute durch Fluor, früher durch Zitrone. Keiner kann sehen, was der Stift macht, es bleibt unsichtbar.

Ich schreibe also an die Wand. Es hat etwas Archaisches, aber auch ungewohnt Unkontrolliertes und Unkontrollierbares, weil ich selbst nicht sehen kann, ob ich die Gedankenspuren eines anderen kreuze. Ich muss mir das aber auch nicht überlegen, denn ich konnte - selbst wenn ich suchte - keine Regeln und Vorgaben entdecken. Also bleibe ich Anarchist, Erfinder und Kind. Und während das ganz viele Museumsbesucher so in Emden machen und immer weitere unsichtbare Zeichen in dem weißen Raum sprießen, passiert zeitgleich etwas wirklich Unerwartetes: Die Kunst wachst aus dem Museum hinaus mitten ins Leben. Und

1 | Ursula Bertram (Hg.), "Kunst fördert Wirtschaft", transcript Verlag Bielefeld 2012, S. 32-44.

2 | Die partizipatorische Ausstellung WT FT-11/1 fand in der von Henry und Eske Nannen gegründeten Kunsthalle in Emden statt bis zum 29. Januar 2012. Mit Fluorstiften konnte frei und beliebig an die Wand geschrieben werden. Einmal am Tag wurden die Inskriptionen durch Schwarzlicht sichtbar. Siehe unter: www.ndr.de/regional/niedersachsen/olden burg/kunsthalle277.html (Abruf: 01.03.2012). 
das ist das eigentliche Geheimnis, das zunächst oder vielleicht auch für immer unsichtbar bleibt. Während ich mich an den Fluorzeichen aufhalte, schreibt mir die Museumspädagogik einen Prozess in den Kopf, genau so hinterhältig wie fantastisch, der nicht durch Schwarzlicht, sondern durch parallele Erfahrung ans Tageslicht kommt, als eine Art »Geheimschrift der Kunstvermittlung«, die zweifelsohne weit über die Zitronenschrift hinausweist.

Nein, ich bin kein Alchemist. Ich spreche von der Kunst außerhalb der Kunst, genauer gesagt vom künstlerischen Denken und Handeln in außerkünstlerischen Feldern, wie denen der Wissenschaft und der Wirtschaft. Auch wenn ich befürchte, dass in Emden eine Geheimsprache erfunden wurde, die so geheim ist, dass es vermutlich Jahrzehnte dauert, bis sie erkannt und entschlüsselt wird, schließen sich viele dieser Grenzgänger zusammen zu einer Bewegung, die spürbar macht, dass wir noch nicht alle Potentiale erschöpft haben, um die Veränderungen zu bewirken, die für ein Navigieren in Zukunftsfeldern notwendig sind.

Vielleicht bedarf es gar keiner »kreativen Zerstörung«, wie sie der österreichische Ökonom Joseph A. Schumpeter ${ }^{3}$ vorschlug, um in offenen Systemen zu navigieren. ${ }^{4}$ Möglicherweise eignen sich vielmehr Konzepte, die sich wie hier auf leisen Sohlen ins Leben einmischen, mit einer enorm indirekten und daher desto effektiveren Komponente. Partizipationen, die wie gute Kunst ein Geheimnis bewahren, teilen sich nicht durch Wissensvermittlung, sondern über Erfahrung mit. Mit der Erkenntnis des Chemikers und Nobelpreisträgers Ilya Prigogine ${ }^{5}$, dass »die Unbestimmtheit das Schlüsselmerkmal natürlicher Phänomene ist«, hat die Idee des Diffusen längst einen Stellenwert in den Naturwissenschaften gewonnen und sich in den Schriften des Physikers Fritjof Capra fortgesetzt. Die rationale, reduktionistische und lineare Analyse ist einer kontextbezogenen, intuitiven, ganzheitlichen und nicht-linearen Synthese gewichen. ${ }^{6}$

Arbeiten wie »Fashionloop « ${ }^{7}$ der Künstlerin Sabine Groß. beschäftigen sich mit Ordnungssystemen und so mit dem inhärenten Chaos aller Art, das immer wieder die Subjektivität der Wahrnehmung und der Beurteilung verdeutlicht. Groß ließ. Außenstehende an der Auswahl ihrer Kleidung und ihrer Erscheinung partizipieren und versuchte, genau die Ratschlage umzusetzen, die ihr gegeben

3 | Das Konzept der schöpferischen Zerstörung ist ein Grundmotiv von Schumpeters Werk "Kapitalismus, Sozialismus und Demokratie", vgl.: Schumpeter, Joseph A.: Kapitalismus, Sozialismus und Demokratie, Bern: Francke 1946.

4 | Bertram, Ursula \& Preißing, Werner: Navigieren im offenen System, Filderstadt: Container 2007.

5 | Vgl. Prigogine, Ilya \& Stengers, Isabelle: Das Paradox der Zeit. Zeit, Chaos und Quanten, München: Piper 1993.

6 | Vgl. Capra, Fritjof: Lebensnetz. Ein Verständnis der lebendigen Welt, Bern: Scherz 1996.

7 | Fashionloop, Kunsthalle Göppingen 2001, dazu auch der Ausstellungsband: Groß, Sabine: Sabine Groß. Fashionloop, hg. von Goldrausch Künstlerinnenprojekt Frauennetzwerk Berlin e.V., Ausst.-Kat. Kunsthalle Göppingen 2001. 
wurden. Das realisierte Ergebnis ihres neuen Outfits stellte sie dem nächsten Betrachter vor mit der Bitte, einen Rat für Verbesserungen zu geben. Es entstand eine unendliche Reihe von fotografisch festgehaltenen Optimierungsversuchen, die mit jedem neuen Blick eine Variante erfuhr, ohne zu einer Lösung zu kommen.

Der Philosoph Vilem Flusser hat Unsicherheiten als Chance begriffen. »Alles, woran man bisher als etwas Wirkliches glaubte und zu dem man bisher als etwas Realem Vertrauen hatte, hat sich als eine notwendig gewordene, zufällig entstandene Möglichkeit erwiesen [...] Zur Überraschung aller Beteiligten führt dieser Glaubensverlust an die Wirklichkeit nicht in eine dunkle Verzweiflung, als sei uns der Boden unter den Füßen entzogen worden. Sondern es erfasst uns ein Taumel der Befreiung für kreatives, künstlerisches Leben. ${ }^{8}$

Das mag für Flusser, Heisenberg, Prigogine, Capra, Bazon Brock und andere innovative Wissenschaftler und Künstler als Lebenskonzept gelten und zudem für einige wenige Unternehmen, darunter die erfolgreichen wie Google und Apple. In den Alltag unseres Bildungs- und Wirtschaftssystems sind dissipative

Wir sollten nicht ständig versuchen, das Chaos zu besiegen, sondern eine neue Haltung zur Unsicherheit entwickeln. Strukturen und nicht-lineare Systeme jedoch noch nicht eingezogen.

Unsicherheiten sind noch immer negativ konnotiert, trotz aller Erkenntnisse, dass instabile oder flexible Systeme zur Selbstorganisation des Lebens gehören. Der Künstler Joseph Beuys beklagte in den 8oer Jahren bereits die »Aufsplitterung des ganzheitlich angelegten Menschen in Spezialisten « und die Atomisierung der Welt in Fachbereiche. Erst langsam gewinnt die Einsicht Boden, dass wir möglicherweise nicht ständig versuchen sollten, das Chaos zu analysieren, zu besiegen und aufzuräumen, sondern lernen sollten, damit umzugehen und eine neue Haltung zur Unsicherheit zu entwickeln, die bei Flusser kreatives, künstlerisches Leben genannt wird, bei Edward de Bono laterales Denken und im Zentrum für Kunsttransfer ${ }^{9}$ in Dortmund schlicht IDdenken. »Wir kümmern uns um non-lineares Denken«, haben wir in Dortmund auf die Außenfassade unserer Querdenkerfabrik inmitten einer technischen Universität geschrieben, um künstlerische Kompetenz mit anderen zu teilen.

Kunst als Lust, ohne Orientierung auszukommen. Angstfrei Worte und Satze entwickeln, ins Ungewisse schreiben, Fehler zulassen, aus Lust an Strukturen mitwirken, deren Ergebnisse sich erst im gemeinsamen Prozess ergeben, Unsichtbares und Non-lineares als EntwicklungsPotential für intuitive Prozesse nutzen, bewusst spielen und unnütz sein, sich fallen lassen und Unerwartetes zulassen, entspannen und so sein, lachen, das Gegenteil von etwas denken, künstlerisch an Wissenschaft herangehen und wissenschaftlich an Kunst, neugierig werden, Begeisterung entfachen, mit Lust arbeiten, Neues erzeugen [...]

8 | Vgl. Flusser, Vilém: Das Ende der Tyrannei, arch+ 111, 1992, S. 20-25.

9 | www.id-factory.com 
Wie klingt das? Und vor allem: Wie geht das?

Die Wirtschaft hat großes Interesse an diesen Prozessen, die aus jedem Mitarbeiter einen Überzeugungstäter seiner Aufgabe machen wurden, so wie in der Kunst. Das ist also einfach. Je näher man an die Kunst kommt, je näher kommt man an das Profil der Zukunft. Machen wir uns auf den vielversprechenden Weg. Versuchen wir also ganz einfach ein Ziel non-linear anzugehen.

Nur wie das geht, haben wir leider fast vergessen. Non-linear war in den letzten 500 Jahren nicht gefragt, seit Descartes begann,

Die Wirtschaft hat großes Interesse an diesen Prozessen, die aus jedem Mitarbeiter einen Überzeugungstäter seiner Aufgaben machen würden, so wie in der Kunst. die Welt mit einem Filter zu versehen, der nur noch objektiv nachvollziehbare Beweisketten zuließ. Erst Mitte des letzten Jahrhunderts hat das Non-lineare in der Chaosforschung einen bescheidenen Platz gefunden. Da dynamische Systeme jedoch sehr schwierig $\mathrm{zu}$ berechnen sind, erwiesen sie sich als untauglich für unseren Alltag, der auf ein funktionstüchtiges mechanistisches System kalkulierbarer Fakten setzt, wo die Vernunft vorherrscht. Die Unvernunft durfte in der »Natur« vorkommen, die sich dem Fortschrittsdenken nicht anschloss.

Sie zeigt sich beispielsweise in wilden Wolkenformationen, in Wildwasserbachen und Wetterveränderungen, die sich immer noch nicht, beziehungsweise allenfalls für eine banale Zeit von Tagen berechnen lassen. Non-lineare Prozesse zeigen sich auch in der Vielfalt der Gesichter und Gestalten, die unsere Gene produzieren, und überhaupt in allem, was nicht linear zu verstehen, zu kategorisieren, zu ordnen, zu fixieren und zu lernen ist wie künstlerisches Handeln. Nun zeigt sich jedoch das Unbestimmbare plötzlich auch in der Kommunikation, deren festgelegte hierarchische Konventionen nicht mehr funktionieren seit das Internet alle Möglichkeiten der Partizipation zulässt, auch die der Anonymität. Am Hohepunkt der Unordnung sind wir aktuell gerade angekommen, nachdem die Bienenkönigin unseres Systems sich als unzuverlässig erwiesen hat. Das Banken- und Finanzsystem als Wertegarant ist angeschlagen. Alan Greenspan hat abgeschworen.

\section{Und jetzt?}

Nun reiben sich die Experten aller Disziplinen die Augen und beginnen mit einem System zu hadern, das uns in den vergangenen Jahrhunderten getragen und durchaus großen Fortschritt gebracht hat. Haben wir etwas übersehen? Müde und gefasst schauen wir nach Inseln aus, die andere Überlebensstrategien entwickelt haben und versuchen herauszufinden, nach welchen Mechanismen sie funktionieren und was ihr Geheimnis ist. Managementtheoretiker schauen hinter die Kulissen des Kulturbetriebs und interessieren sich für dessen Organisation und dessen Arbeitsbedingungen. Lange Zeit überwogen in den Wirtschaftsunternehmen Tugenden wie Pünktlichkeit, Sparsamkeit, Gehorsam et cetera, die langsam aber stetig durch künstlerische Kompetenzen beziehungsweise individuelle Talente wie Kreativität, Spontanität, Improvisationsvermögen 
abgelöst werden. ${ }^{10}$ Zudem hat eine weltweit angelegte Untersuchung von Prof. Dr. Anne Bamford ${ }^{11}$ bezüglich der Grundlagen für die Innovationsentwicklung bei Heranwachsenden ein erstaunliches Ergebnis hervorgebracht: Die Innovationsqualität steigt mit der Partizipation an Kunst und Kultur.

Und nun wird diese Insellage Kunst nicht nur als gesellschaftsfähig, sondern vielleicht sogar als betriebsfähig in Augenschein genommen. Eine unverbrauchte Ressource für anderes Handeln, deren unkonventionelle Zugangsweisen eine Art Muster für unkontrollierbare Vorgänge hervorgebracht hat. So hofft man jedenfalls. Aber dieses Muster ist schwer zu erkennen, da es sich aus der Anti-

Wenn man nur die Produkte in den Mittelpunkt der Bemühungen stellt, verflüchtigt sich das Muster. these von linearer Berechenbarkeit und Logik heraus entwickelt hat, erfahrungsbasiert und in ständiger Wandlung begriffen ist. Und es kommt noch schlimmer: Das Muster der Kunst, das uns Bilder gibt, Bewegung, Tanz, Klange, Farben und unsere Fantasie entfacht, ist kein Kleid, es ist eine Haut. Es lasst sich nicht einfach ausziehen und weitergeben. Das Muster muss mit der Person wachsen, ganz langsam, Schicht für Schicht. Es existiert nicht als käufliches Produkt, auch nicht in der Verpackung einer Kreativtechnik. Es bedarf eines Prozesses, der eine Haltung hervorbringt. Die Abfallprodukte dieser Haltung erzeugen die Produkte. Wenn man nur die Produkte in den Mittelpunkt der Bemühungen stellt, verflüchtigt sich das Muster. Alle blicken gespannt und neugierig auf ein unsichtbares Muster, das ganz besonders wertvoll erscheint für die Felder außerhalb der Kunst und das verspricht, die Zukunft zu verändern.

\section{Wie Sich NON-LiNeARE MUSTER biLden}

Um dieses Muster zu entwickeln brauchen wir
Orte der Selbstvergewisserung, des Loslassens von Regeln, Routinen und Normen, der Ignoranz und des Zweifelns, eine fehlerfreie Zone, einen Raum für ungestrafte Versuche und Irrtum, eine Nische der freien Umsetzung, was immer betrifft und betroffen

10 | Vgl. dazu die Studien von Doris Ruth Eikhoff: www.management.stir.ac.uk/people/ stirling-institute-for-socio-management/academic-staff/dr-doris-ruth-eikhof (Abruf: 23.02. 2012).

11 | Anne Bamford erstellte 2006 die von der UNESCO beauftragte Studie "Der Wow-Faktor", die unter anderem feststellt, dass Innovationsfähigkeit extrem erhöht wird durch: Human Capital, Openess, Diversity, Culture environment, Technology, Institutional Environment, and Creative Output. Vgl.: Bamford, Anne: Der Wow-Faktor. Eine weltweite Analyse der Qualität künstlerischer Bildung, Münster/New York/München/Berlin: Waxmann 2010. 
macht, ein Ermöglichungsfeld für Potentialentwicklung und Begeisterung.

Einen Acker zum persönlichen Umpflügen mit einer Freiluftzone für

Empörung. Eine Fläche für das Ausprobieren eigener Fähigkeiten,

für übersprachliche Kommunikation, für tiefes Schweigen und Ausmustern

von Ideenplunder.

Einen Raum für Ideen aus der Kinderstube, spielen und So-Sein.

Eine Insel der unangefochtenen Sicherheit, auf die ich mich retten

kann, wenn ich Orientierung und Liebe brauche.

Eine Werkstatt, in der ich selbst denken darf und nicht etwas Bestimmtes rauskommen muss.

Einen Ort, an dem ich Vorbilder sichten und wieder wegwerfen darf.

Einen Weg, der Probewege erlaubt

in Augenhohe zu anderen Zugangsweisen.

Alle diese Orte fuhren zum Muster des künstlerischen Denkens und Handelns. Damit ist nicht das Denken gemeint, das zur Kunst führt oder führen muss, sondern vielmehr das Denken und Handeln, das übrig bleibt, wenn ich die Bilder von der Kunst subtrahiere. Es ist eine Zugangsweise, die dem Feld der Kunst entwächst. Sie basiert vor allem auf non-linearen Denk- und Handlungsoptionen, auf dem Umgang mit Ungewissen und Unbestimmten, dem Einbezug des Subjektiven, der individuellen Erfahrung und der Begeisterung.

Ihre Absicherung findet sich nicht durch Beweise, wie es dem Verfahren in den Naturwissenschaften entspricht, sondern in der Durchsetzungskraft in offenen und unbestimmten Systemen.

Das sollten wir dringend üben und diese Orte schon morgen einrichten. Zweifellos ist das der geeignete Boden für die Entwicklung von Kompetenzen, die wir in Zukunft brauchen, um in einem System bestehen zu können, das ständig mutiert, global rotiert und nicht mehr auf Druck, sondern auf Sog gepolt ist. Eine Kompetenz, die nicht fachlich gebunden ist. Eine Kunst in außerkünstlerischen Feldern, die in den innovativsten Köpfen von Wissenschaftlern und Ökonomen genauso zu Hause ist wie in den Köpfen guter Künstler.

Die Strukturen sind mit dem World Wide Web längst Wirklichkeit geworden, lediglich das Navigieren im offenen System haben wir noch nicht wirklich als notwendig erkannt, geschweige denn gelernt.

Der Maler Gerhard Richter ${ }^{12}$ weiß es. An der Düsseldorfer Akademie hat er einer Studentin innerhalb kürzester Zeit zu einer Haltung und Entscheidungsfähigkeit verholfen, was manche ihr ganzes Leben nicht erreichen. Und dies ganz schlicht mit drei Würfeln, einem roten, einem gelben und einem blauen. Er regte an die Objekte zu malen. Nach dem ersten Bild veränderte er die Position der Würfel leicht und forderte das nächste Bild ein. Das wiederholte sich solange, bis

12 | Gerhard Richter (* 9. Februar 1932 in Dresden) ist einer der bekanntesten deutschen Maler. Er war von 1971 bis 1993 Professor für Malerei an der Kunstakademie Düsseldorf. 
sie sich endlich weigerte ihm zu folgen. Sie begann zu malen, was sie wirklich interessierte und wechselte das Atelier.

Der Choreograf und Regisseur Nullo Facchini ${ }^{13}$ weiß es auch und erachtet Umwege als notwendig und effizient. Seine dänische Tanztheatergruppe war gerade dabei Dantes Göttliche Komödie auf dem Gelände der 1990 aufgelassenen Cruise Missile Station im Hunsrück/Rheinland-Pfalz zu entwickeln. Er setzte immer auf die Kreativität des Teams und ließ Choreografien von mehreren Tänzern erproben, hier im Nachlass des Kalten Krieges, in den ehemaligen Raketenbunkern, dem Übungsgelände und in den großen Hangars, deren graugrüne Leere gespenstig war. An einem Morgen gab er jeweils zwei männlichen Tänzern die Anweisung so zu tanzen, dass sie immer wieder erneut eine einzige Skulptur aus ihren zwei Körpern bildeten. Sie sollten sich in Zeitlupe versetzen.

Die abendliche Präsentation fand im technisch anmutenden kargen Hangar statt. Alle drei Teams aus je zwei Männern zeigten ihre Choreografie, jeder in einer anderen Raumecke, jemand spielte Geige. Immer wieder glitten die männlichen Körper langsam aneinander herunter in eine neue Position, in der sie kurz verharrten als untrennbares Ganzes.

Das Ergebnis war eindrucksvoll. Was die Tanzer nicht wussten und was sie somit in der Entwicklung der Choreografie nicht behinderte: Es ging um die Rolle der Homosexuellen, bei Dante noch als Missetat angesehen. Die Tanzer arbeiteten ausschließlich und unbelastet am Prozess, nicht aber am unmittelbaren Ziel einer visuellen »Übersetzung « oder gar der Illustration von Homosexualitat. Der Choreograf Facchini eliminierte so jegliche Musterbildung und Klischees. Diese Vorgehensweise lässt sich übertragen auf alle Prozesse, die Innovationen erforderlich machen und begreift sich als eine non-lineare Methode.

Und die zeitgenössische Wissenschaft weiß es auch. Prof. Dr. Hans Peter Dürr erklärt die Unordnung als das Normale und weist darauf hin, dass die Instabilität ein Moment der höchsten Sensibilität ist. Der ehemalige Mitarbeiter von Heisenberg und Direktor des Max-Planck Instituts für Physik wirft der modernen Naturwissenschaft Fundamentalismus vor, die einer westlichen »wissenschaftlich-technisch-wirtschaftlichen Ideologie« folgt und andere Sichtweisen vernachlässigt. Er benutzt als Beispiel das Bild einer Schallplatte, bei der die Musik in Rillen verpresst ist. Sucht man den Sopran, wird man diesen nicht finden, indem man die Rille mit einem Vergrößerungsglas untersucht. »Der Sopran mit seinen vielfaltigen Klangfarben ist nämlich in der Gestalt der Rille verborgen, in einer Beziehungsstruktur verschlüsselt.« Er nennt diese Sichtweisen»poetisch«. Im Gegensatz zur »Scharfe« des Blicks auf isolierte Details richtet sich die »poetische Betrachtung « auf die Beziehungsstruktur. Wer dafür keinenSinn entwickeln kann, verhalt sich wie ein »Analphabet«, der zum Beispiel ein Gedicht von Goethe nicht lesen und schon gar nicht verstehen kann und stattdessen stolz dar-

13 | Dantes Göttliche Komödie, Tanztheater im Raketengelände in Hahn-Hasselbach, 1990, Nullo Facchini, Ursula Bertram. 
auf ist, die Buchstaben des Gedichtes ihren Formen nach zuordnen und auf diese Weise eine übersichtliche Struktur zu schaffen. ${ }^{14}$

Der Schweizer Künstler Ursus Wehrli verdeutlicht auf seine humorvolle Weise, dass die ordnende Strategie bei künstlerischen Produkten nicht zielführend ist. Der Versuch non-lineare ganzheitliche Gefüge durch Analyse und Ordnung $\mathrm{zu}$ verstehen, generiert zweifelsohne verblüffende Ergebnisse. ${ }^{15}$

Eine Anzeige im Magazin Brand Eins, bekannt für das andere Denken in wirtschaftlichen Kontexten, lasst darauf schließen, dass das hoffnungsvolle Konzept in unternehmerischen Nischen bereits Eingang findet. Die Annonce hatte folgenden Text: »Wir suchen einen Mitarbeiter. Ihre Fachrichtung ist uns egal. Wir bieten neue Arbeitsfelder für Menschen, die in der Lage sind, eigene Qualitäten zu entdecken, zu fordern, die bewusst selbst handeln und die im Austausch ihre Intelligenz und ihren Einfallsreichtum gemeinsam im Pulk entwickeln und sich mit einer Idee identifizieren konnen.«16

Trotz der sich etablierenden Ahnung, dass Kunst ein spezifisches Potential besitzt, das unsere wirtschaftliche und wissenschaftliche Entwicklung weiterbringt,

Wir suchen einen Mitarbeiter. Ihre Fachrichtung ist uns egal. zusätzlich genährt durch das Versagen der bestehenden Systeme, sind die Berührungspunkte von Kunst und Wirtschaft heute immer noch auf einem höchst oberflächlichen, geradezu naiven

Niveau. Vielleicht liegt das Missverständnis in der allzu direkten Verdrahtung von Künstlern und Unternehmern, Kunstwerken und Wirtschaftsprodukten, Kunststrategien und Wirtschaftsstrategien, die regelmäßig zum Kurzschluss fuhren. Kurzatmige Angebote und lineare Kreativtechniken ersetzen keine fundamentale und nachhaltige Verankerung in Aus- und Weiterbildung.

Das wirkliche Problem beim Erlernen des künstlerischen Denkens liegt in der bestehenden Standardisierung des Denkens über Lernen und über Kunst und die damit einhergehende Abwehrhaltung. Was »Sinn« macht, wird uns in der schulischen Ausbildung vermittelt und betrifft sicher nicht die beschriebenen non-linearen Übungen. Solange aber künstlerisches Denken in der Schublade der Konventionen oder in der Schublade der Wissenschaften gesucht wird, kommt es nicht zum educational turn. Wenn allein diese Schublade Gültigkeit für unsere Bildungsstruktur hat, wird es nicht zur Heranbildung dieses Potentials kommen. Nach Walter Grasskamp gehört künstlerisches Denken zur schönsten und priviligiertesten Form der Arbeit. »Diese Privilegien werden (den Kunstakademien) aber nicht gewährt, weil der Staat bestimmte Reservate unterhält, in denen Exoti-

14 | Vgl. Dürr, Hans-Peter: Das Lebende lebendiger werden lassen, oekom: München 2011; Stephan Wehowsky, Journal 21, vom 05.11.2011, www.journal21.ch/die-lebendigewelteines-physikers (Abruf: 05.08.2012).

15 | Wehrli, Ursus: Die Kunst aufzuräumen, Zürich: Kein \& Aber 2010.

16 | Siehe Stellenanzeige, Magazin Brand Eins 3/2001. 
sches getan werden soll, sondern weil etwas extrem Schwieriges zu lernen ist « ${ }^{17}$, hinzugefügt: und etwas enorm Wertvolles.

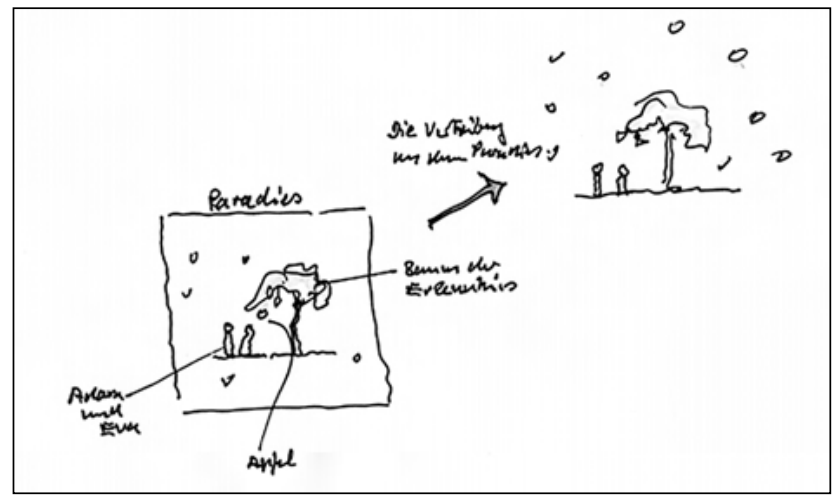

Abbildung 1: Werner Preißing, »Geschlossene und offene Systeme«, Zeichnung

Künstlerisches Denken entwickelt sich allmählich. Durch das Verlassen des kreativen Paradieses im zarten Alter von sechs Jahren wird das Potential mit Wissensbergen erstmal verschüttet. Künstlerisches Denken bedeutet Abstand nehmen von gewohnten Mustern und Denkklischees.

Ich habe festgestellt, dass studierende Erstsemestler voller Elan beginnen, Kunst zu studieren. Es gibt schnelle Erfolge in den Grundkursen, es wird modelliert, geschweißt und gemalt. Die meisten sind sich sicher, dass die ersten mühevollen oder kecken Werke zutiefst Kunst sind. Ab Ende des zweiten bzw. dritten Semesters kommt ein Loch. Sie spüren, dass etwas nicht stimmt, dass es wohl um eine andere Art des Zugangs geht, ihnen jedoch nicht verständlich ist. In diesem Moment findet eine nachhaltige Verabschiedung von bekannten Mustern statt meist zunächst ohne sichtbare Alternativen. Das Verlassen fester Raume ist nicht einfach und keinesfalls bequem. Schon gar nicht, wenn Copy-Strategien sich im Sinne der Nachhaltigkeit als nutzlos erweisen und nur noch das Navigieren im offenen System bleibt.

Hier hilft ein Ort, der ohne das Handlungskonzept von richtig oder falsch auskommt, an dem persönliche Kompetenzen und Starken ausgebildet werden. Eine Freiluftzone, um in eigener Verantwortung Erfahrungen zu machen, die nicht durch Wissen generiert werden, sondern die Wissen erzeugen. Ein überfachlicher Ort, der Kreativität zulasst, die auch die Grenzen der Kunst überwindet.

17 | Grasskamp, Walter: ohne Titel, in: Klasse Olaf Metzel: Küssen und Fahrradfahren, München: Akademie der Bildenden Künste/Martin Luther Verlag 1996, S. 9. 


\section{WOZU KÜNSTLERISCH DENKEN?}

Wir brauchen die Fähigkeit des künstlerischen Denkens und Handelns als Korrektiv, wie die Logik die Intuition. Es ist der Motor für Innovation, das Gleichgewicht für komplexe Entscheidungen, das Korrektiv für Objektivität, eine Plattform für Probierbewegungen und Erfahrung, ein Labor für Neuentwicklungen und seismografische Zukunftserscheinungen. Ein Exzenter für unentdeckte Perspektiven, ein Kraftfeld für Energien, die nicht nur Produkte, sondern Prozesse und auf Dauer eine Haltung erzeugen.

Künstlerisches Denken ist eine Kompetenz, die nicht fachlich gebunden ist, genauso wenig wie wissenschaftliches Denken fachlich gebunden ist. Es geht um eine Kunst in außerkünstlerischen Feldern, die perspektivisch in den Köpfen von Wissenschaftlern und Ökonomen genauso zu Hause ist wie in den Köpfen der Künstler. Eine Option, die einen neuen Umgang mit dem Ungewissen verspricht. Ein Modell für Forschung aus eigenem Antrieb und in eigener Verantwortung nach Zielen, die erst durch deren Erscheinung sichtbar werden, die uns begeistern und jedes Engagement wert sind.

Wir brauchen künstlerisches Denken und Handeln als Selbstvergewisserung, als Potentialentwicklung für Erfahrung, als Garungsprozess eigener Positionierung. Solche Prozesse sind transferierbar auf alle Disziplinen und Organisationsprozesse.

Und wir brauchen dies, um Fehlentwicklungen zu vermeiden, Ressourcen und Finanzen zu sparen und um endlich die Organisationsstrukturen in der Wirtschaft und in der Wissenschaftssociety zu kreieren, die Unbestimmtheit und Offenheit implizieren, ohne beliebig zu werden und authentischen Haltungen Wert beimessen.

\section{FAZIT}

Künstlerisches Denken muss zunächst in Augenhöhe zu wissenschaftlichem Denken erkannt und erprobt werden. Der Prozess, bei dem es zu subjektiver Erfahrung kommt, muss als genauso wichtig angesehen werden, wie objektive Wissensanreicherung. Die Empfehlung sind Impulswerkstätten und Erfinderlabore, die die Potentialentwicklung unterstützen durch Aufgaben, die keine Fehler haben können, die non-lineares Denken fordern durch offene Prozesse ohne vorgegebene Lösungen.

Die Innovationswerkstätten sollten so früh wie möglich in der Schule ver-

Wir brauchen die Fähigkeit des künstlerischen Denkens und Handelns als Korrektiv, wie die Logik die Intuition. ankert und in der Weiterbildung angestoßen werden. Um Missverständnisse $\mathrm{zu}$ vermeiden, sollten sie nicht in den Kunstunterricht integriert werden, sondern ein eigenständiges Erfahrungslabor bilden, an dem verschiedene Diszi- 
plinen beteiligt sind. Hierzu bedarf es Vermittler, die nicht das Produkt im Auge haben, sondern den Prozess: Den transferierbaren Prozess, der zu einer Haltung führt und erst von hier aus wieder zum Produkt. Hier müssen wir von den künstlerischen Produkten zum künstlerischen Denken abstrahieren.

Es ist sicher für niemanden verkehrt, in seinem Leben ein Porträt modelliert zu haben, aber nur, wenn es nicht zum rezeptiven Selbstlaufer wird. Sobald Kreativität in definierten Bahnen, als Dressur und zur Verfestigung der Ästhetik dient, ist sie zum Feind der Kunst geworden, subsumiert Heiner Goebels.

Er plädiert daher für Modellprojekte zeitgenössischer Produktionsweise, die keiner institutionellen Schwerkraft unterliegen, sondern sich als Labor der Zukunft eignen. ${ }^{18}$ Nichtwissen erproben, Zutrauen zur eigenen Erfahrung gewinnen, zu multiplen Problemlösungen und auf diesem Weg Ballast abwerfen und Freiraume für Neuentwicklungen schaffen, auch an der eigenen Persönlichkeit.

»Creativity is not a prisoner of Art« habe ich an die Wand geschrieben in der Kunsthalle Emden mit einem Stift aus Fluor in Geheimschrift, die verhindert, dass wir frontal darauf zugehen können und unser Verstand es sofort in sein dafür vorgesehenes Kästchen packt und ins Archiv verfrachtet. Überlistet!

Wir müssen es nicht verstehen, wir müssen es einfach nur leben.

\section{LITERATUR}

Bertram, U. (Hg.) (2010): Innovation - wie geht das?, Dortmunder Schriften zur Kunst, Studien zur Kunst in außerkünstlerischen Feldern, Bd. 1, Norderstedt. Bertram, U: \& Preißing, W. (2007): Navigieren im offenen System, Filderstadt: Container.

Capra, F. (1996): Lebensnetz. Ein Verständnis der lebendigen Welt, Bern: Scherz. Dürr, H.-P. (2011): Das Lebende lebendiger werden lassen. Wie uns neues Denken aus der Krise fuhrt, München: oekom.

Flusser, V. (1992): Das Ende der Tyrannei, arch+111, 1992, 20-25.

Grasskamp, W. (1996): ohne Titel, in: Klasse Olaf Metzel: Küssen und Fahrradfahren, München: Akademie der Bildenden Künste/Martin Luther Verlag.

Groß, S. (2001): Sabine Groß. Fashionloop, hrsg. von Goldrausch Künstlerinnenprojekt Frauennetzwerk Berlin e. V., Ausst.-Kat. Kunsthalle Göppingen 2001. Magazin Brand Eins 3/2001.

Popper, K. R. (2009): Alles Leben ist Problemlosen. Über Erkenntnis, Geschichte und Politik, München: Piper.

Preißing, W. (2008): Visual Thinking, Probleme lösen mit der Faktorenfeldmethode, Freiburg: Haufe.

Prigogine, I. \& Stengers, I. (1993): Das Paradox der Zeit. Zeit, Chaos und Quanten, München: Piper.

18 | Heiner Goebels, Rede auf dem „Forum d’Avignon Ruhr», 09.03.2012. 
Schumpeter, J. A. (1946): Kapitalismus, Sozialismus und Demokratie, Bern: Francke.

Wehowsky, S. (2011): Die lebendige Welt eines Physikers. Wie Hans-Peter Dürr Mut zur Zukunft macht, Journal 21, Buchbesprechung vom 05.11.2011, http:// journal21. ch/die-lebendige-welt-eines-physikers (Abruf: 04.07.2012).

Wehrli, U. (2010): Die Kunst, aufzuräumen, Zürich: Kein \& Aber. 
Teil 2

Forschung, Anwendung und Praxis 



\title{
Organisationspartituren
}

\section{Die implizite Dimension des Organisierens erforschen}

\author{
David Vossebrecher
}

\begin{abstract}
"Die Kunst ist der Versuch, einem größeren Teil der Realität Zusammenhang und Sinn abzuringen, als wir es üblicherweise tun."

Peter B. Valll
\end{abstract}

\section{EinLEITUNG}

Es ist heute unstrittig, dass bei einer Reihe von Themen in Organisationen und sozialen Systemen - Innovation bzw. Innovationsstrategien, organisationales Lernen, Vernetzung und Dezentralisierung bzw. Enthierarchisierung - und bei Problemstellungen, in denen es um allägliche soziale Phänomene geht (Kühl \& Strodtholz 2002: 19), implizite Faktoren eine gewichtige Rolle spielen. Um diese impliziten Faktoren und Dimensionen komplexen organisationalen Geschehens zu untersuchen, fehlen der Organisationsforschung weiterhin geeignete Methoden und Zugänge (Kühl \& Strodtholz 2002). Zwar ermöglichen ethnographische, handlungstheoretisch orientierte und andere Ansätze qualitativer Organisationsforschung, mehr von jenen Facetten von Organisationen zu erfassen, aber nur wenige bieten tatsächlich Wege jenseits kognitivistischer bzw. >intellektualistischer Zugänge (Gilbert Ryle); sie setzen weiterhin lediglich oder ganz vorrangig auf verbal-sprachliche Methoden, statt auf bspw. performative Zugänge (z.B. Jones et al. 2008).

Wie hängen - aus der Sicht von Akteuren an verschiedenen Positionen in der Organisation - Ereignisse, Herausforderungen, Elemente, Abteilungen, Arbeitsschritte und Arbeitsweisen zusammen? Wie sind sie verbunden und wo sind sie trotz bisheriger Bemühungen noch unverbunden? Welche Muster von Interaktion und Vergemeinschaftung bestehen? Wo nehmen die Organisationsmitglieder die Zusammenarbeit als Gemeinschaft wahr, wo nicht? Welches verdeckte Handlungswissen bzw. implizite Wissen und welche Werte und Überzeugungen sind dabei besonders wichtig? Solche und ähnliche Fragen gibt es in beinahe jeder Organisation. In stärker theoretischer Sprache formuliert handelt es sich um 
Fragen der Verbindung und Beziehungen zwischen Elementen der Organisation, Fragen der Vergemeinschaftung sowie Fragen von impliziten Wissensbeständen und Werten. Insbesondere die beiden letztgenannten sind aber mittels Sprache und Text - üblicherweise das Hauptmedium der Verständigung - nur unvollständig und unbefriedigend zugänglich. Dieses Manko gilt umso mehr, je stärker wir wissenschaftlich- technische, rationalistische Sprech- und Schreibweisen verwenden. Vergemeinschaftung wie auch die implizite Dimension bleiben großenteils unverständlich, da eine geeignete Repräsentationsweise weiterhin fehlt. Wie lässt sich ein anderer Zugang, ein anderer Kanal öffnen? Wie lässt sich das Implizite des Könnens ${ }^{1}$, wie lässt sich - jenseits von Sprache und Text - die implizite Dimension organisationaler Praxis anschaulich machen (repräsentieren) und damit ein Weg zur Reflektion und Veränderung von Praxis finden? Versteht man Organisationen als dynamische und >performative< Prozesse des Organisierens und nicht (vorrangig) als Strukturen, Formen oder neutrale »Behälter« (Dell 2012, 17), wird die Not, andere Repräsentationsformen jenseits von Text und (technischer) Sprache zu finden, noch gravierender.

Die hier beschriebene Methode entstand im Rahmen des Forschungsprojekts Music - Innovation - Corporate Culture $(M I C C)^{2}$, das Möglichkeiten untersucht und entwickelt, mit Hilfe von Musik und mittels eines musikalischen Verständnisses von Organisationen deren Innovationsfähigkeit zur erhöhen, zur Weiterentwicklung von Innovationsstrategien beizutragen und Management-Innovationen, insbesondere Prozessinnovationen anzuregen (MICC-Projekt 2009).

\section{Organisationspartituren als Methode MUSIKALISCHER ORGANISATIONSANALYSE}

\section{Partituren als Notationen von Organisationen und Musik}

Wie können Prozesse des Organisierens so aufgezeichnet werden, dass ihre dynamische, prozesshafte, performative Qualität tatsächlich wiedergegeben wird? Musik, das heißt musikalische Technologien und Verfahren, können einen Zugang bieten, da Musik eine performative Kunst ist, sie ist immer zeitlicher Verlauf und zeitliche Ausdehnung. Sie ist nicht >da<, wenn sie nicht aufgeführt oder die Auf-

1 | Zum Konzept der Könnerschaft Neuweg (2001), Vossebrecher et al. (2012).

2 | Projekt Music, Innovation, Corporate Culture (MICC) in Federführung des Labor für Organisationsentwicklung (OrgLab) an der Universität Duisburg-Essen (www.orglab.org), unter Beteiligung des Institut für Improvisationstechnologie (IFIT) Berlin (www.ifit.de), sowie vier Organisationen bzw. Unternehmen als Projektpartnern. Projektwebseite: www. micc-project.org. Das Projekt wurde 2009-2011 gefördert im Programmschwerpunkt "Innovationsstrategien jenseits traditionellen Managements" vom Bundesministerium für Bildung und Forschung (BMBF) und vom Europäischen Sozialfonds (ESF). 
zeichnung der Aufführung abgespielt wird. In der Musik wurden verschiedene Systeme der Notation, der Aufzeichnung entwickelt. Dieser Notationstechniken bedient sich die hier vorgestellte Methode Organisationspartituren.

Partituren sind eine zentrale musikalische Technik der Darstellung und Organisierung von Ereignissen in der Zeit. Entsprechend bieten Organisationspartituren jenseits von Sprache und Text eine Möglichkeit, Gleich- und Ungleichzeitigkeiten von Ereignissen zu visualisieren, Verbindungen zwischen Elementen, Interaktionen zwischen Akteuren sowie Muster der Praxis und des Wissens zu entdecken, von denen sich auch auf zugrundeliegende Werthaltungen, Prinzipien oder Handlungsdispositionen schließen lässt. Musik wird also nicht als Metapher (vgl. Organization Science 1998), sondern als Modell für Prozesse des Organisierens herangezogen, ist sie doch selbst das Organisieren von (Klang-) Ereignissen in der Zeit und bedarf zu ihrer Aufführung einer spezifisch organisierten Gruppe von Musikerinnen und Musikern³.

Musikgeschichtlich war der Zweck der Aufzeichnung musikalischer Werke in Partituren lange Zeit, die musikalischen Vorstellungen des Komponisten für die spätere Aufführung möglichst getreu und exakt festzuschreiben. Im Laufe des 20. Jahrhunderts entstehen dann Notationsweisen für sehr freie musikalische Formen (Karkoschka 2004), welche die tradierte Form der Aufzeichnung sprengen. Dies gilt insbesondere für die Notationsweisen aus der Neuen Musik und Aleatorik4 ${ }^{4}$ z.B. von John Cage, Earle Brown, Pierre Boulez und anderen (Karkoschka 2004) sowie des Jazz. Diese neuartigen Notationsformen für sehr freie musikalische Formen sind Vorbild für die Organisationspartituren. Die neuen Partituren sind keine eins-zu-eins-Repräsentationen, keine möglichst lückenlosen Planungen mehr (ebd.), sie zeigen nur mehr den ungefähren Verlauf eines Werkes an und enthalten Freiheitsgrade. Sie erzeugen somit Räume für Kreativität und führen den Interpreten zu spontanen Entdeckungen, also zu musikalisch Neuem. Die Musiker sind somit nicht nur Aufführende, sondern Mit-Komponisten; sie wirken an der Sinnproduktion durch entsprechende Handlungsformen entscheidend mit. Neben radikalen Beispielen aus der Neuen Musik ist natürlich die freie Jazzimprovisation ein Bezugspunkt, welche ebenfalls mit offenen Verfahrensweisen arbeitet. Freie Notationsweisen setzen auf das implizite Können der Aufführenden.

Organisationspartituren - ebenso wie die Musikpartituren, von denen sie abgeleitet sind - lassen sich als Diagramme sehen, die wesentliche Charakteristika

3 | Auch im Fall eines Solointerpreten sind spezifische (Selbst-)Organisationsweisen erforderlich.

4 | Aleatorik/aleatorisch: vom Zufall abhängig, auf Zufall beruhend, dem Zufall überlassen (von lat. aleatorius "zum Würfelspieler gehörend", alea "Würfel, Risiko, Zufallı) meint in der Musik die Verwendung von nicht-systematischen, nicht-deterministischen Operationen, die zu offenen, unvorhersehbaren Ergebnissen führen; vgl. Dudenredaktion (2013) sowie Karkoschka (2004), S. 2 f. 
und bestimmte Elemente in ihrer Relation hervorheben: Mit ihnen lassen sich Prozesse, Ereignisse, Muster, Perspektiven und implizites Wissen in organisationalen Kontexten erheben bzw. rekonstruieren. Als Diagramme folgen Partituren einer diagrammatischen Logik (Bauer \& Ernst 2010). Das heißt, sie sind hybride Zeichen jenseits von Schrift und Bild, die mit anschaulichem, bildlichem Wissen arbeiten und besonderen Formen von Erkenntnis unterstützen (vgl. Abschnitt Könnerschaft, Performanz, Diagrammatik in diesem Beitrag; sowie Vossebrecher 2017 i.d. Band). Sie lassen sich im Rahmen des unten beschriebenen, vergleichsweise einfachen Workshop-Formats in Organisationen einsetzen, um implizite Muster, verschiedene Perspektiven auf Prozesse und Ereignisse, implizite handlungsleitende Theorien etc. zu erheben und für die Selbstreflexion von Organisationen und für organisationales Lernen, z.B. im Sinne des double loop learning (Argyris \& Schön 1978) zugänglich zu machen. Sie fördern somit implizites Wissen zutage, das für Veränderungsprozesse in Organisationen ebenso wie für (Prozess-)Innovationen oder neue Steuerungsformen wichtig ist.

Organisationspartituren sind ein nicht-standardisiertes, qualitatives Instrument bzw. eine Methode zur rekonstruierenden Datenerhebung im Rahmen praktischer Veränderungsprozesse in Organisationen ebenso wie in eher wissenschaftlich ausgerichteten Organisationsanalysen. Organisationspartituren lassen sich mit verschiedenen Methoden und Vorgehensweisen qualitativer Sozialforschung gut kombinieren. Sie können zum Beispiel Ausgangspunkt für fokussierte Interviews sein, mit Gruppeninterviews oder -diskussionen verbunden werden oder Teil einer ethnographischen Feldstudie sein. Zudem machen Organisationspartituren insbesondere als Serie von Erhebungen Sinn, in denen gleiche Teilnehmende mit wechselndem Fokus und Fragestellungen Partituren gestalten.

Die Organisationspartituren-Methode wurde zum einen aus einem neueren handlungstheoretischen Verständnis des Sozialen - orientiert an Pierre Bourdieus kritischer praxeologischer Soziologie - entwickelt. Im Vordergrund steht zum anderen ein musikalisches, künstlerisch-ästhetisches und performatives Verständnis, wie es an anderer Stelle beschrieben ist (Dell 2011; Stark et al. 2011; Vossebrecher et al. 2012; Stark \& Dell 2012; Vossebrecher 2017). Sie lässt sich aber - soweit man die diagrammatischen Organisationspartituren als spezifische >Narrationen< ansieht - ebenso in narrative und andere qualitative Zugänge zur Organisationsanalyse einfügen.

\section{Durchführung und Varianten von Organisationspartituren-Workshops}

Das generelle Ziel und die Stärke des Instruments Organisationspartituren liegt darin, über die eigene Organisation in musikalischer Weise zu reflektieren, d.h. sie als Handeln in der Zeit zu betrachten, als performativ, als Zusammenspiel, als groove - das heißt hier: als mehr oder weniger gut funktionierendes und 
>stimmendes< Ineinandergreifen von Ereignissen oder Prozessen -, und als dynamisch. Um einen Eindruck vom Einsatz der Methode in organisationsanalytischem Kontext zu geben, soll ein Workshop-Format vorgestellt werden, dass im Rahmen des Projekts MICC erprobt wurde. ${ }^{5}$

\section{Organisatorisches}

Wie in anderen Workshops auch wird zu Beginn das Ziel bzw. der Zweck des Workshops - >Wer will warum etwas über was herausfinden? Warum jetzt? - vorgestellt, der Kontext erläutert oder in der Gruppe zusammen präzisiert, sowie das Vorgehen und die Aufgaben der Teilnehmerinnen und Teilnehmer erläutert. Für den Workshop muss eine Fragestellung entwickelt bzw. abgesprochen werden. Solche Fragestellungen können sich unter anderem richten auf: bestimmte Prozesse, bestimmte Ereignisse in Organisationseinheiten, organisationale Muster im Sinne wiederkehrender und/oder typischer Handlungsweisen, Elemente der Organisationskultur und ihr Niederschlag in Handlung, die Geschichte oder Zukunft der Organisation oder eines Projekts etc.

Organisationspartituren-Workshops lassen sich auch ohne besonderen vorgegebenen Fokus durchführen, dann wählen die Teilnehmenden einen jeweils eigenen Fokus, was interessant sein kann, weil dann oft umso stärker ihre eigene Position in der Organisation erkennbar wird.

\section{Konzeptionelles Input zur Einführung}

Ein Input relativ zu Beginn des Workshops erläutert kurz den Hintergrund, insbesondere die Vorstellung des >musikalischen Denkens von Organisation< und schafft so ein Grundverständnis der Methode. Es geht hier vor allem darum, Analogien zwischen sozialer Organisation und Musikensemble - Musikensembles als sich organisierende Gruppen, die mit unterschiedlich weitgehenden Absprachen zusammen arbeiten - herzustellen sowie die musikalische Organisation selbst zu thematisieren: Musik als Organisieren von Klängen bzw. Ereignissen in der Zeit, die aufgeführt werden (können). Damit wird Musik zum Modell des Organisierens bzw. von Organisation, und nicht mehr nur als Metapher herangezogen. Im Input wird auf Konzepte und Technologien aus der Musik Bezug genommen: Der Verzicht auf lückenlose Planungen und eins-zu-eins-Repräsentation zugunsten der Arbeit mit Freiheitsgraden, der Eröffnung von Kreativitätsräumen, der Entdeckung und Innovation und der Ko-Komposition statt nur Ausführung. Insgesamt wird herausgestellt, dass es möglich ist, die nötige Kompetenz zu entwickeln, mit sunscharfen< Vorgaben und Absprachen zu arbeiten.

Im Input werden in geeignet kurzer Form die Bezüge zwischen Organisationspartituren und freien Formen musikalischer Notation erläutert. Es kommt

5 | Die Darstellung gibt den derzeitigen Stand der Entwicklung der Methode wieder. Für Hinweise und kritische Anmerkungen ist der Autor ebenso dankbar wie für die Möglichkeit, die Methode weiterhin praktisch einzusetzen und weiter zu entwickeln. 
dabei nicht darauf an ein fundiertes musiktheoretisches Verständnis zu sichern, sondern ein Feld des Möglichen und eine innere Offenheit zu erzeugen. Zur Veranschaulichung werden Partituren der Neuen Musik gezeigt und Klangbeispiele vorgespielt. An deren Beispiel wird auch herausgestellt, dass die Partituren, die die Teilnehmenden später gestalten sollen, skizzenhaft, ggf. vorläufig und unvollständig - oder: diagrammatisch - sein können und sollen, anders ausgedrückt: sie sind reduzierend und fokussiert bzw. konzentriert zugleich. Eine Version des üblicherweise verwendeten Inputs findet sich unter www.david-vossebrecher. $\mathrm{de} / ? \mathrm{p}=253$.

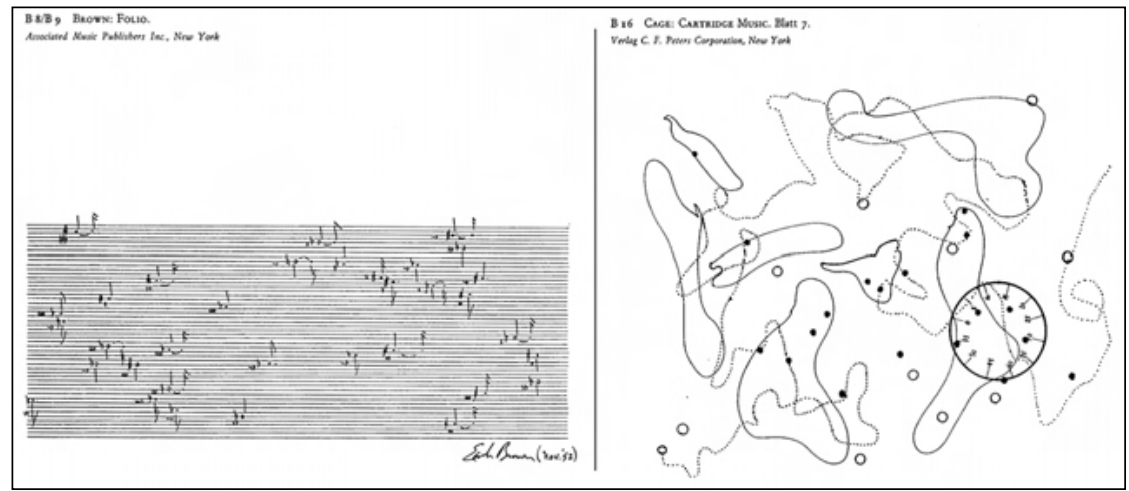

Abbildung 1a: Earle Brown, Partitur $z u>$ Folio<

und Abbildung 1b: John Cage, Blatt 7 der Partitur $z u>$ Cartridge Music<

Insgesamt wird mittels der Erläuterungen der >musikalischen Kanal geöffnet<, das heißt eine spielerische, ästhetisch-künstlerische Herangehensweise befördert, wie sie für die folgende Gestaltung von Organisationspartituren durch die Workshop-Teilnehmenden wichtig ist. Mit der Betonung des Spielerischen, Erprobenden und Skizzenhaften ist die musikalisch-bildhafte Visualisierung von Prozessen und Verfahrensweisen aus Organisationen aus ihrer subjektiven Perspektive für einige Teilnehmende erheblich leichter.

Für die Zwecke des Workshops ist eine umfangreiche und womöglich komplizierte musiktheoretische Einführung unnötig. Das Input ist tendenziell kurz, ca. 10 bis 20 Minuten, da zu viele Erläuterungen den Moment der Kreativität bzw. das >künstlerische< Moment eher stören oder jedenfalls nicht befördern. Das künstlerische Moment befördert eher, die Bereitschaft aufzubringen, sich einer freien, zunächst kaum strukturierten Situation auszusetzen, die z.B. ein leeres Blatt bedeutet; siehe dazu auch den folgenden Abschnitt (c). Neben dieser >Situation des leeren Blatts < ist die Anforderung wichtig, sich im (für die meisten) ungewohnten Medium und Kontext - Zeichnen und Musik - ausdrücken zu sollen. Dann werden, da auf keine oder kaum Routine zurückgegriffen werden kann, Kreativität und implizite Aspekte (bspw. so etwas wie Intuition) bedeutsam. 
Die musikalische Betrachtungsweise löst oft zunächst Befremden und Skepsis aus. Bei der Präsentation der Musikpartituren-Beispiele geht es nicht darum, all ihre musikalischen und weiteren Details zu klären, sondern darum, auftretende Irritation produktiv werden zu lassen. Die Beispiele sollten durchaus sehr >freie < und ungewöhnliche oder irritierende Darstellungen (Partituren) und Klänge (Musik) präsentieren (vgl. Abbildung 1), denn gerade wenn das Präsentierte krass dem persönlichen Geschmack entgegen steht und zunächst nicht einsortierbar klingt und aussieht, wird ein kreativer Raum eröffnet.

Optional kann vor (b) ein hinführender Schritt geschaltet werden, der mit zwei nicht-musikalischen Organisationsdiagrammen arbeitet, die unterschiedliche Perspektiven auf Interaktionen in Organisationen eröffnen. Dafür eignen sich beispielsweise die Organisationsdiagramme wie in Abb. 2. Dieser Schritt hat den Vorteil, dass er nicht direkt auf der musikalischen Ebene ansetzt, sondern einfach eine Alternative zur ausschließlich strukturellen Sicht eröffnet, die v.a. formale Hierarchien im Blick hat und die vielen Teilnehmenden als erste in den Sinn kommt, wenn von Organisationsdiagrammen die Rede ist.

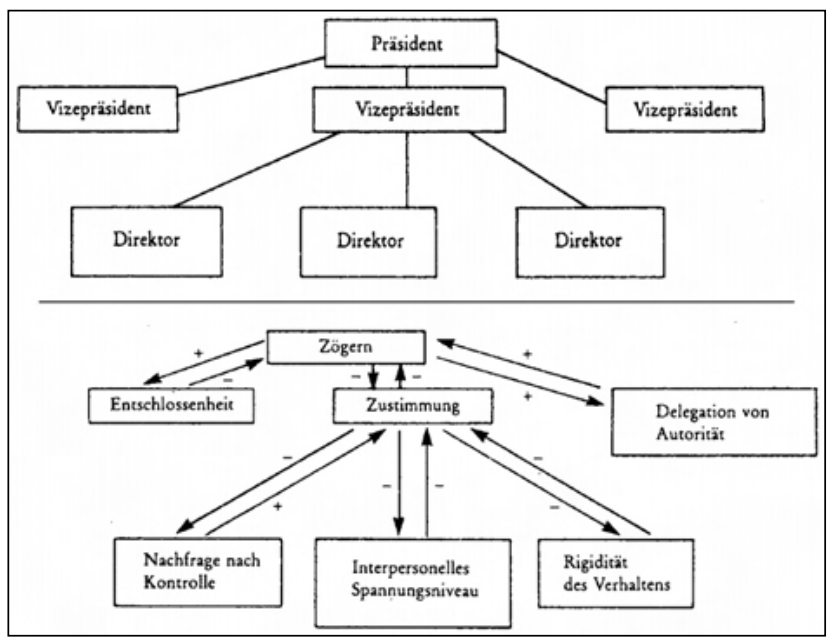

Abbildung 2a und 2b: Konventionelles und modifiziertes Organisationsdiagramm; aus: Weick 1995, 358f.

Indem die Unterschiede zwischen beiden Diagrammen gemeinsam erörtert werden, entsteht ein Verständnis dafür, wie unterschiedliche Darstellungen jeweils andere Perspektiven eröffnen und andere Schwerpunkte setzen. Im nächsten Schritt gestalten die Teilnehmenden ihre Organisationspartituren.

\section{Entwerfen und repräsentieren}

$\mathrm{Zu}$ Beginn des Entwurfsprozesses müssen sich die Teilnehmenden einer freien, zunächst unstrukturierten Situation aussetzen: dem leeren Blatt. Aus Sicht der 
Workshop-Moderation ist es wichtig, diesem Moment nicht das Irritierende bzw. seine Spannung zu nehmen. Man kann, wenn Teilnehmende unruhig werden, noch einmal bekräftigen, dass es nicht um eine richtige, wahre oder vollständige Darstellung geht, sondern darum, eine ungewöhnliche und möglicherweise offene oder skizzenhafte, aber in jedem Fall konzentrierte Notation für ein - diesmal >musikalisch gedachtes $<$ - Phänomen zu finden, das zur Organisation gehört. Dabei kommt es darauf an, für die persönliche, subjektive Perspektive eine Form zu finden bzw. - wie beim Komponieren auch - zu entwickeln, mit anderen Worten: Der eigenen Perspektive eine Form zu geben. Diejenigen, die zunächst meinen, das nicht zu können, lassen sich oft mit der Bekräftigung beruhigen, dass es sich auch um einen ersten Entwurf, eine unvollständige, ausschnitthafte Skizze handeln darf - übrigens ein typisches Vorgehen im künstlerischen Produktionsprozess.

Ein Teil der Teilnehmenden berichtet explizit, dass ihnen während des Zeichnens neue Erkenntnisse kamen, dass z.B. in der Partitur dargestellt Elemente (Personen, Organisationseinheiten etc.) eine wichtigere Rolle erhielten, als die Zeichnerinnen/Zeichner vorher gedacht hätten, oder dass die Perspektive auf die eigene Position oder Rolle sich verändert. Häufig ist auch die Erfahrung, an einem bestimmten Punkt zu wissen, dass die Partitur in Bezug auf das, was sie zeigen soll, fertig und/oder >richtig< ist. Dies spricht dafür, dass der >diagrammatische< Erkenntnisprozess (Bauer \& Ernst 2010) mit seinen gleichermaßen induktiven, deduktiven und abduktiven Erkenntnismöglichkeiten tatsächlich greift.
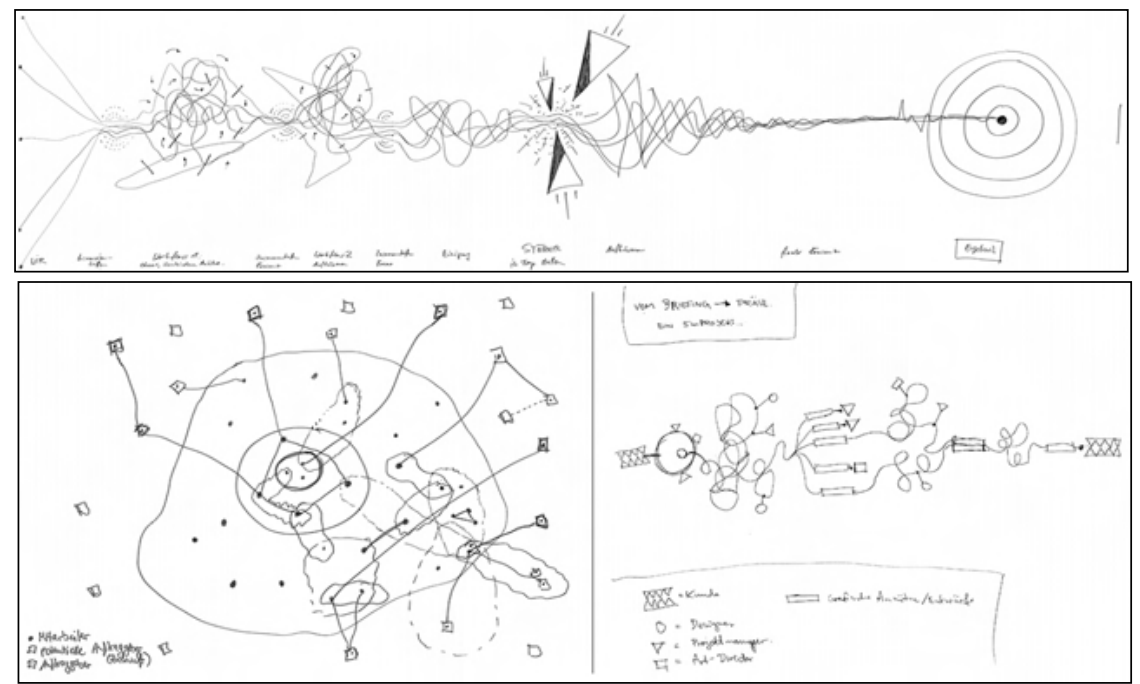

Abbildung 3a-c: Organisationspartituren

Zum Gestalten der Partitur gehört abschließend, ihre Legende anzugeben, die die Bedeutung der einzelnen Elemente, Symbole und relationalen Zeichen (z.B. 
Pfeile) erläutert. Die Legende wird, wie bei einer Landkarte, in der Regel an den Rand der Partitur geschrieben.

\section{Präsentieren und Assoziieren}

Jede bzw. jeder Teilnehmende des Workshops stellt anhand der erläuternden Legende ihre/seine Partitur kurz vor. Dabei wird auch das Gesamtthema der Partitur, z.B.: »unser Projektteam in seiner Verbindung zu anderen Akteuren und Stellen der Organisation«, benannt.

Die daran anschließenden Schritte des Assoziierens sind schon der Übergang zur verstehenden Analyse und Interpretation der Partituren und werden im Abschnitt >Organisationspartituren analysieren « näher beschrieben.

\section{Gruppendiskussion oder Gruppeninterview über Fokusthemen aus den Partituren}

Man kann Organisationspartituren-Workshops direkt in eine Gruppendiskussion oder ein Gruppeninterview münden zu lassen. Diese bezieht sich dann auf die Themen der zuvor entstandenen Partituren und verwendet diese als Fokus und Material. Dieser Schritt ist eine Mischung aus Auswertung mehrerer Partituren in einer Gruppe und der Erhebung weiterer, neuer Daten aus einer Organisation oder einem Arbeitszusammenhang. Er lässt in eine qualitative, offene Forschung sehr gut integrieren.

\section{Organisationspartituren analysieren: Perspektiven auf Rhythmus, Groove und Tacitness}

Alle drei in der Überschrift genannten Dimensionen - Rhythmus und Groove einerseits und Tacitness (implizite Dimension) andererseits - kommen in den folgend dargestellten Analyseschritten zum Tragen. Zuvor werden sie aber kurz näher (aber nicht erschöpfend) bestimmt, denn sie bedürfen in Bezug auf Organisation sowie auf die Partituren der Erläuterung:

Rhythmus meint die Verteilung der Elemente der Partitur (und der organisationalen Situationen, die darin dargestellt sind) im Hinblick auf Zeit und Raum: Wiederholen sich Teile beständig und mehr oder minder gleichmäßig oder wechseln verschiedene Dynamiken? Gibt es unterscheidbare Sequenzen des Rhythmus? etc. Groove meint vor allem die Bezogenheit der Elemente aufeinander, d.h. ihre Relationalität. Sind sie verbunden und wenn ja, wie? Sind sie separat, fallen sie auseinander ${ }^{6}$ ? In welchem Verhältnis stehen sie zueinander? So ist Groove insbesondere auch eine Qualität von (sozialer) Beziehung und bezeichnet Zu-

6 | Diese Formulierung ist ein gutes Beispiel für die Gefahr, wie sich Sprechen über Musik unbemerkt mit Wert- und ästhetischen Urteilen ("auseinanderfallen ") aufladen kann; das ist nach Möglichkeit zu vermeiden. 
sammenspiel und abgestimmtes, gemeinsames Handeln. Außerdem ist hier Intensität wichtig, das heißt: Gibt es z.B. eine enge und dichte oder eine >luftige< Verteilung?

Tacitness, also die implizite Dimension des Organisierens, wird in der Reflexion von Partituren deutlich, wenn zum einen der/die Gestaltende im Zeichnen auf Dinge stößt, die vorher nicht so klar waren (s.o.) - in diesem Fall ist sie also einfach zu entdecken. Zum zweiten eröffnet die Art, wie jeweils Andere eine Partitur verstehen, die Tür zur Erkenntnis von nicht oder nicht mehr bewussten und benennbaren Fragen eigener organisationalen Praxis. Drittens arbeiten die Partituren nicht mit Wortsprache, das heißt, dort sind Sachverhalte vom Gestalter der Partitur musikalisch-visuell dargestellt und können als solche von jeder Betrachterin bzw. jedem Betrachter ihrem bzw. seinem Verständnis gemäß aufgenommen und weiterverarbeitet werden. Dieser nicht-sprachliche Grundmechanismus bleibt erhalten, auch wenn beide zusätzlich noch Wortsprache (Text oder Gespräch) verwenden, um sich über den Inhalt der Partitur zu verständigen. Es handelt sich also um einen Prozess von Konstruktion und Re- bzw. NeuKonstruktion von Erfahrungswissen aus einer bestimmten Praxis. Und viertens ist Tacitness bzw. das Implizite nicht so zu verstehen, dass es sich um nicht mehr bewusste Wissensbestände - Wissen im Sinne rationaler, kognitiv zu verarbeitender Kenntnisse - handelt, sondern es ist Teil von Könnerschaft, von gelingendem Handeln in Praxissituationen. Da Organisationspartituren Prozesse, Ereignisfolgen, Muster etc. in der Zeit repräsentieren, besitzen sie eine besondere Stärke dafür, den Blick auf Tacitness eröffnen. Wie im nächsten Abschnitt (>Könnerschaft, Performanz, Diagrammatik ...<) weiter erläutert wird, haben sie als Diagramme besondere >diagrammatische< Eigenschaften, die man u.a. mit den Prinzipien der Evidenz, Kontinuität und Virtualität beschreiben kann.

Vor Beginn der ersten Analyse in der Workshop-Gruppe sollte jede Gestalterin bzw. jeder Gestalter eine Legende ihrer/seiner Organisationspartitur erstellt haben, die die Bedeutung der verwendeten Elemente, Symbole und Relationen erläutert.

\section{Sichtweisen und Interpretationen aus Sicht Dritter}

Die Gestalterin bzw. der Gestalter der Organisationspartitur gibt zunächst ein Minimum an Informationen zum Inhalt und Kontext: Was zeigt die Partitur? Um was für eine Organisation, einen Bereich oder einen Prozess handelt es sich generell?

Anschließend sammelt die Workshop-Gruppe Assoziationen und Vorstellungen zur Partitur, um viele mögliche Verständnisse (Klangfarben, Facetten, Dimensionen) zu eröffnen. Dabei sollte jede/jeder kurz beschreiben, was sie/er sieht und von da aus zu den eigenen Deutungen kommen. In der Beschreibung macht es Sinn, >strukturelle< beschreibende Adjektive zu verwenden, wie sie auch in der auch in der Beschreibung von Musik verwendet werden, z.B. >dicht<, >langsam<, >lauter werdend (bzw. >mehr werdend $<$ ), oder auch solche wie >langgezo- 
gen<, >kantig<. Weniger geeignet sind dagegen Adjektive wie >lebhaft< oder >romantisch<, da sie bereits eine Interpretation oder Emotionalisierung mitführen. Zudem kann beschrieben und gedeutet werden, wo man räumliche und, soweit erkennbar, zeitliche Verbindungen zwischen Elementen oder das Fehlen von Verbindungen erkennt.

Diese Deutung der Partitur in der Gruppe ist der erste Schritt, um wenig explizite Inhalte und implizite Bedeutungen und Zusammenhänge an die Oberfläche zu holen.

\section{Erläuterungen der Partitur und ihrer Symbolik als kontrastierende Analyse}

Die oder der Gestaltende stellt die Legende - welches Symbol bedeutet was? der Partitur vor, erläutert die Partitur ausführlicher und beschreibt, welches Verständnis der Organisation, des Prozesses etc. sie präsentiert. Die Ähnlichkeiten und die Unterschiede zwischen beiden Interpretationen werden im Sinne einer kontrastierenden Analyse aufgegriffen und daraus das Verständnis der Partitur weiter vertieft. Hier sollte noch einmal besonders nach Punkten geschaut werden, die in der Partitur fehlen (Leerstellen), obwohl man sie in dem thematischen $\mathrm{Zu}-$ sammenhang erwarten würde.

Unbestimmtheit oder Mehrdeutigkeit in den Deutungen ist willkommen, sie ist in der Regel ohnehin unvermeidbar, und kann zudem ein Charakteristikum der in der Partitur beschriebenen Organisation sein. Obwohl letztlich der/die Gestaltende Ihren Blick auf die Organisation am besten kennt, sind andere, ggf. widersprechende Perspektiven ebenso gültig und helfen, implizite Bedeutungen oder Muster (Patterns) aufzudecken.

\section{Generelle, stärker universelle Analyseebenen}

Dieser Schritt muss nicht in der Workshop-Situation gemacht werden, er ist eher für stärker konzeptuelle Interpretationen von Organisationspartituren sinnvoll und weniger für unmittelbar praktische Anwendungen. Allerdings sollten die im Folgenden benannten drei Dimensionen - Raum, Zeit, Dynamik - auch in den beiden obigen Schritten (a) und (b), d.h. in der Deutungsarbeit im Workshop berücksichtigt werden. Folgende drei generelle Dimensionen sollten für die Interpretation berücksichtigt sein:

Raum: Wie sind die bedeutenden Elemente in der Partitur (= im Diagramm) verteilt und ausgebreitet? Wie sind ihre räumlichen Beziehungen? Gibt es bspw. ein Zentrum-Peripherie-Verhältnis?

Zeit: Wie ist Zeit in der Partitur repräsentiert? Häufige Formen der Repräsentation sind: linear, zirkulär, spiralförmig, überlagernd, diskontinuierlich.

Dynamik: Wie intensiv, z.B. eher dicht, eher ruhig usw., ist die Konfiguration der Elemente in der Partitur? Wie verändert sie sich in verschiedenen Teilbereichen oder >Sequenzen«? 
Das (nicht nur) musikalische Phänomen Rhythmus ist ein raum-zeitliches; das Phänomen Groove lässt sich als eines von Raum-Zeit und Intensität beschrieben. Zudem ist, obwohl man auch von einzelnen Musikerinnen bzw. Musikern sagt, dass sie grooven oder swingen, Groove insbesondere eine >soziale< Qualität von Beziehung und gemeinsamem Handeln (s.o.).

\section{Blickrichtung auf organisationale Veränderung und zukünftige Praxis}

Was bewirken die Vorstellungen, Interpretationen und Befunde der Analyse bei der/dem Gestaltenden der Partitur? Was kommt in der Analyse insgesamt, also auch bei den anderen Beteiligten an die Oberfläche? Was würde eine nächste, anknüpfende Partitur zum Thema und Inhalt nehmen und wie könnte sie aussehen? Welche Veränderungen der Praxis und welche Entwicklungen der Organisation werden sicht- und vorstellbar?

Diese Fragen, vor allem die beiden letzten, machen in praxisbezogenen Anwendungen der Organisationspartituren Sinn, z.B. in Organisationsentwicklungsprozessen oder bei der Suche nach Innovationsstrategien. Aber auch für stärker forschungsorientierte Organisationsanalysen können Zukunftsfragen aufschlussreich sein. Die auf Zukünfte gerichteten Fragen betonen den Aspekt Komposition - im Gegensatz zu Darstellung gegenwärtigen Zusammenspiels -, der in Partituren immer vorhanden ist. Im Sinne von Komposition sind sie Instruktionen für andere. Im Sinne des Verständnisses der Aleatorik und verwandten Neuen Musik sowie im Sinne der Jazzimprovisation, auf die im folgenden Kapitel eingegangen wird, sind sie eine absichtlich unscharfe Instruktion.

Bisher könnte der Eindruck entstehen, die Gestaltung der Partituren (Diagramme) sei nur ein nicht-sprachbasiertes Intermezzo, dem man sich dann wiederum sprechend/sprachlich zuwendet. Es ist aber so, dass das nichtsprachliche Material der Diagramme als solches die nicht hintergehbare Basis für Deutungen und jegliche Erzeugung von Erkenntnissen, Wissen du Praxis aus den Partituren bildet. Auch ohne dass über die entstandenen Partituren gesprochen wird, vermitteln sie Verständnisse und implizites Handlungswissen auf ihre spezifische, diagrammatische Weise, sind also epistemologisch bedeutsam (vgl. dazu den folgenden Abschnitt).

\section{Könnerschaft, Performanz, Diagrammatik: KONZEPTIONELLER HINTERGRUND}

Organisationspartituren sind eine performative diagrammatische Methode, deren konzeptionelle Hintergründe anderswo ausführlich entwickelt sind (Vossebrecher 2014; Vossebrecher et al. 2012; Stark \& Dell 2012; Dell 2011; Stark et al. 2011). Mit ihnen lassen sich vor allem subjektive, qualitative Daten >inter-subjektivieren $<$ und somit Erkenntnismöglichkeiten auf der >kulturellen< Ebene organisa- 
tionaler Praxis eröffnen. Da Organisationspartituren aus der diagrammatischen Notation sowie den musikalischen Produktionsweisen Komposition und Improvisation hergeleitet sind, eignen sie sich besonders für die Darstellung und Analyse von Prozessen in Organisationen und der sozialen Welt - wobei mit Darstellung hier eine nicht-repräsentationale Repräsentation gemeint ist. Sie erlauben also eine prozessuale und performative Perspektive, die für die implizite Dimension des Organisierens steht (Vossebrecher 2014). Die wichtigsten Stichworte sind dabei Diagrammatik, Könnerschaft und implizites Wissen sowie Performanz.

Könnerschaft ist ein Begriff, den Neuweg (2001, 2005) in die Diskussion um implizites Wissen (Nonaka et al. 2001; Nonaka \& Takeushi 1997) einbringt und der die impliziten Gehalte und Dimensionen gelingenden Handelns oder gelingender Praxis in den Vordergrund stellt. Neuweg (a.a.O.) argumentiert gegen die sintellektualistische< Verkürzung (Ryle 1969), nach der Handeln quasi unmittelbar und einzig durch Wissen angeleitet wird und nach der dieses implizit das Handeln anleitende Wissen einfach expliziert werden könne. Stattdessen ist nur ein mehr oder minder kleiner Teil dessen, was zu gelingender Handlungspraxis gehört, überhaupt als Wissen explizierbar. Ein großer Teil muss implizit bleiben, ist häufig in die Körper >eingeschrieben ` (sembodied<) und entsprechend besser als Können zu bezeichnen. Das Problem, andere zu instruieren, ist somit nicht vorrangig eines des Intellekts und der Sprache, sondern der Praxis und des experimentierenden und übenden Handelns in Verbindung mit sprachlicher Begleitung.

Eine Perspektive der Performanz versteht soziale Phänomene wie Institutionen, Beziehungen, Normen, Kultur, Organisationen, Identität, Strukturen usw. als durch wiederholte, hochgradig ähnliche Handlungen bzw. hochgradig ähnliche Praxis konstruierte Phänomene, nicht mehr als Entitäten, die außerhalb ihrer fortgesetzten Aufführung Substanz hätten und existierten. Die sozialen Phänomene sind also angemessener als Prozesse zu verstehen denn als >Gegenstände< von Dauer (Wulf et al. 2001). Einerseits eignen sich die Mitglieder einer Kultur bzw. eines Systems im Rahmen eines Enkulturations- oder Sozialisationsprozesses die dortigen Aufführungsregeln an - und zwar stark in Form körperlicher und impliziter Einschreibung. Andererseits ist aber das (subversive) Anders-handeln möglich. Beispiele sind Judith Butlers (2002) performatives Konzept der Geschlechtsidentität und Bourdieus Praxeologie mit der habitualisierten sozialen Distinktion und den inkorporierten Machtwirkungen (Bourdieu 1987). Mit Performanz ist also nicht nur eine künstlerische Aufführung (Theater, Musik) gemeint, sondern alltägliches Handeln und Sprechen in seiner Bedeutung für die Erzeugung sozialer Wirklichkeiten. Im Begriff der Performanz können sich aber Ideen, die aus der Ausweitung musikalischer Erfahrung (und Epistemologie) auf die gesamte >Welt< entspringen, treffen mit sozial- und kulturwissenschaftlichen Theorien, da Musik als performative Kunst nur im Moment ihrer Aufführung wirklich und >da< ist. (z.B. Dell 2009)

Diagrammatik geht der Frage nach, welche Wissensformen und Erkenntnismöglichkeiten in Diagrammen enthalten sind - und Partituren sind vor allem 
als Diagramme zu verstehen. Diagramme sind grundsätzlich ein Zeichentypus jenseits von Wort/Text einerseits und Bild andererseits. Somit weisen sie eigene Besonderheiten auf, die Bauer und Ernst (2010) unter anderem mit den drei Prinzipien der Evidenz, Kontinuität und Virtualität beschreiben. Das Evidenzprinzip steht dafür, dass eine »diagrammatische Konfiguration [...] illustriert, aus welchen Elementen oder Relationen « (a.a.O.: 24) ein Sachverhalt oder ein Ereigniszusammenhang besteht. Damit werden auch Schlussfolgerungen nahegelegt, die der Konfiguration inhärent sind.

Zum zweiten steht - das ist das Kontinuitätsprinzip - eine Organisationspartitur in einem Zusammenhang mit der Realität, hier verstanden als Kontinuum geteilter Erfahrungen, wie es bspw. innerhalb einer Organisation und ihrer Kultur besteht. Die die diagrammatische Darstellung bildet m.a.W. einen Fall, »der anderen Fällen analog « (a.a.O.) ist. Ohne solchen Zusammenhang könnte ein Diagramm keinen Aufschluss über sein Bezugsobjekt geben.

Das Virtualitätsprinzip schließlich verweist darauf, dass die in einem Diagramm dargestellte Ordnung der Elemente zwar einerseits spezifisch und plausibel ist, dass die Elemente eines Diagramms andererseits aber leicht in Bewegung $\mathrm{zu}$ bringen sind (zumindest vor dem geistigen Auge, also mental und hypothetisch bzw. virtuell). Somit eröffnen sich Möglichkeiten der Re-Konfigurationen oder des Re-Designs. Hier liegt also auch ein Innovationspotential, das Diagramme unmittelbar mitbringen.

Den drei Prinzipien lassen sich als Typen von Schlussfolgerungen: Deduktion, Induktion und Abduktion zuordnen (Bauer \& Ernst 2010; Vossebrecher 2016). Zusammen ergeben sie unter anderem die Möglichkeit, über organisationsbezogene Diagramme organisationale Muster im oben genannten Sinn zu entdecken.

Die Konzepte - Könnerschaft/implizites Wissen, Performanz, Diagrammatik stehen für ein Verständnis von Organisationen als ähnliches-routiniertes oder auch innovatives-veränderndes Handeln, als performative Praxis. Diese Praxis hat stets eine implizite Dimension (Vossebrecher 2016; Vossebrecher et al. 2012), unter anderem weil die Körper als Träger des individuellen wie kollektiven Handlungswissens eine gewichtige Rolle haben. Die drei Konzepte stehen nicht für drei jeweils voneinander klar abgegrenzte Perspektiven, sondern überschneiden sich teils deutlich; durch ihre unterschiedlichen Traditionen und Herkünfte aus z.B. Kulturwissenschaften, Philosophie des Geistes, Organisationstheorie, Kunst, Sprachtheorie sind Grenzgänge erforderlich und entsprechende konzeptuelle Suchbewegungen unumgänglich. Organisationen sind in diesem Verständnis Prozesse statt statischer, überzeitlicher Strukturen. Daher wird es im Rahmen des Projekts MICC auch als musikalisches Denken von Prozessen des Organisierens bezeichnet (Vossebrecher et al. 2012). 


\section{Zusammenfassung Und kURZer Ausblick}

Die in diesem Text vorgestellte Methode Organisationspartituren ist ein Instrument für die Analyse von Organisationen, das auf musikalischen Konzepten und einem entsprechenden Verständnis von Organisationen basiert. Zu diesem Verständnis gehört, das Prozesshafte, Veränderungsbezogene und Performative von Organisationen bzw. des Organisierens zu betonen. Organisationspartituren sind insbesondere geeignet, organisationale Tacitness, d.h. die impliziten Dimensionen des Organisierens darzustellen und darauf aufbauend neue Praxis zu instruieren. Sie können dies, weil sie als gruppenbasierte Methode vielfältige Interpretationsund Verständigungsräume eröffnen, weil sie nicht mit Wortsprache, sondern mit musikalisch-visuellem Material arbeiten und weil sie, als diagrammatische Darstellungen von Prozessen, Mustern etc. in der Zeit, diejenigen Elemente veranschaulichen und aufzeigen können, die implizit zu gelingendem Handeln und Könnerschaft gehören; erst wenn jene bekannt(er) sind, wird in Organisationen die Übertragung von funktionierenden Antworten auf Herausforderungen auf andere, neue Situationen möglich.

In Organisationspartituren lassen sich komplexe Situationen und Prozesse, gegenwärtige Strukturierungen, Rhythmen, Interaktionen, Muster anderes mehr aus verschiedenen Perspektiven aufzeichnen (Rekonstruktion, Repräsentation). Dies kann zum einen dazu genutzt werden, Dritten eine bestimmte Perspektive zu verdeutlichen (Instruktion), zum anderen können die in einer Partitur enthaltenen Elemente - Personen, Organisationseinheiten, Prozessschritte usw. - und deren Anordnung in Bewegung gebracht werden und neue Ordnungen erzeugt werden (Komposition, Innovation), die Grundlage für neue Praxis sind. Geübte Teams könnten zudem mit den Elementen spielen, d.h. im Prozess ad hoc neue Vorgehensweisen und Ordnungen erfinden (Improvisation). Für all dies stellen dann Organisationspartituren das nicht-sprachliche (!) Material dar. Da Partituren Diagramme sind, befördern sie in besonderer Weise Erkenntnis - siehe das Virtualitäts-, das Evidenz- und das Kontinuitätsprinzip - und können so als Innovationstool genutzt werden.

Der praktische Nutzen für Organisationen liegt in der Rekonstruktion und Repräsentation von impliziten Dimensionen des Organisierens, der darauf aufbauenden Instruktion Dritter und in der Möglichkeit, Organisationspraxis neu und in innovativer Weise - ggf. sogar experimentell, improvisierend - zu komponieren. Alle diese Schritte sind für Reflexions- und Veränderungsprozesse in Organisationen und sozialen Systemen elementar. Die Methode nutzt das beschriebene Workshop-Format und ist sehr gut mit anderen, verbreiteteren Methoden der Organisationsanalyse und -entwicklung kombinierbar.

Die oben genannten Begriffe Komposition und Improvisation entspringen am deutlichsten einem musikalischen Kosmos. Sie stehen für ein Kontinuum mit den Polen vollständige Planung versus minimale Planung. Dabei ist, neben radikalen Beispielen aus der Neuen Musik (Vossebrecher 2016), natürlich die freie 
Jazzimprovisation (Free Jazz) als nicht durchkomponierte, ausnotierte Musik ein Bezugspunkt. Als Kontinuum gedacht, bilden also freier Jazz und Teile der Neuen Musik mit ihrer minimalen Planung den einen Pol und die quasi vollständige Planung, wie wir sie aus der klassischen sinfonischen Musik kennen, den anderen Pol (Dell 2002, 2012). Aus dieser Gegenüberstellung lassen sich in Organisationen Handlungs- und Praxisformen entwickeln, die auf diesem Kontinuum an geeigneter Stelle angesiedelt sind und keine möglichst vollständige Planung mehr zur Grundlagen haben müssen. Die Organisationspartituren eignen sich, um diese Handlungs- und Praxisformen zu visualisieren.

\section{LITERATUR}

Argyris, C. \& Schön, D. (1978): Organizational learning: A theory of action perspective. Reading, MA, Addison Wesley.

Bauer, M. \& Ernst, C. (2010): Diagrammatik. Einführung in ein kultur- und medienwissenschaftliches Forschungsfeld. Bielefeld, transcript.

Bourdieu, P. (1987): Sozialer Sinn. Kritik der theoretischen Vernunft. Frankfurt a.M., Suhrkamp.

Butler, J. (2002): Performative Akte und Geschlechterkonstitution. Phänomenologie und feministische Theorie. In: Uwe Wirth (Hg.), Performanz. Von der Sprachphilosophie zu den Kulturwissenschaften. Frankfurt a.M., Suhrkamp, S. 301-321.

Dell, C. (2002): Prinzip Improvisation. Köln, Verlag der Buchhandlung Walther König.

Dell, C. (2009): Notation und Performanz. Arbeitspapier Nr. 7 aus dem Projekt MICC. Essen: Universität Duisburg-Essen. Online verfügbar: http://micc-pro ject.org/wp-content/uploads/MICC_WP_o7-notation-und-performanz1.pdf.

Dell, C. (2011): Organisation musikalisch denken. In: praeview - Zeitschrift für innovative Arbeitsgestaltung und Prävention, 01-2011, 24-26.

Dell, C. (2012): Die improvisierende Organisation: Management nach dem Ende der Planbarkeit. Bielefeld, transcript.

Dudenredaktion (2013): Duden. Mannheim: Bibliographisches Institut. [Online: www.duden.de/rechtschreibung/aleatorisch und www.duden.de/rechtschrei bung/Aleatorik; Zugriff: 11.6.2013]

Jones, K.; Gergen, M.; Guiney Yallop, J.J.; Lopez de Vallejo, I.; Roberts, B. \&Wright, P. (Hg.) (2008). Performative Social Science (Special Issue). Forum Qualitative Sozialforschung/Forum: Qualitative Social Research, 9(2). Online verfügbar: www.qualitative-research.net/index.php/fqs/issue/view/10.

Karkoschka, E. (2004): Das Schriftbild der Neuen Musik. Celle, Moeck Verlag. Kühl, S. \& Strodtholz, P. (Hg.) (2002): Methoden der Organisationsforschung. Ein Handbuch. Reinbek, Rowohlt. 
MICC-Projekt (2009): Forschungsaufbau: Musik und Klang als Medium der Organisationskultur? Internetdokument. URL: http://micc-project.org/?page_ $\mathrm{id}=2$; Zugriff 21.7.2013.

Neuweg, G.H. (2001): Könnerschaft und implizites Wissen. Zurlehr-lerntheoretischen Bedeutung der Erkenntnis- und Wissenstheorie Michael Polanyis. Münster, Waxmann.

Neuweg, G.H. (2005): Der Tacit Knowing View. Konturen eines Forschungsprogramms. In: Zeitschrift für Berufs- und Wirtschaftspädagogik, 101, 4, Stuttgart: F. Steiner Verlag, 557-573.

Nonaka, I. \& Takeuchi, H. (1997): Die Organisation des Wissens. Wie japanische Unternehmen eine brachliegende Ressource nutzbar machen. Frankfurt, Campus.

Nonaka, I.; Toyama, R. \& Byosière, P. (2001): A theory of organizational knowledge creation: under-standing the dynamic process of creating knowledge. In: Meinolf Dierkes, Ariane Berthoin Antal, John Child, Ikujiro Nonaka (Eds.), Handbook of organizational learning and knowledge. Oxford University Press, 487-491.

Organization Science (1998). Special Issue: Jazz Improvisation and Organizing. Organization Science, Vol. 9, No. 5 .

Ryle, G. (1969): Der Begriff des Geistes. Stuttgart, Philipp Reclam Jun.

Stark, W. \& Dell, Christopher (2012): Organisationskultur revisited - Transdisziplinäre Schnittstellen zwischen Wissenschaft und Kunst beim Versuch, das Ungenannte und Unerwartete in Organisationen zu erfassen. In: Fritz Böhle, Sigrid Busch (Hg.), Management von Ungewissheit. Neue Ansätze jenseits von Kontrolle und Ohnmacht. Bielefeld, transcript, 327-346.

Stark, W.; Vossebrecher, D.; Bluszcz, O.; Humpert G.; Wendekamm, M. \& Margiciok, M. (2011). Music - Innovation - Corporate Culture - die Tiefendimension von Organisationskulturen musikalisch erfassen. In: praeview - Zeitschrift für innovative Arbeitsgestaltung und Prävention, 01-2011, 22-24.

Vossebrecher, D. (2016): The Shape of Tacitness to come. Erweiterte Zugänge zum Impliziten in Organisationen durch musikalisches Denken. In: Wolfgang Stark, David Vossebrecher, Christopher Dell \& Holger Schmidhuber (Hg.): Innovation und Improvisation in Organisationen und sozialen Systemen. Bielefeld, transcript.

Vossebrecher, D.; Bluszcz, O.; Humpert, G. \& Stark, W. (2012). Organisation musikalisch denken: die implizite Dimension des Organisierens entdecken. Arbeit: Zeitschrift für Arbeitsforschung, Arbeitsgestaltung und Arbeitspolitik. 21/2\&3, 132-146.

Weick, K. E. (1995): Der Prozess des Organisierens. Frankfurt a.M., Suhrkamp. Wulf, C.; Göhlich, M. \& Zirfas, J. (2001): Grundlagen des Performativen. Eine Einführung in die Zusammenhänge von Sprache, Macht und Handeln. Weinheim, Juventa. 



\section{Phoenix aus der Asche}

\section{Muster industrieller Transformation auf Zollverein ${ }^{1}$}

Oliver Bluszcz, Anne Suchalla und Katrin Heymann

\section{Geschichte}

Am 23.12.1986 schließt die einst schönste, leistungsfähigste und modernste Zeche $^{2}$ der Welt endgültig. Damit geht sowohl für die Bergleute der Zeche Zollverein als auch für das Ruhrgebiet und die Stadt Essen eine Epoche zu Ende. Christoph Zöpel, damaliger Minister für Stadtentwicklung, Wohnen und Verkehr des Landes Nordrhein-Westfalen, nimmt sich seinerzeit einen Tag lang Zeit, um das Bergwerksareal zu begehen. Am Ende des Tages steht für ihn fest: Die Zeche Zollverein muss für die Nachwelt erhalten bleiben. Er stellt sie unter Denkmalschutz und stellt damit die Weichen für den Aufbau des neuen Zollverein. Er steht aber auch für den Ansatz in der Stadtplanung Neues zu entwickeln, ohne das Vergangene zu negieren. Damit wird auch eine Initialzündung für einen neuen Trend im Ruhrgebiet begründet. In der Folge werden zahlreiche weitere ehemalige Industrieanlagen im Ruhrgebiet erhalten und umgenutzt.

Zollverein geht auf Initiative Zöpels in den Besitz des Grundstücksfonds Ruhr über. Er wird von der Landesentwicklungsgesellschaft $(L E G)^{3}$ verwaltet. Seine Aufgabe ist es, vormals industriell genutzte Brachflächen einer neuen gewerblichen Nutzung zuzuführen. Die Herausforderung wird schnell klar: Der Fortbestand des Areals und seinen Bauten ist nur möglich, wenn neue Nutzungen für die alten Hallen und Anlagen gefunden und diese wieder mit Leben gefüllt werden. Erhalt durch Umnutzung, lautet das Schlagwort für die 23 Gebäude auf dem

1 | Mit einer Ergänzung von Delia Bösch, Leiterin Kommunikation und Marketing und Pressesprecherin der Stiftung Zollverein.

2 | Der Begriff Zeche wird im Ruhrgebiet synonym zu "Bergwerk" oder "Steinkohlenbergwerk" gebraucht.

3 | Die LEG NRW GmbH ist der 1970 entstandene landeseigene Wohnraumversorger des Landes Nordrhein-Westfalen. Seit dem 1. Februar 2013 ist die GmbH ein börsennotiertes Immobilienunternehmen. (www.leg-nrw.de). 
fast 27 Hektar großen Gelände rund um den Hauptförderschacht XII mit dem markanten Doppelbock-Fördergerüst. Der Doppelbock erwächst im Laufe der Entwicklung des Areals schnell zur Erkennungs-Marke, unter der sich sowohl die dort neu angesiedelten Nutzer als auch die Besucher und Touristen versammeln. ${ }^{4}$

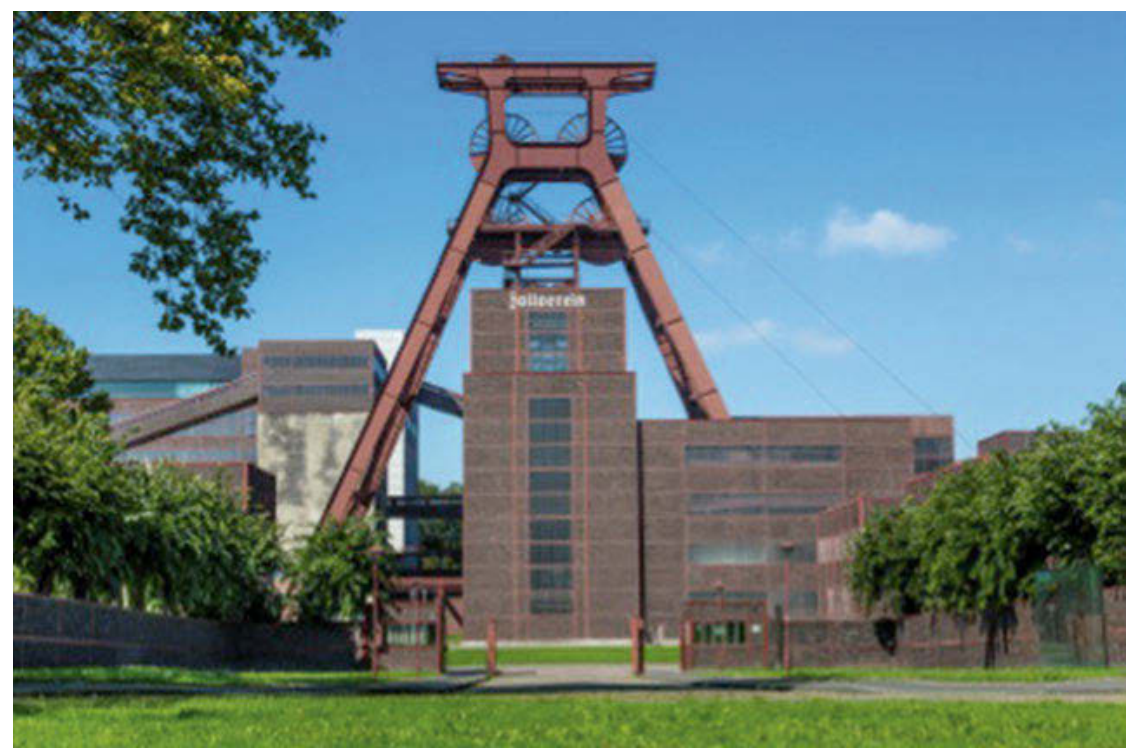

Abbildung 1: Zollverein-Markenzeichen: Doppelbock-Fördergerüst ${ }^{5}$

(Bild: (C) Jochen Tack/Stiftung Zollverein)

Neben der touristischen Erschließung wird der ehemalige Montanstandort zum Wirtschaftszentrum für Design, Kunst und Kultur umgestaltet. Die Stiftung Zollverein ${ }^{6}$ verantwortet die Planung aller Investitionen auf dem Gelände sowie die Entwicklung und Umsetzung von Maßnahmen zur Entwicklung der Infrastruktur. Bereits während des vergangenen Jahrzehnts ist auf Zollverein ein bedeutender Anziehungspunkt für Kreativagenturen und Design-Vordenker gewachsen. Heute sind auf dem Gelände neben vielfältigen Kunst- und Kulturprojekten ebenso zahlreiche kleine und mittelständische Unternehmen der Kreativwirtschaft, aus Wissenschaft, Technik und Dienstleistung angesiedelt. Auf dem Areal erwächst im Laufe der Zeit eine besondere Organisationsform mit einer spezifisch eigenen Organisationskultur, die sich nicht ohne weiteres in bestehende Formen

4 | Vgl. zur Gesamtentwicklung Zollvereins bzw. zur Ur-Historie und zur Geschichte der Umnutzung: Tiggemann 2007.

5 | Photographie von Schacht XII, Zeche Zollverein, Essen; (C) Jochen Tack/Stiftung Zollverein.

6 | Am 12. November 1998 wurde die Stiftung Zollverein Schacht XII gegründet. (www. uni-due.de/ gpo202/denkmal/zeche.htm\#wandel). 
gießen lässt. Die Frage >Was ist Zollverein?<, also um was für eine Organisationsform handelt es sich letztlich, dominiert weite Strecken der Überlegungen und Aktivitäten in dem hier vorgestellten Teilvorhaben im Rahmen des Forschungsprojektes MICC.

Die Herausforderung bei der Auseinandersetzung mit der Organisationskultur des Standortes Zollverein liegt, wie bereits angedeutet, in der außergewöhnlichen Zusammensetzung der Akteure vor Ort. Schließlich handelt es sich nicht um ein einzelnes Unternehmen oder relativ abgeschlossenes Gebilde wie das ehemalige Bergwerk. Vielmehr findet man hier eine Vielzahl verschiedener Organisationen auf einer gemeinsamen Plattform, wie u.a. die Stiftung Zollverein, zwei Museen (Ruhr Museum ${ }^{7}$ und Red Dot Design Museum Essen ${ }^{8}$ ), den Künstler Thomas Rother mit seinem privaten Kunstschacht ${ }^{9}$, das Casino als gehobene Gastronomie $^{10}$, das Tanzzentrum PACT Zollverein ${ }^{11}$, eine Keramikwerkstatt ${ }^{12}$, diverse kleine und mittelständische Betriebe, Galerien, Ateliers, Büros sowie ein Bistro und ein Café - alles eigenständige Einrichtungen, die unabhängige Einheiten darstellen und eigenen unternehmerischen Zielen folgen. ${ }^{13}$ Eine Ausnahme bildet die Stiftung Zollverein, die ausschließlich durch das Stiftungskapital und Fördermittel existieren kann. Die Gemengelage an Akteuren und die damit verbundene Berücksichtigung der Interessen der Stadt Essen, des Landes NordrheinWestfalen, des Bundes und der Europäischen Union, sowie die Auflagen die sich aus dem Status >Weltkulturerber ergeben, erweisen sich dabei als vielschichtig und komplex.

Eine erste Bestandsaufnahme zu den mittelbaren und unmittelbaren Akteuren des Standortes Zeche Zollverein hat deutlich gemacht, dass zur Betrachtung der Organisationskultur insbesondere die Geschichte(n) der einzelnen Nutzer auf dem Gelände Zollvereins und deren Beziehung(en) untereinander berücksichtigt werden müssen.

7 | Vgl. www.ruhrmuseum.de/.

8 | Vgl. http://de.red-dot.org/371.html.

9 | Vgl. www.zollverein.de/\#/angebote/kunstschacht-zollverein-thomas-rother-kunst-ausder-bergbaulichen-erinnerung.

10 | Vgl. www.casino-zollverein.de/.

11 | Vgl. www.pact-zollverein.de/.

12 | Vgl. www.zollverein.de/\#/angebote/gefaesse-keramische-arbeiten-von-young-jaelee.

13 | Das "Forschungsgebiet“ ist aus Gründen der Handhabbarkeit des Forschungsgegenstandes bewusst eingegrenzt worden: Berücksichtigt wurden die Areale der SchachtanIagen XII, 1/2/8 und der Kokerei, also genau die Flächen, die auch der Masterplan zur Entwicklung des Areals von Rem Koolhaas berücksichtigt. 


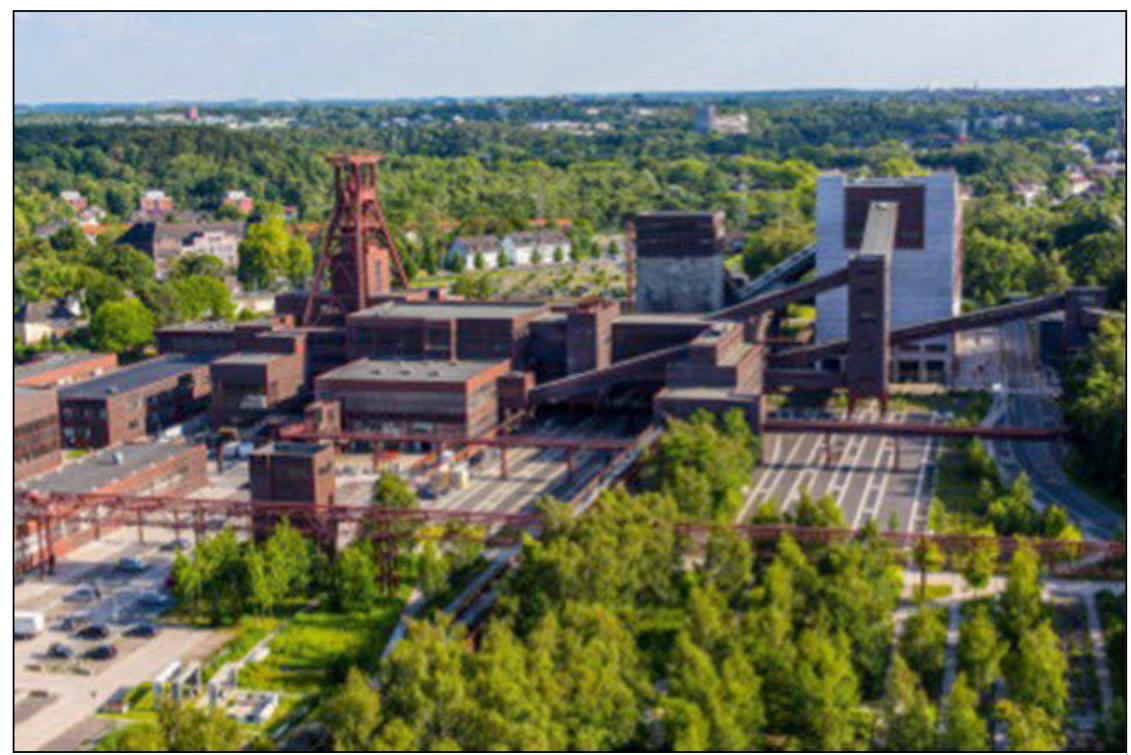

Abbildung 2: Luftaufnahme des Zollverein Areals

(Bild: (C) Jochen Tack/Stiftung Zollverein)

\section{Fragestellung und Durchführung}

Im Rahmen des Projekts bestanden übergreifende Fragestellungen (Gesamtfragestellung) und spezifische Fragestellungen für den jeweiligen Verbundpartner bzw. das jeweilige Teilprojekt. Dabei wurden ausschließlich >qualitative «, nichtstandardisierte Erhebungs- und Auswertungsmethoden eingesetzt mit dem Ziel, im Sinne einer >Grounded Theory< (Strauss \& Corbin 1996; Strauss 1991), ein in den Daten fundiertes Verstehen der jeweiligen Organisationskultur zu erreichen. Diese Form der qualitativen Praxisforschung erlaubt, dass die zunächst formulierte Fragestellung mit der fortschreitenden Erkenntnis über den Untersuchungsgegenstands weiter entwickelt wird (iterativer Erkenntnisprozess). Somit ist es beispielsweise möglich, das Teilaspekte der initialen Fragestellung vollständig wegfallen und/oder neue Aspekte hinzukommen bzw. andere Aspekte ungeahnt, stärker in den Vordergrund treten können.

In den Jahren 2008 bis 2011 befassten sich die Anne Suchalla und Katrin Heymann, als Mitarbeiterinnen der Stiftung Zollverein und Verbundpartner im Forschungsprojekt MICC, mit der Untersuchung der Organisationskultur auf Zollverein. Zielstellung von MICC als Forschungs- und Entwicklungsprojekt im grundlegenden Sinn war die Untersuchung der Frage, wie Musik und ein musikalisches Verständnis von Organisation (Bluszcz et al. 2010; Vossebrecher et al. 2012) zur Explikation von impliziten Mustern der Innovation und deren Weiterentwicklung im Sinne einer Innovationsstrategie nutzbar gemacht werden können. 
Die Spezifische Teil-Fragestellung im Falle Zollvereins zielt in Richtung des dort stattfindenden Wandels von einer tradierten Industriekultur, hin zu einer Entwicklung eines neuen sozialen Systems. Dabei sollten insbesondere die Faktoren herausdestilliert werden, die diesen Wandel ermöglicht, möglicherweise beschleunigt und/oder aufrechterhalten haben sowie auch in die Zukunft wirken. Die im Spannungs- bzw. Strömungsfeld dieses Prozesses entstehenden Momente der Innovation waren dabei von besonderem Interesse.

Vor dem Hintergrund des zugrunde gelegten Arbeitsmodells der Unternehmens- bzw. Organisationskultur von Edgar Schein (1991) wurde im Frühsommer 2009 mit der Datenerhebung, -aufbereitung sowie -auswertung begonnen. Folgende Aktivitäten, Methoden und Instrumente charakterisieren die Forschungsarbeiten:

- Durchführung von leitfadengestützten Interviews mit Nutzern am Standort Zollverein, wie auch mit aktuellen und ehemaligen Verantwortlichen der Standortentwicklung

- Durchführung- und Auswertung einer Selbst-Analyse mit dem Fokus auf organisationale Muster um ein >Erstes Bild der Organisation $<$ zu erhalten

- Analysen von verschieden Dokumenten (Zeitungsartikel, Fachartikel, Fachbücher, historische Literatur, wissenschaftliche Arbeiten)

- Durchführung von Experteninterviews (Schwerpunkt Innovation)

- Durchführung und Auswertung eines Organisationspartituren-Workshops (entstanden sind 8 Organisations-Partituren), die der Erhebung der jeweils subjektiven Perspektiven der Teilnehmenden auf relevante Organisationselemente bzw. organisationale Prozesse, gedacht als musikalische Phänomene (Verläufe), dienen

- Auswertung der gewonnen Daten unter Zuhilfenahme des Software-Tools Atlas.ti ${ }^{14}$, das die komplexe Auswertung qualitativer empirischer Daten unterstützt und die Daten wie die Ergebnisse verwaltet

- Erstellung einer umfangreichen Abschlussdokumentation nach Abschluss der Datenerhebung gegen Ende des Jahres 2010

Die Datenerhebung und -auswertung zur Analyse der Organisationskultur erfolgte im gemeinsamen Tandem zwischen einem Mitarbeiter des Forschungsteams des Labors für Organisationsentwicklung (Vossebrecher et al. 2010) der Universität Duisburg-Essen und den genannten Mitarbeiterinnen der Stiftung Zollverein.

Zwischenergebnisse der Auswertung wurden im MICC-Verbund regelmäßig in den dafür vorgesehenen >Auswertungskolloquien< diskutiert und reflektiert, sowie weiterentwickelt und abgesichert (Validierung).

14 | Die Datenanalyse und -verwaltung wurde durch die QDA-Software Atlas.ti unterstützt, die auch eine projektübergreifende Gesamtanalyse ermöglichte. 


\section{Die Diversität des Standortes}

Das Areal des Welterbes Zeche Zollverein ist eine Plattform mit einem vielschichtigen Beziehungs- und Kommunikationsgefüge, dessen Komplexität und Dynamik durch die unterschiedlichen Akteuren, sprich Nutzer, am Standort bedingt wird. Dieses ist auch gleichzeitig ein bedeutendes Merkmal der Organisationsbzw. Standortkultur. Ein wesentliches Ergebnis, der angestellten Untersuchungen ist eine Analyse der Nutzer. Als Bezeichnungen für die identifizierten Nutzertypen wurden Tiere als Metapher zur Veranschaulichung der Rollen gewählt.

\subsection{Die 'Hofhunde،}

Die Hofhunde bewachen ihr Terrain, sie sind sich ihrer Funktion bewusst und prägen das heutige Bild von Zollverein: Das Casino, der Kunstschacht, das Red Dot Design Museum Essen, das Tanzzentrum PACT Zollverein sowie die Keramikwerkstatt. Einige dieser Akteure verdienen

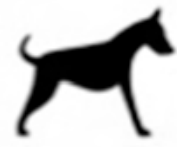
hier nicht nur ihren Lebensunterhalt, sondern sie verwirklichen einen persönlichen Lebensentwurf bzw. leben ein Erfolgsmodell. Sie sind aus Überzeugung am Standort und ihre (Geschäfts-)Ideen sind zum Teil an diesen Standort gebunden. Die Hofhunde haben darüber hinaus nicht nur eine Wächterfunktion, sondern sie prägen, kreieren, entwickeln Ideen und setzen sie um. Sie beleben den Standort und füllen die Fassade mit starken Inhalten. Somit verleihen sie dem Standort ein Gesicht.

Die Hofhunde arbeiten selbstbewusst und gelten als >Macher< auf Zollverein. Sie beherrschen und verteidigen ihren Wirkungskreis und achten dabei auf ihre Unabhängigkeit. Darüber hinaus präsentieren sie sich professionell in der Öffentlichkeit und stärken damit ihr Image.

\subsection{Die 'Füchse،}

Die Füchse haben den Standort Zeche Zollverein sehr bewusst gewählt und nutzen ihn für den Betrieb von Agenturen oder kleineren Firmen. Oft sind sie frühe Siedler auf Zollverein, ohne die Sichtbarkeit nach außen, gleichsam der Hofhunde, zu erreichen. Sowohl die Hofhunde als

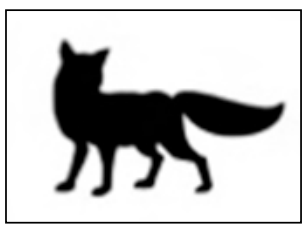
auch die Füchse bezeichnen sich selbst als >die Ersten $<$ am Standort. Sie arbeiten aus Überzeugung und mit Engagement auf dem Areal und wollen in das Geschehen vor Ort mit einbezogen werden. Bezogen auf diesen Punkt existiert ein Spannungspotential in Richtung der Stiftung Zollverein. Ein weiterer Charakterzug der Füchse ist, dass sie die unkomplizierten, informellen Kommunikationswege am Ort bevorzugen. Sie operieren in nationalen und internationalen Netzwerken und profitieren von der attraktiven Adresse. 


\subsection{Die ıZugvögel،}

Die Zugvögel sind zunächst Neuankömmlinge mit hohen Erwartungen an den Standort. Sie stoßen schnell an Grenzen, wenn es darum geht, die Strukturen und Möglichkeiten des Standortes auszuloten. Informationen müssen sie hauptsächlich über den Webauftritt der Stiftung Zollverein

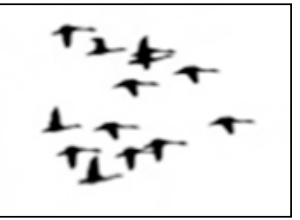
beziehen, da seit dem Ende der sog. Nutzerkonferenzen keine ähnlich organisierte Kommunikation auf Zollverein existiert. Begegnungen am Standort ergeben sich demnach unorganisiert und eher zufällig. Das gelegentlich auf Zollverein stattfindende Design-Frühstück der IHK ${ }^{15}$, ist lediglich den Designern als Plattform für den regelmäßigen Austausch vorbehalten. Aufgrund der relativen Unverbindlichkeit ziehen diese Nutzer weiter, sobald die Standortbedingungen nicht mehr ihren Bedürfnissen entsprechen oder den Erwartungen standhalten.

\subsection{Die ıKuckucke،}

Bei dem Kuckuck handelt es sich vor allem um kleine Unternehmen und Einzelunternehmen, die die Attraktivität des Standortes nutzen, denn das Weltkulturerbe Zollverein verfügt über eine große Ausstrahlung, die umso mehr zu wirken scheint, je weiter man vom Ruhrgebiet entfernt ist. Am Standort befinden sich viele Unterneh-

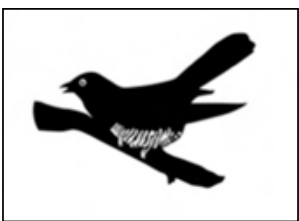
men, die diese internationale Strahlkraft für ihr Image nutzen (Füchse und Zugvögel). Der Standort Zollverein erscheint aus Sicht der Kuckucke durch die eher randständige Lage innerhalb Essens, die erschwerte Auffindbarkeit am Standort selbst, den fehlenden Ausblick aufgrund der Milchglasfenster und die kaum vorhandene Netzwerkzusammenarbeit vor Ort in mehrfacher Hinsicht als unkomfortabel. Sie leben von der elektronischen Datenautobahn, die sie in nationale und internationale Netzwerkgemeinschaften einbindet. Offenbar nutzen auswärtige Firmen über diese Möglichkeit ansässige Unternehmen auf Zollverein gerne auch als imageträchtige Briefkastenadresse (Kuckucke).

\subsection{Das 'Dino-Baby،}

Einen besonderen Stellenwert auf dem Standort nimmt das neue Ruhr Museum in der ehemaligen Kohlenwäsche $^{16}$ ein. Lange Zeit war die Planung für die Neunutzung dieses Gebäudekomplexes unklar. Entscheidende Impulse

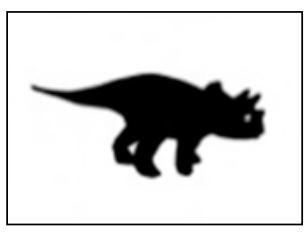

15 | Industrie- und Handelskammer (www.essen.ink24.de/).

16 | Vgl. www.ruhrmuseum.de/museum/standort/kohlenwaesche/. 
gingen schließlich vom Masterplan Zollverein des OMA aus, so dass im Jahr 2003 der Umbau der ehemaligen Kohlenwäsche begonnen wurde. Im Januar 2010 eröffnete schlussendlich das vormalige Ruhrland Museum als Ruhr Museum, welches formal an die Stiftung Zollverein angeschlossen ist, in der Kohlenwäsche auf Zollverein seine Pforten. Gemeinsam mit dem Besucherzentrum ${ }^{17}$ wurde es zu einem bedeutenden Publikumsmagneten im Rahmen der Kulturhauptstadt Ruhr 2010 und ist ein Best-Practice-Beispiel für die Verbindung zwischen Tradition und moderner Umnutzung.

\subsection{Der `Platzhirsch،}

Die Stiftung Zollverein erscheint in der Rolle des Platzhirsches am Standort: Sie ist die rechtliche Eigentümerin und Vermieterin der Liegenschaften auf dem Areal von Zollverein und verwaltet die Finanzen. Auf der Grundlage ihrer Satzung, der sie verpflichtet ist, stellt sie die Basis, auf

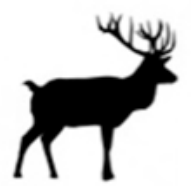
der die Nutzer des Areals agieren können, sicher. Mit der Zusammenlegung der Stiftung Zollverein Schacht XII und der EGZ ${ }^{18}$ zur neuen Stiftung Zollverein ist Anfang 2009 eine Umstrukturierung in Richtung einer Organisationsform erfolgt, die behördlichen Strukturen ähnelt.

Gemäß ihrer Rolle versucht die Stiftung auch Akzente im Rahmen der Entwicklung des Standortes zu setzen, wie z.B. der Ausbau zum Design und Kreativstandort als auch in Richtung der kulturellen und musealen Nutzung sowie als Eventort.

Die Erwartung der Nutzer an die Leitungs- und Führungsinstanz Stiftung Zollverein gehen über das reine Verwalten des Standortes hinaus. Vielmehr scheint die Stiftung vor der Herausforderung zu stehen, die Kommunikation mit den Nutzern am Standort in Richtung Ansprechstelle für Probleme sowie in Richtung des Aufgreifens, Verarbeitens und Umsetzens von Ideen und Vorschlägen zur Standortentwicklung zu optimieren.

\section{Muster der Organisationskultur auf Zeche Zollverein}

Die Entdeckung von Mustern in der Art, wie die Unternehmen bzw. sozialen Organisationen im MICC-Forschungsverbund mit Herausforderungen umgehen, war wesentlicher Bestandteil des Forschungsprojektes. Es geht zunächst um organisationstypische, im weiteren Schritt auch um verallgemeinerbare Muster. Mit Patterns lassen sich prozesshaft grundlegende Lösungsstrategien für wiederkeh-

17 | Vgl. www.route-industriekultur.de/besucher-zentrum.html.

18 | Entwicklungsgesellschaft Zollverein mbH (gegr. 2001), vgl.: www.zollverein.de/\#/ business/standortentwicklung-und-betrieb/entwicklungsgesellschaft-zollverein-mbh. 
rende Herausforderungen und Problemstellungen systematisch beschreiben und zwar in Relation zum Kontext, in dem sie auftreten. Sie ermöglichen es komplexe Systeme als Ganzes zu verstehen und in seinen Einzelheiten in das Ganze eingebunden zu betrachten. ${ }^{19}$ Sie erschließen vorhandenes Erfahrungswissen sowohl für die Organisationen selbst als auch für den Transfer.

Patterns werden entdeckt, aufgeschrieben, verdichtet und kommuniziert. In MICC ist die Empirie aus gemeinsamer Arbeit mit den Daten (Interviews, Beobachtungen, Dokumente, Partituren) in den Organisationen sowie wissenschaftliche Theorien das Ausgangsmaterial, um Patterns zu entdecken.

Das Ergebnis der Organisationskultur-Analyse wurde in Form von Mustern festgehalten. Die Form der hier verwendeten Muster (engl. Patterns) folgenden weitestgehend einer Logik, wie sie Design-Patterns oder den aus der Architektur bekannten Patterns von Christopher Alexander (1977) zugrunde liegen. Die Suche nach Patterns (Mustern) der Organisationskultur bedeutet, die Analyse auf wiederkehrende, sich ähnelnde Handlungsweisen zur Bearbeitung oder Bewältigung organisationaler Herausforderungen zu fokussieren. Die Muster sind den Handelnden oft selbst nicht klar, d.h. sie sind implizit vorhanden, können aber dennoch entdeckt und expliziert werden. Die Nutzung von Patterns als Dokumentationsform, soll die Handhabbarkeit, Vergleichbarkeit, Übertragbarkeit, Gültigkeit und Verwertbarkeit der gefundenen Muster erhöhen.

Folgende in Kurzform beschriebene Patterns charakterisieren im Wesentlichen das Ergebnis der Untersuchung. Sie geben Auskunft über den Kontext von Herausforderungen und die für den Standort Zollverein typischen praktizierten Lösungen, im Wandel von einer der größten Schachtanlagen der Welt hin zu einem Kunst-, Kultur-, Design-, Technik- und Museumsstandort.

\subsection{Muster: Phoenix aus der Asche}

\section{Kontext}

Die Herausforderungen und die dazugehörigen Lösungen greifen, im Rahmen des Entwicklungsprozesses der Umnutzung des ehemaligen Bergwerks Zeche Zollverein, ineinander und überlappen sich. Nachdem die Basis für die Neuausrichtung der Nutzung gelegt ist, also Gebäude und Räume instand gesetzt worden sind, wird mit der inhaltlichen Umnutzung begonnen. Zuständig dafür ist die Stiftung Zollverein.

\section{Herausforderung}

Da die Zinsen des Stiftungskapitals nicht ausreichen, um die laufenden Betriebsund Unterhaltskosten zu decken, bleibt Zollverein im Besitz der Landesentwicklungsgesellschaft NRW (LEG NRW). Die Stiftung widmet sich der kulturellen

19 | Vgl. Alexander et al. 1977; zum MICC-spezifischen Verständnis: Stark 2013; Vossebrecher u. Kamin 2011. 
Nutzung des Areals und öffnet die Zeche damit einem breiten Publikum. Mit dem Beginn dieser Entwicklung stehen die Akteure und insbesondere die Stiftung auf dem Standort vor der Herausforderung, Zollverein immer wieder neu zu erfinden, auch um die Investition öffentlicher Gelder zu legitimieren.

\section{Lösung}

Zum Ende der Internationalen Bauausstellung Emscher Park ${ }^{20}$ im Jahr 1999 schreitet die Hallenvermietung und die Nutzung der Gebäude um den Schacht XII weiter voran. Allerdings fehlt ein nachhaltiges, strategisches Zukunftskonzept, aus dem sich konkrete Ziele und Maßnahmen für die eröffneten Räume ableiten lassen.

In Folge entsteht die Denkschrift $2010^{21}$, die die Richtung für die nächsten zehn Jahre vorgibt. Danach soll Zollverein nicht nur Kultur-, sondern auch Wirtschaftsstandort werden. Der Zeitachse der Entwicklung Zollvereins wird Rechnung getragen, unter anderem durch die Berücksichtigung der Vergangenheit:

- die Denkmal-Landschaft ${ }^{22}$

- der Denkmalpfad ZOLLVEREIN $\circledR^{23}$

- das Ruhr Museum

- das Red Dot Design Museum Essen mit Bezügen zur Gegenwart

Ebenso werden Gegenwart und Zukunft einbezogen:

- Lehre und Forschung: Zollverein School24

20 | Die Internationale Bauausstellung Emscher Park (IBA Emscher Park) war ein auf zehn Jahre angelegtes Zukunftsprogramm des Landes Nordrhein-Westfalen (Start: 21. April 1989; Ende: 1999). Es war die Aufgabe der IBA mit neuen Ideen und Projekten im städtebaulichen, sozialen, kulturellen und ökologischen Bereich Impulse zu geben für den wirtschaftlichen Wandel der Emscher-Region, einer tradierten Industrieregion im nördlichen Ruhrgebiet.

21 | Internationale Bauausstellung Emscher Park (1999): Denkschrift Zollverein 2010. Impulse für die Fortentwicklung des Zukunftsstandortes Zollverein. Vgl. dazu auch: Tiggemann 2007, S. 397.

22 | Vgl. Zeche Zollverein in Essen. Eine Denkmal-Landschaft von Weltrang im Herzen Europas. Essen 1999. Denkmalschrift und Antrag zur Aufnahme in die UNESCO-Liste des Welt-Kulturerbes. Vgl. auch dazu: Ganzelewski, Michael/Slotta, Rainer (2000): Die Denkmal-Landschaft "Zeche Zollverein “. Eine Steinkohlenzeche als Weltkulturerbe?! Bochum: Deutsches Bergbau-Museum.

23 | Vgl. www.zollverein.de/\#/angebote/denkmalpfad-zollverein.

24 | Zollverein School of Management and Design gGmbH, gegründet 2003. Der Betrieb dieser privaten Bildungseinrichtung mit dem Masterstudiengang Business Design, wurde letztlich aus wirtschaftlichen Gründen im Jahr 2008 eingestellt. 
- Design Gewerbepark: Ansiedlung von Klein- und mittelständischen Betrieben

- Weltausstellung Design »Interform $\aleph^{25}$

Ähnlich wie der Phönix der Asche entstiegen ist, wird die einst stillgelegte Zeche Zollverein zu neuem Leben erweckt. Den vorläufigen Höhepunkt dieser Geschichte bildet die Eintragung in die Liste der UNESCO Weltkulturerbe im Jahr 2001. Damit wird die postindustrielle Kulturlandschaft Zollverein zur ersten World-Heritage-Site im Ruhrgebiet.

\section{Konsequenzen aus der Lösung}

Wird die Umsetzung der Denkschrift 2010 sowie die des Masterplans Zollverein ${ }^{26}$ weiterhin konsequent fortgesetzt, wird Zollverein als Symbol und Vorbild für die Umnutzung von Hinterlassenschaften des Steinkohlebergbaus sowie der Montan- und Schwerindustrie Bestand haben. Der Erhalt und die Fortentwicklung des Standortes sind dabei allerdings nach wie vor abhängig von Fördergeldern.

\subsection{Muster: Pioniergeist entwickeln}

\section{Kontext}

Pioniergeist war für die Existenz des früheren Bergwerkes Zeche Zollverein, wie auch für das heute bekannte Areal ausschlaggebend. Der Duisburger Unternehmer und Zechen-Gründer Franz Haniel ${ }^{27}$ bewies schon mit der Namensgebung eine innovative Einstellung. Am o1. Januar 1834 war eine Freihandelszone - der Deutsche Zollverein - aus 14 Staaten des Deutschen Bundes in Kraft getreten. Und statt seine Zeche, wie üblich, mit einem Namen der Krupp'schen Tanten (Alma, Helene) oder der eines Generals (Blumenthal) ${ }^{28}$ zu belegen, setzte Haniel mit der Namensgebung ein eher politisches Zeichen: Die Zeche hieß Zollverein. Immer wieder wurde sie im Laufe ihrer Geschichte erweitert und mit Superlativen in Verbindung gebracht und galt als sschönste und modernste Zeche der Welt<. Pioniergeist bewiesen die vielen Bergmannsfamilien, die sich um die Ze-

25 | "Interform“ Weltausstellung zur Neu-Definition des Designs und zur Neu-Positionierung des Design-Standortes Zollverein (vgl. Blick zurück nach vorn. Das Design Zentrum Nordrhein Westfalen auf Zollverein (1997-2010). Hintergrundinformation, hg. vom DesignZentrum Nordrhein-Westfalen, Mai 2010.

26 | Masterplan Zollverein; Büro OMA (http://oma.eu/oma), Rem Koolhaas, Rotterdam, Jahr 2003. Vgl. auch: Vanderlinden, Barbara (Hg.) (2002): Was ist Zollverein? Essen: Entwicklungs-Gesellschaft Zollverein.

27 | Johannes Franciscus (Franz) Haniel (1779-1868, geb. in Ruhrort, heute Duisburg), war ein im Speditionswesen und Großhandel (z.B. mit Kohlen) erfolgreich tätiger, deutscher Unternehmer.

28 | Bergwerk, benannt nach Graf von Blumenthal (www.general-blumenthal.de/Chro nik \%20GBL.html). 
che herum ansiedelten und hier hauptsächlich nach dem zweiten Weltkrieg eine neue Heimat fanden.

Pioniergeist war vor allem nach der Schließung der Zeche erforderlich. Den zeigte zunächst die Stadt Essen, die die Essener Arbeit Beschäftigungsgesellschaft $\mathrm{mbH}(\mathrm{EABG})^{29}$ gründete. Bis zu 120 Langzeitarbeitslose und Jugendliche packten bei der Sanierung mit an, und qualifizierten sich so selbst für neue Aufgaben.

Pioniergeist bewies ebenso die Bauhütte. Die Bauhütte war eine Organisation, die durch die Vorschläge des Forum Ruhrkultur angeregt wurde, und die ab 1989 für 10 Jahre Entwicklungs- und Aufbauarbeit leistete. ${ }^{30}$ Während dieser Zeit initiierte und verantwortete sie fast alles, was heute auf Zollverein zu sehen ist, mit Ausnahme des SANAA-Gebäude ${ }^{31}$.

Vom Pioniergeist gepackt waren auch die ersten kleinen Betriebe/Agenturen etc. die sich zum Teil erst formierten und dann ansiedelten. Dabei handelte es sich u.a. auch um Designstudenten der Folkwang-Hochschule, die sich auf dem Gelände umsahen und sich inspirieren ließen.

Ohne den Pioniergeist der Natur, die sich das Areal eroberte, gäbe es heute keinen Zollverein Park. Seit der IBA Emscher Park spricht man von Industrienatur oder postindustrieller Spontanvegetation. Sie erstreckt sich über ein Gebiet von 180.000 Quadratmetern.

\section{Herausforderung}

Die Herausforderung bestand in der erfolgreichen Erschließung im Sinne einer Eroberung und Belebung des Areals - unter gleichzeitiger Herausbildung einer dazu geeigneten, impliziten Entwicklungsstrategie für Zollverein.

\section{Lösung und ihre Logik}

Die von Karl Ganser ${ }^{32}$ beschriebene >Partisanenmentalität< war bei der Ansiedlung von Nutzern und der Eroberung, also Erschließung des Areals durch diese Nutzer, hilfreich. Sicherlich übte die damit einhergehende >Besetzermentalität< und die vorherrschende Goldgräberstimmung ebenso ihren Reiz aus: Zollverein als Abenteuerspielplatz für Erwachsene. Das Areal und dessen Nutzung waren massiv von Grauzonen, Unschärfe und gleichzeitig von Offenheit gekennzeichnet. Kreative Potentiale konnten sich in diesem Milieu (zunächst) frei entfalten.

29 | Vgl. www.eabg.essen.de/.

30 | Am 22. September 1989 gründeten die LEG und die Stadt Essen die Bauhütte Zeche Zollverein Schacht XII GmbH. Diese wurde mit der Erhaltung der Anlagen sowie der Planung und Organisation der Neunutzung beauftragt. (www.uni-due.de/ gpo202/denkmal/ zeche.htm\#wandel).

31 | Vgl. www.zollverein.de/\#/angebote/sanaa-gebaeude-events-mit-ein-und-ausblicken. 32 | Karl Ganser (geb. 1937 in Mindelheim, Geograph und Stadtplaner) war Geschäftsführer der Internationalen Bauausstellung (IBA) Emscher Park. 


\section{Konsequenzen aus der Lösung}

Die Attraktivität des Standortes lässt sich zu Beginn der Umnutzung als Pionierfeld charakterisieren. Junge Unternehmen (২Zugvögel<), zogen sich ggf. auch wieder vom Gelände zurück, wenn ihnen beispielsweise die Unterstützung durch die anderen Nutzer fehlte bzw. der Standort keinen direkten Vorteil brachte. In der Folge überlebten nur diejenigen Nutzer langfristig am Standort, deren individueller Pionier- und Entdeckergeist und ihr Überlebenswille groß genug waren.

\subsection{Muster: Große Namen einladen}

\section{Kontext}

Nicht zuletzt durch die Fingerabdrücke der großen Gestalter und Künstler von Weltruf verfestigt sich der >Mythos Zollverein $<$. Das Areal wird gerne mit einem Leuchtturm verglichen, dessen Strahlkraft vor allem überregional wirkt. Diese Attraktion erhält mit der Eröffnung der Kulturhauptstadt RUHR.2010 33 auf dem Gelände des Weltkulturerbes einen kräftigen Schub. Fast zeitgleich mit der Eröffnungsfeier findet auch die Eröffnung des Ruhr Museums in der ehemaligen Kohlenwäsche der Zeche Zollverein statt. Bereits Ende April 2010 werden auf dem Areal von Zollverein circa 1 Millionen Besucher gezählt - so viele, wie für das Kulturhauptstadtjahr insgesamt erwartet worden sind.

\section{Herausforderung}

Die Herausforderung besteht darin, das Areal des Welterbes vor allem mit großformatigen kulturellen Ereignissen zu beleben und zu versorgen. Format und Bühne müssen passgenau sein, um die optimale Anziehungskraft des Weltkulturerbes zu entfalten.

\section{Lösung}

Architekten von Weltrang hinterließen eindrückliche Visitenkarten ihres Könnens auf Zollverein: Lord Norman Foster ${ }^{34}$ stellte 1996 den Umbau des Kesselhauses für das Design Zentrum Nordrhein-Westfalen. Professor Christoph Mäckler ${ }^{35}$ gestaltete den Ausbau der ehemaligen Kaue für das Choreographische Zentrum NRW/PACT Zollverein. Und Rem Koolhaas ${ }^{36}$ entwickelte schließlich den soge-

33 | Vgl. www.essen-fuer-das-ruhrgebiet.ruhr2010.de/.

34 I Norman Robert Foster, Baron Foster of Thames Bank (geb. 1935 in Manchester), britischer Architekt, betreute mit seinem Team bzw. mit seinem Büro Foster + Partners zahlreiche renommierte und spektakuläre Projekte. Vgl. auch: www.fosterandpartners.com/ practice-data/.

35 | Vgl. auch: www.chm.de/de/proj_overview.html.

36 | Rem Koolhaas (geb. 1944 in Rotterdam), niederländischer Architekt und einer der renommiertesten Vertreter wegweisender zeitgenössischer Architektur. Vgl. auch: http:// oma.eu/partners\#Rem Koolhaas und http://deu.archinform.net/arch/434.htm. 
nannten Masterplan für Zollverein. Er stellte damit endgültig die Weichen zur Umnutzung von Zollverein.

Entsprechend attraktiv wirkte der Standort sowohl auf bildende als auch auf darstellende Künstler. Musikalische Highlights waren u.a. Konzerte mit Alfred Brendel, Jan Garbarek mit dem Hilliard Ensemble, die WOMEX (Weltmusik-Messe), Clueso, Bohren und der Club of Gore. Als bildende Künstler wirkten neben Ulrich Rückriem auch Markus Lüppertz sowie Ilya und Emilia Kabakov auf dem Gelände und hinterließen zum Teil dauerhaft ihre Handschrift (z.B. >KabakovSchnecke< im Salzlager auf der Kokerei Zollverein).

Der Ansturm war überwältigend und wieder wurde ein Name zu Hilfe genommen, der vor allem in Österreich für Schlagzeilen gesorgt hat: Martin Hel$l^{37}{ }^{37}$, Chef der Kulturhauptstadt Linz $2009^{38}$. Er selbst sieht sich als Kulturunternehmer und schreibt ein Gutachten für die Vorgehensweise auf Zollverein. In der Öffentlichkeit auf Zollverein trat er aber nicht weiter in Erscheinung.

\section{Konsequenzen aus der Lösung}

Die Attraktivität des Standortes und die Projekte von Künstlern, Architekten und kreativen Köpfen am Ort bilden bis heute eine prosperierende Symbiose von der alle Seiten profitieren. Seit 2009 steht fest: Der Fachbereich Design der renommierten und international bekannten Folkwang Hochschule aus Essen-Werden wird erwartungsgemäß 2013/2014 das SANAA-Gebäude beziehen. Außerdem sollen auf dem Gelände im Bereich der Schächte 1, 2 und 8 weitere Gebäude für die Folkwang Universität errichtet werden. Dieses Projekt ist bereits seit Jahrzehnten im Gespräch. Es wäre eine weitere gelungene Facette im Bereich der großen Namen: Architekten für die Sanierung und die räumlich nachhaltige Nutzung, Künstler und Musiker für die temporäre Attraktion, die Hochschule für das innovative Element des sich immer wieder Erneuernden durch die Ausbildung potentiell >großer Namen<.

\subsection{Muster: Fördergelder kreativ einsetzen}

\section{Kontext}

Die Fördermittel dienen streng zweckgebunden der Konservierung des Areals mit seinem eindeutigen industriellen Hintergrund und müssen doch gleichzeitig auch die Öffnung des Geländes gegenüber einer neuen Zielgruppe (Kreativwirtschaft) sowie vielen und unterschiedlichen Besuchergruppen bewirken. Mit anderen Worten: Die Fördermittel dienen dem Erhalt des industriellen Erbes Zollverein, und sollen doch auf dem Gelände durch eine Vielzahl von Dienstleistungen neue Nutzer und Besucher anziehen.

37 | Martin Heller (geb. 1952 in Basel) ist ein Schweizer Kulturunternehmer, Ausstellungsmacher, Kurator und Autor. Vgl. www.hellerenter.ch/.

38 | Vgl. www.linz09.at/. 
Die Stiftung Zollverein muss sich damit streng an die engen Bestimmungen von Fördermitteln halten. Die Beantragung von Fördermitteln ist an langfristige Zyklen und zeitraubende Genehmigungsprozeduren gekoppelt, der Nachweis der Zweckgebundenheit verlangt einen hohen bürokratischen Aufwand, und jede andere zeitliche oder inhaltliche Anpassung verwirkt zukünftige Mittel, verpflichtet u.U. sogar zur Rückzahlung bereits geflossener Mittel.

\section{Herausforderung}

Der Stiftung muss der Spagat gelingen; sie muss beiden Zielsetzungen gerecht werden. Es gibt keine Alternative als allen denkbaren Möglichkeiten nach öffentlichen Mitteln nachzugehen, da eine andere Form der Finanzierung nicht möglich ist. Über die Verwendung dieser Mittel ist mit der notwendigen Sorgfalt Rechenschaft abzulegen.

Gleichzeitig muss es gelingen, die Umwandlung des Areals erfolgreich voranzutreiben. Dazu verpflichtet nicht nur die Satzung der Stiftung. Es gilt auch, die hohen öffentlichen Zuwendungen gegenüber der Öffentlichkeit zu rechtfertigen, in dem Zollverein einer möglichst breiten Gruppe von Nutzern und Besuchern zugänglich gemacht wird.

\section{Lösung}

Die Stiftung arbeitet daran, beiden Zielsetzungen gerecht zu werden: Konservierung des Industriedenkmals bei gleichzeitiger Umwandlung und Öffnung zum Dienstleistungsstandort. Die Stiftung will flexibler und innovativer Ansprechpartner für die Kreativ- und Veranstaltungswirtschaft sein, um neue, zusätzliche Nutzer und Besucher zu gewinnen. Gleichzeitig müssen öffentliche Fördermittel eingeworben werden, um die Kosten zu decken, die die Umwandlung und der Betrieb des Areals verlangen.

Die Lösungen sind oft Kompromisse, die ein Maximum an Einfallsreichtum erfordern - wenn es etwa darum geht, dass die Mitarbeiterinnen und Mitarbeiter der Stiftung, schnell und flexibel reagieren müssen. Ebenso gefordert sind die Nutzer, die ihre Entscheidungen und ihr Handeln im Spannungsfeld eigener (wirtschaftlicher) Bedürfnisse und Anforderungen oder mit den Einschränkungen des Denkmalschutzes abwägen müssen. Die Besucher, die Einschränkungen und Rücksichtnahme bei anderen Stätten des Weltkulturerbes (z.B. dem Kölner Dom) selbstverständlich finden, zeigen dieses Verständnis für das Areal von Zollverein in diesem Maße in der Regel nicht.

\section{Konsequenzen aus der Lösung}

Das bedienen vielschichtiger Interessen und Anforderungen: Langwierige Bürokratie, die öffentliche Fördergelder mit sich bringen, die Schnelllebigkeit der Kreativwirtschaft, wechselnde künstlerische Ausstellungen, eine Vielzahl von großen und kleinen Veranstaltungen über das Jahr verteilt, erfordern von den 
Mitarbeitern und der Leitung der Stiftung ein hohes Maß an Anpassungsfähigkeit, Geduld, Flexibilität und auch Innovationsfreude.

\subsection{Muster: Sich immer neu erfinden}

\section{Kontext}

Während der aktiven Zeit der Kohleförderung, war Zollverein von einer Mauer umgeben und nicht für die Bevölkerung der umgebenden Stadtteile zugänglich. Aber sie war das Zentrum des Lebens, denn die Väter verdienten dort als Bergleute den Unterhalt für die Familien. Nach der Schließung der Zeche wurde die >Verbotene Stadt< geöffnet, verlor aber gleichzeitig den Status als Mittelpunkt der Existenz.

\section{Herausforderung}

Trotz der Öffnung nach außen scheint es, dass das Areal von Zollverein nach wie vor eine Art Insel darstellt. Dabei steht diese Insel unter dem Druck, sich einerseits in Richtung eines exklusiven Design-Standortes zu entwickeln ${ }^{39}$ und anderseits aber auch den Anschluss an die umliegenden Stadtteile und deren Menschen herzustellen. Die Herausforderung besteht demnach darin, den Spagat zwischen der Legitimation für öffentliche Förderung und damit der Öffnung für ein breites Besucherpublikum und dem Anspruch an einen exklusiven Designstandort zu bewerkstelligen - also, den Gegensatz zwischen exklusivem und populärem Standort zu überbrücken.

\section{Lösung}

Mit der Ausrichtung zum Designstandort geht im Laufe der Zeit die Öffnung für die Kreativwirtschaft einher. Darunter fallen Tätigkeitsfelder wie Verlagsund Filmgewerbe, Rundfunkwirtschaft, Musik, visuelle und darstellende Kunst, Journalisten- und Nachrichtenbüros, Museumsshop und Kunstausstellungen, Einzelhandel mit Kulturgütern, Architekturbüros, Designwirtschaft wie auch Lehre und Forschung durch die Ansiedlung von Teilen der Folkwang Universität für Künste ${ }^{40}$. Architektonisch werden, z.B. durch das SANAA-Gebäude, ebenfalls neue Akzente gesetzt. Zollverein verträgt große Formate, so das Fazit des Vorstandsvorsitzenden Hermann Marth ${ }^{41}$ nach der Eröffnung des Ruhr Museums 2010 und des Kulturhauptstadtjahrs 2010. Zollverein öffnet sich weiter. Noch während des Kulturhauptstadtjahres werden die Weichen für ein populäreres

39 | Vgl. dazu die Denkschrift Zollverein 2010.

40 | Vgl. www.folkwang-uni.de/.

41 | Herrmann Marth (geb. 1953), seit 2008 Vorstandsvorsitzender der Stiftung Zollverein, vorher Vorstand der RAG Immobilien GmbH, vgl. auch www.zollverein.de/\#/welterbe/ stiftung-zollverein/team. 
Zollverein gestellt, das sich im Veranstaltungsbereich auf ein breiteres Publikum einstellt.

\section{Konsequenzen aus der Lösung}

Das SANAA-Gebäude ist durch sein Erscheinungsbild und der Platzierung im Gesamtareal ein Gebäude mit hoher Attraktivität, dass ein hohes Maß an Aufmerksamkeit auf sich zieht, aber auch polarisiert, denn von der Bevölkerung der umliegenden Stadtteile wird das Gebäude kritisch gesehen.

Die Folkwang Hochschule wird mit ihren Studenten eine entsprechende Infrastruktur benötigen. Es wird erwartet, dass das studentische Leben sich nachhaltig auf das Leben in den Stadtteilen auswirkt und die Anbindung an Zollverein fördert, d.h. eine entsprechende Zimmervermietungen, Läden, Gastronomie usw. werden sich entwickeln. Maßnahmen, die weg von einem Inseldasein Zollvereins führen, wären somit eingeleitet bzw. und vollzogen.

\subsection{Muster: Arbeiten unter Denkmalschutz}

\section{Kontext}

Zollverein ist Aushängeschild und Chance für viele Firmen, allerdings ergeben sich unter den Auflagen des Denkmalschutzes immer wieder Probleme. So wird beispielsweise oft über die Art und die Typographie der Beschilderung auf dem Gelände diskutiert und eine einvernehmliche Lösung dazu steht offenbar nach wie vor aus. Es ist also Kreativität, Einfallsreichtum und Improvisationstalent gefragt, wenn man effektiv und schnell auf dem Areal gefunden werden möchte.

Die Mitarbeiter eines kleinen Grafikbüros erweisen sich in diesem Punkt als sehr erfinderisch. Kündigen sich Kunden an, stellen sie einfach einen roten Blecheimer vor die Tür ihres Eingangs und werden so deutlich leichter gefunden. Nach dem Eintreffen des Besuches wird das Hilfsutensil umgehend wieder entfernt. Mit jeder Nutzung des Eimers, weist man gleichsam auch auf die Notwendigkeit einer wirksamen Beschilderung hin.

\section{Herausforderung}

Die Herausforderung war und ist, ein Konzept zu finden, das es erlaubt, einerseits den Stiftungszweck der Stiftung Zollverein und andererseits die Auflagen des Denkmalschutzes zu erfüllen, sowie die damit verbundenen Fördergelder sinnvoll einzusetzen. Die Lösung liegt einerseits in vielen Kompromissen, andererseits müssen Nutzer, Planer und Denkmalschützer nach neuen Möglichkeiten suchen, um den verschiedenen Anforderungen gerecht zu werden.

Da der Stiftungszweck sehr vielfältig ist, sich gelegentlich sogar schwer vereinen lässt (Erhaltung versus Wiedernutzbarmachung) und Raum für Interpretationen bietet, können nur in begrenztem Maße bisher anderswo erworbenen Erfahrungen in Bezug auf die Einhaltung des Denkmalschutzes auf Zollverein 
umgesetzt werden. Für alles andere muss nach kreativen, praktikablen Lösungen gesucht, manchmal sogar darum gerungen werden.

\section{Lösung}

Die Beteiligten auf dem Standort, die Nutzer, die Besucher und die Mitarbeiterinnen und Mitarbeiter der Stiftung Zollverein finden ihre eigenen, spezifischen Lösungen und häufig bestehen diese zunächst aus dem Versuch, eine unkonventionelle Herangehensweise zu wählen (roter Eimer als Orientierungshilfe). In der Folge werden entweder die neuen Vorgehensweisen akzeptiert und verstetigen sich im Laufe der Zeit sogar oder sie scheitern weil sie im Rahmen der geltenden Regeln und Vorschriften gänzlich unhaltbar sind.

Für den Besucher werden touristische Hinweise auf Schildern geschaffen, die dem Denkmalschutz entsprechen, die aber häufig nicht ausreichend im Hinblick auf Sichtbarkeit und Informationsgehalt sind. Darüber hinaus hat man im Jahr der Kulturhauptstadt beispielsweise Sondergenehmigungen für das Aufstellen von Imbisswagen erwirkt, an denen preiswerte Verpflegungsmöglichkeiten bestehen. So wird versucht, besser auf die Bedürfnisse von Besuchern einzugehen. Die Anstellung von Pförtnern hilft, Besucherströme zu lenken.

Für die Mitarbeitenden der Stiftung in den Hallen, die ursprünglich für Maschinen gebaut worden sind, ist es manchmal nicht einfach, einen guten Kompromiss zwischen dem Erhalt der Gebäude, der Sichtbarkeit ihrer ursprünglichen Funktion und den Anforderungen an ein modernes Büro zu finden. Als Beispiel sei hier der Sonnenschutz an den großen Fenstern erwähnt: Laut Denkmalschutz dürfen die Fenster nicht verhängt und damit das Gesamtbild der Hallen nach außen verändert werden. Da es für Mitarbeitenden aber unmöglich ist, bei Sonnenschein den Bildschirm ihres Computers abzulesen, hat man sich darauf geeinigt, Sonnenrollos anzubringen, die nach außen durch ihre netzartige Struktur möglichst wenig zu sehen sind. Diejenigen Mitarbeiter, die bisher nicht in den Genuss solcher Rollos gekommen sind, beginnen, nach eigenen Lösungen zu suchen, die keine Rücksicht auf den Denkmalschutz nehmen, dafür aber einen Sonnenschutz bieten: z.B. hängen sie Plakate zwischen die Fenster.

\section{Konsequenzen aus der Lösung}

Die manchmal nicht mit dem Denkmalschutz konformen Lösungen sind aus der Not geborene »kreative« Lösungen, um den Alltag auf Zollverein zu bestehen und seinen heutigen Anforderungen gerecht zu werden. Da sich Zollverein auch weiterhin in einem Entwicklungsprozess befindet, wird es immer wieder Unterschiede zwischen den Auflagen des Denkmalschutzes und deren Auslegung für eine heutige Nutzung der Flächen und Gebäude geben. Lösungen dafür müssen immer wieder gesucht und ausgehandelt werden. 


\subsection{Muster: Gegensätze zulassen}

\section{Kontext}

Zollverein soll ein Designstandort werden. So wird es in der Denkschrift Zollverein 2010 beschrieben, die die Internationale Bauausstellung Emscher Park 1999 für Zollverein entworfen hat: »Für die nächste 10jährige Entwicklungsperiode gilt es, die großen Entwicklungschancen mit neuen und aufsehenerregenden Projekten zu besetzen und dazu eine leistungsfähige Betriebsform zu geben $[. ..] \ll^{42}$ und »Die Plattform Design und die Interform Weltausstellungen sollen den Standort so attraktiv machen, dass Unternehmen von außerhalb ins Ruhrgebiet nach Zollverein gehen. « $^{43}$

\section{Herausforderung}

Das Areal des Weltkulturerbes Zollverein erscheint nach der Schließung der Schachtanlage und der Kokerei wie eine Insel in mitten der traditionellen Arbeiter-Stadtteile des Essener Nordens. Die Stadtteilbewohner haben lange Zeit vom Bergbau gelebt und die Zeche Zollverein bildete den Existenzmittelpunkt. Wie ist es möglich das neue Zollverein, das von einem Bergbaustandort sukzessive in einen Designstandort umgewandelt werden soll, in dieses tradierte Umfeld zu integrieren?

Daraus ergeben sich die zwei Herausforderungen für die Entwicklung des Standortes:

1. Die Stadtteilbewohner müssen das alte, ehemals abgeschlossene Gelände für sich entdecken und nutzen.

2. Das Areal muss als Designstandort erschlossen werden, darf damit aber nicht überfrachtet werden.

Die Exklusivität, die der Standort vermittelt, wirkt auf die Anwohner und Nachbarn befremdlich. Das Interesse der ehemaligen Bergleute und Familien mit Zuwanderungsgeschichte (z.B. für Preisverleihungen im Designbereich oder modernen Tanz) scheint gering. Auf der Suche nach einer Balance zwischen Popularität und Exklusivität drängen auch die Städteplaner im Essener Rathaus auf mehr Integration und Vernetzung des Welterbes mit den anliegenden Stadtteilen.

\section{Lösung}

Um den Standort Zollverein für die Bevölkerung der umliegenden Stadtteile aktiv zu öffnen, wird im September jeden Jahres ein großes Zechenfest organisiert, das regen Zuspruch findet. Das Kulturhauptstadtjahr hat die Popularität Zollvereins

42 | Internationale Bauausstellung Emscher Park (1999): Denkschrift Zollverein 2010. Impulse für die Fortentwicklung des Zukunftsstandortes Zollverein. S. 10.

43 | Ebd. S. 48. 
national und international noch gesteigert. Zusätzlich wird der enge Fokus auf das Thema Design dadurch erweitert, dass die Kreativwirtschaft in Gänze eine Plattform auf Zollverein erhält. Dazu gehören Bereiche wie: Musikwirtschaft, Buchmarkt, Kunstmarkt, Filmwirtschaft, Rundfunkwirtschaft, Markt für darstellende Künste, Designwirtschaft, Architekturmarkt, Pressemarkt, Werbemarkt sowie Software- und Games-Industrie. Mittlerweile gehören auch innovativ orientierte Ingenieurbüros und eine medizinische Forschungseinrichtung zu den Nutzern von Zollverein. Essens »Kreative Klasse Ruhr« ${ }^{44}$ wird drei Mal hintereinander ${ }^{45}$ eingeladen, um auf Zollverein zu präsentieren und sich zu feiern.

\section{Konsequenzen aus der Lösung}

Der Balanceakt zwischen Popularität und Exklusivität muss ständig neu ausgelotet werden. Das Extremum zwischen der ehemals menschenfeindlichen Arbeitskathedrale und dem heutigen Ort für modernste kulturelle Entwicklungen, unterstreicht die Faszination, die von Zollverein ausgeht. Das verbindende Element scheint dabei die Show zu sein. Schon die Architektur der damaligen Zeche sollte eine weitgehend automatisierte und menschenfreie Schachtanlage zeigen und damit beeindrucken. Heute bedienen sich Veranstalter und Künstler dieser Kulisse, um ihre Projekte zu inszenieren. Dazu kommen zahlreiche Firmen, sie nutzen Zollverein für Workshops, Veranstaltungen und auch als Ort für Firmenevents. Die Geschäftswelt scheint sich auf Zollverein wohlzufühlen und sich dort gerne zu feiern. ${ }^{46}$

$\mathrm{Ob}$ die Begeisterung für den heutigen Standort Zollverein auch auf die Bevölkerung der umliegenden Stadtteile überspringt, ist weiterhin abzuwarten. ${ }^{47}$ Vermutlich findet eine Integration des Welterbes Zollverein erst dann statt, wenn die Nachbarschaft unmittelbar wirtschaftlichen Nutzen daraus ziehen kann, wie zum Beispiel durch die Ansiedlung von Kiosken, Restaurants, Copyshops, Kneipen, Cafés etc.

\subsection{Muster: Den Mythos pflegen}

\section{Kontext}

Die Zeche Zollverein gilt in den zoer Jahren des letzten Jahrhunderts als die größte, modernste, leistungsfähigste und schönste Zeche der Welt. Der Erfolg

44 | Vgl. www.kreativeklasseruhr.de/.

45 | In den Jahren: 2007, 2008 und 2009.

46 | In den Jahren 2009 und 2010 erhielt Zollverein den sog. Conga Award (www.conga-award.de). Darüber hinaus ist Zollverein bei Privatpersonen als Hochzeitsstandort populär.

47 | Inzwischen gibt es ein soziales Projekt (seit 2012), das die Integration und Akzeptanz des Welterbes in den angrenzenden Stadtteilen fördern bzw. erhöhen soll: vgl www.zollverein.de/\#/business/standortentwicklung-und-betrieb/welterbe-zollverein-mittendrin. 
beruht auf einer effizienten Ablauforganisation von maschinell vollzogenen Produktionsschritten in bis dato unbekannter Dimension. Durch die Automatisierung wirkt die Anlage selbst bei Hochbetrieb menschenleer. Während unter Tage rund 8.700 Bergleute arbeiten, sind in den Hallen über Tage lediglich circa 200 Menschen tätig. Die Anlage wird 1962 durch die Inbetriebnahme der seinerzeit größten Zentralkokerei Europas erweitert. Die von Fritz Schupp ${ }^{48}$ geplante Anlage vereinigt somit die Steinkohlenförderung und die Koksproduktion an einem Standort. Sechs Jahre nach der Zechenstilllegung wird 1993 auch die Zentralkokerei stillgelegt.

\section{Herausforderung}

Wie kann Zollverein als Mythos weiterhin gelebt und belebt werden?

\section{Lösung}

Nach der Schließung des Bergwerks 1986 wird das scheinbar Unmögliche zur Realität: Die Zeche Zollverein entwickelt sich zum Vorzeigeprojekt für den Strukturwandel im Ruhrgebiet. Ab 1989 leistet die Bauhütte Pionierarbeit ${ }^{49}$ und richtet innerhalb der folgenden zehn Jahre einen Großteil der Gebäude von Schacht XII wieder her. Weitere Impulse enthält Zollverein durch die Internationale Bauausstellung Emscher Park, den Masterplan des renommierten Architekten Rem Koolhaas und durch Fördergelder der Europäischen Union. Ein weiterer Meilenstein, die den neuen Mythos Zollverein festigt, ist die Ernennung zum UNESCO Weltkulturerbe im Jahre 2001.

Der Mythos Zollverein wirkt anziehend und verfügt über eine enorme Ausstrahlung. Besonders Künstler und Kleinunternehmer siedeln sich auf dem Standort an, dabei ist niemand rein zufällig dort. In Befragungen und Interviews wird das Thema Mythos Zollverein sehr persönlich und emotional kommentiert:

"Zollverein ist mein Leben[...]", "Ich bin die Hüterin von Zollverein[...]", "Ich wurde mit stillgelegt[...].$^{50}$

Zollverein scheint mehr zu sein, als nur ein austausuchbarer Ort für eine Arbeitsstätte oder ein Atelier. Viele der Befragten verwirklichen an diesem und durch diesen originellen Standort ein Stück ihres Lebenstraums. Wie Hofhunde achten

48 | Dt. Architekt (1896-1974): vgl. dazu Busch, Wilhelm/Scheer, Thorsten (Hg.) (2002): Symmetrie und Symbol. Die Industriearchitektur von Fritz Schupp und Martin Kremmer. Köln.

49 | Siehe Muster: Pioniergeist entwickeln.

50 | Zitierte Aussagen von Interviewpartnerinnen und -partnern während der Datenerhebung. 
sie darauf, dass der Mythos des Standortes möglichst unverändert erhalten bleibt oder sogar noch gesteigert wird.

\section{Konsequenzen aus der Lösung}

Der Mythos Zollverein lebt aufgrund dieser emotionalen Bindungen und der Vielfältigkeit der Nutzer mit ihren Ideen und Aktivitäten. Bedeutsam ist dabei auch die Ausgewogenheit der Unternehmer, der Künstler und der Kulturbetriebe am Standort. Daher ist anzunehmen, dass eine zu einseitige Ausrichtung in der Nutzung - etwa nur museal oder als Designstandort - die Faszination und damit den >Mythos Zollverein< verblassen liesse.

\section{ZuSAMmENFASSUng: InNOVATIONSPOTENTIALE AUf Zollverein}

Bereits im September 2006 hat sich eine wissenschaftliche Studie mit Innovationskulturen im Ruhrgebiet und in anderen europäischen Regionen beschäftigt. ${ }^{51}$ Demnach sind innovative Räume durch die folgenden Faktoren gekennzeichnet: ${ }^{52}$

- Inhomogenität der Kulturen (in ausgewogenem Verhältnis) => Vielzahl von Impulsen => Eigendynamik und Offenheit, die Neues hervorbringt

- Zukunftsorientierung => konkrete Bezugspunkte untereinander, Symbole, Identitätsprofile $=$ Versprechen auf eine gute Zukunft

- freier Austausch von Wissen

- unterschiedliche Formen der Interaktion wie Vertrauen, aber auch Konflikt und Wettbewerb

- hohes Maß an Toleranz

- Basis für gemeinsame Lernprozesse $=>$ Balance finden zwischen interner gemeinsamer Strategie, Vernetzung und Offenheit für Entwicklungen und Impulse von außen

Wendet man diese Kriterien heute auf Zollverein an, zeigt sich, dass eine Diagnose durch das hohe Maß an Komplexität der Beziehungen, Verflechtungen und aus der Historie herauswirkenden Einflüsse erschwert wird. D.h., die genannten Kriterien waren in Teilen zu verschieden Zeiten der Entwicklung des Standortes mehr oder weniger erkennbar, sind aber nicht allesamt zur selben Zeit in gleichem Ausmaß aufgetreten. Es ist nach den hier gezeigten Ergebnissen anzunehmen,

51 | Vgl. Grote-Westrick, Dagmar; Rehfeld, Dieter (2006): Innovationskulturen im Ruhrgebiet?! Studie für das Ministerium für Wirtschaft, Mittelstand, Energie und Verkehr in NRW. 52 | Vgl. Pantel, Paul: Jenseits von Clustern und Technologien, Innovative Räume, in: Magazin der Gesellschaft für innovative Beschäftigungsförderung des Landes NRW, Februar 2010, S. 19. 
dass insbesondere in der Anfangsphase der Besiedlung des Areals diese Merkmale deutlicher hervortraten. Innovationsprozesse finden bzw. fanden auf Zollverein an unterschiedlichen Orten, zu unterschiedlichen Zeiten, in unterschiedlichem Tempo und in unterschiedlichen inhaltlichen Kontexten statt. Einzelne Teileinheiten (Nutzer) sind daher durchaus in der Lage, Innovationen in ihrem Segment, ihrer Branche hervorzubringen. Dies steht jedoch nicht in einem unmittelbaren Zusammenhang mit dem Innovationspotenzial des Standortes an sich.

Der Standort Zollverein, dessen Weiterentwicklung und Profilierung, ist an Förderprogramme bzw. an eine externe Finanzierungen gebunden. In Folge der daraus resultierenden Aktivität(en) auf dem Standort und der passend ausgewählten Namen, Inhalte und Formate, erscheint dieser innovativ bzw. wird als fortschrittlich wahrgenommen. Optionen in Richtung Umnutzung, Neuansiedlung und kultureller Wiederbelebung sind mit öffentlichen Fördermitteln vorangetrieben worden. Demnach haben sich Prosperität und Fortschritt nicht aus einer am Standort vorhandenen Innovationskraft oder innovationsförderlichen Organisationskultur heraus entwickelt. Die Fortentwicklung ist vielmehr ein Vorgang, der im Wesentlichen aus externen Ressourcen gespeist wurde. Prosperität bedeutet hier Ansiedlung von Unternehmen, Kulturbetrieben und anderen Nutzern, und die Auslastung der sanierten Liegenschaften sowie eine möglichst hohe Besucherfluktuation $^{53}$. Fortschritt meint im Sinne der Ziele der Stiftung Zollverein im Wesentlichen die fortschreitende Umnutzung der ehemaligen Zechenanlagen bzw. Flächen und Gebäude; also die wirtschaftliche Verwertung (Sanierung und Vermietung).

Dennoch kann Zollverein als potentiell innovativer Kern bezeichnet werden. Rehfeld ${ }^{54}$ beschreibt den Zustand des Standortes dahingehend so: »Noch ist es [Zollverein] politisch organisiert, noch hat sich keine Eigendynamik entwickelt, noch gibt es keine Treiber, die das Thema Kreativität bzw. Design in das Denken der Menschen dort [angrenzende Stadtteile] hineingebracht haben. $\ll^{55}$

Trotzdem es scheinbar an (personifizierten) Treibern mangelt, kann davon ausgegangen werden, dass Zollverein als altes und neues Symbol für Prosperität, wirtschaftlichen Erfolg, Größe und Macht, die Akteure am Standort und die Menschen weit darüber hinaus inspiriert. Nicht zuletzt die Architektur und die darin zu findenden palastartigen Muster in der Art eines Bergwerks à la Metropolis, scheinen unterschwellig weiter zu wirken. Zugleich ist Zollverein ein interessanter Ort für mannigfaltige Aktivitäten und im Besonderen attraktiv für kleinere

53 | Diese Kriterien werden gemessen und in entsprechenden Publikationen veröffentlicht. Sie sind demnach auch Indikatoren des Erfolges bzw. Misserfolges und dienen der Legitimierung.

54 | PD Dr. Dieter Rehfeld, Direktor des Forschungsschwerpunktes Innovation, Raum \& Kultur beim Institut Arbeit und Technik der Westfälischen Hochschule in Gelsenkirchen. (www.iat.eu).

55 | Ebd. S. 21. 
Unternehmen. Zollverein verträgt aber auch große Formate, und hat im Rahmen der kulturellen Bespielung die Trendführerschaft unter den Industriedenkmälern bzw. den neu erschlossenen und >umgenutzten<, ehemaligen Standorten der Montanindustrie im Ruhrgebiet übernommen. Diese treibende Kraft scheint den >Mythos von Zollverein auszumachen, und ebenfalls die Menschen, die von diesem Mythos fasziniert sind.

\section{Die aktuelle Situation (von Delia Bösch)}

Die Studie zur Organisationskultur auf Zollverein bezieht sich auf den Untersuchungszeitraum 2008 bis 2011. Bis zum Erscheinungstermin als Buchbeitrag ist auf dem UNESCO-Welterbe Zollverein viel passiert: auf der baulich-planerischen Ebene, organisatorisch-strukturell und medial-kommunikativ.

\section{Die baulich-planerische Ebene}

Mit dem Kulturhauptstadtjahr RUHR.2010 und der Eröffnung des Ruhr Museums, sowie des Besucherzentrums in der umgebauten Kohlenwäsche, war die Erschließung der ehemaligen Schachtanlage XII als touristisches Zentrum im Wesentlichen abgeschlossen. Seit 2011 treibt die Stiftung Zollverein unter dem Arbeitstitel ZOLLVEREIN 2020! federführend die Entwicklung der Kokerei Zollverein voran und unterstützt ihren Partner, die NRW.URBAN, bei der Entwicklung der ehemaligen Schachtanlage 1/2/8. Im Jahr 2014 war der Durchbruch mit wichtigen Partnern geschafft.

Der erste Spatenstich für den Umbau der denkmalgeschützten Sauger- und Kompressorenhalle auf der Kokerei Zollverein zu einer Veranstaltungshalle für bis zu 2.500 Personen fand im Mai 2014 statt. Bauherr und Betreiber der EventLocation ist eine private Investorengemeinschaft. Im Herbst 2014 fiel der Startschuss für zwei neue Großprojekte: Bis Sommer 2017 wird auf einem ehemaligen Materiallagerplatz auf Schacht 1/2/8 der Neubau für den Fachbereich Gestaltung der Folkwang Universität der Künste errichtet. Außerdem soll bis Ende 2017 ein Hotelneubau bezugsfähig sein. 2015 steht ein weiterer Spatenstich für den neuen Unternehmenssitz der RAG AG an der Peripherie des Kokerei-Areals an; Bauherr ist die RAG Montan Immobilien GmbH. Das private Investitionsvolumen für die nächsten Jahre beläuft sich auf rund 150 Mio. Euro. Insgesamt entstehen durch die Neuansiedlungen und Projekte bis zu 1.000 Arbeitsplätze. Mit dem Ausbau des Standortes zu einem Wirtschaftsstandort und Bildungscampus sollen die umliegenden Stadtteile von der positiven Ausstrahlung Zollvereins weiter profitieren. 


\section{Die organisatorisch-strukturelle Ebene}

Bei der Stiftung Zollverein haben sich die Verantwortlichkeiten verändert. Hermann Marth ist seit Mitte 2008 Vorstandsvorsitzender der Stiftung Zollverein und führt gemeinsam mit Jolanta Nölle, Mitglied des Vorstands, die Geschäfte der Stiftung. Zudem ist die Stiftung Zollverein seit 2010 Eigentümerin sämtlicher Liegenschaften im Zentralbereich der ehemaligen Zeche und Kokerei Zollverein.

Seit der Kulturhauptstadt Europas RUHR.2010 setzt die Stiftung den Fokus auf langfristige und kurzfristige Vermietungen der im Stiftungsbesitz befindlichen Immobilien sowie auf die buchbaren Führungsangebote des Denkmalpfad ZOLLVEREIN®. Im Jahr 2014 haben 150.000 Besucher an einer geführten Tour im Denkmalpfad ZOLLVEREIN@ teilgenommen. Zur Auswahl stehen 28 verschiedene Führungsformate und 9 Sprachen. 110 ausgebildete Gästeführer begleiten pro Monat mehr als 800 Führungen. Seit 2011 haben sich die Besucherzahlen auf 1,5 Mio. jährlich gefestigt, Tendenz steigend.

\section{Die medial-kommunikative Ebene}

Mit neuen Kommunikationsstrukturen und -medien hat die Stiftung Zollverein eine aktive und offene Kommunikationskultur etabliert, die praktische und inhaltliche Bedarfe der verschiedenen Akteure und Zielgruppen berücksichtigt.

Zollverein Convention: Der Zusammenschluss aller Location-Anbieter auf Zollverein trifft sich auf Einladung der Stiftung seit 2013 monatlich zum Informationsaustausch und zur Planung gemeinsamer Marketing-Aktivitäten, darunter Messeauftritte und Publikationen - wie der 2015 eingeführte Convention-Newsletter.

Akteurstreffen: Seit 2012 initiiert und moderiert die Stiftung den Informationsaustausch durch regelmäßige Treffen für alle Akteure, Mieter, Institutionen, Firmenvertreter auf Zollverein.

Zollverein mittendrin: Zur Stärkung der nachbarschaftlichen Beziehungen mit den umliegenden Stadtteilen im >Stadtbezirk VI - Zollverein< initiiert und realisiert das bei der Stiftung Zollverein angesiedelte Projekt >Zollverein mittendrin< seit 2012 verschiedene Projekte und Maßnahmen in den Bereichen Kunst, Kultur und Bildung. Das von der RAG-Stiftung geförderte Projekt wurde Anfang 2015 bis zum Jahr 2018 verlängert.

Zollverein. Das Magazin. Das kostenlose Standortmagazin mit Dreimonatsprogramm und journalistisch aufbereiteten Berichten zu touristischen Themen erscheint seit 01/2014 quartalsweise in Public Private Partnership mit einem Essener Verlags- und Redaktionsbüro in einer Auflage von 80.000 Exemplaren. Es liegt auf dem Standort aus und wird darüber hinaus anlass- und zielgruppen- 
orientiert per Post- und Mehrfachversand sowie per Briefkasteneinwurf in den Anliegerstraßen und in ausgewählten, wechselnden Stadtteilen in Essen distribuiert.

Tätigkeitsbericht. Die jährliche Publikation der Stiftung erscheint seit 2014. Sie informiert über die wichtigsten Ereignisse und Projekte und gibt einen Überblick über künftige Entwicklungen auf dem UNESCO-Welterbe Zollverein.

Facebook. Für die schnelle und direkte Information nutzt die Stiftung seit 2013 Social Media-Kanäle. Auf Facebook hat die >Zeche Zollverein< inzwischen mehr als 24.000 Fans (Stand: Juli 2015).

\section{LITERATUR}

Alexander, C.; Ishikawa, S.; Silverstein, M. \& Jacobson, M. (1977): A Pattern Language. Towns, buildings, construction. New York, Oxford University Press.

Bluszcz, O.; Vossebrecher, D. \& Humpert G. (2011): Neue Innovationsstrategien durch musikalisches Denken. In: Heike Jakobsen, Burkhard Schallock (Hg.), Innovationsstrategien jenseits traditionellen Managements. Wissenschaftliche und praktische Ergebnisse des Förderschwerpunktes. Stuttgart: Fraunhofer IRB Verlag, 280-288.

Ganzelewski, M. \& Slotta, R. (2000): Die Denkmal-Landschaft »Zeche Zollverein«. Eine Steinkohlenzeche als Weltkulturerbe?! Bochum: Deutsches Bergbau-Museum.

Grote-Westrick, D. \& Rehfeld, D. (2006): Innovationskulturen im Ruhrgebiet?! Studie für das Ministerium für Wirtschaft, Mittelstand, Energie und Verkehr in NRW.

Internationale Bauausstellung Emscher Park (1999): Denkschrift Zollverein 2010. Impulse für die Fortentwicklung des Zukunftsstandortes Zollverein.

Pantel, P. (2010): Jenseits von Clustern und Technologien. In: Magazin der Gesellschaft für innovative Beschäftigungsförderung des Landes NRW, Februar 2010, 19 .

Schein, E. H. (1991): Organizational Culture and Leadership. A Dynamic View. San Francisco, Jossey-Bass.

Stark, W. (2017): Innovationsmuster und Improvisation in Organisationen. Musikalische Muster impliziten Wissens als Schlüssel für innovative Prozesse. In: Stark, Wolfgang, Vossebrecher, David, Dell Christopher \& Schmidhuber, Holger (2017): Improvisation und Organisation. Muster zur Innovation sozialer Systeme. Bielefeld: transcript.

Strauss, A. \& Corbin, J. (1996): Grounded Theory: Grundlagen qualitativer Sozialforschung. Weinheim, Beltz. 
Strauss, A. (1991): Grundlagen qualitativer Sozialforschung. Datenanalyse und Theoriebildung in der empirischen und soziologischen Forschung. Stuttgart, UTB.

Tiggemann, R. (2007): Zollverein Schacht XII: von der größten Zeche der Welt zum Weltkulturerbe. Essen, Klartext-Verlag

Vanderlinden, B. (Hg.) (2002): Was ist Zollverein? Essen, Entwicklungs-Gesellschaft Zollverein.

Vossebrecher, D.; Bluszcz, O.; Humpert, G. \& Stark, W. (2012): Organisation musikalisch denken: die implizite Dimension des Organisierens entdecken. Arbeit: Zeitschrift für Arbeitsforschung, Arbeitsgestaltung und Arbeitspolitik. 21/2+3, Stuttgart, Lucius \& Lucius, 132-146.

Vossebrecher, D. \& Kamin, T. (2011): Ergebnisse der Organisationskulturanalysen bei der Fuenfwerken Design AG. Projektbericht einer qualitativen Organisationskultur-Analyse im Rahmen des Projekts >Music, Innovation, Corporate Culture< (MICC). Universität Duisburg-Essen.

Vossebrecher, D. (2010): Organisationspartituren als Methode. Präsentation beim Meeting >Methoden und OE-Tools am OrgLab<. Verfügbar unter: http://miccproject.org/?p=821; Zugriff 2011-01-20.

\section{Internet-Links in der Reihenfolge der Erwähnung:}

Zugriff: $24.07 \cdot 2013$

www.leg-nrw.de/

www.ruhrmuseum.de/

http://de.red-dot.org/371.html

www.zollverein.de/\#/angebote/kunstschacht-zollverein-thomas-rother-kunst-aus-

der-bergbaulichen-erinnerung

www.casino-zollverein.de/

www.pact-zollverein.de/

www.zollverein.de/\#/angebote/gefaesse-keramische-arbeiten-von-young-jae-lee www.orglab.de/

www.essen.ihk24.de/

www.ruhrmuseum.de/museum/standort/kohlenwaesche/

www.route-industriekultur.de/besucher-zentrum.html

www.zollverein.de/\#/business/standortentwicklung-und-betrieb/entwicklungs

gesellschaft-zollverein-mbh

www.zollverein.de/\#/angebote/denkmalpfad-zollverein

http://red-dot.org/fileadmin/bilder/Presse/

http://oma.eu/oma

www.general-blumenthal.de/Chronik \%2oGBL.html

www.eabg.essen.de/

www.uni-due.de/ gporo2/denkmal/zeche.htm\#wandel 
www.zollverein.de/\#/angebote/sanaa-gebaeude-events-mit-ein-und-ausblicken www.essen-fuer-das-ruhrgebiet.ruhr2o10.de/

www.chm.de/de/proj_overview.html

http://oma.eu/partners\#RemKoolhaas

http://deu.archinform.net/arch/434.htm

www.hellerenter.ch/

www.linzog.at/

www.folkwang-uni.de/

www.zollverein.de/\#/welterbe/stiftung-zollverein/team

www.kreativeklasseruhr.de/

www.conga-award.de

www.zollverein.de/\#/business/standortentwicklung-und-betrieb/welterbe-zoll verein-mittendrin

www.iat.eu

\section{Bildnachweis/Fotonachweis}

Zollverein Doppelbock, Schacht XII, (C) Jochen Tack/Stiftung Zollverein Zollverein Luftbild, (C) Jochen Tack/Stiftung Zollverein

Appendix: Delia Bösch (2015)/Stiftung Zollverein 


\title{
Innovation und kreatives Denken als Produkt
}

\author{
Organisationskultur als Managementinstrument
}

in Designprozessen

David Vossebrecher und Thorsten Kamin

\section{Organisationskultur, Innovation und die Kreativbranche}

Die in diesem Beitrag präsentierte Organisationskultur-Analyse ist Teil des Forschungsprojekts Music - Innovation - Corporate Culture (MICC) ${ }^{1}$, das Möglichkeiten untersucht und entwickelt, mit Hilfe von Musik und mittels eines musikalischen Verständnisses von Organisationen deren Innovationsfähigkeit zur erhöhen, zur Weiterentwicklung von Innovationsstrategien beizutragen (MICCProjekt 2009) und Management-Innovationen, insbesondere Prozessinnovationen (Bluszcz 2010: 7) anzuregen. In diesem Sinne stehen in den Forschungen weniger strukturelle Merkmale der Organisationen im Vordergrund der Untersuchungen, als vielmehr die Prozesse des Organisierens (Weick 1985) und der organisationalen Performanz selbst. Die gewählte Zugangsweise zu Problemen des Organisierens bzw. der Organisation ist selbst neuartig und innovativ: Der musikalische Ansatz geht von der Frage aus, was sich von Musik lernen und für Organisations-Analysen und Organisations-Entwicklungsmaßnahmen nutzbar machen lässt.

Begonnen wurde mit dem Versuch, eine eins-zu-eins-Vertonung von Unternehmenskulturen zu produzieren und diese als musikalisch-akustisches Diagnose- und Feedbackinstrument einzusetzen. Diese ursprüngliche Idee der musika-

1 | Projekt Music, Innovation, Corporate Culture (MICC) in Federführung des Labor für Organisationsentwicklung (OrgLab) an der Universität Duisburg-Essen (www.orglab.org), unter Beteiligung des Institut für Improvisationstechnologie (IFIT), Berlin (www.ifit.de), sowie vier Organisationen bzw. Unternehmen als Projektpartnern. Projektwebseite: www. micc-project.org. Das Projekt wurde 2009-2011 gefördert im Programmschwerpunkt „Innovationsstrategien jenseits traditionellen Managements" vom Bundesministerium für Bildung und Forschung (BMBF) und vom Europäischen Sozialfonds (ESF). 
lischen Übersetzung der Unternehmenskultur - eine Repräsentation im engen Sinne - hat sich dabei als nicht sinnvoll und umsetzbar erwiesen und wurde zu einer >performativen Modalität hin entwickelt bzw. geöffnet. Das heißt, dass Ereignisse und Prozesse in Organisationen mittels musikalischer Techniken, wie bspw. Formen des Zusammenspiels, die aus der Improvisation kommen oder der Notation mittels Partituren, gespiegelt werden, so dass sich neue Reflexionsmöglichkeiten eröffnen.

Die beteiligte Fuenfwerken Design AG ist im Kommunikationsdesign tätig und hat Büros in Berlin und Wiesbaden. In dieser Agentur fanden qualitative Organisationskultur-Analysen statt, die im MICC-Projekt als empirischer Bezugspunkt für die Entwicklung von Mustern (s.u.) und von praktischen musikalischen Zugängen zu Organisationen genutzt wurden.

\subsection{Organisationskultur}

Die Bedeutung von Organisationskultur für Veränderungsprozesse und Innovationen ist in der Organisationsforschung und -praxis heute unbestritten: Neben den Faktoren Struktur und Strategie ist sie für eine Reihe Dimensionen ausschlaggebend (vgl. Mintzberg et al. 1999). Zu diesen Dimensionen gehören Beziehung und Prozessqualität, Gemeinschaft bzw. >Vergemeinschaftung< und Kohärenz, die Leistung (Performance), sowie das Bild, das nach außen wie nach innen entsteht. Darüber hinaus ist die Kultur einer Organisation mit deren Struktur und Strategie gerade in praktischer Hinsicht eng mit der Gesamterscheinung verbunden. Organisationskultur entsteht und entwickelt sich innerhalb der jeweiligen Strukturen und passt zu ihnen; zumindest zunächst - im Moment der Entstehung einer Organisation (Schein 1991). Andersherum ist die (gravierende) Veränderung von Strukturen ist nur dann erfolgreich, wenn sich die Kultur entsprechend anpasst. Ähnliches gilt für das Verhältnis von Strategie und Kultur.

Trotzdem lässt sich für ein besseres Verständnis die Unterscheidung der drei Komponenten von Organisationen vornehmen (nach Wunderer et al. 1997):

- Die Form des Organisierens beschreibt die Struktur und die Abläufe in einer Organisation, die Art der Hierarchie und die Funktion und Logik der Administration,

- die Strategie bestimmt die Ziele und Ergebnisse einer Organisation und die Frage, wie ökonomische und inhaltliche Werte mit welcher Effizienz (Wirtschaftlichkeit) erzielt werden sollen,

- die Kultur einer Organisation schließlich zeigt Verhaltens- und Handlungsmuster, Formen der Beziehungen zwischen Gruppen und Individuen, beinhaltet (geteilte) Werte und Gebräuche und lässt Rückschlüsse auf Status und Rollen im sozialen System Organisation zu (vgl. Stark \& Dell 2012). 
Die hier genannten Elemente von Organisationskultur gehen auf Schein (1991) zurück, dessen Modell einflussreich, wenn auch vorrangig deskriptiv ist und einige Fragen offen lässt (Vossebrecher et al. 2012). Das Modell beschreibt drei Ebenen, zum einen die Artefakte, das heißt Objekte und Verhaltensweisen, die sichtbar und erlebbar, aber in ihrer Bedeutung nicht leicht zu entziffern sind: Sie müssen interpretiert werden. Zum zweiten die Werthaltungen: offizielle bzw. bekundete Werte (z.B. aus Leitbildern) und nicht-offizielle Werte. Sie sind teils sichtbar, teils der Organisation und ihren Mitgliedern selbst nicht bewusst. Drittens die Basisannahmen der Organisationsmitglieder, dazu zählen bspw. Annahmen hinsichtlich Motivation und menschlicher Aktivität, hinsichtlich Beziehungen zur Umwelt, Annahmen zur Beschaffenheit von Wirklichkeit, Zeit und Raum etc. Sie sind unsichtbar und normalerweise nicht bewusst (Schein 1991). Somit weist das Modell darauf hin, dass Organisationskulturen wesentliche implizite, d.h. nicht sichtbare und den Organisationsmitgliedern nicht unbedingt bewusste Dimension beinhalten.

\subsection{Innovation, Veränderung und die Kreativbranche}

Eine lebendige, authentische Organisationskultur kann aber die Energie und Beweglichkeit, welche für Veränderungsprozesse und Innovationen erforderlich sind, ebenso bereitstellen, wie sie stabilisierende Vergemeinschaftungsprozesse stützen kann. Sie ist also ein wichtiger Faktor gerade für KMUs ${ }^{2}$ der Kreativbranche wie die Fuenfwerken Design AG, deren besondere, flache und netzwerkartige Organisationsstrukturen und flexible Arbeitsformen eine entsprechende Kultur benötigen, um dauerhaft erfolgreich zu sein. Hohe Kreativität und entsprechende Flexibilität sind das Kerngeschäft von Fuenfwerken und sind zugleich spezifische Merkmale sowohl der Produkte als auch der Unternehmenskultur. Vergemeinschaftung und Kohärenz innerhalb der Agentur sowie ihre Identität insgesamt sind in hohem Maße über die Kultur vermittelt. Somit hat sie immense praktisch Bedeutung bspw. für die Bindung von Mitarbeiterinnen und Mitarbeitern und für Veränderungsprozesse in der Organisation.

Die Notwendigkeit zu quasi permanenter Veränderung ergibt sich aus den komplexer werdenden Umwelten und Kontexten, in denen Unternehmen und Organisationen heute agieren. Netzwerkartige Organisationen von kleiner bis mittlerer Größe sind angesichts der Herausforderungen, die sich aus der Komplexität und Unberechenbarkeit ergeben, auf weiche Faktoren wie Vergemeinschaftung (community-building) und entsprechende Organisationskulturen angewiesen. Rein rationale Strategien funktionieren nur noch in sehr engen Grenzen und laufen potentiell ins Leere (vgl. Dell \& Stark 2013).

2 | KMU = Kleine und mittlere Unternehmen (in der Regel bis zu 250 Mitarbeiter) mit einem Umsatz unter 50 Mio. 


\section{Charakteristika der Design-Agentur Fuenfwerken}

Fuenfwerken ist eine Agentur für Design und Kommunikation. Fuenfwerken unterstützt ihre Auftraggeber bei der Weiterentwicklung ihrer Identität in den Bereichen Marke, Corporate Design oder Unternehmenskommunikation, z.B. durch Publishing-Projekte, Messeauftritte oder Online-Präsenzen. Mit außergewöhnlichen Konzepten, herausragendem Design und individueller Beratung. Zusammengefasst sind die Ziele der Agentur: Nachhaltige Lösungen entwickeln und Werte schaffen - wirtschaftliche und weiche. Fuenfwerken wurde 1997 in Wiesbaden gegründet, und existiert seit 2001 als Fuenfwerken Design AG. 2002 kam der Standort Berlin hinzu. In Deutschland zählt Fuenfwerken zu den bekanntesten Beratungs- und Designagenturen. Ihre Projekte werden regelmäßig mit nationalen und internationalen Preisen ausgezeichnet.

Grundsätzlich ist Fuenfwerken projektorientiert organisiert. Dies wird in Abbildung 1 verdeutlicht, in der eine beispielhafte Organisation in einem Projekt dargestellt ist: Mitarbeiter und Vorstand werden je nach notwendigen Qualifikationen und Rollen im Projekt zu einem Team zusammengezogen. Es gibt bei Fuenfwerken keine kundenspezifischen Teams, d.h. es gibt keine Mitarbeiter, die ausschließlich für ein und denselben Kunden arbeiten und ausschließlich für diesen Kunden Lösungen entwickeln. Daraus ergibt sich für die Mitarbeiter im Kreativbereich die Herausforderung, in immer neuen Umfeldern, in immer neuen Zusammenhängen, Branchen kreative Lösungen zu entwickeln. Dieses zum Teil auch parallele Bearbeiten in verschiedenen Projekten für verschiedene Kunden wird von den Mitarbeitern als kreative Herausforderung empfunden, die sie auch bewusst bei Fuenfwerken suchen. Für Fuenfwerken ist diese Herangehensweise gleichzeitig ein strategisches Mittel, um sicherzustellen, dass die kreativen Lösungen der Agentur mit den unterschiedlichsten Einflüssen und Denkweisen konzipiert werden können. Neueres Beispiel dafür ist die Verbindung von visuellgraphischem Design und Musik in Form des >systematischen Designs $<$. Diese Arbeitsweise ist für Fuenfwerken Innovationsstrategie (d.h. Methode, Innovationen hervorzubringen); zugleich steckt in den auf diese Weise entwickelten Designs Innovationspotential für die Auftraggeber und Kunden.

Die Projektteams werden individuell zusammengestellt: Abhängig von der zu beantwortenden Kundenherausforderung werden die Projektteams mit Experten besetzt, die für dieses spezielle Problem die meisten Erfahrungen mitbringen aber auch Mitarbeitern, die Lösungen aus ganz anderen Umfeldern einbringen können (Design Thinking ${ }^{3}$ ). Über diese interdisziplinären Teams, die zum Teil auch mit externen Partnern besetzt werden, ergibt sich ein bewusst gesuchtes Lösungs- und Innovationspotential. Dieses wird zudem durch einen Lösungsprozess unterstützt, der zu Beginn sehr große kreative Freiheit erlaubt und sich erst

3 | Siehe beispielsweise auch den Ansatz der HPI School of Design Thinking (www.hpi.unipotsdam.de). 
im Laufe der Lösungsfindung in konzentrischen Kreisen und mit der Entwicklung diverser Prototypen auf eine beste Lösung hin entwickelt (iterative Herangehensweise).

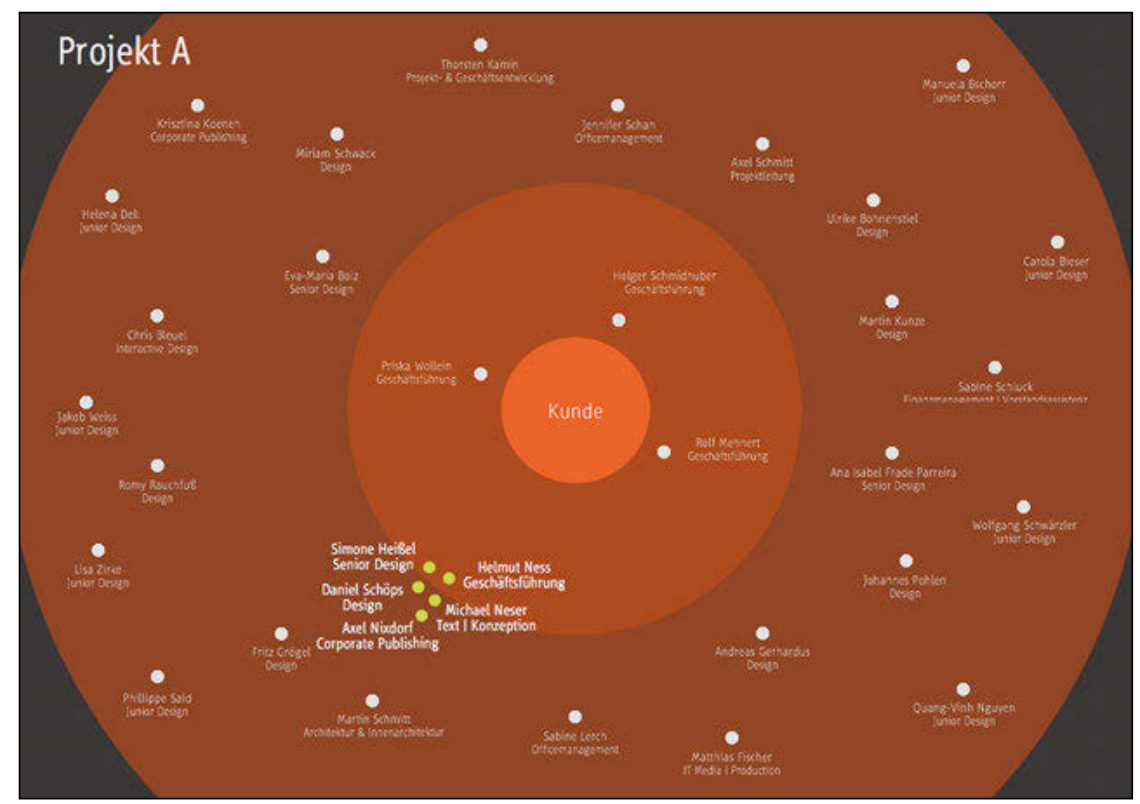

Abbildung 1: Teamorganisation bei Fuenfwerken (Quelle: Fuenfwerken Design AG)

Selbstverständlich gibt es auch bei Fuenfwerken Hierarchieebenen der Zusammenarbeit und Entscheidungsfindung. Hierarchien sind bei Fuenfwerken an sich flach und insgesamt nicht stark ausgeprägt. Das gilt besonders, wenn man auf die Bedeutung der Hierarchiepositionen im Arbeitsalltag schaut, und dieser Sachverhalt wird durch die Kultur der Offenheit noch unterstützt. Die Hierarchieebenen waren zur Zeit der Forschung 2009-2010: Vorstand, Senior Designer, Art Director, Account Director, Junior Designer, Praktikantinnen/Praktikanten. Zudem gehören noch v.a. Texter zur Mitarbeiterschaft und sind entweder auf Ebene des Art Director oder des Senior Designer angesiedelt. Allerdings führt diese Situation auch dazu, dass für länger beschäftigte Mitarbeiterinnen und Mitarbeiter wenige Aufstiegsmöglichkeiten bestehen, weil beispielsweise keine Führungspositionen für Unterabteilungen existieren. ${ }^{4}$

4 | Für weitere Details zu Fuenfwerken siehe Vossebrecher \& Kamin (2011) und www. fuenfwerken.com. 


\section{Fragestellung und Durchführung}

Das Projekt MICC, in dessen Rahmen die hier berichtete OrganisationskulturAnalyse entstanden ist, hat die Möglichkeiten untersucht, mit Hilfe von Musik und mittels eines musikalischen Verständnisses von Organisation zur Erhöhung der Innovationsfähigkeit und zur Weiterentwicklung von Innovationsstrategien beizutragen. Folgende Fragen und Ziele gehen aus dem MICC-Gesamtvorhaben in die Organisationskultur-Analyse von Fuenfwerken ein:

- Die Organisationskultur soll rekonstruiert werden, insbesondere in ihren rein rational und sprachlich kaum zugänglichen, impliziten Elementen (Erfahrungswissen, Praxiswissen, Tacitness, organisationale Muster ${ }^{5}$ ), das heißt also in ihren Tiefendimensionen.

- Organisationale Muster, d.h. wiederkehrende spezifische Handlungsweisen zur Bewältigung organisationaler Herausforderungen, sollen entdeckt und expliziert werden.

- Wie tragen die jeweiligen Organisationskulturen und organisationalen Muster insbesondere zur Innovationsfähigkeit - vorrangig hinsichtlich neuer oder veränderter Prozesse, die zum Erfolg der Organisation beitragen und in die Kultur eingebunden sind (Prozessinnovationen) - der Organisation bei?

Die spezifische Fragestellung der Analyse bei Fuenfwerken richtet sich besonders auf die Kulturmerkmale und die internen Perspektiven der Mitarbeiterinnen und Mitarbeiter. Gerade aus den Forschungsergebnissen zur inneren Kultur wird das Innovationspotential erkennbar, welches die Arbeitsweise von Fuenfwerken für die Kunden birgt. Im Detail wurde - in stark explorativem Vorgehen - nach Folgendem gesucht:

a. Was sind die wichtigen Merkmale der Organisationskultur und wie manifestieren sie sich?

b. Was (und ggf. wer) prägt die Organisationskultur?

c. Ist die Organisationskultur an beiden Standorten gleich?

d. Ist die Organisationskultur ein Teil des Erfolges? In welcher Weise?

e. Wie können notwendige Strukturveränderungen unter Beibehaltung der positiven Elemente der Organisationskultur erfolgen?7

5 | Zu impliziten Mustern vgl. Vossebrecher et al. (2012), Stark und Dell (2012); zu Tacitness vgl. Vossebrecher et al. (2012), Vossebrecher (2017a).

6 | Die Teilfragen (b.) und (c.) werden hier nicht weiter behandelt; zu innen siehe Vossebrecher \& Kamin (2011).

7 | Hintergrund von Frage (e.): Durch die zunehmende Größe der Agentur und die zwei Standorte (Wiesbaden, Berlin) sind Veränderungen in der Organisationsstruktur und in Prozessen erforderlich. 
Die Antworten auf diese Fragen werden hier im Rahmen von drei Fokusbereichen gegeben: Teams und Qualität, Führung, Integration der Mitarbeiter.

In der Untersuchung wurde ein ausschließlich qualitatives Design mit nichtstandardisierten Erhebungs- und Auswertungsmethoden verwendet. In der Erhebung der Daten kamen verschiedene offene Erhebungsverfahren zum Einsatz. Das Ziel, die Tiefendimension der jeweiligen Organisationskultur zu untersuchen, ließe sich mit standardisierten Methoden nicht erreichen (Kühl et al. 2009, Kühl \& Strodtholz 2002, Kaschube 1993 $)^{8}$.

Der Forschungsprozess war iterativ angelegt, d.h. es wurde zwischen Datenerhebung einerseits und der Reflexion über das bereits Erfahrene andererseits gewechselt, um so begründet die nächsten Erhebungsschritte festzulegen. So wurden etwa Entscheidungen, welche Mitglieder des Feldes als nächste interviewt oder welche Situationen teilnehmend beobachtet werden, nicht im Vorfeld, sondern zu fortgeschrittenen Zeitpunkten getroffen. Der Fokus der Untersuchung konnte so - eben iterativ - schrittweise ausdifferenziert werden; dies wird auch als Theoretical Sampling bezeichnet (vgl. Strauss \& Corbin 1996).

Die Erhebung war besonders zentriert auf Perspektiven, Wertungen und das Erleben der Befragten hinsichtlich des Alltags der Organisation wie auch hinsichtlich besonderer Ereignisse. Große Bedeutung wird den Werten und Bewertungen beigemessen, die direkt oder indirekt ausgedrückt werden, und die in der Regel die Begründungen für Handlungen und Entscheidungen gewonnen werden. Für die Untersuchung arbeiteten jeweils ein Mitarbeiter von Fuenfwerken und des Teams der Universität Duisburg-Essen in einer regelmäßigen und engen Kollaboration zusammen. Somit trafen also die Perspektiven von >Insidern und >Outsidern< des organisationalen Geschehens aufeinander und konnten sich gegenseitig produktiv ergänzen.

In der Erhebung der Daten kamen eine Reihe von in der Organisationsanalyse gebräuchlichen, offenen Erhebungsverfahren zum Einsatz (zu Methoden der Organisationsforschung vgl. Kühl et al. 2009). Zusätzlich wurden MICC-eigene $>$ musikalische< Methoden, die >Organisationspartituren< und >Gesprächskonzerte (Vossebrecher \& Stark 2009), verwendet. Zum Einsatz kamen:

- Zehn teilstandardisierte, leitfadengestützte Interviews mit Mitarbeiterinnen und Mitarbeitern und der Führungsebene beider Standorte, orientiert am problemzentrierten Interview (Witzel 2000). Die Interviews dauerten jeweils ca. eine Stunde und wurden zur Auswertung transkribiert.

- Kurze teilnehmende Beobachtungen durch den Mitarbeiter des Uni-Teams (Outsider-Perspektive) bei den jeweils ein- oder zweitägigen Feldaufenthalten statt, in deren Rahmen auch die Interviews geführt wurden.

- Analysen von Dokumente aus der Organisation Fuenfwerken.

8 | Generelle Schwierigkeiten, Organisationskulturen zu untersuchen, diskutieren auch Nerdinger (2007), Osterloh (1988). 
- Drei Gruppen-Interviews, die Teil der Generierung von Patterns waren. Dabei handelt es sich um Autorenwerkstätten (Writer's Workshops)'.

- In Organisationspartituren-Workshops werden die Teilnehmenden aufgefordert, sich ihre Organisation oder Elemente und Prozesse derselben als musikalische Phänomene und als musikalischen Verlauf vorzustellen (>musikalisches Denken $<$ ) und dann - in Orientierung an den Partituren der Neuen Musik aus der Mitte des 20. Jhdt. - zu Papier zu bringen (Vossebrecher et al. 2012; Vossebrecher 2010). Auf diese Weise sind vierzehn Organisationspartituren entstanden; eine fünfzehnte entstand als Arbeit eines der Vorstände.

- Foto: Von alläglichen Situationen und Interaktionen sowie von der räumlichbaulichen Situation, Ausstattung etc. entstanden Fotos. Sie wurden aber aus Zeitgründen nicht intensiver ausgewertet.

Die mit diesen Methoden gewonnenen unterschiedlichen Datentypen aus unterschiedlichen Datenquellen wurde eine intensive Triangulation, insbesondere Methoden- und Datentriangulation (Flick 2008), möglich.

Die Phase des intensiven Forschungskontakts erstreckte sich über etwa 15 Monate. In dieser Zeit fanden elf ein- bis dreitägige Feldaufenthalte statt, sieben davon am Fuenfwerken-Standort Wiesbaden, die übrigen in Berlin. Im Rahmen dieser Aufenthalte wurden die Interviews und die Organisationspartituren-Workshops durchgeführt. Außerdem nahm der Wissenschaftler der Universität Duisburg-Essen am Alltag der Standorte, d.h. vor allem an Pausen, Arbeitsphasen, teils auch an Meetings etc. teil und hatte somit Gelegenheit zu nicht als Forschungsinteraktion im engeren Sinne formalisierte Kontakten.

Die Datenauswertung erfolgte in einem kodierenden Vorgehen nach Grounded Theory Methodology (GTM) (Strauss \& Corbin 1996; Strauss 1991). Auf diese Weise wurden auch die Bilddateien (Partituren, teils auch Fotos) ausgewertet, so dass der gesamte Korpus an Daten in die Kategorienbildung eingehen kann. Bei der Auswertung der Daten fungierte das Team der Uni Duisburg-Essen als eine Art Auswertungsgruppe, allerdings nur relativ sporadisch und auf einem schon vergleichsweise aggregierten Level der Datenauswertung, d.h. nicht während der basalen frühen Auswertungsschritte.

Zwei der drei GTM-Kodierphasen wurden durchgeführt und aus den Daten Kategorien generiert (Strauss \& Corbin 1996). In der Datenanalyse (und zur Verwaltung der Daten) wurde die Auswertungssoftware Atlas.ti ${ }^{10}$ verwendet, die auch eine projektübergreifende Gesamtanalyse ermöglicht. Dabei wurde keine vollständige Grounded Theory - im Sinne einer Integration aller Erkenntnisse in ein Gesamtmodell - entwickelt und auch nicht angestrebt. Ziel war stattdessen die Konstruktion eines Bildes der Organisationskultur sowie die Entdeckung und Niederlegung organisationaler Muster.

9 | Die Methodik wird ausführlich in Gabriel (2002) beschrieben.

10 | http://atlasti.com/de/ 


\section{ERgebNISSE}

Die auf die im vorigen Abschnitt beschriebene Weise erhobenen Daten wurden insbesondere daraufhin betrachtet und interpretiert, inwiefern sie implizite Muster und implizite organisationskulturelle Elemente und Dimensionen erkennbar werden lassen. Im Folgenden werden Ergebnisse der Organisationskulturanalysen zusammenfassend dargestellt, um wesentliche Charakteristika der Fuenfwerken-Organisationskultur zu verdeutlichen. Zunächst werden in mehreren Abschnitten Teilergebnisse in vergleichsweise klassischer Form, als Text des Genres wissenschaftlicher Projektbericht, präsentiert (gesamter Teil 4.1). Dem folgt eine Darstellung dreier Muster, die bei Fuenfwerken entdeckt werden konnten (siehe Abschnitt 4.2). Schließlich werden eine Reihe >Organisationspartituren< vorgestellt und einige davon ausführlicher erläutert (Abschnitt 4.3); sie enthalten Erkenntnisse zur Organisationskultur von Fuenfwerken und den dortigen Prozessen des Organisierens in nicht-sprachlicher bzw. -textlicher Form.

\subsection{Die Tiefendimension des Organisierens}

Die Praktiken, Prozesse und Techniken, die Fuenfwerken einsetzt, sind in ungewöhnlich hohem Maße in eine stimmige, internalisierte Organisationskultur eingebettet. Die dadurch erzielte Kohärenz eröffnet ein Feld, in dem Kreativität, Qualität, Innovation, Flow usw. möglich sind und vergleichsweise einfach erreicht werden. Folgend wird beschrieben, welches die Grundlagen und Voraussetzungen für das Gelingen der Teamarbeit und der Erzeugung von Produkten hoher Qualität sind. Vorweggenommen sind das insbesondere:

i. Ein beruflicher und auch persönlicher Habitus der Mitarbeiterinnen und Mitarbeiter, eine Art und Weise, sich in Team- und andere Zusammenarbeit einzubringen und einzufügen; dieser wird in der Sozialisation und Enkulturation als Mitarbeiterin bzw. Mitarbeiter erworben und entwickelt, allerdings ist nicht jede Mitarbeiterin oder jeder Mitarbeiter gleichermaßen geeignet, sich dies entsprechend anzueignen.

ii. Ein spezifischer Führungsstil, der sich besonders dadurch auszeichnet, dass er den (kulturell fundierten) respektvollen, >freundschaftlichen < und Kreativität ermöglichenden Umgang im Alltag der Agentur erhält und weiter entwickelt.

iii. Die Gesamtkultur, d.h. eine umfassend wirksame, kohärente Kultur, in die die Teamarbeit sowie darüber hinaus alle Praktiken, Prozesse und Techniken einbezogen und eingebettet sind. 


\section{Fokus 'Teams und Qualitätı}

Teamarbeit an Gestaltungsprojekten ist die zentrale Arbeitsweise bei Fuenfwerken, Designs von hoher Qualität werden bei Fuenfwerken in Teams aus Designern und anderen Mitarbeiterinnen und Mitarbeiter, wie zum Beispiel Textern, erzeugt. Das ist nicht profan, denn gut funktionierende Teamarbeit ist alles andere als selbstverständlich. Bei Fuenfwerken funktioniert sie ausgezeichnet, da sie von einer spezifischen, tatsächlich internalisierten und lebendigen Team-Kultur getragen ist. Die Teamarbeit ist mit anderen Worten eine ausgefeilte und hochentwickelte Technologie, die in einer spezifischen Organisationskultur ihr volles Potenzial entfaltet. Das Prinzip oder übergeordnete Muster >Team $<-$ d.h. Team als Strategie, Struktur und zugehörige Kultur - findet Anwendung sowohl auf die Zusammenarbeit der Mitarbeiterinnen und Mitarbeitern, als auch auf die Vorstände und ihre Führungsund Managementpraxis. Teamarbeit als Methode bzw. Vorgehensweise selbst ist wiederum stark in die Kultur der Organisation Fuenfwerken eingebettet und gewinnt aus dieser ihre Spezifik. Das wird im Folgenden weiter erläutert.

Der Prozess >Teamarbeit< ist durch einen strukturierten, aber nicht starren Rahmen gestützt, der je nach kontextuellen Erfordernissen, flexibel gehandhabt wird und flexible Handlungsformen zulässt. Ein wesentliches Merkmal der Vorgehensweise bzw. Methode ist, dass innerhalb des Rahmens eine geeignete und anpassbare >Verschaltung verschiedener Schritte zu einer Reihe möglich wird. Diese Verschaltung kann ad-hoc geschehen und geändert werden und somit kann der Raum für die kreativen Energien offen gehalten werden. Weder die Länge des Gesamtprozesses (des Rahmens) noch die Dauer oder Abfolge innerhalb sind per se festgelegt.

Der Prozess Teamarbeit wird auch in zwei sog. Organisationspartituren ${ }^{11}$ dargestellt, die im Rahmen der Forschung entstanden sind und die unten näher beschrieben werden. Da in einem Kreativprozess wie dem Designprozess niemals schon vorher absehbar sein kann, ob die durchschlagende Idee nach zwei Tagen oder erst nach zwei Wochen gefunden wird, ist diese Vorgehensweise der viable Ersatz für den in vielen Organisationen verbreiteten Modus der >Planung<, der hier von vorneherein zum Scheitern verurteilt wäre.

\section{Fokus 'Führung,}

Fuenfwerken führt großenteils durch die eigene, starke und prägnante Organisationskultur, so dass beinahe schon der Eindruck entsteht, das Unternehmen führe sich in bestimmter Weise selbst. Prozesse, die üblicherweise unter Führung verstanden werden, entwickeln sich bei Fuenfwerken indirekt, vor allem durch Enkulturation in eine stimmige Kultur, also durch die Ausbildung eines bestimmten Habitus im Enkulturationsprozess. Die Kultur grundiert die organisationale Praxis insgesamt und die Führungspraxis im Besonderen. Das eigent-

11 | Zur Organisationspartituren-Methode siehe Abschnitt 4.3 sowie Vossebrecher et al. 2012 und Vossebrecher 2017b). 
liche Führungshandeln gegenüber Mitarbeiterinnen und Mitarbeitern (bzw. formal-hierarchisch Untergebenen) kann sich in wesentlichen Teilen darauf konzentrieren, die Kultur aufrecht und lebendig zu erhalten, sie weiter zu vertiefen sowie neuen Situationen anzupassen und sie auf neue Herausforderungen auszurichten: ein Zukunftsmanagement der Kultur, wenn man so will. Daneben muss natürlich das operative und strategische Handeln der Führung weitergehen, allerdings wird dies aber auch durch die relativ geringe Größe der Agentur erleichtert bzw. überhaupt ermöglicht.
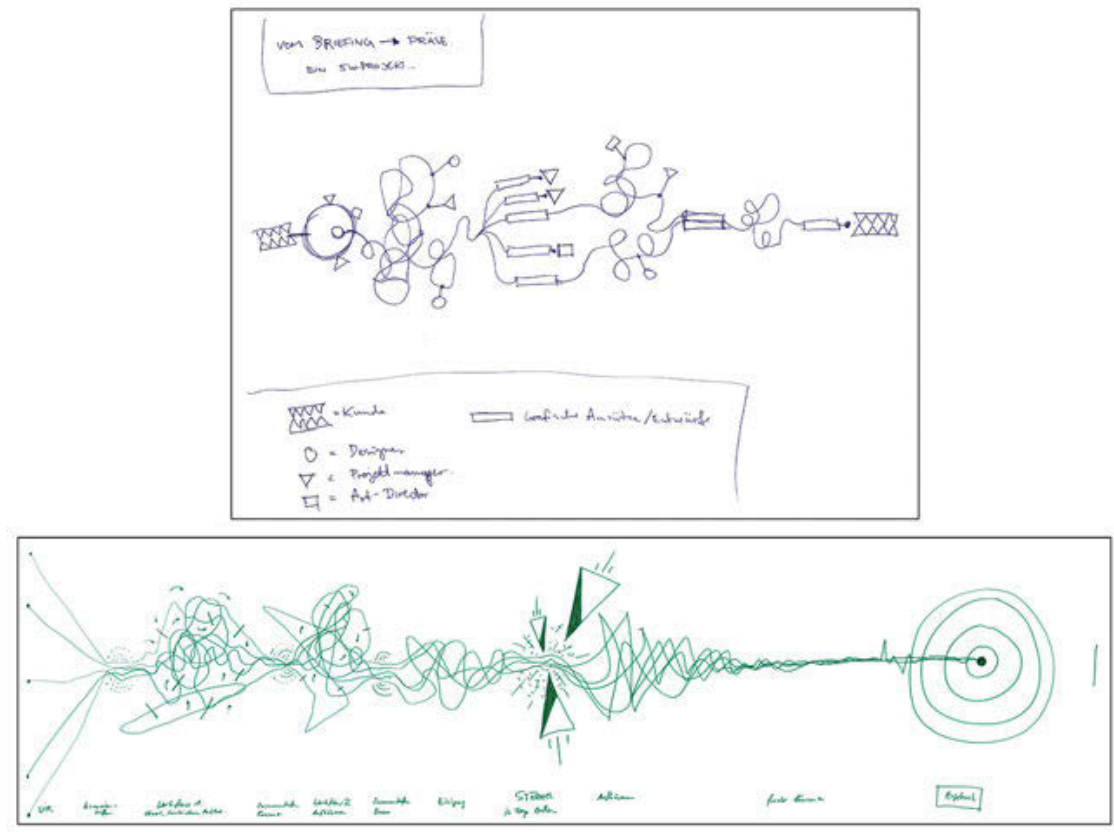

Abbildung 2: Organisationspartituren >Teamarbeit<

Voraussetzung für dieses Forschungsergebnis war die Einsicht, dass die Fuenfwerken-Kultur in hohem Maße stabil ist: Sie ist übergreifend in homogener Weise vorhanden (sie ist generalisiert) und sie ist breit internalisiert und habitualisiert. Einmal als stabile und wenig widersprüchliche Kultur etabliert, vermittelt sich an neu in das Unternehmen Kommende und prägt sie sich in bedeutsamen Teilen quasi eigenständig >selbst<. Trotzdem ist die Kultur nicht starr, sondern kann sich mit den Handlungen - Pierre Bourdieu würde sagen: der Praxis ${ }^{12}$ - der Mitglieder mit und sich ändernden Rahmenbedingungen weiter entwickeln, auch wenn das nur langsam geht.

Über die Bereiche des Führungshandelns der Vorstände kann man aus Perspektive der Kulturanalysen Folgendes sagen:

12 | Zur Bourdieus Theorie der Praxis ('Praxeologie`) vgl. Bourdieu $(1976,1987)$. 
- Die Pflege der Kultur wird als wichtige Managementaufgabe gesehen und angenommen. Beispiele dafür sind: Förderung von kleinen, alltäglichen sozialen Begebenheiten (wie gemeinsames Essen), d.h. diese teils zu initiieren und daran regelmäßig teilzunehmen; für Feedback der Mitarbeiterinnen und Mitarbeiter erreichbar und aufmerksam zu sein; Entwicklungspotentiale und Entwicklungsinteressen der Mitarbeiterinnen und Mitarbeiter zu suchen, zu sehen und aufzugreifen.

- Im Hinblick auf den Bereich Teamarbeit und -kultur spielt im Führungshandeln die Komposition der Teams eine sehr wichtige Rolle, d.h. deren Zusammenstellung, Betreuung mit Aufgaben und Zielen und deren je nach Situation direkte oder indirekte Steuerung. Diese Komposition wird als subtile Fähigkeit beschrieben; in einer gelingenden Komposition sind die individuellen Stärken der Mitarbeiterinnen und Mitarbeiter (Designkreativität, handwerkliches Designkönnen) und deren typische Herangehensweisen (Ansätze, zum Beispiel eher strukturiert-systematisch oder offen-chaotisch, kleinteilig, detailgenau, große Ideen verfolgend etc.) genauso Faktoren wie die Chemie zwischen den Einzelnen und ihren Persönlichkeiten. Voraussetzung dafür ist ein Gefühl für das Zusammenspiel dieser Faktoren. Zudem spielt - so einer der Vorstände - für die Komposition der Teams immer auch Intuition eine Rolle. Das heißt, dass die gelungene Komposition einen nicht oder nicht ohne weiteres erklärbaren Anteil hat. Sie funktioniert natürlich trotzdem.

- Zu Fuenfwerken passende Mitarbeiterinnen und Mitarbeiter müssen gefunden und/oder zu solchen weiterentwickelt werden und sie müssen im Unternehmen gehalten werden. Neben den in den vorigen Abschnitten bereits genannten Dingen müssen solche Mitarbeiterinnen und Mitarbeiter einerseits Ehrgeiz, Einsatzbereitschaft und Lust auf qualitativ hochwertige Designs haben, andererseits aber Profilierung und >Ego < in einer für die Branche eher unüblichen Weise hintenanstellen. Diejenigen, die das nicht können oder wollen, verlassen Fuenfwerken wieder. In die Vorbereitung der Entscheidung über die dauerhafte Beschäftigung neuer Mitarbeiterinnen und Mitarbeiter, teils auch in die Entscheidung selbst, werden langjährige, erfahrene, vertraute Mitarbeiterinnen/Mitarbeiter eingebunden, indem sie um Feedback gebeten werden, ob bzw. inwieweit jemand passt.

Führungspersonen reagieren auf konstruktive Kritik der geführten Mitarbeiterinnen und Mitarbeitern. Dabei werden auch Organisationberater als Hilfe einbezogen, die unter anderem jährliche Workshops ausschließlich mit den Mitarbeiterinnen und Mitarbeitern durchführen. Zur Durchführung solcher Workshops werden sowohl Mitglieder des Fuenfwerken-Aufsichtsrats beauftragt, die erfahrene Organisationsberater sind, aber auch externe Organisations-, Management- und Führungskräfte-Coachs. Konstruktiv-kritischer Austausch wird also eingefordert und gefördert, indem Möglichkeiten und Räume für Kritik erzeugt werden. Dabei wird ein Grundmuster verwendet, das sich auch in der gemeinsa- 
men Arbeit von Designteams an einem Design findet: Dort ist ebenfalls die Kritik an den bisherigen entwickelten Gestaltungsideen ein wichtiges und willkommenes Instrument. Mittels in spezifischer, zur Kultur passender Weise vorgebrachter Kritik werden Vielfalt und Komplexität erhöht; mehr Ideen, Varianten, Alternativen, Fragen und Hinterfragungen eröffnen mehr Handlungsmöglichkeiten ${ }^{13}$.

\section{Fokus 'Recruitment und Integration der Mitarbeiter}

Der soziale Umgang miteinander ist bei Fuenfwerken >freundschaftlich respektvoll - eine zentrale und intensiv gepflegte Dimension des organisationalen Lebens. Bei Neueinstellungen (Recruitment) wird - neben dem Anspruch an die grundsätzliche professionell-fachliche Kompetenz in Design und Gestaltung (oder andere berufliche Kompetenzen) - intensiv geprüft, ob der Bewerber in die Organisationskultur von Fuenfwerken passt. Dies ist in den Augen von Fuenfwerken für die Zusammenarbeit im täglichen Geschäft und im sehr intensiven Austausch wichtiger, als ein hundertprozentiger >Fit < auf die benötigten Design- und anderen fachlichen Kompetenzen, daher wird auf solche ssoziale Passung< von allen sehr viel Wert gelegt: >Was nützt uns ein begnadeter Designer, der menschlich nicht in die Organisation passt?

Die Entscheidung über die Passung basiert sowohl auf >Bauchgefühl bzw. Intuition wie auf anderen Grundlagen. Soweit möglich, werden dabei Wege gefunden, das Recruitment-Prozedere gegenüber dem üblichen Vorgehen, nämlich mittels Portfolio/Profil und einem oder zwei Bewerbungsgesprächen, zu verlangsamen. Dies ist ein Merkmal, das insgesamt in der Unternehmensentwicklung und der Führung auftaucht (Stichwort langsames Wachstum).

- Mitarbeiterinnen und Mitarbeiter werden durch Praktika und über TraineeStellen gesucht und gefunden (Recruitment) mit dem Vorteil, vor einer festen Einbindung ins Unternehmen auf beiden Seiten die Möglichkeit zu erzeugen, die Passung zu erproben und zu entwickeln.

- Bei neuen Mitarbeiterinnen und Mitarbeitern wird häufig eine Art Mentoring eingesetzt und (auch) als Vorgehensweise für die Enkulturation und die Entwicklung des entsprechenden Habitus genutzt.

- Zur Integration gehört auch die Entwicklung der Mitarbeiterinnen und Mitarbeiter. Dies geschieht unter anderem auf dem Wege, deren Weiterentwicklungswünsche zu antizipieren und sehr früh zu bedienen (vgl. Abschnitt 4.1.2). Dies stellt außerdem auch einen Ausgleich dafür dar, dass aufgrund der flachen Hierarchien die formalen Aufstiegsmöglichkeiten relativ begrenzt sind.

13 | Siehe die Organisationspartituren zum Gestaltungsprozess (Abschnitt 4.3) und das Muster Kritische Instanz (s. Abschnitt 4.2). 


\section{Grundannahmen und Basisannahmen}

Zum Abschluss des Abschnitts zur Tiefendimension der Fuenfwerken-Organisationskultur sollen die Ergebnisse zu den impliziten Elementen der FuenfwerkenOrganisationskultur noch einmal anhand des Organisationkultur-Modells von Schein (1991) diskutiert werden, das für die Analyse eine grundlegende Orientierung bildete. Dabei werden zunächst auch die >kollektiven Werte<, die nach Scheins Modell teilweise bekannt, teils auch nicht oder nur in geringem Maße >bewusst< sein können, komprimiert dargestellt ${ }^{14}$.

Zum großen Teil handelt es sich bei den kollektiven Werten um solche, die auf soziale Beziehungen, die Zusammenarbeit und Interaktion bezogen sind, beispielsweise Vertrauen. Dagegen ist von Werten, die auf die Einzelne/den Einzelnen bezogen sind, wie individuelle Anerkennung, individuelles Weiterkommen/ Karriere, und ebenso von businessbezogenen Werten (wie Geld, Auszeichnungen/Preise, Leistung) in expliziter Form viel weniger die Rede. Letztere Werte stehen nicht im Vordergrund der Kultur.

Respekt und Vertrauen: Die Begriffe >Vertrauen $<$ und >Respekt< spielen, das zeigen die erhobenen Daten, eine bedeutende Rolle als grundlegende Werte, beide werden in der Beschreibung verschiedener Facetten der Organisation (bzw. Organisationskultur) intensiv und in sehr ähnlicher Weise verwendet, quasi egal wen man fragt. Sie sind v.a. bezogen auf den Umgang mit- und Verantwortung füreinander, den Erhalt des funktionierenden sozialen Gefüges (s.u.), das für die Strategien und Arbeitsweisen von Fuenfwerken eminent wichtig ist, wie auch die Zusammenarbeit innerhalb der Hierarchieebenen, d.h. zwischen Mitarbeiterinnen/Mitarbeitern. Respekt und Vertrauen sind die Grundlage für weitere Werte, die Fuenfwerken prägen: Lockerheit, Beweglichkeit/Flexibilität, Selbständigkeit, Gemeinschaft, Offenheit, Freundschaftlichkeit usw. Praktisch bedeutet das zum Beispiel darauf zu achten, dass sich Stressphasen und weniger stressige Phasen ausgleichend abwechseln.

>Freundschaftlichkeit< und Gemeinschaft: Das Miteinander wird in den Daten als freundschaftlicher, offener Umgang miteinander beschrieben, also als intensiver und von größerer sozialer Nähe, als es beispielsweise das Wort >kollegial bedeuten würde. Andererseits ist freundschaftlich nicht gleichbedeutend mit Freundschaft. Dass es grundsätzlich sich um ein Verhältnis zwischen Kolleginnen/Kollegen bzw. ein Arbeitsverhältnis handelt, bleibt klar und deutlich; Freundschaftlichkeit beschreibt also eine Atmosphäre zwischen neutral-kollegial und Freundschaft im privaten Sinne. Gemeinschaft drückt sich in der alltäglichen Praxis unter anderem des Essens und Kochens in der Agentur aus; mit diesen und anderen Aktivitäten wird dafür gesorgt, dass Fuenfwerken keine anonyme, unübersichtlich große Agentur wird. Gemeinschaft und Freundschaftlichkeit stehen in einem Verhältnis gegenseitiger Voraussetzung: Die eine fördert und stützt

14 | Ausführlicher siehe Vossebrecher \& Kamin (2011); dort werden auch bei Fuenfwerken identifizierte wichtige Artefakte (1. Ebene in Scheins Modell) und weiter bekundete kollektiven Werte (2. Ebene) berichtet. 
die Existenz der jeweils anderen. Die kollektiven Werte Freundschaftlichkeit und Gemeinschaft, ebenso wie die davor beschriebenen, Respekt und Vertrauen, sind mit Anforderungen an die Mitarbeiterinnen und Mitarbeiter verbunden, in der Arbeit auch sehr selbständig zu agieren und Verantwortung zu übernehmen.

Hinsichtlich der Tiefendimension von Organisationskultur wird bei Schein (2006) ein Problem beschrieben, das Organisationen praktisch bedroht: Unter der Oberfläche liegen vor langer Zeit erworbene, basale und tiefliegende Annahmen, die konträr zu den gegenwärtig propagierten und erkennbaren kollektiven Werten und, vor allem, zu den jetzigen praktischen Herausforderungen liegen, denen die Organisation gegenübersteht - mit anderen Worten: Die Tiefendimension der Organisationskultur stünde den praktischen Erfordernissen in existenzbedrohlicher Weise im Wege. Dafür bestehen allerdings im Fall von Fuenfwerken keine Anzeichen. ${ }^{15}$

$\mathrm{Zu}$ grundlegenden Annahmen und Werten lassen sich, den methodischen und anderen Schwierigkeiten der Untersuchung der Tiefendimension der Organisationskultur, auf die bereits hingewiesen wurde (Abschnitt 3) zum Trotz einige Aussagen treffen; die >große< Entdeckung von Basiswerten, deren Existenz die Agentur komplett überrascht, weil sie bisher keinem bewusst waren, gibt es aber nicht. Das ist auch darauf zurückzuführen, dass sich Fuenfwerken intensiv mit der eigenen Praxis (den eigenen Arbeitsweisen) und der zugehörigen Kultur beschäftigt und sie in weiten Teilen explizit pflegt.

Die Analysen ergeben insgesamt das Bild, dass das Klima der Zusammenarbeit und die Organisationskultur ein starker Grund für die einzelnen Mitarbeiterinnen und Mitarbeiter sind, bei Fuenfwerken zufrieden zu sein, langfristig zu bleiben und ihren individuellen Ehrgeiz in dem gesetzten Rahmen einzubringen.

In den Interviews wird auffällig viel über beziehungsbezogene Werte - wie beispielsweise Vertrauen, mit Respekt und Freundschaftlichkeit verbundene $O f$ fenheit und flexibler Umgang miteinander - gesprochen. Dagegen werden Werte, die eher für Einzelne von Bedeutung wären - Selbstverwirklichung, individueller Ehrgeiz (Ambition, Motivation) und Erfolg oder Aufstieg/Karriere - gar nicht oder kaum genannt und sind womöglich weniger bedeutsam; das ist eine Abgrenzung zur einen Seite. Zur anderen Seite kann man die beziehungsbezogenen Werte abgrenzen gegen wirtschaftlichkeits- oder businessmäßige Werte wie Leistung, Effizienz oder Erzielen von Profit ${ }^{16}$, die nach unserer Analyse bei Fuenfwerken

15 | Dass diese nicht zu erkennen sind, kann allerdings auch an der den bekannten Schwierigkeiten liegen, die Tiefendimension von Organisationskultur zu erforschen: Konflikte und tabuisierte Themen werden gegenüber von extern Kommenden ebenso wie intern oft nicht besprochen; zudem fehlt es an geeigneten Methoden zur Analyse gerade der Tiefendimension von Organisationskulturen. (vgl. Abschnitt 3)

16 | Auch zu diesem Befund stellt sich die Frage, ob darüber nur weniger gesprochen wird, weil es sich um tabuisierte Sachverhalte handelt, oder ob es sich bei den beziehungsbezogenen Werten wirklich um das dominante Werte-Set in der gelebten Kultur handelt. Das ist aus den Analysen nicht eindeutig zu beantworten. 
ebenfalls eine sehr nachrangige Rolle innehaben. Die businessmäßigen Werte sind bei Fuenfwerken durchaus wichtig, aber (im Kontext unserer Analysen) wenig Thema ${ }^{17}$. Das ist typisch für die Fuenfwerken-Kultur, da es im Sinne einer kreativen Neugier stärker darauf ankommt, neue Möglichkeiten zu eröffnen und auszuloten, als vorrangig ressourceneffizient und ökonomisch Designs anzufertigen - Effizienz in diesem Sinne wäre mit leichten Variationen von bereits erarbeitetem Material besser erreichbar.

Zu dem spannungsreichen Komplex von Qualität (der Gestaltung und Designprodukte) einerseits und Wirtschaftlichkeit andererseits lassen sich am ehesten Grundannahmen bzw. >Basiswerte< formulieren, die der Agentur zum Zeitpunkt der Forschung selber nur ansatzweise bewusst sind. Sie zeigen, dass die >soziale< Form der Zusammenarbeit (Respekt, Freundschaftlichkeit, Vertrauen, Gemeinschaft etc.), die mit der Erzeugung von Designqualität in Teams so eng verbunden ist, tendenziell als wichtiger und erfreulicher bzw. befriedigender gesehen wird als ökonomischer, finanzieller Erfolg (Geld verdienen). Auffällig ist dabei, dass Zusammenarbeit/Qualität versus Wirtschaftlichkeit einander tendenziell gegeneinander gestellt wird - obwohl weder selbstverständlich noch zwingend nachvollziehbar ist, weshalb man, zugespitzt formuliert, nur das eine oder nur das andere zugleich haben könne. Insbesondere diese Gegenüberstellung ist der Agentur nur sehr wenig bewusst.

Die folgenden >Losungen geben diesen Komplex und die Gegenüberstellung wieder: >Geld ist weniger wichtig als Kreativität, Qualität und Beziehung<, >wirtschaftliche Effizienz bedroht Qualität<, >maximale Qualität kommt vor maximalem Profit<, >angenehme Arbeitsweise kommt vor Profit<, >Kreativität ist >soziak, >Austausch ist gut für Qualität< und >das Ergebnis von Zusammenarbeit ist immer besser als von Einzelnen<.

\subsection{Muster der Organisation Fuenfwerken}

Mit einem auf Christopher Alexanders Pattern Language und Konzept von Entwurfsmustern (design patterns) (Alexander et al. 1977) aufbauenden Ansatz lassen sich Muster in Organisationen als prozesshaft grundlegende Lösungsstrategien für wiederkehrende Herausforderungen bzw. Problemstellungen systematisch beschreiben, und zwar in Relation zum Kontext, in dem sie auftreten und ihren Sinn erhalten. Ein ausreichend großer Pool von Mustern mit ihren Verbindungen untereinander ermöglicht es, komplexe Systeme als Ganzes zu verstehen und in ihren Einzelheiten in das Ganze eingebunden zu betrachten (vgl. Alexander et al. 1977; zum MICC-spezifischen Verständnis: Stark 2017; Stark \& Dell 2012; Vossebrecher \& Kamin 2011). Die Entdeckung von Mustern in der Art und Weise, wie Organisationen mit Herausforderungen umgehen, war wesentlicher Bestandteil des

17 | Allerdings haben sie aber zuletzt an Bedeutung gewonnen, einhergehend mit der Entscheidung, als Unternehmen die nächste Wachstumsstufe und Größe zu erreichen. 
Forschungsvorhabens MICC ${ }^{18}$. Muster erschließen vorhandenes, aber zu wesentlichen Teilen zunächst implizites Erfahrungswissen sowohl für die Organisationen selbst als auch für den Transfer, d.h. die Verallgemeinerung auf ganz Branchen.

Muster werden entdeckt, geschrieben, verdichtet und kommuniziert. Das Ausgangsmaterial zur Entdeckung von Mustern sind in unserem Fall die erhobenen Daten aus Interviews, Beobachtungen, Dokumenten, Partituren etc. Die >Verdichtung ist eine Weiterentwicklung von Mustervorschlägen durch eine Gruppe von Autorinnen bzw. Autoren in einem oder mehreren Writer's Workshops (Coplien 2001; e-teaching.org 2011; Gabriel 2002; Schmidt o.J.). Muster werden nicht so weit abstrahiert, dass ihr Entstehungskontext und ihr ursprünglicher Praxisbezug verloren gehen, aber doch so weit generalisiert, dass sie auch in anderen, neuen organisationalen Kontexten als Basis für veränderte Praxis dienen können.

\section{Cross-Habitat Kommunikation}

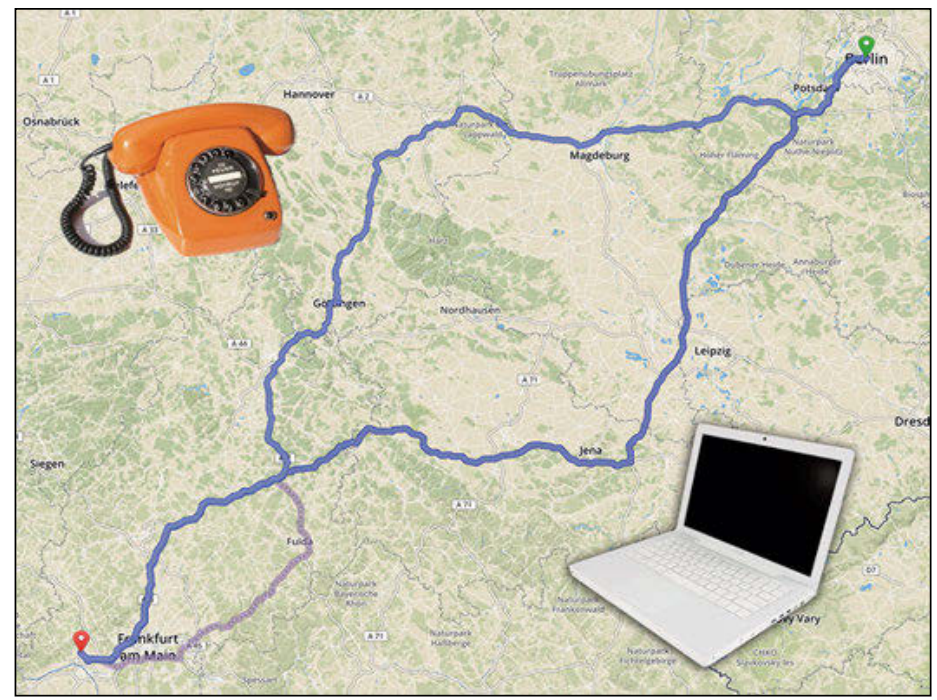

Abbildung 3: Cross-Habitat Kommunikation

Muster sind in der Regel formalen ähnliche aufgebaut, wenig abhängig davon, ob es sich um eine Mustersprache bspw. zur e-Learning-Didaktik oder zu Human-Computer-Interfaces handelt. In dieser Form wird der Kontext der Entstehung bzw. Anwendung beschrieben, die Herausforderung, zu der das Muster eine Antwort vorschlägt, die Lösung bzw. Antwort selbst mitsamt ihrer inneren Logik, sowie die Konsequenzen bzw. Folgen aus der Anwendung. Schließlich werden Bezüge zu anderen Mustern derselben Mustersprache (soweit vorhanden) benannt.

18 | Es geht zunächst um organisationsspezifische, im zweiten Schritt dann um verallgemeinerbare Muster. 


\section{Kontext}

Ein Unternehmen im Bereich Design/Gestaltung hat zwei Standorte mit großer geographischer Distanz. Der Austausch in Projekten über den gesamten Prozess hinweg (Briefing, Kreativprozess, Losungspräsentation) erfordert normalerweise neben sprachlicher und bildlicher Kommunikation (Texte/Rede; Visualisierung von Entwürfen) auch die Kommunikation auf gestischer, mimischer und paraverbaler Ebene (Stimmlage etc.). Zum Beispiel zeigt sich Skepsis eher und stärker auf nonverbaler Ebene als auf verbaler.

Das Unternehmen ist in der Situation, Projekte mit Mitarbeiterinnen und Mitarbeitern aus beiden Standorten (>cross-habitat‘) zu besetzen. Diese Teams müssen sich über die Gestaltungsaufgabe und über Lösungen verständigen. Durch die räumliche Trennung entsteht ein erheblicher Mehraufwand durch die hohen und spezifischen Anforderungen an die Qualität und Häufigkeit der erforderlichen Kommunikation.

Ein Kreativprozess ist insbesondere geprägt durch ein ausführliches Briefing und das inhaltliche Verständnis der Aufgabe. Insbesondere das Re-Briefing als Bestätigung des Verständnisses (der Aufgabe, des Ziels, der Beweggründe, der begleitenden Umstände, Einschränkungen und Regeln), ist oft eine Voraussetzung für die Entwicklung einer geeigneten Lösung. Weiterhin werden in einem Kreativprozess verschiedene Prototypen entwickelt, weiterentwickelt oder verworfen. Dafür ist ein regelmäßiger Austausch zu den entwickelten Prototypen notwendig, der naturgemäß in persönlichen Treffen einfacher ist.

\section{Herausforderung der Alltagsanwendung}

Insbesondere in Kreativitätsprozessen (Entwicklung neuer Lösungen in Teams) kann die Kommunikation über die Standorte hinweg ein Problem sein, vor allem, da gestische und mimische Anteile der Kommunikation fehlen, wenn man nicht face-to-face zusammentrifft. Es müssen Wege gefunden werden, »vollständige« Kommunikation zu gewährleisten oder zumindest in ausreichendem Maße (in diesem Fall eine hoch liegende Latte) zu ersetzen oder auszugleichen. Die Herausforderung ist umso größer, da technische Hilfsmittel die Kreativität auch in der einen oder anderen Weise stören können.

\section{Lösung und ihre Logik}

Die fortlaufende Verbesserung der Kommunikation über die Standorte hinweg wird durch technologisch basierte Hilfsmittel (online-basierte Video-Telefonkonferenzen, online-basierter Workspace zum Austausch von Informationen, Ideen und Entwürfen), aber auch durch regelmäßige persönliches Treffen der Projektbeteiligten erreicht. Persönliche Treffen sind gerade dann wichtig, wenn die Gewöhnung an technologisch vermittelte Kommunikationsformen noch nicht abgeschlossen ist. Mit zunehmender Gewöhnung sinkt voraussichtlich die Irritation durch fehlende gestische, mimische etc. Kommunikationssignale, steigt die Sensibilität für die Besonderheiten technologiebasierter Zusammenarbeit, und somit steigt der Nutzen der Lösung. 


\section{Konsequenzen aus der Lösung}

Verstärkte Kommunikation über die Entwicklungen in den Niederlassungen wird möglich (auch jenseits konkreter Designprojekte). Damit wird auch die Kommunikation über Entwicklungen für einen bestimmten Kunden, für den über die Standorte hinweg Projekte bearbeitet werden, einfacher und verbessert. D.h. die regelmäßige Kommunikation der Vorstände und Kundenverantwortlichen über die Entwicklungen bei Kunden, in Projekten, zu allgemeinen standortbezogenen Themen wird besser, intensiver und einfacher.

Die im Vergleich zur realen face-to-face-Kommunikation fehlenden Elemente und Ebenen können so gut es eben geht kompensiert werden. Da gelingt umso besser, je mehr die involvierten Personen persönlich miteinander bekannt sind.

\section{Kritische Instanz}

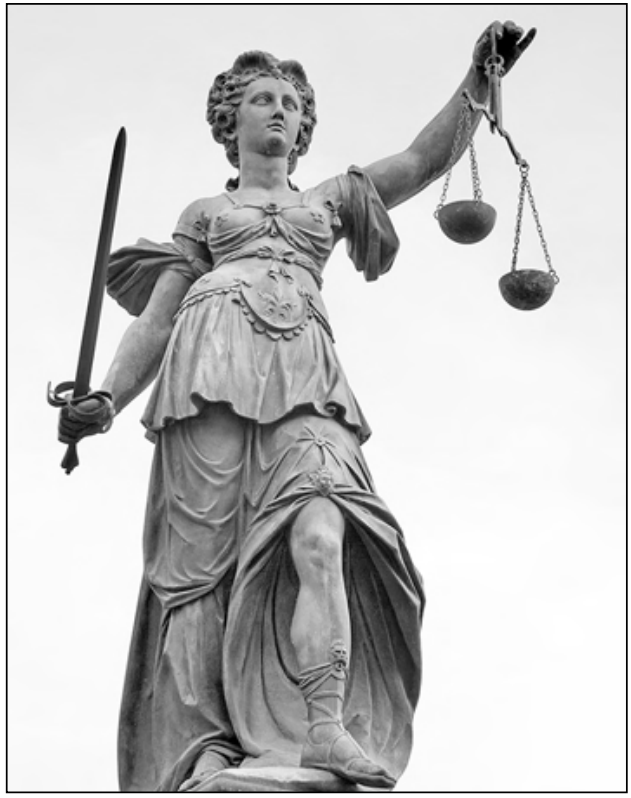

Abbildung 4: Kritische Instanz

Durch Übung nimmt die Vertrautheit im Umgang mit technologischen Tools (Video-Telefonie, online-basierter Workspace) für die cross-Habitat- bzw. long distance-Kommunikation zu. Somit wächst die Kraft bzw. das Potential der Lösung. Das Verständnis der Arbeitsweisen der handelnden Personen (Kolleginnen und Kollegen) verbessert sich mit der Zeit auch dann, wenn die Zusammenarbeit in hohem Maße technologisch vermittelt ist. Die trifft umso mehr zu, wenn wo immer möglich auch face-to-face-Arbeitstreffen stattfinden. 


\section{Bezüge zu anderen Mustern}

Das Muster >Kreativität und Struktur in Gestaltungsprozessen< beschreibt Elemente und Phasen eines typischen Designprozesses als Zusammenarbeit eines Teams.

\section{Kontext}

Es hat viele Vorteile, an Ideen und Entwürfen in Teams zu arbeiten. Zum Beispiel werden durch Austausch und gegenseitige Anregung zusätzliche Ressourcen verfügbar; hohe Qualität der Produkte wird möglich bzw. erheblich wahrscheinlicher. Entwürfe werden in Teamarbeit über mehrere Schritte entwickelt. Der Prozess der Teamarbeit erfordert vielfältige Kompetenzen, unter anderem respektvolles Zuhören und konstruktives Kritisieren.

Die Kritik noch-nicht-guter Ergebnisse mit dem Ziel der Qualitätssteigerung ist wichtig. Dazu gehören mehrere Elemente: Eine >Kritikkultur< entwickeln und leben, über Hierarchiestufen hinweg kritisieren (zum Beispiel Junior-Mitarbeiter kritisiert den Vorschlag des Senior Designers), und die Interaktion verschiedener Charaktere (»Typen«) im Team.

\section{Herausforderung der Alltagsanwendung}

Wie werden im Gestaltungsprozess beste Resultate erreicht? Dazu muss die Qualität bislang erreichter Entwürfe weiter gesteigert werden, was die Kritik noch nicht guter Ergebnisse beinhaltet. In Teams arbeiten und interagieren verschiedene Charaktere (»Typen«) miteinander, die unterschiedlich kritisieren und mit Kritik unterschiedlich umgehen. Zudem sind Entwürfe Produkte, in die Mitarbeiterinnen und Mitarbeitern ihre Kreativität und Persönlichkeit einbringen und mit denen sie sich identifizieren, d.h. die leicht als >eigenes Baby< ansehen. Kritik muss sich daher in einem Bereich zwischen deutlichen Formulierungen und der Wahrung von Respekt bewegen. Übergroße und falsch verstandene freundliche Vorsicht kann für die Qualität genauso problematisch sein wie Respektlosigkeit gegenüber der geleisteten Kreativarbeit. Weder kritisieren alle Mitarbeiterinnen/ Mitarbeiter gleichermaßen gerne und in angemessener Weise, noch werden alle gleichermaßen gerne kritisiert bzw. können mit Kritik umgehen.

\section{Lösung und ihre Logik}

Es wird eine >kritische Instanz< etabliert und damit der Kritik ein bestimmter Rahmen gegeben. Zur kritischen Instanz sind in der Geschichte des Unternehmens ein oder mehrere Mitarbeiterinnen und Mitarbeitern geworden. >Kritische Instanz ist eine besondere Rolle und alle im Unternehmen wissen - oder lernen schnell - dass dieser oder diese Mitarbeiterinnen und Mitarbeitern deutlich Kritik üben wenn es erforderlich ist.

Da somit deutliche Kritik Teil einer bestimmten, gewachsenen Rolle ist, wird diese Kritik in aller Regel nicht persönlich genommen. Obwohl die >kritischen Instanzen einzelne Personen sind, ist das Muster »kritische Instanz« ein struktureller Teil des Unternehmens. 


\section{Konsequenzen aus der Lösung}

Die >kritische Instanz ist ein nicht an formale Hierarchien gebundenes Element; im Prinzip wird der Senior Designer oder auch der Vorstand ebenso kritisiert wie der Praktikant oder Junior Designer.

In einer möglichen Weiterentwicklung des beschriebenen Musters wird die >kritische Instanz< zu einer Rolle, die stets Teil des (Team-)Arbeitsprozesses ist und temporär eingenommen werden kann, die also weniger an bestimmte Personen gebunden ist.

\section{Bezüge zu anderen Mustern}

Die >kritische Instanz $<$ hat eine Rolle z.B. im Muster >Kreativität und Struktur in Gestaltungsprozessen<.

\section{Kreativität und Struktur in Gestaltungsprozessen}

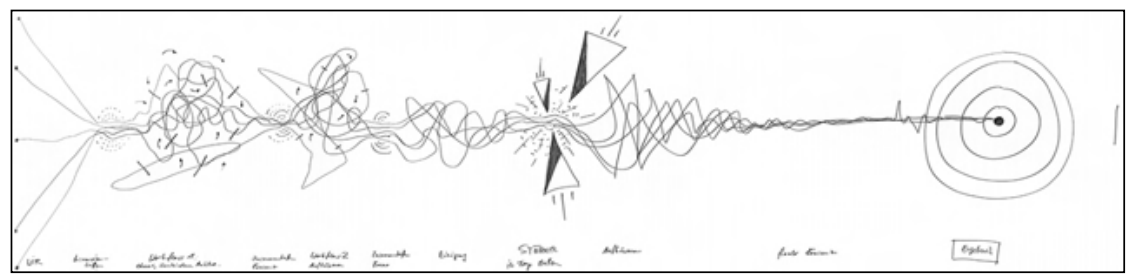

Abbildung 5: Gestaltungsprozess

\section{Kontext}

Eine Kreativ- und Gestaltungsagentur hat den Anspruch und die Arbeitsweise, jedem ihrer Kunden ein individuelles Produkt und Ergebnis zu liefern, d.h. keine Gestaltung »von der Stange«. Um dabei wirtschaftlich sinnvoll zu arbeiten, muss sie selbstverständlich in der Gestaltung sehr ergebnisorientiert sein. Zugleich sind hohe Kreativität und Innovativität Kern des Produkts und der Tätigkeit der Agentur.

\section{Herausforderung der Alltagsanwendung}

Geschäftlich sinnvolles, ergebnisorientiertes Arbeiten und kreative, innovative Gestaltung müssen täglich in ein für das wirtschaftliche Überleben der Agentur sinnvolles Gleichgewicht gebracht werden. Dazu sind Arbeitsprozesse und Vorgehensweisen erforderlich, mit denen das gelingt. Designideen und ihre Ausarbeitung zu erfolgreicher Gestaltung sind von einer einzelnen, allein verantwortlichen Person oft nicht zu meistern. Die Qualität der Produkte darf nicht zu sehr von einer oder wenigen Personen abhängen.

\section{Lösung und ihre Logik}

Der beschriebenen Herausforderung wird folgendermaßen begegnet: Zum kreativen und ergebnis-orientierte Gestaltungsergebnis führt ein iterativer Prozess 
(in dem wiederum eigene Herausforderungen stecken), der in Teams verfolgt wird: (a) Auf Grundlage des Kundenbriefings findet ein Brainstorming statt, aus dem heraus erste Ideen und konzeptuellen Ansätze formuliert werden. (b) Iterativ (wiederkehrend) wird ein Prozess mit mehreren Schritten (Meilensteinen) durchlaufen, die man als Workflow, Konsens erzielen, Aufbäumen, Einigung, Störung/Hinterfragung stellen bezeichnen kann. (c) Insbesondere die Sequenz aus experimentierendem, per se offenen Workflow und der einigenden Einengung auf wenige weiter zu verfolgende Ideen (Konsens erzielen) wird mehrfach hintereinander im Wechsel durchlaufen. (d) Eine Person übernimmt dabei den >Lead < und entwickelt die Idee zum Vorschlag; mit oder ohne Einbindung weiterer Mitarbeiterinnen und Mitarbeitern für bestimmte Aufgaben. (e) Andere im Team (neben dem Lead) hören nicht auf, über die Gestaltungsaufgabe nachzudenken und sind daher in den entsprechenden gemeinsamen Phasen wichtiger Teil der Weitergestaltung durch Reflexion, sie sind zum Beispiel gute »Störer«.

\section{Konsequenzen aus der Lösung}

In gemeinsamer Arbeit wird die Qualität mit sehr erhöhter Wahrscheinlichkeit zunehmen. Das Zusammentreffen verschiedener Perspektiven, Arbeitsweisen, Stärken und Vorlieben erhöht die Qualität (eine offene, respektvolle Kultur der Zusammenarbeit vorausgesetzt).

\section{Bezüge $z u$ anderen Mustern}

Da das Muster den Gestaltungsprozess auf einer generellen Ebene beschreibt, kommen innerhalb des Musters (z.B. in den verschiedenen Phasen) viele weitere Muster zum Tragen. Zudem spielt das Muster >Kritische Instanz<in diesem Muster eine wichtige Rolle.

\subsection{Organisationspartituren zu Fuenfwerken}

Im Forschungs- und Entwicklungsprojekt MICC wurden als >musikalische< Methode der Organisationsforschung die »Organisationspartituren« entwickelt, und im Rahmen der Organisationskulturanalyse zur Datenerhebung eingesetzt. Sie sind eine nicht-standardisierte, qualitative Methode zur Erhebung und Re-Konstruktion von Prozess- und Handlungswissen (Mustern) der Mitglieder einer Organisation und, soweit prinzipiell möglich, von implizitem Wissen in organisationalen Kontexten. Die Besonderheit ist, dass sie dabei nicht (vorrangig) auf Sprache setzen. Die Organisationspartituren haben die freien und experimentellen Notationsformen der Partituren der Neuen Musik des 20. Jahrhunderts, insbesondere der sog. aleatorischen Musik von Earle Brown, John Cage u.a. (Karkoschka 2004) zum Vorbild. Grundsätzlich sind Partituren stets Notationen für zeitliche Verläufe, in der Musik oder auch in Organisationen, enthalten also immer spezifische Darstellungsweisen von Zeit. 
Organisationspartituren bieten einen Zugang zu impliziten Mustern und zum implizitem Praxis- und Handlungswissen in Organisationen - Relationen, Verbindungen und Schnittstellen zwischen Einheiten, Akteuren, Personen; typische Handlungsmuster -, und lassen somit auch handlungsleitende und -begründende Prinzipien, Problembestimmungen und Handlungsvorschläge sowie Grundannahmen und Werte der Organisation erkennbar werden (Vossebrecher et al. 2012; Vossebrecher 2017b). Sie sind persönliche, zunächst subjektive Darstellungen (Diagramme).

Die Datenerhebung mittels Organisationspartituren bedient sich eines Workshop-Formats (Vossebrecher 2017b), in dem die Teilnehmenden aufgefordert werden, sich Verläufe, Ereignisfolgen und Prozesse in ihrer Organisation als musikalische Phänomene und als musikalischen Verlauf vorzustellen und dann zeichnend in selbst->erfundenen Symbolen zu Papier zu bringen (Vossebrecher 2010; Vossebrecher \& Stark 2009).

Die im Folgenden gezeigten Partituren wurden als eine Datenquelle für die Organisationskultur-Analyse ausgewertet, allerdings nicht alle in gleicher Intensität und Tiefe. Daher wird auch nicht jede einzelne erläutert, sondern es werden auf ähnliche Sachverhalte und Fragestellungen bezogene Partituren nebeneinander gestellt. Die betreffenden Fragestellungen bzw. Sachverhalte sind: modulare bzw. musterbasierte Prozesse gemeinsamer Gestaltung (vgl. 4.3.1), Qualität erzeugen (4.3.2), Rhythmen und zeitliche Abstimmung von Prozessen (4.3.3), und Gesamtblick auf die Agentur (4.3.4).

\section{Prozesse gemeinsamer Gestaltung}

Die langgezogene Partitur in Abbildung 6 zeigt einen Teamprozess, in dem fünf Beteiligte (Designer und andere Mitarbeiter) mitwirken ${ }^{19}$. Einem Briefing zu Beginn (Zusammentreffen, erste Klärung des Auftrags etc.) folgt ein Wechsel von Kreativphasen (»Workflow«) - in denen teilweise in chaotisch erscheinender Weise eine Reihe in verschiedene Richtungen laufender Ideen entsteht und entwickelt wird - und Phasen in denen Entscheidungen getroffen und vorläufiger Konsens erzeugt wird, welche Ideen weiter zu verfolgt werden. Die dann folgende Arbeitsphase wird in der Legende zur Partitur auch als »aufbäumen« bezeichnet; dies drückt aus, dass es sich um eine kämpferische Situation handelt, in der um Lösungen gerungen werden muss. Zum Prozess gehört dann noch eine absichtsvolle, gravierende Störung, die bisher Erreichtes noch einmal erschüttert und für die Hinterfragung öffnet.

19 | Legende/Erklärung der Symbole am unteren Rande der Partitur: Wir; Zusammentreffen; Workflow 1: Chaos, verschiedene Ansätze; Zusammentreffen Konsens; Workflow 2: Aufbäumen; Zusammentreffen, Konsens; Einigung; Störer/in Frage stellen; Aufbäumen; finaler Konsens; Ergebnis. 


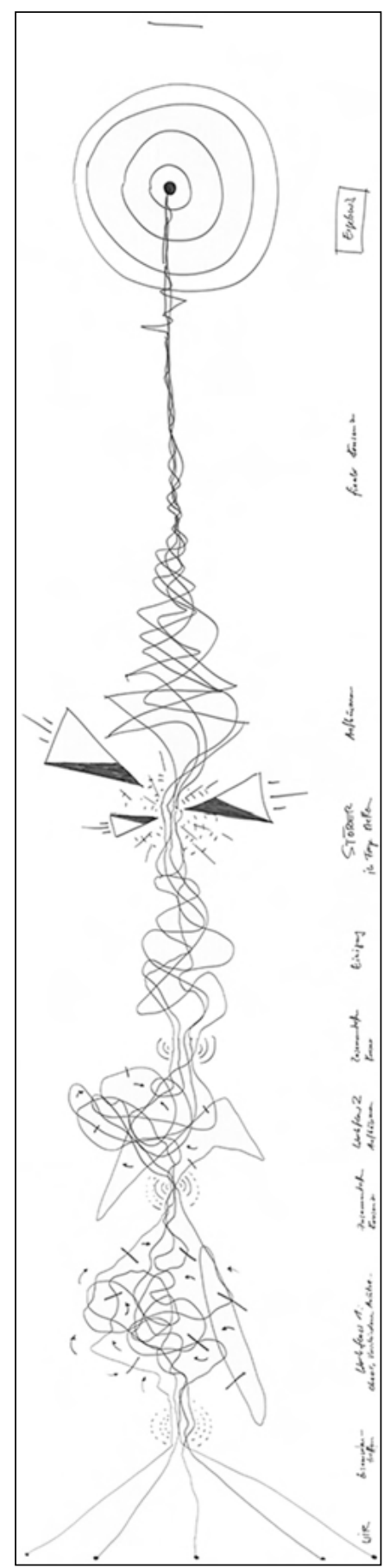

Abbildung 6: Prozesse gemeinsamer Gestaltung 


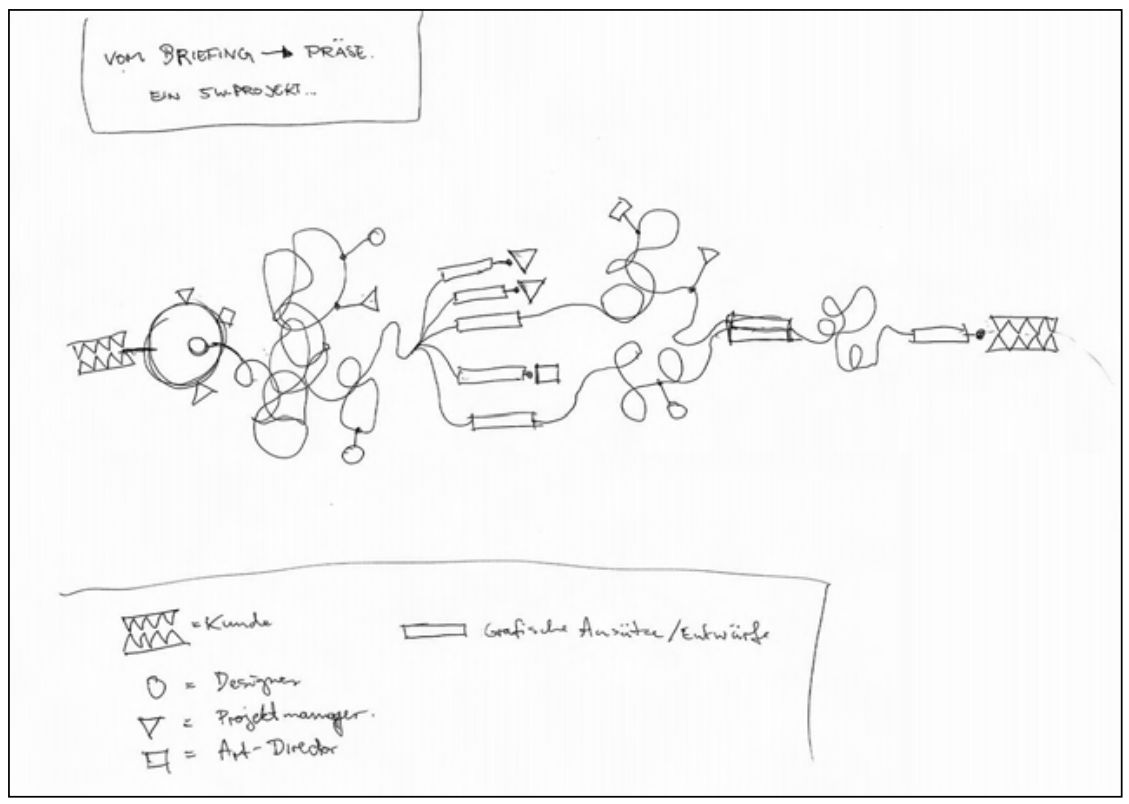

Abbildung 7: Vom Briefing zur Präsentation

Legende/Erklärung der Symbole: Kreis = Designer, Dreieck = Projektmanager; Quadrat = Art-Director; langgezogenes Rechteck = grafische Ansätze/Entwürfe; Kreuze = Kunde

Auffällig ist an dieser Darstellung zudem, dass keine der Linien (die bisherige Entwurfsideen darstellen) gänzlich ins Leere läuft und abbricht. Stattdessen nähern sie sich einander an und gehen schließlich in anderen Linien auf, so dass sich die Anzahl zum Schluss hin verringert; bis zum Ende sind, soweit erkennbar, alle Teil-Ideen noch als getrennte vorhanden, aber in sehr nah beieinander liegender Darstellung, die auf eine in sich passende Lösung und homogene Gestalt als Ergebnis des Prozesses hinweist.

Die Partitur verdeutlicht in ihrer Form sowohl den oben genannten Rahmen für die Zusammenarbeit, als auch einzelne Phasen und Aktivitäten: Das Team arbeitet in einem >Raum < in dem die verschiedenen Muster/Module phasenartig je nach Bedarf zu einem konkreten Prozess zusammen geschaltet werden können. Zudem stecken in der Partitur in Ansätzen auch Hinweise auf Prozesse innerhalb der Teamarbeit. Zum Beispiel, dass gezielt chaotisch und in sehr verschiedene Richtungen gedacht und entworfen werden muss. Zudem lassen sich anschließende Fragen entwickeln: Wie muss in den Phasen der Konsensfindung miteinander gesprochen und interagiert werden, damit einerseits Entwürfe nicht abgewertet werden und andererseits aber Entscheidungen zustande kommen? Welche Kultur gibt es in Konsens- und Entscheidungsfindungsprozessen? Durch weitere Partituren ließe sich das weiter ermitteln und dann reflektieren. 
Eine Variante dieser Darstellung findet sich in einer zweiten Partitur mit dem Titel »Vom Briefing zur Präsentation - ein Fuenfwerken-Projekt«. Auch hier wird der Gestaltungsprozess zwischen dem eröffnenden und dem abschließenden Kundenkontakt dargestellt.

\section{Qualität erzeugen}

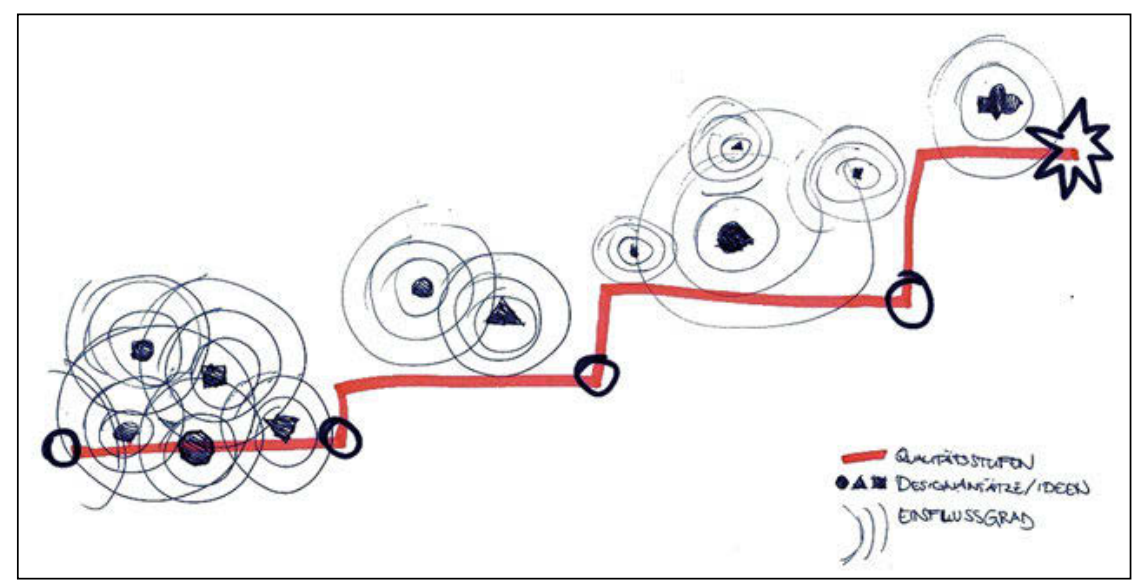

Abbildung 8: Qualität erzeugen

Legende/Erklärung der Symbole: Fette rote Linie = Qualitätsstufen; Kreis, Dreieck, Quadrat $=$ verschiedene Designansätze $/$ Ideen; Kreise $=$ Einflussgrad

Erläuterung zum Verständnis: Die Qualität des Designs steigt in der gemeinsamen Arbeit bzw. Teamarbeit von Stufe zu Stufe. Dabei ist nicht der Einfluss von Personen dargestellt, sondern der Einfluss von Ideen. Auf der letzten Stufe wird eine einzigartige Form erreicht, die eine Kombination aus mehreren der einfachen Symbole (Kreis, Dreieck, Quadrat) ist. 


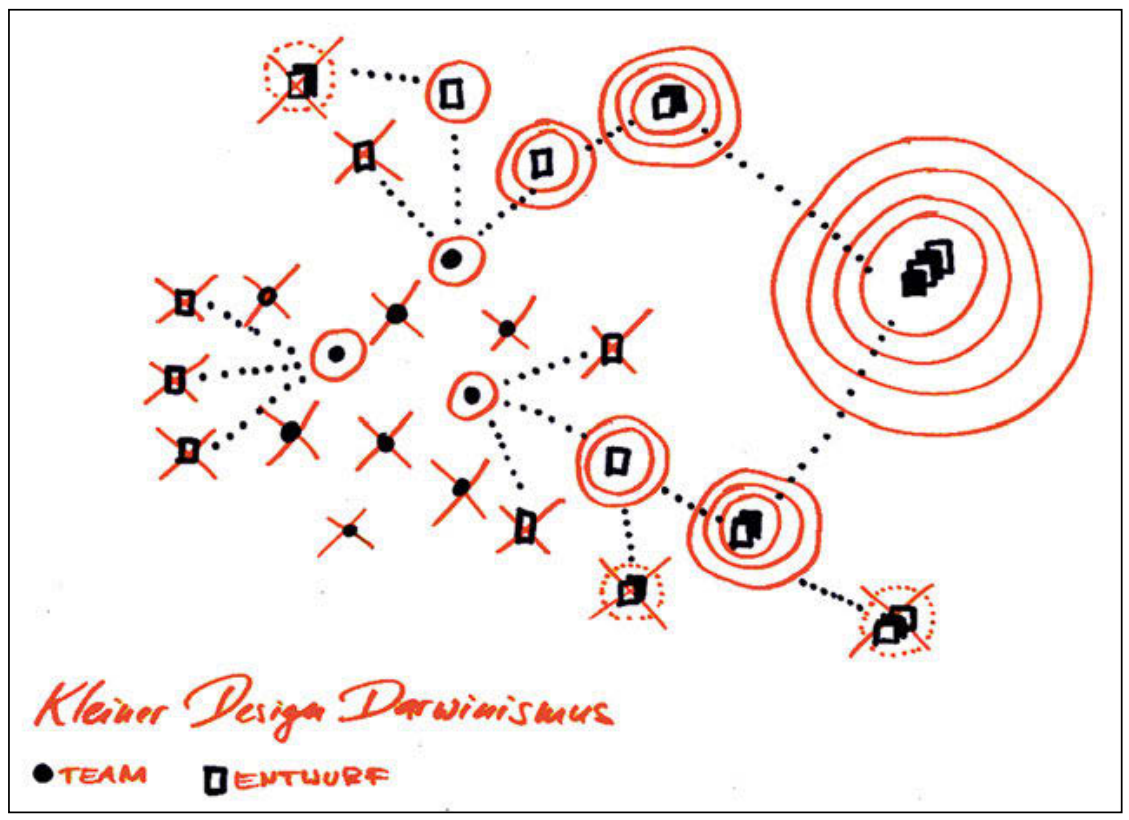

Abbildung 9: Kleiner Design-Darwinismus

Legende/Erklärung der Symbole: fette Punkte = Teammitglieder; Quadrat = Entwurf; konzentrische Kreise: Wichtigkeit/Bedeutung des Entwurfs

Erläuterung zum Verständnis: Der Titel wie die Darstellung sind humorvoll gemeint, d.h. die Konkurrenz der Ideen und ihr Auswahlprozess - vgl. Charles Darwins survival of the fittest als Selektionskriterium - ist nicht überernst. Das Team ist hier aus drei Mitarbeiter/innen gebildet, andere Mitarbeiter sind nicht ausgewählt (bzw. weggestrichen). Entwürfe des einen Teammitglieds kommen nicht zum Tragen, werden nicht weiter verfolgt; andere bestehen die >darwinsche $<$ Selektion. Es wird in viele Richtungen gedacht und experimentiert. Das Endergebnis ist wiederum eine Kombination verschiedener Ideen verschiedener Akteure, d.h. Mitarbeiterinnen/Mitarbeiter. 


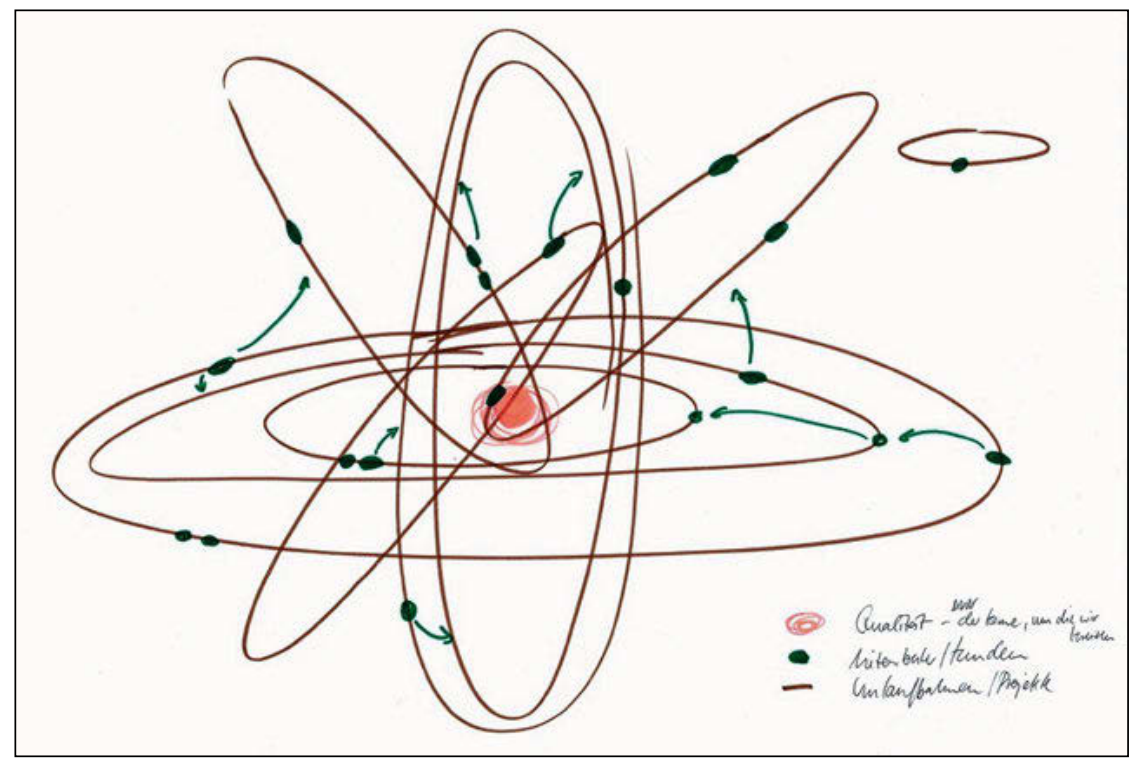

Abbildung 10: ohne Titel

Legende/Erklärung der Symbole: zentral liegender oranger Punkt = Qualität - einer der Kerne, um die wir kreisen; grüne Punkte = Mitarbeiter $/$ Kunden; braune Ovale = Umlaufbahnen/Projekte

Erläuterung zum Verständnis: Die Darstellung weckt die Assoziationen Atommodell oder Sonnensystem, d.h. in der Mitte liegt der Kern oder Fixstern, hier ist das: Qualität. Mitarbeiter und Kunden sind als ein Element gezeichnet (grüne Punkte), da sie in einer gemeinsamen Umlaufbahn sind und Qualität umkreisen. Einige Umlaufbahnen liegen dabei so, dass die Mitarbeiter/Kunden zu bestimmten Zeitpunkten >der Qualität< sehr nah sind, zu anderen Zeitpunkten ferner. Mitarbeiterinnen/Mitarbeiter wechseln von einer in eine andere Umlaufbahn, d.h. in andere Projekte ${ }^{20}$ - das ist eine Darstellung der Flexibilität. Es gibt auch ein Projekt, das fern der Qualität um nichts/um sich selbst kreist (oben rechts).

$$
* * * * *
$$

20 | An dieser Stelle sind die ,Kundenı nicht mitgemeint, sondern nur die Mitarbeiter. 


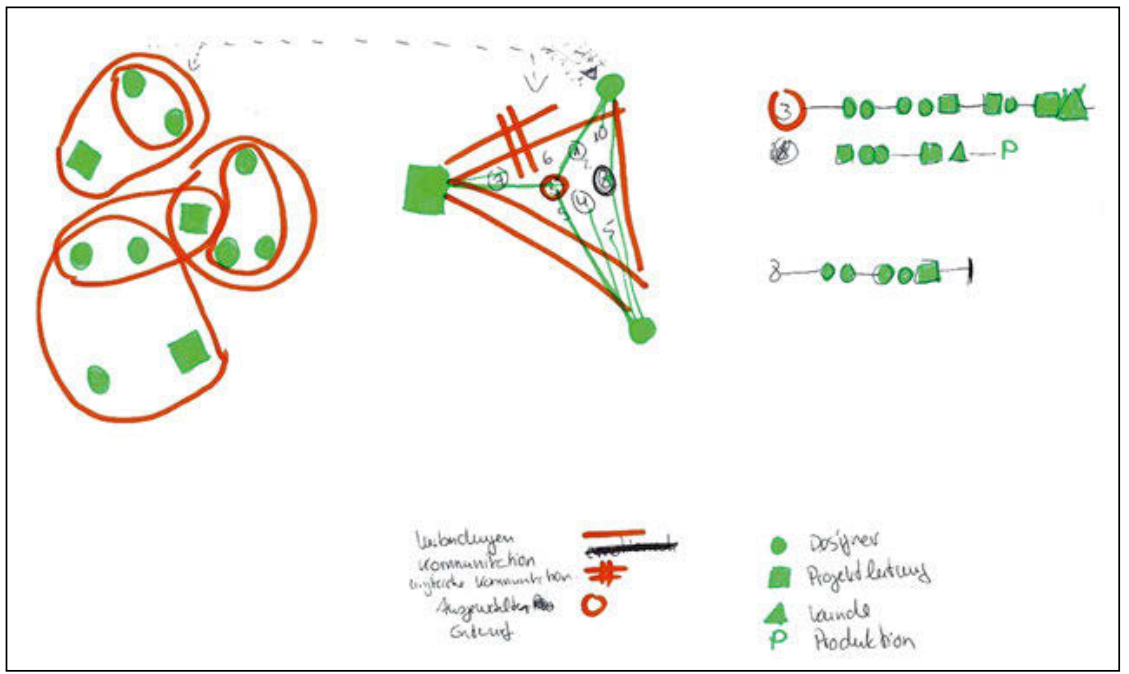

Abbildung 11: ohne Titel

Legende/Erklärung der Symbole: grüne Kreise = Designer; grüne Quadrate = Projektleiter; grüne Dreiecke = Kunden; grünes $>\mathrm{P} \prec=$ Produktion; Doppelkreuz/Hash $(\#)=$ ungleiche Kommunikation; orange fette Linien = Verbindungen und/oder Kommunikation; oranger Kreis = ausgewählter Entwurf

Erläuterung zum Verständnis: Im linken Drittel sind mehrere Teams aus Designern und Projektleitung gezeigt. Teils leitet ein Projektleiter mehrere Designteams, teils bilden die Designer nochmal ein Subsystem innerhalb des Projekts. Das unterste der Teams bildet kein Subsystem.

In der Mitte ist ein Prozess eines der Teams gezeigt, die eingekreisten Zahlen in der Mitte sind verschiedene Entwürfe/Designansätze. Es gibt eine ungleiche Kommunikation zwischen dem Projektleiter und einem der Designer. Trotz der ungleichen Kommunikation gibt es einen Entwurf, den alle drei favorisieren (\#3). Rechts sind Prozessschritte für zwei Entwürfe mit den jeweils Beteiligten dargestellt. Entwurf Nr. 3 (der obere) geht schließlich in Produktion, nach einer Reihe von Interaktionen zwischen Designern, Projektleitern und Kunden. Entwurf Nr. 8 (unten) wird nach einiger Arbeit nicht weiter verfolgt. 


\section{Rhythmen und zeitliche Abstimmung von Prozessen}

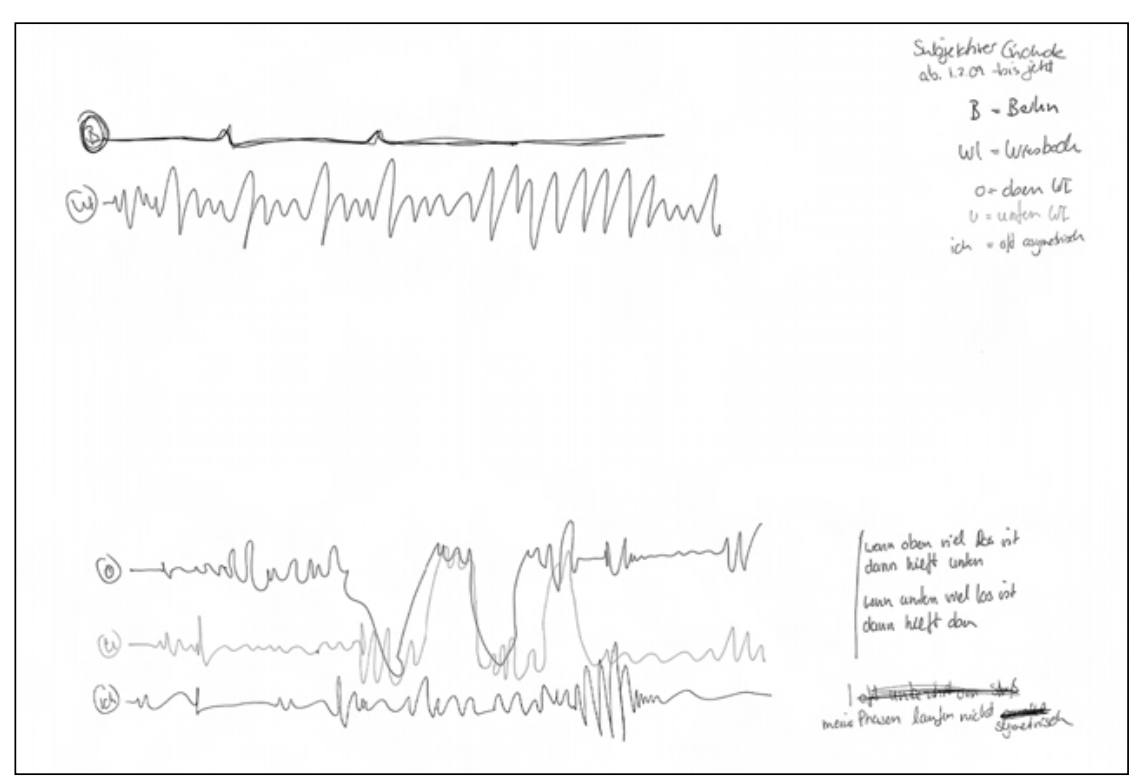

Abbildung 12: Rhythmen - subjektiver Eindruck ab 1.2.2009 bis jetzt

Legende/Erklärung der Symbole: B/dunkelblaue Linie = Berlin (Standort); W/türkise Linie $=$ Wiesbaden (Standort); O/türkise Linie = oben (obere Etage in Wiesbaden), »wenn oben viel los ist dann hilft unten«; U/hell türkise Linie = unten (untere Etage Wiesbaden), »wenn unten viel los ist dann hilft oben«; ich/schwarze Linie = oft asymmetrisch, »meine Phasen laufen nicht symmetrisch«

Erläuterung zum Verständnis: Die obere Hälfte zeigt unterschiedliche Rhythmen der beiden Standorte (Büros Berlin und Wiesbaden) aus streng subjektiver Perspektive. Die beiden Standorte werden deutlich unterschiedlich >hektisch< wahrgenommen. Die untere Hälfte zeigt innerhalb des Wiesbadener Standortes Rhythmen auf den beiden Etagen. Die Mitarbeiter unterstützen sich jeweils in stressigen Phasen. Die Autorin der Partitur stellt ihre eigenen Arbeitsrhythmen (ganz unten, d.h. unterste Zeile) als von den übrigen Rhythmen wiederum abweichend dar. 


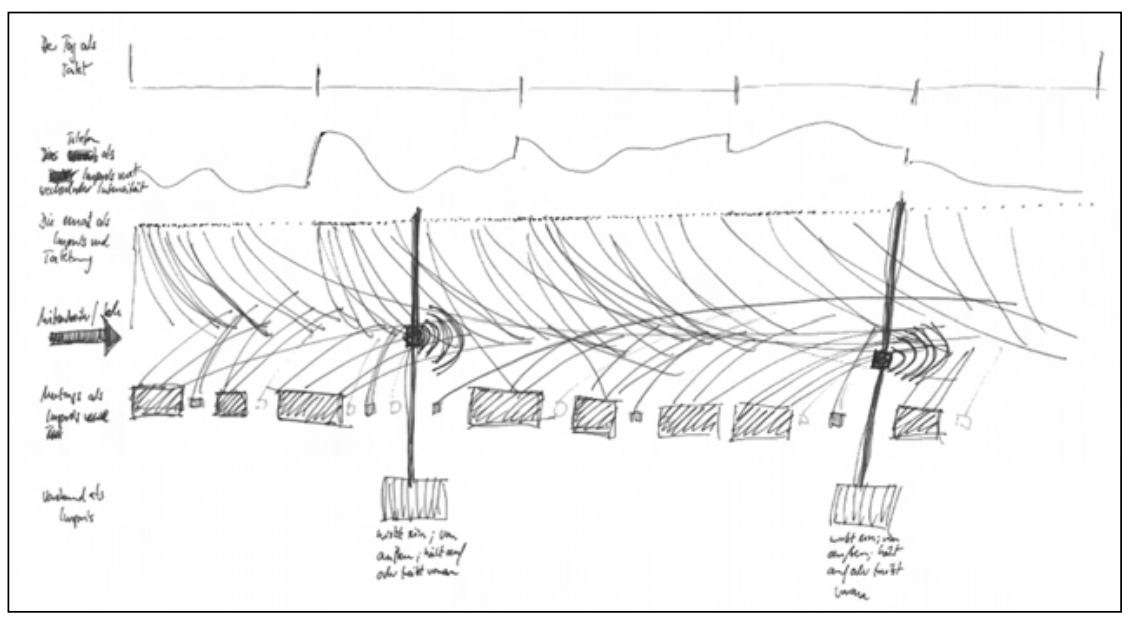

Abbildung 13: ohne Titel

Legende/Erklärung der Symbole: 1. Zeile = »Der Tag als Takt«; 2. Zeile/steigender und fallender Graph = »Das Telefon als Impuls mit wechselnder Intensität«; 3. Zeile: enger oder weiter gestreute Punkte $=»$ Die Mail als Impuls und Taktung«; 4. Zeile/fetter Pfeil $=»$ Mitarbeiter $/$ Ich «; 5. Zeile $=»$ Meetings als Impuls «; 6. Zeile $=»$ Vorstand als Impuls«, »wirkt ein; von außen; hält auf oder treibt voran«

Erläuterung zum Verständnis: Neben dem physikalischen Takt des Tages bzw. der Uhr stehen weniger vorhersehbare Rhythmen; deren Ineinandergreifen und deren Interferenzen sind dargestellt. So entsteht eine multiple Rhythmik, die mitunter schwer zu handhaben ist und für Stress sorgen kann: Von den Rhythmen gehen Impulse aus, auf die mehr oder weniger stark Bezug genommen wird/ werden muss (z.B. >Vorstände< als starker Impuls). Der Mitarbeiter steht in einer intensiven Dynamik. 


\section{Gesamtblick auf die Agentur}

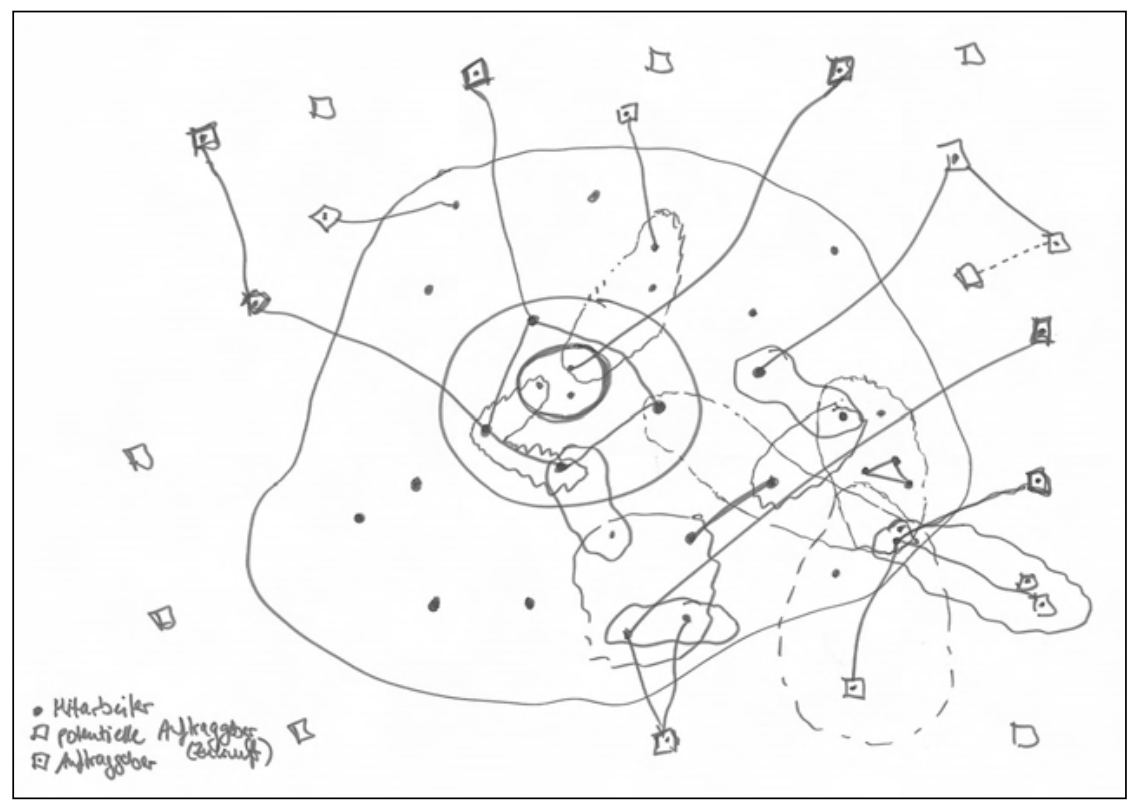

Abbildung 14: ohne Titel

Legende/Erklärung der Symbole: Punkte = Mitarbeiter; Quadrate mit Punkt = Auftraggeber; Quadrate ohne Punkt = potenzielle Auftraggeber (Zukunft); Punkte, die mit einer Linie umkreist sind $=$ Mitarbeiter in Teams; gerade Linien $=$ Verbindungen $z u$ Kunden

Erläuterung zum Verständnis: Im Zentrum sind die drei Vorstände als eine Art besonderes Team, sie sind aber auch Teil anderer Teams. Die gleichzeitige Mitwirkung in mehreren Teams/an mehreren Projekten ist weit verbreitet. Teams arbeiten längerfristig oder kürzer zusammen, visualisiert durch Unterschiede in den einkreisenden Linien. In dieser Partitur ist die gesamte Organisation (des Wiesbadener Büros) zu sehen; der Autor hat tatsächlich bei Fuenfwerken eine Funktion inne, die diesen Blick erlaubt. Spannend ist u.a., dass die Zeitachse nicht linear verläuft (bspw. von links nach rechts), sondern mit in die zweidimensionale, räumliche Darstellung eingefügt ist, nämlich in Form der zukünftigen Kunden. 


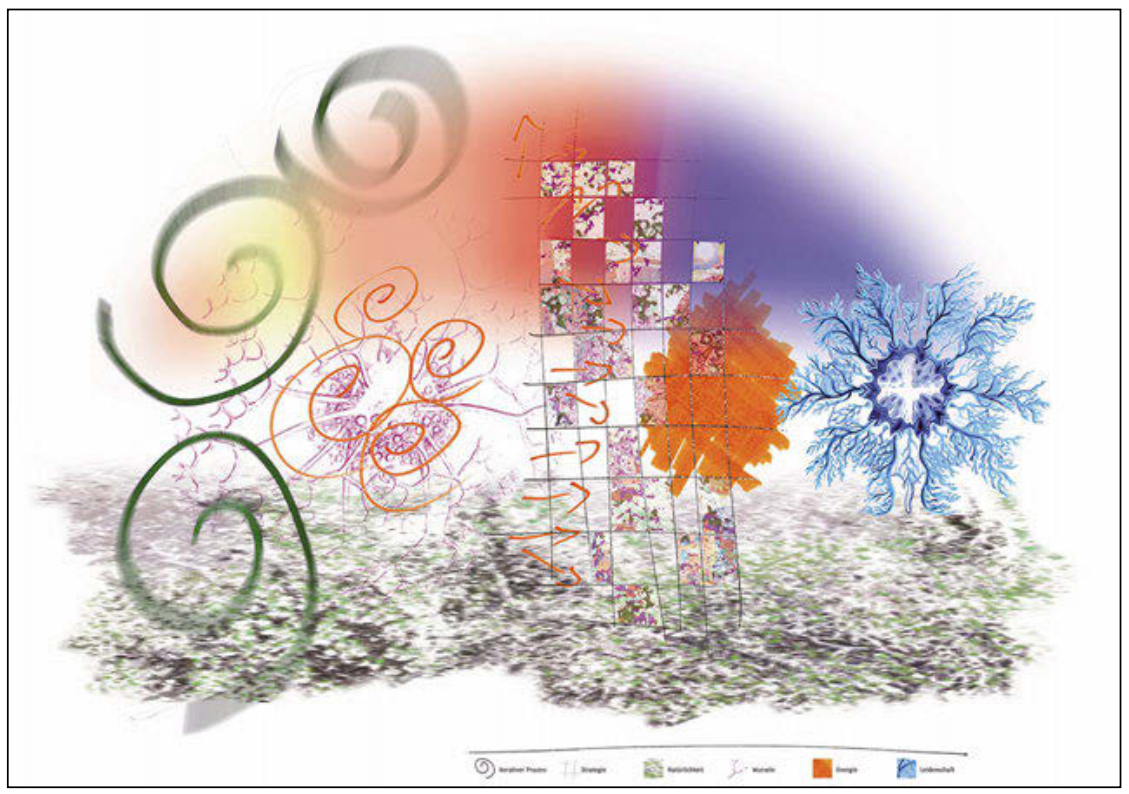

Abbildung 15: ohne Titel

Legende/Erklärung der Symbole: Kringel = Iterativer Prozess; Gitter-Raster = Strategie; grün-weißer >Boden $<=$ Natürlichkeit; blasses Geflecht = Wurzeln; orange Fläche = Energie; blaue Struktur = Leidenschaft

Erläuterung zum Verständnis: Diese Partitur zeigt eine sehr umfassende Gesamtdarstellung der Agentur Fuenfwerken aus Perspektive eines der Vorstände. In der eigentlichen Legende sind nur die sechs oben genannten Elemente angegeben. Anhand eines kurzen Interviews zur ausführlichen Erläuterung der Partitur wurde die folgende erläuternde Darstellung entwickelt: 


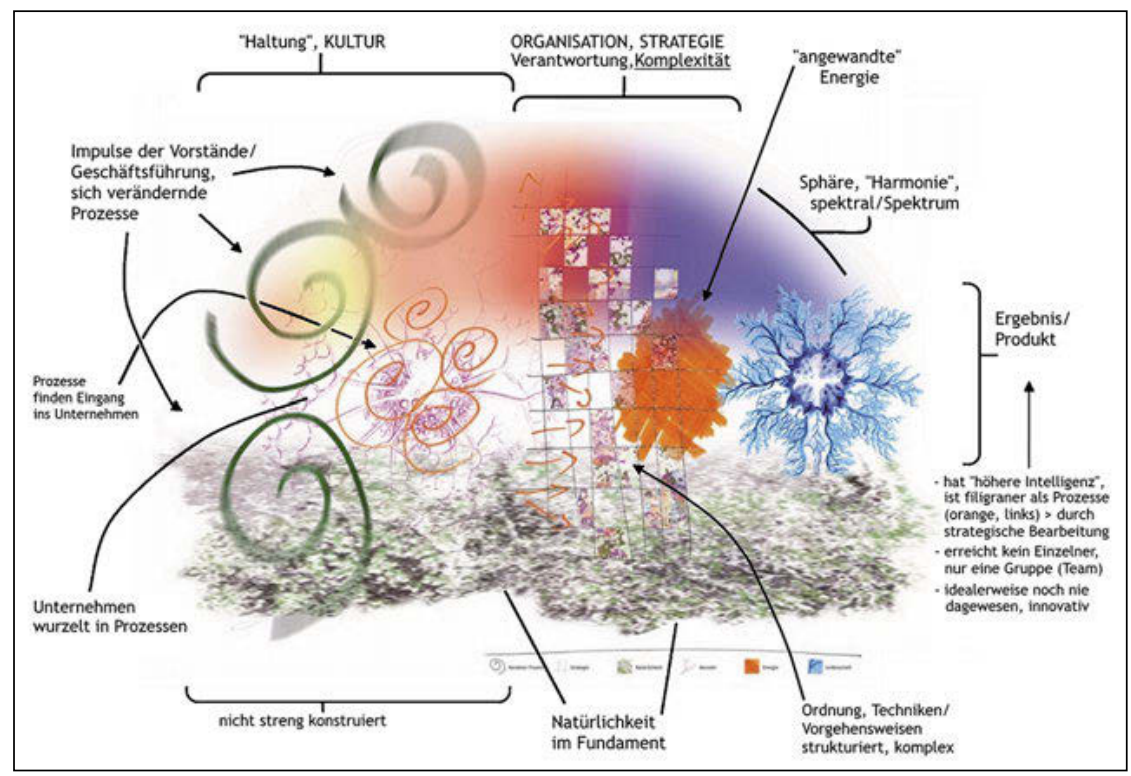

Abbildung 16: ohne Titel

\section{KuLtURELEMENTE als InNOVATIONSPOTENZiale}

In der Organisationskulturanalyse wird deutlich, wie intensiv bei Fuenfwerken die Kultur des Umgangs miteinander, der sozialen Interaktionen im Arbeitsalltag und fein entwickelte Arbeitsweisen bzw. -formen aufeinander bezogen und miteinander verbunden sind. Als Paket bilden sie die Basis für die flexible Entfaltung kreativer Energien - einschließlich deren (wirtschaftlich) sinnvoller Rahmung -, aus der die Agentur ihre innovativen Arbeitsergebnisse gewinnt.

Charakteristisch für die Situation bei Fuenfwerken ist, dass die Organisationskultur von den Mitarbeiterinnen und Mitarbeitern als authentisch angesehen wird und dass sie sehr breit geteilt wird, d.h. dass keine (versteckten) Bereiche der Agentur existieren, in denen eine tatsächlich konträre Kultur herrscht und Reibungsverluste erzeugt. Drei Faktoren lassen sich zusammenfassend noch einmal hervorheben:

Fuenfwerken hat Technologien, also Verfahrensweisen, Prozesse und Instrumente entwickelt, um passende neue Mitarbeiterinnen und Mitarbeiter zu finden und sie vor der langfristigen Bindung ans Unternehmen in der Zusammenarbeit zu erproben sowie um neue Mitglieder in die Arbeits- und Organisationskultur zu sozialisieren bzw. ihre Enkulturation zu gewährleisten. Damit verfügt die Agentur zugleich über eine fein entwickelte Art und Weise der Kulturpflege und -weiterentwicklung. In den Details dieser Technologien liegen viele kleinere und größere Prozessinnovationen, die als Management- und Prozessmuster für an- 
dere Unternehmen beispielhaft sein können. Besonders die Langfristigkeit und Nachhaltigkeit in der Personalentwicklung ist eine Besonderheit, wenn man Vergleiche innerhalb der Design-Branche zieht.

Die formale Organisationsstruktur mit den überschaubaren Hierarchien ist wenig kompliziert, aber durchaus komplex ${ }^{21}$, denn die Mitarbeiterinnen und Mitarbeiter werden flexibel und in vielfältiger Weise zu wechselnden, je nach Projekt kürzer oder länger währenden Teams zusammengeführt. Vor diesem Hintergrund ist die Technologie der Teamarbeit mit ihrer umfassenden Einbettung des sozialen Umgangs, der Arbeitsweise etc. in die Gesamtkultur ein Potenzial für Innovation in doppelter Hinsicht: Zum einen ist für Fuenfwerken intern diese Teamarbeit ein strategisches Tool zu Innovativität oder, anders formuliert, eine Innovationsstrategie. Denn sie gibt die Möglichkeit, auf neue Herausforderungen und Situationen, die aus der Entwicklung des eigenen Unternehmens entstehen oder die in individuellen, neuen Kundenwünschen ihren Ursprung haben, erfolgreich zu reagieren. Der eigene Anspruch, für Kunden jeweils individuelle und neue Lösungen (Designs, Technologien) zu finden, lässt sich so zu einem hohen Grad realisieren. Damit ergibt sich - zum zweiten - aus der Kultur und Arbeitspraxis, dass Fuenfwerken den Kunden besondere Innovationspotenziale zur Verfügung stellen kann.

Die Teilprozesse, die Fuenfwerken in der Teamarbeit nutzt, funktionieren wie ein Modul-Set (modular bzw. musterbasiert) oder wie eine Sprache und sind hochgradig flexibel und situational einsetzbar, je nach Erfordernissen der konkreten Aufgabe. Diese spezifische Arbeitsform hat Fuenfwerken sehr weit verfeinert und kulturell internalisiert. Sie ist vor allem deshalb so wirkungsvoll, weil sie in eine passende Arbeits- und Organisationskultur eingebunden ist, die u.a. durch Werte wie Respekt, Freundschaftlichkeit, Vertrauen und Gemeinschaftlichkeit grundiert ist usw.

\section{LITERATUR}

Alexander, C.; Ishikawa, S.; Silverstein, M. \& Jacobson, M. (1977): A Pattern Language. Towns, buildings, construction. New York, Oxford University Press.

Baecker, D. (1994): Postheroisches Management. Ein Vademecum. Berlin, Merve Verlag.

Bluszcz, O. (2010): Grundlagenpapier Innovation. Grundlegendes zu Innovationsprozessen in Unternehmen. Arbeitspapiere aus dem Projekt MICC, Nr. 11, Universität Duisburg-Essen.

Bourdieu, P. (1976): Entwurf einer Theorie der Praxis. Auf der ethnologischen Grundlage der kabylischen Gesellschaft. Frankfurt a.M., Suhrkamp.

21 | Vgl. dazu die kurze Beschreibung von Dirk Baecker (1994, 32). 
Bourdieu, P. (1987): Sozialer Sinn. Kritik der theoretischen Vernunft. Frankfurt a.M., Suhrkamp.

Coplien, J. (2001): Writer's Workshop Patterns. Internetdokument, URL: http:// c2.com/cgi/wiki? WritersWorkshopPatterns, Zugriff: 18.7.2013.

Dell, C. \& Stark, W. (2013): Tuning in to organizational innovation - music as a metaphor to understand the improvisational field in organizations. In: Scala, Klaus et al., Learning for the Future in Management and Organizations. Charlotte NC, Information Age Publishing.

e-teaching.org (2011): Muster veröffentlichen. Internetdokument, URL: www.eteaching.org/didaktik/konzeption/entwurfsmuster/publizieren, Zugriff: 18.7 . 2013 .

Flick, U. (2008): Triangulation: Eine Einführung. Wiesbaden, VS Verlag.

Gabriel, R. (2002): Writer's Workshops and the Way of Making Things. New York, Pearson.

Karkoschka, E. (2004): Das Schriftbild der Neuen Musik. Celle, Hermann Moeck Verlag.

Kaschube, J. (1993): Betrachtung der Unternehmens- und Organisationskulturforschung aus (organisations-)psychologischer Sicht. In: Meinolf Dierkes, Lutz von Rosenstiel, Ulrich Steger (Hg.), Unternehmenskultur in Theorie und Praxis. Konzepte aus Ökonomie, Psychologie und Ethnologie. Frankfurt a.M., Campus, 90-146.

Kühl, S. \& Strodtholz, P. (2002): Methoden der Organisationsforschung. Ein Handbuch. Reinbek, Rowohlt.

Kühl, S.; Strodtholz, P. \& Taffertshofer, A. (Hg.) (2009): Handbuch Methoden der Organisationsforschung. Quantitative und Qualitative Methoden. Wiesbaden, VS Verlag.

Mehnert, R. (2006): Abgleich der Soll-Ist-Analyse der Organisation Fuenfwerken Design AG. Unveröffentlichtes Dokument, Wiesbaden.

Mehnert, R. (o.J.): Was mich im Leben (unter anderem) bewegt konnte ich in meiner Master-Thesis nun endlich mal zu Papier bringen. Online verfügbar unter: www.fuenfwerken.com/index.php?inhalt=team_detail\&id=1267; 2011-01-20.

MICC-Projekt (2009): Forschungsaufbau: Musik und Klang als Medium der Organisationskultur? Internetdokument, URL: http://micc-project.org/?page_ id=2; Zugriff 21.7.2013.

Mintzberg, H.; Ahlstrand, B. \& Lampel, J. (1999): Strategy Safari. Eine Reise durch die Wildnis des strategischen Managements. Wien, Überreuter.

Nerdinger, F. W. (Hg.) (2007): Ansätze zur Messung von Unternehmenskultur. Möglichkeiten, Einordnung und Konsequenzen für ein neues Instrument. Arbeitspapier aus dem Projekt >TiM - Transfer innovativer Unternehmensmilieus<, Nr. 7. Rostock: Universität Rostock, Lehrstuhl Wirtschafts- und Organisationspsychologie. 
Osterloh, M. (1988): Methodische Probleme einer empirischen Erforschung von Organisationskulturen, in: Dülfer, E. (Hg.), Organisationskultur: Phänomene - Philosophie - Technologie, Stuttgart, 139-151.

Schein, E. H. (1991): Organisational Culture and Leadership. A Dynamic View. San Francsico, Jossey-Bass.

Schein, E. H. (2006): Aufstieg und Fall von Digital Equipment Corporation. Eine Learning History oder: DEC ist tot - lang lebe DEC. Bergisch Gladbach, EHP. Schmidhuber, H. (2012): Forschungsprojekt Corporate Culture und Innovation. In: PAGE - Ideen und Know-how für die Entscheider in der Kreativbranche, 07.2012. Ulm, Ebner Verlag, 47-49.

Schmidt, D. (o.J.): How to Hold a Writer's Workshop. Internetdokument, URL: www.cs.wustl.edu/ schmidt/writersworkshop.html, Zugriff: 18.7.2013.

Stark, W. (2017): Innovationsmuster und Improvisation in Organisationen. Musikalische Muster als Schlüssel für innovative Prozesse. In: Wolfgang Stark, David Vossebrecher, Christopher Dell, Holger Schmidhuber (Hg.), Innovation und Improvisation in Organisationen und sozialen Systemen. Bielefeld, transcript.

Stark, W. \& Dell, C. (2012): Organisationskultur revisited - Transdisziplinäre Schnittstellen zwischen Wissenschaft und Kunst beim Versuch, das Ungenannte und Unerwartete in Organisationen zu erfassen. In: Fritz Böhle, Sigrid Busch (Hg.), Management von Ungewissheit. Neue Ansätze jenseits von Kontrolle und Ohnmacht. Bielefeld, transcript, 327-346.

Strauss, A. (1991): Grundlagen qualitativer Sozialforschung. Datenanalyse und Theoriebildung in der empirischen und soziologischen Forschung. Stuttgart, UTB.

Strauss, A. \& Corbin, J. (1996). Grounded Theory: Grundlagen qualitativer Sozialforschung. Weinheim, Beltz.

Vossebrecher, D. (2010): Organisationspartituren als Methode. Präsentation beim Meeting >Methoden und OE-Tools am OrgLab<. Verfügbar unter: http://miccproject.org/?p=821; Zugriff 2011-01-20.

Vossebrecher, D. (2017a): The Shape of Tacitness to Come - Erweiterte Zugänge zum Impliziten in Organisationen durch musikalisches Denken. In: Wolfgang Stark, David Vossebrecher, Christopher Dell, Holger Schmidhuber (Hg.), Innovation und Improvisation in Organisationen und sozialen Systemen. Bielefeld, transcript.

Vossebrecher, D. (2017b): Organisationspartituren: die implizite Dimension des Organisierens erforschen. In: Wolfgang Stark, David Vossebrecher, Christopher Dell \& Holger Schmidhuber (Hg.), Innovation und Improvisation in Organisationen und sozialen Systemen. Bielefeld, transcript.

Vossebrecher, D.; Bluszcz, O.; Humpert, G. \& Stark, W. (2012): Organisation musikalisch denken: die implizite Dimension des Organisierens entdecken. Arbeit: Zeitschrift für Arbeitsforschung, Arbeitsgestaltung und Arbeitspolitik. 21/2+3, Stuttgart, Lucius \& Lucius, 132-146. 
Vossebrecher, D. \& Kamin, T. (2011): Ergebnisse der Organisationskulturanalysen bei der Fuenfwerken Design AG. Projektbericht einer qualitativen Organisationskultur-Analyse im Rahmen des Projekts >Music, Innovation, Corporate Culture $<$ (MICC). Universität Duisburg-Essen.

Vossebrecher, D. \& Stark, W. (2009): Music, Innovation, Corporate Culture - innovative Organisationskulturen musikalisch verstehen. In: Inken Gatermann; Miriam Fleck (Hg.), Innovationsfähigkeit sichert Zukunft. Berlin, Duncker \& Humboldt, 129-137.

Weick, K. E. (1985): Der Prozess des Organisierens. Frankfurt a.M., Suhrkamp.

Witzel, A. (2000): Das problemzentrierte Interview [25 Absätze]. Forum Qualitative Sozialforschung/Forum: Qualitative Social Research, 1(1), Art. 22, http:// nbn-resolving.de/urn:nbn:de:o114-fqsooo1228.

Wunderer, R.; Gehrig, V. \& Hauser, R. (1997): Qualitätsorientiertes Personalmanagement: Das Europäische Qualitätsmodell als Unternehmerische Herausforderung. München, Hanser. 


\section{Musik und Markenentwicklung}

Holger Schmidhuber und Rolf Mehnert

\section{Einleitung}

Als Spezialist für Corporate Design, Corporate Identity und Markenentwicklung beschäftigte sich die Fuenfwerken Design AG im Rahmen des Forschungsprojektes MICC mit den Mustern von Gestaltung und Kreativität im Kommunikationsdesign, vorwiegend im Bezug auf die genannten Teilgebiete der Disziplin, sowie mit den Möglichkeiten, Musik in struktureller Hinsicht als Kommunikationstool oder als eine Art Katalysator für das Systematische Design fruchtbar zu machen. Beim Systematischen Design handelt es sich um einen von Fuenfwerken entwickelten Gestaltungsansatz, der im Folgenden kurz erklärt werden soll. Da die weiteren genannten Termini weder im alltäglichen Sprachgebrauch noch in den Fachsprachen einheitlichen Definitionen unterliegen, soll zunächst ebenfalls erläutert werden, in welchem Sinne sie hier zu verstehen sind.

Die gezielte Auseinandersetzung mit Musik im Bezug zum visuellen Gestaltungsprozess entstand bei Fuenfwerken zunächst inspiriert durch Ergebnisse aus der Hirnforschung. Musik regt das Gehirn in unterschiedlicher Weise an, was sich allem Anschein nach auch im kreativen Prozess positiv auswirkt (Altenmüller 2005). Zudem scheint es beim Hören von Musik eine Art nonverbales Verstehen zu geben und beim aktiven, interpretierenden Hören durch musikalische Laien spielt implizites Wissen bzw. Intuition eine entscheidende Rolle. Wir ordnen beispielsweise einzelnen Klängen Bedeutungen zu, indem wir sie als sanft, aggressiv, lebendig, monoton, unheimlich oder heiter beschreiben. Dieser Aspekt ist insofern von Interesse als das Sprechen über visuelle Gestaltung häufig an Grenzen stößt. Hier wurde ein Potenzial gesehen, die Kommunikation über Gestaltung und Markenentwicklung durch die Ausdrucksmöglichkeiten der Musik und ihre auf implizitem Wissen basierende Interpretation zu erweitern. 


\subsection{Erläuterung der Begriffe}

Corporate Design ist die kohärente grafisch-visuelle Gestaltung von Artefakten, die als Bestandteil einer Identität fungieren (Beyrow et al. 2007). Aufgabe des Corporate Designs ist es im Allgemeinen, Organisationen oder Unternehmungen, aber auch Ereignissen oder Prozessen ein prägnantes, einprägsames und individuelles visuelles Erscheinungsbild zu verleihen, um sie als ein geschlossenes Ganzes identifizierbar und ihre Identitätsbestandteile oder Produkte auch außerhalb des unmittelbaren Kontextes zuordenbar zu machen. Zentraler Bestandteil eines Corporate Designs ist im Kontext von Unternehmen und Organisationen zumeist eine Wort-, Bild- oder Wort-Bildmarke und weitere Bestandteile wie >Corporate Colours<, >Corporate Type (Typografie)< etc.

Corporate Identity ist die komplexe Gesamtheit aller kommunikativen und handlungsbezogenen Teilaspekte einer Organisation oder Unternehmung, ein Überbegriff der heute eine Vielzahl von Teilaspekten bündelt wie >Corporate Design <, >Corporate Communication<, >Corporate Architecture<, >Corporate Sound<, >Corporate Language<, >Corporate Behavior<, >Corporate Culture< etc. (Olins 1996). Im Gegensatz zum Corporate Design ist die Corporate Identity nichts, was von Grund auf zu entwickeln wäre. Im Grunde ist eine basale Unternehmensidentität immer schon vorhanden; sie muss lediglich herausgearbeitet respektive kultiviert werden.

Der Begriff Systematisches Design wurde von Fuenfwerken im Hinblick auf das Corporate Design entwickelt und die in diesem Feld geläufige Praxis, starre Verregelungen, sogenannte >Styleguides oder Gestaltungsrichtlinien, für die Anwendung der einzelnen Designelemente zu definieren (Ludes \& Schmidhuber 2005). Diese Praxis war ursprünglich aus dem Bedürfnis heraus entstanden, möglichst effizient einheitliche visuelle Erscheinungsbilder gewährleisten zu können. Der gestalterische Rahmen in den Regelwerken war aus diesem Grund so eng gesteckt, dass innerhalb des gegebenen Spielraums keine Abweichung möglich ist, die nicht dem gewünschten Erscheinungsbild entspricht, was allerdings oft auch keinen Raum für neue kreative Ansätze lässt, durch die das Erscheinungsbild und somit das Unternehmen einen lebendigen Charakter erhält. Auch im Hinblick auf die rasante Entwicklung der neuen Medien erwiesen sich solche starren Regelwerke zunehmend als nicht mehr praktikabel, da die im ständigen Wandel begriffenen digitalen Anwendungen immer neue gestalterische Anforderungen mit sich bringen. Das Systematische Design zielt darauf ab, anstelle starrer Verregelungen visuelle Sprachsysteme respektive Gestaltungssprachen zu entwickeln, die es dem Anwender erlauben, freier und dennoch konsistent mit der Visualität eines Unternehmens umzugehen.

Ein weiterer zentraler Begriff in diesem Zusammenhang ist die Marke. Eine Marke ist das Zusammenspiel aller Elemente der Corporate Identity sowie des jeweiligen Produktes oder der Leistung in der Vorstellung des Empfängers. Produkt und Absender werden hierbei vom Empfänger mit emotionalen Werten 
aufgeladen - es entsteht eine Beziehung. Hinter einer erfolgreichen Marke steht auch immer eine gewisse Geisteshaltung mit der sich der Empfänger identifizieren kann und anhand derer er die Authentizität und die Glaubwürdigkeit der Marke verifizieren kann. Die Entwicklung oder Kultivierung starker Marken ist das vorrangige Ziel der Arbeit von Fuenfwerken.

\subsection{Grundlagen für den Markenentwicklungsprozess}

Als wichtigste Grundlage für den originären Gestaltungs- oder Markenentwicklungsprozess dient in der Kommunikationsbranche für gewöhnlich ein sogenanntes Briefing, in dem der Auftraggeber mündlich oder schriftlich seine Erwartungen und Bedürfnisse verbalisiert. Für komplexere Aufgaben, wie die Entwicklung einer kompletten Marke, ist diese Praxis jedoch nicht hinreichend. Um eine authentische und charakteristische Marke entwickeln zu können, ist ein möglichst tiefgreifendes Verständnis von der Branche, dem Kerngeschäft und der gesamten Identität, allem voran der Unternehmenskultur notwendig. Um dies zu erlangen, gehen dem eigentlichen gestalterischen Prozess bei Fuenfwerken Workshops voraus, in denen das Unternehmen unter verschiedenen Gesichtspunkten analysiert wird, um seine Werte, seine Unternehmensphilosophie und seine Kultur herauszuarbeiten. Eine der zentralen Informationsquellen ist dabei die qualitative Befragung eines möglichst breiten Mitarbeiterspektrums, in dem sämtliche Hierarchieebenen des Unternehmens abgebildet werden. Häufig treten in dem so entstandenen kollektiven Bild vom Unternehmen, wichtige Aspekte zutage, die dem Einzelnen unabhängig von dessen Position - in dieser Form nicht bewusst waren, die jedoch das Unternehmen, seine Prozesse und seine gesamte Kultur quasi >unbewusst<, jedoch oft umso einflussreicher prägen. Das ist darauf zurückzuführen, das Unternehmen in fast allen Fällen stärker durch un- oder teilbewusst >gewachsene< Strukturen geprägt sind als durch planvoll >geschaffene «. Auch werden im Rahmen des Analyse-Prozesses die Diskrepanzen deutlich zwischen dem individuellen und dem kollektiven Selbstbild vom Unternehmen sowie dem Fremdbild.

\subsection{Grenzen der Verbalisierbarkeit des Visuellen}

Wenn es darum geht, Anknüpfungspunkte für den gestalterischen Prozess zu finden oder zu schaffen, erweist sich die Alltagssprache oft als nicht hinreichend. Die vermeintlich rationale Verbalisierung der gestalterischen Zielsetzungen sind weder objektiv und präzise genug, um Missverständnissen zwischen Auftraggeber und Gestalter vorzubeugen, noch sind sie in der Lage, kulturelle Zwischentöne und entscheidende emotionale Aspekte zu transportieren. Noch größere Hürden können durch fachsprachliche Differenzen entstehen. Beispielsweise haben bereits sehr grundlegende Begriffe wie >Marke< in unterschiedlichen Fachgebieten wie Kommunikationsdesign, Marketing und Markenrecht nicht gänzlich kongruente oder auch widersprüchliche Bedeutungen. 
Ganz grundsätzlich ist die Kommunikation zwischen den einzelnen Disziplinen im Markenbildungsprozess die zentrale Herausforderung. Ein Auftraggeber ohne jeglichen gestalterischen Hintergrund, und das ist der Normalfall, wird auf spezifische Fragen zur Gestaltung zwangsläufig auf das rekurrieren, was er bereits aus der Erfahrung kennt. Er wird seine visuellen Eindrücke, mit dem abgleichen, was ihm in ähnlichen Kontexten bereits begegnet ist, und er wird in den meisten Fällen versuchen, den Gestaltungsprozess dahingehend zu beeinflussen. Abweichende Lösungsansätze werden vor diesem Hintergrund als >unpassend oder >falsch < beurteilt, was die Entwicklung sinnovativer oder individueller Ansätze, durch die sich das Unternehmen sehr viel besser charakterisieren und vom Wettbewerb abgrenzen ließe, erheblich erschwert.

In Teilen des Analyseprozesses bei Fuenfwerken hat es sich vor diesem Hintergrund als hilfreich erwiesen, dass beide Seiten (Auftraggeber und Agentur) das Terrain ihrer jeweiligen Fachsprache verlassen und sich über non-verbale Kommunikationsvehikel wie die Musik oder die freie visuelle Assoziation verständigen.

\section{MUSiK Versus Sprache}

Der Philosoph Matthias Vogel (2007) hat sich ausgiebig mit dem Verstehen von Musik beschäftigt und dargelegt, inwiefern es sich als sinnvoll erweist von musikalischem Sinn zu sprechen und wie sich dieser vom sprachlichen Sinn unterscheidet. Anders als eine Sprache hat Musik keine >prädikative Struktur< (Vogel 2007). Dennoch ist es denkbar, sich mit musikalischen Mitteln in rudimentärer Form beispielsweise über Emotionen zu verständigen. Musik löst beim Hören Gefühle in uns aus, die Empfindungen wie Trauer, Freude, Stress, Gelassenheit oder Euphorie sehr ähnlich sind. Auch bestimmte visuelle Phänomene wie Farben, Formen oder Muster lassen sich >sinnvoll < und nachvollziehbar in Beziehung zu musikalischen Phänomenen setzen. Insofern ist es also durchaus möglich, über Musik auch bestimmte Eigenschaften einer Organisation zum Ausdruck zu bringen und diese wiederum in grafisch-visuelle Phänomene zu übertragen.

\subsection{Musik als nonverbales Briefing - ein Experiment}

Im Rahmen eines Seminars von Holger Schmidhuber im Studiengang Kommunikationsdesign an der Hochschule RheinMain wurde ein solcher Ansatz mit Studierenden erprobt. Sie erhielten im Rahmen des Kurses die Aufgabe, vorgegebene Stücke aus dem Jazz, der Neuen Musik und progressivere und experimentelle Formen der Popularmusik im Rahmen ihrer Fähigkeiten zu analysieren und die so erarbeiteten akustischen Parameter in eine visuelle Gestaltungssystematik zu transferieren. Um zu vermeiden, dass die Musikstücke lediglich auf emotionaler Ebene illustriert würden, standen dabei weniger emotive oder gar verbale 
als vielmehr strukturelle und formale Aspekte im Zentrum der Analyse. Darüber hinaus mussten sich die Studierenden im Rahmen des Seminars mit den jeweiligen Musikstilen und den Erzeugungs- bzw. Kompositionsformen auseinandersetzen. Erst in einem zweiten Schritt sollten die Gestaltungssystematiken dann in konkrete Anwendungen wie Corporate Designs, Kommunikationsmedien oder Schriftentwicklung umgesetzt werden.

Der Ablauf des Seminars wurde in folgende fünf Phasen untergliedert:

\section{Phase I: Zuhören}

In den ersten beiden Seminaren geht es erst einmal nur ums Zuhören. Nach einer Einführung zum Thema Musik/neue Musik werden die Kompositionen mehrmals vorgespielt. Erste Eindrücke werden besprochen und diskutiert. Als Übung beschäftigen sich die Studenten mit den verschiedenen Titeln/Interpreten und recherchieren darüber.

\section{Phase II: Analyse}

In dieser Phase sollen Eigenschaften und Kriterien, welche die Musikstücke möglichst exakt beschreiben, gefunden werden. Wichtig ist, dass nicht semantische Gesichtspunkte im Vordergrund stehen, sondern analytische/strukturelle Aspekte herausgearbeitet werden. Begriffe wie Instrumentenanzahl, Dynamik, Tempo, Komplexität, Harmonie/Disharmonie, Determiniertheit etc. werden definiert und zugeordnet.

\section{Phase III: Parameter}

Die Erkenntnisse aus der Analyse werden nochmals in Überbegriffe, in so genannte Parameter übersetzt. Die Parameter wie beispielsweise >Unvorhersehbarkeit<, >Irritation<, >Widersprüchlichkeit<, >Übergang<, >Dialog/Streit<, >Raster $<$ sind die essenziellen Hauptbegriffe, welche die Musikstücke umschreiben.

\section{Phase IV: Basiselemente}

Die Begrifflichkeiten aus der Analyse-Phase werden visuell übersetzt. Hier konzentrieren sich die Studierenden bereits auf einen, bzw. einer kleineren Auswahl von Musiktiteln. Die Basiselemente gliedern sich in >Farbe <, >Typografie $<, ~>B i l d-$ sprache $<$, >Formensprache $<$ und $>$ Materialität $<$ und bilden gemeinsam die Toolbox der Gestaltungssprache.

\section{Phase V: Themenfindung und Realisation}

Die Grundbausteine der visuellen Sprache bilden die Basiselemente. In der letzen und längsten Phase geht es nun um den Ausbau dieser systematischen Gestaltungssprache, welche sich in Anwendungsbeispielen unter Beweis stellen muss. Die Studenten können sich hierbei ein fiktives Thema aussuchen, welches über 
die Organe Corporate Design, Print- oder digitale Medien, Schriftentwicklung, Ausstellungsdesign oder Film/Video, kommuniziert wird.

Die Ergebnisse des ersten Seminars an der Hochschule RheinMain ließen bereits erkennen, dass die erarbeiteten Lösungen der Studierenden deutlich weniger von internalisierten Mustern geprägt waren und im Durchschnitt ein sehr viel höheres Maß an Eigenständigkeit aufwiesen, als das bei vergleichbaren Semesterarbeiten in herkömmlichen Kursen der Fall war. Mittlerweile wurde die musikbasierte Systematische Designentwicklung auch im Rahmen von Lehrveranstaltungen (Holger Schmidhuber) an der Freien Universität Bozen im Bereich Visuelle Kommunikation sowie an der Hochschule Mainz erprobt, wo sie im Studiengang Zeitbasierte Medien zum festen Bestandteil des Lehrplans wurde. ${ }^{1}$

\subsection{Musik im experimentellen Markenentwicklungsprozess}

Auf Basis der Erfahrungen aus den Hochschulseminaren wurde der Ansatz, Musik als >nonverbales Briefing z zu nutzen, in einem fiktiven Markenentwicklungsprozess von Fuenfwerken mit dem MICC-Verbundpartner >Gesundes Kinzigtal als Probanden (im Folgenden GKT) experimentell untersucht. Die Ausgangsbedingungen für das Experiment unterschieden sich in den folgenden Punkten vom Experiment an der Hochschule:

1. Die reale Organisation GKT in der Auftraggeberrolle musste in den Versuchsaufbau integriert werden.

2. Die Musik wurde nicht willkürlich vom Versuchsleiter ausgesucht, sondern von den Mitarbeitern des GKTs mit einer kommunikativen Absicht.

3. Durch die Mitarbeiter des GKTs waren erstmals Teilnehmer ohne gestalterisches Fachwissen in das Experiment involviert.

Ziel des Experimentes war die Untersuchung der folgenden Fragestellungen:

1. Inwieweit können musikalische Laien Musik als ein Kommunikationsvehikel im komplexen CD-Prozess nutzen und welchen Einfluss nimmt diese Vorgehensweise auf die Gestaltung?

2. Wie kann man Musik für das Grafikdesign fruchtbar machen, ohne dass die akustischen Ereignisse lediglich auf einer visuellen Ebene illustriert werden?

3. Wie werden Musik, Kommunikationsdesign und Unternehmen grundsätzlich organisiert?

1 | Die Ergebnisse des ersten Seminars wurden in der Publikation "beep. musikalische Strukturen, systematisches Design“ (Ludes \& Schmidhuber, Fachhochschule Wiesbaden, 2005) dokumentiert. 
Mitarbeiter aus dem Kernteam sollten ein Musikstück aussuchen, das aus ihrer Sicht das Unternehmen und insbesondere die Unternehmenskultur widerspiegelt respektive in irgendeiner Weise zum Unternehmen >passt<. Es wurde ausdrücklich darauf hingewiesen, dass dabei nicht die persönliche Geschmackspräferenz das vorrangige Auswahlkriterium darstellen soll, sondern allgemein nachvollziehbare Kriterien wie Rhythmus, Tempo, Komplexität, Struktur, Muster, Hierarchie etc. Die Kriterienliste war bewusst offen gehalten.

Zunächst wurden die Musikstücke mit den GKT-Mitarbeitern ausgewertet. Jeder Teilnehmer erläuterte die Beweggründe zur Wahl des Stückes. Begriffe wie Dynamik, Lautstärke, Kontrast, Flexibilität, Struktur und Rhythmus spiegelten die Organisationskultur und Arbeitsweise der Einrichtung wider. Im zweiten Schritt wurden die Musikstücke mehrfach im Fuenfwerken-Team gehört und analysiert. Die im ersten Schritt gewonnenen Erkenntnisse wurden hierbei zunächst nicht berücksichtigt, um die >reine Musik ohne ihre verbalisierte Interpretation als Erkenntnisquelle und Kommunikationsmedium zu nutzen.

Folgende Parameter wurden auf dieser Basis festgelegt und entsprechend gewichtet:

\section{Referenzwerte mit höchster Präferenz}

oberes Mittelfeld:__ Lautstärke _ Harmonie _ Dynamik

Konzentration im Mittelfeld:_ Kontrast

Referenzwerte mit geringer Präferenz:_ Schnelligkeit_Komplexität_ Abwechslungsreichtum_ »Exotik« (nicht-westliche musikkulturelle Einflüsse)_ Strukturierung_ Härte_ Rhythmus

Die Parameter wurden pro Musikstück einzeln bewertet, tabellarisch erfasst und grafisch mittels Diagrammen dargestellt.

\section{Erstellen von Basiselementen}

Im nächsten Schritt wurden zu den wichtigsten Parametern (Lautstärke, Harmonie, Dynamik, Kontrast) entsprechende Designelemente (Bildwelten, Typografie, Farben, Formensprache) entwickelt. Die gefundenen Elemente wurden im Anschluss wieder den Titeln zugeordnet, nach ihrer Häufigkeit aussortiert, sodass nur noch Elemente mit Relevanz berücksichtigt wurden. Die essenzielle Auswahl der Basiselemente bildete die Design-Toolbox, aufgrund derer Gestaltungstools und Medien entstanden. 

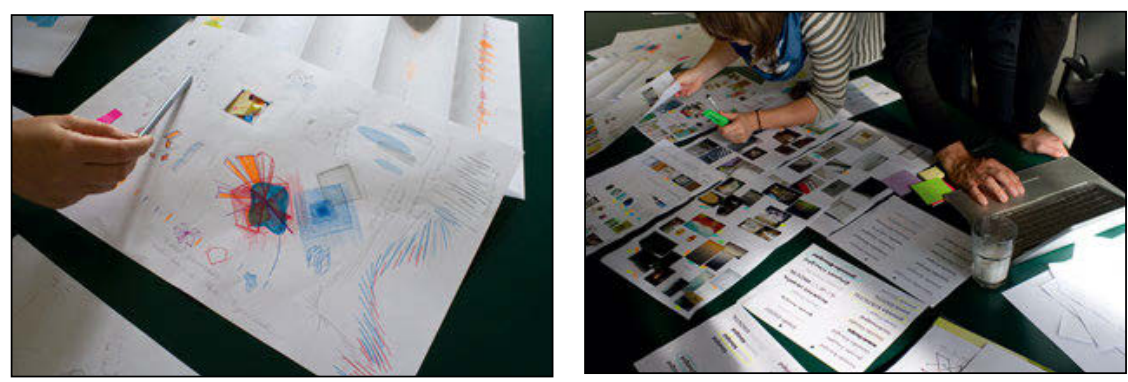

Abbildung 1a und 1b: Das Gestalter-Team von Fuenfwerken entwickeln grafischvisuelle Interpretationen der Musikstücke, welche die Mitarbeiter des Gesunden Kinzigtals ausgewählt hatten.

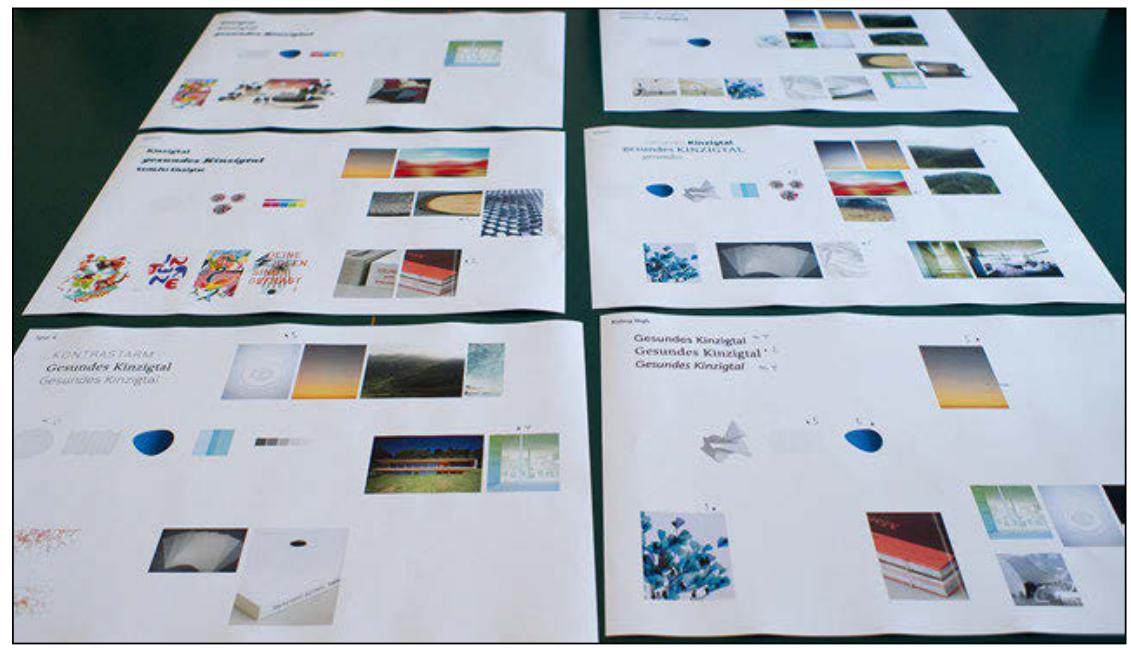

Abbildung 2: Die Ergebnisse des visuellen Interpretationsprozesses werden gemeinsam gesichtet und diskutiert. Hierbei fiel vor allem die relative visuelle Homogenität, also die Übereinstimmung der individuellen Interpretationen auf, die darauf schließen lässt, dass hier ein gemeinsames implizites Wissen angewendet wurde. 


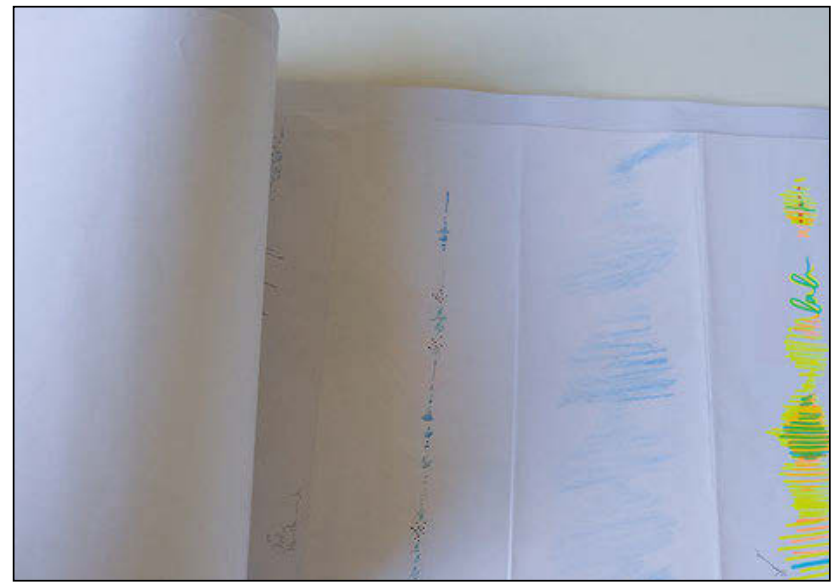

Abbildung 3a: Sammlung der ausgewählten visuellen Patterns aus dem Interpretationsprozess
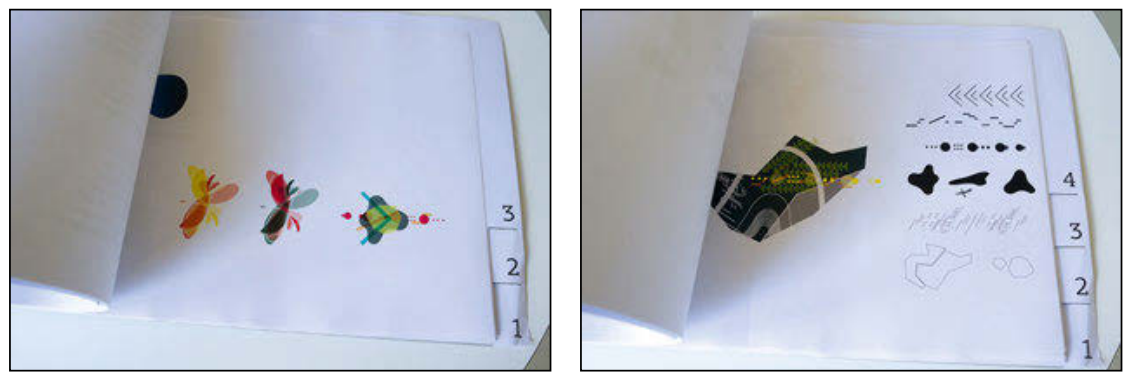

Abbildung 3b-3c: Sammlung der ausgewählten visuellen Patterns aus dem Interpretationsprozess
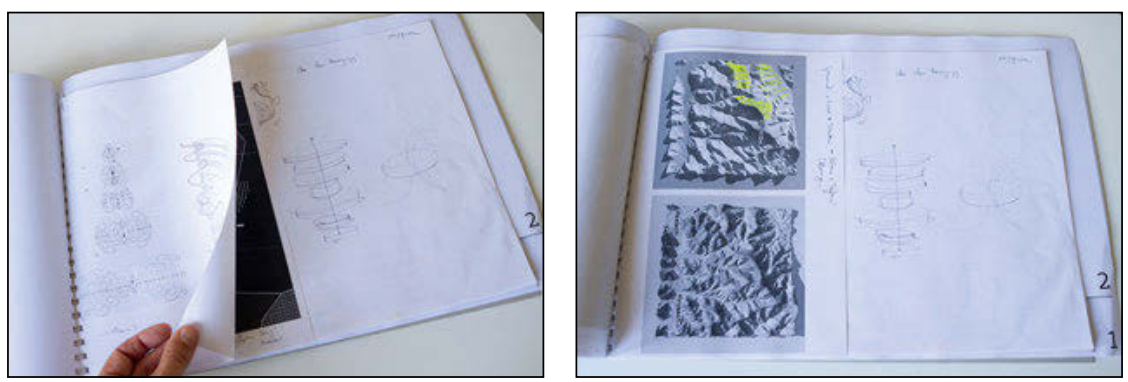

Abbildung 3d-3e: Sammlung der ausgewählten visuellen Patterns aus dem Interpretationsprozess 

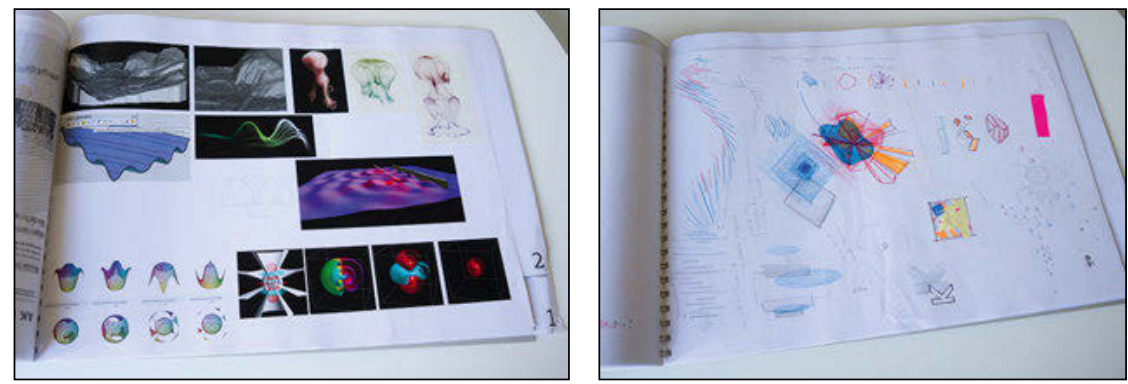

Abbildung 3f-3g: Sammlung der ausgewählten visuellen Patterns aus dem Interpretationsprozess

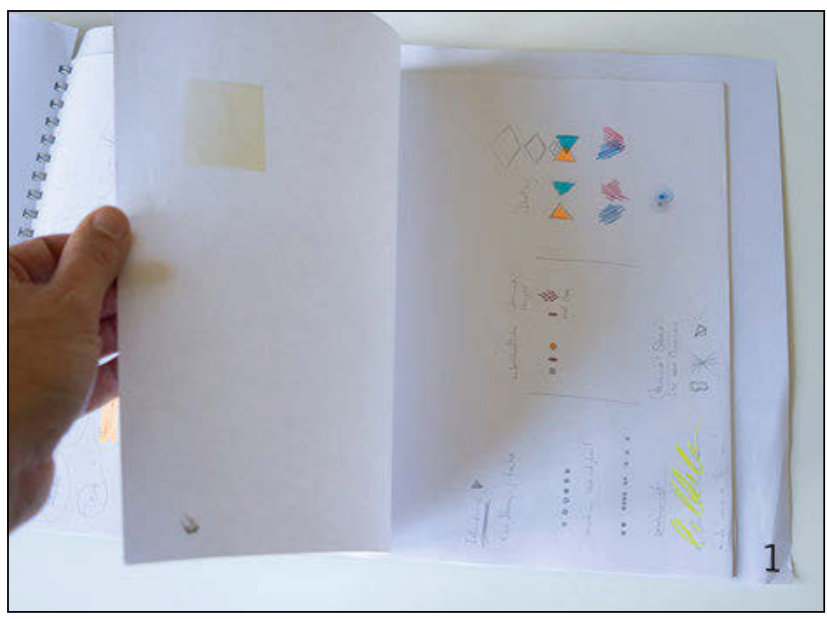

Abbildung 3h: Sammlung der ausgewählten visuellen Patterns aus dem Interpretationsprozess

\section{STEP 1 / Analyse}

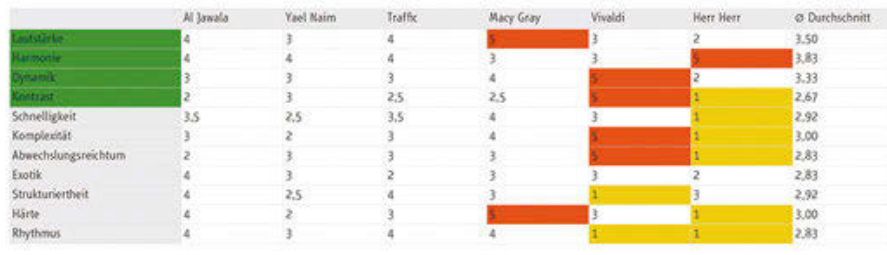

Abbildung 4: Analytisch-abstraktive Aufarbeitung der Ergebnisse aus dem Interpretationsprozess 


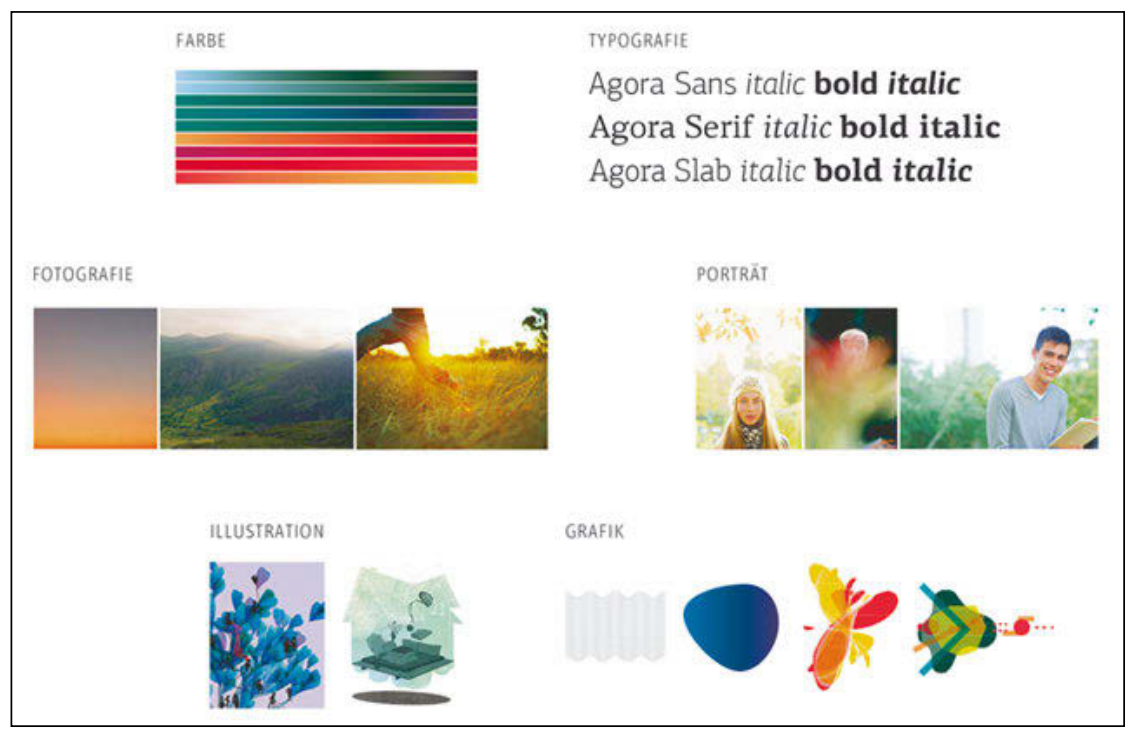

Abbildung 5: Die Toolbox der Gestaltungssprache mit Farbwelt, fotografischer Bildssprache, Typografie und visuellen Basiselementen

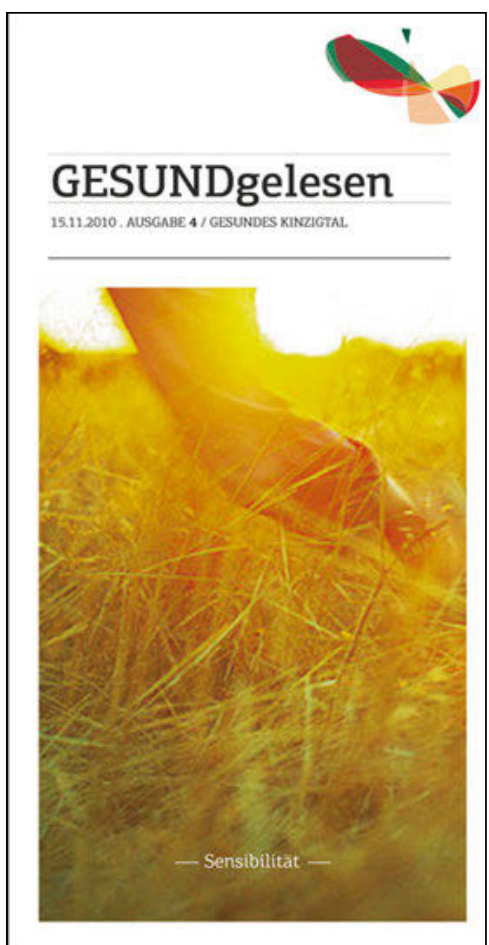

Abbildung 6: Visuelle Gestaltung eines

Broschürentitels, einer Website-Anmutung und eines Plakats auf Basis der Gestaltungssprache 


\subsection{Musik im Corporate-Design-Prozess der Landesbank Saar}

Im Anschluss an diese Testprojekte kam das Verfahren bei der Entwicklung des neuen Corporate Designs der Landesbank Saarland erstmals in einem realen Projekt zum Einsatz. Aus Gründen der Vertraulichkeit können die einzelnen Prozessschritte hier nicht wiedergegeben werden. Hier zeigte sich, dass das musikalische Verfahren es den Beteiligten auf Auftraggeberseite ermöglichte, sich dem Prozess spielerischer und fantasievoller zu nähern, als dies in vergleichbaren Projekten üblich ist. Denn obwohl es eine der wesentlichen Aufgaben einer Marke ist, Emotionen auszulösen, ist der Markenentwicklungsprozess zumeist sehr rational geprägt. Emotionale Aspekte spielen sich dann lediglich während der Entwurfsarbeit im Gestalter selbst ab, ohne kommuniziert zu werden, oder beim Betrachter des fertigen Markenerscheinungsbildes. Im Gegensatz dazu wurde der Markenentwicklungsprozess der Saar LB über den >Umweg $<$ Musik von Anfang an auf eine emotionale Ebene gehoben, was zu einem sehr individuellen und augenfällig branchenuntypischen Ergebnis führte, dass sich gerade deshalb umso charaktervoller, sympathischer und ausdrucksstärker erweist. Auffallend war dabei auch die einhellige und extrem positive Akzeptanz des Ergebnisses auf Auftraggeberseite. Es scheint, als wäre hier durch den Prozess bereits im Vorfeld eine starke emotionale Bindung zum neuen Erscheinungsbild entstanden.

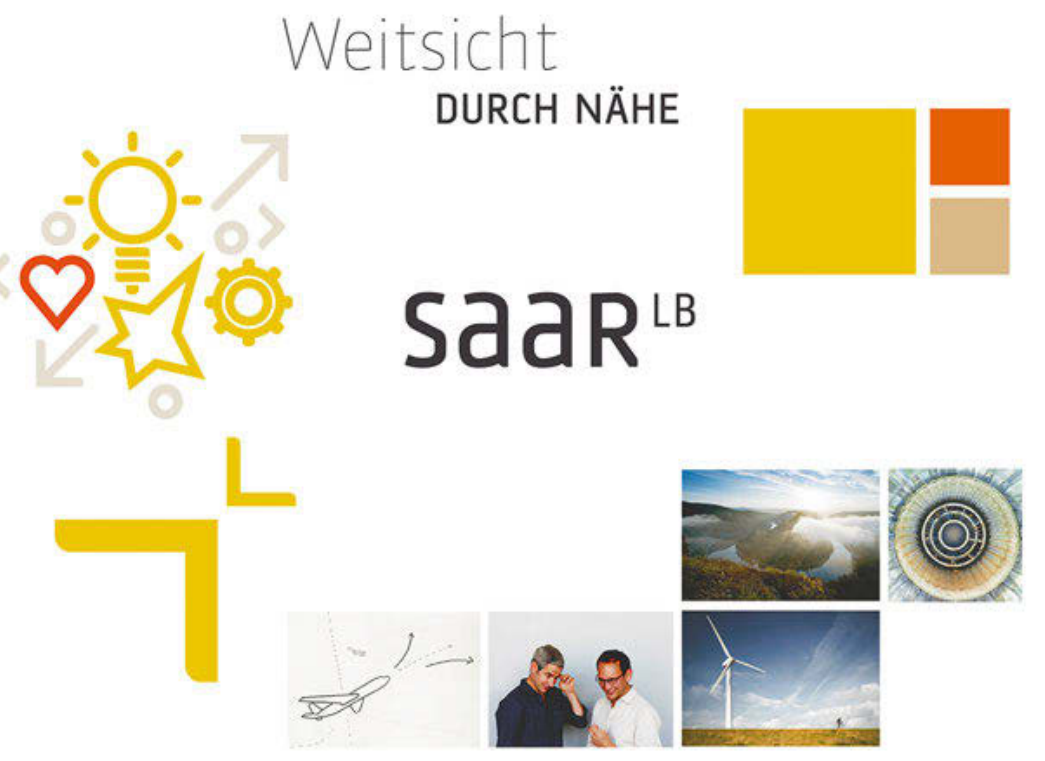

Abbildung 7: Die Toolbox der Gestaltungssprache mit Wortbildmarke, Farbwelt, fotografischer Bildssprache, Typografie und visuellen Basiselementen 


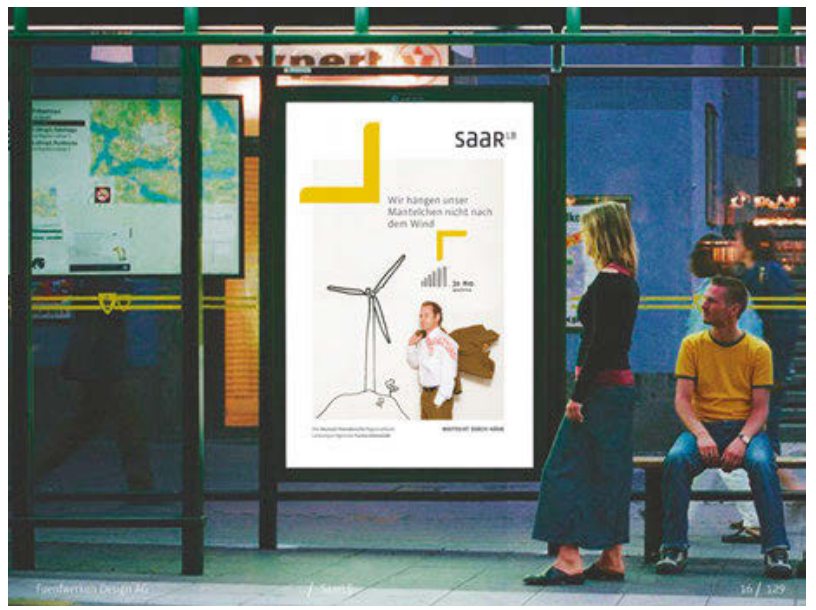

Abbildung 8: Entwurffür ein Kampagnenplakat im öffentlichen Raum
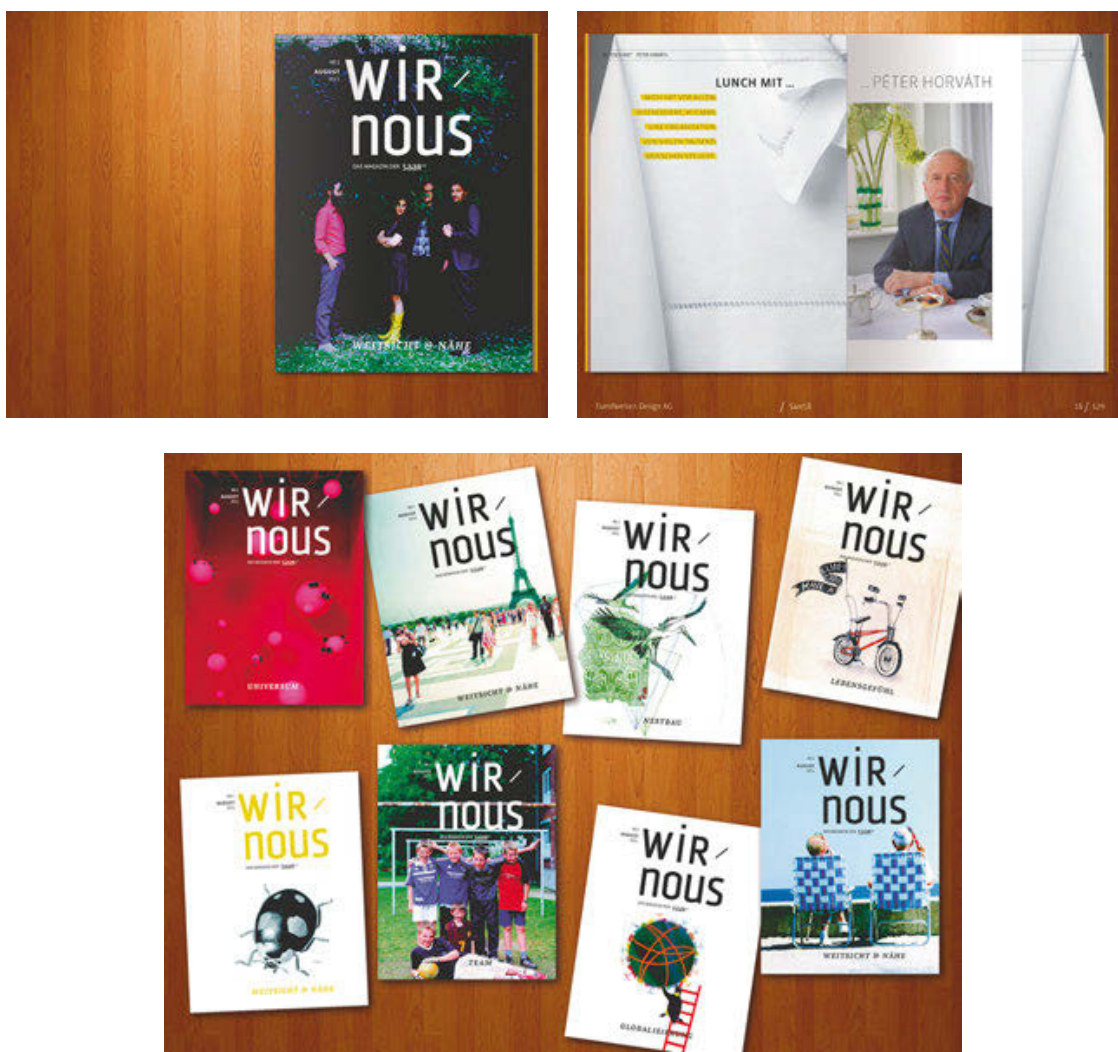

Abbildung ga-c: Konzeption und Layout eines Kundenmagazins auf Basis der Gestaltungssprache 


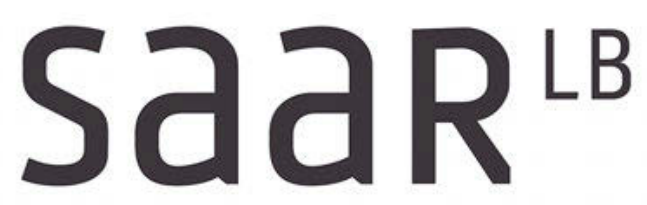

Abbildung 10: Für das Logo der Saar LB wurde auf Basis der Gestaltungssprache eine eigene Schrift entwickelt, die dem individuellen Charakter des Unternehmens Rechnung trägt

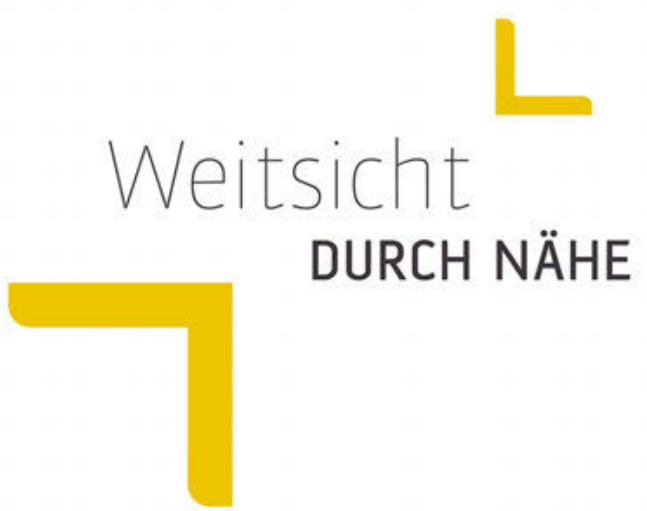

Abbildung 11: Der Claim des Unternehmens, >Weitsicht durch Näher, wird durch die visuellen Elemente illustriert 


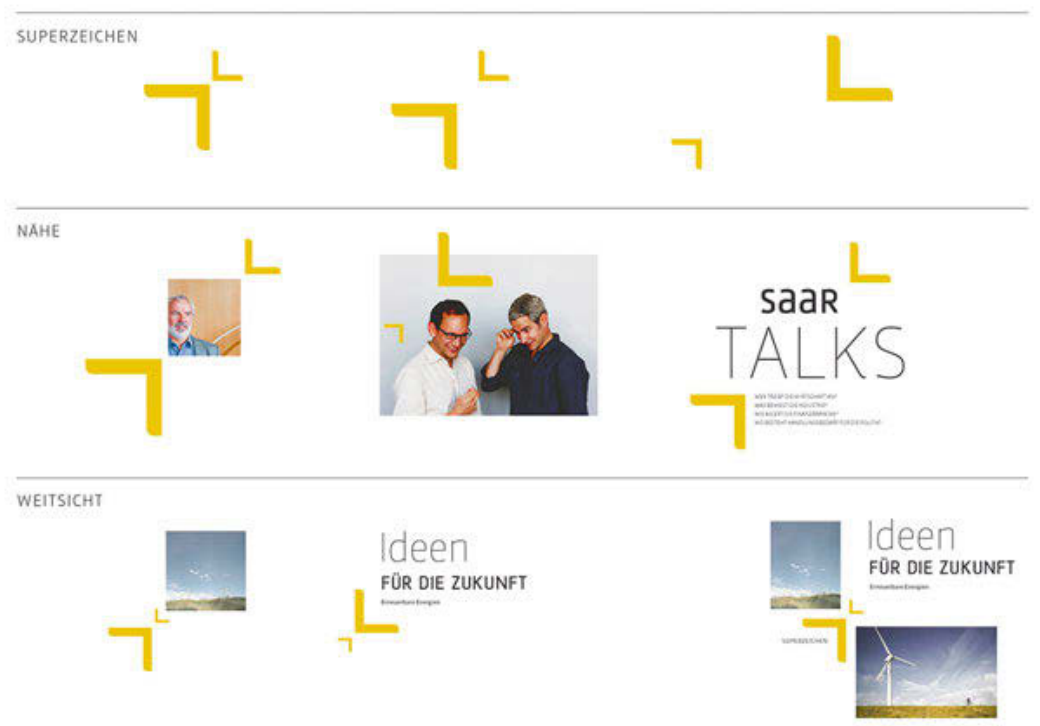

Abbildung 12: Die prägnanten visuellen Elemente des Corporate Designs in unterschiedlichen Anwendungssituation

\section{Fazit - Erkenntisisse aus dem Forschungsprojekt Und Ausblick}

Der Einsatz von Musik ist heute ein fester und zentraler Bestandteil des Markenentwicklungsprozesses bei Fuenfwerken. Als Kommunikationsmedium trägt Musik hier dazu bei, dass emotionale Aspekte in der Analyse des Auftraggebers besser zum Tragen kommen und vermeintlich rationale, etablierte Muster im Bewusstsein der Auftraggeber in der gestalterischen Zielsetzung leichter aufgebrochen werden können - zugunsten einer individuelleren und der Unternehmensidentität angemessenen kreativen Lösung. Natürlich kann das musikalische Verfahren die verbale Kommunikation im Prozess nicht ersetzen, aber es erweist sich als äußerst wertvolle Ergänzung, indem es die emotionalen Faktoren, die auch in der Wahrnehmung der Marke später zum Tragen kommen sollen, zu einem prozessimmanenten Phänomen macht, während das Emotionale im konventionellen Entwicklungsprozess künstlich generiert und vermittelt werden muss. Auch scheint der durch die Musik selbst stark emotional geprägte Prozess zu bewirken, dass eine stärkere emotionale Bindung und Akzeptanz bei den Prozessbeteiligten entsteht. Zudem zwingt das musikalische Verfahren das gewohnte fachsprachliche Terrain und die damit verbundenen Denkmuster zu ver- 
lassen und auf >Umwegen $<$ zu denken, was bereits in der Analysephase zu einem >kreativeren< Betrachten der Gegebenheiten führt. Insbesondere für das systematische Design als betont offenes Gestaltungsverfahren erweist sich dies als äußerst fruchtbar. Im Hinblick auf den ausgeprägten Standardisierungsgrad bei der Entwicklung von Markenstrategien und Unternehmensleitbildern, wie er sich vor allem in den Entwicklungsprozessen von betriebswirtschaftlich und marketingtheoretisch geprägten Beratungsdienstleistern manifestiert, lässt sich feststellen, dass das musikbasierte Verfahren es besser ermöglicht, die Individualität einer Marke herauszuarbeiten und somit ein entscheidendes Abgrenzungsmerkmal zum Wettbewerb zu fördern. Dieser Aspekt wurde vor allem auch von Auftraggebern bestätigt, die gegenüber der unkonventionellen Herangehensweise zunächst eine kritische Haltung einnahmen. Insofern hat sich die Funktionalität und Effektivität der Methode mittlerweile in der täglichen Arbeit von Fuenfwerken und in zahlreichen Markenentwicklungsprozessen bestätigt. Die Methode unterliegt in den Anwendungsdetails einem permanenten Wandel, um zu gewährleisten, dass sie sich nicht als statisches Handlungsmuster verselbständigt.

\section{LITERATUR}

Altenmüller, E. (2005): Warum wir Musik lieben. Zur Neurobiologie der Sprache des Gefühls. Müllheim-Baden, Auditorium.

Beyrow, M., Daldrop, N., Kiedaisch, P. \& Samesch, S. (2007): Corporate Identity und Corporate Design, Stuttgart, Avedition.

Ludes, G., Schmidhuber, H. (2005): Beep - Musikalische Strukturen und Systematisches Design. Wiesbaden, Hochschule RheinMain.

Olins, W., (1996): New Guide to Identity. Aldershot (UK), Taylor \& Francis.

Vogel, M. (2007): Nachvollzug und die Erfahrung musikalischen Sinns, in: Becker/Vogel (Hg.) Musikalischer Sinn. Frankfurt a.M. Suhrkamp. 


\title{
Organisationspatterns entdecken und in der Praxis nutzen
}

Monika Bobzien

\author{
"Nur was man aufschreiben kann, \\ hat man richtig verstanden." \\ Tim Wellhausen, 2013
}

Denkweisen, Theorien und Methoden der Organisationsentwicklung beschäftigen sich seit langem mit Musterbildung in Organisationen als ein notwendiger Teil der Organisationskultur. Muster beziehen sich nicht auf das >Was< sondern sie regeln das >Wie< unseres Tuns. Aus den meist unbewussten und ungeplanten Basisannahmen in der Interaktion der Mitglieder, den so genannten mentalen Modellen (Kantor, 1996), entstehen nach und nach grundlegende Orientierungsund Vorstellungsmuster als >bevorzugte Wege des Denkens und Problemlösens< (Schreyögg 1992), mit denen immer wieder auf neu auftretende Ereignisse reagiert wird und die koordiniertes und koordinierbares Handeln in einer Organisation überhaupt erst ermöglichen. In der Organisationskultur haben sich, als sichtbares Ergebnis der ordnenden und identitätsstiftenden Wirkungen von kollektiven mentalen Modellen, eine Vielzahl von Mustern verstetigt, die an neue Mitglieder weitergegeben und so in der Organisation tradiert werden. Organisationsmuster werden bislang insbesondere danach untersucht, inwieweit latente Regeln dazu beitragen, dass es in der Organisation zu >Lernhemmnissen< (Senge, 1990, Ameln \& Zech, 2011) kommt, die einen Veränderungsprozess erschweren oder ihn gar unmöglich machen.

Eine gleichbleibende Struktur kann aber auch dem impliziten Wissen einer Organisation zugrunde liegen. Die Möglichkeit, dieses an bestimmte Situationen und Verhaltensweisen gebundene Wissen auf geregelte und leicht verständliche Weise zu explizieren und damit interessierte Personen in ihrer Entscheidungsfindung zu unterstützen, hat vor allem zur Optimierung von Prozessen und Produkten in der Software-Entwicklung, in der Didaktik ${ }^{1}$ und im Bereich von E-Learning

1 | Kohls/Wedekind (2008) fassen den Nutzen von Pattern für die Lehrpraxis wie folgt zusammen: "Didaktische oder pädagogische Patterns sammeln das Erfahrungswissen 
und E-Teaching² zur Beschreibung von Mustern (patterns) geführt. Dieser Ansatz wird im Folgenden weiterhin als Pattern bezeichnet, um ihn von den Mustern zu unterscheiden, die eine Organisationskultur prägen.

Beraterisches Handeln ist auf Vorstellungen und Bilder und das Verständnis, was eine Organisation ausmacht und im besonderen wie sie stickt<, angewiesen, also auf das Erkennen von Musterbildung. Da organisationstheoretische Diskussionen zu Musterbildung wie auch die Herleitung von Pattern an anderer Stelle in diesem Band geführt werden, beleuchtet dieser Beitrag beide Ansätze vor dem Hintergrund der praktischen Anschlussfähigkeit. Es ist ein Herantasten an die Frage, inwieweit beide Ansätze zusammenwirken müssen, das heißt, Organisationsmuster den Kontext für Pattern darstellen, damit organisationales Handeln sinnvoll und zielgerichtet weiterentwickelt werden kann. An der Ausführung eines Praxisbeispiels soll dies abschließend versucht werden.

\section{Das Verständnis von Mustern aLS Hindernis in Veränderungsprojekten}

Die Muster in der Organisationskultur zu erkennen, sie aufzudecken und ihre Funktionalität zu hinterfragen, wird seit einigen Jahren von verschiedenen Personen, Gruppen und Institutionen betrieben, die solche Organisationsmuster im Rahmen komplexer organisatorischer Veränderungsprozesse verstehen wollen. Die sich selbst organisierende Struktur dieser Muster zeichnet sich aus durch Phänomene der Wiederholung, der Ähnlichkeit, der Rhythmik, der Gerichtetheit und Regelhaftigkeit. Diese >Musterhaftigkeit in Organisationen< (Looss, 1996) ermöglicht einerseits, dass produktivitätsorientiert gearbeitet werden kann, sie gibt Orientierung und ermöglicht Kommunikation und Kooperation. Andererseits hält sie in Zeiten der Unsicherheit für deren Mitglieder die Erwartung nach stabilen Strukturen wach. Eine >starke< Organisationskultur hat ausgeprägte Selektions- und Stabilisationsmuster (z.B. >wir $<$ und die >anderen $<$ ) und soll die Systemidentität vor Außeneinflüssen bewahren. Sie sichert den inneren Frieden, »[...] denn nur, wer im Sinne des bisher Üblichen handelt, kann davon ausgehen, dass er Konsens findet«. (Luhmann, 2000, S. 245). Die erfolgreiche Abwehr von Störungen führt jedoch dazu, dass »[...] es die Organisation für ihre eigenen Verfahrensweisen >blind < werden lässt und die Verhaltensmuster werden >von selbst

von Experten und Expertinnen aus der Lehrpraxis. Basierend auf Best-Practice-Beispielen werden die wiederkehrenden Komponenten erfolgreicher instruktionaler Designs erfasst und analysiert mit der Zielsetzung, beim Entwurf neuer didaktischer Szenarien auf bewährte Methoden zurückzugreifen." (S. 217)

2 I Zum Thema Educational Patterns stellen Bauer/Baumgartner in ihrem Buch schaufenster des Lernens، (2012) eine Mustersammlung zum Umgang mit E-Portfolios vor, in der auch das dahinterliegende pädagogische Konzept erläutert wird. 
verständlich<, sind also nicht mehr der Gegenstand von interner Kommunikation oder Problematisierung.« (Looss, S. 235). In der beraterischen Praxis erweisen sich eingeschliffene kulturelle Muster häufig als Hemmnisse für Veränderungsprozesse, da auf der Ebene des faktischen Handelns alles beim Alten bleibt: »Unangenehme, dem herrschenden Weltbild zuwiderlaufende Vorschläge werden frühzeitig blockiert oder gar nicht registriert. Dies bringt in der Summe potentiell das Problem der Starrheit und mangelnder Anpassungsfähigkeit mit sich«. (Schreyögg 1992: 1553 vgl. auch Ameln \& Zech 2011).

In die Überlegungen zum organisationalen Lernen (Argyris \& Schön 1996) hat Wolfgang Looss (1996) mit seinem Beitrag über Musterformation in Organisationen einen Aspekt beigesteuert, der Organisationen daraufhin betrachtet, welchem Grundmuster sie insgesamt folgen. Demnach schaffen Organisationen einen Bezugsrahmen entsprechend ihrer Sinnorientierung und Identitätsgewichtung, der sie auszeichnet und als »typisch« angesehen werden kann. Der Autor unterscheidet hier zwischen drei Grundmustern, die den Logiken Zielorientierung, Regelorientierung und Werteorientierung folgen, wonach sich eine Organisation (es kann auch eine Organisationseinheit sein) überwiegend formiert und sich ihre Mitglieder verpflichtet fühlen. »Ziele, Regeln und Werthaltungen bilden die Qualitäten, mit denen strukturelle Anpassungen und Innovationen einerseits und organisatorische Festlegungen andererseits vollzogen werden.« (Looss 1996: 235)

Denk- und Verhaltensmuster von Organisationsmitgliedern werden sich daher in Bezug auf Handlungs-, Kommunikations- und Entscheidungsfelder tendenziell unterscheiden, je nachdem welchen Stellenwert und welche Interpretation die Organisation diesen Logiken einräumt. Entsprechend dem vorherrschenden Grundmuster unterscheidet sich eine Softwarefirma (eher zielorientiert) in ihren >typischen< Handlungs-, Kommunikations- und Entscheidungsmustern von einer kommunalen Behörde (eher regelorientiert) oder einer karitativen Einrichtung (eher wertorientiert). Das Selbstverständnis, mit der die Organisation (bzw. Organisationseinheit) diese Logiken praktiziert, wirkt in Abstimmungs- und Entscheidungsprozessen einerseits implizit, oft auch explizit nach innen und nach außen. In Kombination mit weiteren konstituierenden Bedingungen, wie beispielsweise die Konzentration oder Verteilung von Macht, wirken die drei Grundmuster ebenfalls so, dass sie eine Organisation vor >Störungen ‘ aus der Umwelt schützen können und »tiefergreifende Lernanstrengungen der Organisation vermieden oder hinausgezögert werden« (a.a.O.: 240).

Bekannte Beispiele für eine bewusste Änderung eines Grundmusters mit all seinen Implikationen finden sich beim >Umbau< von staatlichen oder kommunalen Betrieben in privatwirtschaftliche Dienstleister. Auch innerhalb einer Organisation kann es zu Kollisionen zwischen den Grundmustern kommen, wenn beispielsweise ein kommunales Amt einerseits Dienstleister für die Bürger/innen sein möchte und andererseits hoheitliche Aufgaben wahrnehmen muss. 
Der von Looss angebotene Blickwinkel ist insofern interessant, da für die Beschreibung eines Pattern die Komponente des >Kontexts < eine wichtige Rolle spielt, wie im folgenden Kapitel noch ausgeführt wird. Teil dieses Kontextes ist die Organisationskultur. Sie ist auch dem lösungsorientierten Patternansatz immanent. In Anlehnung an den Informatiker Conway (1968) könnte man sagen, dass die Gestaltung eines Pattern das Grundmuster der Organisation wiederspiegelt, in der das Pattern entsteht.

Die bisherige Annäherung an das Thema Musterbildung macht deutlich, dass es hier vor allem darum geht, in Veränderungsprojekten Wege zu finden, latente, als dysfunktional wirkende Muster aufzudecken, zu durchbrechen oder zumindest soweit zu stören, um bei den Organisationsmitgliedern Lernbereitschaft $\mathrm{zu}$ wecken, damit für eine Veränderungsstrategie förderlich Regeln entwickelt werden können. Diesem >Verlernen< alter Muster folgt im besten Falle ein funktionaleres Handlungsmuster, das im Handlungsrepertoire der Organisation verankert werden kann. Die generelle Tendenz zur Veränderungsresistenz von organisationskulturellen Mustern kann allerdings dazu führen, dass sehr bald nachhaltige Veränderung und Innovation erneut gefährdet sind, folgt nicht eine regelmäßige Überprüfung auf Stimmigkeit (Ameln/Zech 2011).

\section{Muster zUr Verbesserung VON KOMMUNIKATIONSSITUATIONEN NUTZEN}

Im Umfeld der Vertreter der >lernenden Organisation< und der Systemtheorie wird angenommen, dass die Gestaltung und Förderung einer dialogischen Kommunikation einen wesentlichen Erfolgsfaktor unternehmerischen Handelns darstellt. Diesem Ansatz geht auch David Kantor Buch Reading the Room (2012) nach, indem er konkrete Gesprächssituationen untersucht und feststellt, dass diesen Muster zugrunde liegen, die verbale Interaktionen beeinflussen. Für das >Miteinander-in-Beziehung-treten greift er die Struktur des bereits im Kontext von Familiensystemen beobachteten Four-Player-Modells auf (Kantor \& Lehr 1975), das später auf Organisationsteams übertragen wurde (Ancona \& Isaacs, 2007) ${ }^{3}$. Demnach kann ein ausbalanciertes Team, in dem sich die Akteure in den vier Rollen bewegen und auf geeignete Weise zusammenwirken, zu produktiven Entscheidungen kommen. Nach Kantor ist ein verbaler Austausch laufend von dieser weitgehend unbewussten Struktur durchzogen. Damit die Konversation in Gang gehalten werden kann, konstruieren und befolgen die am Gespräch Beteiligten ein implizites Verständnismuster entsprechend dieser Struktur. Funktional oder

3 | Kantor's Four-player model unterscheidet folgende Rollen: Mover - Antreiber initiiert und gibt Richtung; Follower - Anhänger unterstützt und schafft Vollständigkeit; Opposer Widersacher fordert heraus und liefert Korrektur; Bystander - Zuschauer beobachtet und zeigt Perspektiven auf. 
dysfunktional werden die Muster dann, wenn sich zur Struktur die persönliche Dynamik der Beteiligten gesellt. Dysfunktionale Muster entstehen nach Ansicht des Autors vor allem in Situationen, in denen die persönliche Dynamik mit der Struktur kollidiert, das heißt, in angespannten oder krisenhaften Situationen.

Kantor belässt es allerdings nicht bei seinem Erklärungsmodell, sondern beschreibt eine umfangreiche Kommunikationstypisierung, die Führungskräfte in Teams praktisch erkennen, lernen und sie bewusst für eine Problemlösung einsetzen können. Zur Erweiterung ihrer kommunikativen Kompetenzen sollen Führungskräfte darin geschult werden, wahrzunehmen (to sense), wie sich Menschen in Gesprächssituationen aufeinander beziehen, die dahinter liegenden impliziten Strukturen und Dynamiken explizit zu machen und das erkannte Wissen als Muster für eine erfolgreiche Gesprächsgestaltung zu nutzen. Muster sollen für die Beteiligten erkennbar werden können und sie sollten von diesen selbst, aus ihrem Handlungsfeld heraus, generiert werden. Kantor's Vorschlag ist damit einer der wenigen Ansätze zur Musterbildung in einem allgemeinen organisationalen Zusammenhang, der die Sichtweise einer überwiegend negativen Auswirkung auf die Lernbereitschaft einer Organisation verlässt ${ }^{4}$ und deren Nutzen betont.

\section{Mit Patterns Handlungswissen austauschen}

Bei der Suche nach Wissensquellen zur Ankurbelung von Innovationsprozessen wird in Organisationen auch nach implizitem Wissen Ausschau gehalten, das uns als Hintergrundwissen beim Handeln und beim Treffen von Entscheidungen zur Verfügung steht, ohne dass wir uns dieses Wissens (jederzeit) bewusst wären. Zusammengefasst dargestellt, umfasst unbewusstes Wissen Vorstellungen, Werte und Einschätzungen und entwickelt sich subjektiv, unter anderem über durch Sinneseindrücke angesammelte Reize und deren Interpretation und Bewertung vor dem Hintergrund bereits gemachter Erfahrungen (vgl. Polanyi 1985; Nonaka \& Takeuchi 1985: 59-60; Spender 1996: 48, Wiig 1993: 136-138). Implizites Wissen kann demnach kontextbezogen Verfahrensweisen zur Verfügung stellen, mit deren Hilfe, zahlreiche Unsicherheiten überwunden werden können. Es wird langfristig im Gedächtnis gespeichert und situationsabhängig erinnert und kann somit als eine Art von >Problemlösungs-Know how (tacit knowing) oder Handlungswissen bei der Entscheidungsfindung am Arbeitsplatz wie auch im täglichen Leben eingesetzt werden (vgl. Büschken \& Blümm 2000: 10; Vossebrecher et al. 2012).

4 | Von Kritkern wird angemerkt, dass dieser in der Organisationsliteratur (z.B. bei Dutton and Ragins, 2006) beschriebene Ansatz einen rein mechanistischen Blick auf Teams wirft. Der Schlüssel des Erfolgs bestünde demnach darin, Teams zu verbessern, indem jedes Mitglied optimiert wird (vgl. MIT Sloan Management Leadership Center, 2006). 
Das Denken in einem Problem-Lösungs-Schema ist weit verbreitet und der Pattern-Ansatz damit eine Möglichkeit, dieses implizite Wissen $\mathrm{zu}$ >heben < und niederzuschreiben. »Organisationale Patterns können als Verfahren Teile des kollektiven impliziten Wissens in Organisationen aufdecken: Sie werden im Rahmen eines gemeinsamen Lernprozesses entdeckt und dokumentiert, in den die Perspektiven unterschiedlicher Akteure in der Organisation hinsichtlich einer spezifischen Herausforderung und ihrer gangbaren Vorgehensweisen einfließen. Sie konstruieren damit auch einen Möglichkeitsraum förderlicher, in verschiedenen Situationen unterschiedlich einsetzbarer Handlungen.« (Vgl. Vossebrecher et al. 2012: 5)

Ein Pattern stellt einen dokumentierten Lösungsvorschlag für ein wiederkehrendes Problem dar, in den das vorhandene Experten- und Erfahrungswissen einfließt, um es später unabhängig von der/dem Verfasser/in wieder zu verwenden. Ein Lösungsvorschlag wird prototypisch für ein konkretes, klar begrenztes Problem bzw. für eine spezifische Herausforderung erstellt. Komplexe Problembereiche werden daher zerlegt und mehrere aufeinander aufbauende Pattern zu einer Pattern Language (Muster-Sprache) zusammengefasst. Unter organisationstheoretischem Gesichtspunkt kann dieses System von Pattern eine verdichtete Form des aktuellen Standes der Kulturbildung in Organisationen darstellen, da sie auch eine organisational sinngebene Struktur aufzeigen (a.a.O.: 6).

Für Patterns gibt es bisher keine allgemein akzeptierte Definition (Fowler, 2002). Vielmehr hat der Begriff seine Wurzeln in verschiedenen Disziplinen, insbesondere folgt er der von dem Architekten C. Alexander in seinem Werk >The Timeless Way of Building (1979) beschriebenen grundlegenden Formel, als »[...] dreiteilige Regel, die eine Beziehung zwischen einem bestimmten Kontext, einem Problem und einer Lösung ausdrückt« (247).

\section{Patterns sind gelebte Praxis}

Patterns haben sich vor allem auf Betreiben einer aktiven Szene in der Softwareentwicklung (siehe Hillside Group, 1993) weiterentwickelt, die sich auch mit organisationalen Patterns beschäftigt. Der Fokus dieser organisationalen Patterns liegt nicht so sehr auf der technischen Seite von Software-Projekten, sondern auf den >weichen< Faktoren des Projektmanagements, wie zum Beispiel der Aufbau von Kundenbeziehung, Kommunikation innerhalb und zwischen Teams, Teamdynamiken und Teamgeist, Motivation, Empowerment, Commitment und ein unterstützendes Management (vgl. Coplien 2004, Rising \& Manns 2010). Solche Themen sind für professionelle Organisationen allgemein relevant und der Pattern-Ansatz kann daher in der Organisationsentwicklung besonder offene Prozesse, wie es in Innovations- und Veränderungsprojekten der Fall ist, effektiv unterstützen ${ }^{5}$.

5 | Insbesondere Rising/Manns (2010) beschreiben Patterns, die auf flexible Weise die Schritte im Veränderungsprozess - Wissen, Überzeugung, Entscheidung, Implementierung 
Der Kern eines Pattern besteht darin, dass es aus der Praxis begründet ist. Pattern können nicht >erfunden< werden, sondern sie werden >gefunden< bzw. >entdeckt<, indem man mit zB mit MitarbeiterInnen gemeinsam herausfindet, wie sie etwas tun, Dinge beobachtet, die funktionieren und dann das Wesentliche daran mit den an der Problemlösung Beteiligten herausarbeitet. »Prozesse des Wahrnehmens, Beurteilens, Antizipierens, Denkens, Entscheidens, Handelns [...] (Neuweg, 2005: 557) spielen bei der Erstellung von Patterns eine große Rolle, die von verschiedenen Personen diskutiert, wiederverwendet, verbessert und mit eigenen Beobachtungen überprüft werden. Ein Pattern ist weder statisch noch stellt es eine einfache Beschreibung in Form einer Fallstudie oder eine Betriebsanleitung dar, die blind für die anstehende Problemlösung übernommen werden könnte. Vielmehr werden in einem Pattern das Problem und die Lösung abstrakt dargestellt, so dass es auf die spezifischen Bedingungen des eigenen Projekts bzw. Situation hin angepasst werden kann (Fowler, 2002).

Der Zugang zu einem Pattern beginnt meistens damit, dass positive oder negative Beispiele beobachtet werden, mit denen versucht wird, ein erkanntes Problem zu lösen. Damit sich die Entwicklung eines (oder mehrerer) Patterns als gemeinsamer Lernprozess gestaltet, sollten hinsichtlich einer spezifischen Herausforderung oder Problems die Perspektiven und möglichen Vorgehensweisen aus Sicht unterschiedlicher Akteure in der Organisation einfließen. »Zentral ist dabei die Triade von Herausforderung, Kontext und Lösung mit den zwischen ihnen wirkenden Kräften (Keidel 1995). Durch das Offenlegen der zugrundeliegenden Prinzipien im Spannungsfeld der Kräfte wird nicht nur das Verfahren selbst vermittelt, sondern auch die dahinterliegende Erkenntnis (Kohls/Scheiter 2008)« (Vossebrecher et al. 2012: 5).

\section{Aufbau von Patterns}

In Ihrer Anleitung >How to write a pattern?< (2011) benennen Wellhausen \& Fießer Kernelemente von Patterns, die miteinander in Wechselwirkung stehen:

\section{Der Kontext}

setzt den Rahmen, in dem das Problem bzw. die Herausforderung auftritt und in welchem das Pattern sinnvoll eingesetzt werden kann. Schon hier ist zu beachten, dass der dokumentierte Kontext mit dem eigenen übereinstimmen muss, da sonst ein Pattern nicht anwendbar ist.

und Bestätigung - unterstützen. Diese Elemente entlang des Innovation-Decision Process Modells von Rogers (1995) beschreiben, wie im allgemeinen Innovationen von einem Organisationssystem radoptiertı werden. 
Das Problem bzw. die Herausforderung

beschreibt konkret eine schwierige Situation, die das Pattern überwinden helfen soll. Häufig wird die Herausforderung bereits als Ziel formuliert.

\section{Das Spannungsfeld}

erklärt, warum das Problem schwierig zu lösen ist.

Die einwirkenden Kräfte (Forces)

müssen beachtet werden, wenn man nach einer passenden Lösung sucht, da sie den Lösungsprozess unterstützen (förderliche Bedingungen) oder behindern (Grenzen) können.

\section{Die Lösung}

schlägt eine Vorgehensweise vor, welches das Problem löst und dabei möglichst viele Rahmenbedingen berücksichtigt.

\section{Die Konsequenzen}

zeigen die Folgen auf, die sich durch die Anwendung der Lösung ergeben. Zu beachten ist, dass es sich dabei um positive aber auch um negative Konsequenzen handeln kann, so dass neue Probleme aufgeworfen werden.

Hilfreich ist es für die künftigen Benutzer auch, einige Beispiele aufzuzeigen, wie das Pattern in der Praxis angewendet werden kann. Schließlich wird dem Pattern ein Name gegeben, der es ermöglicht über das Pattern zu reden, ohne jedes Mal erklären zu müssen, worum es geht. Ein eingängiger Titel erleichtert die Weiterentwicklung. Da sich ein Pattern Schritt für Schritt entwickelt, kann sich der Name ändern, bis er schließlich das Wesentliche benennt.

Im Vorfeld der Beschreibung eines Pattern können die einzelnen Schritte mit den Akteuren gründlich durchdacht werden, ohne dass im Brainstorming die obige Reihenfolge zwingend eingehalten werden muss. Wellhausen (2013) schlägt sogar vor, mit der Beschreibung der Lösung zu beginnen: »Die Lösung ist schließlich das, was man am genauesten kennt.«

Ein Pattern entsteht über einen iterativen Ansatz, das heißt: »[...] immer wieder von vorne das schon Geschriebene zu überarbeiten, um zu einem in sich geschlossenen und konsistenten Stand zu gelangen.« (Ebda) Für dieses Herantasten an ein optimales Pattern hat sich ein Verfahren bewährt, dass sich beim Schreiben von Pattern in der Softwareentwicklung durchgesetzt hat: Shepherding. Damit ist ein strukturierter Prozess gemeint, in dem ein oder mehrere erfahrene Personen im Schreiben bzw. Kommentieren von Patterns den oder die Autor/in mit intensivem Feedback betreut und iterativ darin unterstützt, das vorgelegte Pattern zu verbessern (Schütz, Fießer \& Wellhausen, 2009: 2). Im Allgemeinen sind drei Überarbeitungschritte nötig, bis aus einer Lösungsbeschreibung ein aussagekräftiges Pattern wird (vgl. Harrison, 1999). 
Der Wert des Pattern-Ansatzes besteht im ersten Moment vor allem darin, eine Problemlösung strukturiert in ein Format zu bringen, so dass Handlungswissen auf leicht zugängliche Weise kommuniziert werden kann. Mit dem Erlernen des Handwerks ist es jedoch nicht getan, denn zwischen dem Verstehen des Konzepts von Pattern und seiner erfolgreichen Anwendung liegen einige Hürden. Die Aussage aus der Softwareentwicklung zu Design Patterns kann auch allgemein für organisationale Patterns gelten: »Der Entwickler von Patterns benötigt ausgezeichnete Kenntnisse des Problemraums, aus dem das Pattern stammt. Er benötigt die Fähigkeit, diese Kenntnisse so zu abstrahieren, dass eine wieder verwendbare Lösung entsteht.« (Hahsler, 2001: 41)

$\mathrm{Da}$ auch jede/r Benutzer/n von Patterns selbst entscheiden muss, ob er/sie die Anwendung des Pattern für ein bestimmtes Problem für sinnvoll hält, werden auch an ihn/sie hohe Anforderungen gestellt: »Er muss genügend Patterns kennen, um das richtige Pattern für sein Problem auswählen zu können. Dabei reicht es nicht aus, nur die Namen verschiedener Patterns zu kennen, sondern er muss das abstrakte Modell dahinter verstehen. Erst dadurch wird es möglich, zu erkennen, wo und wie das Pattern eingesetzt werden kann. Diese relativ hohen Anforderungen erschweren den Einsatz von Patterns.« (Ebda.)

\section{Viele Akteure tragen zur Generierung eines Patterns bei}

Mit einem konkreten Beispiel aus dem Bereich der Organisationsberatung soll nachfolgend der Aufbau eines Patterns veranschaulicht werden. Der gefundene Lösungsvorschlag - eine Intervention zum Start eines Veränderungsprojektes wurde im Verlauf eines inzwischen abgeschlossenen Beratungsprozesses entwickelt und bereits in anderen Beratungssituationen mehrfach angewendet. Daraus entstand die Überlegung, zu diesem Lösungsvorschlag ein Pattern aus Beratersicht zu schreiben. Optimal wäre jedoch ein Vorgehen, bei dem das zu beratende System aktiv in die Entwicklung eines Patterns eingebunden ist.

Inhaltlich setzt das Pattern an dem bereits erwähnten Four-Player-Modell (move, follow oppose, bystand) für Teams an. Rollen können sich verfestigen, die unproduktive Entscheidungsroutinen und Veränderungsresistenz nach sich ziehen. Mit dem gefundenen Lösungsansatz wird versucht, aktiv dieses Kommunikationsmuster zu beeinflussen, indem eine Praxis installiert wird, die Rollenträger bewusst zur Akzeptanzförderung für ein Veränderungsprojekt einsetzt.

Das vorgestellte Pattern hat bereits ein Shepherding durch Kollegen ${ }^{6}$ aus der Berater-Community durchlaufen, kann jedoch sicher in Form und Inhalt noch

6 | Mein besonderer Dank gilt hier meinen Basler Kollegen Andreas Hänggi, Philippe Staehelin und Nicolas Passavant, für die engagierte Diskussion und hilfreichen Anregungen. Ihnen verdanke ich auch den Namen des Pattern "Spurgruppe". Vorspuren ist eine anschauliche schweizerische Bezeichnung, sich mit Skiern durch den noch unberührten Schnee zu 
weiter verbessert werden. Dazu dienen auch die Fragen, die neben den jeweiligen Punkten in Klammern gesetzt wurden. Ein Feedback wird von der Autorin unter ihrer mail-Adresse monika.bobzien@arcormail.de gern entgegengenommen.

\section{Patternname: Veränderungen vorspuren (Die Spurgruppe)}

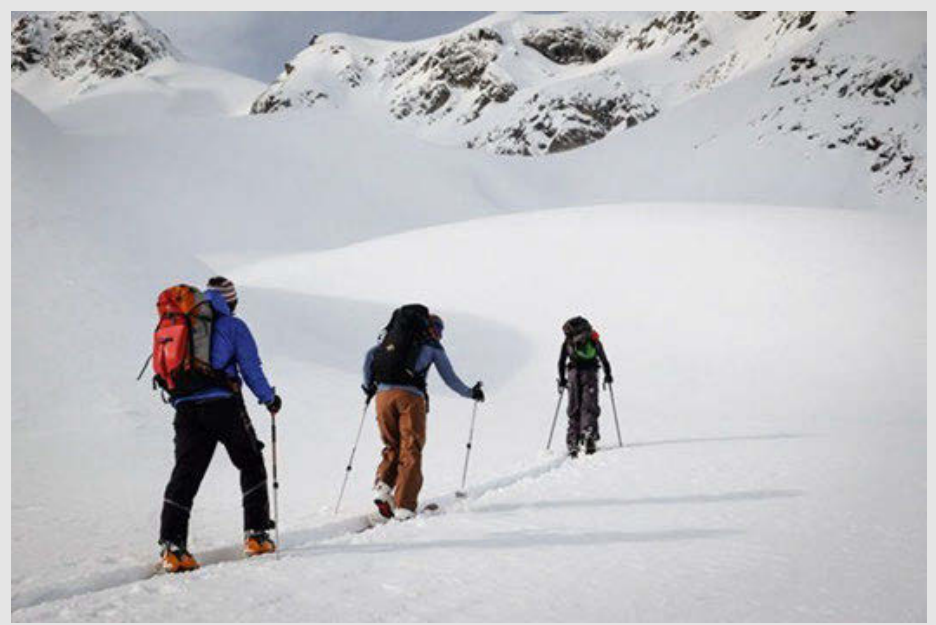

(Abbildung 1: Quelle: Martin Ziegler 2015)

1. Der Kontext (ändert sich nicht, wenn die Lösung angewendet wird!)

Alle Kooperationsformen, in denen grundlegende Veränderungen (im folgenden Veränderungsprojekt genannt) auf den Weg gebracht werden sollen und Entscheidungen stärker von informellen Strukturen bestimmt werden als von formalen Entscheidungsprämissen.

2. Das Problem bzw. die Herausforderung (beschreibt die Lösung die Überwindung des Problems? Was passiert, wenn die Lösung nicht angewendet wird?)

Bestehende Kommunikationsgefäße zur Entscheidungsvorbereitung entsprechen nicht der Komplexität der Organisation. Informelle Hierarchien, unklare Kommunikationswege und unproduktive Entscheidungsroutinen, in denen sich Rollen verfestigt haben, blockieren die zu treffenden Entscheidungen im Veränderungsprozess.

bewegen und eine Spur zu legen. Zu einer 'Spurgrupper werden interessierte Mitwirkende eingeladen oder können sich bewerben, deren Profil zur Fragestellung passt, die kreativ gelöst oder kritisch begleitet werden soll. Zum Ablauf einer Spurgruppe in einem Bürgerbeteiligungsprozess siehe das Beispiel unter www.youtube.com/watch?v=2RBkV-Vm6MY. 
3. Das Spannungsfeld (Warum ist das Problem schwierig zu lösen?)

Das >strukturelle Durchwursteln< mit der Regel >Alle entscheiden alles< passt nicht mehr zum Reifegrad der Organisation. Die Organisationsmitglieder fühlen sich davon einerseits überfordert, befürchten jedoch eine Einbuße ihrer Privilegien, wenn sie diese Routine aufgeben und boykottieren daher eine Veränderung des Bestehenden.

4. Die einwirkenden Kräfte (Forces) (Welche förderliche Bedingungen und welche Grenzen wirken auf die Lösung des Problems ein?)

Förderliche Bedingungen, die auf die Lösung einwirken:

- Bei Entscheidungen zu grundlegenden Veränderungen legen die Organisationsmitglieder Wert auf ein partizipatives Vorgehen.

- Der Leidensdruck der Überforderung ist groß genug, um einen dialogischen Prozess zu beginnen.

- Die Organisationsmitglieder wissen selbst am besten, wie Veränderungsschritte in Form und Inhalt Akzeptanz finden, damit sie entschieden werden können.

Grenzen, die auf die Lösung einwirken:

- Ein zusätzlicher Einsatz von Arbeitszeit und Energie ist nötig.

- Möglicherweise stehen einzelne Organisationsmitglieder grundsätzlich einer Veränderung des Status quo skeptisch gegenüber.

- Der Dialog muss auf professionelle Weise angestoßen und moderiert werden (z.B. externe/r Berater/in als Prozessbegleiter).

5. Die Lösung (Was kann die Lösung?)

Zur Planung und Einleitung eines partizipativen Veränderungsprojektes richtet die Organisation eine hierarchie- und bereichsübergreifende Spurgruppe ein, die mit ihrer Expertise die anstehenden Entscheidungen im Vorfeld unterstützt, jedoch im Veränderungsprozess selbst keine Entscheidungsbefugnis hat.

In die Spurgruppe werden Befürworter und Skeptiker des Veränderungsprojekts eingeladen, um gemeinsam Vorschläge zu erarbeiten, die allen Mitgliedern der Organisation zu einem verabredeten Zeitpunkt vorgestellt werden.

Die Zielsetzung der Spurgruppe und Regeln der Zusammenarbeit sind für alle Organisationsmitglieder transparent.

Der Stand des Veränderungsprojekts ist für die Organisationsmitglieder jederzeit erkennbar und abrufbar.

Die Spurgruppe bearbeitet im »geschützten Rahmen« mit ihrer Expertise einzelne Veränderungsschritte, in dem sie Szenarien entwirft, das Für und Wider betrachtet und im Rahmen der geltenden Struktur die ihrer Einschätzung nach bestmögliche Vorgehensweise zur Entscheidung vorschlägt.

Die Spurgruppe tastet sich in einem iterativen Prozess an eine für alle akzeptable Lösung heran. Indem sie in mehreren Feedbackschleifen die Anregungen und Kritiken von denjenigen Organisationsmitgliedern aufnimmt, die nicht Teil der Spurgruppe sind, werden diese in den Veränderungsprozess integriert. 
Die Spurgruppe ist ein Lösungsansatz der auf weitere Veränderungsprojekte übertragbar ist, wenn es darum geht, Vorhaben partizipativ umzusetzen und dabei die Komplexität auf ein bearbeitbares Niveau zu reduzieren.

\section{Die Konsequenzen}

Positiv:

- Die Lösung eröffnet ein kreatives Lernfeld, wie ein Veränderungsprojekt unter Einbeziehung der Beteiligten hierarchie- und bereichsübergreifend geplant und kommuniziert werden kann und ist daher für alle Involvierte motivierend.

- Die Lösung kann als vertrauensbildende Maßnahme angesehen werden, mit der ein größeres Verständnis füreinander erreicht wird. Dies fördert auch die Akzeptanz, sich mit der anstehenden Veränderung konstruktiv auseinander zu setzen.

- Mit der Lösung wird Komplexität reduziert, weil die Beteiligten mit ihrer Expertise auf das Wesentliche fokussieren, ohne dass sich alle Organisationsmitglieder mit jedem Detail im Veränderungsprozess befassen müssen.

Negativ:

- Der Erfolg des Lösungsansatzes ist abhängig vom persönlichen Commitment der Mitwirkenden. Fluktuation in der Spurgruppe kann das bereits Erreichte auf der Sach- wie auf der Beziehungsebene wieder in Frage stellen.

- Bestehende Machtkämpfe können sich in der Spurgruppe fortsetzen und Bedenkenträger können versuchen, den Prozess zu boykottieren. Die Begleitung der Spurgruppe durch eine kompetente Moderation kann dem entgegenwirken, in dem sie mit den Mitwirkenden Regeln der Zusammenarbeit erarbeitet, Impulse setzt, den Prozess strukturiert sowie Konfliktlinien erkennt und diese managt.

- Im Ergebnis sorgt die Spurgruppe >nur< für einen tragfähigen Entscheidungsvorschlag. Nach wie vor muss die Organisation sicherstellen, dass die Entscheidung zur Veränderung in dem bis dahin gültigen Entscheidungsgefäß tatsächlich getroffen wird.

\section{Beispiele, in denen das Pattern in der Praxis angewendet werden kann}

Eine grundlegende Neuorganisation der Strukturen steht häufig mit dem Ausscheiden einer Gründerin/eines Gründers der Organisation an.

Die Organisation möchte ein größeres Veränderungsvorhaben einführen, z.B. ein umfassendes Qualitätsmanagement, das alle Organisationsmitglieder tangiert.

Über den oben genannten Organisationskontext hinaus, kann das Pattern auch in Kooperationsformen wie Bürgerbeteiligungsprozesse angewendet werden, wenn es beispielsweise um die Planung von Stadtentwicklungsprojekten geht. 


\section{Diskussion UND nÄChSTE SChRITTE}

Organisationale Patterns zeigen auf, wie sich das Handeln in einer Organisation schrittweise verbessern lässt. Dazu muss in der Organisationsarchitektur als erstes der Schwachpunkt identifiziert werden, den es zu >beheben $<$ gilt. Aus technischer Sicht würde sich daran anschließen, dass ein Pattern generiert und angewendet wird, das diese Schwachstelle stärkt. Wird die Wirksamkeit evaluiert und stellt sich heraus, dass die Dinge sich verbessern, kann erneut eine Schwachstelle identifiziert und bearbeitet werden oder aber das Pattern wird verworfen und eine Alternative erprobt.

Nach diesem Regelkreis lassen sich prinzipiell alle Verbesserungsmaßnahmen technischer Art auf systematische Weise angehen. Bei der Generierung von organisationalen Patterns müssen jedoch die Besonderheiten des sozialen Handelns mit berücksichtigt werden, insbesondere die Botschaften des Widerstands ${ }^{7}$. So war es im aufgezeigten Beispiel >Spurgruppe< einerseits wichtig, vorab ein Verständnis für die spezifische Organisationskultur mit ihren formalen und informellen Strukturen und deren Geschichte zu gewinnen, wie auch herauszufinden, welche negativen Erwartungen mit der Veränderung einhergingen, wie auch die Werte, die mit dem Pattern weiterhin wertgeschätzt und bewahrt werden sollten. In dieser Vorarbeit zu den Kontextbedingungen wurde die Organisation extern begleitet.

Die Frage, was den Einsatz eines organisationalen Pattern erfolgreich macht, lässt sich dahingehend beantworten, dass die Beteiligten letztlich die einzigen sind, die wirklich wissen, welche Interventionsform für sie jetzt hilfreich ist. Am Beispiel >Spurgruppe < war es die aktive Einbindung in den Veränderungsprozess. So konnten sie die Situation kontrollieren, für die das Pattern eine Lösung darstellt. Sie lernten jedoch nicht nur die Lösung ihres »offensichtlichen« Problems kennen, sondern entwickelten in diesem Prozess auch ein Problembewusstsein für die dahinterliegenden mentalen Modelle des Problems.

Schließlich konnte die Organisation insoweit von dem Prozess profitieren, indem sie fähig war zu lernen, wie sie ihre Probleme erkennen und künftig lösen könnte. Das Beispiel des Pattern >Spurgruppe`dokumentiert ja auch einen Lösungsvorschlag für ein wiederkehrendes Problem, in den das vorhandene Experten- und Erfahrungswissen einfließt, um es später unabhängig von der/dem Verfasser/in wieder zu verwenden. Der Lösungsvorschlag, der prototypisch für das

7 | Klaus Doppler und Christoph Lauterburg (2000) beschreiben im Wesentlichen drei Ursachen für Widerstand: "1. Der oder die Betroffenen haben die Ziele, die Hintergründe oder die Motive einer Maßnahme nicht verstanden. 2. Die Begroffenen haben verstanden, worum es geht, aber sie glauben nicht, was man Ihnen sagt. 3. Die Betroffenen haben verstanden, und sie glauben auch, was gesagt wird, aber sie wollen oder können nicht mitgehen, weil sie sich von den vorgesehenen Maßnahmen keine positiven Kosequenzen versprechen." (294) 
spezifische Problem - ein Veränderungsprojekt durchzuführen - entwickelt wurde, konnte auch für die nächste Herausforderung genutzt werden: Ein Entscheidungsgremium einzusetzen. Es hat sich als sinnvoll herausgestellt, über eine >Spurgruppe eine neue Entscheidungsstruktur zu entwickeln, die ausreichend Raum für Delegation und Mitsprache lässt und die bewusst installiert wird. Weitere komplexe Problembereiche, wie beispielsweise das Thema Entscheidungswege, könnten infolge ebenfalls zerlegt und mehrere aufeinander aufbauende organisationale Pattern im Organisationsentwicklungsprozess zu einer Pattern Language (Muster-Sprache) zusammengefasst werden.

Das standardisierte und iterative Vorgehen (Shepherding) bei der Entwicklung von organisationalen Pattern sollte nicht nur isoliert auf die Lösung von organisationstechnischen oder managementtechnischen Probleme beschränkt sein, wie es beispielsweise für die Unterstützung der Phasen im Projektmanagement eingesetzt werden kann. Vielmehr ist es eine wesentliche Aufgabe bei der Entwicklung von organisationalen Pattern für die daran Beteiligten, festzulegen, welche gemeinsame Struktur in ihrem sozialen Netzwerk und welche corporate memory sie bereit sind, formal in einem Pattern offen zu legen. Für viele Aspekte in der Praxis von Organisationen, wie beispielsweise Kommunikationswege oder Rollenerwartungen, gibt es formale wie auch informelle Strukturen zwischen denen permanent hin- und hergewechselt wird ${ }^{8}$. Organisationale Pattern können daher den Organisationsmitgliedern einerseits >mehr Orientierung` geben, sie erhöhen aber auch die Formalisierung der Organisation und damit den Bürokratisierungsgrad der Beziehungen untereinander.

Damit die Motivation erhalten bleibt, organisationale Patterns nicht nur zu beschreiben, sondern sie zu finden und damit die Organisationskultur lebendig zu gestalten, kann es hilfreich sein, regelmäßige gemeinsame Retrospektiven ${ }^{9}$ durchzuführen, in denen die Erfahrungen mit den vorliegenden Pattern insgesamt reflektiert, aus den Ereignissen gelernt und Verbesserungen aus dieser kritischen Betrachtung gezogen werden.

8 | Stefan Kühl (2010) bezeichnet das "Zusammenspiel von formalen und informalen Wegen als eine zentrale Besonderheit von Organisationen gegenüber anderen sozialen Gebilden wie Ehen, Gruppen, Staaten oder sozialen Bewegungen". (S. 17)

9 | Ausführliche Hinweise zur Durchführung von Retrospektiven in Teams gibt Norman L.Kerth (2001) in seinem Buch Project Retrospectives. 


\section{LITERATUR}

Ameln, F. v. \& Zech, R. (2011): Musterwechsel in Organisationen. Latente Organisationsregeln als Schlüsselfaktoren gelingenden Change Managements. In Organisations-Entwicklung - Zeitschrift für Unternehmensentwicklung und Change Management, 4/2011, 49-55.

Ancona, D. \& Isaacs, W (2007): Structural Balance in Teams. In: Jane E. Dutton, Belle Rose Ragins (eds.): Exploring Positive Relationships at Work. Building a Theoretical and research Foundation. 225-243, Routledge, New York.

Argyris, C., Schön, D.A. (1996): Organizational Learning II, Addison-Wesley, San Francisco.

Bauer, R., Baumgartner, P. (2012): Schaufenster des Lernens. Eine Sammlung von Mustern zur Arbeit mit E-Portfolios. Waxmann, Münster.

Baumgartner, P. (2011): Taxonomie von Unterrichtsmethoden. Ein Plädoyer für didaktische Vielfalt. Waxmann, Münster.

Buber, M. (2008): Ich und Du. Reclam, Stuttgart.

Büschken, J. \& Blümm, C. (2000): Zur Rolle von implizitem Wissen im Innovationsprozeß. Diskussionsbeiträge der Kath. Universität Eichstätt, Wirtschaftswissenschaftliche Fakultät Ingolstadt, Nr. 142, Ingolstadt.

Coplien, J. O. \& Harrison, N. B. (2004): Organizational Patterns of Agile Software Development. Prentice Hall, New Jersey.

Conway, M. E. (1968): How Do Committees Invent? F. D. Thompson Publications, Inc.

Doppler, K. \& Lauterburg, C. (2000): Change Management. Den Unternehmenswandel gestalten. Campus, Frankfurt a.M.

Eigen, M., Winkler, R. (1978): Das Spiel. München, Zürich.

Fowler, M. (2002): Patterns of Enterprise Application Architecture. Addison-Wesley, San Francisco.

Hahsler, M. (2001): Analyse Patterns im Software-Entwicklungsprozess. Dissertation an der Wirtschaftsuniversität Wien, Abt. für Informationswirtschaft.

Harrison, N.B. (1999): The Language of Shepherding. A Pattern Language for Shepherds and Sheep. Lucent Technologies, Denver, Col.

Hillside Group (1993): http://hillside.net letzter Zugriff am 30.9.2013.

Hinnen, H., Krummenacher, P. (2012): Großgruppen-Interventionen. Konflikte klären - Veränderungen anstoßen - Betroffene einbeziehen. Schaeffer-Poeschel, Stuttgart.

Kantor, D. (2012): Reading the Room. Group Dynamics for Coaches and Leaders. Jossey-Bass - Wiley.

Kantor, D. \& Lohnstein, N.H. (1996): Die Neurahmung von Teambeziehungen: Wie die Grundsätze der >strukturellen Dynamik einem Team dabei helfen können, mit seiner >dunklen Seite < umzugehen. In: Senge, P. et al. (Hg.) Das Fieldbook zur Fünften Disziplin, Stuttgart, S. 472-483.

Kantor, D. \& Lehr, W. (2003): Inside the Family. Meredith Winter Press. 
Keidel, R. W. (1995): Seeing Organizational Patterns. Berrett-Koehler Publ, San Francisco.

Kerth, N. L. (2001): Project Retrospectives. A Handbook for Team Reviews. Dorset House Publishing, New York.

Kohls, C. \& Scheiter, K. (2008): The Psychology of Patterns. In: Proceedings of the 2008 Conference on Pattern Languages of Programs (PLoP). ACM, Nashville.

Kohls, C., Wedekind, J. (2008): Die Dokumentation erfolgreicher E-LearningLehr-/Lernarrangements mit didaktischen Patterns. In: S. Zauchner, P. Baumgartner, E. Blaschitz, \& A. Weissenbäck (Eds.), Offener Bildungsraum Hochschule: Freiheiten und Notwendigkeiten (pp. 217-227). Waxmann, Münster.

Kühl, S. (2010): Die formale Seite der Organisation. Überlegungen zum Konzept der entschiedenen Entscheidungsprämissen. Working Paper 2/2010, Universität Bielefeld www.uni-bielefeld.de/soz/forschung/orgsoz/Stefan_Kuehl/pdf/ Formale-Seite-Workingpaper-1-25052010-endgultig.pdf letzter Zugriff am 30. 9. 2013 .

Looss, W. (2002): >Der unsichtbare Tanz zur lautlosen Musik < - institutionelle Funktionen und persönliches Verhalten im Wechselspiel. In: Lenz, A. und Stark, W. (Hg.): Empowerment. Neue Perspektiven für psychosoziale Praxis und Organisation. Fortschritte der Gemeindepsychologie und Gesundheitsförderung, 239-242, DGVT-Verlag, Tübingen.

Looss, W. (1996): Die nicht-lernende Organisation: Grundlegende Spielmuster im Umgang mit Störungen. In: Fatzer, G. (Hg.), Organisationsentwicklung und Supervision: Erfolgsfaktoren bei Veränderungsprozessen. EHP, Köln.

Luhmann, N. (2000): Organisation und Entscheidung. Westdeutscher Verlag, Wiesbaden.

Manns, M. L. \& Rising, L. (2005): Fearless Change: Patterns For Introducing New Ideas. Addison-Wesley, Boston, MA.

Meszaros, G. \& Doble J. (1997): A Pattern Language for Pattern Writing. In: R.C. Martin, D. Riehle F. Buschmann (Hg.) Pattern Languages of Program Design. (pp. 529-574). Addison-Wesley, Boston, MA.

MIT Sloan Management Leadership Center (2006): The 4-Player Model: A Framework for Healthy Teams http://mitleadership.mit.edu/r-fpmodel.php letzter Zugriff am 30.9.2013.

Nonaka, I. \& Takeuchi, H. (1995): The Knowledge-Creating Company - How Japanese Companies Create the Dynamics of Innovation, New York/Oxford.

Polanyi, M (1985): Implizites Wissen, Frankfurt a.M.

Rogers, E. M. (2003): Diffusion of innovations. Free Press, New York.

Schreyögg, G. (1992): Organisationskultur. In: Handwörterbuch der Organisation, Schäffer-Poeschel, Stuttgart.

Schütz, D.; Fießer, A. \& Wellhausen, T. (2009): Patterns selbst gemacht. Eine interaktive Gebrauchsanleitung. Java User Group, München http://hillside. net/europlop letzter Zugriff am 30.9.2013.

Senge, P. (1990): The fifth discipline. Doubleday, New York. 
Tröndle, M. (2006): Entscheiden im Kulturbetrieb. Integriertes Kunst- und Kulturmanagement. h.e.p. verlag, Bern.

Vossebrecher, D.; Bluszcz, O.; Humpert, G. \& Stark, W. (2012): Organisation musikalisch denken: die implizite Dimension des Organisierens entdecken. In: Zeitschrift für Arbeitsforschung, Arbeitsgestaltung und Arbeitspolitik. - Vol. 21 (2/3), 2012: 132-146.

Wellhausen, T. \& Fießer, A. (2011): How to write a pattern? A Guideline for firsttime authors, 16th European Conferene on Pattern Languages of Programs. www.europlop.net/sites/default/files/files/o_How to write a pattern-2011-11-30_ linked.pdf, letzter Zugriff am 30. 9. 2013.

Wellhausen, T. (2013): Wie schreibe ich ein Pattern? In http://freiberufler-team. de/category/patterns, letzter Zugriff am 30.9.2013.

Wiig, K. M. (1993): Knowledge Management Foundations: Thinking About Thinking - How People and Organizations Create, Represent and Use Knowledge. Schema Press, Arlington, Texas. 



\title{
Eine Mustersprache für die Didaktik
}

\author{
Service Learning Patterns auf Grundlage der Mustertheorie
}

Jörg Miller und Nadine Ruda

\section{EinLEITUNG}

"There was always one great difficulty with the theory of pattern languages, and with the languages my colleagues and I, and others, published. Where did the patterns come from? Much of our early work implicitly made use of the idea that good patterns were to be derived, somehow, from existing culture, thus ensuring a relation to the subtleties of culture variation, and preserving things that were good and important, which had been swept aside in the onrush of techno-civilization. But there was always hanging over this process, a sword of Damocles. If - as a procedure - one takes the patterns from existing culture, then one merely reiterates what is being built. That is not necessarily good." (Alexander 2002: 349)

Die Mustertheorie ist kein völlig neues Konzept. Bereits in den 8oer Jahren veröffentliche Christopher Alexander The Nature of Order, ein Aufsatz in vier Bänden, der die grundlegende Herleitung enthält. Alexander und sein Team beschäftigten sich rund 30 Jahre mit der Eigenheit moderner Architektur, oft unzugänglich und leblos zu erscheinen, und suchten nach regelmäßigen Ordnungen in der Natur, die dem Menschen zeigen können, wie jene namenlose Qualität, die der Mensch allgemeinhin als Lebendigkeit empfindet, kreiert werden kann. Das Ziel war es Maximen für Qualität von Lebensräumen zu entwickeln.

Innovativ ist der Ansatz, diese Theorie von der Architektur loszulösen und auf andere fachliche Disziplinen und Bereiche des Lebens zu übertragen. Die Entwicklung einer Mustersprache, eine Sammlung einheitlich charakterisierter Muster, wird in zahlreichen und verschiedenen Disziplinen, wie der Softwareprogrammierung oder Personalentwicklung, angestrebt (vgl. Leitner 2007: 103120). Dabei wird Gebrauch von Abstrahierung und Generalisierung einerseits, Vereinheitlichung und Kategorisierung andererseits gemacht, um Minimalstrukturen zu identifizieren. Eine Mustersprache zielt auf ein Mosaik aus kleinsten Einheiten einer Struktur ab, das ermöglicht, diese Struktur in ihrem Wirken und 
Zusammenspiel mit anderen Strukturen zu verstehen. Das Fixieren, Sammeln und Ordnen der Muster findet innerhalb einer Gruppe statt, die die Mustersprache gemeinsam schreibt. Das Ziel ist, Leitsätze zu Problemlösungen zu entwickeln und Verbesserungen aufder kleinstmöglichen Ebene zu erzielen. Dieser Methode wird grundsätzlich ausgesprochen großes Potential zugeschrieben (vgl. Schuler 2010/ Leitner 2007). Schuler spricht allgemeinhin von »[...]enablers of civic intelligence[...]« (2010: 117), die in der Lage seien komplexes Wissen zu transferieren und einen Rahmen für relevante Informationen abzustecken (vgl. Schuler 2010: 118). Vor diesem Hintergrund erachtet er die fortlaufende Entwicklung von Mustersprachen als essentiell, zu deren fundamentalsten Voraussetzungen es gehört die Effizienz im Gebrauch von Mustersprachen zu steigern, mehr und größere Gruppen zu schaffen, die Mustersprachen schreiben und anwenden, das heißt, Organisationen und Projekte zu unterstützen und vor allem die Forschung weiter voranzutreiben (vgl. Schuler 2010: 120).

Tatsächlich gibt es bereits verschiedene Ansätze, die sowohl aus der praktischen wie auch aus der theoretischen Perspektive eine Mustersprache für die Didaktik in Betracht ziehen und auch erproben. Das Pedagogical Patterns Project (vgl. pedagogicalpatterns.org) beispielsweise oder die EuroPlop Konferenz (vgl. europlop.net) beschäftigen sich auf einer pragmatischen Ebene mit Mustern. Peter Baumgartner legt in seinen Arbeiten zu E-Learning Mustern (vgl. peter.baumgartner.name) den Fokus auf den theoretisch methodischen Anteil von Alexanders Werk. Grundlage für beide Herangehensweisen ist es aber, ein Verständnis für Alexanders fundamentalste Thesen zu erlangen.

\section{Was besagt die Mustertheorie?}

Das mechanistische Weltbild, dessen Grundlagen bis zu René Descartes zurückverfolgt werden können, macht heute die Grundlage jeglicher Konzepte der Naturwissenschaft und Technik aus (vgl. Leitner 2007: 30). Für Alexander ist dieser allumfassende Ansatz problematisch, da sie den Menschen und seine Denk- und Handlungsweise in eine Kausalität drängt, die zu einer »eingeschränkten Auffassung der Realität und ihrer Eigenschaften« (ebd.) führt. Vor allem im Bereich des Schaffens und Erschaffens hemmt diese Anschauung das Hervorbringen von Neuem, von Gutem. Werte existieren lediglich als pluralistisches Nebeneinander, es gibt nichts objektiv Gutes oder Schlechtes, bloß verschiedene Ansichten. Alexander möchte im Gegensatz dazu ein alternatives Verständnis der Welt und ihrer Phänomene finden, in dem Qualität nicht als prinzipiell subjektiv und ungreifbar gilt:

"What we need is a sharable point of view, in which the many factors influencing the environment can coexist coherently, so that we can work together- not by confrontation and 
argument - but because we share a single holistic view of the unitary goal of life." (Alexander 2002: 21)

\section{Zentren Und GanZheitlichKeIt}

Auszeichnend für jede Struktur, sei es ein Raum, eine kulturelle Ordnung oder ein sozialer Vorgang, ist ihre Ganzheitlichkeit. Das bedeutet, sie setzt sich nicht schlicht aus anderen, kleineren Bestandteilen zusammen sondern, ebenso wie im hermeneutischen Zirkel, gibt jede kleinste Einheit Informationen über das Ganze preis, wobei das Verständnis der kleinen Einheiten abhängig vom Verständnis des Ganzen vollzogen wird (vgl. Baumgartner/Bauer 2010: 7). »Ganzheitlichkeit hat einen qualitativ anderen Charakter, Ganzheitlichkeit kann - zum Unterschied vom Ganzen - nicht geteilt werden.« (Baumgartner/Bauer 2010:8). Dieser rekursive Kreislauf beinhaltet außerdem, dass weder zuerst der Teil existiert und dann das Ganze (Aufwärts-Verursachung), noch zuerst das Ganze und dann einzelne Teile (Abwärts-Verursachung), sondern dass beide sich gegenseitig bedingen (vgl. ebd.).

"We may consider any configuration in the world [...]. Each has its wholeness. By that I mean that there are visible within that thing, a huge number of entities, at different scales [...] and that the totality of these entities with the way they are nested constitute the wholeness of that thing. We may think of these entities as parts [...] or as local wholes or sub-wholes. [...] these parts and entities are rarely pre-existing. They are more often themselves created by the wholeness. This apparent paradox is a fundamental issue in the nature of wholeness: the wholeness is made of parts; the parts are created by the wholeness." (Alexander 2002: 83)

Zentral ist also, schlussfolgert Alexander, dass die einzelnen Zentren einander harmonisch ergänzen müssen, um Qualität zu generieren. Um herauszufinden, welche Begebenheiten diese quality wihtout a name, dieses »[...]root criterion of life and spirit[...]« (Alexander 1979: 19) schaffen können, stellt er zahllose Vergleiche an, ständig im Hinblick auf die Frage, ob es irgendwelche Strukturen gebe, die mit einem großen Ausmaß dieser Eigenschaft korrelieren.

\section{Die namenlose Qualität der Lebendigkeit}

Leben oder der Eindruck von Lebendigkeit eines Objektes, einer Person oder einer Struktur ist, so beschreibt Alexander weiter, kein subjektives Gefühl, sondern eine objektiv bewertbare Eigenschaft. Lebendigkeit macht für uns diese Qualität ohne Namen aus und Leben ist, so stellt er fest, in allem vertreten. Er meint damit nicht das biologische Leben in einem Organismus oder die Lebendigkeit einer Person sondern die intuitiv wahrnehmbare Schönheit, Behaglichkeit, Freund- 
lichkeit einfach jede Art von Gefallen. Wir empfinden Lebendigkeit stärker oder schwächer und auch wenn wir diese Wahrnehmung herkömmlich auf subjektive und unterbewusste Gefühle zurückführten, ist Alexander in der Lage, empirisch zu beweisen, dass jeder diese Qualität gleich verspürt, sie somit objektiv und zugleich messbar ist. Das Empfinden von gut oder schön oder ansprechend ist dabei nicht an bestimmte herkömmliche Konventionen gekoppelt. Ein Bild von einem in Armut verkommenen Haus aus dem Ghetto kann durchaus lebendiger auf uns wirken als eine moderne Villa (vgl. Alexander 2002: 73).

Diese Lebendigkeit von Dingen oder Prozessen oder Organismen ist für Alexander die eine zentrale Eigenschaft. Lebendigkeit macht Qualität, sie kategorisiert als besser oder als schlechter. Es handelt sich dabei nicht um eine Opposition, unendlich viele verschiedene Ausmaße sind möglich. »This feeling that there is more life in one case than the other is correlated with a structural difference in the things themselves - a difference which can be made precise, and measured.« (Alexander 2002: 33)

Die Struktur der Dinge, so wie sie in der Natur vorkommen, weist immer, so stellt Alexander fest, eine besonders große Ausprägung von Lebendigkeit auf. Er führt dazu zahlreiche Beispiele, von Tautropfen bis Spinnennetzen, an, die immer auf gewisse Weise ansprechend auf uns wirken. Die Frage, die auf der Hand liegt, und welche Alexander zu beantworten sucht ist also, wie genau diese Perfektion von Lebendigkeit in natürlichen Dingen begründet ist und wie der Mensch sie erschaffen kann.

\section{LEBENSEIGENSCHAFTEN}

"I managed to identify structural features which appear again and again in things which do have life. These are: 1. Levels of Scale, 2. Strong Centers, 3. Boundaries, 4. Alternating Repetition, 5. Positive Space, 6. Good Shape, 7. Local Symmetries, 8. Deep Interlock and Ambiguity, 9. Contrast, 10. Gradients, 11. Roughness, 12. Echoes, 13. The Void, 14. Simplicity and Inner Calm, 15. Not-Separateness." (Alexander 2002: 144)

Größenstufen: Unter Levels of Scale versteht Alexander die große Vielzahl an verschiedenen Größen von Zentren. Setzt sich eine Struktur aus Zentren verschiedener Größe zusammen, die nicht zu stark voneinander abweichen, sich dennoch ausreichend voneinander absetzen, hat sie für gewöhnlich mehr Lebendigkeit inne, als eine Struktur die lediglich identisch große Zentren aufweist. »Es gibt keine Theorie, die das Auftreten solcher Größenabstufungen erklärt. Aber - erklärbar oder nicht - wir haben es mit einer Eigenschaft zu tun, die die ganze Natur durchdringt.« (Leitner 2007: 48).

Starke Zentren: Lebendige Strukturen brauchen starke Zentren und umso stärker die Zentren sind, desto stärker ist die ganzheitliche Struktur. »In many cases there is [...] one principal center, the center of the whole composition - the 
resting place, the middle, the most important place.« (Alexander 2002: 156), so wie beispielsweise der Lehrer in einer Klasse. »In other cases which are equally breathtaking, there is no one center, but an undulating series of minor centers « (ebd.), wie beispielsweise der Trainer, der Kapitän und der Spitzenstürmer einer Fußballmannschaft. Oftmals kommt ein starkes Zentrum durch Symmetrie zustande und in der Natur sind starke Zentren meist wesentlich verantwortlich für wichtige Prozesse (vgl. Leitner 2007: 49).

Grenzen: »Living centers are often - nearly always - formed and strengthened by boundaries « (Alexander 2002: 158). Diese Grenzen bilden einerseits das Zentrum und intensivieren es, andererseits stellen sie die Verbindung zu angrenzenden Zentren dar.

"The boundary must at the same time be distinct from the center being bounded, must keep this center distinct from and separate it from the world beyond it, and yet also have the capacity of uniting that center with the world beyond the boundary. Then the boundary both unites and separates. In both ways, the center that is bounded becomes more intense." (Alexander 2002: 159)

Der Bereich der Wechselwirkung ist dabei von beinahe ebenso großer Bedeutung wie die Zentren die getrennt werden (vgl. Leitner 2007: 50).

Alternierende Wiederholungen: Einfache Wiederholungen sind in der Natur sehr häufig zu finden, aber jene Wiederholungen die eine Struktur lebendig machen, sind rhythmisch alternierende. Bereits die banale Wiederholung schafft eine befriedigende Harmonie und oftmals entsteht Leben, wenn eine Struktur komplett aus der Ableitung eines kleineren Elements besteht. Durch eine subtile Veränderung der Wiederholung aber entsteht eine Art >counterpoint, or opposing beat< (Alexander 2002: 166), der am meisten Leben hervorrufen kann.

Positive Zwischenräume: Um einen großen Grad an Lebendigkeit zu erzielen, sollte kein Raum einfach übrig gelassen werden. Zentren sollen sich »im Raum ausdehnen und ihn zunehmend erfüllen« (Leitner 2007: 51). Zwischenräume besitzen gleichermaßen das Potential positiv genutzt und schön gestaltet zu werden. Idealerweise gilt:

"Every single part of space has positive shape as a center. There are no amorphous meaningless leftovers. Every shape is a strong center, and every space is made up in such a way that it only has strong centers in its space, nothing else besides." (Alexander 2002: 176)

Besondere Formen: Viele lebendige Strukturen weisen laut Alexander eine außergewöhnliche Form auf. Ästhetisch wird eine Form vor allem dadurch, dass sie aus zahlreichen kleineren Zentren von besonderer Form besteht. »A good shape is a center which is made up of powerful intense centers which have good shape themselves « (Alexander 2002: 181). Die Besonderheit ist meist in Einfachheit begründet oder in Anpassung an eine Kräftesituation. »So the good shape is not only 
making things more beautiful; it also makes them work more profoundly, more effectively« (Alexander 2002: 185).

Lokale Symmetrien: Die Existenz eines Zentrums und das Vorliegen einer lokalen Symmetrie sind oft miteinander verbunden. Eine simple, allumfassende und einheitliche Symmetrie kann dabei nachteilig sein, wünschenswert ist vielmehr eine vielfältige Sammlung von untergeordneten Symmetrien, die begrenzt Einfluss auf die gesamte Struktur nehmen (vgl. Alexander 2002: 187). »Symmetrie ist vermutlich die traditionell am meisten beachtete der fünfzehn Lebenseigenschaften « (Leitner 2007: 53), in Alexanders Worten: »When in doubt, make it symmetrical.« (2002: 194). Symmetrien entsprechen »[...]dem Prinzip der einfachsten Lösung, wenn kein Grund für den höheren Organisationsaufwand einer asymmetrischen Lösung gegeben ist[...] (Leitner 2007: 53) und sie funktionieren als Verknüpfung zwischen einzelnen Zentren und tragen so zu einem kohärenteren Verhältnis bei.

Intensive Verzahnung und Zweideutigkeit: Eine Vereinigung von Zentren kann sowohl durch regionale Zweideutigkeit, wie auch durch einen shookingeffect< (Alexander 2002: 195) erzielt werden. Das heißt, es kann eine Zwischenzone bestehen, die sich in zwei Richtungen orientiert, nämlich zum Zentrum hin und gleichzeitig zu seiner Umgebung. Oder die Zentren greifen so ineinander, dass sie gleichsam nicht voneinander loszulösen sind.

"In a surprisingly large number of cases, living structures contain some form of interlock: situations where centers are hooked، into their surroundings. This has the effect of making it difficult to distangle the center from its surroundings. It becomes more unified with the world and with the other centers near it." (Alexander 2002: 195)

Leitner spricht von >Durchdringung und bezieht sich damit auf die Grenzbereiche von Zentren, dessen Zuordnung, zum Zentrum selbst oder seiner Umgebung, schwierig sei (vgl. 2007: 53). »Die Grenze zwischen >männlich< und >weiblich [beispielsweise] ist nicht klar definiert, sondern bildet eine Sphäre, in der viele Spielarten von Selbstverständnis und Sexualität möglich sind « (Leitner 2007: 54).

Kontrast: Leben entsteht durch Differenzierung und Zentren werden vor allem durch den Kontrast zu benachbarten Zentren intensiviert. Generell funktioniert Verständnis anhand von binären Oppositionen und gleichsam definiert sich ein Zentrum über eine Gegenseite (vgl. Alexander 2002: 200). »Viele natürliche Systeme beziehen ihre Organisation und Energie aus der Wechselwirkung von Gegensätzen« (Leitner 2007: 54).

Gradienten: Verläufe, Anstiege und Gefälle, müssen entstehen, auch wenn Harmonie besteht, schlicht aus dem Grunde, dass Umstände sich verändern.

"Gradients will follow as the natural response to any changing circumstance in space, as centers become adapted correctly to the changes which move across space: in doing so, they will vary systematically, thus forming gradients. "(Alexander 2002: 205) 
Alexander gibt zu bedenken, dass die Bedeutung dieser allmählichen Übergänge, die in der Natur selbstverständlich sind, durch Standarisierung, Massenproduktion und Regulierungen für den Menschen nahezu verloren gegangen sind.

Grobheit: Grobheit, als eine Art >Unperfektheit<, macht für Alexander Charme und Harmonie aus. Als Beispiel nennt er die Bemalung einer Schale, in der sich unzählige feine Pinselstriche, die immer wieder dasselbe Muster darstellen, minimal in ihren Eigenschaften voneinander unterscheiden. Diese Individualität führt dazu, dass die Pinselstriche beispielsweise an den vorhandenen Platz angepasst werden können. Einwandfreie Regelmäßigkeit würde diese Anpassung unmöglich machen (vgl. Alexander 2002: 210/211). In der Natur können wir beobachten, dass keine zwei Elemente absolut identisch sind, sondern sie auf »Irregularitäten der Umgebung, der Entstehung oder Lebensgeschichte« (Leitner 2007: 56) antworten. »Will man diese Eigenschaft [...] realisieren, so bedarf es gemäß Alexander einer gewissen Lockerheit und Bescheidenheit.« (Ebd.)

Echos: Die Erklärung dieser Eigenschaft fällt Alexander besonders schwer. Für ihn gibt es zwischen Strukturen eine gewisse »underlying similiarity«, eine »family resemblance«, die als Auswirkung hat, dass alles miteinander verbunden scheint (Alexander 2002: 218). Diese Ähnlichkeit ist vor allem durch wiederkehrende Formen begründet. »Bestimmte Formen, Winkel, Farben oder Proportionen [treten] immer wieder auf, obwohl die einzelnen Teile eines Systems ganz unterschiedlich sind ( (Leitner 2007: 57), so wie das Thema eines Musikstückes in einem kompletten Musical immer wieder aufgegriffen wird.

Leerstellen:»In the most profound centers which have perfect wholeness, there is at the heart a void which is like water, infinite in depth, surrounded by and contrasted with the clutter of the stuff and fabric around it[...] (Alexander 2002: 222). Jede Struktur benötigt diesen leeren Kern, da er Stille und Ruhe mit sich bringt. Ein leeres Zentrum kann so ein Ausgleich zur Dynamik angrenzender Zentren sein, um die allumfassende Energie auszubalancieren und in Bahnen zu lenken.

Einfachheit und innere Ruhe: Diese Eigenschaft kommt zustande wenn alles Überflüssige entfernt wird. Es bleiben lediglich diejenigen Zentren bestehen, die andere aktiv unterstützen. Was dann übrig bleibt ist eine Struktur im Zustand absoluter Ausgeglichenheit (vgl. Alexander 2002: 226). Leitner spricht von einer zunehmenden Dichte und Intensität, die die Zentren mit Leben versehen kann (vgl. 2007: 58).

Ungetrenntheit: Mit dieser vielleicht wichtigsten Eigenschaft bezieht Alexander sich zuletzt wieder auf die Ganzheitlichkeit einer Struktur.

"Any center which has deep life is connected, in feeling, to what surrounds it, and is not cut off, isolated, or separated. In a center which is deeply coherent there is a lack of separation - instead a profound connection - between that center and the other centers which surround it, so that the various centers melt into one another and become inseparable." (Alexander 2002: 231) 
Eine Verbindung zur Umgebung kann vor allem durch die eigene Einstellung geschaffen werden. Dann, wenn man in seinem Schaffen nicht selbstgenügsam ist, sondern in Kauf nimmt und eventuell sogar Wert darauf legt, dass das Geschaffene nicht heraussticht sondern sich in seine Umgebung eingliedert. Bestenfalls sollte man nicht mehr in der Lage sein, zu identifizieren, wo eine Struktur endet und eine neue beginnt. Man sollte es überhaupt nicht mehr versuchen wollen zu identifizieren.

\section{Muster: Generische Regeln oder IMaking Life Enjoyableı}

Muster sind generische Lösungsansätze für einen bestimmten Anwendungszusammenhang. Sie sind nicht dazu bestimmt verständnisführend für alle Probleme in allen erdenklichen Kontexten zu sein. Vielmehr sollte ein Muster ein Werkzeug sein, das gebrauchsfertig ist, um beispielsweise zur Orientierung, Organisation oder zum Verständnis beizutragen. Es sollte nicht nur für Experten vorgesehen sondern uneingeschränkt verständlich sein und es sollte von einer konkreten Situation so losgelöst sein, dass es wiederverwertbar wird. Mustersprachen sind geordnete, ganzheitliche Sammlungen von diesen Werkzeugen. Sie beziehen sich zwar durchaus auf einen bestimmten Bereich, überschreiten aber typischerweise fachliche Grenzen und zeichnen sich daher zu einem großen Teil durch Interdisziplinarität aus. Eine Mustersprache ist nicht nur unendlich facettenreich sondern gleichzeitig dynamisch an ihre Umgebung anzupassen und daher niemals als vollständig zu betrachten (vgl. Schuler 2010: 121).

Eine Mustersprache, so wie auch ein einzelnes Muster, baut vor allem auf Zusammenhängen auf. Im Gegensatz zur Spezialisierung auf einzelne isolierte Elemente beziehen sich Muster auf Generalisierungen.

"Pattern, as we've mentioned, aren't comprehensive or precisely prescriptive: they depict a certain genericity that needs to be instantiated، in some way [...]. It is this genericity that suggests the latent power of pattern languages: the patterns are not precise descriptions to fight over, but (ideally) occasions for collaborations - especially when the patterns have been identified by all parties as being relevant. This lack of specificity [...] suggests the role of pattern languages as various types of intermediary objects between people." (Schuler 2010: 124)

In anderen Worten: Muster beschreiben praktische Lösungen für bestehende Probleme, sie halten Strukturen fest, die sich in der Praxis wiederholt bewährt haben, zeigen wie und wann diese anzuwenden sind, abstrahieren dabei aber vom Konkreten (vgl. Appleton 1999). Alexander hat nach diesem Konzept und unter Einbeziehung seiner Erkenntnisse über Lebendigkeit und Ganzheitlichkeit eine Mustersprache aus 253 einzelnen Mustern aus den Bereichen Städte, Gebäude und Konstruktionen erstellt (vgl. Alexander 1977). Sie alle sind als Leitfaden zu 
verstehen, bestehend aus detaillierten Beschreibungen, wirklichen Beispielen und letztendlich einer Art von Anleitung beispielsweise zur erfolgreichen Realisierung von Parks oder zur effektiven Nutzung ländlichen Raumes (vgl. Alexander 1977: 36).

\section{Ansätze für eine Mustersprache der DidAKtik}

Die Didaktik kann von einer solchen Mustersprache überaus profitieren. Es fehlt ihr noch an einem konsistenten Klassifizierungssystem zur Ordnung von Methoden und Szenarien und eine einheitliche Taxonomie kann sowohl die Kommunikation als auch die Ausübung in einem erheblichen Maße erleichtern. Regelmäßigkeiten funktionierender Prozesse können so in allererster Linie explizit gemacht werden, um sie dann zu generalisieren und zu Mustern zu abstrahieren. Best-Practice Einzelbeispiele werden so zu Rahmenbedingungen der Analyse und Weiterentwicklung didaktischer Methoden, Qualitätsmerkmale können identifiziert und in Gebrauch genommen werden und es entsteht eine systematische Orientierung für eine breite Masse. Vor allem angesichts der Komplexität eines solchen Bestrebens bietet sich der Ansatz der Mustertheorie an. Er sieht eine partizipatorische und schrittweise Entwicklung eines komplexen Netzes aus einzelnen Bausteinen vor, das sich bereits im frühen Stadium ungeachtet der Anzahl von Mustern durch Ganzheitlichkeit auszeichnet.

Tatsächlich gibt es bereits zahlreiche variierende Ansätze, das Konzept der Mustertheorie auf die Didaktik zu übertragen. Im Mittelpunkt können die grundlegenden philosophischen Hintergedanken Alexanders stehen, so wie bei Peter Baumgartner, der diesen Fokus für unerlässlich hält, um nicht »ein bloßes Sammeln und Beschreiben von Best-Practice-Beispielen« (Baumgartner/Bauer 2010: 1) $\mathrm{zu}$ wiederholen. Wenn aber nicht der theoretische Hintergrund sondern der pragmatische Nutzen im Vordergrund steht, dann wird ebendieses Sammeln von Mustern verfolgt, um eine komplexe Sprache zu erschaffen, so wie beispielsweise von Astrid Fricke und Markus Völter oder im Rahmen des Pedagogical Patterns Projects.

\section{MUSter VERStehen - DIE GRUNDLEGENDE TheORIE}

"If we want to transfer Alexander's approach to another subject -, we have to consider unquestioningly his 15 structural properties of living centers; a mere transfer of ,formal characteristics like name - context - solution - forces is insufficient." (Bauer/Baumgartner 2010: 17)

Für Baumgartner wäre es unmissverständlich ein Defizit lediglich die formalen Eigenschaften der Muster aus Alexanders Theorie zu übernehmen. Was eine stupi- 
de Sammlung nach How-to-do-Art seiner Meinung nach von einer Taxonomie trennt, ist der Anspruch isolierte Phänomene in Gruppen zu bündeln, sie zu klassifizieren. Die einheitliche Beschreibung liefert ein beständiges Gerüst, um Gemeinsamkeiten hervorzuheben, Unterschiede deutlich zu machen und implizite Methoden oder Systeme aufzudecken. Dies sind die Kernvorteile einer Mustersprache, die es gilt zu verstehen, um sie zu nutzen. Daher erscheint es ihm essentiell, »die philosophischen Implikationen von Alexanders Konzept der Ganzheitlichkeit als Ausgangspunkt für die Entwicklung einer didaktischen Taxonomie« (Baumgartner/ Bauer 2010: 1) zu diskutieren. Da didaktische Prozesse multidimensional sind und sich daher »all jenen Bestrebungen, einzelne Aspekte isoliert zu betrachten« (Baumgartner/Bauer 2010: 8) verweigern, können sie, analog zum Konzept der Ganzheitlichkeit, nicht zerteilt werden. Obgleich sie sich in der Tat aus einzelnen Komponenten zusammensetzen, sind sie aber dennoch ganzheitliche Geschehen. Konkret bedeutet das, dass der Versuch »ein brauchbares Klassifizierungssystem didaktischer Szenarien zur Verfügung zu stellen« (Baumgartner/Bauer 2010: 9) ein Widerspruch in sich selbst ist.

Baumgartner zufolge liegt der Schlüssel in den vier Dimensionen, die er einem didaktischen Prozess zuspricht: Raum, Lern-Zeit, Soziale Interaktion und inhaltliche Dimension. Um die einzelnen Komponenten der Ganzheitlichkeit nicht voneinander zu trennen, gilt vor allem, dass »eine Taxonomie didaktischer Szenarien nicht bloß eine (weitere) Auflistung von isolierten, formalen Rezepten für >den< Unterricht sein [darf]« (ebd.). Das bedeutet, dass, ebenso wie im hermeneutischen Verstehens Prozess, wo jeder einzelne Satz Rückschlüsse auf das gesamte Werk mit sich bringt, gleichzeitig aber das Verständnis des Gesamtwerkes das Verständnis eines jeden Satzes bestimmt, didaktische Prozesse zirkelförmig zu verstehen sind. Jede der vier Dimensionen bestimmt den Gesamtprozess, aber der Gesamtprozess selbst, auf welchen alle vier Dimensionen einwirken, wirkt auf diese Dimension zurück. »In jedem Einzelaspekt sind jeweils die vier angeführten Dimensionen enthalten« (Baumgartner/Bauer 2010: 8), es besteht ein rekursives Einflussverhältnis zwischen den einzelnen Dimensionen, das niemals außer Acht gelassen werden darf.

"Die Ganzheitlichkeit im Sinn von Alexander bleibt [...] nur dann nicht auf der Strecke, wenn der Analyse- und Entwicklungsprozess sowie die Anwendung als ein roszillodoxes، Unterfangen verstanden wird, wenn zwischen Teil (Kriterium) und Ganzheitlichkeit (dem pädagogischem Ziel) von der anwendenden Lehrperson hin- und hergesprungen wird. Nur so sind Analyse (Zergliederung) und Anwendung (Ganzheitlichkeit) keine Gegensätze, keine Konkurrenten zueinander." (Baumgartner/Bauer 2010: 9)

Im nächsten Schritt kombiniert Baumgartner diese vier Dimensionen mit den 15 fundamentalen Lebenseigenschaften Alexanders, die so »allgemein [seien] dass sie auch für didaktische Unterrichtsszenarien nutzbar gemacht werden können« (Baumgartner/Bauer 2010: 2). Daraus ergibt sich ein Gliederungssystem für di- 
daktische Szenarien mit vier mal 15 Zellen. Die Funktionalität dieses Formats überprüft Baumgartner durch die Anwendung auf die Kugellagermethode. In diesem Exempel wird die Lebenseigenschaft Positive Zwischenräume im Hinblick auf die Dimension soziale Interaktion beispielsweise durch das Peer-to-Peer Verhalten zwischen den Schülerinnen und Schülern, ohne die Unterbrechung des Lehrenden, erfüllt. In der Dimension Raum wird die Lebenseigenschaft Kontrast durch das Wechselspiel zwischen innerem und äußerem Kreis erwirkt. Gradienten findet man in der Dimension soziale Interaktion im ansteigendem Selbstbewusstsein und Verantwortungsgefühl der Schülerinnen und Schüler, Lokale Symmetrie wird im Bezug auf die Dimension Zeit durch gleichlang dauernde Präsentationen sichergestellt. Auf diese Weise lässt sich die Kugellagermethode unter Berücksichtigung aller vier Dimensionen eines didaktischen Szenarios auf alle 15 Lebenseigenschaften hin überprüfen. In Baumgartners Beispiel wird jede einzelne Kategorie bedient, bei anderen Beispielen könnte es selbstverständlich auch der Fall sein, dass gewisse Lebenseigenschaften in bestimmten Dimensionen nicht erfüllt sind. Bei willkürlichen Bewegungen der Schüler im Klassenraum könnte man beispielsweise Lokale Symmetrien in der Dimension Raum in Frage stellen. Um die Lebenseigenschaft Einfachheit und innere Ruhe im Hinblick auf die Dimension Raum zu bedienen schlägt Baumgartner vor, die Möbel beiseite zu räumen. Würde diese Bedingung nicht erfüllt, könnte die Kugellagermethode diese Lebenseigenschaft nicht in allen vier Dimensionen gewährleisten. Wie aber bereits erwähnt, ist Lebendigkeit zwar Teil eines polaren Gegensatzpaares, nicht aber eine entweder-oder-Option, d.h. »wenn also ein bestimmtes didaktisches Szenario nicht in allen Kategorien der obenstehenden Tabelle >punktet<, dann bedeutet das noch lange nicht, dass es überhaupt kein Leben mehr beinhaltet, bzw. gar keine lebendigen pädagogischen Prozesse mehr unterstützt« (Baumgartner/ Bauer 2010: 4). Nichtsdestotrotz zeigt sich, dass durch diese Methode sehr detailgetreu die Lebendigkeit, also die Qualität eines didaktischen Szenarios, überprüft werden kann und vorhandene Schwächen einer Methode ebenso wie ihre Vorteile explizit gemacht werden können.

Um die Funktionalität dieses Klassifizierungssystems zu validieren, wäre es, so Baumgartner, sinnvoll weitere didaktische Szenarien auf ihre Kompatibilität mit den 15 Lebenseigenschaften hin zu überprüfen (Bauer/Baumgartner 2010: 17).

\section{Muster suchen - Methodik beschreiben}

In den >Vorarbeiten zu einer didaktischen Taxonomie für E-Learning (2006) entwickelte Baumgartner bereits einen Ansatz, den er von Alexanders Theorie ableitete. Er führt den Begriff >Muster< ein, nicht im Sinne von >Schablone <, so betont er, sondern als »unterschiedliche mögliche Konfigurationen einzelner Verhaltensweisen« (Baumgartner 2006: 51) und Handlungssituationen. Sie sind eng 
verknüpft mit jenen Methoden oder theoretischen Modellen, die die Tätigkeiten von Lehrpersonen anleiten.

Unter Modell versteht Baumgartner allgemeinhin ein theoretisches ideelles Abbild möglicher Verfahren, Verhaltensweisen oder Konfigurationen in der Didaktik, also von Unterricht. Bereits zu diesem Zeitpunkt betont er die Notwendigkeit eines >systematisch gegliederten Reservoir[s] an didaktischen Methoden< (ebd.). Dies würde die didaktische Vielfalt in der Form fördern, als dass es einen Überblick verschaffen würde über alle bestehenden Methoden. Des Weiteren würde es dazu anregen, mit noch unbekannten Szenarien zu experimentieren (vgl. ebd.). Vorab sollte jedoch eine Einheitlichkeit über das Verständnis von >Methode< in der Didaktik generell vorhanden sein, so Baumgartner. Er verweist auf insgesamt fünf verschiedene kontemporär existente Auffassungen der Bedeutung.

Methode als zielgerichtete Verfahrensweise: Methoden sind zielgerichtete Planungen von Verfahrensweisen, die auf ein spezifisches Lernziel hingerichtet sind.

Methode als Brücke oder Vermittler: Die gegenstandsbezogene inhaltliche Funktion von Methoden wird betont. Die inhaltliche Intention wird konkretisiert und die Vermittlung zwischen angewandten Techniken und Lehrpersonen steht im Fokus.

Methode als angewandtes Lernprinzip: Methode wird hier als Grundsatz methodischen Handelns verstanden, bzw. als grundsätzliche Orientierung oder als allgemeines Unterrichtsprinzip.

Methode als Muster der Verhaltens von Lehrpersonen: Methoden meinen wiederkehrende Muster besonderer Verhaltenskomponenten, die nicht nur für einzelne Lehrpersonen charakteristisch sind. Im Pluralgebrauch wird im engeren Sinn von Verhaltensweisen und Handlungsmustern gesprochen, im Singulargebrauch bezieht sich $>$ Methode $<$ im weiteren Sinnzusammenhang auf ein theoretisches Modell, das die gesamte Tätigkeit der Lehrperson anleitet und so einzelne Handlungsmuster generiert.

Methode als Muster von Handlungssituationen: Dieses Verständnis kommt, so Baumgartner, seiner eigenen Auffassung am nächsten. »Eine Methode ist dann nicht bloß ein Muster von Verhaltensweisen von [Lehrpersonen] sondern ein Muster von Handlungssituationen, das Lehrende und Lernende gleichermaßen einschließt« (Baumgartner 2006: 54). Die Lehrperson initiiert das Handlungsmuster, aber die Situation ist es, die es bildet. Dieses Verständnis von didaktischer Methode weist, so Baumgartner, eine Analogie zum Begriff Learning Design auf. Das Generieren einer Learning Design Regel läuft über die Schritte Theorie, Best Practice und Muster von Best-Practices, die aus einer Sammlung von Beispielen gewonnen und zusammengesetzt werden (ebd.) ab, ganz ähnlich wie die Erstellung eines Musters nach der Alexanderschen Verfahrensweise.

»Werden Unterrichtsmethoden als Handlungsmuster zur Schaffung lernförderlicher Situationen verstanden, dann können sie im Sinne von Alexander als Lösungsvorschläge für ein System widerstreitender Kräfte im Lehr-/Lernprozess interpretiert werden. [...] Ein didaktisches Arrangement soll eine lernförderliche 
Szene generieren, die eine spezifische Ausprägungsform des Grundwiderspruchs von Vermittlung und Aneignung zu lösen hilft.« (Baumgartner 2006: 55)

Wenn nun didaktischen Methoden, die in wiederkehrenden Verhaltensweisen und/oder Handlungssituationen zu finden sind Alexanders Ansatz folgend als Muster, also als Lösungen zu einem Konflikt widerstrebender Kräfte, aufgefasst werden, dann soll das Ziel nicht sein, neue Lösungsansätze zu entwickeln. Vielmehr gilt es, die bestehenden Lösungsansätze zu identifizieren, die Muster lediglich zu finden.

"Ich halte das für eine wesentliche Vereinfachung der Fragestellung: Wir konzentrieren uns damit auf reale, empirisch vorfindbare Situationen und nicht mehr auf Techniken zu deren Erreichung; Techniken (bzw. Methoden im traditionellen Sinne), die vielleicht den gewünschten Erfolg bringen - oder aber auch nicht! Wir fokussieren unsere Aufmerksamkeit auf die empirische Analyse von Situationen, die vielleicht auch mit unterschiedlichen Methoden realisiert werden können." (Baumgartner 2006: 58)

Eine Quelle von Mustern müssen dabei nicht zwangsweise jene Analysen von Situationen sein, gleichermaßen kann auch bereits bestehende einschlägige Literatur Potential zur Analyse und Musteridentifizierung bieten.

\section{Muster Sammeln - die pragmatische Annäherung}

"Patterns are not step-by-step recipes. Each of these offers a format and a process for recording knowledge that can then be used by a variety of different teachers in many different ways." (Eckstein/Manns/Sharp/Sipos 2002:)

Im Rahmen des Pedagogical Patterns Project und anderer Projekte werden Muster gesammelt und in Alexanderscher Form niedergeschrieben, um in eine einheitliche Mustersprache integriert werden zu können. Baumgartner warnt, dass dies der »theoretisch differenzierten und philosophischen Grundlegung von Christopher Alexander nicht gerecht« (2006) werde. »Es handelt sich überwiegend um rezeptartige Sammlungen von Ratschlägen[...]« (ebd.), die zu eindimensional und zu wenig tiefgreifend seien. Dennoch:

»Letztlich benötigen wir aber natürlich beides: Einerseits den abstrakten und damit (noch!) >leeren< Begriff der Methode, des Didaktischen Szenarios. Hier wirkt der Begriff in die Zukunft; er soll die Planung des Designs steuern, bezieht sich also auf das Konzept der Lehr-/Lernhandlung, ist ein imaginierter Handlungsentwurf, ein Entwurfsmuster. Andererseits die davon zu unterscheidende tatsächlich bereits vollzogene Lerneinheit, die Performanz der Methode, die mit Inhalten, Aktivitäten und Personen >gefüllte< didaktische Situation. Hier wirkt der Begriff also in die Vergangenheit auf bereits vollzogene Handlungsmuster, 
die sich in Szenen realisieren (Gegenwartsaspekt) um schließlich (retrospektiv betrachtet) sich zu Situationen kristallisiert haben.« (Baumgartner 2006: 58)

Tatsächlich also entwickeln Muster sich nicht aus einer prospektiven Planung, es geht vielmehr darum zu beobachten, was sich retrospektiv in der Praxis bewährt hat. »Patterns take up a position in between theory and best practice in that they are abstracted from best practice $($ Koper 2005: 3). »A pattern is about [...] a certain class of problem paired with a type of solution that has endured the test of time, proving itself to be a good [...] way of tackling that problem « (De MouraFilho/ Derycke 2005: 114). Diese Lösungen, die sich über die Zeit in der Praxis bewährt haben, zu sammeln erscheint daher als zwar in der Tat sehr pragmatischer, aber dennoch lohnender Ansatz.

In dem partizipatorischen System des Pedagogical Patterns Project können Lehrende durch Revision ihres eigenen Verhaltens Muster identifizieren, die vor allem Neulinge auf dem Gebiet zu Rate ziehen können, die gleichzeitig aber auch eine Bereicherung für Experten darstellen können.

"For professional educators, these patterns may seem obvious, even trivial, because they have used them so often. For those newer to the teaching, they offer a way for experienced teachers to pass on their experiences. But even experienced professionals will benefit a lot by learning from one another. Because Nobody is Perfect and furthermore everybody has developed her own little secrets that she can share." (Eckstein/Bergin/Sharp 2002)

Die einhergehenden Herausforderungen sind die Ausgangssituation, sprich das Problem, zu welchem das Muster eine Lösung darstellt, sowie die Ergebnissituation, sprich das Resultat der Musteranwendung, zu identifizieren. Außerdem und vor allem sollte die Anbindung an den Kontext des Anwendungsbereiches durchschaubar sein, um erfolgreich mögliche Wechselwirkungen feststellen zu können. Der Mustersammlungsprozess zeichnet sich also durch große Ausmaße von Abstraktion aus und es ist jederzeit möglich, geradezu vorhersehbar, dass man einstweilen feststellen muss, dass Problem und Lösung nicht korrelieren oder dass das Muster im Grunde verschiedene Probleme und/oder verschiedene Lösungen enthält.

Ist ein Muster schließlich abgeschlossen, so reiht es sich in eine Sammlung ein, bekommt einen spezifischen Platz in einer Vernetzung zu anderen Mustern und kann so auch eine Ressource zur Lösung komplexerer Probleme darstellen. Das übergreifende Ziel dieses Projektes und ähnlicher ist der Gebrauch von einer Mustersprache als Erfassungs- und Kommunikationswerkzeug (vgl. Eckstein/Bergin/Sharp 2002), die wesentliche Eigenart von Mustern ist ihre Verteilbarkeit und das Potential zur gemeinsamen Benutzung von erfolgreichen Praktiken. 


\section{Potentialförderung einer didaktischen Methode DURCH MUSTERSPRACHE}

Das überregionale Verbundprojekt Potentialförderung für bürgerschaftliches Engagement und Service Learning an deutschen Hochschulen strebt in einem Ansatz, der aus allen vorgestellten Bereichen bestimmte Arbeits- und Betrachtungsweisen bezieht, eine Mustersprache für die Lehr- und Lernmethode Service Learning (dt.: Lernen durch zivilgesellschaftliches Engagement) an Hochschulen an.

Angesichts der Heterogenität in der Praxis, ist es bei einer möglichst detaillierten Ausführung des Musterschreibens besonders wichtig zu berücksichtigen, dass Service Learning trotz seiner Vielfältigkeit in der Ausübung ein Spannungsfeld beinhaltet, dessen Ganzheitlichkeit nicht außer Betracht gelassen werden darf. Grundlegend für eine erfolgreiche Mustersprache ist das Bewusstsein dass es sich bei dem didaktischen Vorgang Service Learning um ein omnipräsentes Wechselspiel zwischen den Akteuren Lehrender, Lernender und Kooperationspartner handelt. Es war daher wesentliche Grundlage zu verstehen, dass die Erstellung von einzelnen isoliert anwendbaren Mustern immer einen Spagat darstellt zwischen Zerstreuung in einzelne Bestandteile und Erhalt der Gesamtheit der didaktischen Methode. Die Identifizierung von Erfolgsmustern wird im weiteren Verlauf des Projektes außerdem unter Beleuchtung des von Baumgartner hervorgebrachten Konzeptes der Handlungssituation ablaufen. Muster als spezifische Verhaltens- oder Handlungssettings zu betrachten, bedeutet nicht etwa den Fokus darauf zu legen, zielgerichtet etwas Neues zu entwickeln, sondern retrospektiv zu reflektieren, um Bestehendes zu identifizieren. Indem wir aus unserem persönlichen Erfahrungswissen Konfigurationen einzelner Handlungs- und Verhaltensweisen ableiten, halten wir die Schwelle zwischen Vermittlung und Aneignung sehr niedrig und ermöglichen bestmögliche Anwendung. Die Spannung zwischen gesamtheitlicher Betrachtung der didaktischen Methode Service Learning und der Einbringung individueller aber zugleich klassischer Situationen zu überbrücken und zur gleichen Zeit möglichst generalisierend und empirisch zu arbeiten, ist ein Ziel, das wir uns im Rahmen des Projektes gesetzt haben. Dieses Ziel soll durch die Einbindung der Service Learning Community erreicht werden, dessen Mitwirkung zur Stärkung der Musterpräsenz beitragen wird. Die partizipatorische Einbeziehung einer nicht muster-affinen Zielgruppe ist insofern unerlässlich, als dass auf keine andere Weise eine so starke Steigerung der Mustervielfalt erreicht werden kann. Desweiteren ist eine Mustersprache unserer Auffassung nach trotz der komplexen wissenschaftlichen Grundlage ein System, das die Praxis der Theorie stets vorzieht und nur durch pragmatische Handhabung ihren Nutzen entfaltet. Die Wahl einer Herangehensweise an eine Mustersprache für Service Learning muss im Rahmen dieses Verständnisses also keine Entscheidung sein zwischen Theorie, Methodik und/oder Pragmatik. Vielmehr betrachten wir unser Projekt als eine Synthese aus allen dreien Perspektiven. 


\section{LITERATUR}

Alexander, C., Ishikawa, S. \& Silverstein, M. (1977): A Pattern Language. Towns, Buildings, Construction. New York.

Alexander, C. (1979): The Timeless Way of Building. New York.

Alexander, C. (2002): The Nature of Order. Berkeley, CA, Center for Environmental Structure.

Appleton, B. (1999): Patterns in a Nutshell. www.redbrick.dcu.ie

Bauer, R. \& Baumgartner, P. (2010): A First Glimpse at the Whole: Christopher

Alexander's Fifteen Fundamental Properties of Living Centers and Their Implications for Education. www.hillside.net/europlop/

Baumgartner, P. (2006): Unterrichtsmethoden als Handlungsmuster: Vorarbeiten zu einer didaktischen Taxonomie für E-Learning. In: Mühlhäuser, M.; Rößling, G. \& Steinmetz, R. (Hg.): 4. E-Learning Fachtagung Informatik. Gesellschaft für Informatik.

Baumgartner, P. \& Bauer, R. (2010): Handlungsmuster und Ganzheitlichkeit: Implikationen des Muster-Ansatzes von Christopher Alexander für die Didaktik. Zürich.

Bergin, J.; Eckstein, J. \& Sharp, H. (2002): Patterns for Active Learning: Submission to the PPP Pattern Language Project. www.hillside.net

De MouraFilho, C. O. \& Derycke, A. (2005): Pedagogical Patterns and Learning Design: When Two Worlds Cooperate. Available at: http://dspace.ou.nl/ bitstream/1820/474/9/09_DBU_review.pdf

Eckstein, J.; Manns, M. L.; Sharp, H. \& Sipos, M. (2002): Teaching from Different Perspectives. Proceedings of the $13^{\text {th }}$ EuroPlop Conference. Irsee

Koper, R. (2005): An Introduction to Learning Design. In: Koper, R. \& Tattersall, C. (Hg.): Learning Design: A Handbook on Modelling and Delivering Networked Education and Training. Berlin-Heidelberg, 3-20.

Leitner, H. (2007): Mustertheorie: Einführung und Perspektiven auf den Spuren von Christopher Alexander. Graz.

Schuler, D. (2010): Pattern Languages as Critical Enablers of Civic Intelligence. In: International PUARL Symposium (Hg.): Current Challenges for Patterns, Pattern Languages and Sustainability. Portland, 117-126. 


\title{
Wenn das die Lösung ist, will ich mein Problem zurück
}

\author{
Angewandte Improvisation als Werkzeug für resiliente Führung
}

Gabriele Amann und Martin Ciesielski

\section{Einleitung}

Die Zeiten sind geprägt von chronischen Stressbelastungen. Mitarbeiter und Führungskräfte leiden unter den immer rascheren Veränderungsprozessen. Die Medien berichten täglich von nahezu existenzbedrohenden Krisen. Großprojekte scheitern oder verzögern sich signifikant. Keiner weiß mehr zu planen und sich sicher in die Zukunft zu bewegen. Die allgemeine Verunsicherung nimmt zu. Immer öfter sind Mitarbeiter gezwungen zu improvisieren, weil ihnen für Planungsphasen keine Zeit mehr zur Verfügung steht oder weil gemachte Planungen obsolet werden. Für das Thema Improvisation im Berufsalltag interessieren uns dabei besonders folgende Fragen:

- Wie funktionieren Selbstorganisation, Kommunikation und Teamarbeit in jenen Arbeitsphasen, in denen das improvisierte Handeln aufgrund von Zeitknappheit, Stress und hoher Arbeitsbelastung, im Zentrum der Aufmerksamkeit steht?

- Mit welchen Zielen, Haltungen und Einstellungen Führungskräfte und Mitarbeiter an ihre Arbeit herangehen und mit welchen Herausforderungen sie klarkommen müssen, um Höchstleistungen, auf ihrem jeweiligen Gebiet der Improvisation, erbringen zu können?

- Wenn die Arbeitsbedingungen schon zum Improvisieren zwingen, wie kann man lernen, dies professionell und auf hohem Niveau zu tun? Inwieweit kann in diesem Zusammenhang die Ensemblearbeit eines Improvisationstheaters als Modell dienen?

Die Autoren arbeiten seit über 15 Jahren mit Improvisationstechniken im Weiterbildungs- und Business-Kontext. Ein wichtiger Schwerpunkt der Angewandten 
Improvisation liegt dabei in der betrieblichen Resilienz- und Gesundheitsförderung. Seit 2007 bieten die Autoren umfassende Train-the-Trainer-Qualifizierungen für Multiplikatoren, wie Trainer, Berater und Führungskräfte. Der Beitrag zeigt im ersten Teil inwieweit das Improvisationsvermögen ein wesentlicher Schutzfaktor zum Aufbau der persönlichen Widerstandskraft im Umgang mit Krisen-Situationen ist. Im zweiten Teil zeigen die Autoren anhand praktischer Beispiele, wie verschiedene Ansätze und Techniken der Angewandten Improvisation im Rahmen von Qualifizierungsmaßnahmen zum Einsatz kommen, dort für Irritationen, Überraschungen, Spaß sowie gemeinsames, einsichtsvolles Lernen und Verstehen sorgen.

\section{Resilienz - Begriff Und Forschung}

"Resilience is neither ethically good or bad. It is merely the skill and the capacity to be robust under conditions of enormous stress and change."

Diane Coutu

Resilienz steht heute synonym für Krisenkompetenz und umschreibt die Fähigkeit, Krisen und Veränderungsprozesse durch Rückgriff auf persönliche und sozial vermittelte Ressourcen zu meistern. Krisen gehören zum Alltagserleben und dienen als Anlass für Weiterentwicklung und persönliches Wachstum.

Der Begriff Resilienz leitet sich ab aus dem englischen Wort >resilience< und umschreibt die Fähigkeit, erfolgreich mit belastenden Lebenssituationen umzugehen, d.h. widerstandsfähig gegenüber Krisensituationen zu sein. Die Wurzel des Begriffes geht auf das lat. Resilire zurück, was zurückspringen und abprallen bedeutet. Entlehnt aus der Physik und Werkstoffkunde bezeichnet Resilienz die Fähigkeit eines Werkstoffes, sich verformen zu lassen und dennoch in die ursprüngliche Form zurückzufinden. Im Deutschen wird Resilienz mit Widerstandsfähigkeit übersetzt. Der Begriff Resilienz wird ebenfalls zur Umschreibung von Stressresistenz, psychische Robustheit oder psychische Elastizität verwendet.

"Wenn man alles, was einem begegnet, als Möglichkeit zu innerem Wachstum ansieht, gewinnt man innere Stärke." (Milarepa, Tibetischer Meditationsmeister [1052-1135])

Die Resilienzforschung hat eine Reihe von lern- und trainierbaren Schutzfaktoren herausgearbeitet, welche die Widerstandsfähigkeit eines Menschen im Umgang mit Krisen erhöhen können: 
1. Entwicklung einer optimistischen Grundhaltung gegenüber Veränderungen

2. Akzeptanz der Umstände und realistische Einschätzung von Rahmenbedingungen

3. Lösungs-, ziel- und ergebnisorientiertes Vorgehen

4. Selbstregulation, in Form von Stress-Management und Selbstfürsorge

5. Ergreifen von Eigeninitiative und Übernahme von Selbstverantwortung

6. Inanspruchnahme von Hilfe, die Pflege von Netzwerken und Beziehungen

7. Zukunftsorientiertes Handeln, flexibler Wechsel zwischen Makro - und Mikroplanung

8. Improvisationskompetenz in Hinblick auf den Umgang mit Unvorhergesehenem

Resilienz an sich ist keine Methode oder Technik, sondern ein Metamodell, welches günstige Faktoren, Eigenschaften, Einstellungen, Strategien und Verhaltensweisen beschreibt, die helfen, Krisen zu meistern und im besten Falle gestärkt aus Ihnen hervorzugehen. Dieses Metamodell hilft dabei, vorhandene Ressourcen zu entdecken, sie aus neuen Perspektiven zu betrachten und auf neue Art und Weise anzuwenden. Auch resiliente Menschen sind verletzlich und verletzbar. Jedoch verfügen sie über schützende Bedingungen in ihrer Person und/ oder Umgebung, die ihnen helfen, schwierige Situationen besser zu meistern.

Das Meta-Modell der Resilienz zeigt Muster (Patterns und Role-Sets) auf, nach denen resiliente Menschen, Mitarbeiter, Führungskräfte, aber auch Organisationen und Systeme vorgehen können, um Krisen zu überwinden, sich in den immer wiederkehrenden Stürmen des Lebens zu biegen, aber nicht an ihnen zu zerbrechen und im besten Falle gestärkt aus ihnen hervorzugehen. Diese Muster des resilienten Verhaltens und des Denkens lassen sich auf vielen verschiedenen Ebenen unserer Gesellschaft beobachten: ökologisch, biologisch, ökonomisch, organisational, sozial, psychisch, gesundheitlich.

"Resilienz ist kein Charaktermerkmal, sondern das Endprodukt von Pufferungsprozessen, welche Risiken und belastende Ereignisse zwar nicht ausschließen, es aber dem Einzelnen ermöglichen, mit innen erfolgreich umzugehen." (Emmy E. Werner)

In unserer gegenwärtigen Zeit, in der permanente Restrukturierungen, ChangeProzesse und das subjektive Erleben von Krisen zum persönlichen und beruflichen Lebensalltag gehören, stellt das Resilienz-Konzept einen wichtigen Orientierungsrahmen für die Schaffung einer konstruktiven, produktiven und lernfähigen Unternehmenskultur dar. Denn die Frage ist nicht, ob es Krisen im Leben der einzelnen Mitarbeiter und Führungskräfte gibt, sondern wie sie es schaffen mit der Krise als Herausforderung kreativ, wenn nicht sogar innovativ umzugehen. 


\section{Von der wissenden zur (hinter-)fragenden Organisation}

Bei der Resilienzförderung geht es primär darum, die Beteiligten zum Fragen zu aktivieren. Es geht darum, herauszufinden, mit welchen Mindsets wir den Problemen, Aufgaben und Zielen unserer Zeit begegnen wollen. »Wie können wir das Leben lebenswerter gestalten, unsere Lebensweise gesünder ausrichten und uns im Umgang mit Krisen stark machen?« Das Resilienz-Konzept hält sehr konkrete Antworten für uns bereit, die sich nicht aus Hypothesen und Theorien ableiten, sondern aus der Best Practice von den Menschen, Institutionen und Systemen, die bereits gezeigt haben, wie Überleben trotz widriger Umstände funktioniert, die ein erfolgreiches Krisenmanagement bewiesen und die aus Fehlern gelernt haben. Es geht uns darum zu erkennen, dass jeder Mensch und die meisten Systeme von Natur aus resiliente Eigenschaften und Fähigkeiten besitzen, die nur nicht unbedingt beobachtet, erkannt und abgerufen werden (können).

Das Aufspüren, Entdecken und Aktivieren der latenten Resilienz ist daher eine der wichtigsten Aufgaben für uns als Trainer, Berater und Coaches.

\section{IMPROVISATIONSKOMPETENZ ALS ZENTRALER SCHUTZFAKTOR DER RESILIENZ}

"Within an arena of personal capabilities or company rules, the ability to solve problems without the usual or obvious tools is a great strength." (Diane Coutu)

Ein wichtiger Schlüssel zur Steigerung der Resilienz ist der selbstbewusste und aktive Gebrauch unseres Improvisationstalents. Die amerikanische Wissenschaftlerin Diane Coutu (2002), betonte in ihrem Artikel »How Resilience Works«, dass Improvisationsvermögen eine der drei wichtigsten und fundamentalsten Charakteristika für resiliente Menschen und Unternehmen ist, denn

- nicht alles ist voraussehbar und kontrollierbar,

- Mitarbeiter, die mit dem arbeiten können was da ist, die aus allem etwas machen können, haben in Krisensituationen einen entscheidenden Vorteil: Sie sind handlungsfähig,

- hierzu müssen Mitarbeiter in der Lage sein, sich von übertriebenen Perfektionsansprüchen zu trennen und eine produktive Fehler- und Lernkultur entwickeln,

- Irrtümer und Rückschläge gehören zum Leben dazu.

Die anderen beiden Faktoren, die Coutu nennt, sind »face down reality«, also die Fähigkeit der Akzeptanz der Rahmenbedingungen sowie »search for meaning «. Die Bedeutungs- oder Sinnfrage ist in der Resilienzforschung zentral. So sind 
z.B. Optimismus, Zukunftsorientierung, Selbstregulation und Selbstverantwortung stark an Fragen der Sinnhaftigkeit des eigenen Tuns gebunden.

Zentral für die Resilienzförderung ist daher der Aufbau von inspiriertem, sinnstiftendem und selbstwirksamen Verhalten. Dies ist insbesondere im Umgang mit Situationen wichtig, auf die wir nicht vorbereitet sind, für die wir noch keine eingespielten Routinen und Verhaltensmuster entwickelt haben und die daher auch geeignet sind, uns zu verunsichern, unter Stress zu setzen und das subjektive Gefühl eines Krisenerlebnisses zu erhöhen. Gerät der Mensch unter Stress, werden rudimentäre Überlebensstrategien aktiviert, wie Kampf, Flucht und Erstarrung. Zeit für kreative Ideenfindungen und Brainstormings, für die Entwicklung neuer, strategischer Lösungsansätze, steht ihm schlicht nicht zur Verfügung. Dafür greift er zur Bewältigung der Situation reflexhaft auf altbekannte und beherrschbare Verhaltensmuster bzw. Routinen zurück.

Dies bedeutet für unseren Beratungs- und Trainings-Kontext: Die Klienten und Seminar-Teilnehmer erlernen in einem sicheren Trainingsrahmen die Regeln für eine erfolgreiche Improvisation unter Stress. Hat ein Mitarbeiter zuvor bereits in unbelasteten Situationen die Regeln und Prinzipien für eine gelungene Improvisation erlernt und angewendet, dann wächst die Wahrscheinlichkeit, dass er auf diese Prinzipien auch in einer echten Stress-Situation schnell und sicher zurückgreifen kann. Er stellt sich durch das Resilienz- und Improvisations-Training auf die mögliche Krisen-Situation X ein, baut seine Routinen und Handlungsmuster aus.

\section{Resilienzförderung durch Improvisationstraining}

"The manager who can quickly discern emerging patterns, imaginatively create new ways of capturing and shaping human energy, and capture the flow of the moment will most likely build an adaptable and resilient organization that can not only survive challenges but also prosper when the unexpected happen. [...] What is needed instead is a capacity for "acting in the moment", something that is better attained through quick adaptability, imagination, ingenuity, spontaneity, creativity, rapidly shifting networks and patterns, and highly improvised behavior." (Janet and Robert Denhardt, Building Organizational Resilience and Adaptive Management, in: Reich/Zautra/Hall Handbook on Adult Resilience, 2010, S. 333)

Wie wir Menschen im Umgang mit Krisen und unvorhergesehenen Situationen Inspiration, Sinnhaftigkeit und Selbstwirksamkeit erleben können, zeigen uns die verschiedenen Spielarten der professionellen Improvisation, wie wir sie bei Musikern, Tänzern, freischaffenden Künstlern und beim Improvisations-Theater erleben können. In unseren Qualifizierungsmaßnahmen nutzen wir vor allem die Grundlagen der Ensemblearbeit beim Improvisations-Theater als Modell für resilienzförderndes Verhalten im Unternehmen. Wir beziehen uns in unserer Arbeit u.a. auf die spezielle Improvisationstheaterform, die z.B. Keith Johnstone in seinem Buch »Theaterspiele« beschreibt und welche sich seit Mitte der 199oer 
Jahre auch in Deutschland wachsender Beliebtheit erfreut. Das Impro-TheaterEnsemble kommt in seinen Strukturen und den von ihm zu bewältigenden Aufgaben der Teamarbeit im Unternehmen am nächsten.

Die Arbeit eines Improvisationstheaterensembles eignet sich besonders, um die Herausforderungen des modernen Arbeitsalltags modellhaft zu beschreiben, so dass Mitarbeiter und Führungskräfte für Ihren Führungsalltag lernen können. Die vier wichtigsten Transfer-Aspekte sind:

- Das Improvisationsensemble (=Team) produziert nach Vorgaben des Publikums (=Kunden) eine Szene bzw. Geschichte (=Produkt/Dienstleistung).

- Das Improvisationsensemble ist dabei auf ein konsequent lösungsorientiertes Vorgehen (=Produktivität) und sehr gute interne Zusammenarbeit (=Teamarbeit) sowie ein ausgesprochen professionelles Kommunikationsverhalten angewiesen.

- Die Teamarbeit ist in hohem Maße von Prinzipien der Selbstorganisation (=Führungsstil) geprägt.

- Zugleich müssen Improvisationsschauspieler sowohl ausgesprochene (Selbst) Führungs- als auch Team-Player-Kompetenzen aufweisen.

\section{Lernen durch Emotionen und Begeisterung}

Die Ergebnisse der Resilienz-, der modernen Hirn- und Embodiment-Forschung belegen eindeutig: Eine der wichtigsten Aufgaben im Training besteht darin, für Teilnehmer erlebnisorientierte Lernsettings zu schaffen, in denen sie die Wirkfaktoren der Resilienz neu erfahren und für sich kontextuell re-aktivieren und stärken können. In unser Improvisations- und Resilienz-Training integrieren wir Ansätze aus dem Systemischen Coaching, dem NLP, dem Embodiment und damit auch der Körperarbeit. Durch den Einsatz von Methoden aus dem Improvisationstheater wird dabei körper- als auch kognitiv-orientiert gearbeitet. Der Körper kann ebenso Gedanken beeinflussen, wie Gedanken Einfluss auf den Körper haben. Von vorhandenen Denkmustern loszulassen kann somit eine kognitive oder aber auch eine physisch-körperliche Herausforderung sein. Ebenso kommt es beim Trainieren alternativer Verhaltensweisen zum einen auf die kognitive Simulation an, wie auch auf das körperliche Erleben und den damit einhergehenden geistigen Aktivitäten.

Resilienz- und Soft-Skills-Labore schaffen dabei einen gehirngerechten, erlebnisorientierten Lernkontext für Führungskräfte und Mitarbeiter. Hier können konkrete Themen und Fragestellungen bearbeitet werden - und quasi im Vorbeigehen resiliente Verhaltensweisen kennen gelernt und trainiert werden. $\mathrm{Ob}$ in der Mitarbeiter-, Führungskräfte- oder Trainer-Weiterbildung, im Mittelpunkt eines Resilienztrainings mit Improvisationsmethoden stehen - neben der begleitenden Vermittlung der wichtigsten theoretischen Hintergründe - das Erschaffen eines praxisnahen und nachhaltigen Erfahrungs-Settings. Nicht zuletzt 
darf und soll in den Laboren nicht nur eine Menge reflektiert, sondern sollen vor allem auch Fehler gemacht und gemeinsam gelacht werden - gemäß der Aussage von John Cleese: »If you cannot laugh about a tough problem, you will not solve it! $\ll$.

Die konsequente Aktivierung der kreativen Potentiale und die Stärkung des Improvisationstalentes ist dabei ein wichtiger Resilienz-Faktor unterer mehreren. Als ein weiterer wichtiger Faktor hat sich die Re-Aktivierung von (oft verloren gegangenen) kreativem Handeln erwiesen und die Schaffung von situativen Voraussetzungen, die nicht nur Kreativität stimulieren und damit die Erzeugung von Ideen, sondern Kontexte kreieren, in denen die Ideen auch konkret in Handlungs- und Verhaltensmotive umgesetzt werden können. Denn nur die Idee, die in der Praxis umgesetzt und erprobt und gegebenenfalls mehrfach überprüft und optimiert wird, bietet die Basis für echte Veränderung und Innovation. Klassische Seminar- und Trainingskontexte bieten hierzu nur wenig Raum.

\section{Resilienz trainieren im Leadership-Lab}

In Leadership-Labs erfolgt der Erkenntnisprozess daher über die Interaktion mit dem Team, über direktes und persönliches Erleben. Im Zentrum dieser prozessorientierten Workshops sind die konkreten Themen der Teilnehmer. An diesen Themen wird auf Grundlage der Resilienzforschung mit Methoden des Improvisationstheaters und anderen systemischen Ansätzen gearbeitet.

Das Erleben von Wahl- und Entscheidungsfreiheit ist ein wesentlicher Kern des Resilienz-Trainings mit Improvisationstechniken. Der Teilnehmer bestimmt selbst, wann und wie er sein Verhalten ändern und neues ausprobieren möchte. Gelernt wird über die Reflektion neuer Fragestellungen und der Aktivierung ur-eigener, kreativer Ressourcen. Maßgeblich hierfür sind keine Soll-Standards, sondern der Erfahrungshorizont des Teilnehmers. Beim Resilienztraining geht es um die Aktivierung und Stärkung der acht Schutzfaktoren durch

- das Erleben von Kompetenz, Sinnhaftigkeit und Selbstwirksamkeit

- das Erkennen von Leitgedanken und Handlungs-Prinzipien, die beim Umgang mit dem Ungewissen hilfreich und förderlich sind

- den Aufbau neuer, Denk-, Bewertungs- und Handlungsmuster im Umgang mit stressauslösenden Ereignissen

- die Erweiterung der Handlungskompetenzen und Wahlfreiheiten durch die Aktivierung alter oder die Entwicklung neuer, erwünschter und nützlicher Routinen.

- die Befähigung zur spontanen Selbstpositionierung, der Aufbau von Stabilität und Entscheidungssicherheit

Auf Basis der acht inneren und äußeren Schutzfaktoren der Resilienz vermitteln wir den Teilnehmern eine fundierte Einführung in die Grundlagen und Metho- 
denvielfalt des Improvisationstrainings. Anhand von Wahrnehmungsübungen, Auflockerungsspielen, Assoziationstechniken und klassischen Improvisationsübungen, sowie neu entwickelten Interventionen, erfahren die Teilnehmer wie effektiv und einfach die Wirkung grundlegender Improvisationsleitsätze in der Zusammenarbeit, aber auch für jeden Einzelnen sein kann. Die Teilnehmer erleben, wie wichtig Beweglichkeit, Flexibilität und Anpassungsfähigkeit sind, um mit neuen, unvorhergesehenen Situationen besser umzugehen.

\section{Erfahrungsberichte aus der Trainings-Praxis}

Aus der Vielzahl von Leitgedanken, die für eine erfolgreiche Improvisation im Team maßgeblich sind, möchten wir nachfolgend beispielhaft drei Grundregeln der Improvisation vorstellen, die sich in der beruflichen Praxis als besonders resilienzfördernd herausgestellt haben:

\section{Leitsatz 1:}

"Sag ja, nimm das Angebot an! - oder die Krise als Chance betrachten

Die Teilnehmer erfahren im Training wie konstruktiv es ist, sich für die neue und überraschende Angebote von Mitspielern zu öffnen, diese nicht zu blockieren, sondern anzunehmen und schlicht »Ja!« zu sagen. Denn nur wer sich einer neuen Situation oder Idee gegenüber öffnet, kann Optimismus entwickeln und die hinter der Krise liegenden Chancen und Möglichkeiten erkennen. So erleben die Teilnehmer beim Improvisationstraining, dass auch Krisen und Problemstellungen Angebote sind, welche es anzunehmen gilt. Wie wichtig hierbei das Wissen und die Lösungskompetenz des ganzen Teams sind, fasst der nachfolgende Erfahrungsbericht einer Führungskraft zusammen:

"Die Ideen und Angebote der Mitspieler erst einmal anzunehmen. Ja-sagen, zu allem was kommt. Das fand ich zuerst schrecklich. Ich habe festgestellt, dass ich fast immer 'geblockt , habe, wie man das beim Improvisieren nennt. Nein. Ich will dies nicht. Nein, ich will das nicht. Damit konnte natürlich auch keine Geschichte richtig weitergehen. Und wenn das ein Mitspieler in umgekehrter Richtung bei mir gemacht hat, dann habe ich richtig gemerkt, wie frustrierend dieses Verhalten ist. Das war mir vorher nicht bewusst. Ich bin eben so aufgewachsen: Erst mal alles kritisch sehen und ablehnen - es könnte ja ein Haken dran sein. Am herausforderndsten fand ich in diesem Zusammenhang zu lernen, mich in den Übungen immer nur auf den nächsten Schritt zu konzentrieren und die Lösungen, die ich mir zurechtgelegt hatte, immer wieder loszulassen. Wenn ich eine Idee hatte, um in eine Szene einzusteigen, dann wusste ich in meinem Kopf gleich, wie der Rest der Szene auszusehen hatte. Und ich musste erleben, dass das beim Improvisieren im Team eben nicht durchsetzbar ist. Man muss ständig offen sein, für die Ideen und Angebote anderer Mitspieler. Denn in dem Moment, wo ich einem Mitspieler meine Ideen aufdrängen und inn kontrollieren will, dann geht nichts mehr richtig voran. Mich hat das an unsere Meetingkultur erinnert. Ehrlich 
gesagt, wenn ich als Chef eine Idee habe, dann will ich die meistens auch durchsetzen. Ich dachte mir bisher immer, das ist weniger anstrengend als mich auf die Ideen und Diskussionen meiner Mitarbeiter einzulassen. Jetzt habe ich gelernt, dass das völlig unproduktiv ist und dass es uns als Team total schwächt. Ich dachte immer, dass ich als Chef, gerade in schwierigen Situationen, gleich besonders gute Lösungsideen parat haben muss. Damit habe ich mich selbst sehr gestresst und unter Druck gesetzt. Zum Beispiel bei der Übung "Wort für Wort", die wir zum Storytelling gemacht haben, erlebt man unmittelbar, wie viel mehr Wissen und Ressourcen sich aktivieren lassen, wenn man alle aktiv in die Lösungsprozesse einbezieht. Jetzt habe ich auch verstanden, dass man gute Mitarbeiter einstellt, damit sie gute Ideen haben! Ich muss nicht alles alleine machen, planen und kontrollieren. Ich habe beim Resilienztraining gelernt, wie leicht es ist, meine Mitarbeiter und mein Team stark zu machen, indem ich deren Angebote wahrnehme und annehme. Das auf diese Art und Weise einmal gesehen und erlebt zu haben, ist für mich eine echte Erleichterung." (Michael M., Bauingenieur und Projektleiter aus Berlin)

\section{Leitsatz 2:}

»Wir dürfen auf der Bühne auch gnadenlos und grandios scheitern.« oder: neues Verhalten und neue Routinen im Umgang mit Stress erlernt man nur durch Übung

Gerade in Krisensituationen benötigen Mitarbeiter Zeit, um sich an die neuen Umstände zu gewöhnen, um alte Verhaltensmuster aufzubrechen und neue Routinen aufzubauen. Beim Improvisationstraining erfahren die Teilnehmer, wie wichtig es ist, für das Erlernen von neuem Verhalten vom Perfektionismus abzulassen und für sich die spielerische >Lust am Scheitern< wiederzuentdecken und damit auch die Angst vor dem Fehlermachen zu überwinden. Denn für das Resilienz-Training gilt: Fehler dürfen und müssen sein! Nur so wird es möglich, sich für kreative und lösungsorientierte Prozesse zu öffnen. Dass dies für viele Teilnehmer oft eine sehr neue und ungewohnte Erfahrung ist, zeigt der nachfolgende Erfahrungsbericht einer Teilnehmerin:

„Fehler machen. Was für ein Tabu. Und was für ein Erlebnis, das Scheitern so einen Spaß machen kann! Wir haben viele Übungen gemacht, in denen musste man zwangsläufig Fehler machen. Zum Beispiel bei der Übung "Impulskreis", da mussten wir Impulse im Team weitergeben, und dabei nach und nach viele verschiedene neue Abläufe gleichzeitig managen. Nachdem wir eine Weile lang versucht haben, alles richtig und perfekt zu machen, mussten wir irgendwann den Druck rausnehmen und loslassen. Das war wie beim Multitasking im wahren Leben - wir kamen sehr schnell an unsere Kapazitätsgrenze, mussten schnell und spontan reagieren. Doch es ist wichtig seine Grenzen zu erkennen und zu akzeptieren, dass es in der Realität einfach Überforderungssituationen gibt, die sich objektiv nicht mehr nach den alten Mustern organisieren lassen. Wir haben dann untersucht, wie es zu den Fehlern kommt und welche neuen Abläufe oder Verhaltensweisen wir entwickeln müssen, damit wir weniger Fehler machen. Meist mussten wir den Takt und den Rhythmus ändern, unser Kommunikationsverhalten klarer gestalten und die Prozesse entschleunigen. Dann den Transfer 
für unseren Arbeitsalltag zu ziehen, das war gleichermaßen hilfreich, wie beeindruckend. Dank der Improvisationsübungen habe ich aus dem Resilienztraining für unsere Arbeitsorganisation im Team eine Menge mitgenommen.

Aber am meisten beeindruckt hat mich die Tatsache, dass wir im Team immer dann am meisten gelacht und uns entspannt haben, wenn wir einen Fehler gemacht haben. Wir haben die Fehler dann förmlich extra gemacht, damit wir noch mal eine Strafrunde rennen müssen. Natürlich könnte man meinen, dass ist jetzt wie im Kindergarten. Aber, so ist es ganz und gar nicht. Es ist eher kindisch, dass wir als Führungskräfte darauf getrimmt werden zu glauben, dass Fehler nicht sein dürfen, oder dass es ein Leben ohne Fehler tatsächlich gibt. Ich bin beim Improvisationstraining daran erinnert worden, dass Fehler zum Lernen dazugehören. Wie soll ich eine neue Sache beherrschen, wenn ich sie nicht übe? Wie produktiv eine offene Fehlerkultur ist, das werde ich auf jeden Fall als ein für mich spannendes Lernfeld aus dem Training mitnehmen." (Pia H. Eventmanagerin aus Frankfurt)

\section{Leitsatz 3:}

»Den anderen gut dastehen lassen « oder: Konflikte und Krisen managen

durch die aktive Übernahme von Selbstverantwortung

Bei der Entwicklung von Resilienz im Umgang mit Krisen und Konflikten ist es zentral, sich aus dem Teufelskreis von Schuldvorwürfen, Kritik am Verhalten anderer und der Opferrolle herauszubewegen, aktiv zu werden und Verantwortung für das eigene Handeln zu entwickeln. Beim Improvisationstraining erfahren die Teilnehmer, wie entlastend und konstruktiv es ist, wenn man (sich und) seine Mitspieler auch in schwachen Momenten gut dastehen lässt! Die Suche nach dem Schuldigen wird zur Suche nach den Ressourcen. Die Teilnehmer geben ihre Opferhaltung auf, verlassen die Warteposition, werden aktiv und übernehmen Selbstverantwortung für ihr Handeln. Wie wichtig dabei die Überwindung von alten Verhaltensmustern und Reflexen ist, zeigt der nachfolgende Erfahrungsbericht:

"Beim Impro- und Resilienztraining war für mich besonders wichtig zu lernen, meine eigenen Fehler oder die Fehler anderer Mitspieler während des Spiels nicht zu kommentieren. Denn das unterbricht sofort den Spielfluss. Die Arbeit kann nicht weiter gehen, die Aufmerksamkeit wird unnötig abgelenkt. Es war spannend zu sehen, wie sich das Team - auch ohne unsere Kommentare - viel schneller wieder selbst organisiert hat. So entstanden auch keine unnötigen Diskussionen. Die Fehler anderer zu kommentieren, dass ist zunächst wie ein Reflex. Aber, beim Improvisieren macht man das nicht. Man denkt nicht lange über den Fehler oder das Problem nach, man registriert die Irritation, bleibt dann aber lösungsorientiert, insofern, als dass man selbst verantwortlich dafür ist, den Spielfluss am Laufen zu halten. Das geht eben dann am besten, wenn ich mich auf meine eigene Aufgabe konzentriere und den Spielfluss selbst wieder herstelle, anstatt Bemerkungen über den Kollegen zu machen. Beim Transfer war es für uns alle verblüffend zu erkennen, wie viel Energie im Arbeitsalltag damit verschwendet wird, über Probleme zu diskutieren, anstatt sie einfach zu lösen. Beim Improvisieren nennt man das auch ,den anderen gut dastehen lassen،. Eine neue und sehr hilfreiche Sicht der Dinge, vor allem wenn man im Management arbeitet. Man 
spart sich endlose Diskussionen, Rechtfertigungszwänge und Machtspiele. Vor allem aber eine Menge Zeit!“ (Werner A., Pharma-Manager aus München)

\section{ZUSAMMENFASSUNG}

\section{Übersicht: Krisen-Management, Resilienzförderung} und die zentralen Vorannahmen bei der Improvisation

- Jeder Mensch besitzt Improvisationstalent.

- Improvisationsvermögen ist überlebensnotwendig.

- Improvisation beruht auf vielseitigen Fähigkeiten und Kompetenzen.

- Jeder Mensch kann intuitiv, kreativ und spontan sein.

- Menschen lieben Probleme und Herausforderungen.

- Die Improvisation lebt von Überraschungen und vom Unvorhergesehenen.

- Improvisierer arbeiten im Hier und Jetzt.

- Die Herausforderung bei der Improvisation liegt im Handhaben paradoxer, sich widersprechender, zunächst nicht vereinbarer Vorgaben.

- Fehler zu machen und die Lust am Scheitern gehören zum lernenden ErLeben.

- Improvisation lebt von Experimenten und lösungsorientiertem Vorgehen.

- Intuition, Achtsamkeit und wertschätzende Wahrnehmung gehören zu den zentralen Quellen für eine gelungene Improvisation

Wie wir gesehen haben trägt das Improvisationsvermögen wesentlich dazu bei, in Krisen-Situationen entscheidungs- und handlungsfähig zu bleiben. Improvisationskompetenz gehört zu einer positiven und optimistischen Lebenshaltung, prägt das Maß an Flexibilität und Beweglichkeit im Umgang mit ungewohnten bzw. unerwarteten Lebenssituationen und ist maßgeblich daran beteiligt in Systemen neue Routinen, Strukturen und Muster aufzubauen, die ein Gefühl von Sicherheit geben und den Beteiligten die nötige Orientierung verleihen. Beim Improvisations- und Resilienztraining lernen die Teilnehmer wie man ad hoc mit unbekannten Situationen und Problemstellungen umgeht. Gefördert und trainiert werden das natürliche Improvisationstalent und besondere Eigenschaften wie Kreativität, Flexibilität und Spontanität im Umgang mit anderen. Improvisationstechniken und Übungen stärken den Teamgeist, regen die Wahrnehmungsfähigkeit an und fördern die Phantasie. Gefragt sind ein hohes Maß an Aufmerksamkeit für den Mitspieler, Einfühlungsvermögen, Achtsamkeit und empathisches Teamwork. Das Improvisationstraining wirkt von Natur aus resilienzfördernd. Es bietet praktische Antworten auf wichtige Fragestellungen: 
- Wie kann ich eine konstruktive Haltung entwickeln? Wie kann ich schwierigen Situationen gegenüber mit einer Haltung von Präsenz, Offenheit, Optimismus und Akzeptanz begegnen?

- Wie kann ich mein Stress-Management verbessern? Welche Leitsätze der Improvisation helfen mir, auch in stressigen Situationen gut für mich (und andere) zu sorgen, so dass wir als Team entscheidungs- und handlungsfähig bleiben?

- Wie kann ich in unbekannten Settings produktiv und leistungsfähig bleiben? Wie gehe ich für mich selbst, aber auch in der Teamarbeit ziel-, lösungs- und aufgabenorientiert an Situationen heran, die ich (noch) nicht beherrschen und kontrollieren kann?

- Wie kann ich von Ambivalenz-Management profitieren? Wie gehen wir mit paradoxen Situationen, Widersprüchen, Fehlern und Schwächen um? Was Vorteile bietet es hierbei in einem Netzwerk und Team selbstorganisiert zu arbeiten?

Doch bei allen Antworten, methodischen Herangehensweisen und theoretischen Fundierungen kommt es beim Einsatz von Improvisation im Business Kontext ganz zentral auf ein wesentliches Element an, wie es David K. Hurst in »The new Ecology of Leadership« auf den Punkt bringt:

"It's all about in the moment and paying attention to what is happening right here, right now, waiting for kairos to appear. It is a process that is closely connected with, and invariably accompanied by, humor."

\section{LITERATUR}

Coutu, D. L. (2002): How resilience works, Harvard Business Review May 2002.

Frankl, V. E. (2006): Man's Search for Meaning. Boston, Beacon Press.

Gruhl, M. (2010): Die Strategie der Stehauf-Menschen: Krisen meistern mit Resilienz. Stuttgart, Kreuz Verlag.

Hurst, D. K. (2012): The New Ecology of Leadership - Business Mastery in a Chaotic World, Columbia Business School, New York.

Johnstone, K. (2004): Impro - Improvisation und Theater. Berlin, Alexander Verlag.

Milarepa, J. (1040-1123, Übers. 1996): Milarepas gesammelte Vajra-Lieder, Band 1+2. Berlin, Theseus Verlag.

Reich, J. W.; Zautra, A. J. \& Hall, J. S. (2010): Handbook of Adult Resilience. New York, Guilford Press.

Scharnhorst, J. (2008): Resilienz - Neue Arbeitsbedingungen erfordern neue Fertigkeiten. In: Psychologie Gesellschaft Politik 2008, Psychische Gesundheit 
am Arbeitsplatz in Deutschland. Köln, Berufsverband Deutscher Psychologinnen und Psychologen.

Storch, M.; Cantieni, B.; Hüther, G. \& Tschacher, W. (2010): Embodiment. Die Wechselwirkung von Körper und Psyche verstehen und nutzen. Bern, Huber.

Taleb, N. N. (2012): Antifragile. New York, Penguin Random House.

Walker, B. \& Salt, D. (2006): Resilience Thinking - Sustaining Ecosystems and People in a Changing World. Washington D.C., Island Press.

Weick, K. E. \& Sutcliffe, K. (2010): Das Unerwartete managen - Wie Unternehmen aus Extremsituationen lernen. Stuttgart, Schäffer-Pöschel.

Werner, E. J. (2001): Unschuldige Zeugen. Hamburg, Europa Verlag.

Welter-Enderlin, R. \& Hildenbrand, B. (Hg.) (2008): Resilienz - Gedeihen trotz widriger Umstände. Heidelberg, Carl-Auer-Verlag.

Wustmann, C. (2006): Das Konzept der Resilienz und seine Bedeutung für das pädagogische Handeln. In: Irina Bohn (Hg.), Dokumentation der Fachtagung >Resilienz - Was Kinder aus armen Familien stark macht<, September 2005 in Frankfurt a.M. ISS-Aktuell 2/2006.

Zander, M. (Hg.) (2011): Handbuch Resilienzförderung. Heidelberg, Verlag für Sozialwissenschaften. 



\title{
Silence, Patterns, Structures
}

\author{
Music and Improvisation within the Context \\ of Organisational Praxis
}

Michael Spencer

\section{INTRODUCTION}

I have approached my contribution to this collection of papers as an empirically based practitioner. That is to say, my comments are based upon a wide range of opportunities to observe musical process both as a performer and as a facilitator of interactive, educational arts-based workshops. Although I studied formally as a classical violinist and had the opportunity to perform at the highest international level with the London Symphony Orchestra, these experiences have served more as a springboard into many other avenues of involvement distant from my musical training. My workshop practice has been similarly diverse and given me the chance to work across cultures, age ranges, sectors, levels of ability, and with groups both large and small.

Later in this paper I will discuss in greater detail the content of some of these workshops including observations arising from the experience of working with music in non-conventional circumstances. Improvisation plays an integral role in this, influencing both material outcomes and the social interactions and bonds that form during the course of a workshop programme. I will begin by addressing the origins and nature of the art form upon which the research for MICC ${ }^{1}$ study has been based. The reasons for this are twofold; cultural and socio-physiological.

It is a fact that our musical opinions are heavily influenced by the culture within which we grew up, and research suggests that we start to develop our own unique musical identities and preferences from approximately the age of seven (Lamont, 2002). So, our perceptions of what may or may not be considered music will differ considerably depending upon the nature and degree of immersion we have experienced from childhood.

1 | Music, Innovation, Corporate Culture. University of Duisburg-Essen (www.miccproject.org). 
The socio-physiological reason is important because of the integrated role music has played in our development as human beings and how it is both a product of, and an influence upon our biologies and social interactions. In-depth studies have revealed the importance of music in building and reinforcing social groupings (DeNora, 2000), and there is a significant body of neuroscientific research showing music to have cross-modal properties and a complex interrelated weave of processing functions that reach across the brain (Cross, 2003). These statements are in reality two sides of the same musical coin and emphasise how much we are indeed >hot-wired < for music.

We frequently gauge our musical experiences in terms of depth of emotional connection. However, this restricts us to a comparatively narrow band of assessment and one that tends to deny the effectiveness of music when applied to other domains. In effect it becomes reduced solely to the role of elaborate decoration. If we appreciate how much our personal judgement is skewed by pervasive external influences on our musical perceptions, and understand the deep-seated relevance of music to our development as human beings, it encourages a more forensic view of music and its processes.

Generally, music tends to be classified as either a skill, such as that acquired from learning an instrument, or as a service, for example in the form of entertainment. These are both concerned with the performance aspects of music and for most people are perceived as having tangible value. For the purposes of using music as a learning device however, whether practical or metaphorical, it requires us to consider music as a process. That is to say, the action by which a composer creates a piece of music, or the means by which a performer or an ensemble prepares for and delivers a performance whether this be improvised or based on an existing piece In this guise music takes on a deeper significance and one that is germane to this research topic.

Therefore I feel it helpful to consider music's origins and physical properties in order to establish a common point of reference for this discussion.

\section{OrIGINS}

Anthropologists have suggested that the first music-like utterances made by Man may have been 2 million years ago, long before we developed referential speech (Mithen, 2005). The DNA of these vocalisations remains with us today in the prosodic patterns that enhance the content of our speech. They create heightened meaning by adding stress, rhythm, and intonation to our spoken words. We know, for example, from the >interrogative upward lift of the voice at the end of a sentence that a question is being asked. These types of speech patterns are universal (Bryant, Gregory A., Bennet, H Clark, 2005) and are of particular relevance when addressing young children. Technically this is known as Infant Directed Speech, and it is not too great a stretch to move from this form of heightened speech into song. 


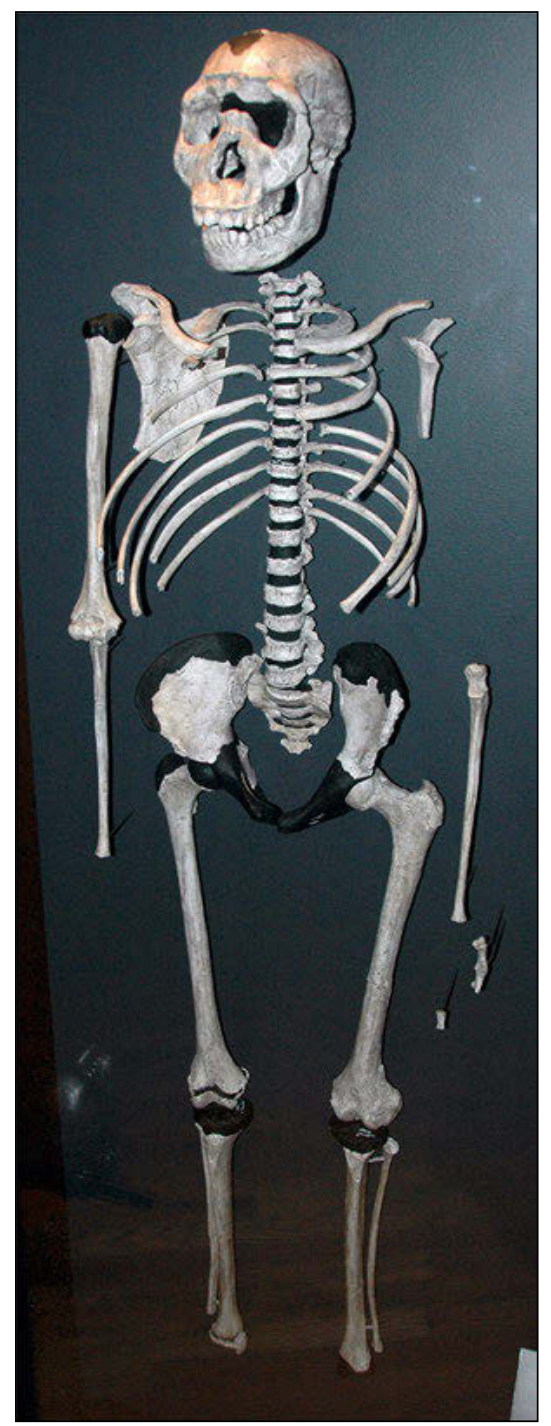

Figure 1: Homo Ergaster

It is suggested that originally these non-verbal sounds had a practical purpose in helping to establish bonds between tribe members, and differentiate them from others (Mithen, 2005). Over generations they became more ornate, eventually creating formalised structures that evolved into a rich canon of indigenous song that served many different social purposes; ritualistic, story-telling, informational, signalling, preservation of heritage etc. Fundamentally, music was an elaborate aural tool for defining and affirming social relationships and we still hear its modern counterparts on the football terraces today. Each culture has its own distinctive 
indigenous music and it is frequently associated with physical movement (Sievers et al., 2012).

A high percentage of the music to which we listen has a regular metre of two beats. The reason for this is thought to relate to the fact that we have two legs and move rhythmically. Dance has always been associated with music and we can see, for example, how this is perpetuated currently if we observe the clubbing scene amongst young adults. The commercial music industry thrives on its dance music catalogue. At base level the glue that unites the dancers is a shared sense of pulse, and pulse is fundamental to most forms of music.

Some years ago I was director of the music project for the Royal School for Deaf Children. We frequently worked with children who, in addition to being deaf, had many other disabilities. These ranged from mobility restrictions to autism, visual impairment and so on. A common challenge for these children was the development of an adequate level of interpersonal social skills when standard methods of communication were more restricted. It was during one series of workshops we came to realise that many of them were able to maintain and share a common sense of pulse; an immediate challenge to our own assumptions about deafness. If they were able, therefore, to feel a pulse together, there was the potential for creating a viable ensemble.

Over a number of workshops they became increasingly secure in developing this fundamental musical skill, and started to take turns in adding more sophisticated rhythmical patterns over the top. Eventually we helped them form their own simple samba group; essentially, samba is constructed from the iteration of simple rhythmic motifs over a constant pulse, this forms a reinforcing spiral of effectiveness as the ensemble becomes better integrated. The physicality of performing on basic percussion elements also helped to create a more cohesive ensemble.

This stepwise progression of layering, from simple rhythmic patterns to more complex compound structures, enabled the participants to build sophisticated poly-rhythmical structures and in time they became a self-organising ensemble. Interestingly, this structure worked best when the core pulse came from within the group rather than being imposed from an external source i.e. the teacher or the facilitator, and its periodicity often seemed to relate closely to the frequency of a natural heartbeat. For the participants it created an intense socialising experience, possibly for the first time, and over the following weeks there was a dramatic change in their ability to interact with each other in contexts away from the music project.

Even at this basic level we can see how musical processes can lead to the creation of strong cohesive bonds and generative action. Whilst general perceptions may hold that music creation is a highly sophisticated activity, in essence, the way music functions is relatively simple; by organising its simple basic components in accordance with certain rules and conventions. The manipulation of patterns is fundamental to this. 


\section{Components}

Nucleotides are the four building blocks of DNA that clump together in two >base pairs < to form the strands of DNA. Music too has its own base pair. Frequency and time. They exist interdependently and it is from their management that the components for the creation of all musical styles are made.

"Music is the depiction of the passage of time in sound." (Sir Peter Maxwell Davies. Composer)

The components of music are rhythm, melody, harmony, dynamics (i.e. loud, soft etc.), timbre and silence. Rhythm, melody, harmony and silence combine to build structures. Dynamics and timbre are nuances that are employed almost in the same way herbs and spices are used in cooking to emphasise and contrast flavours and colour.

Different genres of music are created from the manipulation of these components according to sets of rules and conventions that are in turn dictated by culture and context. For example ssamba< sounds like samba because of its rhythmic, melodic and timbral qualities and these emerged from the collision of African, Spanish and indigenous South American cultures during the period of the slave trade.

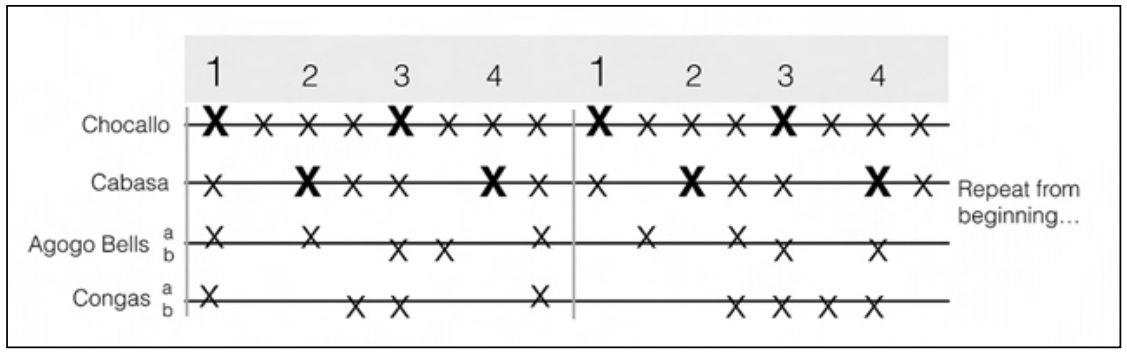

Figure 2: Samba Schematic

These components have a hierarchy and except for certain free form genres, rhythm takes the dominant role. It usually sits within an implicit metre ( 2 beats, 3 beats, 4 beats etc.) which remains constant throughout a piece of music, but not necessarily exclusively so. One of the advances in classical music during the $20^{\text {th }}$ century, from Stravinsky onwards, was the juxtaposition of contrasting meters.

Within this metrical framework of music, almost irrespective of genre, you will find widespread use of the periodic repetition of rhythmical patterns that be contrasted, modified or embellished. Consider the simple children's song Frère Jacques. 
It consists of three repeated rhythmical patterns.

The second, which could be considered a modification of the first, is repeated at the end of the song. The third pattern is an embellishment of the first.

Pieces can be created from rhythm alone (c.f. Reich, Clapping Music), however to form melodies rhythm has to intertwine with systemised patterns of pitches known in the West as scales or modes. Again, the periodic repetition of patterns plays an important part. Consider Frère Jacques once more. The first half consists of two repeated melodic patterns each of three rising notes (Fig. 3a, $3 \mathrm{~b}$ ).

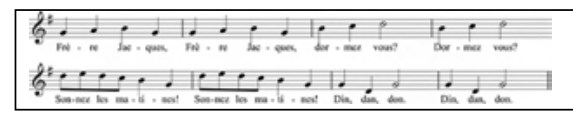

Figure 3a: Frere Jacque

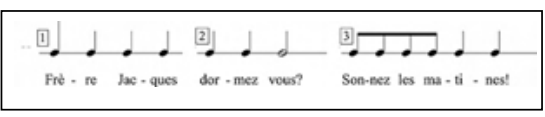

Figure 3b: Frere Jacque Rhythmic Patterns

Harmony is largely a Western concept. The sophisticated harmonies used in larger ensemble pieces such as those by Gil Evans or Pierre Boulez, or the complex polyphonic structures of J.S Bach, were only possible because a system was devised to coordinate separate musical lines within a set time frame. A music score determines both pitch and temporal alignment and its origins go back to the $11^{\text {th }}$ century when a Benedictine monk, Guido d'Arezzo, first devised a system for notating pitch. It wasn't, however, until the $14^{\text {th }}$ century that the systematic method of notation upon which our current system is based was devised, including a method for measuring the passage of time. Immediately prior to this an alternative method of coordinating simple polyphonic vocal lines by the use of short, reiterated, fixed rhythmic patterns or >modes $<$ was attempted, but this method was short-lived and localised.

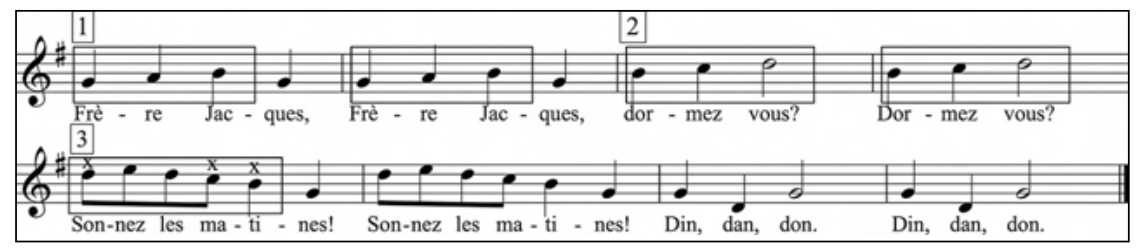

Figure 3c: An inverted version of Fig. $1(X)$ that is embellished.

This is repeated, as are the final two measures.

By way of contrast, because music of non-Western origin doesn't apply this method of organising multiple voices vertically in a score, its essential characteristics concern more the creation of highly nuanced and linear solo melodic lines. 


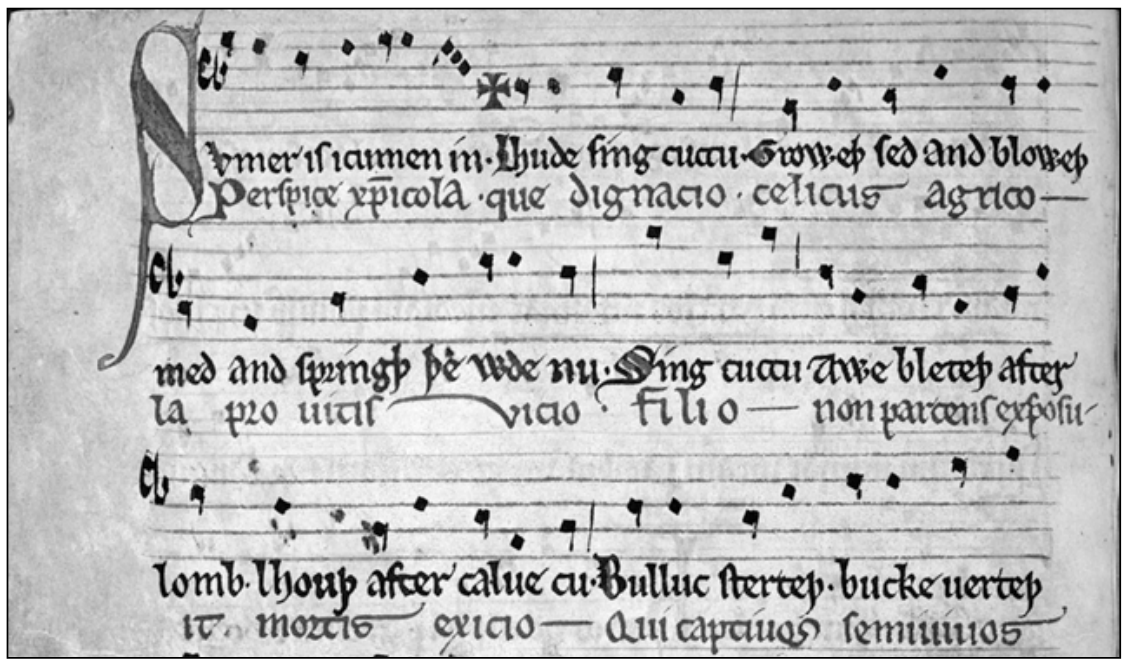

Figure 4: Sumer is icumen in

Chords are created by distributing notes of different pitches in vertical patterns. Although simple harmony can be created from static, sustained chords, for example as in the manner of bagpipes or hurdy-gurdies, more usually harmonic structures are created from the linear progression of chords each of which has a musical relationship with those on either side. The notes used within a chord and the way in which their relationship is defined is largely determined by historical or cultural context. For example, the harmonies of art music in the late $19^{\text {th }}$ and $20^{\text {th }}$ centuries is much more chromatic than that of the $18^{\text {th }}$ century. Blues from the Delta is harmonically much simpler than the modal jazz of Miles Davis.

Musical structures are the framework which house the patterns created from the components of rhythm, melody, harmony and silence, and they function much in the same way that a building gives sense to the materials from which it is made.

Silence holds an interesting place in music making. It is not simply a period marking inaction. For the composer John Cage, the iconoclast who composed $>4$ '33<, silence provided a viable performance space from which one could witness the sounds of the patterns of everyday life (Cage. 1973). For an ensemble, when a voice or instrument falls silent, it indicates an implicit change in musical texture. Silence in musical improvisation is often an underused component but it provides a period for observation and reflection for the performers in an ensemble. In fact we never really experience true silence because we live our lives to the sound of our own heartbeat and nervous system. The nearest experience to silence one can achieve is in an anechoic chamber. This, however, is also a highly disorienting experience because we lose all sense of the considerable locational information provided by our auditory system. 
In my own practice I encourage the idea that music is in part shaped by the silences that both surround and are embedded within it. Artists use a similar construct as a drawing aid. >Negative space $<$, the void that surrounds an object, is used to define the shape of an object rather than its more obvious >positive form (Edwards. 1979). In this way sound and silence complement each other in a relationship where one could be considered Ying to the other's Yang.

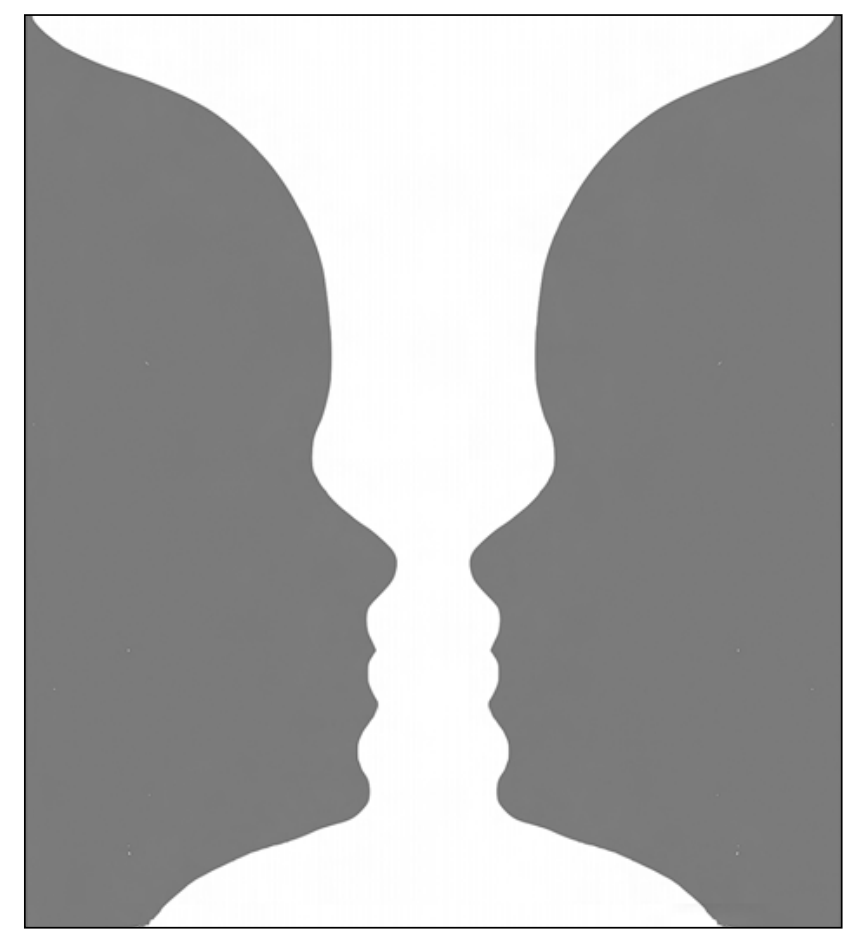

Figure 5: Rubin's Vase

In the architectural design of buildings, the materials have little intrinsic meaning when viewed independently. Although they may carry innate potential it is the establishment of the relationships between them during the design and construction stages that bring sense and meaning. So it is with the components of music.

\section{Patterns in music}

Essentially, music making is an exercise in the management of expectation. Creators achieve this by applying their judgement and sensibilities to manipulate aural patterns created from music's components. How these are balanced influences the auditory processing of their listeners' neurological functions and the degree of emotional engagement. Research shows that the iteration and disruption of 
musical patterns creates neurological activity that bears a direct relationship to the building of expectation (Abdullah \& Plumbley, 2010). There is also evidence linking the sense of anticipation and pleasure received from listening to music with the stimulation of dopamine production. This has a direct influence on our reward system as it mediates the reinforcement of positive stimuli. (Salimpoor et al., 2010).

In simple functional terms, music can be considered as a sequential series of cycles each of which has a structure consisting of four stages created from a series or matrix of repeated patterns. Stage 1 is a state of equilibrium. Expectation starts to build through Stage 2 when the emotional tenor is intensified to the point of disruption, Stage 3, which marks the point of climax. The resolution, Stage 4, returns to the next state of equilibrium from which the process is repeated. It can happen on an expansive architectural scale such as Beethoven's Egmont Overture, or in miniature, as in the opening motive of >Take That< (Miles Davis). The patterns are implicit within each musical structure but may have different degrees of prominence.

This overt and extended use of simple patterns is a predominant characteristic of the genre known as minimalism, and composers such as Phillip Glass or Steve Reich have created extensive structures almost entirely from the interaction of evolving pattern structures; Glass's Einstein on the Beach lasts over five hours.

Gestalt principles suggest that our psychological tendency towards sense making, conceiving incomplete objects as a unified whole, assists in the recognition of patterns even when they are barely perceptible. For example, during the process of improvisation, as a jazz performer leads the audience away from the original statement of a sstandard < into a more elaborate rendition, the connection with the original remains implicit. This is often achieved by maintaining the pattern of harmonies that underpin the original melody. The evolutionary nature of this process helps the listener to maintain and comprehend the connection. However, were the listener to join the performance mid-way the connection with the source material would not necessarily be quite so readily perceived.

In the preface to his book, >Sensemaking in Organisations< Karl Weick described a similar process but within the context of social dialogue. »You are being thrown into the middle of the sense-making conversation with only a vague idea of how it constitutes a perspective. But as you listen, you will begin to see patterns as well as create them, which coincides with a move from the periphery to the centre« (Weick, 1995).

When patterns are concealed to the level at which they become undetectable and with little by way of reference points, for most people this seems to be the moment at which musical comprehension becomes most challenging. The later music of Arnold Schoenberg and his successors was organized by the systematic use of patterns in a form known as serial or 12-tone technique. This method is simple in concept, however the aural result was highly complex with few obvious structural indicators or easily identifiable patterns. The result was music that is 
still, for many listeners, perceived as being chaotic and without form when in reality it is highly structured.

As the middle of the $20^{\text {th }}$ century approached and more avant-garde, experimental styles of music making emerged, greater challenges were offered to audiences demanding much more of their listening skills and sense-making processes. It also required a redrawing of the boundaries with regard to what constitutes music and how it should be newly perceived; a redefinition of its axes and variables as it were.

A similar sort of realignment was needed by the mathematician Lorenz when he created a more comprehensible visual realization to explain his mathematical model of a chaotic strange attractor; in this case a mathematical system for defining atmospheric convection. He took the model's three non linear equations and by remapping them in three different dimensions produced the >butterfly< pattern which, because of its new visual domain, gave a more immediate and tangible understanding of its operation. (Wheatley, 1992).

The nature of the transaction between composer or performer and listener could perhaps be considered a form of knowledge transfer where the coherency of the information being transmitted is determined largely by the degree to which the patterns received are identified subliminally. This relies both upon the information content and the manner of its presentation. In other words, patterns received and recognized as being familiar or derived from source material with which an association can be created are more readily accepted than those that are more unconventional and distant from the experience of the listener.

Steve Reich commented on this in an interview evaluating the success of the minimalist movement:

"[...] it was a restoration of harmony and rhythm in a whole new way, but it did bring back those essentials that people wanted, that people craved, but in a way they hadn't heard. Now, we're living back in a normal situation where the window is open between the street and the concert hall." (Petridis, 2013)

As a practitioner, I find that the participants who are generally more accepting of complex and innovative concepts are those with a background rich in a diverse range of provocations. Therefore, for those who have had less access to such experiences, in the practical context of a workshop, a much more measured process of reframing has to take place when introducing new and unfamiliar patterns of thinking and acting.

In 2002, during my tenure as Head of Education at the Royal Opera House, we were given the task of introducing a new opera to 1000 inner-city school students. This was Sophie's Choice by the composer Nicholas Maw and based on the novel by William Styron. Not only was this challenging subject matter, but also it was to be held in an unfamiliar setting and with a musical vernacular distant from that to which the young people were familiar. 


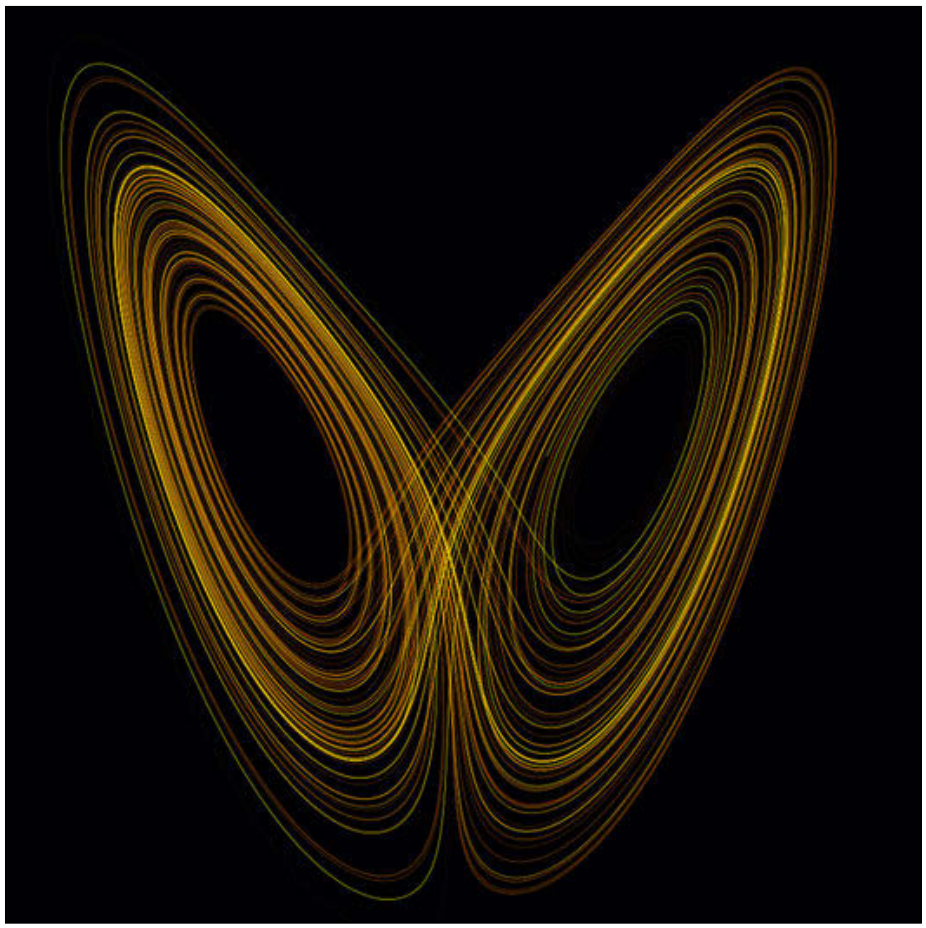

Figure 6: Lorenz' Butterfly Pattern

In the weeks prior to the performance we ran a programme of structured, interactive workshops that encouraged personal and individual engagement with both the narrative and the ways in which the music functioned. In this way the participants acquired a fluency of understanding with the new genre. When the day arrived, during the four-hour performance the only break from the rapt concentration of the audience was when the two main characters on stage embraced. This was greeted by a chorus of wolf whistles from the balcony! A modest triumph and an object lesson in how to deal with the transmission of complex and challenging subjects.

The discussion so far has focused largely on the role of the observer or listener and their relationship with music rather than the workshop participant. As the most powerful learning experiences come from experiential participation I intend a more forensic examination of the workshop process and some of the outcomes. 


\section{Workshops: Applied Methodologies}

\section{Background}

The workshop practice I employ originates from the methodologies developed for symphony orchestra education programmes in the UK in the late 80's. Orchestras were not the instigators of this type of interactive exchange however, and the type of group engagement upon which they are based has links with theatre education methodologies; in particular those of Augustus Boal and the Theatre of the Oppressed developed during the 1960 s in Brazil.

The core tenet for this style of workshop is that participants are encouraged to work together in groups to create original pieces. Technical expertise is not a prerequisite even though there is considerable emphasis on practical involvement i.e. learning by doing. A single facilitator will generally lead the process, acting as both a resource and a guide. Workshops may also involve other specialist facilitators, sometimes from different art forms. The aim is always to encourage the participants to take over the creative direction of their group.

Originally designed for children the scope of these workshops has widened considerably to encompass different musical genres, artistic disciplines and participant groups. For example I have a particular speciality with working with organisations' brand and corporate communications teams and when I ran a programme for Unilever Japan I involved jazz musicians, visual artists and one of Japan's most highly regarded hair stylists.

Experimentation plays an important role in the creation of all original music, whether composed or improvised, and is fundamental to workshop practice. It allows for the generation of nascent ideas that evolve, by use of music's components, into cohesive structures. There is a four-stage pattern to this that has been described as the >Learning Cycle< $(\mathrm{Kolb}, 1983)$. These are: concrete experience reflective observation - abstract conceptualisation - active experimentation. The periodicity at which this takes place is generally over a longer time span for composed music in contrast to when performances are improvised.

\section{COMPOSITION vs IMPROVISATION: A COMPARISON}

Formal compositional methods follow an iterative process of rebalancing and experimentation in reworking and refining the initial material produced, and the time frame over which this takes place is immaterial to the final outcome. When improvising, however, experimentation is placed within a dynamic context where reflection and conceptualisation become contracted to a state of almost instinctive response. Composer and performer become one and the safety net of revision possibilities is removed creating a higher degree of risk and, some would say, a more intense level of creativity. The risk is partially mitigated by the personal skill 
of the performing artist whose practice routines create a reservoir of patterns that can be drawn on as required.

Improvisation for most people is inextricably linked with Jazz. However, Jazz is only one category of improvisation. In reality improvisation has a long and multicultural history. For example traditional music from Romania and Indian classical music often use lengthy, freely improvised preambles as an introduction to the main body of music; respectively known as >doina and salap<.

In Western art music the ability to improvise was a fundamental part of a musician's training. We know from contemporary accounts that Bach and Mozart had considerable skill as improvisers. Unlike Jazz, which coincided with the invention of recording, we have no accurate representation of how they actually sounded. Instead, there remain annotated scores of musical forms such as theme and variations or inventions, which are, essentially, transcribed improvisations. Bach's Unaccompanied Sonatas and Partitas, for example, contain many movements that are improvisatory in nature and comprised of melodic elaboration around harmonic structures.

The final outcomes for these two methods of music creation - composition and improvisation - are different; one is finite and capable of reproduction, the other ephemeral and, in practical terms, irreproducible. Both, however, have a common motivation; the intention of the creator, and the purpose of the music which can also be linked to context.

Purpose is more easily defined, but the intention of the performer is more elusive. It appears to be comprised of two complementary elements; judgment and intuition. The emerging doctrine of behavioral economics gives insight into this relationship (Kahneman, 2011). It identifies two modes of thinking. System 1 relates to the primitive area of our brain that works intuitively and quickly, System 2 is influenced by cognitive reasoning and past subjective experience. They function as a »psychodrama with two characters « (Kahneman, 2011), but at times of high emotional involvement System 1 tends to dominate System 2. Kahneman's research suggests that composition, because of its more deliberate and reflective nature, relates more to System 2 thinking whereas improvisation is influenced more by System 1. This is not an exclusive arrangement, however. Within an improvisation there are often moments of repose for each performer that can offer periods for reflection, and it seems that these often bear some influence on the evolving structure of the performance. Recall of what has gone before and its restatement reinforces the overall architecture of the music that is being created, and from the listener's perspective can be an aid to their sense-making process. There is, it seems, a correlation between familiarity and emotional engagement (Pereira et al. 2011). The fewer the familiar clues left by the performer the more distant the connection for the listener.

During an improvised performance, this reduction in familiar references often seems to accompany a change in focus with regard to its intention and purpose. This is represented by an almost imperceptible move in attention of the artists from engagement with the audience towards their own private discourse. In doing this they become more attuned to their own internal system of commu- 
nication and less aware of their listeners who can experience a growing state of disconnectedness.

\section{Case Study 1}

This >outward to inward modulation became noticeable in some of the work we undertook with the Intercontinental Hotel Group (IHG), and it was something that had far reaching consequences. During the course of a workshop we held in Abbey Road Studios, London, we challenged the global marketing team to create sounds/music they felt were appropriate for their brand (Spencer 2010). This presented them with two specific challenges. They were required both to work in a practical medium with which they were unaccustomed, and also to explore unfamiliar musical territories. Despite all participants sharing a deep understanding of their brand's identity, working with sound in this way subverted their familiar responses and internalized modes of communication to the point that they started to question their brand's values. In particular, the process highlighted how much they had come to rely upon their internal discrete patterns of behavior familiar only to the members of their team that alienated them from their wider global audience and front line staff.

During the discussion which followed their Director of Global Marketing suggested that although their internal conversations as a team were immediately coherent the real challenge they faced was to be able to communicate the brand message much more effectively outside of their group. And in order to do this he felt they had to leave behind their customary references and associations and explore other processes that were more attuned to their potential audience. This insight was the ignition point for what became a major new brand positioning initiative that started shortly afterwards.

We were involved in the creation and dissemination of the internal engagement programme that formed the core of this initiative, and In hindsight it is interesting to note how much the shaping of its design had resonances with the process of improvisation. We started from reference points that were familiar to the staff and began to unfold the programme making frequent use of commonly understood metaphors or patterns of behaviour from both the hospitality industry and musical practice. To this we slowly added more radical ideas that encouraged a move away from their old positioning. Within this process we also created opportunities for the staff to contribute to the transition when they felt it appropriate. Had we started mid >performance $<$, as it were, the context would have appeared too unfamiliar with the consequence of discouraging participants and reducing the level of collaboration we actually achieved. Upon its conclusion the programme was assessed as being »the first programme that the whole company bought into without any obvious return on ROI« (Vice-President of Brand Delivery. IHG) 


\section{Rationale and Design}

The aim of workshop programmes I feel is to move participants away from the activities with which they make the most familiar associations - the equivalent of the performing and listening aspects of music - and more towards unfamiliar territory such as the processes and functions used in musical creation. Also, when using music as a tool in this arena, I prefer acoustic instruments to their technological equivalents. There are a number of reasons for this. They provoke and stimulate the participants' natural, innate musical skills; their tactile nature requires a great deal more concentration and control; they place higher demands on good, responsive teamwork and encourage a higher level of commitment in performance. These are surely desirable qualities in any organization

Past experiences and the predominant influence of the record industry are pervasive and powerful, and their impact tends to spill over into the workshop situation. In order to escape the safety net of familiarity and encourage a free and fertile innovative environment therefore, one has to encourage the participants to leave behind some of their preconceptions about what they feel may or may not constitute music. An example of how this can affect full engagement with creative work occurs often at the start of a workshop series.

On being presented with a room full of acoustic instruments the participants proceed through a characteristic pattern of behavioral responses based on past knowledge. These form a series of complex emotional barriers each of which has to be breeched.

The first is the result of a mixture of embarrassment, fear, and apprehension. Unlike children, adults rarely allow their curiosity to lead them along pathways of discovery and experimentation. This is largely a product of imagined peer pressure and fear of ridicule. Where children would happily leap at the instruments without any encouragement, adults are mistrustful and tend to view them with suspicion. More often than not the instruments remain untouched.

The next barrier is a perceptible atmosphere of disdain for what the participants mistakenly consider to be a collection of children's toys rather than a sophisticated set of >sound generators $<$. The final challenge occurs when work begins with the instruments. For this I often set some very simple exploratory compositional tasks (e.g. »Find five completely different qualities of sound on your triangle«). Generally the room becomes peppered with familiar musical clichés firmly rooted in past associations that constrict more freely flowing creative thoughts. The role of the facilitator is to navigate these stages as rapidly as possible, although the passage through them can be equally enlightening.

Music, in this instance, acted both as a mirror and a lens on the way the participants interacted with each other, reflecting their current patterns of behavior and prompting deeper investigation into the identification and implementation of more effective supportive strategies. The feedback from the participants included 
the observation that sometimes one had to look beyond the familiar in order to highlight the need for change.

\section{Case Study 2}

Early in my career I was invited to run a series of workshops in Eastern Europe for an international accountancy firm as part of their leadership programme. All three emotional barriers were very much in evidence to the point that the purpose of the whole workshop started to be undermined. This collection of executives began to resemble more a classroom of unruly children than a group of influential leaders, and in the ensuing discussion that followed the participants roundly criticized the process. It came as something of a surprise to them when their department head, a senior executive in the company, pointed out that they had displayed exactly the same behaviors as they did in the workplace and that this was the reason for running the workshop. From this revelation we were able to move forwards and explore through the use of music more collaborative and supportive ways of working.

Once the induction process into the workshop environment has been successfully navigated I often include a number of activities for heightening musical awareness that build on the latent skills of the participants. For those unused to working within this medium it is unrealistic and unfair to those participating to leap immediately into creativity mode without introducing and agreeing some simple guidelines. One of the simplest applies to listening. There is a common misconception that performing is solely about the active creation of sound, whereas I would suggest that the quality of individual listening, and the silences associated with it, have an equally important role particularly in improvisation.

When improvising, the elements for which one listens are not really that dissimilar from some of the rules we use, or opportunities we take, when structuring effective conversations. Spaces give the opportunity for introducing new ideas or expanding from what has been said earlier; generative dialogues are created from the interlinking and sharing of concepts; taking turns enables different solo voices to be heard; interjections can show approval and express support for the principle speakers. One aspect in which music differs from spoken intercommunication is that it allows for several voices to talk simultaneously about different subjects, for example the sextet in the third act of Mozart's Marriage of Figaro. This is, however, more a matter of coordination and there are simple techniques for developing the abilities to achieve this that rely, again, on the development of good listening skills.

There is a common misapprehension that improvisation gives you the liberty to do whatsoever takes your fancy. In reality there are a number of shared rules, values and techniques for helping to create structures that are not only meaningful to the performer, but also for the listener. One effective technique is the use of constraints. 
Presented with a completely open brief the tendency is to rely upon patterns and structures that have been used before, particularly those that have been successful (Stokes 2006). The use of carefully chosen constraints impedes the return to familiar ground and does not, paradoxically, detract from artistic license but encourages creativity. As the former director of the brand management consultancy Interbrand, John Simmons, puts it >liberation through constraint<. (Simmons 2009)

\section{TOOLS AND OUTCOMES}

>Soundworlds $<$ is a term I use for an exercise in group composition which is based largely on the use of timbre. This is achieved by the use of constraints and starts with the participants forming a large circle. Over a silent but shared pulse, each adds their own simple, clapped rhythm one after the other. The instructions for this are crucial. Simple rhythms are best; silences are helpful; try to create something different from the rhythms already in use; each rhythmic motif must remain unchanged and be capable of sustained performance over a long period. The result is, once the whole room has become involved, a compound rhythmic continuum that can then be manipulated by the facilitator or individual participants who take turns at becoming the >conductor<.

Because rhythmic, melodic, and harmonic development is constrained, musical creation relies purely on the remaining three components. Dynamic modification can be applied to individual or multiple motifs; timbre, by the introduction of simple percussion instruments and changes the manner in which they are played (usually one per person; tuned percussion is selected to correspond to a particular mode or scale); silence, by the removal and replacement of specific voices when indicated.

The large collaborative instrument that results can then be manipulated by the >conductor to improvise contrasting walls of sound to create original structures and textures. It also encourages both personal discipline and commitment from the performers, and emphasizes cooperative, supportive behaviors as a team. It is not unusual for this exercise to last for over one hour without the participants realizing the passage of time.

Another exercise I use often follows on from this example. I call it >One note symphony< and as the name suggests, both melodic and harmonic invention is constrained to the use of one note. This is more of an extended composition task and is carried out in separate groups. It relies in particular on the negotiation and collaborative skills of the participants in addition to their creative abilities. The $>$ note< can be performed at any octave, on any instrument/s, and repeated as little or often as necessary. The removal of melody and harmony means that the participants have to rely on the use of the other four remaining musical components; rhythm, dynamics, timbre and silence. Experimentation is fundamental and improvisation often has a role both in preparation and performance. 


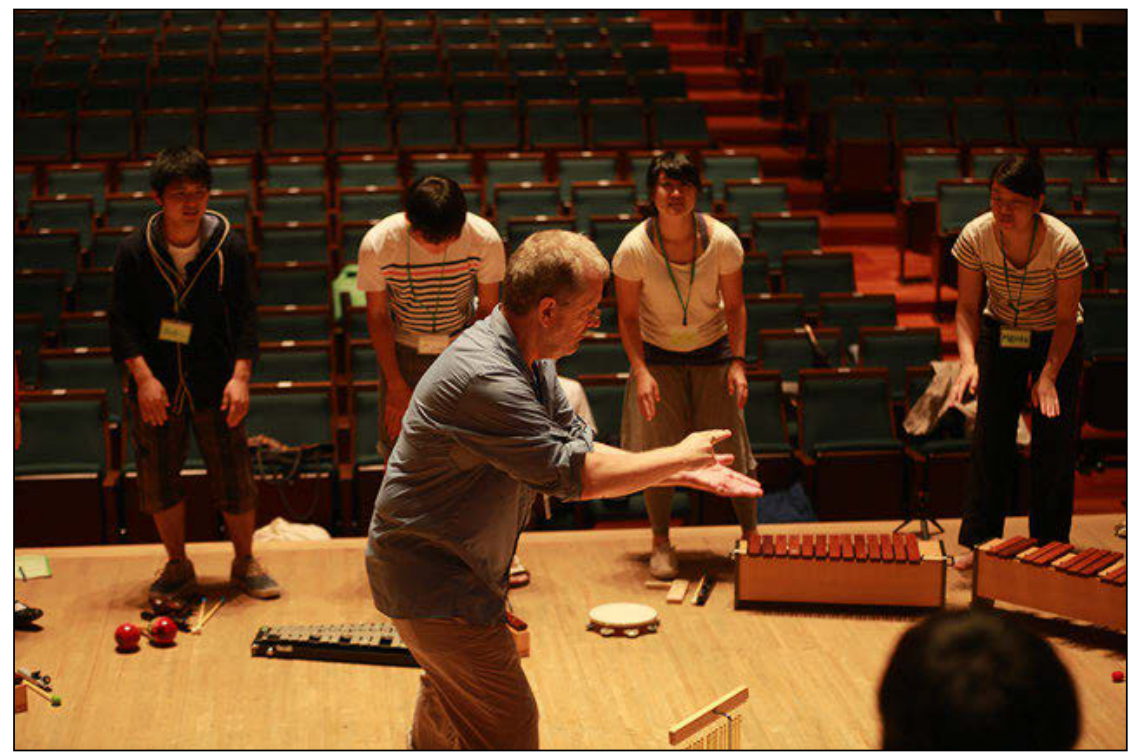

Figure 7: Sound World Workshop

Both of these examples rely heavily on the integration of patterns, structures and silence. Success, however, depends on the commitment and expertise of the participants and how they combine these with their collaborative skills and creative intuition. And for creativity to prosper I would suggest that three essential ingredients are required; trust, permission and curiosity.

Trust lies in the ability to rely on your own innate skills and to acknowledge that others do also. Permission from your peers gives you the sanction to explore without condemnation. The presence of trust and permission enables curiosity to develop freely. I know of no improvising musician who doesn't employ all three as part of their professional practice, and they do so liberally and often with a spirit of playfulness. In the previous example of the leadership training programme, the emotional defence mechanisms of the participants were so deeply entrenched that it was a challenge within the time constraints of the first workshop to establish these three ingredients effectively. The reason for this was that in reality we were challenging their organizational working practices and behaviours at a systemic level.

This might, for some, raise questions about the suitability of this type of intervention in certain contexts. Experience tells me, however, that much depends upon the preparation that takes place beforehand, and also how the programme fits within the larger organizational context. This was a major contributing factor to the success of the Royal Opera House project I mentioned earlier, and also with the IHG example (Case Study 1). In both cases we were allowed the time to determine the required outcomes, research the business or cultural context, and interview the participants. With the bank we were sparachuted $<$ in as musical sgurus< with the expectation of performing transformational miracles despite the 
fact that we had only limited access to background information and no common understanding of the larger business context. There were also considerable cultural conflicts for them internally in addition to a disjunction between business and arts-based practice; this despite the fact that one of the managers was an accomplished pianist.

\section{Case Study 3}

Sometimes the obstacles are created by an organization's culture and management structure within which it sits. One of the most graphic examples of this was during a programme I initiated with the graduate recruitment team in a global investment bank. The team was divided into two sections. The largest group, predominantly women, had the task of working face to face with their prospective candidates. A management team of two monitored them, and trust, permission and curiosity were obviously scarce commodities.

This area of the banking industry is highly competitive. Eligible graduates are few and the recruitment requirements for each organization outweigh the number available. There is a need, therefore, for creative, flexible and distinctive ways in which to attract candidates. Financial remuneration alone is not necessarily the ultimate inducement to give differentiation from competitors. The purpose behind our involvement was to help the team find new ways of thinking about how they might engage with this graduate market. And for this to work effectively they needed the freedom to experiment with new ideas and models.

Working with this client exposed two characteristics that seem endemic to this business sector; the almost brutalizing and aggressive nature of the working environment, and the way in which the fear of making mistakes or missing targets drove creativity out of the system. This became particularly evident during the workshops. With the larger group the experience was lively, stimulating and collaborative. When the management team were involved the climate changed abruptly. The sense of playful risk taking evaporated and almost immediately the creative activity that had been taking place became arid and lacking in vibrancy. One comment in particular stayed with me. When we encouraged the managers to allow their team the freedom to explore possibilities without their intervention, as they left the room their instruction to their team was >You have two hours to get this right [...] and no whinging!«. The managers themselves were not immune from this system and as one of them mentioned later, had any of his immediate superiors known in more detail of the content of the workshops the likelihood would be that he would be asked to clear his desk.

Some years ago I remember taking part in a joint performance between the London Symphony Orchestra and the Lincoln Centre Jazz Orchestra; two completely different musical genres and cultures, each with rigorously organized but different structures. The reason why these types of partnerships work so well is 
that alignment is created both by the preparation beforehand (i.e. the specially prepared musical arrangements that played to the strengths of each ensemble) and the powerful sense of mutual respect that is based on trust, permission and curiosity. When such interventions are positioned well, the effects can be far reaching and, as the IHG example shows, move into areas distant from the original brief.

"This process showed me that music plays a much more powerful role than I had ever imagined [...] particularly with regard to management skills and leaving room for other peoples creativity“ (Senior VP Global Brand Management. Holiday Inns)

\section{Observations}

The preparation of this paper has revealed three byways that I feel would merit further investigation because they relate directly to the better functioning of organisations in the current global context.

1. How, for example, are improvisatory behaviours influenced by the cultural predispositions of different societies? The separating of cultural predispositions into different dimensions by Gert Hofstede raises interesting questions with regard to the tolerance of uncertainty (Hofstede.2003), a significant element of improvisation. It is interesting to note, for example, that India and the USA are assessed as having a high tolerance of uncertainty. They are also cultures that have considerable musical traditions based around improvisation. By contrast, Japan's traditional music and its art forms in general incorporate little by way of improvisation in the normal understanding of the term, and by Hofstede's measurements it also has the lowest tolerance of ambiguity. Might improvisation therefore give insights into this cultural dimension of business?

2. Peter Senge refers to >personal mastery< as being one of the five competencies vital to the building of effective learning organizations (Senge 1990). What does personal mastery mean in musical improvisation and how might this translate into personal performance elsewhere?

3. How might musical improvisation play into new business paradigms such as the emerging entrepreneurial movement in Japan. Particularly in technology, collaborative communities are evolving that are based on trust, reciprocity and informal (more personal) relations, and characterized by a sharing of purpose, active participation, and the equal allocation of tasks and responsibilities (Toivonen 2013). Relationships within this arena seem also to possess a transience not unlike some of the internal associations that occur within the context of a jazz ensemble. Can improvisation help us understand the connections being made in the new world order more deeply? 
The investigation of these territories lies beyond the scope of this paper. They do however, suggest an intriguing case for using familiar disciplines in different ways to understand better, and bring added value to the systems within which we operate.

In her address at the 2013 Leonardo European Corporate Learning Awards, Dorothy Leonard (Professor of Business Administration Emerita, Harvard University) emphasized the importance of both pattern recognition and system thinking in the solving of complex problems, and how this was a highly developed skill common to >deeply smart< people (see also Leonard \& Swap 2005). However, she added this important caveat.

"Whilst pattern recognition helps them [experts] make decisions, it also leads them astray. If they see a pattern and don't question the underlying assumptions, but immediately apply a familiar solution, in this case they are not open to innovation." (Dorothy Leonard 2013 Leonardo European Learning Award, Award Ceremony Address, Petersberg/Bonn)

Musical improvisation involves the constant reworking of ideas. As in workshops, this is generally carried out in groups or ensembles. The collaborative nature of this type of engagement and the transience of the output leads to constant reassessment and challenge. It is rare, therefore, for patterns to be repeated without modification, and it is this that maintains the freshness of the content and the attention of the listener. If Leonard's proposition is that innovation is a product of pattern recognition and the constant interrogation of these, perhaps musical improvisation offers one of the purest examples of the effective exposition of this practice.

Despite its lineage and integration within societal development, music is considered by many as an adjunct to their daily lives, and certainly an experience distant from the organizational challenges that face global business. Its well-established, robust processes and use of highly nuanced human emotions and sensibilities, however, reveal, I believe, a forensic tool with a much wider potential application. In this context it is no longer an elaborate form of decoration or entertainment but it offers the promise of an alternative and provocative tool for exploring organizational behavior and ultimately, the development of alternative, humanistic solutions.

"The real voyage of discovery exists not in discovering new landscapes but in seeing things with new eyes." (Marcel Proust) 


\section{References}

Abdallah, S. \& Plumbley, M. (2010): Information dynamics: patterns of expectation and surprise in the perception of music. Connection Science.

Bryant, G. A. \& Bennet, H. C. (2008): Evidence for Universals in Infant-directed speech Journal of Cognition and Culture 5 (2), 233-254.

Cage, J. (1973): Silence: Lectures and Writings. Wesleyan University Press.

Cross, I. (2003): Music, Cognition, Culture and Evolution. The Cognitive Neuroscience of Music. Oxford University Press.

DeNora, T. (2000): Music in Everyday Life. Cambridge University Press.

Edwards, B. (1979): Drawing on the Right Side of the Brain. Harper Collins.

Hofstede, G. (2003): Cultural Consequences: Comparing Values, Behaviors, Institutions and Institutions across Organisations. Sage Publications Inc.

Jones, P. (2009): A >sound strategy< for Intercontinental Hotels. Tourism and Hospitality Research. Palgrave-Macmillan.

Kahneman, D. (2011): Thinking, Fast and Slow. Penguin.

Kolb, D. A. (1983): Experiential Learning: Experience as a source of learning and development. Prentice Hall.

Lamont, A. (2002): Musical Identities and the School Environment. Musical Identities. Oxford University Press.

Leonard, D. \& Swap, W. (2005): Deep Smarts. How To Cultivate and Transfer Enduring Business Wisdom. Harvard Business School Press.

Mithin, S. (2007): The singing Neanderthals: The origins of music, language, mind, and body. Harvard University Press.

Pereira, C. S.; Teixeira, J.; Figueiredo, P.; Xavier, J. \& Castro S. L. (2011): Music and Emotions in the Brain: Familiarity Matters. PLoS ONE 6 (11): e27241.

Petridis, A. (2013): Steve Reich on Schoenberg, Coltrane and Radiohead. The Guardian online.

Salimpoor, V. N.; Larcher, K.; Dagher, A. \& Zatorre, R. J. (2010): Anatomically distinct dopamine release during anticipation and experience of peak emotion to music. In: Nature Neuroscience, 14, 257-262.

Senge, P. (1990): The Fifth Discipline: The Art \& Practice of the Learning Organisation. Doubleday.

Sievers, B.; Polansky, L.; Casey, M. \& Wheatley, T. (2013): Music and movement share a dynamic structure that supports universal expressions of emotion. In: PNAS (Proceedings of the National Academy of Science of the US), Vol 110 (1), 70-77.

Simmons, J. (2009):: Twenty-six ways of looking at a blackberry. How to let writing release the creativity of your brand. A\&C Black. London.

Spencer, M. (2010): If Intercontinental were a sound. In: Journal of Business Strategy, Vol 10 (4), 39-46.

Stokes, P. (2006): Creativity from Constraints: The Psychology of Breakthrough. Springer Publishing. 
Toivonen, T. (2013): Seminar: The New Economy in East Asia - Japan and beyond. Said Business School, University of Oxford.

Wheatley, M. J. (1992): Leadership and the New Science. Berret Koehler, San Francisco.

Weick, K. E. (1995): Sense-making in organisations. Foundations for Organizational Science. Sage Publications, Inc. 



\title{
Erfolgsmuster, künstlerische Zugänge und Improvisation - ein Glossar
}

\author{
Wolfgang Stark, Christopher Dell, Holger Schmidhuber
}

Das Glossar soll das Verständnis und den Umgang mit den Themen und Begriffen um das Thema >Innovation und Improvisation in Organisationen< erleichtern und einige Hintergründe ästhetisch-performativer Zugänge zur Organisationsforschung verdeutlichen. Naturgemäß kann hier nicht der Anspruch einer erschöpfenden Darstellung aller Facetten erhoben werden. Dennoch bieten die Begriffe des Glossars einen Einstieg in eine interdisziplinäre Materie, die das Geheimnis innovativer und lernender Organisations-und Systemkulturen entziffern und beschreiben kann.

Komplexe Systeme - wie Organisationen, Unternehmen oder auch zivilgesellschaftliche Strukturen - stehen heute ständig unvorhersehbaren oder unerwarteten Situationen gegenüber, die die ihnen bekannten Möglichkeiten der Planbarkeit oft überschreiten. Um dieser Unvorhersehbarkeit in organisatorischen Prozessen nicht nur adäquat zu begegnen, sondern sie auch aktiv zu gestalten und zu nutzen, sind Kreativität, ein spielerischer Umgang mit offenen Situationen und das Einlassen mit allen Sinnen gute Voraussetzungen. Das im Alltag häufig mit Begriffen wie >Intuition< oder >Improvisation< beschriebene Handeln bleibt jedoch fast immer entweder in einem reaktiven Reparaturmodus (improvisieren, wenn der Plan nicht funktioniert) oder verschwindet im Unsagbaren (>das war eben Intuition $<$ ). Damit werden aber die Chancen und Potentiale, die die >Kunst der Improvisation < für innovative Prozesse darstellen kann, kaum genutzt.

Der reflexive Umgang mit Intuition und dem ihr zugrunde liegenden, oft verdeckten Erfahrungswissen (implizites Wissen oder >tacit knowing〈) und den dort zu entdeckenden Mustern (Patterns) innerhalb einer Organisation sind die Basis für eine Organisationskultur, die in der Lage ist, unerwartete und mehrdeutige (kontingente) Situationen nicht als Störung, sondern als Potenzial für Innovationen zu begreifen und nutzen.

Muster verknüpfen in der künstlerischen Forschung gewinnbringend Kunst und Strukturen. Ähnlich wie im künstlerischen Prozess bietet die tiefergehende, neugierige, lernende und übende Beschäftigung mit dem Material, nämlich 
die Analyse und Reflexion organisationaler Muster, die Chance, daraus Neues hervorzubringen und kontingente Situationen für sich zu nutzen.

Aus Musik, Tanz und Theater lernen wir für Organisationen, Improvisation als Technik und Kunst jenseits des Reparaturmodus zu nutzen und zu entwickeln. Improvisation beinhaltet die performative Arbeit an und mit dem jeweiligen Material, den spielerischen Umgang mit Mustern, die aufmerksame und annehmende Haltung zur Unsicherheit und die Dynamik die über einen Zeitraum hinweg dem Zusammenspiel verschiedener Akteure innewohnt.

\section{Patterns oder Muster}

Muster (engl. patterns) sind erfolgreiche Problemlösungen, die nicht die Form statischer Handlungsanweisungen einnehmen. Die in den Mustern enthaltenen Werte und Kräfte zeigen, nach welchen Prinzipien verschiedene Herausforderungen gemeistert werden können. Damit sind sie flexibel und variabel einsetzbar und können sich durch die Anwendung selbst verändern oder neue Muster hervorbringen. Die Entdeckung, Dokumentation und Nutzung von Mustern in den jeweiligen Organisationen ist daher entscheidend die Reaktions- und Innovationsfähigkeit von Organisationen - insbesondere in komplexen und unsicheren settings.

Muster sind in einer wachsenden Zahl unterschiedlicher Disziplinen (Architektur, Software-Entwicklung, Stadtentwicklung, Pädagogik, Organisationsforschung, performative Kunst und Musik) eine erprobte Möglichkeit, auf implizites Wissen (individuelles und kollektives Erfahrungswissen) aufmerksam zu werden und dies gezielt zu nutzen. Die Grundform der Dokumentation von Patterns umfasst: Name, Beschreibung der Problemstellung (challenge) und des Kontexts (setting und Zeitdynamik), die Analyse der Wirkkräfte (forces) und die Darstellung ein oder mehrerer Lösungsvorschläge, möglichst mit Beispielen und Konsequenzen.

Muster können so die Klammer zum Verständnis der Organisation auf verschiedenen Ebenen bilden. Sie bieten insbesondere einen Zugang zur Tiefendimension, zum >Ungenannten lehnung an die grundlegenden Arbeiten des Architekten sowie Architektur-und Systemtheoretikers Christopher Alexander $(1995)^{1}$ kann durch die Verbindung verschiedener Muster eine auf Situationen bezogene Mustersprache für Organisationen entwickelt werden.

Da Muster und eine Mustersprache für moderne Organisationen die Möglichkeit bieten sollen, sie beweglicher in ihrem organisationalen Handeln zu machen und einen schöpferischen Prozess des Erfindens anzustoßen, ist es wichtig, dass

1 | Alexander, C. et al. (1995): Eine Mustersprache. Städte, Gebäude, Konstruktion. Wien, Löcker Verlag. 
die Mustersprache (die Verbindung zwischen verschiedenen Mustern) flexibel und variabel bleibt.

\section{Forces}

Forces $(f)$ sind die zentral wirkenden, oft konkurrierenden Kräfte in Organisationen. Nach Keidel (1995) $)^{2}$ bewegen sich diese Wirkkräfte immer in den Kategorien Autonomie, Kontrolle und Kooperation. Alle drei kräftebezogenen Kategorien sind fundamental wichtig zum Verständnis der Dynamik in Organisationen. Sie bestimmen die Beziehungen in den sozialen Systemen der Organisation: Autonomie ist das Bestreben des Individuums und der Organisation, selbstständig agieren bzw. entscheiden zu können. Kontrolle ist das koordinierende Bestreben, gesetzte Ziele zu erreichen sowie individuelle und kollektive Interessen auszubalancieren. Als Kooperation wird die integrative Kraft des Gemeinsamen bezeichnet sowie die Notwendigkeit, nur durch Zusammenarbeit Neues zu erreichen und wachsen zu können.

Während der Kontext die spezifische Herausforderung enthält, auf die sich die Lösung beziehen muss, und beide umklammert, beschreiben die Forces die inhaltliche Auseinandersetzung, die Feed-Back-Schleifen zwischen Herausforderung Kontext -Lösung. Im Priorisierungsprozess der wiederstrebenden Kräfte kristallisiert sich letztlich heraus, welche effektive Lösung sich in einer Organisation als gangbar erweist.

\section{Generic Codes}

Generic Codes sind aus der Mustertheorie von Christopher Alexander abgeleitet. Sie verweisen auf Prinzipien, die es ermöglichen, dass sich Prozesse rekursiv aus sich selbst heraus erzeugen (emergent sind). Grundlegend bedeuten Codes eine Vereinbarung über einen Satz von Verweisen zwischen Sendern und Empfängern, der es erlaubt, in effizienter Weise komplexe Informationen zu übertragen. Das Verstehen dieser Botschaften ist Bestandteil der Kultur von Systemen. Generic Codes geben Raum für Entwicklungen, die zu Beginn des Prozesses noch nicht vollständig sichtbar waren und die zur Lösung beitragen. In Organisationen können somit ein non-lineare Prozesse angestoßen werden, der partizipativ und reflexiv die richtungsweisende Orientierung des Codes aufnimmt.

\section{Grounded Theory}

Grounded Theory ist ein sozialwissenschaftlicher Ansatz zur systematischen Auswertung und Interpretation vor allem qualitativer Daten in unterschiedlicher Form (Interviews, Beobachtungen, Texte, Bilder, Filme, Töne und Klänge). Ziel ist es, auf Grundlage der erhobenen Daten eine realitätsnahe und praktikable

2 | Keidel, R.W. (1995): Seeing Organizational Patterns. A New Theory and Language for Organizational Design. San Francisco, Berrett-Koehler. 
Theorie zu entwickeln (Glaser \& Strauss 2008). ${ }^{3}$ Das Verfahren, implizite und übergreifende Kategorien durch den iterativen (schrittweisen) Prozess des Kodierens $\mathrm{zu}$ entdecken, zielt als sozialwissenschaftlicher Forschungsansatz auf die Identifikation von Mustern in sozialen Systemen (Pattern Mining).

\section{Kontext}

Der Kontext formt und begründet eine spezifische Problemstellung (Herausforderung); daher muss sich jede Lösung auf den jeweiligen Kontext beziehen. Der Kontext bestimmt aber auch, ob ein Muster in der gegebenen Situation anwendbar ist. Gemeinsam mit der Herausforderung und der gangbaren Lösung bildet der Kontext das Grund-Dreieck innerhalb des jeweiligen Patterns.

\section{Pattern-Form}

Die Pattern-Form ist das Format der Notation, in der ein Muster (pattern) dokumentiert wird. Zu den bekanntesten Patternformen zählen u.a.: die Alexandrian Form, Coplien Form und Portland Form. ${ }^{4}$ Sie entstammen va. unterschiedlichen Anwendungsbereichen (Architektur/Stadtplanung, Software-Entwicklung, Kommunikation etc.). Die Form hilft bei der schnellen Kommunikation über PatternInhalte und zur Verbindung verwandter oder passender Muster untereinander (pattern language). Damit können einzelne Patterns variabel und flexibel verbunden und iterativ (sich einer Lösung annähernd) verdichtet werden.

\section{Pattern-Katalog}

In einem Pattern-Katalog sind Patterns gesammelt, die nach unterschiedlichen Kriterien (z.B. nach Anwendungsbereich oder Herkunftsbranche) organisiert werden. In Christopher Alexanders Architekturtheorie (Alexander et al. 1995) sind sie nach Maßstabsebenen und thematisch geordnet. Querverweise am Anfang und am Ende eines Patterns verdeutlichen die Beziehungen der Patterns untereinander in der praktischen Anwendung. Erst in Kombination mit >verwandten Patterns entsteht eine lebendige und anwendbare Pattern Language.

\section{Pattern Language}

Werden >verwandte Patterns oder Pattern-Kataloge kombiniert, entsteht eine Pattern Language, in der einzelne Lösungsmuster als Bausteine für eine oft komplexere Lösung in ein System von Patterns eingebettet werden. Vergleichbar mit einer Sprache definiert sie ein Netzwerk von Patterns oder Pattern-Katalogen, in denen die Beziehungen der Muster untereinander geregelt werden, so dass sie sich optional oder unbedingt aufeinander beziehen.

3 | Glaser, B.C. \& Strauss, A.L. (2008): Grounded Theory: Strategien qualitativer Forschung. Bern, Huber.

4 | http://c2.com/cgi/wiki?PatternForms und http://groupworksdeck.org/deck 


\section{Pattern Mining}

Bezeichnet den Prozess der Entdeckung und Strukturierung von Patterns in einem abgrenzten Feld (Kontext). Der Prozess entwickelt sich entlang von Leitfragen und Arbeitshypothesen und steht in enger Verbindung zur Grounded Theory. Alexander (1979) nennt drei Vorgehensweisen des Pattern Mining: a) Die Beobachtung und Analyse guter Beispiele; b) Analyse schlechter Beispiele und Ableitung einer Lösung; c) Ableitung aufgrund abstrakter Argumente.

\section{Pattern Writing}

Beschreibt neben dem Entwickeln und (Auf-)Schreiben eines Lösungsmusters vor allem den Prozess der Qualifizierung und Verdichtung. Damit bezieht sich das Pattern Writing auf das Pattern Mining. Patterns sind grundlegend offen und werden kontinuierlich weiter entwickelt. Je nach Anwendungsbereich werden sie unterschiedlichen Review-Verfahren unterzogen und sind Gegenstand von so genannten Writers - Workshops sowie Mentoring-Prozessen (shepherding). ${ }^{5}$ Die durch das Pattern Mining erkannten Muster werden in einer Pattern-Form dokumentiert.

\section{KÜNSTLERISCHE FORSCHUNG}

Kunst und Wissenschaft werden in unserer Gesellschaft häufig als zwei verschiedene Bereiche angesehen: Obwohl jedes Feld innerhalb des anderen behandelt wird und beide versuchen, die Welt im Kleinen und in ihrer Ganzheit zu verstehen, sind Kunst und Wissenschaft dennoch zwei Dimensionen im gleichen kulturellen Raum. Während Forschung im rational-naturwissenschaftlichen Sinn eher die Dinge zerlegt, um ihre Natur zu entdecken, konzentriert sich Kunst stärker auf die impliziten Phänomene (künstlerisches Wissen) und die - manchmal auch ungewohnte oder überraschende - Verbindung zwischen den Dingen. Die Wissenschaft geht eher mithilfe anerkannter, nachprüfbarer und wiederholbaren Methoden vor, während die künstlerische Forschung freier in ihren Methoden sowie Ausdrucksweisen ist und die Erkenntnisse (auch und häufiger) sinnlich (Hören - Sehen - Riechen - Tasten) dargestellt werden. In diesem Sinne ist künstlerische Forschung eher ein Versuch, durch künstlerisches Handeln und Wissen das Implizite, Verborgene in den Dingen zu erfahren und sichtbar, hörbar oder spürbar zu machen.

\section{Exploratives Vorgehen}

beschreibt die Arbeitsweise der Kunst, den (Forschungs)Gegenstand tastend und experimentell zu entdecken. Dabei wird davon ausgegangen, dass der Forschungsgegenstand bzw. das Material auch >Eigensinn « aufweist, der neue Wege weisen

5 | Vgl. www.europlop.net/sites/default/files/files/3_TheLanguageOfShepherding1.pdf 
oder neue Möglichkeiten entdecken kann. Ohne vorgefasste Meinung werden aus dem eigenen Handeln und Beobachten und der Performanz neue Erkenntnisse gefunden und entdeckt.

\section{Kreativität}

Kreativität bezeichnet die Fähigkeit eines oder mehrerer Individuen, auf fantasievolle, unorthodoxe oder überraschende Weise ein Problem zu lösen. Ihr zuträglich ist das unbefangene Sich-Einlassen auf Neues oder auch die sinnlich-körperliche Wahrnehmung eines Gegenstands. Die Überraschung und das sich Überraschen lassen ist dabei ein wesentliches Grundelement von Kreativität.

\section{Künstlerische Ästhetik}

Künstlerische Ästhetik meint die sinnliche Wahrnehmung, jenseits der subjektiven Einteilung in >schön « und >hässlichく. Hier geht es um Qualitäten wie Stimmigkeit, Relevanz, Schlüssigkeit und Anwendbarkeit, weswegen der Begriff auch in Zusammenhang mit der Entwicklung und Evaluation von Patterns in den Sozial- und Naturwissenschaften genutzt wird. ${ }^{6}$

\section{Künstlerische Erfahrung}

ist ein Modus des ästhetischen Erlebens, in dem implizites Wissen und subjektives Erleben (Erfahrung) als Wahrnehmung selbst präsent und fühlbar und gleichzeitig von außen betrachtet wird - ein Modus gefühlter interferierender Rahmungen. Nach Klein (2010) ist die »Künstlerische Erfahrung [...] ein aktiver, konstruktiver und aisthetischer Prozess, in dem Modus und Substanz untrennbar miteinander verschmolzen sind« (Klein, 2010: 2).?

\section{Künstlerisches Handeln}

bezeichnet das Vorgehen einzelner Kunsthandelnder. Künstlerisches Handeln ist wesentlich bestimmt durch einen offenen Ausgang, nicht nur zu Beginn, sondern auch während des Schaffensprozesses über einen längeren Zeitraum hinweg. Die Unbestimmtheit wird spielerisch rausgehalten< und in der intensiven Auseinandersetzung mit dem Material produktiv angewendet.

\section{Künstlerisches Wissen}

Künstlerisches Wissen ist der verfügbare Bestand von Fakten, Theorien und Regeln einer Künstlerin oder eines Künstlers und Ausgang oder Erkenntnis seines Schaffens. »Wer sind wir? Was bedeuten die Dinge? Was ist wirklich? Was hat Schuld? Was ist Zeit« (Klein 2010: 3) sind Fragen, mit denen sich in künstleri-

6 | Vgl. auch Böhme, G. (2003): Aisthetik. Vorlesungen über Ästhtetik als allgemeine Wahrnehmungslehre. Paderborn, Fink Verlag.

7 | Klein, J. (2010): Was ist künstlerische Forschung? in: Gegenworte 23 - Berlin-Brandenburgische Akademie der Wissenschaften 2010, S. 24-28. 
schen Prozessen auseinandergesetzt wird. Das Material, materiell oder immateriell, wird dabei sinnlich erlebt und gerät zum >embodied knowledge ${ }^{8}$

\section{Offene Prozesse}

In Abgrenzung zu >geschlossenen< Prozessen sind in >offenen Prozessen Ergebnisse Teil des Entstehungsprozesses. Offene Prozesse und der spielerische Umgang mit Unbestimmtheit sind wichtige Voraussetzungen für Innovation und Partizipation und bieten die Möglichkeit, auch subjektive Erfahrungen in den Schaffensprozess einzubringen.

\section{Spielen}

Spielen ist ernsthafte Arbeit am Material - eine künstlerisch entdeckende Erforschung. Spielen besteht aus einem bewusst absichtslosen Vorgehen, einem Modus, der die Optionen eröffnet, jenseits des Bekannten und Geordneten, das neue Interpretationen und Wahrnehmungen des Materials und des Gegenstands generieren kann.

\section{Unsicherheit}

ist im Bereich künstlerischer Prozesse ein geläufiger Zustand weil sich künstlerisches Handeln bzw. künstlerische Arbeit über den offenen Ausgang definiert. Die Unklarheit über das aus dem Prozess folgende Ergebnis führt häufig zu einem krisenhaften Zustand. Deswegen könnte man Improvisation auch als die Kunst bezeichnen, Sicherheit im Umgang mit der Unsicherheit zu gewinnen.

\section{IMPROVISATION}

Im allgemeinen Sprachgebrauch versteht man unter Improvisation den spontanen praktischen Gebrauch von Kreativität zur Lösung auftretender Probleme. In der Musik wird sie als Form musikalischer Darbietung verstanden, in der das ausgeführte Tonmaterial in der Ausführung selbst entsteht und nicht vorher schriftlich fixiert worden ist. ${ }^{9}$ In unserem Fall gibt es zwei verschiedene Modi des Improvisierens. Improvisation Modus 1 agiert allein als reaktives, reparierendes, Mangel ausgleichendes Prinzip. Man kann diesen Modus als Reparaturmodus bezeichnen. Als Modus 2 (Improvisation 2. Ordnung) ist sie der konstruktive Umgang mit Unordnung in Gemeinschaft. Gemeint ist damit das Überführen erlernter Regeln und Praxen in ein vorwegnehmendes (antizipatorisches) Konzept, das nicht auf Planung oder Rahmung verzichtet, sondern diese kreativ zu überschreiten sucht. Und zwar als permanentes Experiment und andauernde Na-

8 | Vgl. http://embodiedknowledge.blogspot.de/p/emobodied-knowledge.html

9 | Ähnliches gilt für den Tanz, in der die Performance aus der Bewegung im Raum entsteht (Forsythe, W. [2003]: Improvisationstechnologien. Karlsruhe, ZKM.). 
vigationsübung, die mal mehr und mal weniger krisenhaft ist. Improvisation 2. Ordnung ist Organisationsproduktion als Kreation. Improvisation ist eine nichtstandardisierbare Methode, die helfen kann, Handlungsverläufe bei der Organisationsproduktion zu organisieren.

\section{Bestimmende Urteilskraft}

»Ist das Allgemeine [...] gegeben, so ist die Urteilskraft, welche das Besondere darunter subsumiert, [...] bestimmend $(\text { Kant } 1788)^{10}$. Bestimmende Urteilskraft ist dann zu gebrauchen, wenn Regeln schon vorliegen und auf Situationen angewendet werden.

\section{Minimal Structures}

In der Musik entsprechen Minimal Structures melodischen Fragmenten ${ }^{11}$ bzw. Themen und Motiven, die z.B. in der Improvisation aufgegriffen, variiert und neu verschaltet werden. Aus der Architektur lassen sich aus den 15 Properties der Theorie Alexanders (2004) bezüge zu Minimal Structures von organisationalen Mustern herleiten. Die Center Theorie beschreibt die wirksamen Prinzipien, die die Grundstrukturen eines lebendigen Systems bilden. Minimal Structures können auch die grundlegenden Eigenschaften eines (sozialen) Systems beschreiben, aus denen Patterns gebildet werden können.

\section{Bricolage}

meint die Fähigkeit, in Situationen bereits vorhandene materiale, kognitive und soziale Ressourcen zu nutzen, um ein bestimmtes Problem zu lösen. Bricolage hebt damit vor allem auf den strukturellen Modus des Umgangs mit Situationen ab.

\section{Groove}

Eine Jazzperformance zB ist dann im Groove, wenn Improvisation gelingt und die Musik in ästhetischer sowie körperlicher Weise stimmig ist. Umgekehrt ist der Groove Voraussetzung, um mit Mustern strukturell so arbeiten zu können, dass ein neues Verschalten der Muster Sinn macht, bzw. sich >richtig anfühlt<. Der Groove setzt sozusagen den Vektor in die Struktur - Struktur beginnt sich zu bewegen. Im Groove sein heißt, dass die Musiker fühlen >wo was hingehört<.

\section{Impromptu}

Impromptu ist die Befähigung, Aufmerksamkeit für den Moment und Spontaneität bzw. Handlungsschnelligkeit auszuüben (act-in-an-instant). ${ }^{12}$

10 | Kant, I. (1788): Kritik der Urteilskraft. Akademieausgabe der gesammelten Schriften Immanuel Kants. Berlin: Akademie der Preussischen Wissenschaften.

11 | Vgl. Coker, Casale \& Campbell (1970): Patterns for Jazz. A Theory Text for Jazz Composition and Improvisation. Miami, Warner Bros.

12 | Ungeplant, ohne Vorbereitung, spontan. 


\section{Musikalische Muster}

sind musikalische Ereignisse, Situationen oder Konstellationen. Sie sind zerlegbar in serielle oder sequentielle Blöcke von Elementen. Auch wenn sie aus unterschiedlichen Teilen bestehen, so sind ihre Möglichkeiten doch erst in Form des relationalen Gebildes zu erkennen. Diese Relationen können auch in Zahlen ausgedrückt werden. Das spielt vor allem im Jazz eine Rolle und zwar dann, wenn man über eine ganze Reihe von Parametern ein Muster beschreiben will. ${ }^{13}$

\section{Performative Organisation}

Tsoukas und Chia (2002) $)^{14}$ sprechen von Organisation als »an attempt to order the intrinsic flux of human action, to channel it toward certain ends, to give it a particular shape, through generalizing and institutionalizing particular meanings and rules.« (573) Organisationen sind nach diesem Verständnis keine starren Gebilde, sondern entstehen durch zielgerichtete Handlungen. Damit wird die poietische bzw. emergente und kreative Seite des Organisationsverlaufs in den Vordergrund gerückt. So erweist es sich als adäquat, die Performanz-Theorie auf Organisationen zu übertragen und sie mit Weick und Chia als spermanent im Wandel zu beschreiben.

\section{Reflektierende Urteilskraft}

ist die Fähigkeit, von einem speziellen Einzelfall (dem Besonderen) zu verallgemeinern. »Ist aber das Besondere gegeben, wozu sie das Allgemeine finden soll, so ist die Urteilskraft bloß reflektierend« (Kant 1988 - siehe Fußnote 7). Reflektierende Urteilskraft ist dann am Werk wenn gefragt wird >Was ist hier los? Prozess reflektierenden Urteilens konstruiert und wählt Deutungen und Bedeutungen, Strategien, Handlungsvorschläge und Ziele. Um Handlung zu sichern wird ein Konsens darüber erzielt, welche Deutung aus einer Reihe von Schlüssen zu ziehen und zusammenzufassen ist, um sie für folgendes Handeln verbindlich zu machen.

\section{Session}

Die >Session < bietet die Form, die eine informelle Aktion gleichsam rahmt. Die Session ermöglicht es den Musikern in unterschiedlichsten Konstellationen zusammenzukommen um - ausgehend von einem bestimmten Thema - einem bestimmten Material oder eines Versuchsaufbaus (wie einer grafischen Partitur) miteinander $\mathrm{zu}$ interagieren, Ideen auszutauschen und von dem Erfahrungsschatz und Wissen der Beteiligten zu profitieren.

13 | Vgl. Dell, C.: Die improvisierende Organisation. Bielefeld, transcript.

14 | Tsoukas, H. \& Chia, R. (2002): On Organizational Becoming. Rethinking Organizational Change. In: Organization Science, 13 (5), 567-582. 



\section{Die Autorlnnen}

\section{Ella Gabriele Amann, Coach und Beraterin}

leitet in Berlin die impro live! Akademie für Angewandte Improvisation und ist Mitbegründerin des ResilienzForum Berlin (www.impro-live-akademie.de).

\section{Ursula Bertram, Prof., Künstlerin}

ist Professorin im Fachbereich für Kunst und ihre Didaktik an der TU Dortmund und Gründerin der IDFactory - Zentrum für Kunsttransfer (www.id-factory.de).

\section{Oliver Bluszcz, Dipl. Päd.}

war wissenschaftlicher Mitarbeiter im Projekt >Music, Innovation and Corporate Culture < (www.micc-project.de) und ist seit 2012 Leiter der Stabstelle für Strategie und Innovation der Hochschule Düsseldorf (www.hs-duesseldorf.de/personen/ bluszcz-weinem).

\section{Monika Bobzien, Dipl. Psychologin}

ist freiberuflich tätig als Organisationsberaterin, Coach, Supervisorin, Mediatorin und Auditorin (www.monikabobzien.de).

Fritz Böhle, Prof. Dr.

Professor für Sozioökonomie der Arbeits- und Berufswelt an der Universität Augsburg und Vorsitzender des Vorstands des Instituts für sozialwissenschaftliche Forschung e.V. in München (www.isf-muenchen.de).

\section{Martin Ciesielski, MA, Dipl.-Betriebswirt}

Geschäftsführender Gesellschafter der medienMOSAIK GbR und Mitbegründer des ResilienzForum Berlin (www.medienmosaik.de).

\section{Christopher Dell, Prof. Dr.}

Musiker und Komponist (zahlreiche internationale Auszeichnungen, ua German Jazz Award in Gold 2015), Gründer und Leiter des >Institut für Improvisations- 
technologie< in Berlin, Gastprofessur für Urban Design an der HafenCity University Hamburg (www.christopher-dell.de).

\section{Thorsten Kamin, Dipl. Kaufmann}

Client Services Director - Geschäftsentwicklung bei www.fuenfwerken.de.

\section{Rolf Mehnert, MBA Business Design}

Managing Partner/CMO der Fuenfwerken Design AG (www.fuenfwerken.com/ de/mehnert).

\section{Jörg Miller, Dipl. Päd.}

wiss. Mitarbeiter am Zentrum für Hochschul- und Qualitätsentwicklung der Universität Duisburg-Essen. Mitgründer von UniAktiv - Zentrum für gesellschaftliches Lernen und soziale Verantwortung (https://www.uniaktiv.org/uni aktiv/team/).

\section{Manfred Moldaschl, Prof. Dr. Dr.}

Audi-Stiftungslehrstuhl für unternehmerisches Handeln, globale Verantwortung \& Nachhaltigkeit und Leiter des European Center for Sustainability Research | ECS an der Zeppelin Universität Friedrichshafen (https://www.zu.de/lehrstueh le/audi/index.php).

Hajo Neis, Associate Professor, PhD, MArch, M.C.P., Dipl. Ing.

Direktor des Portland Architecture Program und des Portland Urban Architecture Research Laboratory der University of Oregon, Portland, USA (http://puarl. uoregon.edu).

\section{Miguel Pina e Cunha, Professor, PhD}

Professor für Organizational Studies an der Nova School of Business and Economics in Lissabon (Portugal) (www.novasbe.unl.pt/en/faculty-research/faculty/ faculty-members/item/cunha-miguel-pina-e).

\section{Nadine Ruda, MA}

wiss. Mitarbeiterin am Labor für Organisationsentwicklung und dem Zentrum für gesellschaftliches Lernen und soziale Verantwortung der Universität Duisburg-Essen (https://www.uniaktiv.org/connect/connect-dozierende/nadine-ruda/).

\section{Pedro Texeira Santos, MBA}

Teaching Assistant an der Nova School of Business and Economics in Lissabon (Portugal) (www.novasbe.unl.pt/en/). 


\section{Holger Schmidhuber, Prof.}

Managing Partner/CEO der Fuenfwerken Design AG (www.fuenfwerken.com/ de/schmidhuber), Professur für Typografie und Gestaltungssprache an der Hochschule Mainz und bildender Künstler (www.holgerschmidhuber.com).

\section{Michael Spencer, Musiker und Berater}

Musiker (Violine), ehemals London Symphony Orchestra und Director of Education, Royal Opera House, London. Managing Director von http://sound-strategies. co.uk. Cultural Consultant in Europa und Asien.

\section{Wolfgang Stark, Prof. Dr.}

Direktor, Labor für Organisationsentwicklung der Universität Duisburg-Essen und Steinbeis Transferzentrum Innovation and Sustainable Leadership (www. stw.de); wissenschaftlicher Leiter >Music - Innovation - Corporate Culture (www.micc-project.org) und Zentrum für gesellschaftliches Lernen und soziale Verantwortung (www.uniaktiv.org).

\section{David Vossebrecher, Dipl. Psychologe}

wiss. Mitarbeiter (2008-2011) im Projekt >Music, Innovation and Corporate Culture (www.micc-project.org). Seit 2012 Leiter der Stabsstelle Planung, Monitoring und Evaluation der Rosa-Luxemburg-Stiftung in Berlin (www.rosalux.de). 


\section{Kultur und soziale Praxis}
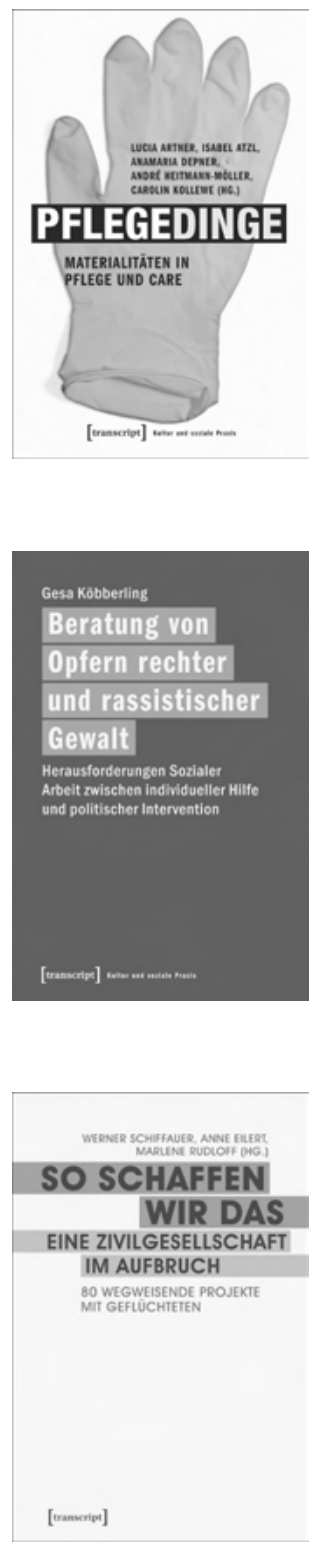

Lucia Artner, Isabel Atzl, Anamaria Depner, André Heitmann-Möller, Carolin Kollewe (Hg.) Pflegedinge

Materialitäten in Pflege und Care

Juli 20I7, ca. 250 Seiten, kart., zahlr. Abb., ca. 32,99€, ISBN 978-3-8376-384I-7

\section{Gesa Köbberling}

Beratung von Opfern rechter und rassistischer Gewalt Herausforderungen Sozialer Arbeit zwischen individueller Hilfe und politischer Intervention

Juli 2017 , ca. 370 Seiten, kart., ca. 34,99€, ISBN 978-3-8376-3866-0

Werner Schiffauer, Anne Eilert, Marlene Rudloff (Hg.) So schaffen wir das eine Zivilgesellschaft im Aufbruch 80 wegweisende Projekte mit Geflüchteten

März 20I7, ca. 350 Seiten, kart., ca. 24,99 €, ISBN $978-3-8376-3829-5$ 


\section{Kultur und soziale Praxis}

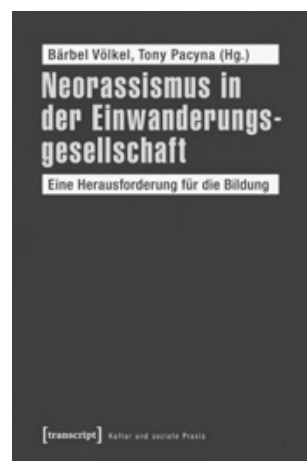

Bärbel Völkel, Tony Pacyna (Hg.)

Neorassismus in der Einwanderungsgesellschaft Eine Herausforderung für die Bildung

Januar 20I7, 258 Seiten, kart., 29,99 €, ISBN 978-3-8376-3454-9

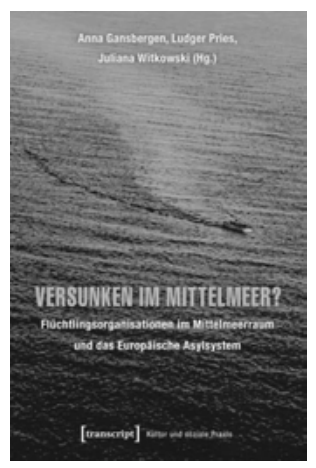

Anna Gansbergen, Ludger Pries, Juliana Witkowski (Hg.)

Versunken im Mittelmeer?

Flüchtlingsorganisationen im Mittelmeerraum und das Europäische Asylsystem

Oktober 2016, I92 Seiten, kart., 27,99 €, ISBN 978-3-8376-3676-5

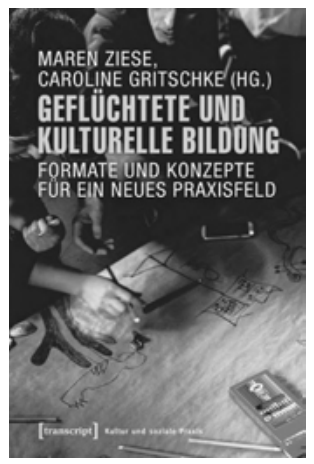

Maren Ziese, Caroline Gritschke (Hg.) Geflüchtete und Kulturelle Bildung Formate und Konzepte für ein neues Praxisfeld

September 2016, 440 Seiten, kart., 29,99 €, ISBN 978-3-8376-3453-2 


\section{Kultur und soziale Praxis}

Käthe von Bose

Klinisch rein

Zum Verhältnis von Sauberkeit, Macht und Arbeit im Krankenhaus

Juli 20I7, ca. 300 Seiten, kart., ca. 34,99€, ISBN 978-3-8376-38II-O

\section{Maria Grewe}

Teilen, Reparieren, Mülltauchen

Kulturelle Strategien

im Umgang mit Knappheit

und Überfluss

Mai 20I7, ca. 3I0 Seiten, kart., ca. 34,99€, ISBN 978-3-8376-3858-5

\section{Laila Huber}

Kreativität und Teilhabe in der Stadt Initiativen zwischen Kunst und Politik in Salzburg

Mai 20I7, ca. 370 Seiten, kart., ca. 39,99€, ISBN 978-3-8376-3664-2

\section{Daniel Volkert}

\section{Parteien und Migranten}

Inkorporationsprozesse innerhalb der SPD und der französischen PS

Mai 20I7, ca. 375 Seiten, kart., ca. 39,99€, ISBN 978-3-8376-3828-8

Christian Lahusen, Stephanie Schneider (Hg.)

Asyl verwalten

Zur bürokratischen Bearbeitung eines gesellschaftlichen Problems März 20I7, 244 Seiten, kart., 29,99€, ISBN 978-3-8376-3332-0

Christian Lahusen, Karin Schittenhelm, Stephanie Schneider

Europäische Asylpolitik und lokales Verwaltungshandeln Zur Behördenpraxis in Deutschland und Schweden Februar 20I7, ca. 300 Seiten, kart., ca. $29,99 €$, ISBN 978-3-8376-3330-6
Daniel Kofahl, Sebastian Schellhaas (Hg.)

Kulinarische Ethnologie Beiträge zur Wissenschaft von eigenen, fremden und globalisierten Ernährungskulturen Februar 20I7, ca. I80 Seiten, kart., zahlr. Abb., ca. 29,99€, ISBN 978-3-8376-3539-3

Marie-Theres Modes

Raum und Behinderung

Wahrnehmung und Konstruktion aus raumsoziologischer Perspektive August 20I6, 246 Seiten, kart., 29,99 €, ISBN 978-3-8376-3595-9

Christoph Bareither

Gewalt im Computerspiel

Facetten eines Vergnügens

Juni 20I6, 368 Seiten, kart., 34,99€, ISBN 978-3-8376-3559-I

\section{Francis Müller}

Mit Behinderung in Angola leben Eine ethnografische Spurensuche in einer von Tretminen verletzten Gesellschaft

Mai 20I6, I52 Seiten, kart., zahlr. Abb.; 24,99€, ISBN 978-3-8376-3480-8

\section{Donja Amirpur}

Migrationsbedingt behindert? Familien im Hilfesystem. Eine intersektionale Perspektive

Mai 20I6, 3I2 Seiten, kart., 29,99€, ISBN 978-3-8376-3407-5

Dieter Haller

Tanger

Der Hafen, die Geister, die Lust.

Eine Ethnographie

April 2016, 356 Seiten, kart., zahlr. Abb., 34,99 €, ISBN 978-3-8376-3338-2 